\title{
Low-Temperature Intramolecular [4+2] Cycloaddition of Allenes with Arenes for the Synthesis of Diene Ligands
}

\author{
Durga Prasad Hari, ${ }^{+[a]}$ Guillaume Pisella, ${ }^{+[a]}$ Matthew D. Wodrich, ${ }^{[a]}$ Artem V. Tsymbal, ${ }^{[a]}$ Farzaneh \\ Fadaei Tirani, ${ }^{[b]}$ Rosario Scopelliti ${ }^{[b]}$ and Jerome Waser ${ }^{*[a]}$
}

\begin{abstract}
The intramolecular [4+2] cycloaddition between arenes and allenes first reported by Himbert gives rapid access to rigid polycyclic scaffolds. Herein, we report a one-pot oxyalkynylation/cycloaddition reaction proceeding under mild conditions $\left(23-90^{\circ} \mathrm{C}\right)$ and providing complex polycyclic architectures with high efficiency, atom and step economy. The bicyclo[2.2.2]octadiene products were obtained with a wide variety of useful functional groups and were successfully applied as chiral ligands for metal catalysis. Computational studies gave a first rationalization of the low activation energy for the cycloaddition based on counter-intuitive favorable dispersive interactions in the transition state.
\end{abstract}

\section{Introduction}

The development of multiple bond-forming transformations to increase molecular complexity and diversity from simple precursors is a constant quest in synthetic chemistry with important applications in the pharmaceutical and agrochemical industries. ${ }^{[1]}$ Among multiple bond-forming transformations, cycloadditions occupy a privileged position. ${ }^{[2,3]}$ They have found applications in the synthesis of natural products, ${ }^{[4]}$ organic materials, ${ }^{[5]}$ and pharmaceutical agents. ${ }^{[6]}$ In particular, the DielsAlder reaction has been investigated extensively. ${ }^{[7]}$ When using cyclic dienes, it gives access after reduction to bicyclo[2.2.2]octane derivatives, an important class of organic compounds due to their rigidity allowing a precise disposition of functional groups in space. Numerous bioactive natural products, such as the alkaloid kopsinine $(1),{ }^{[8]}$ or synthetic compounds, such as the broadly prescribed opioid analgesic buprenorphine (2), ${ }^{[9]}$ contain this scaffold (Scheme 1A). Less saturated bicyclo[2.2.2]octadienes constitute another interesting subclass, as they have found broad applications as (chiral) ligands for late transition metal catalysts (Scheme $1 \mathrm{~A}$, dienes 3 and 4) ${ }^{[10]}$ As unsaturated compounds, they are also ideal starting materials for the synthesis of more functionalized saturated derivatives. Two different strategies can be envisioned to access them by a

[a] Dr. Durga Prasad Hari, Guillaume Pisella, Dr. Matthew D. Wodrich, Artem V. Tsymbal and Prof Dr. Jerome Waser

Laboratory of Catalysis and Organic Synthesis

Ecole Polytechnique Fédérale de Lausanne

EPFL SB ISIC LCSO, BCH 1402, 1015 Lausanne $(\mathrm{CH})$

Fax: (+)41216939700

E-mail: jerome.waser@epfl.ch

tThese authors contributed equally.

Dr. R Durga Prasad Hari

Present address: School of Chemistry

University of Bristol

Cantock's Close, Bristol BS8 1TS, UK

[b] Dr. Farzaneh Fadaei Tirani, Dr. Rosario Scopelliti

Institute of Chemistry and Chemical Engineering

Ecole Polytechnique Fédérale de Lausanne

EPFL SB ISIC-GE, BCH 2111, 1015 Lausanne $(\mathrm{CH})$

Supporting information for this article is given via a link at the end of the document. convergent [4+2] cycloaddition (Scheme 1B): reaction of cyclohexadienes with alkynes (a), or reaction of arenes with alkenes (b). The first approach is now well established. ${ }^{[11]}$ In contrast, the second strategy is less investigated due to the large aromatic stabilization energy of arenes. ${ }^{[12]}$ From the synthetic point of view however, such an approach is highly attractive, as arenes are easier to access than cyclohexadienes.

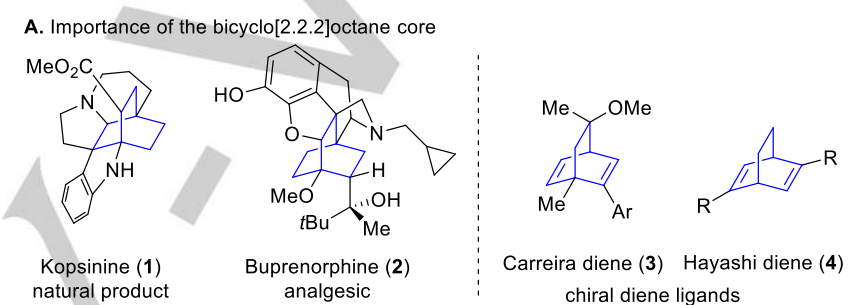

B. Possible [4+2] cycloaddition for accessing bicyclo[2.2.2]octadienes

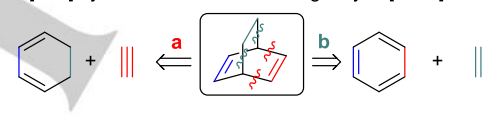

c. [4+2] Cycloaddition of allenes and arenes (Himbert reaction)

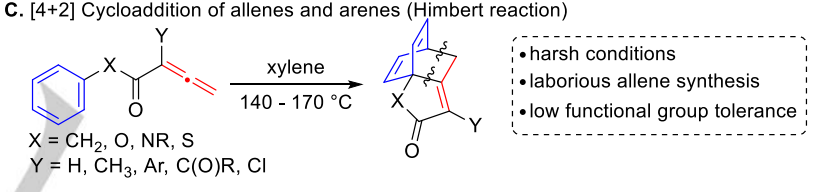

$\mathrm{Y}=\mathrm{H}, \mathrm{CH}_{3}, \mathrm{Ar}, \mathrm{C}(\mathrm{O}) \mathrm{R}, \mathrm{Cl}$

D. Unexpected observation: Himbert reaction at room temperature

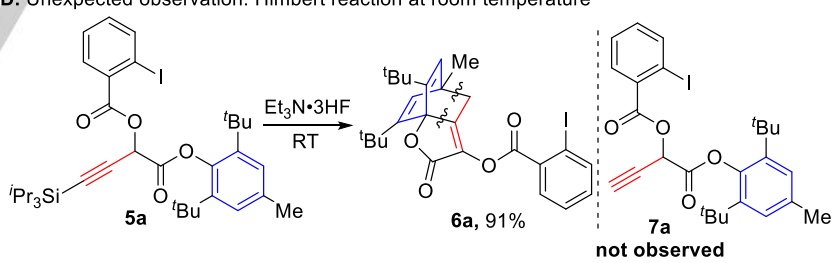

E. One-pot sequential oxy-alkynylation/Himbert reaction

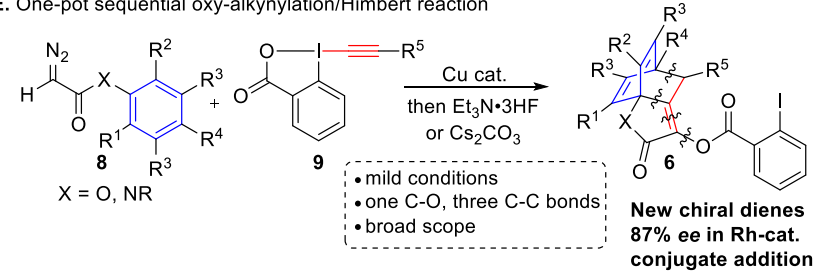

Scheme 1. A. Importance of the bicyclo[2.2.2]octane core. B. [4+2] cycloadditions for accessing bicyclo[2.2.2]octadienes. C. Himbert reaction. D. Unexpected Himbert reaction at room temperature. E. One-pot oxyalkynylation/Himbert reaction.

In 1982, Himbert and Henn reported an unusual thermal intramolecular [4+2] cycloaddition of allenecarboxanilides to access complex bridged polycyclic architectures. ${ }^{[13]}$ The Himbert and Orahovats groups then studied the scope of allenecarboxylic acid derivatives including esters, ${ }^{[14]}$ amides, ${ }^{[15]}$ thioesters, ${ }^{[16]}$ 
imides, ${ }^{[17]}$ phosphinamides, ${ }^{[18]}$ and phosphinic esters (Scheme 1C) ${ }^{[19]}$ In 2013, Vanderwal and co-workers extended the Himbert cycloaddition to benzyl allenyl ketones. ${ }^{[20]}$ In 2015, Li and coworkers reported a Ugi/Himbert reaction sequence to synthesize strained polycyclic skeletons. ${ }^{[21]}$ Despite its great potential to assembly complex molecules in a single step, the [4+2] cycloaddition of allenes and arenes has found only a few applications in synthetic chemistry. ${ }^{[22]}$ The Himbert reaction often requires high reaction temperatures. Examples at ambient temperature required conformationally constrained amides ${ }^{[17,23]}$ or were performed under light irradiation. ${ }^{[24]}$

Our group has been interested in electrophilic alkynylation reactions using hypervalent iodine reagents for more efficient and flexible alkyne synthesis. ${ }^{[25]}$ Recently, we developed a coppercatalyzed oxyalkynylation of diazo compounds using ethynylbenziodoxol-(on)e (EBX) reagents. ${ }^{[26]}$ When attempting the deprotection of silyl alkyne $\mathbf{5 a}$ with $\mathrm{Et}_{3} \mathrm{~N} \cdot 3 \mathrm{HF}$ at room temperature, we did not obtain the expected terminal alkyne 7a. Instead, polycyclic product 6 a was isolated in excellent yield, probably resulting from a [4+2] cycloaddition of the arene on the in situ formed allene (Scheme 1D). The exceptionally mild conditions combined with synthetic accessibility motivated us to investigate this transformation.

Herein, we report our studies on this fascinating reaction. The cycloaddition proceeded under mild conditions (RT to $90^{\circ} \mathrm{C}$ ) and exhibited a broad scope of substituents on both arene and allene. By developing a one-pot oxy-alkynylation/cycloaddition process, complex tricyclic compounds are now accessible in a single manipulation from broadly available EBX reagents and diazo esters (Scheme 1E). Preliminary computational studies shed first light on the exceptionally low activation energy of the cycloaddition step, resulting from a combination of attractive interactions from the benzene substituents with the allene and an electronic effect of the oxygen substituent on the allene. This interesting class of heteroatom-substituted allenes has been only rarely investigated so $\operatorname{far}^{[27]}$ and the high reactivity observed is promising for other transformations. Furthermore, the iodobenzoyl ester could be easily removed for further modification. Finally, the diene products were effective ligands for rhodium, resulting in quantitative complexation. Preliminary investigations showed that good enantioselectivity can be achieved in rhodiumcatalyzed conjugate addition of boronic acids to cyclohexenone using these chiral diene ligands.

\section{Results and Discussion}

\section{Optimization and Scope}

We started our investigations on developing a one-pot oxyalkynylation/Himbert reaction by screening various fluoride sources, using 2,6-di-tert-butyl-4-methylphenyl 2-diazoacetate (8a) with 1-[(triiso-propylsilyl)-ethynyl]-1,2-benziodoxol-3(1H)-one (TIPS-EBX (9a)), diimine ligand 10 and $\mathrm{Cu}\left(\mathrm{CH}_{3} \mathrm{CN}\right)_{4} \mathrm{BF}_{4}$ as the copper source in 1,2-dichloroethane (DCE, Table 1). ${ }^{[26 a]}$ Compound $6 \mathrm{a}$ was obtained in $88 \%$ yield when $\mathrm{Et}_{3} \mathrm{~N} \cdot 3 \mathrm{HF}$ was used, whereas trissulfonium difluorotrimethylsilicate (TASF) gave the desired product in $26 \%$ yield only (Table 1, entries 1 and 2). The use of tetrabutylammonium fluoride (TBAF) and pyridine hydrofluoride $(\mathrm{Py} \cdot \mathrm{HF})$ resulted in decomposition of the oxyalkynylated product (Table 1, entries 3 and 4). One equivalent of $\mathrm{Et}_{3} \mathrm{~N} \cdot 3 \mathrm{HF}$ was sufficient, whereas a sub-stoichiometric amount led to a lower yield (Table 1, entries 5 and 6). Addition of $\mathrm{Et}_{3} \mathrm{~N} \cdot 3 \mathrm{HF}$ at the start of the reaction did not lead to the formation of the desired product $6 \mathbf{6}$ (Table 1, entry 7 ). Among the solvents tested, DCE was the best (Table 1, entries, 5 and 8-10). We were able to reduce the amount of diazo $8 \mathrm{a}$ to 1.2 equivalents without a change in yield (Table 1, entry 11). Finally, the yield could be improved to $94 \%$ by lowering the concentration of the reaction (Table 1, entry 12). Furthermore, the reaction proved to be easily scalable, as the yield did not change on gram scale.

Table 1. Optimization of the Reaction Conditions ${ }^{[a]}$

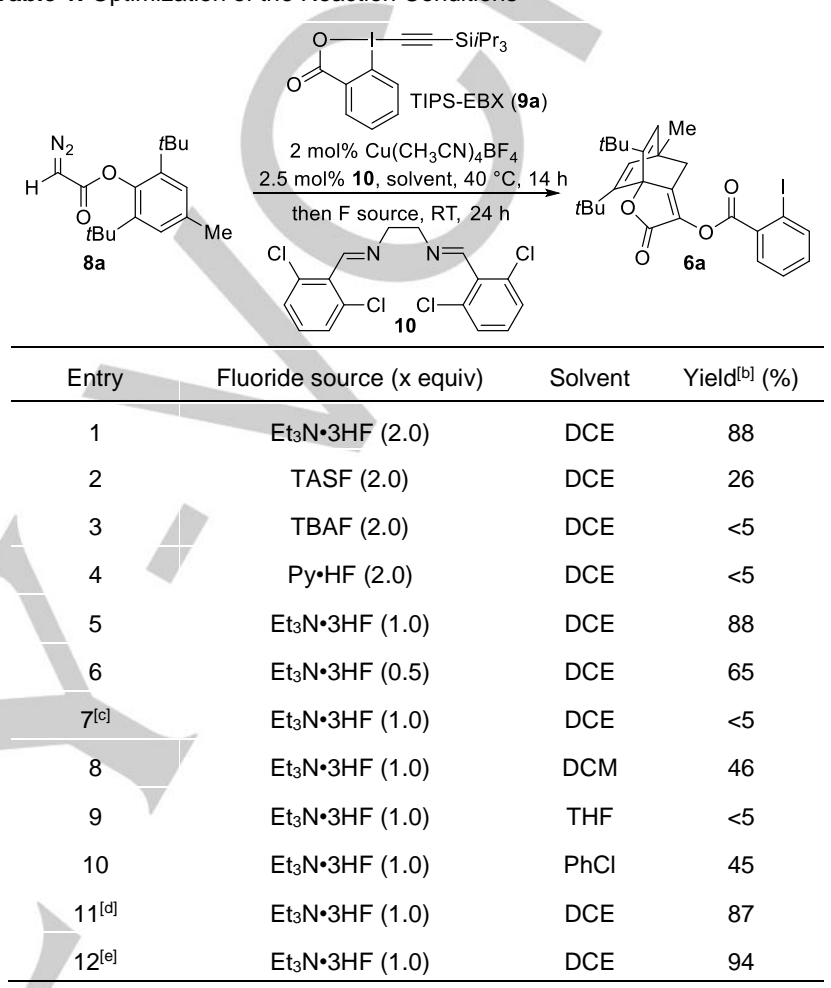

[a] Reaction conditions: $0.30 \mathrm{mmol}$ diazo ester (8a), $0.15 \mathrm{mmol}$ TIPS-EBX (9a), copper catalyst $(2.0 \mathrm{~mol} \%), 10(2.5 \mathrm{~mol} \%)$, solvent $(0.05 \mathrm{M})$. ${ }^{[b]}$ Yield after purification by column chromatography. ${ }^{\left[{ }^{[c]}\right.} \mathrm{Et}_{3} \mathrm{~N} \cdot 3 \mathrm{HF}$ was added at the start of the sequence. ${ }^{[d]} 1.2$ equiv of diazo ester instead of 2.0 equiv. ${ }^{[\mathrm{e}]} 0.025 \mathrm{M}$ instead of $0.05 \mathrm{M}$. DCM = dichloromethane, THF = tetrahydrofuran.

With the optimized conditions in hand, the scope of the reaction was first examined using TIPS-EBX (9a) and various diazo esters bearing tert-butyl substituents in ortho positions of the benzene ring (Scheme 2A). Para-substituted products 6a-f with alkyl, ether, bromine or hydrogen substituents were obtained in $83-96 \%$ yield, showing that there was no strong steric or electronic effects at this position. ${ }^{[28]}$ In contrast, the ortho substituent size had a strong effect on the reaction outcome. When 2,6-di-iso-propyl-phenyl 2diazoacetate $(\mathbf{8 g})$ was subjected to the standard reaction conditions, we could not observe the desired product $6 \mathbf{g}$. Heating to higher temperature led to decomposition. This was due to the presence of the copper catalyst. Removal of the catalyst and heating the reaction at $90{ }^{\circ} \mathrm{C}$, gave the product $6 \mathrm{~g}$ in excellent yield. This temperature is significantly lower than reported for similar substrates lacking the oxygen substituent on the allene $\left(140{ }^{\circ} \mathrm{C}\right) .{ }^{[14 a]}$ Diphenyl- and dimethyl-benzene substituted diazo esters could also be used in the reaction (products $\mathbf{6 h}$ and $\mathbf{6 i}$ ). The formation of the product $6 \mathbf{i}$ is particularly interesting as a similar o-dimethylbenzene substituted allene without $\alpha$-oxygen substitution failed to give the corresponding Himbert product even at $140{ }^{\circ} \mathrm{C} \cdot{ }^{[14 a]}$ Mono-substituted benzene diazo esters also 
underwent the desired transformation successfully to give products $\mathbf{6 j}$ and $\mathbf{6 k}$ as single diastereoisomers in $91 \%$ and $55 \%$ yield, respectively. ${ }^{[29]}$ Substitutions at different positions than ortho were envisaged: $p$-Substituted and unsubstituted benzene diazo esters gave the corresponding products 6I-n in moderate to good yield. Dimethyl-substituted benzene diazo esters also gave the desired products 60 and $6 \mathrm{I}$ in moderate yields. Amide tethered Himbert product $6 p$ was obtained in $40 \%$ yield.

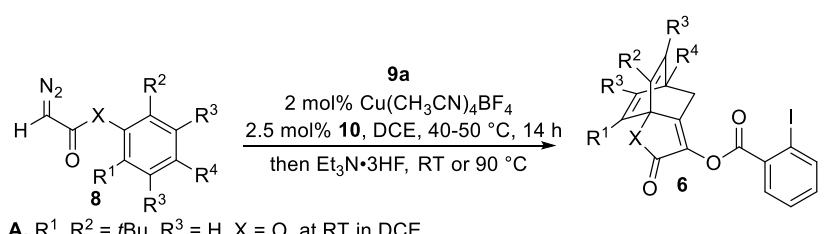

A. $R^{1}, R^{2}=t B u, R^{3}=H, X=O$, at $R T$ in DCE

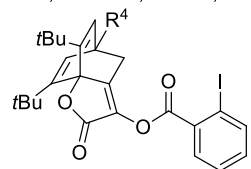

6a, $\mathrm{R}^{4}=\mathrm{Me}, 94 \%$

6b, $R^{4}=\mathrm{Et}, 96 \%$

6d, $\mathrm{R}^{4}=\mathrm{OMe}, 85 \%$

6e, $R^{4}=B r, 83 \%$

B. $R^{1}, R^{2} \neq t B u$, at $90^{\circ} \mathrm{C}$ in $\mathrm{THF}$

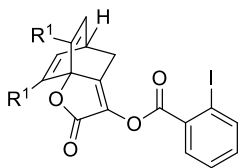

6g, $\mathrm{R}^{1}=i \mathrm{Pr}, 90 \%$

6h, $\mathrm{R}^{1}=\mathrm{Ph}, 71 \%$

$6 \mathbf{i}, \mathrm{R}^{1}=\mathrm{Me}, 84 \%$

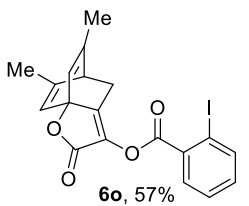

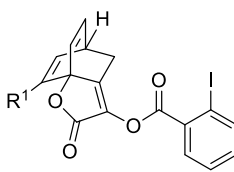

6j, $R^{1}=t \mathrm{Bu}, 91 \%$ $6 k, R^{1}=M e, 55 \%$

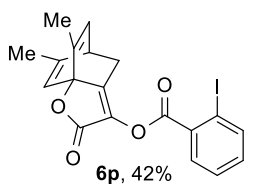

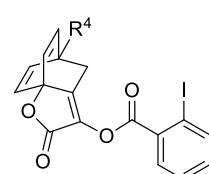

6I, $\mathrm{R}^{4}=\mathrm{OMe}, 81 \%$ $6 \mathrm{~m}, \mathrm{R}^{4}=\mathrm{Me}, 41 \%$ 6n, $\mathrm{R}^{4}=\mathrm{H}, 33 \%$
Scheme 2. Scope of diazo esters with TIPS-EBX (9a).

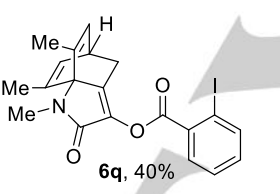

limited to linear alkyl-EBX reagents: Cyclo-propyl, -pentyl, and hexyl substituted products 6aj-I were obtained in $60-93 \%$ yield. The formation of product 6 aj exclusively indicated that radical intermediates were probably not involved in the reaction.
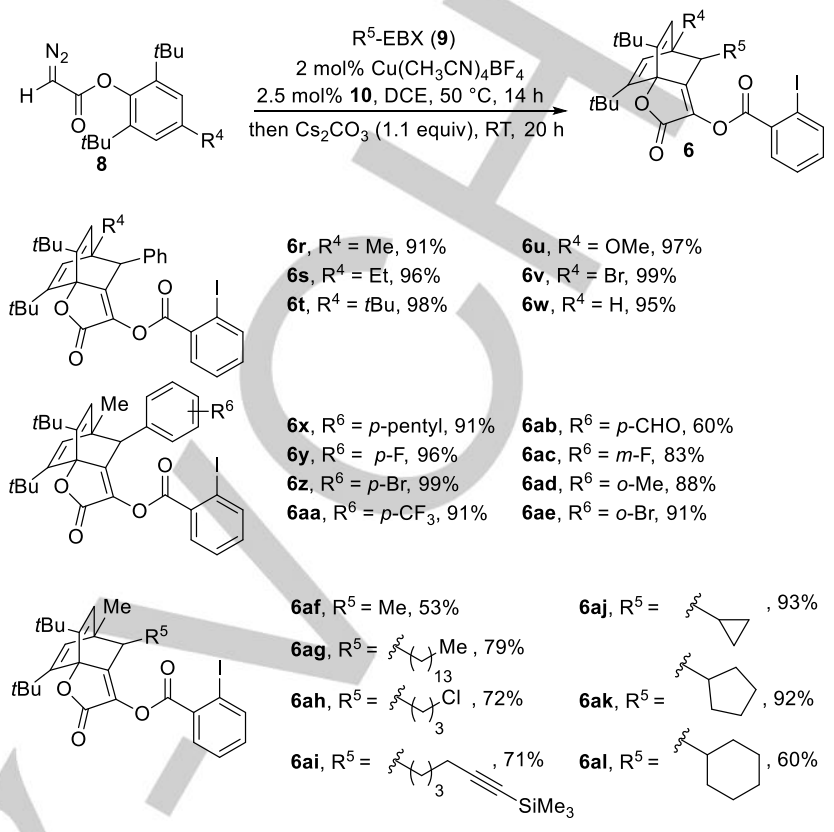

Scheme 3. Scope of diazo esters with different EBX reagents.

\section{Mechanism Investigations}

To confirm our hypothesis for a successive oxyalkynylation/allene formation/ [4+2] cycloaddition sequence, we isolated each intermediate before engaging it in the next step using less reactive alkyne $\mathbf{5 g}$ (Scheme $4 \mathrm{~A})$.

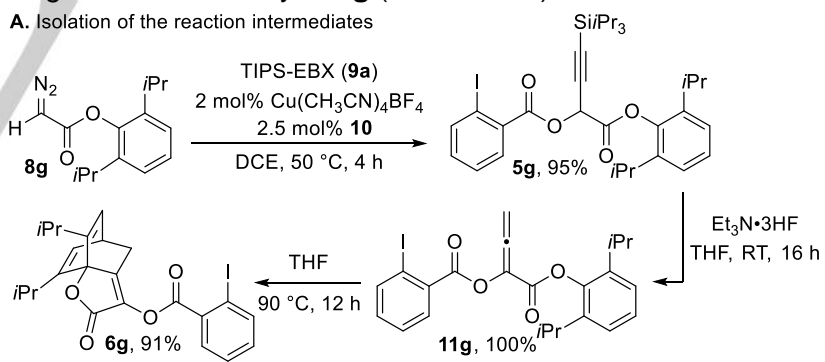

B. Allene racemization

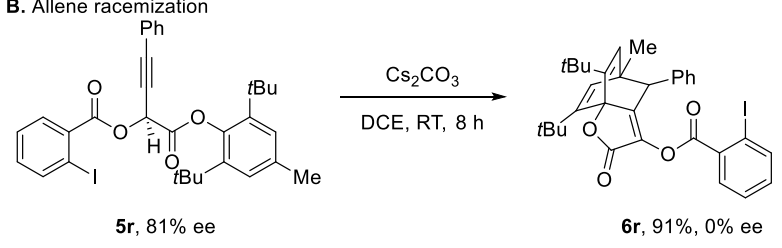

Scheme 4. Control experiments.

In presence of $\mathrm{Et}_{3} \mathrm{~N} \cdot 3 \mathrm{HF}$ after removal of the copper catalyst, $\mathbf{5 g}$ was cleanly converted to allene $\mathbf{1 1} \mathrm{g}$, which was stable at room temperature. Upon heating to $90{ }^{\circ} \mathrm{C},[4+2]$ cycloaddition then occurred in $91 \%$ yield. As allene $\mathbf{1 1} \mathrm{g}$ is non-chiral, no transfer of chirality is possible when starting from enantioenriched alkynes. However, when using aryl- or alkyl- substituted alkynes, a chiral allene would be formed. We wondered if in this case transfer of 
chirality would be possible. However, racemic $6 r$ was isolated starting from enantioenriched alkyne $5 r$ (Scheme 4B). ${ }^{[34]}$

Having established that the reaction most probably proceeds via a [4+2] cycloaddition of the allene with the arene ring, we turned to density functional theory computations (at the PBE0$\mathrm{dDsC/TZ2P//M06-2X/def2-SVP} \mathrm{level,} \mathrm{see} \mathrm{SI} \mathrm{for} \mathrm{full} \mathrm{computational}$ details) to better understand the observed amazing reactivity. When comparing the transition state energies of nine different cycloadditions in dependence of the substituents on the benzene ring and allene, computations clearly show the favorable nature that bulky tert-butyl groups have on the transition state barrier heights (Scheme 5). The free energies with tert-butyl groups $(14.7-18.3 \mathrm{kcal} / \mathrm{mol})$ were significantly lower than with methyl $(20.3-25.3 \mathrm{kcal} / \mathrm{mol})$ or hydrogen $(22.1-25.3 \mathrm{kcal} / \mathrm{mol})$, independently from the substituent on the allene. In addition, the reactivity was further enhanced by the carboxy substituent on the allene, although the effect was weaker. These results are in good accordance with the reaction rates observed experimentally.
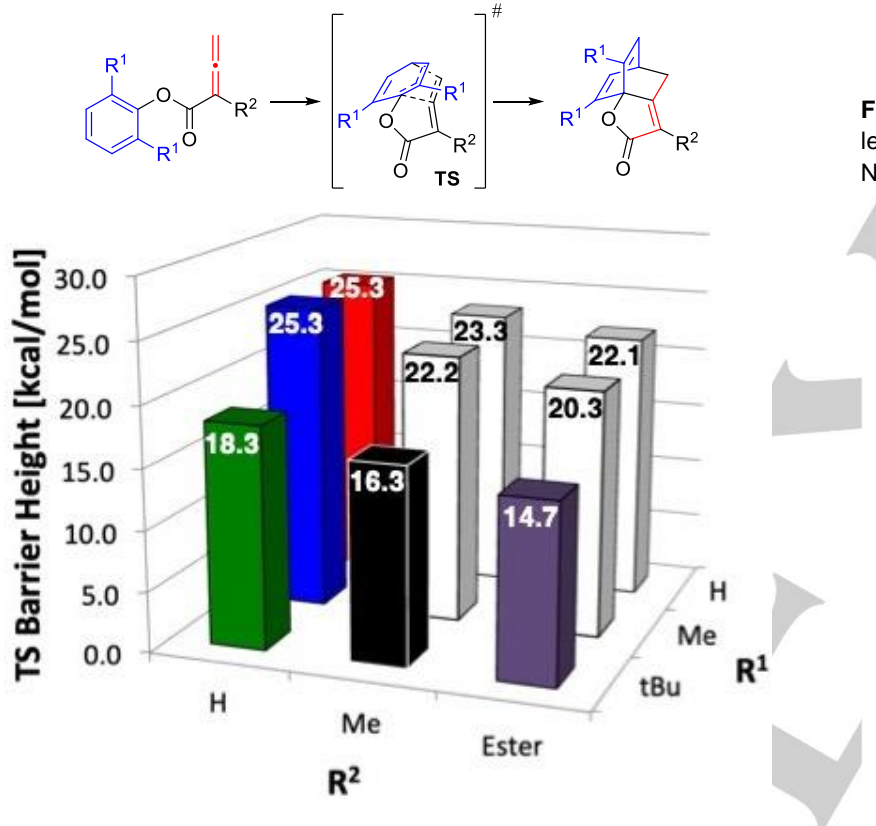

Scheme 5. Free energies of transition states in dependence of substituents on benzene and allene. Free energies computed at the PBE0-dDsC/TZ2P//M06$2 \mathrm{X} /$ def2-SVP level). Ester $=2$-iodobenzoate. Note that column colors correspond to those of the activation strain model computations shown in Figures 1 and 2.

To gain additional insight, we analyzed the energetic profiles of these nine reactions using the activation strain model. ${ }^{[35]}$ Initially, we speculated that the bulky tert-butyl groups in $\mathrm{R}^{1}$ could diminish the planarity of the benzene ring, lowering the distortion energy and making it easier to break aromaticity. However, the calculation results showed that the presence of the bulky substituents in $R^{1}$ causes energetically favorable dispersive interactions at longer $\mathrm{C}-\mathrm{C}$ distances, whereas no major difference in strain energy was observed (Figure 1). This results in an earlier, lower energy transition state for the tert-butyl containing variant relative to methyl or hydrogen. Substitution on the allene is characterized by a more complicated picture in which both the unfavorable strain energy and stabilizing interaction energy are influenced by the substituent (Figure 2). Replacing the hydrogen atom with either a methyl or a carboxy group slightly reduces the strain energy. However, this substitution also results in a less favorable interaction energy for the methyl variant while the ester variant provides a more favorable interaction. Overall, this results in the ester having a lower energy transition state barrier relative to either a hydrogen or methyl group.

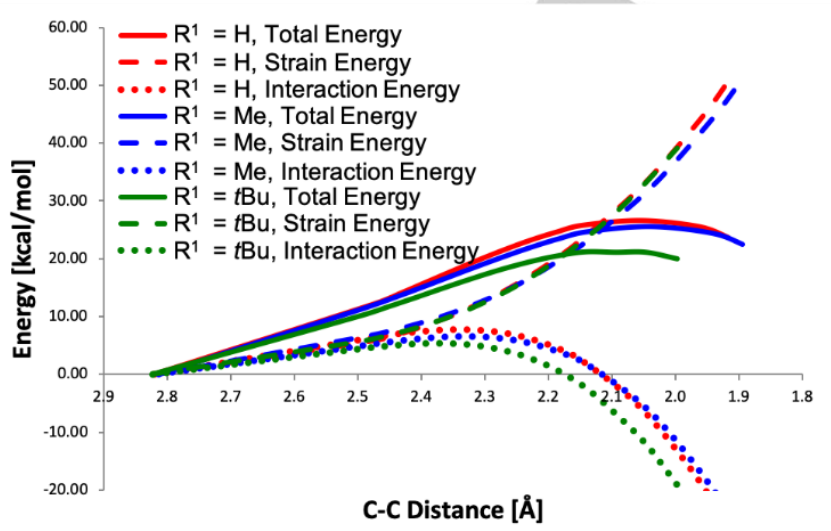

Figure 1. Activation strain model results (computed at the M06-2X/def2-SVP level) in dependence on the $R^{1}$ group on the benzene for $R^{2}=H$ on the allene. Note that the plots depict electronic energies, as opposed to free energies.

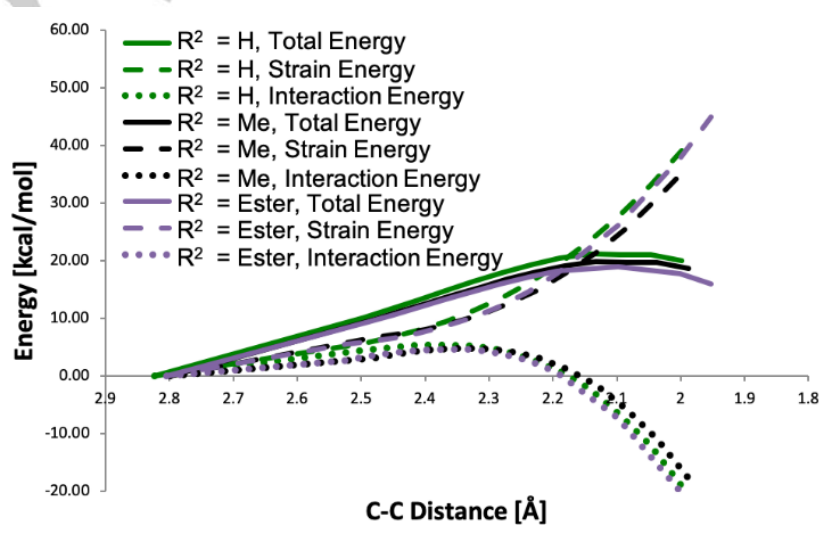

Figure 2. Activation strain model results (computed at the M06-2X/def2-SVP level) in dependence on the $R^{2}$ group on the allene for $R^{1}=t B u$ on the benzene. Ester $=2$-iodobenzoate. Note that the plots depict electronic energies, as opposed to free energies.

\section{Synthetic Applications}

The cycloaddition of allene and benzene rings gave access to $[6,6,5]$ ring systems. It is also important to access other polycyclic systems. In this respect, an interesting preliminary result was obtained with furan-derived diazoester 12: The oxyalkynylationHimbert sequence gave a new $[5,5,6]$ ring system 13 in $83 \%$ yield (Scheme 6A). Furthermore, the iodobenzoyl ester on the product can be cleaved directly after cycloaddition, giving access to ketoesters 14a and 14b (in their enol form) on gram-scale in onepot (Scheme 6B). Bromination of 14a yielded highly strained cyclopropane 15 in $86 \%$ yield. ${ }^{[36]}$ Alcohol 14a was quantitatively transformed into the corresponding triflate $\mathbf{1 6}$ by reaction with triflic anhydride. Palladium catalyzed reduction of 16 gave unsaturated ester 17 in $88 \%$ yield. Reaction of triflate 16 with 3 phenylprop-2-yn-1-ol or diethyl phosphonate gave access to products 18 and 19 respectively. 
A. Himbert reaction to form a $[5,5,6]$ ring system

$$
\prod_{0}^{12}
$$

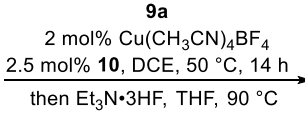

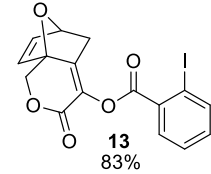

B. Functionalization of the products

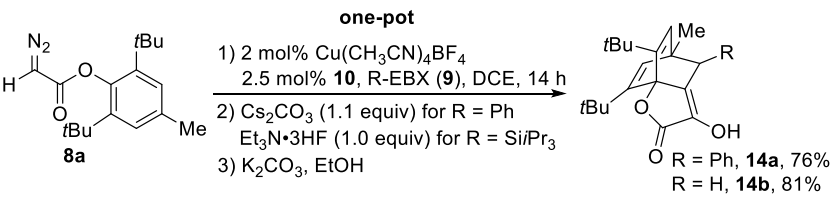

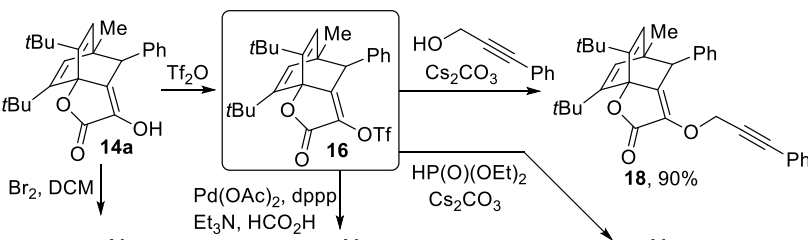

$$
\text { (15,87\% }
$$

Scheme 6. [4+2] Cycloaddition with furan and product derivatization. $\mathrm{Tf}=$ Triflyl.

When considering that bicyclo[2.2.2]octadienes are an important class of ligands for late transition metals, ${ }^{[10]}$ we then attempted the formation of a rhodium complex. The complexation was not successful when using tert-butyl substituted dienes, probably due to excessive steric hindrance. In contrast, dimer 20a was cleanly formed, by just mixing diene $6 \mathrm{~m}$ with $\left[\mathrm{RhCl}\left(\mathrm{C}_{2} \mathrm{H}_{4}\right)_{2}\right]_{2}$ in chloroform (Scheme 7A). X-ray quality crystals of 20 a could be obtained, allowing us to confirm its structure. ${ }^{[37]}$
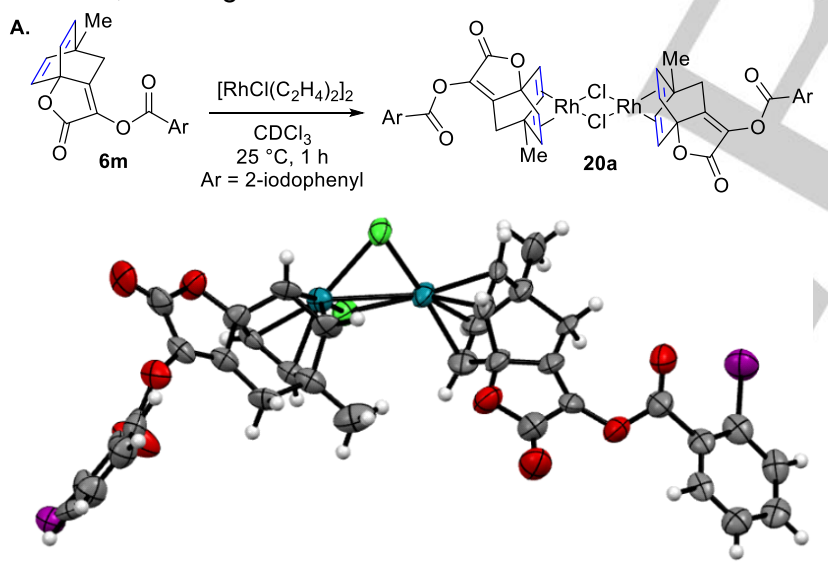

B.

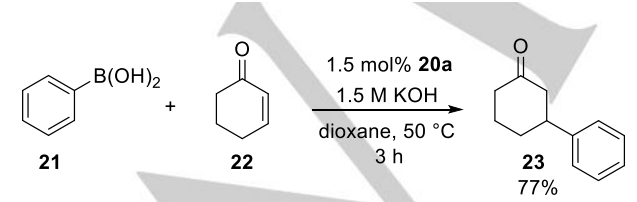

Scheme 7. A. Synthesis and X-ray structure of Rhodium complex 20a. B. Conjugate addition of phenylboronic acid (21) on cyclohexenone (22) with 20a as catalyst.

Complex 20a was a good catalyst for the conjugate addition of phenyl boronic acid (21) to cyclohexenone (22) under standard conditions (Scheme 7B). ${ }^{[10 d]}$

Next, we envisioned an enantioselective transformation. We decided to take advantage of the pseudo-C2 symmetry of compound $6 \mathbf{p}$, making it similar to the successful Hayashi-type ligand 4. Enantiopure (+)-6p was isolated by preparative chiral high performance liquid chromatography (HPLC). We were able to obtain a X-ray crystal structure of the corresponding dimeric complex 20b (Scheme $8 \mathrm{~A})^{[38]}$ and we could compare it with the diene complex 20c reported by Hayashi and co-workers (Scheme 8B). ${ }^{[39]}$ The immediate coordination sphere around the rhodium was not distorted by the lower symmetry of ligand $20 \mathrm{~b}$ : all bonds between the metal and the olefins were of same length, and within error margin also identical to those in complex 20c. ${ }^{[40]}$ In contrast, the ${ }^{13} \mathrm{C}$ and even more the ${ }^{1} \mathrm{H}$ NMR signals on the olefins were clearly separated for complex $\mathbf{2 0 b}$, indicating that this ligand will induce a non-symmetrical electronic environment. From this point of view, it is clearly different from the classical Hayashi dienes.

As a proof of concept for its use in asymmetric catalysis, we then used $(+)-6 p$ as chiral ligand for the rhodium-catalyzed conjugate addition of phenyl boronic acid (21) to cyclohexenone (22) under standard reported conditions (Scheme $8 \mathrm{C}$ )..$^{[10 \mathrm{~d}]}$ The resulting $\beta$-functionalized ketone $\mathbf{2 3}$ was obtained in $\mathbf{7 5 \%}$ yield with $87 \%$ ee. This is promising when considering that the methyl substituent is smaller than the phenyl or benzyl groups used in previous works ${ }^{[10 d]}$ and no attempt was made to optimize the reaction conditions.
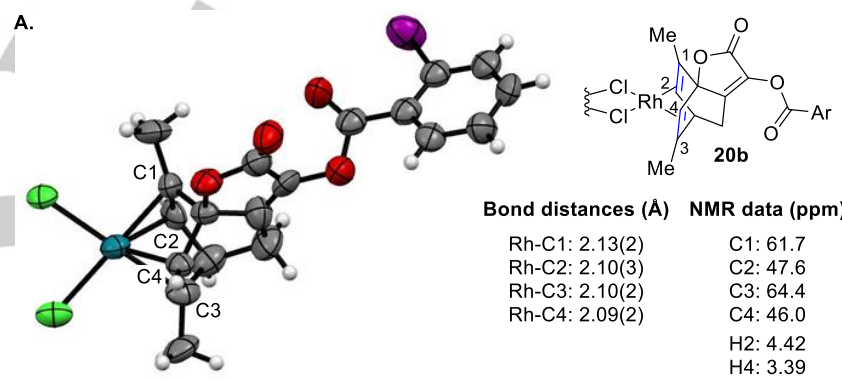

Bond distances (A) NMR data (ppm) Rh-C1: 2.13(2) C1: 61.7 Rh-C2: $2.10(3) \quad$ C1: 61.7 C2: 47.6 C3: 64.4 H2: 4.42

B.
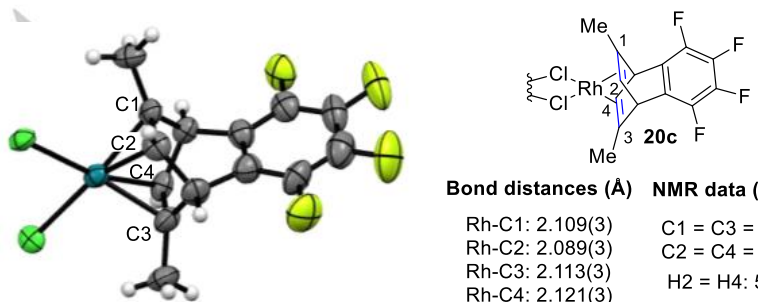

Bond distances (A) NMR data (ppm) Rh-C1: $2.109(3) \quad \mathrm{C} 1=\mathrm{C} 3=66.1$ Rh-C2: $2.089(3) \quad \mathrm{C} 2=\mathrm{C} 4=49.3$ Rh-C3: $2.113(3) \quad \mathrm{H} 2=\mathrm{H} 4: 5.29$

c.
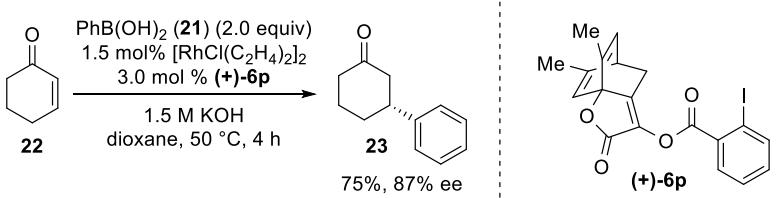

Scheme 8. A. X-ray structure of Rhodium complex 20b with bond lengths and ${ }^{1} \mathrm{H}$ and ${ }^{13} \mathrm{C}$ NMR data. B. X-ray structure of Hayashi's Rhodium complex 20c with bond length and ${ }^{1} \mathrm{H}$ and ${ }^{13} \mathrm{C}$ NMR data. C. Enantioselective conjugate addition with ligand (+)-6p. For simplification, only half of the dimeric complexes $20 \mathbf{b}$ and $20 \mathrm{c}$ is shown.

\section{Conclusion}

In summary, we have developed a highly efficient strategy for the rapid assembly of bicyclo[2.2.2]octadienes starting from simple diazo esters and EBX reagents via a one-pot sequential oxyalkynylation/[4+2] cycloaddition reaction proceeding between 25 and $90{ }^{\circ} \mathrm{C}$. The reaction tolerated a broad range of functional groups on both diazo esters and EBX-reagents. Isolation of the reaction intermediates support a cycloaddition of an in situ formed 
allene with the arene ring. The exceptionally low activation energy for the cycloaddition could be rationalized by counter-intuitive favourable dispersive interactions in the transition state, combined with a weaker effect of the carboxy substituent. The obtained products were transformed into useful building blocks and preliminary results indicated that other polycyclic ring systems could also be accessed using this strategy. Importantly, this methodology allows straightforward access to versatile diene ligands for rhodium catalysis with easy variation of the substituents. Pseudo C2-symmetric ligand $6 p$ could be used in the enantioselective addition of phenyl boronic acid (21) to cyclohexenone (22) with $87 \%$ enantioselectivity. Our future work will focus on catalysis of the cycloaddition step with the goal of developing an enantioselective reaction for a more straightforward access to enantioenriched chiral ligands, and further study the reactivity of this new type of easily accessible "push-pull" allenes.

\section{Acknowledgements}

We thank the European Research Council (ERC; Starting Grant iTools4MC, number 334840) the Swiss National Science Foundation (Grant No. 200020_182798) and the EPFL for financial support. MDW acknowledges Prof. C. Corminboeuf for financial support and the Laboratory for Computational Molecular Design for providing computational resources.

Keywords: [4+2] cycloaddition • alkynes • diene ligands • hypervalent iodine reagents $\bullet$ diazo compounds

[1] J. Rodriguez, D. Bonne, Stereoselective Multiple Bond-Forming Transformations in Organic Synthesis, John Wiley \& Sons, Inc, Hoboken, NJ, USA, 2015.

[2] a) W. Carruthers, Cycloaddition Reactions in Organic Synthesis, WileyVCH Verlag GmbH, Weinheim, FRG, 1990; b) S. Kobayashi, K. A. Jørgensen, Eds., Cycloaddition Reactions in Organic Synthesis, WileyVCH Verlag GmbH, Weinheim, FRG, 2001; c) N. Nishiwaki, Methods and Applications of Cycloaddition Reactions in Organic Syntheses, Wiley, 2014.

[3] a) G. Brieger, J. N. Bennett, Chem. Rev. 1980, 80, 63; b) K. C. Nicolaou, S. A. Snyder, T. Montagnon, G. Vassilikogiannakis, Angew. Chem., Int. Ed. 2002, 41, 1668.

[4] K. Takao, R. Munakata, K. Tadano, Chem. Rev. 2005, 105, 4779.

[5] a) N. Zydziak, B. Yameen, C. Barner-Kowollik, Polym. Chem. 2013, 4, 4072; b) W. Binder, C. Kluger, Curr. Org. Chem. 2006, 10, 1791.

[6] L. C. Bouchez, M. Rusch, M.-H. Larraufie, Curr. Org. Chem. 2016, 20, 2358.

[7] F. Fringuelli, A. Taticchi, The Diels - Alder Reaction: Selected Practical Methods, John Wiley \& Sons, Ltd, Chichester, UK, 2002.

[8] D. W. Thomas, H. Achenbach, K. Biemann, J. Am. Chem. Soc. 1966, 88, 3423.

[9] M. Connock, A. Juarez-Garcia, S. Jowett, E. Frew, Z. Liu, R. Taylor, A. Fry-Smith, E. Day, N. Lintzeris, T. Roberts, A. Burls, R. S. Taylor, Health Technology Assessment 2007, 11, 1-171.

[10] a) C. Fischer, C. Defieber, T. Suzuki, E. M. Carreira, J. Am. Chem. Soc. 2004, 126, 1628; b) C. Defieber, H. Grutzmacher, E. M. Carreira, Angew. Chem., Int. Ed. 2008, 47, 4482; c) N. Tokunaga, Y. Otomaru, K. Okamoto, K. Ueyama, R. Shintani, T. Hayashi, J. Am. Chem. Soc. 2004, 126, 13584; d) Y. Otomaru, K. Okamoto, R. Shintani, T. Hayashi, J. Org. Chem 2005, 70, 2503; e) K. Okamoto, T. Hayashi, V. H. Rawal, Chem. Commun. 2009, 4815.

[11] Selected examples: a) N. Kumar, M. Kiuchi, J. A. Tallarico, S. L. Schreiber, Org. Lett. 2005, 7, 2535; b) M. Dai, D. Sarlah, M. Yu, S. J.
Danishefsky, G. O. Jones, K. N. Houk, J. Am. Chem. Soc. 2007, 129, 645; c) K. Ishihara, M. Fushimi, J. Am. Chem. Soc. 2008, 130, 7532; d) J.-P. Krieger, G. Ricci, D. Lesuisse, C. Meyer, J. Cossy, Angew. Chem., Int. Ed. 2014, 53, 8705; e) K. B. Hamal, R. Bam, W. A. Chalifoux, Synlett 2016, 27, 2161; f) M. Hatano, T. Sakamoto, T. Mizuno, Y. Goto, K. Ishihara, J. Am. Chem. Soc. 2018, 140, 16253.

[12] F. Fringuelli, A. Taticchi, Dienes in the Diels-Alder Reaction, Wiley, 1990.

[13] G. Himbert, L. Henn, Angew. Chem., Int. Ed. 1982, 21, 620.

[14] a) G. Himbert, D. Fink, Tetrahedron Lett. 1985, 26, 4363; b) G. Himbert, D. Fink, M. Stürm, Z. Naturforsch. B; Chem. Sci. 1994, 49, 63.

[15] a) L. Henn, G. Himbert, K. Diehl, M. Kaftory, Chem. Ber. 1986, 119, 1953; b) G. Himbert, K. Diehl, H.-J. Schlindwein, Chem. Ber. 1986, 119, 3227; c) K. Diehl, G. Himbert, Chem. Ber. 1986, 119, 3812; d) H. - J. Schlindwein, K. Diehl, G. Himbert, Chem. Ber. 1989, 122, 577; e) G. Himbert, H.-J. Schlindwein, Z. Naturforsch. B; Chem. Sci. 1992, 47 1785; d) G. Himbert, D. Fink, J. Org. Chem. 1996, 338, 355.

[16] G. Himbert, D. Fink, J. Prakt. Chem. 1994, 336, 654.

[17] a) L. S. Trifonov, A. S. Orahovats, Helv. Chim. Acta 1986, 69, 1585; b) L. S. Trifonov, A. S. Orahovats, Helv. Chim. Acta 1987, 70, 1732; c) L. S. Trifonov, A. S. Orahovats, Helv. Chim. Acta 1987, 70, 262; d) L. S. Trifonov, A. S. Orahovats, Helv. Chim. Acta 1989, 72, 59.

[18] G. Himbert, M. Ruppmich, H. Knöringer, J. Chinese Chem. Soc. 2003 , $50,143$.

[19] L. S. Trifonov, S. D. Simova, A. S. Orahovats, Tetrahedron Lett. 1987, 28, 3391.

[20] Y. Schmidt, J. K. Lam, H. V. Pham, K. N. Houk, C. D. Vanderwal, J. Am. Chem. Soc. 2013, 135, 7339.

[21] G. Cheng, X. He, L. Tian, J. Chen, C. Li, X. Jia, J. Li, J. Org. Chem. 2015 80, 11100.

[22] For the only example of application of the Himbert reaction in total synthesis, see: J. K. Lam, Y. Schmidt, C. D. Vanderwal, Org. Lett. 2012 14,5566 .

[23] X. Mo, B. Chen, G. Zhang, Angew. Chem., Int. Ed. 2020, DOI: 10.1002/anie.202000860.

[24] U. Streit, F. Birbaum, A. Quattropani, C. G. Bochet, J. Org. Chem. 2013 78,6890 .

[25] a) J. Waser, Top. Curr. Chem. 2015, 373, 187; b) Y. Li, D. P. Hari, M. V. Vita, J. Waser, Angew. Chem., Int. Ed. 2016, 55, 4436.

[26] a) D. P. Hari, J. Waser, J. Am. Chem. Soc. 2016, 138, 2190; b) D. P. Hari, J. Waser, J. Am. Chem. Soc. 2017, 139, 8420.

[27] There are no reports of carboxy-substituted allene esters and only rare reports of alkoxy substituted allene esters: a) M. J. Sleeman, G. V Meehan, Tetrahedron Lett. 1989, 30, 3345; b) Y. Nagao, K. Kim, S. Sano, H. Kakegawa, W. S. Lee, H. Shimizu, M. Shiro, N. Katunuma, Tetrahedron Lett. 1996, 37, 861. Simple alkoxy-substituted allenes have been more often used: c) R. Zimmer, H.-U. Reissig, Angew. Chem., Int Ed. 1988, 27, 1518; d) V. M. Schmiedel, H. U. Reissig, Curr. Org. Chem. 2019, 23, 2976.

[28] The structure of $6 r$ was confirmed by $X$-ray analysis (available at the Cambridge Crystallographic Centre, CCDC number 1848760).

[29] The structure of the diastereoisomers was assigned in analogy to the work in ref 20 and 22.

[30] In the case of less reactive substituted alkynes, the presence of the tert butyl groups was necessary for the success of the cycloaddition.

[31] See Supporting Information for details on the optimization of the reaction conditions.

[32] The structure of $6 \mathbf{r}$ was confirmed by X-ray analysis (available at the Cambridge Crystallographic Centre, CCDC number 1848773).

[33] The reaction with alkyl-EBXs required $50{ }^{\circ} \mathrm{C}$ to form allenes, which undergo spontaneous cyclization to give the corresponding Himbert products.

[34] Enantionenriched $\mathbf{5 r}$ was obtained following our previously published methodology, ref. 25b.

[35] F. M. Bickelhaupt, K. N. Houk, Angew. Chem., Int. Ed. 2017, 56, 10070. And references cited therein

[36] The structure of $\mathbf{1 5}$ was confirmed by X-ray analysis (available at the Cambridge Crystallographic Centre, CCDC number 1850113).

[37] Available at the Cambridge Crystallographic Centre, CCDC number 1945514. 
[38] The X-ray structure of $\mathbf{2 0 b}$ is available at the Cambridge Crystallographic Centre, CCDC number 2027174 See Supporting Information for details.

[39] T. Nishimura, Y. Ichikawa, T. Hayashi, N. Onishi, M. Shiotsuki, T. Masuda, Organometallics 2009, 28, 4890.

[40] See Figure S1 in Supporting Information for an overlay of the structures of $20 \mathrm{~b}$ and $20 \mathrm{c}$. 


\section{Entry for the Table of Contents}

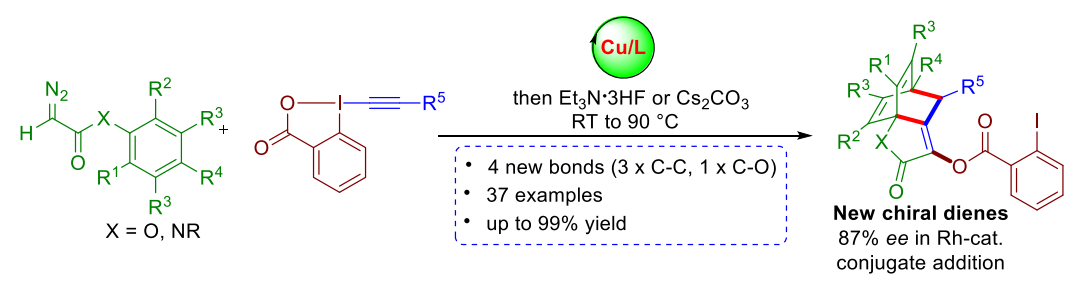

Breaking aromaticity: A highly efficient strategy for the rapid assembly of bicyclooctadienes starting from simple diazo esters and EBX reagents via a one-pot sequential oxyalkynylation/ [4+2] allene-arene cycloaddition reaction at low temperature $\left(23-90{ }^{\circ} \mathrm{C}\right)$ is reported. The obtained products are good chiral ligands for rhodium-catalyzed conjugate addition.

@EPFL_CHEM_Tweet @LcsoLab 


\section{Table of Contents}

244 pages

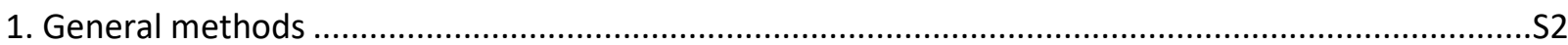

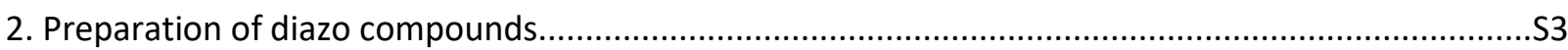

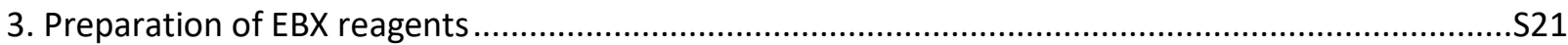

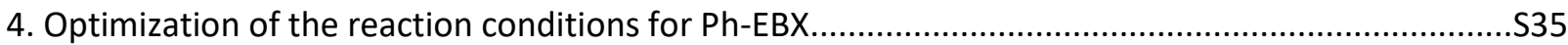

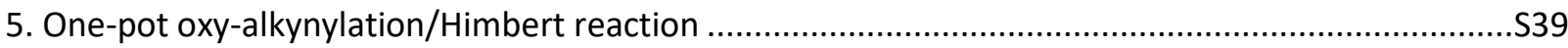

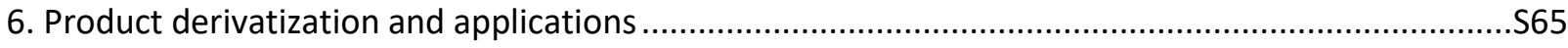

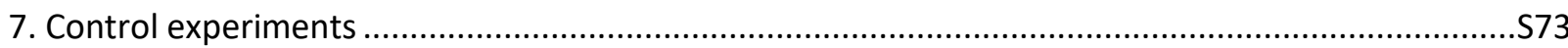

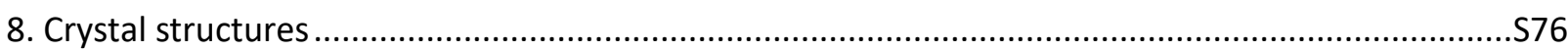

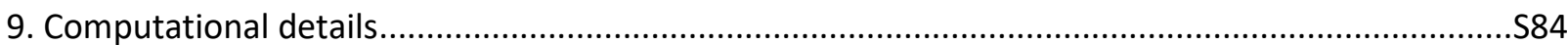

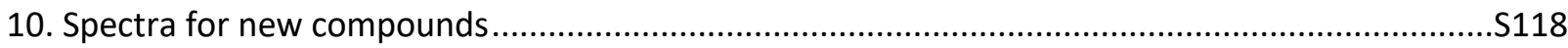




\section{General methods}

All reactions were carried out in oven dried glassware under an atmosphere of nitrogen, unless stated otherwise. For quantitative flash chromatography, technical grade solvents were used. For flash chromatography for analysis, HPLC grade solvents from Sigma-Aldrich were used. $\mathrm{THF}, \mathrm{Et}_{2} \mathrm{O}, \mathrm{CH}_{3} \mathrm{CN}$, toluene, hexane and $\mathrm{CH}_{2} \mathrm{Cl}_{2}$ were dried by passage over activated alumina under nitrogen atmosphere $\left(\mathrm{H}_{2} \mathrm{O}\right.$ content $<10 \mathrm{ppm}$, Karl-Fischer titration). The solvents were degassed by Freeze-Pump-Thaw method when mentioned. All chemicals were purchased from Acros, Aldrich, Fluka, VWR, Aplichem or Merck and used as such unless stated otherwise. Chromatographic purification was performed as flash chromatography using Macherey-Nagel silica 40-63, $60 \AA$, using the solvents indicated as eluent with 0.1-0.5 bar pressure. TLC was performed on Merck silica gel $60 \mathrm{~F}_{254}$ TLC glass plates and visualized with UV light, permanganate stain, CAN stain or Anisaldehyde stain. Melting points were measured on a Büchi B-540 melting point apparatus using open glass capillaries, the data is uncorrected. ${ }^{1} \mathrm{H}-\mathrm{NMR}$ spectra were recorded on a Brucker DPX-400 $400 \mathrm{MHz}$ spectrometer in chloroform-d, DMSO- $d_{6}$ or methanol- $d_{4}$, all signals are reported in ppm with the internal chloroform signal at $7.26 \mathrm{ppm}$, the internal DMSO signal at $2.50 \mathrm{ppm}$ or the internal methanol signal at $3.30 \mathrm{ppm}$ as standard. The data is being reported as $(\mathrm{s}=$ singlet, $\mathrm{d}=$ doublet, $\mathrm{t}=$ triplet, $\mathrm{q}=$ quadruplet, $\mathrm{qi}=$ quintet, $\mathrm{m}=$ multiplet or unresolved, $\mathrm{brs}=$ broad signal, app = apparent, coupling constant(s) in $\mathrm{Hz}$, integration, interpretation). ${ }^{13} \mathrm{C}-\mathrm{NMR}$ spectra were recorded with ${ }^{1} \mathrm{H}$-decoupling on a Brucker DPX-400 $100 \mathrm{MHz}$ spectrometer in chloroform-d, DMSO- $d_{6}$ or methanol- $d_{4}$, all signals are reported in ppm with the internal chloroform signal at $77.0 \mathrm{ppm}$, the internal DMSO signal at $39.5 \mathrm{ppm}$ or the internal methanol signal at $49.0 \mathrm{ppm}$ as standard. Infrared spectra were recorded on a JASCO FT-IR B4100 spectrophotometer with an ATR PRO410-S and a ZnSe prisma and are reported as $\mathrm{cm}^{-1}$ ( $\mathrm{w}=$ weak, $\mathrm{m}=$ medium, $\mathrm{s}=$ strong, $\mathrm{br}=$ broad). High resolution mass spectrometric measurements were performed by the mass spectrometry service of ISIC at the EPFL on a MICROMASS (ESI) Q-TOF Ultima API (Waters) or (APPI) LTQ Orbitrap ELITE ETD (Thermo Fisher). The raw data obtained from the Q-TOF Waters instrument does not take into account the mass of the electron for the ion, the obtained raw data has been therefore corrected by removing the mass of the electron ( $5 \mathrm{mDa}$ ). HPLC measurements were done on a Agilent 1260 Infinity autosampler using a CHIRALPAK IA, IB, IC or ID column from DAICEL Chemical. 


\section{2,6-Di-tert-butyl-4-methylphenyl 2-diazoacetate (8a)}

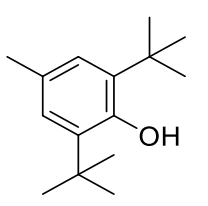

24

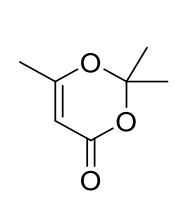

25

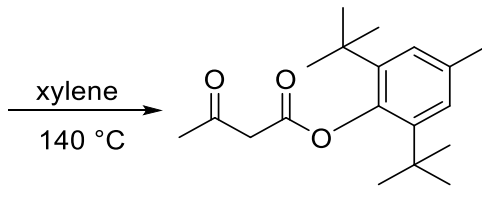

26

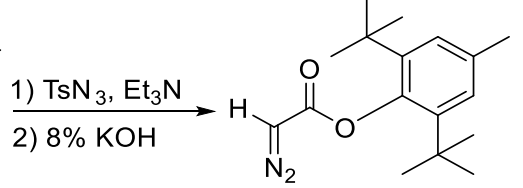

$8 a$

Following a slightly modified procedure, ${ }^{1}$ a mixture of 2,6-di-tert-butyl-4-methylphenol (24) (5.91 g, 25.0 mmol, 1.00 equiv), 2,2,6-trimethyl-4H-1,3-dioxin-4-one (25) (4.43 g, $30.0 \mathrm{mmol}, 1.20$ equiv), and xylene $\left(5 \mathrm{~mL}\right.$ ) was stirred at $140{ }^{\circ} \mathrm{C}$ for $2 \mathrm{~h}$. After cooling to room temperature, the xylene was evaporated and the residue was purified by flash column chromatography using 1:50 EtOAc:pentane as mobile phase to afford 2,6-di-tert-butyl-4-methylphenyl 3-oxobutanoate (26) as a white solid (6.40 g, $21.0 \mathrm{mmol}, 84 \%$ ). Mp: 97-100 ${ }^{\circ} \mathrm{C}$; TLC (EtOAc:pentane, 1:50 v/v): $\mathrm{R}_{\mathrm{f}}=0.34, \mathrm{KMnO}_{4} ;{ }^{1} \mathrm{H} \mathrm{NMR}\left(400 \mathrm{MHz}, \mathrm{CDCl}_{3}\right): \delta 12.16$ (s, $0.55 \mathrm{H}, \mathrm{OH}$ of enol form), $7.13(\mathrm{~s}, 2 \mathrm{H}, \mathrm{ArH}$ of enol and keto form), $5.39-5.24(\mathrm{~m}, 0.55 \mathrm{H}$, vinyl $\mathrm{H}$ of enol form), 3.73 (s, $0.9 \mathrm{H}, \mathrm{CH}_{3} \mathrm{COCH}_{2}$ of keto form), 2.40 (s, 1.35H, $\mathrm{CH}_{3} \mathrm{COCH}_{2}$ of keto form), 2.33 (s, 3H, $\mathrm{ArCH}_{3}$ of enol and keto form), $2.07\left(\mathrm{~s}, 1.65 \mathrm{H}, \mathrm{CH}_{3}\right.$ of enol form), $1.33(\mathrm{~s}, 8.1 \mathrm{H}, t \mathrm{Bu}$ of keto form), $1.32(\mathrm{~s}, 9.9 \mathrm{H}$, tBu of enol form); ${ }^{13} \mathrm{C} \mathrm{NMR} \mathrm{(100} \mathrm{MHz,} \mathrm{CDCl}_{3}$ ), Enol form: $\delta$ 177.4, 173.3, 144.9, 142.2, 134.6, 126.9, 90.4, 35.2, 31.4, 21.5, 21.5; ${ }^{13} \mathrm{C}$ NMR (100 MHz, $\left.\mathrm{CDCl}_{3}\right)$, Keto form: $\delta$ 200.2, 167.7, 145.3, 141.8, 135.0, 127.2, 50.7, 35.2, 31.4, 30.8, 21.5; IR v 2964 (m), 2919 (m), 2880 (w), $2110(\mathrm{w}), 1757(\mathrm{~m}), 1726(\mathrm{~m}), 1633(\mathrm{~s})$, $1408(\mathrm{~m}), 1369(\mathrm{~m}), 1318(\mathrm{~m}), 1219$ (s), 1199 (s), 1143 (s), 1113 (m), 1030 (w), 978 (w), 924 (w); HRMS (ESI) calcd. for $\mathrm{C}_{19} \mathrm{H}_{28} \mathrm{NaO}_{3}{ }^{+}[\mathrm{M}+\mathrm{Na}]^{+} 327.1931$; found 327.1933.

Following a slightly modified procedure, ${ }^{1}$ to a solution of 2,6-di-tert-butyl-4-methylphenyl 3oxobutanoate (26) (1.52 g, $5.00 \mathrm{mmol}, 1.00$ equiv) in acetonitrile $(6 \mathrm{~mL})$ was added triethylamine (660 $\mathrm{mg}, 6.50 \mathrm{mmol}, 1.30$ equiv). The reaction mixture was cooled in an ice bath and a solution of tosyl azide (1.1 g, $5.5 \mathrm{mmol}, 1.1$ equiv) in acetonitrile $(6 \mathrm{~mL})$ was added slowly. The reaction mixture was allowed to warm to room temperature and stirred for $20 \mathrm{~h}$. $8 \%$ aqueous $\mathrm{KOH}$ solution $(25 \mathrm{~mL}$ ) was added and stirred vigorously for $4 \mathrm{~h}$. The reaction mixture was extracted with diethyl ether $(2 \mathrm{X} 30 \mathrm{~mL})$. The combined organic layers were dried over $\mathrm{MgSO}_{4}$, and concentrated under reduced pressure. The crude product was purified by flash column chromatography using 1:30 $\mathrm{Et}_{2} \mathrm{O}$ :pentane as mobile phase to afford 2,6-di-tert-butyl-4-methylphenyl 2-diazoacetate (8a) as a yellow solid (1.20 g, $4.16 \mathrm{mmol}, 83 \%)$. TLC (Et $2 \mathrm{O}:$ pentane, 1:30 v/v): $\mathrm{R}_{\mathrm{f}}=0.36, \mathrm{KMnO}_{4} ;{ }^{1} \mathrm{H}$ NMR $\left(400 \mathrm{MHz}, \mathrm{CDCl}_{3}\right): \delta 7.12(\mathrm{~s}, 2 \mathrm{H}, \mathrm{ArH}), 5.00(\mathrm{~s}$, 
$\left.1 \mathrm{H}, \mathrm{CHN}_{2}\right), 2.32\left(\mathrm{~s}, 3 \mathrm{H}, \mathrm{ArCH}_{3}\right), 1.36(\mathrm{~s}, 18 \mathrm{H}, 2 \times t \mathrm{Bu}) ;{ }^{13} \mathrm{C} \mathrm{NMR}\left(100 \mathrm{MHz}, \mathrm{CDCl}_{3}\right): \delta$ 166.3, 145.1, 142.4, $134.8,127.0,47.3,35.3,31.5,21.5$. The ${ }^{1} \mathrm{H}$ NMR data corresponded to the reported values. ${ }^{2}$

\section{2,6-Di-tert-butyl-4-ethylphenyl 2-diazoacetate (8b)}

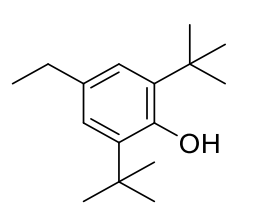

27<smiles>CC1=CC(=O)OC(C)(C)O1</smiles>

25

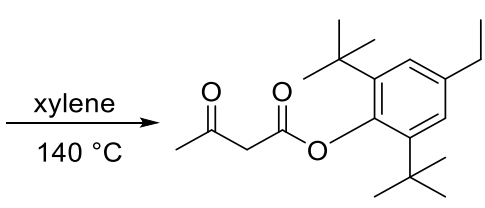

28

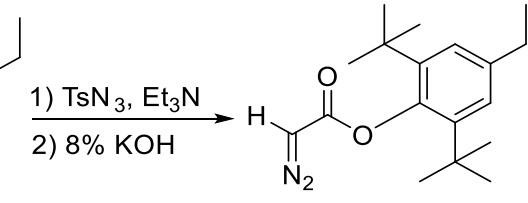

$8 \mathbf{b}$

Following a slightly modified procedure, ${ }^{1}$ a mixture of 2,6-di-tert-butyl-4-ethylphenol (27) (2.34 g, 10.0 mmol, 1.00 equiv), 2,2,6-trimethyl-4H-1,3-dioxin-4-one (25) (1.90 g, $12.0 \mathrm{mmol}, 1.20$ equiv), and xylene $\left(2 \mathrm{~mL}\right.$ ) was stirred at $140{ }^{\circ} \mathrm{C}$ for $2 \mathrm{~h}$. After cooling to room temperature, the xylene was evaporated and the residue was purified by flash column chromatography using 1:50 EtOAc:pentane as mobile phase to afford 2,6-di-tert-butyl-4-ethylphenyl 3-oxobutanoate (28) as a white solid (2.75 g, $8.64 \mathrm{mmol}, 86 \%$ ). Mp: 84.5-86.6 ${ }^{\circ} \mathrm{C} ; \mathrm{TLC}$ (EtOAc:pentane, 1:50 v/v): $\mathrm{R}_{\mathrm{f}}=0.34, \mathrm{KMnO}_{4} ;{ }^{1} \mathrm{H}$ NMR $\left(400 \mathrm{MHz}, \mathrm{CDCl}_{3}\right): \delta 12.15$ (s, $0.54 \mathrm{H}, \mathrm{OH}$ of enol form), $7.15(\mathrm{~s}, 2 \mathrm{H}, \mathrm{ArH}$ of enol and keto form), $5.33-5.32(\mathrm{~m}, 0.54 \mathrm{H}$, vinyl $\mathrm{H}$ of enol form), $3.73\left(\mathrm{~s}, 0.9 \mathrm{H}, \mathrm{CH}_{3} \mathrm{COCH}_{2}\right.$ of keto form), $2.66-2.60$ (m, $2 \mathrm{H}, \mathrm{ArCH}_{2} \mathrm{CH}_{3}$ of enol and keto form), 2.40 (s, $1.3 \mathrm{H}, \mathrm{CH}_{3} \mathrm{COCH}_{2}$ of keto form), 2.07 (s, 1.7H, $\mathrm{CH}_{3}$ of enol form), 1.34 (s, 8.3H, tBu of keto form), 1.33 (s, 9.7H, tBu of enol form), $1.27-1.23$ (m, 3H, $\mathrm{ArCH}_{2} \mathrm{CH}_{3}$ of enol and keto form); ${ }^{13} \mathrm{C} \mathrm{NMR} \mathrm{(100} \mathrm{MHz,}$ $\left.\mathrm{CDCl}_{3}\right)$, Enol form: $\delta 177.4,173.3,145.1,142.2,140.7,125.7,90.5,35.3,31.4,28.8,21.5,15.4 ;{ }^{13} \mathrm{C}$ NMR (100 MHz, CDCl $)$ ), Keto form: $\delta 200.1,167.7,145.4,141.8,141.1,125.9,50.7,35.3,31.5,30.8,28.8,15.4$; IR v 3000 (w), $2965(\mathrm{~m}), 2875(\mathrm{w}), 1758(\mathrm{w}), 1724(\mathrm{w}), 1668(\mathrm{~m}), 1633(\mathrm{~m}), 1425(\mathrm{~m}), 1403(\mathrm{~m}), 1366(\mathrm{w})$, $1318(w), 1266$ (w), 1230 (s), 1227 (s), 1206 (s), 1187 (s), 1146 (s), 982 (w), 933 (w); HRMS (ESI) calcd. for $\mathrm{C}_{20} \mathrm{H}_{30} \mathrm{NaO}_{3}{ }^{+}[\mathrm{M}+\mathrm{Na}]^{+} 341.2087$; found 341.2087 .

Following a slightly modified procedure, ${ }^{1}$ to a solution of 2,6-di-tert-butyl-4-ethylphenyl 3-oxobutanoate (28) (1.59 g, $5.00 \mathrm{mmol}, 1.00$ equiv) in acetonitrile $(6 \mathrm{~mL})$ was added triethylamine $(660 \mathrm{mg}, 6.50 \mathrm{mmol}$, 1.30 equiv). The reaction mixture was cooled in an ice bath and a solution of tosyl azide $(1.1 \mathrm{~g}, 5.5 \mathrm{mmol}$, 1.1 equiv) in acetonitrile $(6 \mathrm{~mL})$ was added slowly. The reaction mixture was allowed to warm to room temperature and stirred for $20 \mathrm{~h} .8 \%$ aqueous $\mathrm{KOH}$ solution $(25 \mathrm{~mL})$ was added and the reaction mixture was stirred vigorously for $4 \mathrm{~h}$. The reaction mixture was extracted with diethyl ether $(2 \mathrm{X} 30 \mathrm{~mL})$. The combined organic layers were dried over $\mathrm{MgSO}_{4}$, and concentrated under reduced pressure. The crude product was purified by flash column chromatography using 1:35 $\mathrm{Et}_{2} \mathrm{O}$ :pentane as mobile phase to afford 2,6-di-tert-butyl-4-ethylphenyl 2-diazoacetate (8b) as a yellow solid (1.10 g, $3.64 \mathrm{mmol}, 73 \%)$. Mp: 126.5-128.0 ${ }^{\circ} \mathrm{C} ; \mathrm{TLC}\left(\mathrm{Et}_{2} \mathrm{O}\right.$ :pentane, 1:35 v/v): $\mathrm{R}_{\mathrm{f}}=0.35, \mathrm{KMnO}_{4} ;{ }^{1} \mathrm{H} \mathrm{NMR}\left(400 \mathrm{MHz}, \mathrm{CDCl}_{3}\right): \delta 7.15(\mathrm{~s}, 2 \mathrm{H}$,

\footnotetext{
${ }^{2}$ M. P. Doyle, V. Bagheri, T. J. Wandless, N. K. Ham, D. A. Brinker, C. T. Eagle, K. L. Loh, J. Am. Chem. Soc. 1990, 112, 1906.
} 
$\operatorname{ArH}), 5.01\left(\mathrm{~s}, 1 \mathrm{H}, \mathrm{CHN}_{2}\right.$ ), $2.63\left(\mathrm{q}, J=7.6 \mathrm{~Hz}, 2 \mathrm{H}, \mathrm{CH}_{2} \mathrm{CH}_{3}\right), 1.37(\mathrm{~s}, 18 \mathrm{H}, 2 \times t \mathrm{Bu}), 1.26(\mathrm{t}, J=7.6 \mathrm{~Hz}, 3 \mathrm{H}$, $\left.\mathrm{CH}_{2} \mathrm{CH}_{3}\right) ;{ }^{13} \mathrm{C} \mathrm{NMR}\left(100 \mathrm{MHz}, \mathrm{CDCl}_{3}\right): \delta 166.8,145.3,142.4,140.8,125.8,47.4,35.4,31.5,28.8,15.4 ; \mathrm{IR}$ v $3105(\mathrm{~m}), 2964(\mathrm{~m}), 2872(\mathrm{w}), 2475(\mathrm{w}), 2114(\mathrm{~s}), 1718(\mathrm{~s}), 1697(\mathrm{~s}), 1597(\mathrm{w}), 1426(\mathrm{~m}), 1364(\mathrm{~m}), 1332$ (s), $1263(\mathrm{w}), 1224(\mathrm{~m}), 1191(\mathrm{~m}), 1181$ (s), $1108(\mathrm{~s}), 928(\mathrm{~m})$; HRMS (ESI) calcd. for $\mathrm{C}_{18} \mathrm{H}_{26} \mathrm{~N}_{2} \mathrm{NaO}_{2}{ }^{+}$ $[\mathrm{M}+\mathrm{Na}]^{+}$325.1886; found 325.1887.

\section{2,4,6-Tri-tert-butylphenyl 2-diazoacetate (8c)}

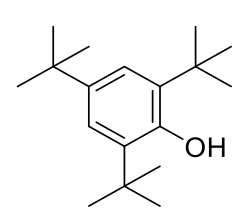

29

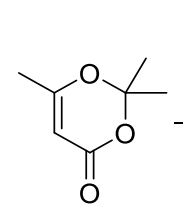

25

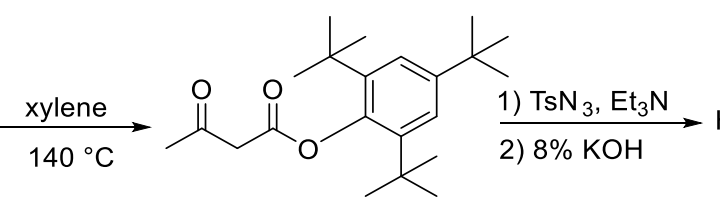

30

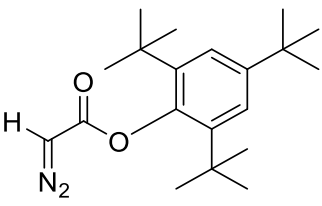

$8 c$

Following a slightly modified procedure, ${ }^{1}$ a mixture of 2,4,6-tri-tert-butylphenol (29) (2.62 g, $10.0 \mathrm{mmol}$, 1.00 equiv), 2,2,6-trimethyl-4H-1,3-dioxin-4-one (25) (1.90 g, $12.0 \mathrm{mmol}, 1.20$ equiv), and xylene ( $2 \mathrm{~mL})$ was stirred at $140{ }^{\circ} \mathrm{C}$ for $2 \mathrm{~h}$. After cooling to room temperature, the xylene was evaporated and the residue was purified by flash column chromatography using 1:50 EtOAc:pentane as mobile phase to afford 2,4,6-tri-tert-butylphenyl 3-oxobutanoate (30) as a white solid (2.65 g, $7.65 \mathrm{mmol}, 76 \%$ ). Mp: 88.9-89.6 ${ }^{\circ} \mathrm{C}$; TLC (EtOAc:pentane, 1:50 v/v): $\mathrm{R}_{\mathrm{f}}=0.4, \mathrm{KMnO}_{4} ;{ }^{1} \mathrm{H} \mathrm{NMR}\left(400 \mathrm{MHz}, \mathrm{CDCl}_{3}\right): \delta 12.14$ (s, $0.54 \mathrm{H}, \mathrm{OH}$ of enol form), $7.35-7.32(\mathrm{~m}, 2 \mathrm{H}, \mathrm{ArH}$ of enol and keto form), 5.33 (s, $0.54 \mathrm{H}$, vinyl $\mathrm{H}$ of enol form), $3.73\left(\mathrm{~s}, 0.92 \mathrm{H}, \mathrm{CH}_{3} \mathrm{COCH}_{2}\right.$ of keto form), 2.40 (s, 1.4H, $\mathrm{CH}_{3}$ of keto form), 2.07 (s, $1.6 \mathrm{H}, \mathrm{CH}_{3}$ of enol form), $1.37-1.28$ (m, 27H, $3 \times t$ Bu of keto and enol form); ${ }^{13} \mathrm{C} \mathrm{NMR} \mathrm{(100} \mathrm{MHz,} \mathrm{CDCl} 3$ ), Enol form: $\delta 177.4$, 173.2, 147.2, 144.7, 141.4, 123.3, 90.5, 35.6, 34.8, 31.6, 31.5, 21.5; $\left.{ }^{13} \mathrm{C} \mathrm{NMR} \mathrm{(100} \mathrm{MHz,} \mathrm{CDCl}_{3}\right)$, Keto form: $\delta 200.2,167.7,147.6,145.1,141.1,123.5,50.8,35.5,31.5,30.7$; IR $\vee 3001$ (w), 2963 (s), $2912(w)$, $2869(w), 2113(w), 1761(m), 1725(m), 1668(m), 1633(m), 1479(w), 1431(m), 1405(m), 1365(m)$, 1226 (s), 1210 (s), 1136 (m), 1108 (s), 978 (w); HRMS (ESI) calcd. for $\mathrm{C}_{22} \mathrm{H}_{34} \mathrm{NaO}_{3}{ }^{+}$[M+Na] ${ }^{+}$369.2400; found 369.2407. Two carbons of keto form were not resolved at $100 \mathrm{MHz}$.

Following a slightly modified procedure, ${ }^{1}$ to a solution of 2,4,6-tri-tert-butylphenyl 3 -oxobutanoate (30) (1.52 g, $5.00 \mathrm{mmol}, 1.00$ equiv) in acetonitrile $(6 \mathrm{~mL})$ was added triethylamine $(660 \mathrm{mg}, 6.50 \mathrm{mmol}, 1.30$ equiv). The reaction mixture was cooled in an ice bath and a solution of tosyl azide (1.1 g, $5.5 \mathrm{mmol}, 1.1$ equiv) in acetonitrile $(6 \mathrm{~mL})$ was added slowly. The reaction mixture was allowed to warm to room temperature and stirred for $20 \mathrm{~h} .8 \%$ aqueous $\mathrm{KOH}$ solution $(25 \mathrm{~mL})$ was added and the reaction mixture was stirred vigorously for $4 \mathrm{~h}$. The reaction mixture was extracted with diethyl ether $(2 \times 30 \mathrm{~mL})$. The combined organic layers were dried over $\mathrm{MgSO}_{4}$, and concentrated under reduced pressure. The crude product was purified by flash column chromatography using 1:30 $\mathrm{Et}_{2} \mathrm{O}$ :pentane as mobile phase to afford 2,4,6-tri-tert-butylphenyl 2-diazoacetate (8c) as a yellow solid (1.40 g, $4.24 \mathrm{mmol}, 85 \%)$. Mp: 130.5-131.5 ${ }^{\circ} \mathrm{C}$; TLC (Et $2 \mathrm{O}$ :pentane, 1:40 v/v): $\mathrm{R}_{\mathrm{f}}=0.4, \mathrm{KMnO}_{4} ;{ }^{1} \mathrm{H} \mathrm{NMR}\left(400 \mathrm{MHz}, \mathrm{CDCl}_{3}\right): \delta 7.33(\mathrm{~s}, 2 \mathrm{H}$, 
$\operatorname{ArH}), 5.01$ (brs, $1 \mathrm{H}, \mathrm{CHN}_{2}$ ), $1.38(\mathrm{~s}, 18 \mathrm{H}, 2 \times t \mathrm{Bu}), 1.32$ (s, 9H, $\left.\left.t \mathrm{Bu}\right) ;{ }^{13} \mathrm{C} \mathrm{NMR} \mathrm{(100} \mathrm{MHz,} \mathrm{CDCl}_{3}\right): \delta$ 166.5, 147.3, 145.0, 141.7, 123.4, 47.4, 35.6, 34.8, 31.6, 31.5; IR v 3101 (w), $2962(\mathrm{~m}), 2910$ (m), $2872(\mathrm{w}), 2252$ (w), $2113(s), 1702(s), 1596(w), 1478(w), 1432(w), 1365(s), 1338(m), 1278(w), 1192(s), 1161(s)$, 1135 (s), 1107 (s), 975 (w); HRMS (ESI) calcd. for $\mathrm{C}_{20} \mathrm{H}_{30} \mathrm{~N}_{2} \mathrm{NaO}_{2}{ }^{+}[\mathrm{M}+\mathrm{Na}]^{+}$353.2199; found 353.2198.

\section{2,6-Di-tert-butyl-4-methoxyphenyl 2-diazoacetate (8d)}

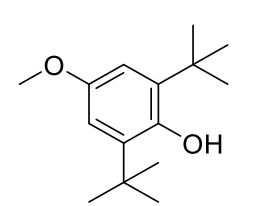

31

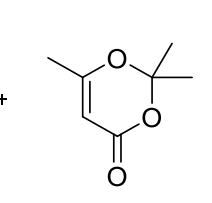

25

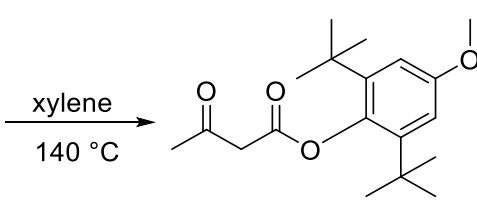

32

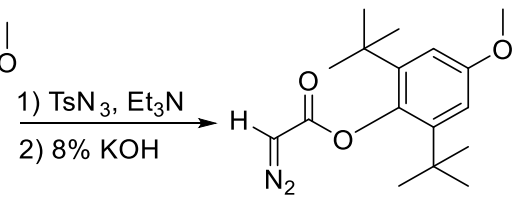

$8 d$

Following a slightly modified procedure, ${ }^{1}$ a mixture of 2,6-di-tert-butyl-4-methoxyphenol (31) (5.91 g, $25.0 \mathrm{mmol}, 1.00$ equiv), 2,2,6-trimethyl-4H-1,3-dioxin-4-one (25) (4.43 g, $30.0 \mathrm{mmol}, 1.20$ equiv), and xylene $(5 \mathrm{~mL})$ was stirred at $140{ }^{\circ} \mathrm{C}$ for $2 \mathrm{~h}$. After cooling to room temperature, the xylene was evaporated and the residue was purified by flash column chromatography using 1:30 EtOAc:pentane as mobile phase to afford 2,6-di-tert-butyl-4-methoxyphenyl 3-oxobutanoate (32) as a white solid (6.64 g, $20.0 \mathrm{mmol}, 80 \%) . \mathrm{Mp}: 67.0-70.5^{\circ} \mathrm{C}$; TLC (EtOAc:pentane, 1:15 v/v): $\mathrm{R}_{\mathrm{f}}=0.46, \mathrm{KMnO}_{4} ;{ }^{1} \mathrm{H}$ NMR (400 MHz, $\left.\mathrm{CDCl}_{3}\right): \delta 12.15(\mathrm{~s}, 0.55 \mathrm{H}, \mathrm{OH}$ of enol form), $6.87(\mathrm{~s}, 2 \mathrm{H}, \mathrm{ArH}$ of enol and keto form), $5.32(\mathrm{~s}, 0.55 \mathrm{H}$, vinyl $\mathrm{H}$ of enol form), 3.80 (s, $3 \mathrm{H}, \mathrm{ArOCH}_{3}$ of enol and keto form), 3.73 (s, $0.9 \mathrm{H}, \mathrm{CH}_{3} \mathrm{COCH}_{2}$ of keto form), 2.40 (s, $1.35 \mathrm{H}, \mathrm{CH}_{3} \mathrm{COCH}_{2}$ of keto form), 2.07 (s, $1.65 \mathrm{H}, \mathrm{CH}_{3}$ of enol form), 1.33 (s, 8.1H, $t \mathrm{Bu}$ of keto form), 1.32 (s, 9.9H, tBu of enol form); ${ }^{13} \mathrm{C}$ NMR (100 MHz, CDCl $)$, Enol form: $\delta 177.4,173.5,156.2,143.6$, $140.7,111.5,90.4,55.2,35.6,31.2,21.5 ;{ }^{13} \mathrm{C} \mathrm{NMR}\left(100 \mathrm{MHz}, \mathrm{CDCl}_{3}\right)$, Keto form: $\delta 200.1,167.9,156.5$, 143.3, 141.1, 111.7, 55.2, 50.6, 35.5, 31.3, 30.8; IR v 2966 (s), 2913 (s), $2118(\mathrm{w}), 1758(\mathrm{~m}), 1724(\mathrm{~m})$, $1634(\mathrm{~s}), 1596(\mathrm{~m}), 1408(\mathrm{~s}), 1310(\mathrm{~m}), 1223(\mathrm{~s}), 1181$ (s), $1143(\mathrm{~s}), 1064(\mathrm{~s}), 979(\mathrm{w}), 922(\mathrm{w}), 861(\mathrm{w})$; HRMS (ESI) calcd. for $\mathrm{C}_{19} \mathrm{H}_{28} \mathrm{NaO}_{4}{ }^{+}[\mathrm{M}+\mathrm{Na}]^{+} 343.1880$; found 343.1884 .

Following a slightly modified procedure, ${ }^{1}$ to a solution of 2,6-di-tert-butyl-4-methoxyphenyl 3oxobutanoate (32) $(1.6 \mathrm{~g}, 5.0 \mathrm{mmol}, 1.0$ equiv) in acetonitrile $(6 \mathrm{~mL})$ was added triethylamine $(660 \mathrm{mg}$, $6.50 \mathrm{mmol}, 1.30$ equiv). The reaction mixture was cooled in an ice bath and a solution of tosyl azide (1.1 $\mathrm{g}, 5.5 \mathrm{mmol}, 1.1$ equiv) in acetonitrile $(6 \mathrm{~mL})$ was added slowly. The reaction mixture was allowed to warm to room temperature and stirred for $20 \mathrm{~h} .8 \%$ aqueous $\mathrm{KOH}$ solution $(25 \mathrm{~mL})$ was added and stirred vigorously for $4 \mathrm{~h}$. The reaction mixture was extracted with diethyl ether $(2 \times 30 \mathrm{~mL})$. The combined organic layers were dried over $\mathrm{MgSO}_{4}$, and concentrated under reduced pressure. The crude product was purified by flash column chromatography using 1:20 EtOAc:pentane as mobile phase to afford 2,6di-tert-butyl-4-methoxyphenyl 2-diazoacetate (8d) as a yellow solid (600 mg, $1.97 \mathrm{mmol}, 40 \%$ ). $\mathrm{Mp}$ (Dec.): $125.3-130.0{ }^{\circ} \mathrm{C}$; TLC (EtOAc:pentane, $\left.1: 15 \mathrm{v} / \mathrm{v}\right): \mathrm{R}_{\mathrm{f}}=0.31, \mathrm{KMnO}_{4} ;{ }^{1} \mathrm{H} \mathrm{NMR}\left(400 \mathrm{MHz}, \mathrm{CDCl}_{3}\right): \delta$ $6.86(\mathrm{~s}, 2 \mathrm{H}, \mathrm{ArH}), 5.01\left(\mathrm{~s}, 1 \mathrm{H}, \mathrm{CHN}_{2}\right), 3.80\left(\mathrm{~s}, 3 \mathrm{H}, \mathrm{ArOCH}_{3}\right), 1.36$ (s, 18H, $\left.2 \times t \mathrm{Bu}\right) ;{ }^{13} \mathrm{C} \mathrm{NMR}(100 \mathrm{MHz}$, 
$\left.\mathrm{CDCl}_{3}\right): \delta$ 166.8, 156.4, 143.9, 141.0, 111.6, 55.2, 47.4, 35.6, 31.4; IR v 3105 (w), 2961 (m), 2114 (s), 1712 (s), $1593(\mathrm{~m}), 1427$ (w), 1365 (s), 1180 (s), 1149 (s), 1103 (w), 1064 (m), 919 (w), 862 (w); HRMS (ESI) calcd. for $\mathrm{C}_{17} \mathrm{H}_{24} \mathrm{~N}_{2} \mathrm{NaO}_{3}{ }^{+}[\mathrm{M}+\mathrm{Na}]^{+}$327.1679; found 327.1679.

\section{4-Bromo-2,6-di-tert-butylphenyl 2-diazoacetate (8e)}

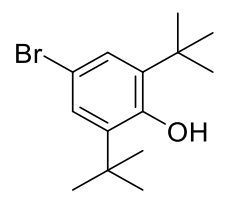

33

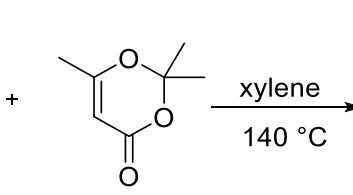

25

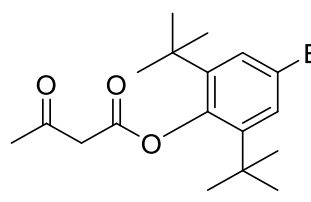

34

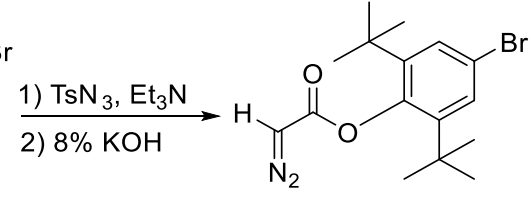

$8 \mathbf{e}$

Following a slightly modified procedure, ${ }^{1}$ a mixture of 4-bromo-2,6-di-tert-butylphenol (33) (2.85 g, 10.0 mmol, 1.00 equiv), 2,2,6-trimethyl-4H-1,3-dioxin-4-one (25) (1.90 g, 12.0 mmol, 1.20 equiv), and xylene $\left(2 \mathrm{~mL}\right.$ ) was stirred at $140{ }^{\circ} \mathrm{C}$ for $2 \mathrm{~h}$. After cooling to room temperature, the xylene was evaporated and the residue was purified by flash column chromatography using 1:50 EtOAc:pentane as mobile phase to afford 4-bromo-2,6-di-tert-butylphenyl 3-oxobutanoate (34) as a pale yellow solid (3.00 g, $8.12 \mathrm{mmol}$, 81\%). Mp: 86.3-91.6 ${ }^{\circ} \mathrm{C}$; TLC (EtOAc:pentane, 1:40 v/v): $\mathrm{R}_{\mathrm{f}}=0.4, \mathrm{KMnO}_{4} ;{ }^{1} \mathrm{H}$ NMR $\left(400 \mathrm{MHz}, \mathrm{CDCl}_{3}\right): \delta$ $11.98(\mathrm{~s}, 0.8 \mathrm{H}, \mathrm{OH}$ of enol form), $7.44-7.41$ (m, $2 \mathrm{H}, \mathrm{ArH}$ of enol and keto form), 5.32 (s, $0.8 \mathrm{H}$, vinyl $\mathrm{H}$ of enol form), $3.73\left(\mathrm{~s}, 0.4 \mathrm{H}, \mathrm{CH}_{3} \mathrm{COCH}_{2}\right.$ of keto form), 2.39 (s, $0.6 \mathrm{H}, \mathrm{CH}_{3} \mathrm{COCH}_{2}$ of keto form), $2.08(\mathrm{~s}, 2.4 \mathrm{H}$, $\mathrm{CH}_{3}$ of enol form), 1.32 (s, 3.6H, tBu of keto form), 1.31 (s, $14.4 \mathrm{H}, t \mathrm{Bu}$ of enol form); ${ }^{13} \mathrm{C}$ NMR (100 MHz, $\left.\mathrm{CDCl}_{3}\right)$, Enol form; $\delta 178.0,172.7,146.5,145.1,129.3,119.5,90.2,35.7,31.2,21.6 ;{ }^{13} \mathrm{C} \mathrm{NMR}(100 \mathrm{MHz}$, $\mathrm{CDCl}_{3}$ ), Keto form: $\delta$ 199.6, 167.2, 146.8, 144.7, 129.6, 119.9, 50.5, 35.6, 31.3, 30.8; IR v 3001 (w), 2965 (m), $2875(w), 1762(w), 1725(w), 1672(m), 1629(m), 1565(w), 1480(w), 1407(m), 1367(m), 1313$ (w), $1261(\mathrm{~m}), 1218(\mathrm{~s}), 1187$ (s), 1148 (s), 1110 (s), 1026 (w), 976 (w), 933 (w); HRMS (ESI) calcd. for $\mathrm{C}_{18} \mathrm{H}_{25} \mathrm{BrNaO}_{3}{ }^{+}[\mathrm{M}+\mathrm{Na}]^{+}$391.0879; found 391.0884 .

Following a slightly modified procedure, ${ }^{1}$ to a solution of 4-bromo-2,6-di-tert-butylphenyl 3oxobutanoate (34) (1.85 g, $5.00 \mathrm{mmol}, 1.00$ equiv) in acetonitrile $(6 \mathrm{~mL})$ was added triethylamine (660 $\mathrm{mg}, 6.50 \mathrm{mmol}, 1.30$ equiv). The reaction mixture was cooled in an ice bath and a solution of tosyl azide (1.1 g, $5.5 \mathrm{mmol}, 1.1$ equiv) in acetonitrile $(6 \mathrm{~mL})$ was added slowly. The reaction mixture was allowed to warm to room temperature and stirred for $20 \mathrm{~h}$. $8 \%$ aqueous $\mathrm{KOH}$ solution $(25 \mathrm{~mL}$ ) was added and the reaction mixture was stirred vigorously for $4 \mathrm{~h}$. The reaction mixture was extracted with diethyl ether $\left(2 \times 30 \mathrm{~mL}\right.$ ). The combined organic layers were dried over $\mathrm{MgSO}_{4}$, and concentrated under reduced pressure. The crude product was purified by flash column chromatography using 1:30 $\mathrm{Et}_{2} \mathrm{O}$ :pentane as mobile phase to afford 4-bromo-2,6-di-tert-butylphenyl 2-diazoacetate (8e) as a yellow solid (0.85 g, 2.4 mmol, 48\%). Mp: $152.5-154.2{ }^{\circ} \mathrm{C}$; $\mathrm{TLC}\left(\mathrm{Et}_{2} \mathrm{O}\right.$ :pentane, 1:30 v/v): $\mathrm{R}_{\mathrm{f}}=0.36, \mathrm{KMnO}_{4} ;{ }^{1} \mathrm{H} \mathrm{NMR}(400 \mathrm{MHz}$, $\mathrm{CDCl}_{3}$ ): $\delta 7.42$ (s, 2H, $\left.\mathrm{ArH}\right), 5.03$ (brs, $1 \mathrm{H}, \mathrm{CHN}_{2}$ ), 1.35 (s, 18H, $\left.\left.2 \times t \mathrm{Bu}\right) ;{ }^{13} \mathrm{C} \mathrm{NMR} \mathrm{(100} \mathrm{MHz,} \mathrm{CDCl}_{3}\right): \delta$ 165.6, 146.7, 145.3, 129.4, 119.7, 47.5, 35.7, 31.3; IR v 3119 (m), 2999 (w), 2967 (m), $2875(w), 2479$ (w), 2291 
(w), $2121(\mathrm{~s}), 1723(\mathrm{~s}), 1700$ (s), $1563(\mathrm{~m}), 1366(\mathrm{~m}), 1338(\mathrm{~s}), 1261(\mathrm{~m}), 1218(\mathrm{~m}), 1184(\mathrm{~s}), 1110(\mathrm{~s})$, 1031 (w), 920 (m); HRMS (ESI) calcd. for $\mathrm{C}_{16} \mathrm{H}_{22} \mathrm{BrN}_{2} \mathrm{O}_{2}{ }^{+}[\mathrm{M}+\mathrm{H}]^{+}$353.0859; found 353.0860 .

\section{2,6-Di-tert-butylphenyl 2-diazoacetate (8f)}

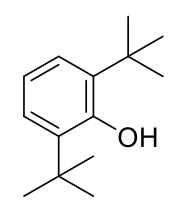

35

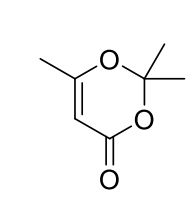

25

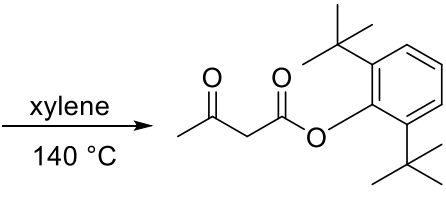

36 $\underset{\text { 1) } \mathrm{TsN}_{3}, \mathrm{Et}_{3} \mathrm{~N}}{\longrightarrow}$

2) $8 \% \mathrm{KOH}$

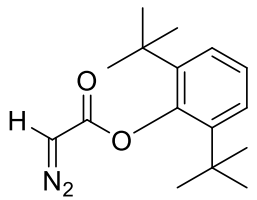

$8 f$

Following a slightly modified procedure,${ }^{1}$ a mixture of 2,6-di-tert-butylphenol (35) (2.06 g, $10.0 \mathrm{mmol}$, 1.00 equiv), 2,2,6-trimethyl-4H-1,3-dioxin-4-one (25) (1.90 g, $12.0 \mathrm{mmol}, 1.20$ equiv), and xylene ( $2 \mathrm{~mL}$ ) was stirred at $140{ }^{\circ} \mathrm{C}$ for $2 \mathrm{~h}$. After cooling to room temperature, the xylene was evaporated and the residue was purified by flash column chromatography using 1:50 EtOAc:pentane as mobile phase to afford 2,6-di-tert-butylphenyl 3-oxobutanoate (36) as a pale yellow solid (2.40 g, $8.26 \mathrm{mmol}, 83 \%$ ). Mp: 61.4-62.0 ${ }^{\circ} \mathrm{C}$; TLC (EtOAc:pentane, 1:50 v/v): $\mathrm{R}_{\mathrm{f}}=0.3, \mathrm{KMnO}_{4} ;{ }^{1} \mathrm{H} \mathrm{NMR}\left(400 \mathrm{MHz}, \mathrm{CDCl}_{3}\right): \delta 12.11$ (s, $0.95 \mathrm{H}, \mathrm{OH}$ of enol form), 7.33 (d, $J=7.9 \mathrm{~Hz}, 2 \mathrm{H}, \mathrm{ArH}$ of enol and keto form), 7.15 (dd, $J=8.3,7.5 \mathrm{~Hz}, 1 \mathrm{H}$, ArH of enol and keto form), $5.34\left(\mathrm{~d}, J=0.8 \mathrm{~Hz}, 0.95 \mathrm{H}\right.$, vinyl $\mathrm{H}$ of enol form), $3.73\left(\mathrm{~s}, 0.1 \mathrm{H}, \mathrm{CH}_{3} \mathrm{COCH}_{2}\right.$ of keto form), $2.40\left(\mathrm{~s}, 0.15 \mathrm{H}, \mathrm{CH}_{3}\right.$ of keto form), $2.08\left(\mathrm{~s}, 2.85 \mathrm{H}, \mathrm{CH}_{3}\right.$ of enol form), $1.35(\mathrm{~s}, 0.9 \mathrm{H}, t \mathrm{Bu}$ of keto form), $1.34\left(\mathrm{~s}, 17.1 \mathrm{H}, t \mathrm{Bu}\right.$ of enol form); ${ }^{13} \mathrm{C} \mathrm{NMR} \mathrm{(100} \mathrm{MHz,} \mathrm{CDCl}_{3}$ ), Enol form: $\delta$ 177.5, 173.1, 147.3, 142.7, 126.2, 125.7, 90.4, 35.4, 31.4, 21.53; IR v 3079 (w), 2962 (w), 2871 (w), 1758 (w), 1724 (w), 1630 $(\mathrm{m}), 1481(\mathrm{w}), 1403(\mathrm{~m}), 1364(\mathrm{~m}), 1317(\mathrm{~m}), 1270(\mathrm{~m}), 1221(\mathrm{~s}), 1183(\mathrm{~s}), 1147(\mathrm{~s}), 1110(\mathrm{~s}), 1024(\mathrm{w})$, $977(\mathrm{~m}), 933(\mathrm{~m})$; HRMS (ESI) calcd. for $\mathrm{C}_{18} \mathrm{H}_{26} \mathrm{NaO}_{3}{ }^{+}[\mathrm{M}+\mathrm{Na}]^{+} 313.1774$; found 313.1776. Keto form carbons were not resolved at $100 \mathrm{MHz}$.

Following a slightly modified procedure, ${ }^{1}$ to a solution of 2,6-di-tert-butylphenyl 3-oxobutanoate (36) (1.45 g, $5.00 \mathrm{mmol}, 1.00$ equiv) in acetonitrile $(6 \mathrm{~mL})$ was added triethylamine (660 mg, $6.50 \mathrm{mmol}, 1.30$ equiv). The reaction mixture was cooled in an ice bath and a solution of tosyl azide $(1.1 \mathrm{~g}, 5.5 \mathrm{mmol}, 1.1$ equiv) in acetonitrile $(6 \mathrm{~mL})$ was added slowly. The reaction mixture was allowed to warm to room temperature and stirred for $20 \mathrm{~h} .8 \%$ aqueous $\mathrm{KOH}$ solution $(25 \mathrm{~mL})$ was added and the reaction mixture was stirred vigorously for $4 \mathrm{~h}$. The reaction mixture was extracted with diethyl ether $(2 \times 30 \mathrm{~mL})$. The combined organic layers were dried over $\mathrm{MgSO}_{4}$, and concentrated under reduced pressure. The crude product was purified by flash column chromatography using 1:30 $\mathrm{Et}_{2} \mathrm{O}$ :pentane as mobile phase to afford 2,6-di-tert-butylphenyl 2-diazoacetate (8f) as a yellow solid (0.96 g, $3.5 \mathrm{mmol}, 70 \%)$. Mp: 88.6$90.7^{\circ} \mathrm{C}$; TLC (Et $2 \mathrm{O}$ :pentane, 1:30 v/v): $\mathrm{R}_{\mathrm{f}}=0.32, \mathrm{KMnO}_{4} ;{ }^{1} \mathrm{H} \mathrm{NMR}\left(400 \mathrm{MHz}, \mathrm{CDCl}_{3}\right): \delta 7.33(\mathrm{~d}, J=7.9 \mathrm{~Hz}$, $2 \mathrm{H}, \operatorname{ArH}), 7.15(\mathrm{dd}, J=8.3,7.5 \mathrm{~Hz}, 1 \mathrm{H}, \mathrm{ArH}), 5.02$ (brs, $\left.1 \mathrm{H}, \mathrm{CHN}_{2}\right), 1.38(\mathrm{~s}, 18 \mathrm{H}, 2 \times t \mathrm{Bu}) ;{ }^{13} \mathrm{C} \mathrm{NMR}(100$ $\left.\mathrm{MHz}, \mathrm{CDCl}_{3}\right):$ : 166.4, 147.5, 143.0, 126.3, 125.8, 47.5, 35.4, 31.5; IR v 3108 (w), 3002 (w), 2962 (w), 2915 (w), $2873(w), 2111(s), 1714(s), 1579(w), 1483(w), 1417(w), 1369(s), 1358(s), 1338(m), 1272(w)$, 
1224 (m), 1185 (s), 1152 (s), 1112 (s); HRMS (ESI) calcd. for $\mathrm{C}_{16} \mathrm{H}_{22} \mathrm{~N}_{2} \mathrm{NaO}_{2}^{+}[\mathrm{M}+\mathrm{Na}]^{+}$297.1573; found 297.1578 .

\section{2,6-Diisopropylphenyl 2-diazoacetate (8g)}<smiles>CC(C)c1cccc(C(C)C)c1O</smiles>

37

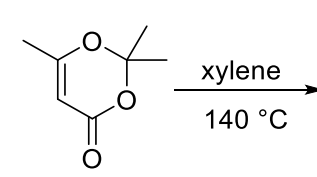

25

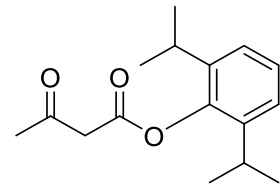

38

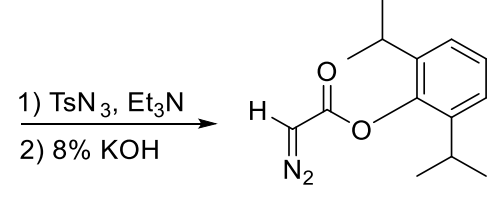

$8 \mathrm{~g}$

Following a slightly modified procedure, ${ }^{1}$ a mixture of 2,6-diisopropylphenol (37) $(4.46 \mathrm{~g}, 25.0 \mathrm{mmol}$, 1.00 equiv), 2,2,6-trimethyl-4H-1,3-dioxin-4-one (25) (4.43 g, $30.0 \mathrm{mmol}, 1.20$ equiv), and xylene (5 mL) was stirred at $140{ }^{\circ} \mathrm{C}$ for $2 \mathrm{~h}$. After cooling to room temperature, the xylene was evaporated and the residue was purified by flash column chromatography using 1:50 EtOAc:pentane as mobile phase to afford 2,6-diisopropylphenyl 3-oxobutanoate (38) as a colorless thick oil (5.00 g, $19.1 \mathrm{mmol}, 76 \%)$. TLC (EtOAc:pentane, 1:20 v/v): $\mathrm{R}_{\mathrm{f}}=0.35, \mathrm{KMnO}_{4} ;{ }^{1} \mathrm{H} \mathrm{NMR}\left(400 \mathrm{MHz}, \mathrm{CDCl}_{3}\right): \delta 12.08(\mathrm{~s}, 0.22 \mathrm{H}, \mathrm{OH}$ of enol form), $7.31-7.24$ (m, 1H, ArH of enol and keto form), $7.24-7.18$ (m, 2H, ArH of enol and keto form), $5.38\left(\mathrm{~s}, 0.2 \mathrm{H}\right.$, vinyl $\mathrm{H}$ of enol form), $3.81\left(\mathrm{~s}, 1.56 \mathrm{H}, \mathrm{CH}_{3} \mathrm{COCH}_{2}\right.$ of keto form), $3.03\left(\mathrm{~m}, 2 \mathrm{H}, 2 \times \mathrm{CH}\left(\mathrm{CH}_{3}\right)_{2}\right.$ of enol and keto form), 2.41 (s, $2.32 \mathrm{H}, \mathrm{CH}_{3} \mathrm{COCH}_{2}$ of keto form), 2.08 (s, $0.6 \mathrm{H}, \mathrm{CH}_{3}$ of enol form), $1.28-1.21$ (m, $\left.\left.12 \mathrm{H}, 2 \times \mathrm{CH}\left(\mathrm{CH}_{3}\right)_{2}\right) ;{ }^{13} \mathrm{C} \mathrm{NMR} \mathrm{(100} \mathrm{MHz}, \mathrm{CDCl}_{3}\right)$, Enol form: $\delta 177.7,171.5,144.5,140.5,126.5,123.9$, 88.7, 23.7, 22.7, 21.4; ${ }^{13} \mathrm{C}$ NMR (100 MHz, $\mathrm{CDCl}_{3}$ ), Keto form: $\delta$ 199.9, 165.7, 145.1, 140.2, 126.8, 124.0, 49.6, 30.4, 27.4, 27.3; IR v 2966 (m), $2876(w), 1760(m), 1723(m), 1634(w), 1447(m), 1410(w), 1360$ $(\mathrm{m}), 1315(\mathrm{~m}), 1222$ (s), 1140 (s), 1102 (m), 1053 (w), 976 (w); HRMS (ESI) calcd. for $\mathrm{C}_{16} \mathrm{H}_{22} \mathrm{NaO}_{3}{ }^{+}[\mathrm{M}+\mathrm{Na}]^{+}$285.1461; found 285.1467.

Following a slightly modified procedure, ${ }^{1}$ to a solution of 2,6-diisopropylphenyl 3-oxobutanoate (38) (1.31 g, $5.00 \mathrm{mmol}, 1.00$ equiv) in acetonitrile $(6 \mathrm{~mL}$ ) was added triethylamine (660 mg, $6.50 \mathrm{mmol}, 1.30$ equiv). The reaction mixture was cooled in an ice bath and a solution of tosyl azide $(1.1 \mathrm{~g}, 5.5 \mathrm{mmol}, 1.1$ equiv) in acetonitrile $(6 \mathrm{~mL})$ was added slowly. The reaction mixture was allowed to warm to room temperature and stirred for 20 h. $8 \%$ aqueous $\mathrm{KOH}$ solution $(25 \mathrm{~mL})$ was added and stirred vigorously for $4 \mathrm{~h}$. The reaction mixture was extracted with diethyl ether $(2 \times 30 \mathrm{~mL})$. The combined organic layers were dried over $\mathrm{MgSO}_{4}$, and concentrated under reduced pressure. The crude product was purified by flash column chromatography using 1:30 $\mathrm{Et}_{2} \mathrm{O}$ :pentane as mobile phase to afford 2,6-diisopropylphenyl 2-diazoacetate $(8 \mathrm{~g})$ as a yellow thick oil $(620 \mathrm{mg}, 2.52 \mathrm{mmol}, 50 \%)$. TLC (Et $\mathrm{t}_{2} \mathrm{O}$ :pentane, 1:30 v/v): $\mathrm{R}_{\mathrm{f}}=$ 0.36, $\mathrm{KMnO}_{4} ;{ }^{1} \mathrm{H}$ NMR $\left(400 \mathrm{MHz}, \mathrm{CDCl}_{3}\right): \delta 7.32-7.25(\mathrm{~m}, 1 \mathrm{H}, \mathrm{ArH}), 7.23-7.20(\mathrm{~m}, 2 \mathrm{H}, \mathrm{ArH}), 5.09$ (br s, $\left.1 \mathrm{H}, \mathrm{CHN}_{2}\right), 3.05$ (sept, $\left.J=6.9 \mathrm{~Hz}, 2 \mathrm{H}, 2 \times \mathrm{CH}\left(\mathrm{CH}_{3}\right)_{2}\right), 1.27\left(\mathrm{~d}, J=6.9 \mathrm{~Hz}, 12 \mathrm{H}, 2 \times \mathrm{CH}\left(\mathrm{CH}_{3}\right)_{2}\right) ;{ }^{13} \mathrm{C} \mathrm{NMR}(100$ 
$\left.\mathrm{MHz}, \mathrm{CDCl}_{3}\right): \delta 165.6,145.1,140.8,126.7,123.9,46.3,27.5,23.4$. The characterization data slightly differ from the reported values. ${ }^{3}$

\section{[1,1':3',1"-Terphenyl]-2'-yl 2-diazoacetate (8h)}

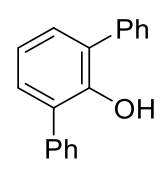

39

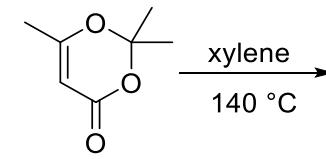

25<smiles>CC(=O)CC(=O)Oc1c(O)cccc1-c1ccccc1</smiles>

40

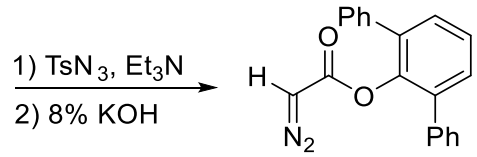

$8 h$

Following a slightly modified procedure, ${ }^{1}$ a mixture of [1,1':3', 1'-terphenyl]-2'-ol (39) (2.46 g, $10.0 \mathrm{mmol}$, 1.00 equiv), 2,2,6-trimethyl-4H-1,3-dioxin-4-one (25) (1.90 g, $12.0 \mathrm{mmol}, 1.20$ equiv), and xylene ( $2 \mathrm{~mL}$ ) was stirred at $140{ }^{\circ} \mathrm{C}$ for $2 \mathrm{~h}$. After cooling to room temperature, the xylene was evaporated and the residue was purified by flash column chromatography using 1:10 EtOAc:pentane as mobile phase to afford [1,1':3',1"-terphenyl]-2'-yl 3-oxobutanoate (40) as a white solid (2.91 g, $8.81 \mathrm{mmol}, 88 \%)$. Mp: 80.2-81.3 ${ }^{\circ} \mathrm{C}$; TLC (EtOAc:pentane, 1:10 v/v): $\mathrm{R}_{\mathrm{f}}=0.38, \mathrm{KMnO}_{4} ;{ }^{1} \mathrm{H}$ NMR (400 MHz, $\mathrm{CDCl}_{3}$ ): $\delta 11.47$ (s, $0.08 \mathrm{H}, \mathrm{OH}$ of enol form), $7.51-7.31(\mathrm{~m}, 13 \mathrm{H}, \mathrm{ArH}$ of enol and keto form), $4.89(\mathrm{~s}, 0.08 \mathrm{H}$, vinyl $\mathrm{H}$ of enol form), $3.12\left(\mathrm{~s}, 1.8 \mathrm{H}, \mathrm{CH}_{3} \mathrm{COCH}_{2}\right.$ of keto form), 1.83 (s, $0.25 \mathrm{H}, \mathrm{CH}_{3}$ of enol form), 1.69 (s, 2.75H, $\mathrm{CH}_{3}$ of keto form); ${ }^{13} \mathrm{C}$ NMR (100 MHz, $\mathrm{CDCl}_{3}$ ), Enol form: $\delta 176.9,170.5,144.4,137.7,136.0,128.9,128.2$, 127.4, 126.5, 88.9, 21.2; $\left.{ }^{13} \mathrm{C} \mathrm{NMR} \mathrm{(100} \mathrm{MHz,} \mathrm{CDCl}_{3}\right)$, Keto form: $\delta$ 199.3, 165.1, 144.7, 137.5, 135.8, 130.1, 129.0, 128.4, 127.7, 126.8, 49.6, 29.0; IR v 3058 (w), 3032 (w), 1957 (w), 1888 (w), 1760 (s), $1721(s)$, $1632(\mathrm{w}), 1601(\mathrm{w}), 1500(\mathrm{w}), 1463(\mathrm{~m}), 1422(\mathrm{~m}), 1361(\mathrm{~m}), 1319(\mathrm{~m}), 1223(\mathrm{~m}), 1175(\mathrm{~s}), 1128(\mathrm{~s}), 1077$ (w), 1022 (w), 975 (w), 921 (m); HRMS (ESI) calcd. for $\mathrm{C}_{22} \mathrm{H}_{18} \mathrm{NaO}_{3}{ }^{+}[\mathrm{M}+\mathrm{Na}]^{+} 353.1148$; found 353.1149. One carbon of enol form was not resolved at $100 \mathrm{MHz}$.

Following a slightly modified procedure, ${ }^{1}$ to a solution of $\left[1,1^{1}: 3^{\prime}, 1^{1}\right.$-terphenyl]-2'-yl 3-oxobutanoate (40) (1.65 g, $5.00 \mathrm{mmol}, 1.00$ equiv) in acetonitrile $(6 \mathrm{~mL}$ ) was added triethylamine (660 mg, $6.50 \mathrm{mmol}, 1.30$ equiv). The reaction mixture was cooled in an ice bath and a solution of tosyl azide $(1.1 \mathrm{~g}, 5.5 \mathrm{mmol}, 1.1$ equiv) in acetonitrile $(6 \mathrm{~mL})$ was added slowly. The reaction mixture was allowed to warm to room temperature and stirred for 20 h. $8 \%$ aqueous $\mathrm{KOH}$ solution $(25 \mathrm{~mL})$ was added and stirred vigorously for $4 \mathrm{~h}$. The reaction mixture was extracted with diethyl ether $(2 \times 30 \mathrm{~mL})$. The combined organic layers were dried over $\mathrm{MgSO}_{4}$, and concentrated under reduced pressure. The crude product was purified by flash column chromatography using 1:10 $\mathrm{Et}_{2} \mathrm{O}$ :pentane as mobile phase to afford [1,1':3',1'-terphenyl]2'-yl 2-diazoacetate (8h) as a yellow solid $(0.71 \mathrm{~g}, 2.3 \mathrm{mmol}, 45 \%)$. Mp: 130.3-135.6 ${ }^{\circ} \mathrm{C}$; TLC $\left(\mathrm{Et}_{2} \mathrm{O}\right.$ :pentane, 1:10 v/v): $\mathrm{R}_{\mathrm{f}}=0.22, \mathrm{KMnO}_{4} ;{ }^{1} \mathrm{H}$ NMR $\left(400 \mathrm{MHz}, \mathrm{CDCl}_{3}\right): \delta 7.52-7.32(\mathrm{~m}, 13 \mathrm{H}, \mathrm{ArH}), 4.54$ $\left(\mathrm{s}, 1 \mathrm{H}, \mathrm{CHN}_{2}\right) ;{ }^{13} \mathrm{C} N M R\left(100 \mathrm{MHz}, \mathrm{CDCl}_{3}\right): \delta 164.3,144.6,137.7,136.2,130.1,129.0,128.3,127.5,126.6$,

${ }^{3}$ D. A. Nicewicz, J. S. Johnson, J. Am. Chem. Soc. 2005, 127, 6170. 
46.4; IR v 3115 (w), $3059(w), 3032(w), 2253(w), 2115(s), 1707$ (s), $1599(w), 1500(w), 1462(w), 1421$ (w), 1367 (s), 1341 (m), 1229 (m), 1181 (s), 1143 (s), 1077 (w), 973 (w), 913 (m); HRMS (ESI) calcd. for $\mathrm{C}_{20} \mathrm{H}_{14} \mathrm{~N}_{2} \mathrm{NaO}_{2}^{+}[\mathrm{M}+\mathrm{Na}]^{+}$337.0947; found 337.0947.

\section{2,6-Dimethylphenyl 2-diazoacetate (8i)}

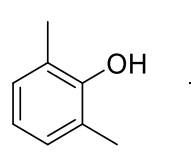

41

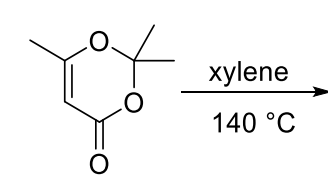

25

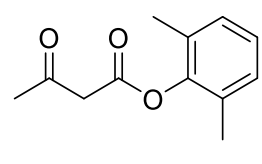

42

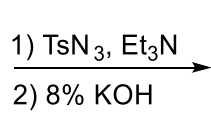

2) $8 \% \mathrm{KOH}$

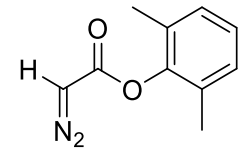

$8 \mathbf{i}$

Following a slightly modified procedure, ${ }^{1}$ a mixture of 2,6-dimethylphenol (41) (1.22 g, $10.0 \mathrm{mmol}, 1.00$ equiv), 2,2,6-trimethyl-4H-1,3-dioxin-4-one (25) (1.90 g, $12.0 \mathrm{mmol}, 1.20$ equiv), and xylene ( $2 \mathrm{~mL}$ ) was stirred at $140^{\circ} \mathrm{C}$ for $2 \mathrm{~h}$. After cooling to room temperature, the xylene was evaporated and the residue was purified by flash column chromatography using 1:30 EtOAc:pentane as mobile phase to afford 2,6dimethylphenyl 3-oxobutanoate (42) as a white solid (1.60 g, $7.76 \mathrm{mmol}, 78 \%)$. Mp: 46.8-47.9 ${ }^{\circ} \mathrm{C}$; TLC (EtOAc:pentane, 1:25 v/v): $\mathrm{R}_{\mathrm{f}}=0.28, \mathrm{KMnO}_{4} ;{ }^{1} \mathrm{H} \mathrm{NMR}\left(400 \mathrm{MHz}, \mathrm{CDCl}_{3}\right): \delta 11.98(\mathrm{~s}, 0.12 \mathrm{H}, \mathrm{OH}$ of enol form), $7.07(\mathrm{~s}, 3 \mathrm{H}, \mathrm{ArH}$ of enol and keto form), $5.31(\mathrm{~m}, 0.12 \mathrm{H}$, vinyl $\mathrm{H}$ of enol form), $3.75(\mathrm{~s}, 1.76 \mathrm{H}$, $\mathrm{CH}_{3} \mathrm{COCH}_{2}$ of keto form), 2.38 (s, 2.64H, $\mathrm{CH}_{3}$ of keto form), 2.19 (s, 5.28H, $2 \times \mathrm{ArCH}_{3}$ of keto form), 2.16 (s, $0.72 \mathrm{H}, 2 \times \mathrm{ArCH}_{3}$ of enol form), $2.06\left(\mathrm{~s}, 0.36 \mathrm{H}, \mathrm{CH}_{3}\right.$ of enol form); ${ }^{13} \mathrm{C} \mathrm{NMR} \mathrm{(100} \mathrm{MHz,} \mathrm{CDCl}_{3}$ ), Enol form: $\delta 177.7,170.7,147.6,130.4,128.5,125.9,88.7,21.4,16.2 ;{ }^{13} \mathrm{C} \mathrm{NMR}\left(100 \mathrm{MHz}, \mathrm{CDCl}_{3}\right)$, Keto form: $\delta$ 199.8, 164.8, 147.8, 130.1, 128.6, 126.2, 49.5, 30.4, 16.4; IR v 2983 (w), 2926 (w), 1761 (s), 1722 (s), $1663(w), 1631(w), 1477(m), 1444(w), 1410(w), 1363(w), 1320(m), 1262(m), 1226(m), 1167(s), 1142$ (s), $1093(w), 1028(w), 983(w), 926(w)$; HRMS (ESI) calcd. for $\mathrm{C}_{12} \mathrm{H}_{14} \mathrm{NaO}_{3}{ }^{+}[\mathrm{M}+\mathrm{Na}]^{+}$229.0835; found 229.0843.

Following a slightly modified procedure, ${ }^{1}$ to a solution of 2,6-dimethylphenyl 3-oxobutanoate (42) (1.03 $\mathrm{g}, 5.00 \mathrm{mmol}, 1.00$ equiv) in acetonitrile $(6 \mathrm{~mL})$ was added triethylamine $(660 \mathrm{mg}, 6.50 \mathrm{mmol}, 1.30$ equiv). The reaction mixture was cooled in an ice bath and a solution of tosyl azide $(1.1 \mathrm{~g}, 5.5 \mathrm{mmol}, 1.1$ equiv) in acetonitrile $(6 \mathrm{~mL})$ was added slowly. The reaction mixture was allowed to warm to room temperature and stirred for $20 \mathrm{~h} .8 \%$ aqueous $\mathrm{KOH}$ solution $(25 \mathrm{~mL})$ was added and the reaction mixture stirred vigorously for $4 \mathrm{~h}$. The reaction mixture was extracted with diethyl ether $(2 \times 30 \mathrm{~mL})$. The combined organic layers were dried over $\mathrm{MgSO}_{4}$, and concentrated under reduced pressure. The crude product was purified by flash column chromatography using 1:20 $\mathrm{Et}_{2} \mathrm{O}$ :pentane as mobile phase to afford 2,6-dimethylphenyl 2-diazoacetate (8i) as a yellow solid (0.50 g, $2.6 \mathrm{mmol}, 53 \%$ ). Mp: 80.5-81.6 ${ }^{\circ} \mathrm{C}$; TLC (Et ${ }_{2} \mathrm{O}$ :pentane, 1:20 v/v): $\mathrm{R}_{\mathrm{f}}=0.25, \mathrm{KMnO}_{4} ;{ }^{1} \mathrm{H} \mathrm{NMR}\left(400 \mathrm{MHz}, \mathrm{CDCl}_{3}\right): \delta 7.07(\mathrm{~s}, 3 \mathrm{H}, \mathrm{ArH}), 5.02$ 
(brs, $1 \mathrm{H}, \mathrm{CHN}_{2}$ ), 2.21 (s, 6H, $\left.2 \times \mathrm{CH}_{3}\right) ;{ }^{13} \mathrm{C} \mathrm{NMR}\left(100 \mathrm{MHz}, \mathrm{CDCl}_{3}\right): \delta 164.5,147.8,130.6,128.5,126.0$, $46.2,16.3$. One carbon was not resolved in the literature reported values. ${ }^{4}$

\section{2-(Tert-butyl)phenyl 2-diazoacetate (8j)}

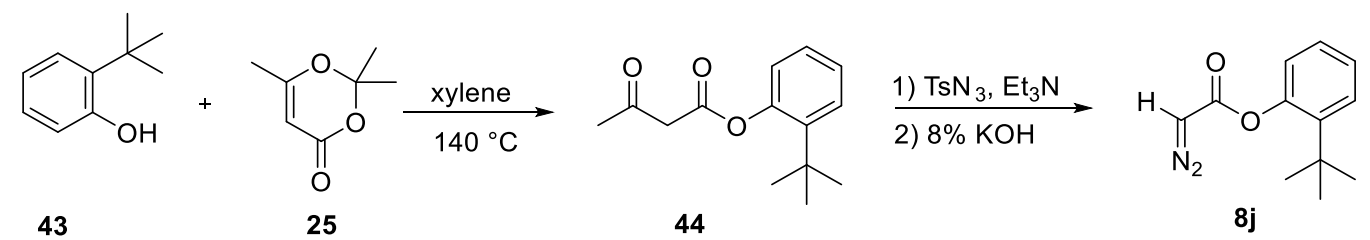

Following a slightly modified procedure, ${ }^{1}$ a mixture of 2-(tert-butyl)phenol (43) (1.50 g, $10.0 \mathrm{mmol}, 1.00$ equiv), 2,2,6-trimethyl-4H-1,3-dioxin-4-one (25) (1.90 g, $12.0 \mathrm{mmol}, 1.20$ equiv), and xylene (2 mL) was stirred at $140^{\circ} \mathrm{C}$ for $2 \mathrm{~h}$. After cooling to room temperature, the xylene was evaporated and the residue was purified by flash column chromatography using 1:30 EtOAc:pentane as mobile phase to afford 2(tert-butyl)phenyl 3-oxobutanoate (44) as a colorless oil (1.70 g, $7.26 \mathrm{mmol}, 73 \%)$. TLC (EtOAc:pentane, $1: 25 \mathrm{v} / \mathrm{v}): \mathrm{R}_{\mathrm{f}}=0.29, \mathrm{KMnO}_{4} ;{ }^{1} \mathrm{H} \mathrm{NMR}\left(400 \mathrm{MHz}, \mathrm{CDCl}_{3}\right): \delta 11.99(\mathrm{~s}, 0.25 \mathrm{H}, \mathrm{OH}$ of enol form), $7.42-7.39$ ( $\mathrm{m}, 1 \mathrm{H}, \mathrm{ArH}$ of enol and keto form), $7.32-7.14(\mathrm{~m}, 2 \mathrm{H}, \mathrm{ArH}$ of enol and keto form), $7.09-7.01$ (m, 1H, ArH of enol and keto form), $5.29\left(\mathrm{~d}, J=0.8 \mathrm{~Hz}, 0.25 \mathrm{H}\right.$, vinyl $\mathrm{H}$ of enol form), $3.73\left(\mathrm{~s}, 1.5 \mathrm{H}, \mathrm{CH}_{3} \mathrm{COCH}_{2}\right.$ of keto form), $2.38\left(\mathrm{~s}, 2.25 \mathrm{H}, \mathrm{CH}_{3}\right.$ of keto form), $2.06\left(\mathrm{~s}, 0.75 \mathrm{H}, \mathrm{CH}_{3}\right.$ of enol form), $1.35(\mathrm{~s}, 9 \mathrm{H}, t \mathrm{Bu}$ of enol and keto form); ${ }^{13} \mathrm{C} \mathrm{NMR} \mathrm{(100} \mathrm{MHz,} \mathrm{CDCl}_{3}$ ), Enol form: $\delta$ 177.7, 171.3, 148.5, 141.3, 127.2, 126.9, 125.8, 123.9, 89.6, 34.5, 30.1, 21.4; Keto form: $\delta$ 199.8, 165.9, 149.0, 140.9, 127.3, 127.0, 126.1, 123.7, 50.3, 34.4, 30.4, 30.2; IR v 3066 (w), 2998 (w), 2962 (w), 2916 (w), 2873 (w), 1763 (s), 1723 (s), 1665 (w), 1629 $(\mathrm{w}), 1578(\mathrm{w}), 1487(\mathrm{~m}), 1443(\mathrm{~m}), 1408(\mathrm{~m}), 1364(\mathrm{~m}), 1316(\mathrm{~m}), 1251(\mathrm{~m}), 1221(\mathrm{~s}), 1188(\mathrm{~s}), 1143(\mathrm{~s})$, $1088(\mathrm{~m}), 1051(\mathrm{w}), 1024(\mathrm{w}), 979(\mathrm{w}), 929(\mathrm{w})$; HRMS (ESI) calcd. for $\mathrm{C}_{14} \mathrm{H}_{18} \mathrm{NaO}_{3}{ }^{+}[\mathrm{M}+\mathrm{Na}]^{+}$257.1148; found 257.1161 .

Following a slightly modified procedure, ${ }^{1}$ to a solution of 2-(tert-butyl)phenyl 3-oxobutanoate (44) (1.17 $\mathrm{g}, 5.00 \mathrm{mmol}, 1.00$ equiv) in acetonitrile $(6 \mathrm{~mL})$ was added triethylamine $(660 \mathrm{mg}, 6.50 \mathrm{mmol}, 1.30$ equiv). The reaction mixture was cooled in an ice bath and a solution of tosyl azide $(1.1 \mathrm{~g}, 5.5 \mathrm{mmol}, 1.1$ equiv) in acetonitrile $(6 \mathrm{~mL})$ was added slowly. The reaction mixture was allowed to warm to room temperature and stirred for $20 \mathrm{~h} .8 \%$ aqueous $\mathrm{KOH}$ solution $(25 \mathrm{~mL})$ was added and the reaction mixture was stirred vigorously for $4 \mathrm{~h}$. The reaction mixture was extracted with diethyl ether $(2 \times 30 \mathrm{~mL})$. The combined organic layers were dried over $\mathrm{MgSO}_{4}$, and concentrated under reduced pressure. The crude product was purified by flash column chromatography using 1:20 $\mathrm{Et}_{2} \mathrm{O}$ :pentane as mobile phase to afford 2-(tert-butyl)phenyl 2-diazoacetate (8j) as a yellow oil $(0.21 \mathrm{~g}, 0.96 \mathrm{mmol}, 20 \%)$. TLC $\left(\mathrm{Et}_{2} \mathrm{O}\right.$ :pentane, 1:20 v/v): $\mathrm{R}_{\mathrm{f}}=0.22, \mathrm{KMnO}_{4} ;{ }^{1} \mathrm{H} \mathrm{NMR}\left(400 \mathrm{MHz}, \mathrm{CDCl}_{3}\right): \delta 7.43(\mathrm{dd}, J=7.8,1.7 \mathrm{~Hz}, 1 \mathrm{H}$,

${ }^{4}$ B. Xu, J. A. Gartman, U. K. Tambar, Tetrahedron 2017, 73, 4150. 
$\operatorname{Ar} H), 7.31-7.14(\mathrm{~m}, 2 \mathrm{H}, \mathrm{ArH}), 7.09(\mathrm{dd}, J=7.8,1.5 \mathrm{~Hz}, 1 \mathrm{H}, \mathrm{Ar} H), 5.03$ (brs, $\left.1 \mathrm{H}, \mathrm{CHN}_{2}\right), 1.39(\mathrm{~s}, 9 \mathrm{H}, t \mathrm{Bu})$; ${ }^{13} \mathrm{C} \mathrm{NMR}\left(100 \mathrm{MHz}, \mathrm{CDCl}_{3}\right): \delta$ 165.0, 148.8, 141.2, 127.2, 126.8, 125.8, 124.1, 47.0, 34.5, 30.2; IR v 3111 (w), $2995(w), 2962(w), 2913(w), 2869(w), 2483(w), 2291(w), 2112(s), 1707(s), 1486(m), 1444(w)$, 1365 (s), 1340 (m), 1286 (w), 1188 (s), 1147 (s), 1084 (s), 1051 (w), 975 (w), 929 (m); HRMS (ESI) calcd. for $\mathrm{C}_{12} \mathrm{H}_{14} \mathrm{~N}_{2} \mathrm{NaO}_{2}^{+}[\mathrm{M}+\mathrm{Na}]^{+} 241.0947$; found 241.0951 .

\section{2-Methylphenyl 2-diazoacetate (8k)}

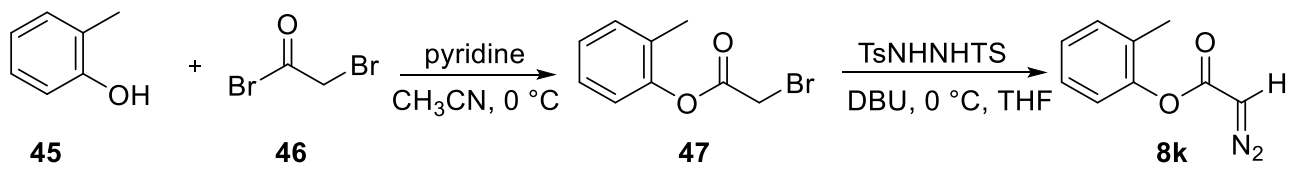

Following a reported procedure, ${ }^{5}$ bromoacetyl bromide (46) $(1.31 \mathrm{~mL}, 15.0 \mathrm{mmol}, 1.50$ equiv) was added to a stirred solution of $o$-cresol (45) $(1.08 \mathrm{~g}, 10.0 \mathrm{mmol}, 1.00$ equiv) and pyridine (1.61 mL, $20.0 \mathrm{mmol}$, 2.00 equiv) in acetonitrile $(50 \mathrm{~mL})$ at $0{ }^{\circ} \mathrm{C}$ over $10 \mathrm{~min}$. The mixture was stirred for further $5 \mathrm{~min}$ at $0{ }^{\circ} \mathrm{C}$ and then quenched with water $(30 \mathrm{~mL})$. The reaction mixture was extracted with $\mathrm{CH}_{2} \mathrm{Cl}_{2}(3 \times 30 \mathrm{~mL})$. The combined organic layers were washed with brine $(50 \mathrm{~mL})$, dried over $\mathrm{MgSO}_{4}$, filtered and concentrated under reduced pressure. The crude product was purified by flash column chromatography using 1:40 EtOAc:pentane as mobile phase to afford $o$-tolyl 2-bromoacetate (47) as a colorless oil $(1.9 \mathrm{~g}, 8.3 \mathrm{mmol}$, 83\%). TLC (EtOAc:pentane, 1:25 v/v): $\mathrm{R}_{\mathrm{f}}=0.42, \mathrm{KMnO}_{4} ;{ }^{1} \mathrm{H} \mathrm{NMR}\left(400 \mathrm{MHz}, \mathrm{CDCl}_{3}\right): \delta 7.35-7.16(\mathrm{~m}, 3 \mathrm{H}$, $\operatorname{ArH}), 7.07(\mathrm{dd}, J=7.7,1.5 \mathrm{~Hz}, 1 \mathrm{H}, \mathrm{ArH}), 4.09\left(\mathrm{~s}, 2 \mathrm{H}, \mathrm{CH}_{2}\right), 2.26\left(\mathrm{~s}, 3 \mathrm{H}, \mathrm{ArCH}_{3}\right) ;{ }^{13} \mathrm{C} \mathrm{NMR}\left(100 \mathrm{MHz}, \mathrm{CDCl}_{3}\right)$ : $\delta$ 165.6, 148.9, 131.3, 130.0, 127.0, 126.5, 121.4, 25.2, 16.0; IR v 3064 (w), 3032 (w), 2961 (w), $2116(w)$, $1758(\mathrm{~s}), 1586(\mathrm{w}), 1492(\mathrm{~m}), 1461(\mathrm{w}), 1423(\mathrm{w}), 1261(\mathrm{~s}), 1221(\mathrm{~m}), 1174(\mathrm{~s}), 1129(\mathrm{~s}), 1112$ (s), 1039 (w), 952 (w); HRMS (ESI) calcd. for $\mathrm{C}_{9} \mathrm{H}_{10} \mathrm{BrO}_{2}{ }^{+}[\mathrm{M}+\mathrm{H}]^{+}$228.9859; found 228.9861 .

Following a reported procedure ${ }^{5} N, N^{\prime}$-Ditosylhydrazine $(2.72 \mathrm{~g}, 8.00 \mathrm{mmol}, 2.00$ equiv $)$ was added to a solution of $o$-tolyl 2-bromoacetate (47) $(0.92 \mathrm{~g}, 4.0 \mathrm{mmol}, 1.0$ equiv) in tetrahydrofuran $(20 \mathrm{~mL})$ and the mixture was cooled to $0{ }^{\circ} \mathrm{C}$. 1,8-Diazabicycloundec-7-ene $(3.0 \mathrm{~mL} 20 \mathrm{mmol}, 5.0$ equiv) was added dropwise over $20 \mathrm{~min}$ at $0{ }^{\circ} \mathrm{C}$. Upon completion of addition of 1,8-diazabicycloundec-7-ene the reaction was quenched by a saturated aqueous $\mathrm{Na}_{2} \mathrm{CO}_{3}$ solution $(30 \mathrm{~mL})$. The reaction mixture was extracted with diethyl ether $(3 \times 20 \mathrm{~mL})$. The combined organic layers were washed with brine $(40 \mathrm{~mL})$, dried over $\mathrm{MgSO}_{4}$, filtered and concentrated under reduced pressure. The crude product was purified by flash column chromatography using 1:20 $\mathrm{Et}_{2} \mathrm{O}$ :pentane as mobile phase to afford $\boldsymbol{o}$-tolyl 2-diazoacetate (8k) as a yellow oil $(0.400 \mathrm{~g}, 2.27 \mathrm{mmol}, 57 \%)$. TLC (Et $2 \mathrm{O}$ :pentane, 1:20 v/v): $\mathrm{R}_{\mathrm{f}}=0.22, \mathrm{KMnO}_{4} ;{ }^{1} \mathrm{H} \mathrm{NMR}(400$ $\left.\mathrm{MHz}, \mathrm{CDCl}_{3}\right): \delta 7.26-7.13(\mathrm{~m}, 3 \mathrm{H}, \mathrm{ArH}), 7.08(\mathrm{dd}, J=7.9,1.5 \mathrm{~Hz}, 1 \mathrm{H}, \mathrm{ArH}), 4.99$ (brs, $1 \mathrm{H}, \mathrm{CHN}_{2}$ ), 2.23 (s, $\left.3 \mathrm{H}, \mathrm{ArCH}_{3}\right) ;{ }^{13} \mathrm{C} \mathrm{NMR}\left(100 \mathrm{MHz}, \mathrm{CDCl}_{3}\right): \delta 165.2,149.0,131.1,130.4,126.9,126.1,122.0,46.5,16.1$; IR v

${ }^{5}$ L. Candish, D. W. Lupton, J. Am. Chem. Soc. 2013, 135, 58-61. 
3115 (w), 2113 (s), 1702 (s), 1590 (w), 1492 (w), 1462 (w), 1366 (s), 1341 (m), 1219 (s), 1172 (s), 1144 (s), 1108 (s), 1041 (w), 975 (w), 928 (w); HRMS (ESI) calcd. for $\mathrm{C}_{9} \mathrm{H}_{8} \mathrm{~N}_{2} \mathrm{NaO}_{2}{ }^{+}[\mathrm{M}+\mathrm{Na}]^{+}$199.0478; found 199.0479.

\section{4-Methoxyphenyl 2-diazoacetate (8I)}

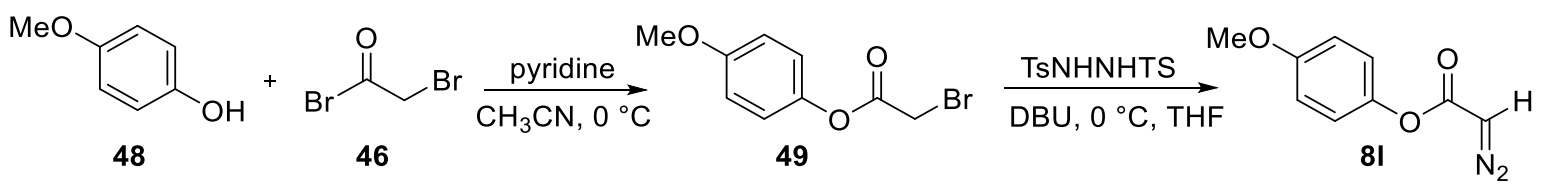

Following a reported procedure, ${ }^{5}$ bromoacetyl bromide (46) $(1.31 \mathrm{ml}, 15.0 \mathrm{mmol}, 1.50$ equiv) was added to a stirred solution of 4-methoxyphenol (48) $(1.24 \mathrm{~g}, 10.0 \mathrm{mmol}, 1.00$ equiv) and pyridine $(1.61 \mathrm{~mL}, 20.0$ mmol, 2.00 equiv) in acetonitrile $(50 \mathrm{~mL})$ at $0{ }^{\circ} \mathrm{C}$ over $10 \mathrm{~min}$. The mixture was stirred for further $5 \mathrm{~min}$ at $0{ }^{\circ} \mathrm{C}$ and then quenched with water $(30 \mathrm{~mL})$. The reaction mixture was extracted with $\mathrm{CH}_{2} \mathrm{Cl}_{2}(3 \times 30$ $\mathrm{mL})$. The combined organic layers were washed with brine $(30 \mathrm{~mL})$, dried over $\mathrm{MgSO}_{4}$, filtered and concentrated under reduced pressure. The crude product was purified by flash column chromatography using 1:20 EtOAc:pentane as mobile phase to afford 4-methoxyphenyl 2-bromoacetate (49) as a colorless oil (2.2 g, $9.0 \mathrm{mmol}, 90 \%)$. TLC (EtOAc:pentane, 1:10 v/v): $\mathrm{R}_{\mathrm{f}}=0.42, \mathrm{KMnO}_{4} ;{ }^{1} \mathrm{H} \mathrm{NMR}(400 \mathrm{MHz}$, $\left.\mathrm{CDCl}_{3}\right): \delta 7.05(\mathrm{~d}, J=9.1 \mathrm{~Hz}, 2 \mathrm{H}, \mathrm{ArH}), 6.90(\mathrm{~d}, J=9.0 \mathrm{~Hz}, 2 \mathrm{H}, \mathrm{ArH}), 4.03\left(\mathrm{~s}, 2 \mathrm{H}, \mathrm{CH}_{2}\right), 3.80\left(\mathrm{~s}, 3 \mathrm{H}, \mathrm{OCH}_{3}\right)$; ${ }^{13} \mathrm{C}$ NMR $\left(100 \mathrm{MHz}, \mathrm{CDCl}_{3}\right): \delta 166.1,157.6,143.9,121.8,114.5,55.6,25.5$. The ${ }^{1} \mathrm{H}$ NMR data corresponded to the reported values. ${ }^{6}$

Following a reported procedure, ${ }^{5} \mathrm{~N}, \mathrm{~N}^{\prime}$-Ditosylhydrazine $(2.72 \mathrm{~g}, 8.00 \mathrm{mmol}, 2.00$ equiv) was added to a solution of 4-methoxyphenyl 2-bromoacetate (49) $(0.98 \mathrm{~g}, 4.0 \mathrm{mmol}, 1.0$ equiv) in tetrahydrofuran (20 $\mathrm{mL}$ ) and the mixture was cooled to $0{ }^{\circ} \mathrm{C} .1,8$-Diazabicycloundec-7-ene $(3.0 \mathrm{~mL}, 20 \mathrm{mmol}, 5.0$ equiv) was added dropwise over $20 \mathrm{~min}$ at $0^{\circ} \mathrm{C}$. Upon completion of the addition of 1,8-diazabicycloundec-7-ene, the reaction was quenched by a saturated aqueous $\mathrm{Na}_{2} \mathrm{CO}_{3}$ solution $(30 \mathrm{~mL})$. The reaction mixture was extracted with diethyl ether $(3 \times 20 \mathrm{~mL})$. The combined organic layers were washed with brine $(40 \mathrm{~mL})$, dried over $\mathrm{MgSO}_{4}$, filtered and concentrated under reduced pressure. The crude product was purified by flash chromatography using 1:10 EtOAc:pentane as mobile phase to afford 4-methoxyphenyl 2diazoacetate (8I) as a yellow solid $(0.600 \mathrm{~g}, 3.12 \mathrm{mmol}, 78 \%)$. TLC (EtOAc:pentane, 1:10 v/v): $R_{f}=0.23$, $\mathrm{KMnO}_{4} ;{ }^{1} \mathrm{H} \mathrm{NMR}\left(400 \mathrm{MHz}, \mathrm{CDCl}_{3}\right): \delta 7.05(\mathrm{~d}, J=9.1 \mathrm{~Hz}, 2 \mathrm{H}, \mathrm{ArH}), 6.89$ (d, J = $\left.9.0 \mathrm{~Hz}, 2 \mathrm{H}, \mathrm{ArH}\right), 4.95$ (brs, $1 \mathrm{H}, \mathrm{CHN}_{2}$ ), 3.80 (s, 3H, OCH $\left.) ;{ }^{13} \mathrm{C} \mathrm{NMR} \mathrm{(100} \mathrm{MHz,} \mathrm{CDCl}\right): \delta 165.8,157.2,143.9,122.4,114.4,55.5,46.6$. The ${ }^{1} \mathrm{H}$ NMR data corresponded to the reported values. ${ }^{5}$

\footnotetext{
${ }^{6}$ T. Mohamad-Ali, S. Stéphane, C. Anne-Caroline, Y. Cédric, C. Jean-Louis, G. Didier, M. Fabrice, F. Jean-Pierre, N. Markus, T. Théophile, et al., Chem. Eur. J. 2014, 20, 5054.
} 
p-Tolyl 2-diazoacetate (8m)

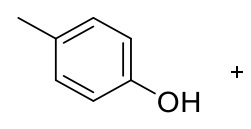

50

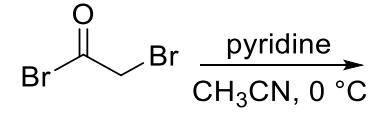

46<smiles>Cc1ccc(OC(=O)CBr)cc1</smiles>

51

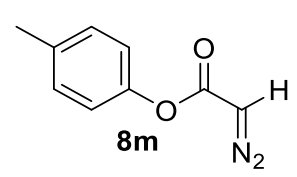

Following a reported procedure, ${ }^{5}$ bromoacetyl bromide (46) $(1.31 \mathrm{~mL}, 15.0 \mathrm{mmol}, 1.50$ equiv) was added to a stirred solution of $p$-cresol (50) (1.08 g, $10.0 \mathrm{mmol}, 1.00$ equiv) and pyridine (1.61 mL, $20.0 \mathrm{mmol}$, 2.00 equiv) in acetonitrile $(50 \mathrm{~mL})$ at $0{ }^{\circ} \mathrm{C}$ over 10 minutes. The mixture was stirred for further 5 minutes at $0{ }^{\circ} \mathrm{C}$ and then quenched with water $(30 \mathrm{~mL})$. The reaction mixture was extracted with dichloromethane $(3 \times 30 \mathrm{~mL})$. The combined organic layers were washed with brine, dried over $\mathrm{MgSO}_{4}$, filtered and concentrated under reduced pressure. The crude product was purified by column chromatography using 1:20 EtOAc:pentane as mobile phase to afford p-tolyl 2-bromoacetate (51) as a colorless oil (2.1 g, $9.2 \mathrm{mmol}, 92 \%)$. TLC (EtOAc:pentane, 1:30 v/v): $\mathrm{R}_{\mathrm{f}}=0.52 ; \mathrm{KMnO}_{4} ;{ }^{1} \mathrm{H} \mathrm{NMR}(400 \mathrm{MHz}$, $\left.\mathrm{CDCl}_{3}\right): \delta 7.23-7.15(\mathrm{~m}, 2 \mathrm{H}, \mathrm{ArH}), 7.05-6.95(\mathrm{~m}, 2 \mathrm{H}, \mathrm{ArH}), 4.04\left(\mathrm{~s}, 2 \mathrm{H}, \mathrm{CH}_{2}\right), 2.35\left(\mathrm{~s}, 3 \mathrm{H}, \mathrm{CH}_{3}\right) ;{ }^{13} \mathrm{C}$ NMR $\left(100 \mathrm{MHz}, \mathrm{CDCl}_{3}\right): \delta 166.2,148.4,136.2,130.2,120.9,25.7,21.0$. The ${ }^{1} \mathrm{H}$ NMR data corresponded to the reported values. ${ }^{7}$

Following a reported procedure $,{ }^{5} \mathrm{~N}, \mathrm{~N}^{\prime}$-Ditosylhydrazine $(3.40 \mathrm{~g}, 10.0 \mathrm{mmol}, 2.00$ equiv) was added to a solution of $p$-tolyl 2-bromoacetate (51) $(1.15 \mathrm{~g}, 5.00 \mathrm{mmol}, 1.00$ equiv) in tetrahydrofuran $(20 \mathrm{~mL})$ and the mixture was cooled to $0{ }^{\circ} \mathrm{C}$. 1,8-Diazabicycloundec-7-ene $(3.8 \mathrm{~mL}, 25 \mathrm{mmol}, 5.0$ equiv) was added dropwise over 20 minutes at $0{ }^{\circ} \mathrm{C}$. The reaction was stirred $2 \mathrm{~h}$ at $0{ }^{\circ} \mathrm{C}$ before being quenched by a saturated aqueous $\mathrm{Na}_{2} \mathrm{CO}_{3}$ solution $(30 \mathrm{~mL})$. The reaction mixture was extracted with diethyl ether $(3 \mathrm{x}$ $20 \mathrm{~mL}$ ). The combined organic layers were washed with brine, dried over $\mathrm{MgSO}_{4}$, filtered and concentrated under reduced pressure. The crude product was purified by column chromatography using 1:20 EtOAc:pentane as mobile phase to afford $p$-tolyl 2-diazoacetate $(8 \mathrm{~m})$ as a yellow oil $(0.450 \mathrm{~g}, 2.55$

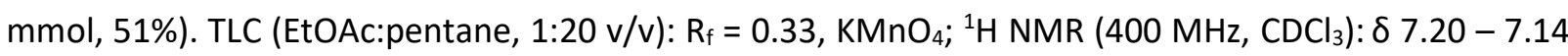
$(\mathrm{m}, 2 \mathrm{H}, \mathrm{ArH}), 7.03-6.98(\mathrm{~m}, 2 \mathrm{H}, \mathrm{ArH}), 4.95\left(\mathrm{br} \mathrm{s}, 1 \mathrm{H}, \mathrm{CHN}_{2}\right), 2.34\left(\mathrm{~s}, 3 \mathrm{H}, \mathrm{CH}_{3}\right) ;{ }^{13} \mathrm{C} \mathrm{NMR}\left(100 \mathrm{MHz}, \mathrm{CDCl}_{3}\right)$ : $\delta$ 148.4, 135.7, 130.1, 121.5, 46.9, 21.0; IR v 3115 (w), 2112 (s), 1699 (s), 1508 (m), 1364 (s), 1342 (s), $1193(\mathrm{~s}), 1167(\mathrm{~s}), 1143(\mathrm{~s}), 923(\mathrm{~m}), 831(\mathrm{~m}), 728(\mathrm{~m})$; HRMS (ESI) calcd. for $\mathrm{C}_{9} \mathrm{H}_{9} \mathrm{~N}_{2} \mathrm{O}_{2}{ }^{+}[\mathrm{M}+\mathrm{H}]^{+}$177.0659; found 177.0656 . One carbon was not resolved at $100 \mathrm{MHz}$.

\footnotetext{
${ }^{7}$ G. Himbert, D. Fink, K. Diehl, Chem. Ber. 1988, 121, 431.
} 
Phenyl 2-diazoacetate (8n)

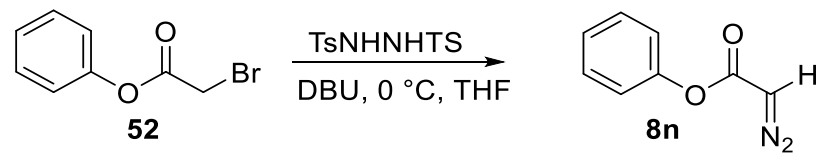

Following a reported procedure ${ }^{5} \mathrm{~N}, \mathrm{~N}^{\prime}$-Ditosylhydrazine $(3.40 \mathrm{~g}, 10.0 \mathrm{mmol}, 2.00$ equiv) was added to a solution of phenyl 2-bromoacetate (52) $(1.07 \mathrm{~g}, 5.00 \mathrm{mmol}, 1.00$ equiv) in tetrahydrofuran $(20 \mathrm{~mL})$ and the mixture was cooled to $0{ }^{\circ} \mathrm{C}$. 1,8-Diazabicycloundec-7-ene $(3.8 \mathrm{~mL}, 25 \mathrm{mmol}, 5.0$ equiv) was added dropwise over 20 minutes at $0{ }^{\circ} \mathrm{C}$. The reaction was stirred $2 \mathrm{~h}$ at $0{ }^{\circ} \mathrm{C}$ before being quenched by a saturated aqueous $\mathrm{Na}_{2} \mathrm{CO}_{3}$ solution $(30 \mathrm{~mL})$. The reaction mixture was extracted with diethyl ether $(3 \mathrm{x}$ $20 \mathrm{~mL}$ ). The combined organic layers were washed with brine, dried over $\mathrm{MgSO}_{4}$, filtered and concentrated under reduced pressure. The crude product was purified by column chromatography using 1:15 EtOAc:pentane as mobile phase to afford phenyl 2-diazoacetate $(\mathbf{8 n})$ as a yellow oil $(0.460 \mathrm{~g}, 2.84$ mmol, 57\%). TLC (EtOAc:pentane, 1:20 v/v): $\mathrm{R}_{\mathrm{f}}=0.30, \mathrm{KMnO}_{4} ;{ }^{1} \mathrm{H} \mathrm{NMR}\left(400 \mathrm{MHz}, \mathrm{CDCl}_{3}\right): \delta 7.40-7.31$ $(\mathrm{m}, 2 \mathrm{H}, \mathrm{ArH}), 7.24-7.18(\mathrm{~m}, 1 \mathrm{H}, \operatorname{Ar} H), 7.08(\mathrm{~m}, 2 \mathrm{H}, \mathrm{ArH}), 4.87\left(\mathrm{br} \mathrm{s}, 1 \mathrm{H}, \mathrm{CHN}_{2}\right)$. The ${ }^{1} \mathrm{H}$ NMR data corresponded to the reported values. ${ }^{8}$

\section{3,5-Dimethylphenyl 2-diazoacetate (80)}

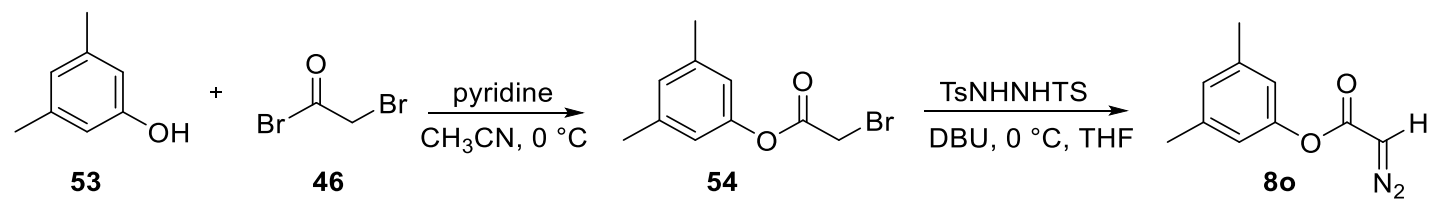

Following a reported procedure, ${ }^{5}$ bromoacetyl bromide $(46)(1.31 \mathrm{~mL}, 15.0 \mathrm{mmol}, 1.50$ equiv) was added to a stirred solution of 3,5-dimethylphenol (53) $(1.22 \mathrm{~g}, 10.0 \mathrm{mmol}, 1.00$ equiv) and pyridine (1.61 $\mathrm{mL}$, $20.0 \mathrm{mmol}, 2.00$ equiv) in acetonitrile $(50 \mathrm{~mL})$ at $0{ }^{\circ} \mathrm{C}$ over 10 minutes. The mixture was stirred for further 5 minutes at $0{ }^{\circ} \mathrm{C}$ and then quenched with water $(30 \mathrm{~mL})$. The reaction mixture was extracted with dichloromethane $(3 \times 30 \mathrm{~mL})$. The combined organic layers were washed with brine, dried over $\mathrm{MgSO}_{4}$, filtered and concentrated under reduced pressure. The crude product was purified by column chromatography using 1:20 EtOAc:pentane as mobile phase to afford 3,5-dimethylphenyl 2bromoacetate (54) as a colorless oil $(2.0 \mathrm{~g}, 8.3 \mathrm{mmol}, 83 \%)$. TLC (EtOAc:pentane, 1:30 v/v): $\mathrm{R}_{\mathrm{f}}=0.57$, $\mathrm{KMnO}_{4} ;{ }^{1} \mathrm{H} \mathrm{NMR}\left(400 \mathrm{MHz}, \mathrm{CDCl}_{3}\right): \delta 6.90(\mathrm{tt}, J=1.6,0.8 \mathrm{~Hz}, 1 \mathrm{H}, \mathrm{ArH}), 6.74(\mathrm{dt}, J=1.5,0.7 \mathrm{~Hz}, 2 \mathrm{H}, \mathrm{ArH})$, $4.03\left(\mathrm{~s}, 2 \mathrm{H}, \mathrm{CH}_{2}\right), 2.32\left(\mathrm{~m}, 6 \mathrm{H}, 2 \times \mathrm{CH}_{3}\right) ;{ }^{13} \mathrm{C} \mathrm{NMR}\left(100 \mathrm{MHz}, \mathrm{CDCl}_{3}\right): \delta 166.2,150.4,139.6,128.2,118.7$, 25.7, 21.4. The ${ }^{1} H$ NMR data corresponded to the reported values. ${ }^{7}$

Following a reported procedure $,{ }^{5} N, N^{\prime}$-Ditosylhydrazine $(3.40 \mathrm{~g}, 10.0 \mathrm{mmol}, 2.00$ equiv) was added to a solution of 3,5-dimethylphenyl 2-bromoacetate (54) (1.21 g, $5.00 \mathrm{mmol}, 1.00$ equiv) in tetrahydrofuran

\footnotetext{
${ }^{8}$ T. Torna, J. Shimokawa, T. Fukuyama, Org. Lett. 2007, 9, 3195.
} 
$\left(20 \mathrm{~mL}\right.$ ) and the mixture was cooled to $0{ }^{\circ} \mathrm{C}$. 1,8-Diazabicycloundec-7-ene ( $3.8 \mathrm{~mL}, 25 \mathrm{mmol}, 5.0$ equiv) was added dropwise over 20 minutes at $0{ }^{\circ} \mathrm{C}$. The reaction was stirred $2 \mathrm{~h}$ at $0{ }^{\circ} \mathrm{C}$ before being quenched by a saturated aqueous $\mathrm{Na}_{2} \mathrm{CO}_{3}$ solution $(30 \mathrm{~mL})$. The reaction mixture was extracted with diethyl ether $\left(3 \times 20 \mathrm{~mL}\right.$ ). The combined organic layers were washed with brine, dried over $\mathrm{MgSO}_{4}$, filtered and concentrated under reduced pressure. The crude product was purified by column chromatography using 1:20 EtOAc:pentane as mobile phase to afford 3,5-dimethylphenyl 2-diazoacetate (80) as a yellow oil (0.480 g, $2.52 \mathrm{mmol}, 51 \%)$. TLC (EtOAc:pentane, 1:20 v/v): $\mathrm{R}_{\mathrm{f}}=0.38, \mathrm{KMnO}_{4} ;{ }^{1} \mathrm{H} \mathrm{NMR}\left(400 \mathrm{MHz}, \mathrm{CDCl}_{3}\right)$ : $\delta 6.87(\mathrm{tt}, J=1.6,0.8 \mathrm{~Hz}, 1 \mathrm{H}, \operatorname{ArH}), 6.75(\mathrm{dt}, J=1.5,0.8 \mathrm{~Hz}, 2 \mathrm{H}, \operatorname{ArH}), 4.94\left(\mathrm{br} \mathrm{s}, 1 \mathrm{H}, \mathrm{CHN} \mathrm{N}_{2}\right), 2.32(\mathrm{~d}, J=0.8$ $\left.\mathrm{Hz}, 6 \mathrm{H}, 2 \times \mathrm{CH}_{3}\right) ;{ }^{13} \mathrm{CNMR}\left(100 \mathrm{MHz}, \mathrm{CDCl}_{3}\right): \delta 174.9,150.5,139.4,127.8,119.4,46.9,21.4 ; \mathrm{IR} v 3109(\mathrm{w})$, $2922(\mathrm{w}), 2112(\mathrm{~s}), 1701(\mathrm{~s}), 1618(\mathrm{~m}), 1364(\mathrm{~s}), 1342(\mathrm{~m}), 1292(\mathrm{~m}), 1219(\mathrm{~s}), 1161(\mathrm{~s}), 1143(\mathrm{~s}), 849(\mathrm{~m})$, 726 (m); HRMS (ESI) calcd. for $\mathrm{C}_{10} \mathrm{H}_{11} \mathrm{~N}_{2} \mathrm{O}_{2}{ }^{+}[\mathrm{M}+\mathrm{H}]^{+}$191.0815; found 191.0812 .

\section{2,5-dimethylphenyl 2-diazoacetate (8p)}

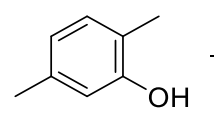

55

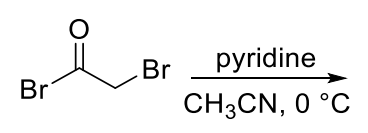

46

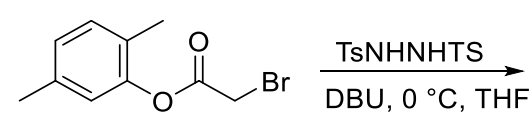

56

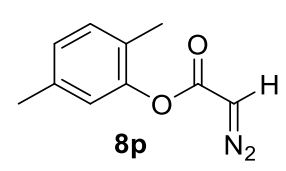

$8 p$

Following a reported procedure, ${ }^{5}$ bromoacetyl bromide (46) $(1.31 \mathrm{~mL}, 15.0 \mathrm{mmol}, 1.50$ equiv) was added to a stirred solution of 2,5-dimethylphenol (55) $(1.22 \mathrm{~g}, 10.0 \mathrm{mmol}, 1.00$ equiv) and pyridine (1.61 mL, $20.0 \mathrm{mmol}, 2.00$ equiv) in acetonitrile $(50 \mathrm{~mL})$ at $0{ }^{\circ} \mathrm{C}$ over 10 minutes. The mixture was stirred for further 5 minutes at $0{ }^{\circ} \mathrm{C}$ and then quenched with water $(30 \mathrm{~mL})$. The reaction mixture was extracted with dichloromethane $(3 \times 30 \mathrm{~mL})$. The combined organic layers were washed with brine, dried over $\mathrm{MgSO}_{4}$, filtered and concentrated under reduced pressure. The crude product was purified by column chromatography using 1:20 EtOAc:pentane as mobile phase to afford 2,5-dimethylphenyl 2bromoacetate (56) as a colorless oil (1.9 g, $8.3 \mathrm{mmol}, 79 \%)$. TLC (EtOAc:pentane, 1:30 v/v): $R_{f}=0.62$, $\mathrm{KMnO}_{4} ;{ }^{1} \mathrm{H} \mathrm{NMR}\left(400 \mathrm{MHz}, \mathrm{CDCl}_{3}\right): \delta 7.12(\mathrm{~d}, J=7.7 \mathrm{~Hz}, 1 \mathrm{H}, \mathrm{ArH}), 7.01-6.95(\mathrm{~m}, 1 \mathrm{H}, \mathrm{ArH}), 6.88-6.81$ $\left.(\mathrm{m}, 1 \mathrm{H}, \mathrm{ArH}), 4.05\left(\mathrm{~s}, 2 \mathrm{H}, \mathrm{CH}_{2}\right), 2.32\left(\mathrm{~s}, 3 \mathrm{H}, \mathrm{CH}_{3}\right), 2.17\left(\mathrm{~s}, 3 \mathrm{H}, \mathrm{CH}_{3}\right) ;{ }^{13} \mathrm{C} \mathrm{NMR} \mathrm{(100} \mathrm{MHz}, \mathrm{CDCl}_{3}\right): \delta$ 165.9, $148.9,137.2,131.2,127.5,126.8,122.0,25.4,21.0,15.8$. The ${ }^{1} H$ NMR data corresponded to the reported values. $^{7}$

Following a reported procedure ${ }^{5} \mathrm{~N}, \mathrm{~N}^{\prime}$-Ditosylhydrazine $(4.77 \mathrm{~g}, 14.0 \mathrm{mmol}, 2.00$ equiv) was added to a solution of 2,5-dimethylphenyl 2-bromoacetate (56) $(1.70 \mathrm{~g}, 7.00 \mathrm{mmol}, 1.00$ equiv) in tetrahydrofuran $(28 \mathrm{~mL})$ and the mixture was cooled to $0{ }^{\circ} \mathrm{C} .1$, 8 -Diazabicycloundec-7-ene $(5.3 \mathrm{~mL}, 35 \mathrm{mmol}, 5.0$ equiv) was added dropwise over 20 minutes at $0{ }^{\circ} \mathrm{C}$. The reaction was stirred $2 \mathrm{~h}$ at $0{ }^{\circ} \mathrm{C}$ before being quenched by a saturated aqueous $\mathrm{Na}_{2} \mathrm{CO}_{3}$ solution $(40 \mathrm{~mL})$. The reaction mixture was extracted with diethyl ether $(3 \times 30 \mathrm{~mL})$. The combined organic layers were washed with brine, dried over $\mathrm{MgSO}_{4}$, filtered and concentrated under reduced pressure. The crude product was purified by column chromatography using 
1:20 EtOAc:pentane as mobile phase to afford 2,5-dimethylphenyl 2-diazoacetate (8p) as a yellow oil (0.802 g, $4.22 \mathrm{mmol}, 60 \%)$. TLC (EtOAc:pentane, 1:20 v/v): $\mathrm{R}_{\mathrm{f}}=0.43, \mathrm{KMnO}_{4} ;{ }^{1} \mathrm{H} \mathrm{NMR}\left(400 \mathrm{MHz}, \mathrm{CDCl}_{3}\right)$ : $\delta 7.11(\mathrm{~d}, J=7.7 \mathrm{~Hz}, 1 \mathrm{H}, \operatorname{ArH}), 6.96(\mathrm{dd}, J=7.9,1.7 \mathrm{~Hz}, 1 \mathrm{H}, \operatorname{ArH}), 6.88(\mathrm{~d}, J=1.7 \mathrm{~Hz}, 1 \mathrm{H}, \operatorname{ArH}), 4.98(\mathrm{br} \mathrm{s}$, $\left.1 \mathrm{H}, \mathrm{CHN}_{2}\right), 2.32\left(\mathrm{~s}, 3 \mathrm{H}, \mathrm{CH}_{3}\right), 2.17\left(\mathrm{~s}, 3 \mathrm{H}, \mathrm{CH}_{3}\right) . ;{ }^{13} \mathrm{C} \mathrm{NMR}\left(100 \mathrm{MHz}, \mathrm{CDCl}_{3}\right): 149.0,137.1,131.0,127.3$, 127.1, 122.7, 46.7, 21.0, 15.9; IR $\vee 3110$ (w), 2112 (s), 1701 (s), 1498 (m), 1365 (s), 1340 (s), 1183 (s), 1167 (s), 1143 (s), 920 (w), 831 (m), 730 (w); HRMS (ESI) calcd. for $\mathrm{C}_{10} \mathrm{H}_{10} \mathrm{~N}_{2} \mathrm{NaO}_{2}{ }^{+}[\mathrm{M}+\mathrm{Na}]^{+}$213.0634; found 213.0632. One carbon was not resolved at $100 \mathrm{MHz}$.

p-Toluenesulfonylhydrazone of glyoxylic acid chloride (59)<smiles>O=CC(=O)O</smiles>

57<smiles>Cc1ccc(S(=O)(=O)NN)cc1</smiles>

58

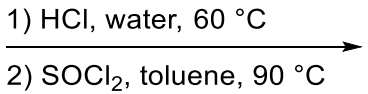

2) $\mathrm{SOCl}_{2}$, toluene, $90^{\circ} \mathrm{C}$

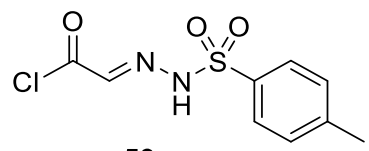

59

Following a modified procedure, ${ }^{9}$ a solution of glyoxylic acid (57) (37.0 g, 50\% in water, 0.25 mole, 1.00 equiv) in water $(250 \mathrm{~mL})$ was placed in a $500 \mathrm{~mL}$ Erlenmeyer flask and warmed to $60^{\circ} \mathrm{C}$. This solution was then treated with a warm $\left(60^{\circ} \mathrm{C}\right)$ solution of $p$-toluenesulfonylhydrazide (58) $(47.0 \mathrm{~g}, 0.250$ mole, 1.00 equiv) in aqueous hydrochloric acid ( $125 \mathrm{~mL}, 2.5 \mathrm{M}, 0.310$ mole, 1.25 equiv). The resulting mixture was stirred at $60{ }^{\circ} \mathrm{C}$ until all the hydrazine was solidified (about 5 minutes is required). The reaction mixture was cooled to room temperature and then allowed to stand in a refrigerator overnight, the solid was collected by filtration, washed with cold water ( 2 times), and allowed to dry for 2 days. Glyoxylic acid $p$-toluenesulfonylhydrazone was collected as a white solid ( $55.5 \mathrm{~g}, 0.23$ mole, $92 \%$ ). ${ }^{1} \mathrm{H}$ NMR (400 MHz, DMSO-d6) $\delta 13.10$ (br s, 1H, $\mathrm{CO}_{2} H$ ), 12.27 (br s, 1H, NHTs), $7.73-7.67$ (m, 2H, ArH), $7.47-7.41$ (m, 2H, ArH), 7.18 (s, 1H, COCHN), 2.39 (s, 3H, CH $).{ }^{13} \mathrm{C}$ NMR (100 MHz, $\delta$ DMSO-d6) $\delta$ 163.6, 144.0, $137.5,135.7,129.9,127.1,21.1$. The NMR data corresponded to the reported values. ${ }^{10}$

Following a modified procedure, ${ }^{9}$ thionyl chloride $(6.03 \mathrm{~mL}, 83.0 \mathrm{mmol}, 2.00$ equiv) was added to a suspension of glyoxylic acid p-poluenesulfonylhydrazone $(10.0 \mathrm{~g}, 41.3 \mathrm{mmol}, 1.00$ equiv) in dry toluene $\left(50 \mathrm{~mL}\right.$ ). The reaction mixture was stirred at $85^{\circ} \mathrm{C}$ for $30 \mathrm{~min}$, until the gaz evolution has ceased. The resulting orange reaction mixture was then cooled to room temperature and filtered through Celite. The filtrate was recovered, concentrated under reduced pressure and the residual solid was treated with hot toluene $\left(10 \mathrm{~mL}, 65^{\circ} \mathrm{C}\right)$. The reaction mixture was cooled to room temperature and the solid was filtered, washed with cold toluene $(2 \times 10 \mathrm{~mL})$ and then washed with pentane to afford $p$ toluenesulfonylhydrazone of glyoxylic acid chloride (59) as pale yellow prisms (7.46 g, $28.6 \mathrm{mmol}, 69 \%$ yield). ${ }^{1} \mathrm{H}$ NMR (400 MHz, CD 3 CN) $\delta 10.36$ (br s, $\left.1 \mathrm{H}, \mathrm{NHTs}\right), 7.86-7.75(\mathrm{~m}, 2 \mathrm{H}, \mathrm{ArH}), 7.43$ (d, J=8.1 Hz,

\footnotetext{
${ }^{9}$ C. J. Blankley, F. J. Sauter, H. O. House, J. H. Ham, R. E. Ireland, Org. Synth. 1969, 49, 22.

${ }^{10}$ H. Lei, J. Atkinson, J. Org. Chem. 2000, 65, 2560.
} 
$2 \mathrm{H}, \mathrm{ArH}), 7.29(\mathrm{~d}, J=0.8 \mathrm{~Hz}, 1 \mathrm{H}, \mathrm{COCHN}), 2.43\left(\mathrm{~s}, 3 \mathrm{H}, \mathrm{CH}_{3}\right) .{ }^{13} \mathrm{C} \mathrm{NMR}\left(100 \mathrm{MHz}, \mathrm{CD}_{3} \mathrm{CN}\right) \delta 165.8,146.5$, $137.7,135.8,131.0,128.7,21.6$. The ${ }^{1} \mathrm{H}$ NMR data corresponded to the reported values. ${ }^{11}$

\section{2-Diazo-N-(2,6-dimethylphenyl)-N-methylacetamide (8q)}<smiles>Cc1cccc(C)c1N</smiles>

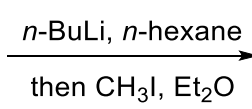

then $\mathrm{CH}_{3} \mathrm{I}, \mathrm{Et}_{2} \mathrm{O}$
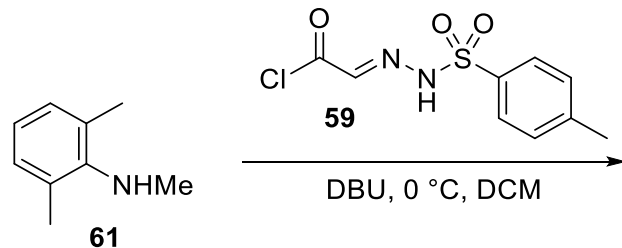

$\mathrm{DBU}, 0^{\circ} \mathrm{C}, \mathrm{DCM}$

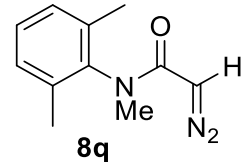

Following a slightly modified procedure, ${ }^{12}$ a solution of $n$-BuLi $(4.35 \mathrm{~mL}, 2.50 \mathrm{M}$ in $n$-hexane, $11.0 \mathrm{mmol}$, 1.10 equiv) was added to a solution of 2,6-dimethylaniline (60) $(1.23 \mathrm{~mL}, 10.0 \mathrm{mmol}, 1.00$ equiv) in $n$ hexane $(15 \mathrm{~mL})$ at $-20^{\circ} \mathrm{C}$. The reaction mixture was warmed to room temperature and stirred for $3 \mathrm{~h}$. The solvent of the reaction mixture was evaporated and the light-yellow solid was dissolved in diethyl ether $(30 \mathrm{~mL})$. The obtained solution was slowly added to a solution of iodomethane $(0.65 \mathrm{~mL}, 10.50$ mmol, 1.05 equiv.) in diethyl ether $(10.0 \mathrm{~mL})$ at $-20^{\circ} \mathrm{C}$. The reaction mixture was warmed to room temperature and stirred overnight. The reaction was then quenched with $\mathrm{H}_{2} \mathrm{O}(20 \mathrm{~mL})$. The layers were separated and the aqueous layer was extracted with diethyl ether $(3 \times 15 \mathrm{~mL})$. The combined organic layers were washed with brine $(30 \mathrm{~mL})$, dried over $\mathrm{MgSO}_{4}$, filtered and concentrated under reduced pressure. The crude product N,2,6-trimethylaniline (61) was obtained as a yellow oil $(1.28 \mathrm{~g}, 9.44 \mathrm{mmol}$, 94\%) and used in the next step without further purification. TLC (EtOAc:pentane, 1:9 v/v): $R_{f}=0.56$, $\mathrm{KMnO}_{4} ;{ }^{1} \mathrm{H}$ NMR $\left(400 \mathrm{MHz}, \mathrm{CDCl}_{3}\right): \delta 7.00(\mathrm{~d}, J=7.5 \mathrm{~Hz}, 2 \mathrm{H}, \mathrm{ArH}), 6.82(\mathrm{t}, J=7.4 \mathrm{~Hz}, 1 \mathrm{H}, \mathrm{ArH}), 2.79(\mathrm{~s}, 3 \mathrm{H}$, $\left.\mathrm{NHCH}_{3}\right), 2.30\left(\mathrm{~s}, 6 \mathrm{H}, 2 \times \mathrm{CH}_{3}\right) .{ }^{13} \mathrm{C} \mathrm{NMR}\left(100 \mathrm{MHz}, \mathrm{CDCl}_{3}\right): \delta 147.6,129.3,129.1,121.9,35.5,18.5$. The NMR data corresponded to the reported values. ${ }^{13}$

Following a slightly modified procedure, ${ }^{[14]}$ to a solution of $p$-toluenesulfonylhydrazone of glyoxylic acid chloride (62) (1.30 g, 5.00 mmol, 1.00 equiv) in $\mathrm{CH}_{2} \mathrm{Cl}_{2}(10 \mathrm{~mL}$ ) were added $\mathrm{N}, 2,6$-trimethylaniline (61) (744 mg, $5.50 \mathrm{mmol}, 1.10$ equiv) and then DBU (1.89 mL, $12.5 \mathrm{mmol}, 2.50$ equiv) dropwise at $0{ }^{\circ} \mathrm{C}$. After stirring for $2 \mathrm{~h}$ at the same temperature, the reaction was stirred $30 \mathrm{~min}$ at room temperature and then poured into saturated $\mathrm{NH}_{4} \mathrm{Cl}$ solution $(10 \mathrm{~mL})$. The organic layer was then extracted with $\mathrm{CH}_{2} \mathrm{Cl}_{2}(3 \times 10$ $\mathrm{mL})$, washed with saturated brine $(20 \mathrm{~mL})$, dried over $\mathrm{MgSO}_{4}$, filtered and concentrated under reduced. The crude product was purified by column chromatography using 1:4 EtOAc:pentane as mobile phase to afford 2-diazo- $N$-(2,6-dimethylphenyl)- $N$-methylacetamide (8q) as a yellow solid $(609 \mathrm{mg}, 3.00 \mathrm{mmol}$, 60\%). TLC (EtOAc:pentane, 1:4 v/v): $\mathrm{R}_{\mathrm{f}}=0.48, \mathrm{KMnO}_{4} ;{ }^{1} \mathrm{H} \mathrm{NMR}\left(400 \mathrm{MHz}, \mathrm{CDCl}_{3}\right): \delta 7.19-7.07(\mathrm{~m}, 3 \mathrm{H}$,

\footnotetext{
${ }^{11}$ H. O. House, C. J. Blankley, J. Org. Chem. 1968, 33, 53.

${ }^{12}$ K. Liu, Q. Wu, W. Gao, Y. Mu, L. Ye, Eur. J. Inorg. Chem. 2011, 2011, 1901.

${ }^{13}$ S. L. Cockroft, J. Perkins, C. Zonta, H. Adams, S. E. Spey, C. M. R. Low, J. G. Vinter, K. R. Lawson, C. J. Urch, C. A. Hunter, Org. Biomol. Chem. 2007, 5, 1062.
} 
$\left.\operatorname{ArH}), 4.30\left(\mathrm{~s}, 1 \mathrm{H}, \mathrm{CN}_{2} \mathrm{H}\right), 3.18\left(\mathrm{~s}, 3 \mathrm{H}, \mathrm{NHCH}_{3}\right), 2.21\left(\mathrm{~s}, 6 \mathrm{H}, 2 \times \mathrm{CH}_{3}\right) ;{ }^{13} \mathrm{C} \mathrm{NMR} \mathrm{(100} \mathrm{MHz,} \mathrm{CDCl}_{3}\right): \delta$ 165.8, 140.0, 136.6, 129.1, 128.6, 46.2, 34.3, 17.7; IR v 2989 (m), 2116 (s), 1706 (s), 1509 (m), 1369 (s), 1343 (m), 1216 (s), 1204 (s); HRMS (ESI) calcd. for $\mathrm{C}_{11} \mathrm{H}_{14} \mathrm{~N}_{3} \mathrm{O}^{+}[\mathrm{M}+\mathrm{H}]^{+}$204.1131; found 204.1128.

\section{Furan-2-ylmethyl 2-diazoacetate (12)}

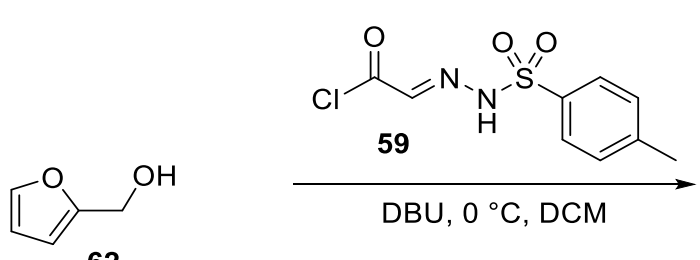

62

Following a slightly modified procedure,${ }^{14}$ to a solution of $p$-toluenesulfonylhydrazone of glyoxylic acid chloride (59) (1.30 g, $5.00 \mathrm{mmol}, 1.00$ equiv) in $\mathrm{CH}_{2} \mathrm{Cl}_{2}(10 \mathrm{~mL}$ ) were added furfuryl alcohol (62) (475 $\mu \mathrm{L}$, $5.50 \mathrm{mmol}, 1.10$ equiv) and then DBU $\left(1.89 \mathrm{~mL}, 12.5 \mathrm{mmol}, 2.50\right.$ equiv) dropwise at $0{ }^{\circ} \mathrm{C}$. After stirring for $2 \mathrm{~h}$ at the same temperature, the reaction was stirred $30 \mathrm{~min}$ at room temperature and then poured into saturated $\mathrm{NH}_{4} \mathrm{Cl}$ solution $(10 \mathrm{~mL})$. The organic layer was then extracted with $\mathrm{CH}_{2} \mathrm{Cl}_{2}(3 \times 10 \mathrm{~mL})$, washed with saturated brine $(20 \mathrm{~mL})$, dried over $\mathrm{MgSO}_{4}$, filtered and concentrated under reduced. The crude product was purified by column chromatography using 1:30 EtOAc:pentane as mobile phase to afford furan-2-ylmethyl 2-diazoacetate (12) as a yellow oil (534 mg, $3.21 \mathrm{mmol}, 64 \%)$. Mp: 76-78 ${ }^{\circ} \mathrm{C}$; TLC (EtOAc:pentane, 1:20 v/v): $\mathrm{R}_{\mathrm{f}}=0.33, \mathrm{KMnO}_{4} ;{ }^{1} \mathrm{H} \mathrm{NMR}\left(400 \mathrm{MHz}, \mathrm{CDCl}_{3}\right): \delta 7.42(\mathrm{dd}, J=1.9,0.9 \mathrm{~Hz}, 1 \mathrm{H}$, $\operatorname{ArH}), 6.42(\mathrm{dd}, J=3.3,0.8 \mathrm{~Hz}, 1 \mathrm{H}, \mathrm{ArH}), 6.36(\mathrm{dd}, J=3.3,1.8 \mathrm{~Hz}, 1 \mathrm{H}, \operatorname{ArH}), 5.14\left(\mathrm{~s}, 2 \mathrm{H}, \mathrm{CH}_{2} \mathrm{O}\right), 4.78(\mathrm{br} \mathrm{s}$, $\left.1 \mathrm{H}, \mathrm{CN}_{2} H\right) .{ }^{13} \mathrm{C} \mathrm{NMR}\left(100 \mathrm{MHz}, \mathrm{CDCl}_{3}\right): \delta$ 166.6, 149.5, 143.5, 111.0, 110.7, 58.3, 46.5. IR v 3117 (m), 2112 (s), 1691 (s), 1383 (s), 1348 (s), 1238 (s), 1173 (s), 1153 (s), 1004 (s), 921 (m), 740 (s); HRMS (ESI) calcd. for $\mathrm{C}_{7} \mathrm{H}_{6} \mathrm{~N}_{2} \mathrm{NaO}_{3}{ }^{+}[\mathrm{M}+\mathrm{Na}]^{+}$189.0271; found 189.0269.

${ }^{14}$ T. Hashimoto, N. Uchiyama, K. Maruoka, J. Am. Chem. Soc. 2008, 130, 14380. 


\section{Preparation of EBX reagents}

The preparation of R-EBX reagents $15 a-q$ except $15 p$ had been already described before. The procedures are taken here from the indicated publications to facilitate reproduction of the results by having all the data in the same file.

1-Hydroxy-1,2-benziodoxol-3-(1H)-one (64)<smiles>O=C(O)c1ccccc1I</smiles>

63

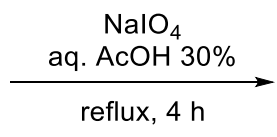

reflux, $4 \mathrm{~h}$

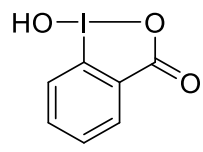

64

Following a reported procedure, ${ }^{15} \mathrm{NaIO}_{4}(7.24 \mathrm{~g}, 33.8 \mathrm{mmol}, 1.05$ equiv) and 2-iodobenzoic acid (63) ( $8.00 \mathrm{~g}, 32.2 \mathrm{mmol}, 1.00$ equiv) were suspended in $30 \%$ (v/v) aq. AcOH (48 mL). The mixture was vigorously stirred and refluxed for $4 \mathrm{~h}$. The reaction mixture was then diluted with cold water $(180 \mathrm{~mL})$ and allowed to cool to room temperature, protecting it from light. After $1 \mathrm{~h}$, the crude product was collected by filtration, washed on the filter with ice water $(3 \times 20 \mathrm{~mL})$ and acetone $(3 \times 20 \mathrm{~mL})$, and airdried in the dark to give the pure product 64 as a white solid $(8.3 \mathrm{~g}, 31 \mathrm{mmol}, 98 \%) .{ }^{1} \mathrm{H}$ NMR (400 MHz, $\left.\left(\mathrm{CD}_{3}\right)_{2} \mathrm{SO}\right): \delta 8.02(\mathrm{dd}, J=7.7,1.4 \mathrm{~Hz}, 1 \mathrm{H}, \mathrm{ArH}), 7.97(\mathrm{~m}, 1 \mathrm{H}, \mathrm{ArH}), 7.85(\mathrm{dd}, J=8.2,0.7 \mathrm{~Hz}, 1 \mathrm{H}, \mathrm{ArH}), 7.71$ (td, $J=7.6,1.2 \mathrm{~Hz}, 1 \mathrm{H}, \mathrm{ArH}) ;{ }^{13} \mathrm{C} N M R\left(100 \mathrm{MHz},\left(\mathrm{CD}_{3}\right)_{2} \mathrm{SO}\right): \delta$ 167.7, 134.5, 131.5, 131.1, 130.4, 126.3, 120.4; IR v $3083(w), 3060$ (w), $2867(w), 2402(w), 1601(m), 1585(m), 1564(m), 1440(m), 1338(s)$, $1302(\mathrm{~m}), 1148(\mathrm{~m}), 1018(\mathrm{w}), 834(\mathrm{~m}), 798(\mathrm{w}), 740(\mathrm{~s}), 694(\mathrm{~s}), 674(\mathrm{~m}), 649(\mathrm{~m})$. The values of the NMR spectra are in accordance with reported literature data. ${ }^{15}$

\section{Triisopropylsilyl trimethylsilylacetylene (66)}

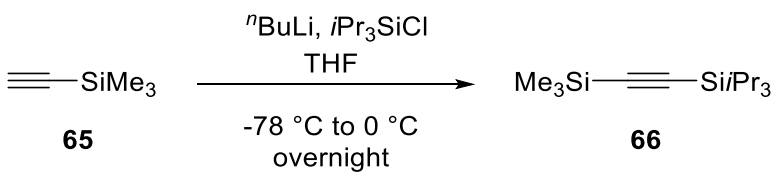

Following a reported procedure, ${ }^{16 n} \mathrm{BuLi}(2.50 \mathrm{M}$ in hexanes, $12.0 \mathrm{~mL}, 29.9 \mathrm{mmol}, 0.98$ equiv) was added dropwise to a stirred solution of ethynyltrimethylsilane (65) $(3.0 \mathrm{~g}, 30 \mathrm{mmol}, 1.0$ equiv) in THF (48 mL) at $-78{ }^{\circ} \mathrm{C}$. The mixture was then warmed to $0{ }^{\circ} \mathrm{C}$ and stirred for $5 \mathrm{~min}$. The mixture was then cooled back to $-78{ }^{\circ} \mathrm{C}$ and chlorotriisopropylsilane $(6.4 \mathrm{~mL}, 30 \mathrm{mmol}, 1.0$ equiv) was added dropwise. The mixture was then allowed to warm to room temperature and stirred overnight. A saturated solution of ammonium chloride $(40 \mathrm{~mL})$ was added, and the reaction mixture was extracted with diethyl ether $(2 \mathrm{x}$

\footnotetext{
${ }^{15}$ L. Kraszkiewicz, L. Skulski, Arkivoc 2003, 2003, 120.

${ }^{16}$ C. J. Helal, P. A. Magriotis, E. J. Corey, J. Am. Chem. Soc. 1996, 118, 10938.
} 
$60 \mathrm{~mL}$ ). The organic layer was washed with water and brine, then dried over $\mathrm{MgSO}_{4}$, filtered and concentrated under reduced pressure to obtain a colorless liquid which was further purified by Kugelrohr distillation $\left(56-57^{\circ} \mathrm{C} / 0.25 \mathrm{~mm}\right.$ of $\mathrm{Hg}$ ) to yield 66 as a colorless liquid $(7.16 \mathrm{~g}, 28.0 \mathrm{mmol}, 92 \%$ yield). ${ }^{1} \mathrm{H}$ NMR (400 MHz, CDCl $): \delta 1.08$ (m, 21H, TIPS), 0.18 (s, 9H, TMS); IR v 2959 (m), 2944 (m), 2896 (w), $2867(\mathrm{~m}), 1464(\mathrm{w}), 1385(\mathrm{w}), 1250(\mathrm{~m}), 996(\mathrm{w}), 842(\mathrm{~s}), 764(\mathrm{~s}), 675(\mathrm{~m}), 660(\mathrm{~m})$. The values of the NMR spectra are in accordance with reported literature data. ${ }^{16}$

\section{1-[(Triiso-propylsilyl)ethynyl]-1,2-benziodoxol-3(1H)-one (9a)}

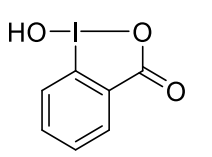

64

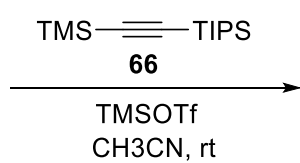

$\mathrm{CH} 3 \mathrm{CN}, \mathrm{rt}$

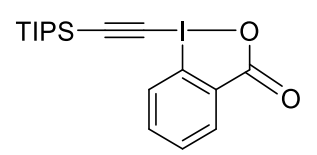

$9 a$

Following a reported procedure, ${ }^{17}$ 2-iodosylbenzoic acid (64) $(21.7 \mathrm{~g}, 82.0 \mathrm{mmol}, 1.00$ equiv) was charged in oven-dried three-neck $1 \mathrm{~L}$ flask equipped with a magnetic stirrer. After 3 vacuum/nitrogen cycles, anhydrous acetonitrile $(500 \mathrm{~mL})$ was added via canula and cooled to $0{ }^{\circ} \mathrm{C}$. Trimethylsilyltriflate (16.4 mL, $90.0 \mathrm{mmol}, 1.10$ equiv) was added dropwise via a dropping funnel over $30 \mathrm{~min}$ (no temperature increase was observed). After $15 \mathrm{~min}$, (trimethylsilyl)(triisopropylsilyl)acetylene (66) (23.0 g, $90.0 \mathrm{mmol}, 1.10$ equiv) was added via canula over $15 \mathrm{~min}$ (no temperature increase was observed). After $30 \mathrm{~min}$, the suspension became an orange solution. After $10 \mathrm{~min}$, pyridine $(7.0 \mathrm{~mL}, 90 \mathrm{mmol}, 1.1$ equiv) was added via syringe. After $15 \mathrm{~min}$, the reaction mixture was transferred in a one-neck $1 \mathrm{~L}$ flask and reduced under vacuum until a solid was obtained. The solid was dissolved in $\mathrm{CH}_{2} \mathrm{Cl}_{2}(200 \mathrm{~mL})$ and transferred in a $1 \mathrm{~L}$ separatory funnel. The organic layer was added and washed with $1 \mathrm{M} \mathrm{HCl}(200 \mathrm{~mL})$ and the aqueous layer was extracted with $\mathrm{CH}_{2} \mathrm{Cl}_{2}(200 \mathrm{~mL})$. The organic layers were combined, washed with a saturated solution of $\mathrm{NaHCO}_{3}(2 \times 200 \mathrm{~mL})$, dried over $\mathrm{MgSO}_{4}$, filtered and the solvent was evaporated under reduced pressure. Recrystallization from acetonitrile (ca $120 \mathrm{~mL}$ ) afforded 9a as colorless crystals (30.1 g, $70.2 \mathrm{mmol}, 86 \%)$. Mp (Dec.): 170.0-176.0 ${ }^{\circ} \mathrm{C} ;{ }^{1} \mathrm{H} \mathrm{NMR}\left(400 \mathrm{MHz}, \mathrm{CDCl}_{3}\right): \delta 8.44$ $(\mathrm{m}, 1 \mathrm{H}, \mathrm{ArH}), 8.29(\mathrm{~m}, 1 \mathrm{H}, \mathrm{ArH}), 7.77(\mathrm{~m}, 2 \mathrm{H}, \mathrm{ArH}), 1.16(\mathrm{~m}, 21 \mathrm{H}, \mathrm{TIPS}) ;{ }^{13} \mathrm{C} \mathrm{NMR}\left(100 \mathrm{MHz}, \mathrm{CDCl}_{3}\right): \delta$ 166.4, 134.6, 132.3, 131.4, 131.4, 126.1, 115.6, 114.1, 64.6, 18.4, 11.1; IR v 2943 (m), 2865 (m), 1716 $(\mathrm{m}), 1618(\mathrm{~m}), 1604(\mathrm{~s}), 1584(\mathrm{~m}), 1557(\mathrm{~m}), 1465(\mathrm{~m}), 1439(\mathrm{w}), 1349(\mathrm{~m}), 1291(\mathrm{~m}), 1270(\mathrm{w}), 1244(\mathrm{~m})$, $1140(\mathrm{~m}), 1016(\mathrm{~m}), 999(\mathrm{~m}), 883(\mathrm{~m}), 833(\mathrm{~m}), 742(\mathrm{~m}), 702(\mathrm{~s}), 636(\mathrm{~m})$. The characterization data corresponded to the reported values. ${ }^{17}$

${ }^{17}$ J. P. Brand, J. Waser, Angew. Chem., Int. Ed. 2010, 49, 7304. 


\section{1-[Phenylethynyl]-1,2-benziodoxol-3(1H)-one (9b)}

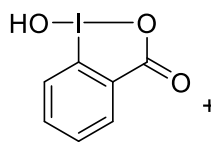

64

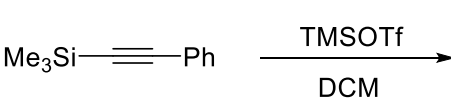

67

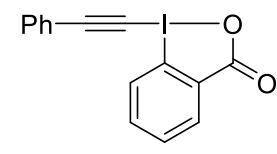

$9 b$

Following a reported procedure ${ }^{18}$ trimethylsilyl triflate $(7.50 \mathrm{~mL}, 41.5 \mathrm{mmol}, 1.10$ equiv) was added to a suspension of 2-iodosylbenzoic acid (64) $\left(10.0 \mathrm{~g}, 37.7 \mathrm{mmol}, 1.00\right.$ equiv) in $\mathrm{CH}_{2} \mathrm{Cl}_{2}(100 \mathrm{~mL})$ at room temperature. The resulting yellow mixture was stirred for $1 \mathrm{~h}$, followed by the dropwise addition of trimethyl(phenylethynyl)silane (67) $(8.10 \mathrm{~mL}, 41.5 \mathrm{mmol}, 1.10$ equiv) (slightly exothermic). The resulting suspension was stirred for $6 \mathrm{~h}$ at room temperature, during this time a white solid was formed. A saturated solution of $\mathrm{NaHCO}_{3}(100 \mathrm{~mL})$ was then added and the mixture was stirred vigorously. The resulting suspension was filtered on a glass filter of porosity 4 . The two layers of the mother liquors were separated and the organic layer was washed with saturated solution of $\mathrm{NaHCO}_{3}(100 \mathrm{~mL})$, dried over $\mathrm{MgSO}_{4}$, filtered and evaporated under reduced pressure. The resulting mixture was combined with the solid obtained by filtration and boiled in $\mathrm{CH}_{3} \mathrm{CN}$ ( $c a 300 \mathrm{~mL}$ ). The mixture was cooled down, filtered and dried under high vacuum to afford $9 \mathrm{~b}$ as a white solid (6.08 g, $17.4 \mathrm{mmol}, 46 \%$ ). Mp (Dec.); 155.0-160.0 ${ }^{\circ} \mathrm{C}$ (lit 153-155 $\left.{ }^{\circ} \mathrm{C}\right) ;{ }^{1} \mathrm{H}$ NMR $\left(400 \mathrm{MHz}, \mathrm{CDCl}_{3}\right) ; \delta 8.46(\mathrm{~m}, 1 \mathrm{H}, \mathrm{ArH}), 8.28(\mathrm{~m}, 1 \mathrm{H}, \mathrm{ArH}), 7.80(\mathrm{~m}, 2 \mathrm{H}, \mathrm{ArH})$, $7.63(\mathrm{~m}, 2 \mathrm{H}, \mathrm{ArH}), 7.48(\mathrm{~m}, 3 \mathrm{H}, \mathrm{ArH}) ;{ }^{13} \mathrm{C}$ NMR (100 MHz, CDCl $): \delta 163.9,134.9,132.9,132.5,131.6$, 131.3. $130.8,128.8,126.2,120.5,116.2,106.6,50.2$. The characterization data corresponded to the reported values. ${ }^{18}$

\section{1-((4-Pentylphenyl)ethynyl)-1,2-benziodoxol-3(1H)-one (9c)}

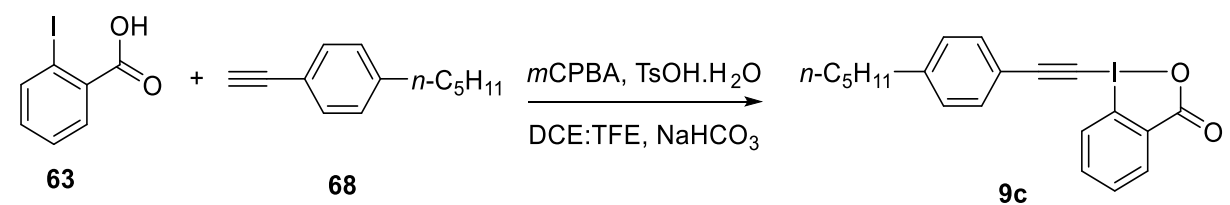

In a sealed tube, 2-iodobenzoic acid (63) (1.00 g, $4.03 \mathrm{mmol}, 1.00$ equiv), 4-methylbenzenesulfonic acid (775 mg, $4.03 \mathrm{mmol}, 1.00$ equiv) and meta-chloroperoxybenzoic acid (mCPBA-70\%, $994 \mathrm{mg}, 4.44 \mathrm{mmol}$, 1.10 equiv) were suspended in DCE:TFE 1:1 (12 mL) and stirred for $1 \mathrm{~h}$ at $55^{\circ} \mathrm{C}$. After $1 \mathrm{~h}$, 1-ethynyl-4pentylbenzene (68) (1.1 mL, $5.6 \mathrm{mmol}, 1.4$ equiv) was added and the reaction was stirred at $55^{\circ} \mathrm{C}$ for 24 h. After $24 \mathrm{~h}$, the solvent was evaporated and the residue was redissolved in $\mathrm{CH}_{2} \mathrm{Cl}_{2}(20 \mathrm{~mL})$ and stirred vigorously with saturated $\mathrm{NaHCO}_{3}$ solution $(30 \mathrm{~mL})$. After $1 \mathrm{~h}$, the reaction mixture was transferred into a separating funnel and the layers were separated. The aqueous layer was extracted with $\mathrm{CH}_{2} \mathrm{Cl}_{2}(2 \times 50$

\footnotetext{
18 J. P. Brand, C. Chevalley, R. Scopelliti, J. Waser, Chem. Eur. J. 2012, 18, 5655.
} 
$\mathrm{mL}$ ). The combined organic layers were washed with saturated $\mathrm{NaHCO}_{3}$ solution, dried over $\mathrm{MgSO}_{4}$, filtered and concentrated under vacuum. The resulting solid was boiled in $\mathrm{MeCN}(20 \mathrm{~mL})$, then filtered and the collected solid was further purified by flash column chromatography using EtOAc. Trituration in pentane afforded 9c as a pale yellow solid (191 mg, $0.457 \mathrm{mmol}, 11 \%$ ). M.p. (Dec.) 104-107 ${ }^{\circ} \mathrm{C}$; TLC (EtOAc): $\mathrm{R}_{\mathrm{f}}=0.21, \mathrm{KMnO}_{4} ;{ }^{1} \mathrm{H}$ NMR $\left(400 \mathrm{MHz}, \mathrm{CDCl}_{3}\right): \delta 8.45-8.40(\mathrm{~m}, 1 \mathrm{H}, \mathrm{ArH}), 8.28-8.21(\mathrm{~m}, 1 \mathrm{H}, \mathrm{ArH})$, $7.79-7.74(\mathrm{~m}, 2 \mathrm{H}, \mathrm{ArH}), 7.56-7.48(\mathrm{~m}, 2 \mathrm{H}, \mathrm{ArH}), 7.26-7.23(\mathrm{~m}, 2 \mathrm{H}, \mathrm{ArH}), 2.71-2.60(\mathrm{~m}, 2 \mathrm{H}, \mathrm{ArCH})$, $1.69-1.54\left(\mathrm{~m}, 2 \mathrm{H}, \mathrm{ArCH}_{2} \mathrm{CH}_{2}\right), 1.40-1.27\left(\mathrm{~m}, 4 \mathrm{H}, \mathrm{CH}_{2} \mathrm{CH}_{2} \mathrm{CH}_{3}\right), 0.90\left(\mathrm{t}, \mathrm{J}=6.8 \mathrm{~Hz}, 3 \mathrm{H}, \mathrm{CH}_{2} \mathrm{CH}_{3}\right) ;{ }^{13} \mathrm{C}$ NMR (101 MHz, $\mathrm{CDCl}_{3}$ ): $\delta$ 166.6, 146.7, 135.0, 133.0, 132.6, 131.7, 131.5, 129.0, 126.3, 117.7, 116.4, 107.4, 49.4, 36.2, 31.5, 31.0, 22.6, 14.1; IR $v 3446(\mathrm{~m}), 3359$ (w), 2349 (w), $1644(\mathrm{~s}), 1482(\mathrm{~m}), 1327(\mathrm{~m}), 1214$ (m), $1121(\mathrm{~m}), 1034(\mathrm{~m}), 840(\mathrm{~s}), 753(\mathrm{~m})$; HRMS (ESI) calcd. for $\mathrm{C}_{20} \mathrm{H}_{20} \mathrm{IO}_{2}{ }^{+}[\mathrm{M}+\mathrm{H}]^{+}$419.0503; found 419.0496. The characterization data corresponded to the reported values. ${ }^{19}$

\section{1-[4-Fluorophenylethynyl]-1,2-benziodoxol-3(1H)-one (9d)}



64

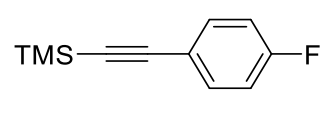

69

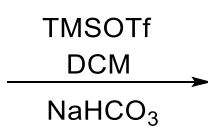

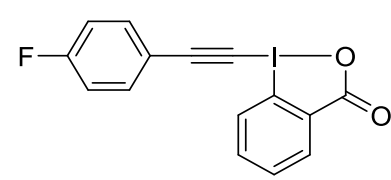

9d

Following a reported procedure, ${ }^{20}$ trimethylsilyl triflate $(1.0 \mathrm{~mL}, 5.5 \mathrm{mmol}, 1.1$ equiv) was added to a suspension of 2-iodosylbenzoic acid (64) (1.32 g, 5.00 mmol, 1.00 equiv) in $\mathrm{CH}_{2} \mathrm{Cl}_{2}$ (15 mL) at room temperature. The resulting suspension was stirred for $1 \mathrm{~h}$, followed by the drop wise addition of ((4fluorophenyl)ethynyl)trimethylsilane (69) (1.1 mL, $5.5 \mathrm{mmol}, 1.1$ equiv), which was dissolved in $\mathrm{CH}_{2} \mathrm{Cl}_{2}$ $(1 \mathrm{~mL})$. The resulting suspension was stirred for $6 \mathrm{~h}$. A saturated solution of $\mathrm{NaHCO}_{3}(2 \mathrm{~mL})$ was then added and the mixture was stirred vigorously for $30 \mathrm{~min}$, the two layers were separated and the organic layer was washed with saturated solution of $\mathrm{NaHCO}_{3}(20 \mathrm{~mL})$, dried over $\mathrm{MgSO}_{4}$, filtered and evaporated under reduced pressure. The resulting solid was boiled in $\mathrm{CH}_{3} \mathrm{CN}(20 \mathrm{~mL})$. The mixture was cooled down, filtered and dried under high vacuum to afford $9 \mathrm{~d}$ as a white solid $(750 \mathrm{mg}, 2.05 \mathrm{mmol}, 41 \%) .{ }^{1} \mathrm{H} \mathrm{NMR}$ $\left(400 \mathrm{MHz}, \mathrm{CDCl}_{3}\right): \delta 8.48-8.34(\mathrm{~m}, 1 \mathrm{H}, \mathrm{ArH}), 8.29-8.16(\mathrm{~m}, 1 \mathrm{H}, \mathrm{ArH}), 7.85-7.69(\mathrm{~m}, 2 \mathrm{H}, \mathrm{ArH}), 7.68-$ $7.53(\mathrm{~m}, 2 \mathrm{H}, \mathrm{ArH}), 7.17-7.05(\mathrm{~m}, 2 \mathrm{H}, \mathrm{ArH}) ;{ }^{13} \mathrm{C} \mathrm{NMR}\left(100 \mathrm{MHz}, \mathrm{CDCl}_{3}\right): \delta 166.8,164.0$ (d, J = 253.9 Hz), $135.2(\mathrm{~d}, J=8.8 \mathrm{~Hz}), 135.0,132.6,131.7,131.50,126.4,116.9$ (d, $J=3.6 \mathrm{~Hz}), 116.4$ (d, $J=22.4 \mathrm{~Hz}), 116.3$, $105.5,50.5$. The characterization data corresponded to the reported values. ${ }^{20}$

\footnotetext{
${ }^{19}$ F. Le Vaillant, M. Garreau, S. Nicolai, G. Gryn'ova, C. Corminboeuf, J. Waser, Chem. Sci. 2018, 9, 5883.

${ }^{20}$ K. Jia, F. Zhang, H. Huang, Y. Chen, J. Am. Chem. Soc. 2016, 138, 1514.
} 


\section{1-[4-Bromophenylethynyl]-1,2-benziodoxol-3(1H)-one (9e)}<smiles>O=C1OI(O)c2ccccc21</smiles>

64

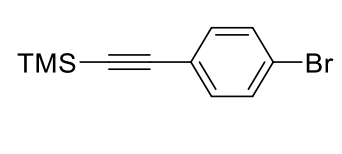

70

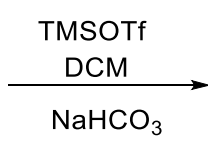

$\mathrm{NaHCO}_{3}$

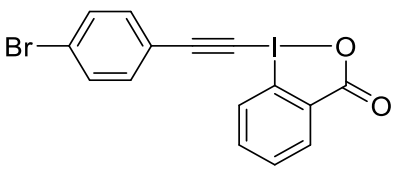

$9 e$

Following a reported procedure ${ }^{21}$ trimethylsilyl triflate $(1.0 \mathrm{~mL}, 5.5 \mathrm{mmol}, 1.1$ equiv) was added to a suspension of 2-iodosylbenzoic acid (64) (1.32 g, $5.00 \mathrm{mmol}, 1.00$ equiv) in $\mathrm{CH}_{2} \mathrm{Cl}_{2}$ (15 mL) at room temperature. The resulting suspension was stirred for $1 \mathrm{~h}$, followed by the drop wise addition of ((4bromophenyl)ethynyl)trimethylsilane (70) (1.17 g, $5.50 \mathrm{mmol}, 1.10$ equiv), which was dissolved in $\mathrm{CH}_{2} \mathrm{Cl}_{2}$ $(1 \mathrm{~mL})$. The resulting suspension was stirred for $6 \mathrm{~h}$. A saturated solution of $\mathrm{NaHCO}_{3}(20 \mathrm{~mL})$ was then added and the mixture was stirred vigorously for $30 \mathrm{~min}$, the two layers were separated and the organic layer was washed with saturated solution of $\mathrm{NaHCO}_{3}(20 \mathrm{~mL})$, dried over $\mathrm{MgSO}_{4}$, filtered and evaporated under reduced pressure. The resulting solid was boiled in $\mathrm{CH}_{3} \mathrm{CN}(20 \mathrm{~mL})$. The mixture was cooled down, filtered and dried under high vacuum to afford $9 \mathrm{e}$ as a pale yellow solid (1.00 g, $2.34 \mathrm{mmol}, 47 \%)$. Mp (Dec.):158.0-163.0 ${ }^{\circ} \mathrm{C} ;{ }^{1} \mathrm{H}$ NMR (400 MHz, $\left.\mathrm{CDCl}_{3}\right): \delta 8.51-8.30(\mathrm{~m}, 1 \mathrm{H}, \mathrm{ArH}), 8.30-8.13(\mathrm{~m}, 1 \mathrm{H}, \mathrm{ArH}), 7.84-$ $7.72(\mathrm{~m}, 2 \mathrm{H}, \operatorname{ArH}), 7.58(\mathrm{~d}, 2 \mathrm{H}, J=8.5 \mathrm{~Hz}, \operatorname{ArH}), 7.46(\mathrm{~d}, 2 \mathrm{H}, J=8.5 \mathrm{~Hz}, \operatorname{ArH}) ;{ }^{13} \mathrm{C} \mathrm{NMR}\left(100 \mathrm{MHz}, \mathrm{CDCl}_{3}\right)$ : $\delta 166.6,135.1,134.3,132.7,132.3,131.9,131.4,126.3,125.7,119.6,116.3,105.4,52.1 ;$ IR $\vee 2155$ (w), $1612(s), 1559(w), 1479(w), 1445(w), 1328(m), 1297(w), 1007(w), 906(w)$. The characterization data corresponded to the reported values. ${ }^{21}$

\section{1-[4-Trifluoromethylphenylethynyl]-1,2-benziodoxol-3(1H)-one (9f)}<smiles>O=C1OI(O)c2ccccc21</smiles>

64

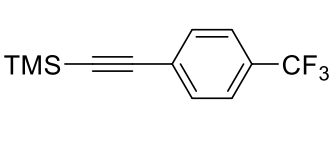

71

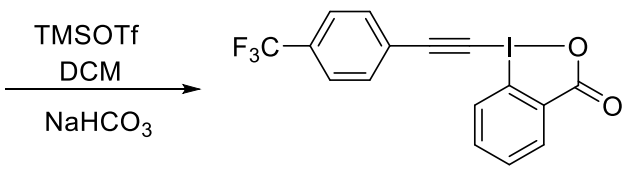

9f

Following a reported procedure, ${ }^{22}$ trimethylsilyl triflate $(0.80 \mathrm{~mL}, 4.4 \mathrm{mmol}, 1.1$ equiv) was added to a suspension of 2-iodosylbenzoic acid (64) (1.06 g, $4.00 \mathrm{mmol}, 1.00$ equiv) in $\mathrm{CH}_{2} \mathrm{Cl}_{2}(15 \mathrm{~mL})$ at room temperature. The resulting yellow mixture was stirred for $1 \mathrm{~h}$, followed by the dropwise addition of trimethyl((4-(trifluoromethyl)phenyl)ethynyl)silane (71) (1.07 g, $4.40 \mathrm{mmol}, 1.10$ equiv). The resulting suspension was stirred for $6 \mathrm{~h}$. A saturated solution of $\mathrm{NaHCO}_{3}(20 \mathrm{~mL})$ was then added and the mixture was stirred vigorously for $30 \mathrm{~min}$, the two layers were separated and the organic layer was washed with saturated solution of $\mathrm{NaHCO}_{3}(20 \mathrm{~mL})$, dried over $\mathrm{MgSO}_{4}$, filtered and evaporated under reduced pressure. The resulting solid was recrystallized in $\mathrm{CH}_{3} \mathrm{CN}$ (ca $20 \mathrm{~mL}$ ) to afford $9 \mathrm{f}$ as a pale yellow solid

\footnotetext{
${ }^{21}$ F. Le Vaillant, T. Courant, J. Waser, Angew. Chem., Int. Ed. 2015, 54, 11200.

22 B. Lu, J. Wu, N. Yoshikai, J. Am. Chem. Soc. 2014, 136, 11598.
} 
(850 mg, $2.04 \mathrm{mmol}, 51 \%) .{ }^{1} \mathrm{H}$ NMR (400 MHz, $\left.\mathrm{CDCl}_{3}\right): \delta 8.46-8.38(\mathrm{~m}, 1 \mathrm{H}, \mathrm{ArH}), 8.28-8.19(\mathrm{~m}, 1 \mathrm{H}$, $\operatorname{ArH}), 7.84-7.74(\mathrm{~m}, 2 \mathrm{H}, \mathrm{ArH}), 7.74-7.65(\mathrm{~m}, 4 \mathrm{H}, \mathrm{ArH}) ;{ }^{13} \mathrm{C} \mathrm{NMR}\left(100 \mathrm{MHz}, \mathrm{CDCl}_{3}\right): \delta$ 166.6, 135.0, 133.0, $132.6,132.2\left(q, J_{C-F}=33.0 \mathrm{~Hz}\right), 131.7,131.2,126.3,125.7\left(q, J_{C-F}=3.6 \mathrm{~Hz}\right), 124.4,123.4\left(q, J_{C-F}=272.6\right.$ $\mathrm{Hz}), 116.1,104.2,53.7$. The characterization data corresponded to the reported values. ${ }^{22}$

\section{1-((4-Formylphenyl)ethynyl)-1,2-benziodoxol-3(1H)-one (9g)}

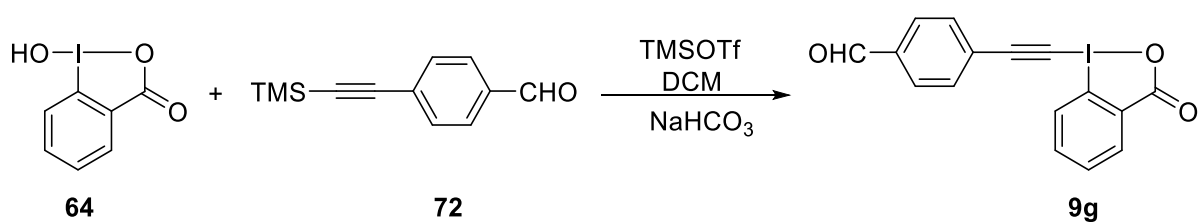

Following a reported procedure ${ }^{23}$ trimethylsilyl triflate $(0.89 \mathrm{~mL}, 4.9 \mathrm{mmol}, 1.1$ equiv) was added to a suspension of 2-iodosylbenzoic acid (64) (1.19 g, $4.49 \mathrm{mmol}, 1.00$ equiv) in $\mathrm{CH}_{2} \mathrm{Cl}_{2}$ (15 mL) at room temperature. The resulting suspension was stirred for $1 \mathrm{~h}$, followed by the drop wise addition of ((4formylphenyl)ethynyl)trimethylsilane (72) (1.00 g, $4.94 \mathrm{mmol}, 1.10$ equiv), which was dissolved in $\mathrm{CH}_{2} \mathrm{Cl}_{2}$ $(1 \mathrm{~mL})$. The resulting suspension was stirred for $6 \mathrm{~h}$. A saturated solution of $\mathrm{NaHCO}_{3}(2 \mathrm{~mL})$ was then added and the mixture was stirred vigorously for $30 \mathrm{~min}$, the two layers were separated and the organic layer was washed with saturated solution of $\mathrm{NaHCO}_{3}(20 \mathrm{~mL})$, dried over $\mathrm{MgSO}_{4}$, filtered and evaporated under reduced pressure. The resulting solid was boiled in $\mathrm{CH}_{3} \mathrm{CN}(20 \mathrm{~mL})$. The mixture was cooled down, filtered and dried under high vacuum to afford $9 \mathrm{~g}$ as a yellow solid $(0.80 \mathrm{~g}, 2.1 \mathrm{mmol}, 41 \%) .{ }^{1} \mathrm{H}$ NMR (400 MHz, DMSO- $d_{6}$ ): $\delta 10.08$ (s, 1H, CHO), 8.35 (d, J = 9.1 Hz, 1H, ArH), 8.14 (dd, J = 7.4, 1.7 Hz, 1H, ArH), 8.02 $(\mathrm{d}, J=8.5 \mathrm{~Hz}, 2 \mathrm{H}, \operatorname{ArH}), 7.96-7.88(\mathrm{~m}, 3 \mathrm{H}, \operatorname{ArH}), 7.82(\mathrm{t}, J=7.3 \mathrm{~Hz}, 1 \mathrm{H}, \operatorname{ArH}) ;{ }^{13} \mathrm{C} \mathrm{NMR}(101 \mathrm{MHz}, \mathrm{DMSO}-$ $\left.d_{6}\right): \delta 192.6,166.3,136.7,135.3,133.2,131.9,131.4,129.8,127.7,126.1,116.4,102.9,56.6$. The characterization data corresponded to the reported values. ${ }^{23}$

\section{1-[3-Fluorophenylethynyl]-1,2-benziodoxol-3(1H)-one (9h)}<smiles>O=C1OI(O)c2ccccc21</smiles>

64

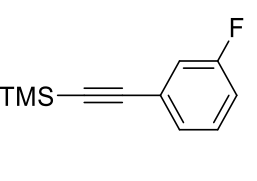

73

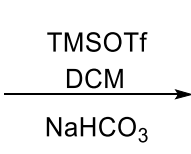

$\mathrm{NaHCO}_{3}$

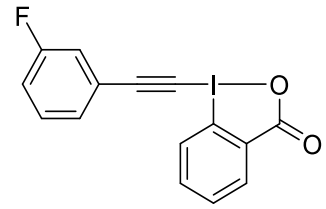

$9 \mathrm{~h}$

Following a reported procedure, ${ }^{20}$ trimethylsilyl triflate $(1.0 \mathrm{~mL}, 5.5 \mathrm{mmol}, 1.1$ equiv) was added to a suspension of 2-iodosylbenzoic acid (64) (1.32 g, $5.00 \mathrm{mmol}, 1.0$ equiv) in $\mathrm{CH}_{2} \mathrm{Cl}_{2}$ (15 mL) at room temperature. The resulting suspension was stirred for $1 \mathrm{~h}$, followed by the drop wise addition of ((3fluorophenyl)ethynyl)trimethylsilane (73) $(1.1 \mathrm{~mL}, 5.5 \mathrm{mmol}, 1.1$ equiv). The resulting suspension was

${ }^{23}$ H. Huang, G. Zhang, L. Gong, S. Zhang, Y. Chen, J. Am. Chem. Soc. 2014, 136, 2280. 
stirred for $6 \mathrm{~h}$. A saturated solution of $\mathrm{NaHCO}_{3}(20 \mathrm{~mL})$ was then added and the mixture was stirred vigorously for $30 \mathrm{~min}$, the two layers were separated and the organic layer was washed with saturated solution of $\mathrm{NaHCO}_{3}(20 \mathrm{~mL})$, dried over $\mathrm{MgSO}_{4}$, filtered and evaporated under reduced pressure. The resulting solid was boiled in $\mathrm{CH}_{3} \mathrm{CN}(20 \mathrm{~mL})$. The mixture was cooled down, filtered and the collected solid was dried under high vacuum to afford $9 \mathrm{~h}$ as a colorless solid (787 $\mathrm{mg}, 2.15 \mathrm{mmol}$, 43\%). M.p. (Dec.) $160-164{ }^{\circ} \mathrm{C} ;{ }^{1} \mathrm{H}$ NMR $\left(400 \mathrm{MHz}\right.$, DMSO- $d_{6}$ ): $\delta 8.33$ (dd, $\left.J=8.2,0.8 \mathrm{~Hz}, 1 \mathrm{H}, \mathrm{ArH}\right), 8.13(\mathrm{dd}, J=7.4$, 1.7 Hz, 1H, ArH), 7.91 (ddd, J = 8.2, 7.2, 1.7 Hz, 1H, ArH), 7.81 (td, J= 7.3, $0.9 \mathrm{~Hz}, 1 \mathrm{H}, \operatorname{ArH}), 7.64-7.59$ $(\mathrm{m}, 1 \mathrm{H}, \operatorname{ArH}), 7.58-7.53(\mathrm{~m}, 2 \mathrm{H}, \operatorname{Ar} H), 7.47-7.37(\mathrm{~m}, 1 \mathrm{H}, \operatorname{Ar} H) ;{ }^{13} \mathrm{C} N M R\left(101 \mathrm{MHz}\right.$, DMSO- $\left.d_{6}\right): \delta 166.3$, $161.8(d, J=245.6 \mathrm{~Hz}), 135.3,131.9,131.3,131.2(\mathrm{~d}, J=8.7 \mathrm{~Hz}), 129.0(\mathrm{~d}, J=2.9 \mathrm{~Hz}), 127.7,122.4$ (d, $J=$ $9.6 \mathrm{~Hz}), 119.2(\mathrm{~d}, J=23.4 \mathrm{~Hz}), 118.1(\mathrm{~d}, J=21.1 \mathrm{~Hz}), 116.4,102.5(\mathrm{~d}, J=3.3 \mathrm{~Hz}), 53.8 ;{ }^{19} \mathrm{~F} \mathrm{NMR}(376 \mathrm{MHz}$, DMSO- $d_{6}$ ): $\delta$-111.7; IR v $3477(w), 3334(w), 2380(w), 1644(s), 1457(m), 1339(w), 1252(w), 1146(m)$, $946(w), 840$ (w), $753(m), 2143(w)$; HRMS (ESI/QTOF) m/z: [M + H] ${ }^{+}$Calcd for $\mathrm{C}_{15} \mathrm{H}_{9} \mathrm{FIO}_{2}{ }^{+}$366.9626; Found 366.9625 . One carbon was not resolved at $100 \mathrm{MHz}$. The characterization data corresponded to the reported values. ${ }^{19}$

\section{1-[2-Methylphenylethynyl]-1,2-benziodoxol-3(1H)-one (9i)}

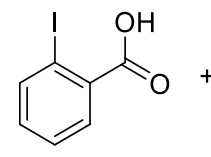

64

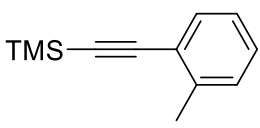

74 $\underset{\text { DCE:TFE, } \mathrm{NaHCO} 3}{\stackrel{m \mathrm{CPBA}, \mathrm{TsOH} . \mathrm{H}_{2} \mathrm{O}}{\longrightarrow}}$

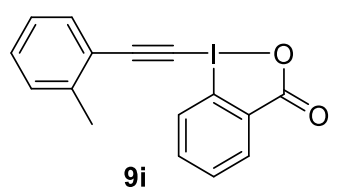

In a sealed tube, 2-iodobenzoic acid (64) (1.00 g, $4.03 \mathrm{mmol}, 1.00$ equiv), 4-methylbenzenesulfonic acid (775 mg, $4.03 \mathrm{mmol}, 1.00$ equiv) and meta-chloroperoxybenzoic acid (mCPBA-70\%, $994 \mathrm{mg}, 4.44 \mathrm{mmol}$, 1.10 equiv) were suspended in DCE:TFE 1:1 $(12 \mathrm{~mL})$ and stirred for $1 \mathrm{~h}$ at $55^{\circ} \mathrm{C}$. After $1 \mathrm{~h}$, trimethyl(otolylethynyl)silane (74) $\left(1.2 \mathrm{~mL}, 5.6 \mathrm{mmol}, 1.4\right.$ equiv) was added and the reaction was stirred at $55^{\circ} \mathrm{C}$ for $24 \mathrm{~h}$. After $24 \mathrm{~h}$, the solvent was evaporated and the residue was redissolved in $\mathrm{CH}_{2} \mathrm{Cl}_{2}(20 \mathrm{~mL})$ and stirred vigorously with saturated $\mathrm{NaHCO}_{3}$ solution $(30 \mathrm{~mL}$ ). After $1 \mathrm{~h}$, the reaction mixture was transferred into a separating funnel and the layers were separated. The aqueous layer was extracted with $\mathrm{CH}_{2} \mathrm{Cl}_{2}(2 \times 50 \mathrm{~mL})$. The combined organic layers were washed with saturated $\mathrm{NaHCO}_{3}$ solution, dried over $\mathrm{MgSO}_{4}$, filtered and concentrated under vacuum. The residue was purified by flash column chromatography using EtOAc to afford $9 \mathrm{i}$ as a pale yellow solid $(0.4 \mathrm{~g}, 1.1 \mathrm{mmol}, 28 \%)$. TLC (EtOAc): $R_{f}=$ $0.21, \mathrm{KMnO}_{4} ;{ }^{1} \mathrm{H}$ NMR $\left(400 \mathrm{MHz}, \mathrm{CDCl}_{3}\right): \delta 8.47-8.36(\mathrm{~m}, 1 \mathrm{H}, \mathrm{ArH}), 8.32-8.22(\mathrm{~m}, 1 \mathrm{H}, \mathrm{ArH}), 7.82-7.68$ (m, 2H, ArH), $7.56(\mathrm{dd}, J=7.7,1.4 \mathrm{~Hz}, 1 \mathrm{H}, \operatorname{ArH}), 7.37(\mathrm{td}, J=7.6,1.4 \mathrm{~Hz}, 1 \mathrm{H}, \operatorname{ArH}), 7.30(\mathrm{~d}, J=7.7 \mathrm{~Hz}, 1 \mathrm{H}$, $\operatorname{ArH}), 7.27-7.21(\mathrm{~m}, 1 \mathrm{H}, \mathrm{ArH}), 2.53\left(\mathrm{~s}, 3 \mathrm{H}, \mathrm{ArCH}_{3}\right) ;{ }^{13} \mathrm{C} \mathrm{NMR}\left(100 \mathrm{MHz}, \mathrm{CDCl}_{3}\right): \delta 166.6,141.9,134.8$, $133.4,132.5,131.5,131.4,130.7,129.9,126.2,126.0,120.4,116.3,105.7,53.2,20.8$. The characterization data corresponded to the reported values. ${ }^{20}$ 


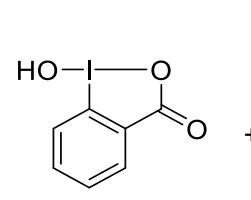

64

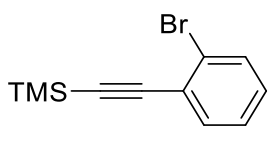

75

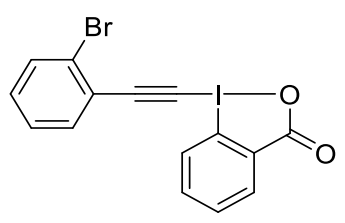

9j

Following a reported procedure,${ }^{21}$ trimethylsilyl triflate $(1.0 \mathrm{~mL}, 5.5 \mathrm{mmol}, 1.1$ equiv) was added to a suspension of 2-iodosylbenzoic acid (64) (1.32 g, 5.00 mmol, 1.00 equiv) in $\mathrm{CH}_{2} \mathrm{Cl}_{2}$ (15 mL) at room temperature. The resulting suspension was stirred for $1 \mathrm{~h}$, followed by the drop wise addition of ((2bromophenyl)ethynyl)trimethylsilane (75) (1.17 g, $5.50 \mathrm{mmol}, 1.10$ equiv). The resulting suspension was stirred for $6 \mathrm{~h}$ at room temperature. A saturated solution of $\mathrm{NaHCO}_{3}(20 \mathrm{~mL})$ was then added and the mixture was stirred vigorously for $30 \mathrm{~min}$, the two layers were separated and the organic layer was washed with saturated solution of $\mathrm{NaHCO}_{3}(20 \mathrm{~mL})$, dried over $\mathrm{MgSO}_{4}$, filtered and evaporated under reduced pressure. The resulting solid was boiled in $\mathrm{CH}_{3} \mathrm{CN}$ (ca $20 \mathrm{~mL}$ ). The mixture was cooled down, filtered and dried under high vacuum to afford $9 \mathrm{j}$ as a white solid $(1.50 \mathrm{~g}, 3.51 \mathrm{mmol}, 70 \%)$. Mp (Dec.): 174.0-177.0 ${ }^{\circ} \mathrm{C} ;{ }^{1} \mathrm{H}$ NMR $\left(400 \mathrm{MHz}, \mathrm{CDCl}_{3}\right): \delta 8.44(\mathrm{td}, J=7.3,2.1 \mathrm{~Hz}, 2 \mathrm{H}, \mathrm{ArH}), 7.84-7.74(\mathrm{~m}, 2 \mathrm{H}, \mathrm{ArH})$, $7.68(\mathrm{~d}, J=1.1 \mathrm{~Hz}, 1 \mathrm{H}, \operatorname{ArH}), 7.61(\mathrm{dd}, J=7.6,1.7 \mathrm{~Hz}, 1 \mathrm{H}, \operatorname{ArH}), 7.36(\mathrm{dtd}, J=22.4,7.5,1.5 \mathrm{~Hz}, 2 \mathrm{H}, \operatorname{ArH})$; ${ }^{13} \mathrm{C} \mathrm{NMR}\left(100 \mathrm{MHz}, \mathrm{CDCl}_{3}\right): \delta 166.6,135.2,134.7,133.0,132.7,131.8,131.3,127.6,126.8,126.4,123.2$, 116.5, 104.3, 55.4; IR v 2358 (w), 2155 (w), 1638 (s), $1616(m), 1585$ (w), 1466 (w), $1316(m), 1147(w)$. The characterization data corresponded to the reported values. ${ }^{21}$

\section{Propynyl-1,2-benziodoxol-3(1H)-one (9k)}

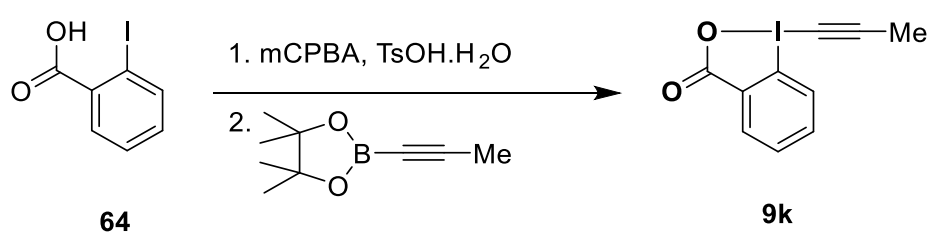

Following a reported procedure, ${ }^{24}$ 2-iodobenzoic acid (64) $(1.07 \mathrm{~g}, 4.30 \mathrm{mmol}, 1.00$ equiv), paratoluenesulfonic acid monohydrate $\left(\mathrm{TsOH} \cdot \mathrm{H}_{2} \mathrm{O}, 818 \mathrm{mg}, 4.30 \mathrm{mmol}, 1.00\right.$ equiv) and metachloroperoxybenzoic acid (mCPBA-70\%, $1.17 \mathrm{~g}, 4.73 \mathrm{mmol}, 1.10$ equiv) were dissolved in $\mathrm{CH}_{2} \mathrm{Cl}_{2}(7 \mathrm{~mL})$ and 2,2,2-trifluoroethanol $(7 \mathrm{~mL})$. The mixture was stirred at room temperature under nitrogen for $1 \mathrm{~h}$, after which propynyl-1-boronic acid pinacol ester ( $4.85 \mathrm{~g}, 21.2 \mathrm{mmol}, 1.40$ equiv) was added in one portion. The reaction mixture was stirred for $2.5 \mathrm{~h}$ at room temperature, filtered and concentrated in vacuo. The resulting oil was dissolved in $\mathrm{CH}_{2} \mathrm{Cl}_{2}(30 \mathrm{~mL})$ and under vigorous stirring, saturated aq.

${ }^{24}$ R. Frei, M. D. Wodrich, D. P. Hari, P. A. Borin, C. Chauvier, J. Waser, J. Am. Chem. Soc. 2014, 136, 16563. 
$\mathrm{NaHCO}_{3}(30 \mathrm{~mL})$ was added. The mixture was stirred for $15 \mathrm{~min}$, the two layers were separated and the aqueous phase was extracted with additional portions of $\mathrm{CH}_{2} \mathrm{Cl}_{2}(3 \times 25 \mathrm{~mL})$. The combined organic layers were washed with brine $(25 \mathrm{~mL})$, dried over $\mathrm{MgSO}_{4}$, filtered and concentrated in vacuo. The crude product was purified by flash column chromatography using ethyl acetate to afford $\mathbf{9 k}$ as a white solid (1.03 g, $3.60 \mathrm{mmol}, 84 \%)$. TLC (EtOAC): $\mathrm{R}_{\mathrm{f}}=0.10, \mathrm{KMnO}_{4} ; \mathrm{Mp}$ (Dec) $124-150{ }^{\circ} \mathrm{C} ;{ }^{1} \mathrm{H} \mathrm{NMR}\left(\mathrm{CDCl}_{3}, 400 \mathrm{MHz}\right):$ ठ 8.41-8.35 (m, $1 \mathrm{H}, \mathrm{ArH}), 8.22-8.14(\mathrm{~m}, 1 \mathrm{H}, \mathrm{ArH}), 7.79-7.68(\mathrm{~m}, 2 \mathrm{H}, \mathrm{ArH}), 2.27\left(\mathrm{~s}, 3 \mathrm{H}, \mathrm{CCCH}_{3}\right) ;{ }^{13} \mathrm{C} \mathrm{NMR}$ $\left(\mathrm{CDCl}_{3}, 100 \mathrm{MHz}\right): \delta$ 166.7, 134.8, 132.5, 131.6, 126.4, 115.6, 105.1, 39.0, 5.7. IR v 2183 (w), 1607 (s), $1559(\mathrm{~m}), 1350(\mathrm{~m}), 746(\mathrm{~m}), 730(\mathrm{~m})$. HRMS (ESI) $\mathrm{C}_{10} \mathrm{H}_{8} \mathrm{IO}_{2}{ }^{+}[\mathrm{M}+\mathrm{H}]^{+}$calc. $=286.9564 ;[\mathrm{M}+\mathrm{H}]^{+}$obs. $=$ 286.9561. The characterization data corresponded to the reported values. ${ }^{24}$

\section{Hexadecynyl-1,2-benziodoxol-3(1H)-one (9l)}

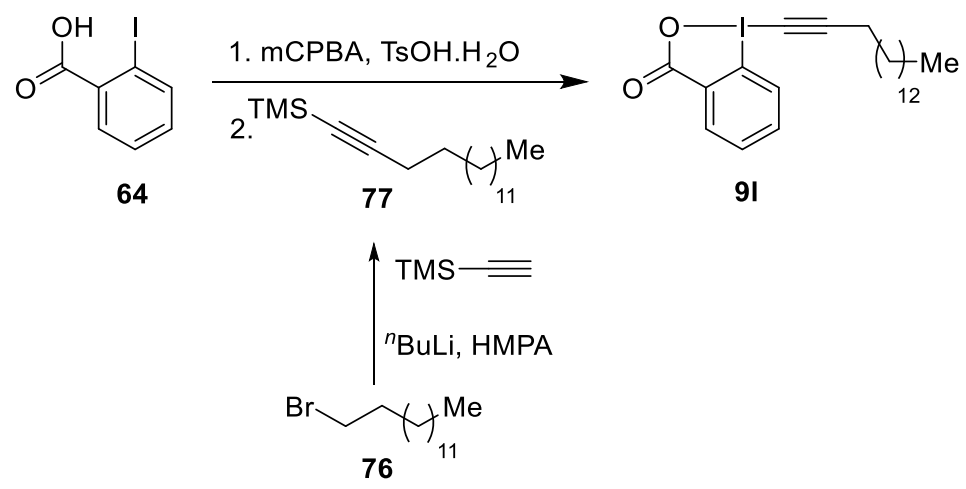

Following a reported procedure, ${ }^{24}$ to a mixture of trimethylsilylacetylene $(8.33 \mathrm{~g}, 85.0 \mathrm{mmol}, 1.20$ equiv) and dry THF (46 mL) was added at $-78{ }^{\circ} \mathrm{C}$ under nitrogen $2.5 \mathrm{M}{ }^{n} \mathrm{BuLi}$ in hexanes $(33.9 \mathrm{~mL}, 85.0 \mathrm{mmol}$, 1.20 equiv) over $10 \mathrm{~min}$. The resulting light yellow solution was stirred at $-78{ }^{\circ} \mathrm{C}$ for $1 \mathrm{~h}$, after which a mixture consisting of 1-bromotetradecane (76) $(19.6 \mathrm{~g}, 70.7 \mathrm{mmol}, 1.00$ equiv), hexamethylphosphoramide (HMPA, $14.2 \mathrm{~mL}, 78.0 \mathrm{mmol}, 1.10$ equiv) and dry THF (23 mL) was slowly added via cannula over $20 \mathrm{~min}$. The reaction mixture was stirred for $1 \mathrm{~h}$ at $-78^{\circ} \mathrm{C}$, followed by $24 \mathrm{~h}$ of stirring at room temperature. The reaction was quenched at $0{ }^{\circ} \mathrm{C}$ with saturated aq. $\mathrm{NH}_{4} \mathrm{Cl}(50 \mathrm{~mL})$ and diluted with water $(10 \mathrm{~mL})$ and EtOAc $(50 \mathrm{~mL})$. The two layers were separated and the aq. layer was extracted with additional portions of EtOAc $(3 \times 50 \mathrm{~mL})$. The combined organic layers were washed with water $(2 \times 100 \mathrm{~mL})$, brine $(100 \mathrm{~mL})$, dried over $\mathrm{MgSO}_{4}$, filtered and concentrated in vacuo. The light brown crude liquid was finally pushed through a small plug of silica gel with pentane as eluent to afford pure hexadec-1-yn-1-yltrimethylsilane (77) as a colorless liquid (19.3 g, $65.5 \mathrm{mmol}, 92.7 \%$ yield). TLC (pentane): $\mathrm{R}_{\mathrm{f}}=0.78, \mathrm{KMnO}_{4} ;{ }^{1} \mathrm{H}$ NMR $\left(\mathrm{CDCl}_{3}, 400 \mathrm{MHz}\right): \delta 2.19\left(\mathrm{t}, J=7.1 \mathrm{~Hz}, 2 \mathrm{H}, \mathrm{CCCH}_{2}\right), 1.54-1.44(\mathrm{~m}$, $\left.2 \mathrm{H}, \mathrm{CH}_{2}\right), 1.42-1.18\left(\mathrm{~m}, 22 \mathrm{H}, \mathrm{CH}_{2}\right), 0.87\left(\mathrm{t}, \mathrm{J}=6.7 \mathrm{~Hz}, 3 \mathrm{H}, \mathrm{CH}_{2} \mathrm{CH}_{3}\right), 0.13(\mathrm{~s}, 9 \mathrm{H}, \mathrm{TMS}) ;{ }^{13} \mathrm{C} \mathrm{NMR}\left(\mathrm{CDCl}_{3}, 100\right.$ MHz): $\delta$ 107.7, 84.3, 32.2, 29.9, 29.8, 29.7, 29.6, 29.3, 29.0, 28.9, 22.9, 20.0, 14.3, 0.3; IR v 2924 (m), 
$2854(m), 2175(w), 1461(w), 1249(w), 910(w), 841(s), 761(w), 736(m)$. The characterization data corresponded to the reported values. ${ }^{24}$

Following a reported procedure, ${ }^{24}$ 2-iodobenzoic acid (64) $(8.00 \mathrm{~g}, 32.2 \mathrm{mmol}, 1.00$ equiv), paratoluenesulfonic acid monohydrate ( $\mathrm{TsOH} . \mathrm{H}_{2} \mathrm{O}, 6.13 \mathrm{~g}, 32.2 \mathrm{mmol}, 1.00$ equiv) and metachloroperoxybenzoic acid (mCPBA-70\%, $8.74 \mathrm{~g}, 35.5 \mathrm{mmol}, 1.10$ equiv) were dissolved in $\mathrm{CH}_{2} \mathrm{Cl}_{2}(60 \mathrm{~mL})$ and 2,2,2-trifluoroethanol (60 $\mathrm{mL}$ ). The mixture was stirred at room temperature under nitrogen for 1 h, after which hexadec-1-yn-1-yltrimethylsilane (77) (13.3 g, $45.1 \mathrm{mmol}, 1.40$ equiv) was added in one portion. The reaction mixture was stirred for $14 \mathrm{~h}$ at room temperature, filtered and concentrated in vacuo. The resulting oil was dissolved in $\mathrm{CH}_{2} \mathrm{Cl}_{2}(400 \mathrm{~mL})$ and under vigorous stirring, saturated solution of $\mathrm{NaHCO}_{3}(400 \mathrm{~mL})$ was added. The mixture was stirred for $1 \mathrm{~h}$, the two layers were separated and the aqueous layer was extracted with additional portions of $\mathrm{CH}_{2} \mathrm{Cl}_{2}(3 \times 100 \mathrm{~mL})$. The combined organic layers were dried over $\mathrm{MgSO}_{4}$, filtered and concentrated in vacuo. The crude product was purified by flash column chromatography using EtOAc to afford $9 \mathrm{l}$ as a white solid $(6.02 \mathrm{~g}, 12.9 \mathrm{mmol}, 40 \%)$. TLC (EtOAc): $\mathrm{R}_{\mathrm{f}}=0.36, \mathrm{KMnO}_{4} ; \mathrm{Mp}: 102.6-105.3{ }^{\circ} \mathrm{C} ;{ }^{1} \mathrm{H}$ NMR ( $\left.\mathrm{CDCl}_{3}, 400 \mathrm{MHz}\right): \delta$ 8.44-8.37 (m, $\left.1 \mathrm{H}, \mathrm{ArH}\right), 8.21-8.14$ $(\mathrm{m}, 1 \mathrm{H}, \mathrm{ArH}), 7.80-7.70(\mathrm{~m}, 2 \mathrm{H}, \mathrm{ArH}), 2.59\left(\mathrm{t}, J=7.1 \mathrm{~Hz}, 2 \mathrm{H}, \mathrm{CCCH}_{2}\right), 1.65\left(\mathrm{p}, J=7.1 \mathrm{~Hz}, 2 \mathrm{H}, \mathrm{CCCH}_{2} \mathrm{CH}_{2}\right)$, 1.52-1.40 (m, 2H), 1.39-1.19 (m, 20H, $\left.\mathrm{CH}_{2}\right), 0.86\left(\mathrm{t}, J=6.7 \mathrm{~Hz}, 3 \mathrm{H}, \mathrm{CH}_{2} \mathrm{CH}_{3}\right) ;{ }^{13} \mathrm{C} \mathrm{NMR}\left(\mathrm{CDCl}_{3}, 100 \mathrm{MHz}\right): \delta$ 166.6, 134.7, 132.5, 131.7, 131.6, 126.2, 115.7, 109.9, 39.5, 32.1, 29.8, 29.7, 29.6, 29.5, 29.2, 29.1, 28.3, 22.8, 20.6, 14.3; IR $v 2924(\mathrm{~s}), 2853(\mathrm{~m}), 2166(\mathrm{w}), 1649(\mathrm{~m}), 1623(\mathrm{~m}), 1439(\mathrm{w}), 908(\mathrm{~m}), 736$ (s). The characterization data corresponded to the reported values. ${ }^{24}$

\section{(5-Chloropent-1-ynyl)-1,2-benziodoxol-3(1H)-one (9m)}

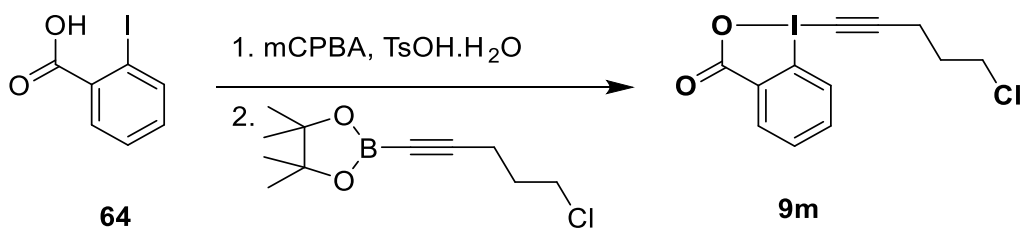

Following a reported procedure, ${ }^{24}$ 2-iodobenzoic acid (64) (3.76 g, $15.2 \mathrm{mmol}, 1.00$ equiv), paratoluenesulfonic acid monohydrate ( $\mathrm{TsOH} . \mathrm{H}_{2} \mathrm{O}, 2.88 \mathrm{~g}, 15.2 \mathrm{mmol}, 1.00$ equiv) and metachloroperoxybenzoic acid (mCPBA-70\%, $4.11 \mathrm{~g}, 16.7 \mathrm{mmol}, 1.10$ equiv) were dissolved in $\mathrm{CH}_{2} \mathrm{Cl}_{2}(30 \mathrm{~mL})$ and 2,2,2-trifluoroethanol ( $30 \mathrm{~mL}$ ). The mixture was stirred at room temperature under nitrogen for 1 h, after which 5-chloro-1-pentynyl-1-boronic acid pinacol ester ( $4.85 \mathrm{~g}, 21.2 \mathrm{mmol}, 1.40$ equiv) was added in one portion. The reaction mixture was stirred for $90 \mathrm{~min}$ at room temperature, filtered and concentrated in vacuo. The resulting oil was dissolved in $\mathrm{CH}_{2} \mathrm{Cl}_{2}(15 \mathrm{~mL})$ and under vigorous stirring, saturated solution of $\mathrm{NaHCO}_{3}(15 \mathrm{~mL})$ was added. The mixture was stirred for $10 \mathrm{~min}$, the two layers were separated and the aqueous layer was extracted with additional portions of $\mathrm{CH}_{2} \mathrm{Cl}_{2}(3 \times 15 \mathrm{~mL})$. The 
combined organic layers were dried over $\mathrm{MgSO}_{4}$, filtered and concentrated in vacuo. The crude product was purified by flash column chromatography using ethyl acetate to afford $9 \mathrm{~m}$ as a white solid $(3.76 \mathrm{~g}$, $10.8 \mathrm{mmol}, 71 \%)$. TLC (EtOAc): $\mathrm{R}_{\mathrm{f}}=0.15, \mathrm{KMnO}_{4} ; \mathrm{Mp}: 138.5-141.7^{\circ} \mathrm{C} ;{ }^{1} \mathrm{H} \mathrm{NMR}\left(\mathrm{CDCl}_{3}, 400 \mathrm{MHz}\right): \delta 8.41-$ $8.34(\mathrm{~m}, 1 \mathrm{H}, \mathrm{ArH}), 8.22-8.13(\mathrm{~m}, 1 \mathrm{H}, \mathrm{ArH}), 7.82-7.68(\mathrm{~m}, 2 \mathrm{H}, \mathrm{ArH}), 3.71\left(\mathrm{t}, J=6.1 \mathrm{~Hz}, 2 \mathrm{H}, \mathrm{ClCH}_{2} \mathrm{CH}_{2}\right), 2.82$ $\left(\mathrm{t}, J=6.9 \mathrm{~Hz}, 2 \mathrm{H}, \mathrm{CCCH}_{2} \mathrm{CH}_{2}\right), 2.18-2.05\left(\mathrm{~m}, 2 \mathrm{H}, \mathrm{ClCH}_{2} \mathrm{CH}_{2}\right) ;{ }^{13} \mathrm{C} \mathrm{NMR}\left(\mathrm{CDCl}_{3}, 100 \mathrm{MHz}\right): \delta 166.8,134.9$, 132.5, 131.6, 131.6, 126.4, 115.8, 107.1, 43.4, 41.2, 30.7, 18.0; IR v 2942 (w), 2866 (w), 2171 (w), 2091 (w), $1727(w), 1617$ (s), $1556(w), 1441(w), 1339(m), 1213(w), 1023(w), 846(w), 742$ (s). The characterization data corresponded to the reported values. ${ }^{24}$

\section{8-(Trimethylsilyl)octa-1,7-diyn-1-yl-1,2-benziodoxol-3(1H)-one (9n)}

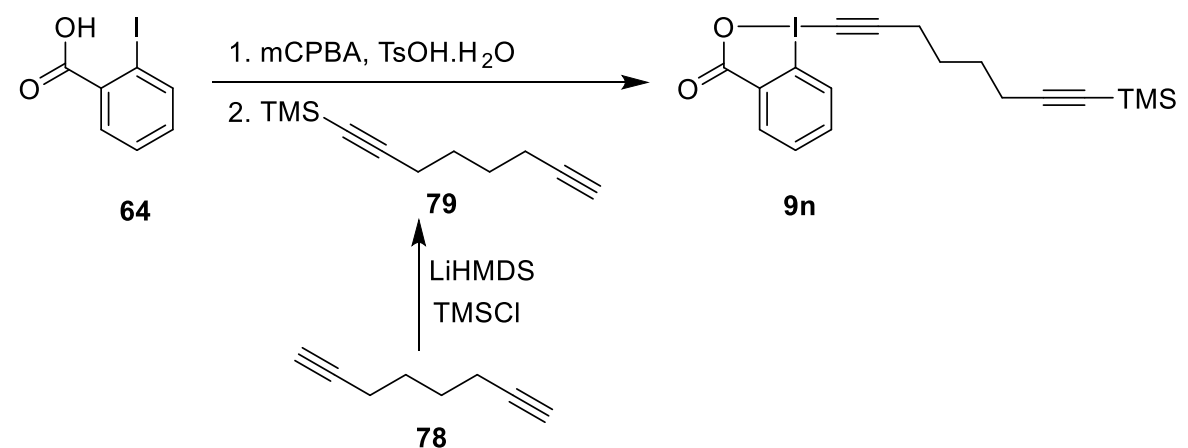

Following a reported procedure, ${ }^{25}$ to a solution of 1,7-octadiyne 78 (10.6 g, $100 \mathrm{mmol}, 1.00$ equiv) in dry THF (150 mL) was added at $-78^{\circ} \mathrm{C}$ under nitrogen $1 \mathrm{M}$ lithium bis(trimethylsilyl)amide in THF (LiHMDS, $100 \mathrm{~mL}, 100 \mathrm{mmol}, 1.00$ equiv). The solution was stirred at $-78^{\circ} \mathrm{C}$ for $30 \mathrm{~min}$, after which trimethylsilyl chloride (TMSCl, $13.0 \mathrm{~mL}, 100 \mathrm{mmol}, 1.00$ equiv) was added dropwise. The reaction was warmed to room temperature and stirred for $2 \mathrm{~h}$. The reaction was cooled to $0{ }^{\circ} \mathrm{C}$ and quenched by adding water $(10 \mathrm{~mL})$. The mixture was diluted with $1 \mathrm{M} \mathrm{HCl}(200 \mathrm{~mL})$ and extracted with diethyl ether $(100 \mathrm{~mL}$ and 2 x $75 \mathrm{~mL}$ ). The combined organic layers were washed with brine $(200 \mathrm{~mL})$, dried over $\mathrm{MgSO}_{4}$, filtered and concentrated in vacuo. The crude product was purified by vacuum distillation using a $20 \mathrm{~cm}$ Vigreux column (oil bath set to $98{ }^{\circ} \mathrm{C}$ at $0.3 \mathrm{mbar}$ ) furnishing pure trimethyl(octa-1,7-diyn-1-yl)silane (79) as a colorless liquid ( $8.37 \mathrm{~g}, 46.9 \mathrm{mmol}, 47 \%)$. TLC (pentane): $\mathrm{R}_{\mathrm{f}}=0.2, \mathrm{KMnO}_{4} ;{ }^{1} \mathrm{H} \mathrm{NMR}\left(\mathrm{CDCl}_{3}, 400 \mathrm{MHz}\right): \delta$ 2.28-2.17 (m, 4H), $1.93(\mathrm{t}, J=2.7 \mathrm{~Hz}, 1 \mathrm{H}, \mathrm{CCH}), 1.68-1.57(\mathrm{~m}, 4 \mathrm{H}), 0.13(\mathrm{~s}, 9 \mathrm{H}, \mathrm{TMS}) ;{ }^{13} \mathrm{C} \mathrm{NMR}\left(\mathrm{CDCl}_{3}, 100\right.$ MHz): $\delta$ 107.0, 84.9, 84.2, 68.6, 27.7, 27.6, 19.5, 18.1, 0.3; IR v 3309 (w), 2951 (w), 2175 (w), 1250 (m), $912(w), 841(s), 761(m), 734(m)$. The characterization data corresponded to the reported values. ${ }^{25}$

Following a reported procedure ${ }^{25}$ 2-iodobenzoic acid (64) $(8.43 \mathrm{~g}, 33.3 \mathrm{mmol}, 1.00$ equiv), paratoluenesulfonic acid monohydrate ( $\mathrm{TsOH} . \mathrm{H}_{2} \mathrm{O}, 6.40 \mathrm{~g}, 33.3 \mathrm{mmol}, 1.00$ equiv) and metachloroperoxybenzoic acid (mCPBA-70\%, $9.04 \mathrm{~g}, 36.7 \mathrm{mmol}, 1.10$ equiv) were dissolved in $\mathrm{CH}_{2} \mathrm{Cl}_{2}(60 \mathrm{~mL})$

${ }^{25}$ D. P. Hari, J. Waser, J. Am. Chem. Soc. 2016, 138, 2190. 
and 2,2,2-trifluoroethanol (60 $\mathrm{mL}$ ). The mixture was stirred at room temperature under nitrogen for 1 h, after which trimethyl(octa-1,7-diyn-1-yl)silane (79) (8.32 g, $46.7 \mathrm{mmol}, 1.40$ equiv) was added. The reaction mixture was stirred for $15 \mathrm{~h}$ at room temperature and then filtered and concentrated in vacuo. The resulting light being solid was dissolved in $\mathrm{CH}_{2} \mathrm{Cl}_{2}(500 \mathrm{~mL})$ and under vigorous stirring, saturated solution of $\mathrm{NaHCO}_{3}(500 \mathrm{~mL}$ ) was added. The mixture was stirred for $1 \mathrm{~h}$, the two layers were separated and the aqueous layer was extracted with additional portions of $\mathrm{CH}_{2} \mathrm{Cl}_{2}(3 \times 150 \mathrm{~mL})$. The combined organic layers were dried over $\mathrm{MgSO}_{4}$, filtered and concentrated in vacuo. The crude product was purified by flash column chromatography using ethyl acetate to afford $9 \mathrm{n}$ as a white solid $(4.2 \mathrm{~g}, 9.9$ mmol, 30\%). Mp: 152.3-155.6 ${ }^{\circ} \mathrm{C}$; TLC (EtOAc:MeOH, 9:1 v/v): $\mathrm{R}_{\mathrm{f}}=0.59, \mathrm{KMnO}_{4} ;{ }^{1} \mathrm{H}$ NMR $\left(\mathrm{CDCl}_{3}, 400\right.$ MHz): $\delta 8.37$ (dd, $J=6.7,2.3 \mathrm{~Hz}, 1 \mathrm{H}, \mathrm{ArH}), 8.17(\mathrm{dd}, J=7.8,1.5 \mathrm{~Hz}, 1 \mathrm{H}, \mathrm{ArH}), 7.82-7.66(\mathrm{~m}, 2 \mathrm{H}, \mathrm{ArH}), 2.63$ $\left.(\mathrm{t}, J=6.8 \mathrm{~Hz}, 2 \mathrm{H}),, 2.29(\mathrm{t}, J=6.7 \mathrm{~Hz}, 2 \mathrm{H}), 1.83-1.62(\mathrm{~m}, 4 \mathrm{H}), 0.13(\mathrm{~s}, 9 \mathrm{H}, \mathrm{TMS}) ;{ }^{13} \mathrm{C} \mathrm{NMR}_{(\mathrm{CDCl}}, 100 \mathrm{MHz}\right)$ : $\delta$ 166.7, 134.8, 132.4, 131.7, 131.5, 126.3, 115.7, 109.1, 106.4, 85.4, 40.0, 27.7, 27.3, 20.2, 19.4, 0.3; IR v $2955(w), 2170(w), 1647(m), 1621(s), 1439(w), 1329(m), 1296(w), 1249(m), 840(s), 746(s)$. The characterization data corresponded to the reported values. ${ }^{25}$

\section{2-Cyclopropylethynyl-1,2-benziodoxol-3(1H)-one (9o)}

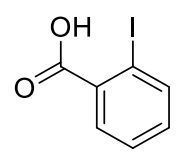

64

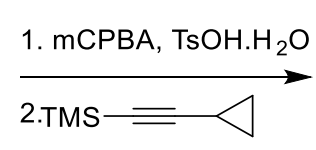

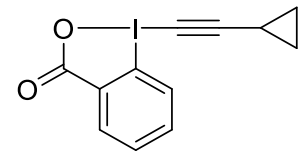

90

Following a reported procedure, ${ }^{25}$ 2-iodobenzoic acid (64) (6.41 g, $25.8 \mathrm{mmol}, 1.00$ equiv), paratoluenesulfonic acid monohydrate $\left(\mathrm{TsOH} \cdot \mathrm{H}_{2} \mathrm{O}, 4.91 \mathrm{~g}, 25.8 \mathrm{mmol}, 1.00\right.$ equiv) and metachloroperoxybenzoic acid (mCPBA-70\%, $7.00 \mathrm{~g}, 28.4 \mathrm{mmol}, 1.10$ equiv) were dissolved in $\mathrm{CH}_{2} \mathrm{Cl}_{2}(48 \mathrm{~mL}$ ) and 2,2,2-trifluoroethanol ( $48 \mathrm{~mL}$ ). The mixture was stirred at room temperature under nitrogen for 1 h, after which (cyclopropylethynyl)trimethylsilane (5.00 g, $36.2 \mathrm{mmol}, 1.40$ equiv) was added in one portion. The reaction mixture was stirred for $12 \mathrm{~h}$ at room temperature, filtered and concentrated in vacuo. The resulting oil was dissolved in $\mathrm{CH}_{2} \mathrm{Cl}_{2}(400 \mathrm{~mL})$ and under vigorous stirring, a saturated solution of $\mathrm{NaHCO}_{3}(400 \mathrm{~mL})$ was added. The mixture was stirred for $1 \mathrm{~h}$, the two layers were separated and the aqueous layer was extracted with additional portions of $\mathrm{CH}_{2} \mathrm{Cl}_{2}(3 \times 100 \mathrm{~mL})$. The combined organic layers were dried over $\mathrm{MgSO}_{4}$, filtered and concentrated in vacuo. The crude product was purified by flash column chromatography using ethyl acetate to afford 90 as a white solid $(2.11 \mathrm{~g}, 6.76 \mathrm{mmol}, 26 \%)$. Mp (Dec.): $174.2-177.6^{\circ} \mathrm{C}$; TLC (EtOAc:MeOH, 9:1 v/v): $\mathrm{R}_{\mathrm{f}}=0.46, \mathrm{KMnO}_{4} ;{ }^{1} \mathrm{H} \mathrm{NMR}\left(\mathrm{CDCl}_{3}, 400 \mathrm{MHz}\right): \delta 8.34$ (dd, J = 7.0, 2.1 Hz, 1H, ArH), 8.18-8.09 (m, 1H, ArH), 7.81-7.63 (m, 2H, ArH), $1.59(\mathrm{tt}, J=8.2,5.0 \mathrm{~Hz}, 1 \mathrm{H}$, $\mathrm{CH}), 1.07-0.85\left(\mathrm{~m}, 4 \mathrm{H}, \mathrm{CH}_{2} \mathrm{CH}_{2}\right) ;{ }^{13} \mathrm{C} \mathrm{NMR}\left(\mathrm{CDCl}_{3}, 100 \mathrm{MHz}\right): \delta$ 166.7, 134.7, 132.3, 131.7, 131.4, 126.2, 115.9, 113.3, 35.0, 9.8, 1.1; IR v $3464(w), 3077$ (w), 3012 (w), 2238 (w), 2159 (m), 1607 (s), $1559(m)$, 
$1438(\mathrm{~m}), 1338(\mathrm{~m}), 1298(\mathrm{~m}), 833(\mathrm{~m}), 744(\mathrm{~s}), 691(\mathrm{~m})$. The characterization data corresponded to the reported values..$^{25}$

\section{2-Cyclopentylethynyl-1,2-benziodoxol-3(1H)-one (9p)}<smiles>O=C(O)c1ccccc1I</smiles>

64

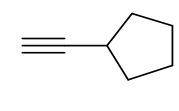

80

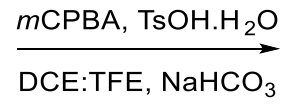

DCE:TFE, $\mathrm{NaHCO}_{3}$

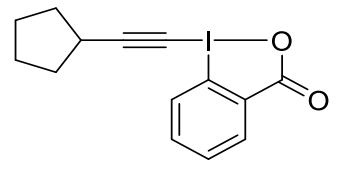

$9 p$

In a sealed tube, 2-iodobenzoic acid (64) (1.00 g, $4.03 \mathrm{mmol}, 1.00$ equiv), 4-methylbenzenesulfonic acid (775 mg, $4.03 \mathrm{mmol}, 1.00$ equiv) and mCPBA (77\%, $994 \mathrm{mg}, 4.44 \mathrm{mmol}, 1.10$ equiv) were suspended in DCE:TFE 1:1 (12 mL) and stirred for $1 \mathrm{~h}$ at $55^{\circ} \mathrm{C}$. After $1 \mathrm{~h}$, ethynylcyclopentane (80) (0.65 mL, $5.6 \mathrm{mmol}$, 1.4 equiv) was added and the reaction was stirred at $55{ }^{\circ} \mathrm{C}$ for $24 \mathrm{~h}$. After $24 \mathrm{~h}$, the solvent was evaporated and the residue was redissolved in $\mathrm{CH}_{2} \mathrm{Cl}_{2}(20 \mathrm{~mL})$ and stirred vigorously with saturated solution of $\mathrm{NaHCO}_{3}(30 \mathrm{~mL})$. After $1 \mathrm{~h}$, the reaction mixture was transferred into a separating funnel and the layers were separated. The aqueous layer was extracted with $\mathrm{CH}_{2} \mathrm{Cl}_{2}(2 \times 50 \mathrm{~mL})$. The combined organic layers were washed with saturated solution of $\mathrm{NaHCO}_{3}(50 \mathrm{~mL})$, dried over $\mathrm{MgSO}_{4}$, filtered and concentrated under vacuum. The crude product was purified by flash column chromatography using ethyl acetate to afford $9 \mathrm{p}$ as a white solid (0.95 g, $2.8 \mathrm{mmol}, 70 \%)$. Mp (Dec.): 151.5-156.6 ${ }^{\circ} \mathrm{C}$; TLC (EtOAc): $\mathrm{R}_{\mathrm{f}}=0.21, \mathrm{KMnO}_{4} ;{ }^{1} \mathrm{H} \mathrm{NMR}\left(400 \mathrm{MHz}, \mathrm{CDCl}_{3}\right): \delta 8.42-8.34(\mathrm{~m}, 1 \mathrm{H}, \mathrm{ArH}), 8.14(\mathrm{dd}, J=7.4,1.8 \mathrm{~Hz}$, $1 \mathrm{H}, \mathrm{ArH}), 7.79-7.67(\mathrm{~m}, 2 \mathrm{H}, \mathrm{ArH}), 3.05-2.92(\mathrm{~m}, 1 \mathrm{H}, \mathrm{CCCH}), 2.10-2.00\left(\mathrm{~m}, 2 \mathrm{H}, 1 \times \mathrm{CH}_{2}\right), 1.85-1.70$ $\left(\mathrm{m}, 4 \mathrm{H}, 2 \times \mathrm{CH}_{2}\right), 1.69-1.62\left(\mathrm{~m}, 2 \mathrm{H}, \mathrm{CH}_{2}\right) ;{ }^{13} \mathrm{C} \mathrm{NMR}\left(100 \mathrm{MHz}, \mathrm{CDCl}_{3}\right): \delta 166.5,134.6,132.3,131.5,131.6$, 126.0, 115.6, 114.0, 38.6, 33.7, 31.5, 25.1; IR 3070 (w), 2960 (m), 2869 (w), 2239 (w), 2169 (w), 1610 (s), $1560(\mathrm{~m}), 1440(\mathrm{w}), 1344(\mathrm{~m}), 1301(\mathrm{w}), 1110(\mathrm{w}), 1010(\mathrm{w}), 910(\mathrm{~m})$; HRMS (ESI) calcd. for $\mathrm{C}_{14} \mathrm{H}_{14} \mid \mathrm{O}_{2}{ }^{+}$ $[\mathrm{M}+\mathrm{H}]^{+}$341.0033; found 341.0037.

\section{2-Cyclohexylethynyl-1,2-benziodoxol-3(1H)-one (9q)}<smiles>O=C(O)c1ccccc1I</smiles>

64

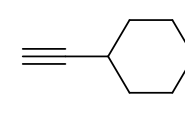

81

$$
\underset{\text { DCE:TFE, } \mathrm{NaHCO}_{3}}{\stackrel{m \text { CPBA, TsOH. }}{2} \mathrm{O}}
$$

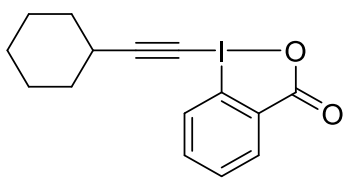

$9 q$

In a sealed tube, 2-iodobenzoic acid (64) (1.00 g, $4.03 \mathrm{mmol}, 1.00$ equiv), 4-methylbenzenesulfonic acid (775 mg, $4.03 \mathrm{mmol}, 1.00$ equiv) and mCPBA (77\%, $994 \mathrm{mg}, 4.44 \mathrm{mmol}, 1.1$ equiv) were suspended in DCE:TFE 1:1 (12 mL) and stirred for $1 \mathrm{~h}$ at $55^{\circ} \mathrm{C}$. After $1 \mathrm{~h}$, ethynylcyclohexane (81) $(0.74 \mathrm{~mL}, 5.6 \mathrm{mmol}$, 1.4 equiv) was added and the reaction was stirred at $55{ }^{\circ} \mathrm{C}$ for $24 \mathrm{~h}$. After $24 \mathrm{~h}$, the solvent was evaporated and the residue was redissolved in $\mathrm{CH}_{2} \mathrm{Cl}_{2}(20 \mathrm{~mL})$ and stirred vigorously with a saturated 
solution of $\mathrm{NaHCO}_{3}(30 \mathrm{~mL})$. After $1 \mathrm{~h}$, the reaction mixture was transferred into a separating funnel and the layers were separated. The aqueous layer was extracted with $\mathrm{CH}_{2} \mathrm{Cl}_{2}(2 \times 50 \mathrm{~mL})$. The combined organic layers were washed with saturated solution of $\mathrm{NaHCO}_{3}(50 \mathrm{~mL})$, dried over $\mathrm{MgSO}_{4}$, filtered and concentrated under vacuum. The crude product was purified by flash column chromatography using ethyl acetate to afford $9 q$ as a white solid $(0.85 \mathrm{~g}, 2.4 \mathrm{mmol}, 60 \%)$. TLC (EtOAc): $\mathrm{R}_{\mathrm{f}}=0.26, \mathrm{KMnO}_{4} ;{ }^{1} \mathrm{H}$ NMR (400 MHz, $\left.\mathrm{CDCl}_{3}\right): \delta 8.45-8.33(\mathrm{~m}, 1 \mathrm{H}, \operatorname{ArH}), 8.21-8.10(\mathrm{~m}, 1 \mathrm{H}, \operatorname{ArH}), 7.83-7.67(\mathrm{~m}, 2 \mathrm{H}, \operatorname{ArH})$, $2.80-2.73(\mathrm{~m}, 1 \mathrm{H}, \mathrm{CCCH}), 1.95-1.89\left(\mathrm{~m}, 2 \mathrm{H}, 1 \times \mathrm{CH}_{2}\right), 1.81-1.69\left(\mathrm{~m}, 2 \mathrm{H}, 1 \times \mathrm{CH}_{2}\right), 1.62-1.53(\mathrm{~m}, 3 \mathrm{H})$, $1.45-1.32(\mathrm{~m}, 3 \mathrm{H}) ;{ }^{13} \mathrm{C} \mathrm{NMR}\left(100 \mathrm{MHz}, \mathrm{CDCl}_{3}\right): \delta$ 166.5, 134.6, 132.3, 131.5, 131.4, 126.0, 115.5, 113.6, $39.1,32.2,30.7,25.5,24.7$. The characterization data corresponded to the reported values. ${ }^{26}$

${ }^{26}$ M. Ochiai, Y. Masaki, M. Shiro, J. Org. Chem. 1991, 56, 5511. 


\section{Optimization of the reaction conditions for Ph-EBX}

\section{a) Screening of bases}

A flame dried $5 \mathrm{~mL}$ microwave vial was charged under nitrogen with $\mathrm{Cu}\left(\mathrm{CH}_{3} \mathrm{CN}\right)_{4} \mathrm{BF}_{4}(1.0 \mathrm{mg}, 3.0 \mu \mathrm{mol}$, 0.02 equiv), ligand 10 ( $1.4 \mathrm{mg}, 3.8 \mu \mathrm{mol}, 0.025$ equiv) and dry DCE ( $1 \mathrm{~mL})$. The resulting solution was stirred at $30^{\circ} \mathrm{C}$ for $1 \mathrm{~h}$ and then added to a mixture of 1-[phenylethynyl]-1,2-benziodoxol-3(1H)-one (9b) (0.15 mmol, 1.0 equiv), 2,6-di-tert-butyl-4-methylphenyl 2-diazoacetate (8a) ( $0.30 \mathrm{mmol}, 2.0$ equiv) and dry DCE $(2 \mathrm{~mL})$ in a $5 \mathrm{~mL}$ microwave vial over $2 \mathrm{~min}$ and the resulting reaction mixture was stirred at 50 ${ }^{\circ} \mathrm{C}$ for $14 \mathrm{~h}$. Next, base $(0.375 \mathrm{mmol}, 2.50$ equiv) was added and the reaction mixture was stirred at 50 ${ }^{\circ} \mathrm{C}$. After the reaction was completed (monitored by $\mathrm{TLC}, \mathrm{Et}_{2} \mathrm{O}$; pentane, 1:10 v/v), the reaction mixture was filtered, evaporated under reduced pressure and the crude product was purified by flash column chromatography ( $\mathrm{Et}_{2} \mathrm{O}$ :pentane, 1:20 v/v) directly without any further work-up.

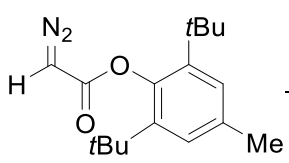

$8 \mathbf{a}$

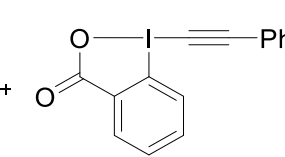

9b

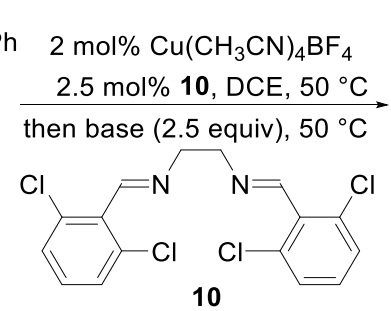

10

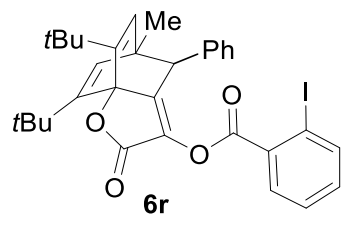

\begin{tabular}{cccc}
\hline Entry & Base & Time & Yield (\%) \\
\hline 1 & $\mathrm{~K}_{3} \mathrm{PO}_{4}$ & $20 \mathrm{~h}$ & 85 \\
2 & $\mathrm{C}_{2} \mathrm{CO}_{3}$ & $1 \mathrm{~h}$ & 88 \\
3 & $\mathrm{~K}_{2} \mathrm{CO}_{3}$ & $16 \mathrm{~h}$ & 84 \\
4 & $\mathrm{DBU}$ & $1 \mathrm{~h}$ & decomposition \\
\hline
\end{tabular}

\section{b) Pre-addition of base}

A flame dried $5 \mathrm{~mL}$ microwave vial was charged under nitrogen with $\mathrm{Cu}\left(\mathrm{CH}_{3} \mathrm{CN}\right)_{4} \mathrm{BF}_{4}(1.0 \mathrm{mg}, 3.0 \mu \mathrm{mol}$, 0.02 equiv), ligand 10 (1.4 mg, $3.8 \mu \mathrm{mol}, 0.025$ equiv) and dry DCE ( $1 \mathrm{~mL})$. The resulting solution was stirred at $30{ }^{\circ} \mathrm{C}$ for $1 \mathrm{~h}$ and then added to a mixture 1-[phenylethynyl]-1,2-benziodoxol-3(1H)-one (9b) (0.15 mmol, 1.0 equiv), 2,6-di-tert-butyl-4-methylphenyl 2-diazoacetate (8a) (0.30 mmol, 2.0 equiv), base $(0.375 \mathrm{mmol}, 2.50$ equiv) and dry DCE $(2 \mathrm{~mL})$ in a $5 \mathrm{~mL}$ microwave vial over 2 min and the resulting reaction mixture was stirred for $14 \mathrm{~h}$ at $50^{\circ} \mathrm{C}$. After $24 \mathrm{~h}$, no product formation was observed by TLC (Et ${ }_{2} \mathrm{O} ;$ pentane, $\left.1: 10 \mathrm{v} / \mathrm{v}\right)$. 


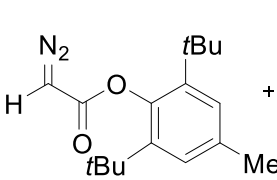

$8 a$

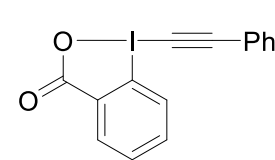

9b

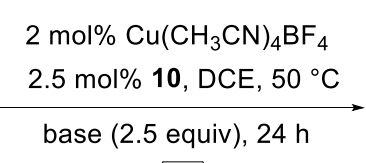

CI
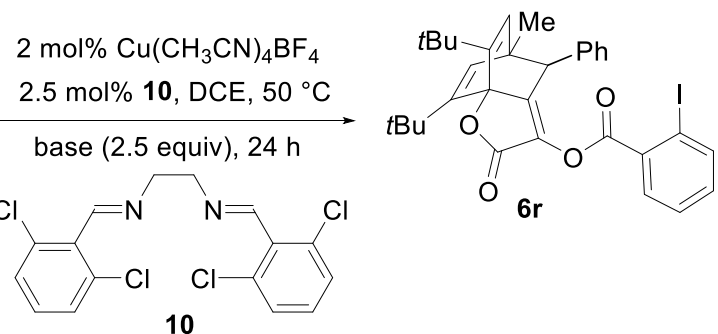

\begin{tabular}{ccc}
\hline Entry & Base & Yield (\%) \\
\hline 1 & $\mathrm{~K}_{3} \mathrm{PO}_{4}$ & 0 \\
2 & $\mathrm{Cs}_{2} \mathrm{CO}_{3}$ & 0 \\
3 & $\mathrm{~K}_{2} \mathrm{CO}_{3}$ & 0 \\
4 & $\mathrm{DBU}$ & 0 \\
\hline
\end{tabular}

\section{c) Screening of temperature}

A flame dried $5 \mathrm{~mL}$ microwave vial was charged under nitrogen with $\mathrm{Cu}\left(\mathrm{CH}_{3} \mathrm{CN}\right)_{4} \mathrm{BF}_{4}(1.0 \mathrm{mg}, 3.0 \mu \mathrm{mol}$, 0.02 equiv), ligand 10 (1.4 mg, $3.8 \mu \mathrm{mol}, 0.025$ equiv) and dry DCE ( $1 \mathrm{~mL})$. The resulting solution was stirred at $30^{\circ} \mathrm{C}$ for $1 \mathrm{~h}$ and then added to a mixture of 1-[phenylethynyl]-1,2-benziodoxol-3(1H)-one (9b) (0.15 mmol, 1.0 equiv), 2,6-di-tert-butyl-4-methylphenyl 2-diazoacetate (8a) ( $0.30 \mathrm{mmol}, 2.0$ equiv) and dry DCE $(2 \mathrm{~mL})$ in $5 \mathrm{~mL}$ microwave vial over $2 \mathrm{~min}$ and the resulting reaction mixture was stirred at $50^{\circ} \mathrm{C}$ for $14 \mathrm{~h}$. Next, $\mathrm{Cs}_{2} \mathrm{CO}_{3}(0.375 \mathrm{mmol}, 2.50$ equiv) was added and the reaction mixture was stirred. After $20 \mathrm{~h}$, the reaction mixture was filtered, evaporated under reduced pressure and the crude product was purified by flash chromatography $\left(\mathrm{Et}_{2} \mathrm{O}\right.$ :pentane, 1:20 v/v) directly without any further work-up. 


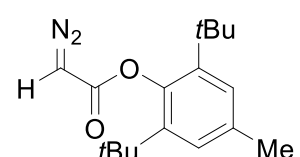

$8 a$

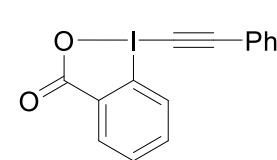

9b

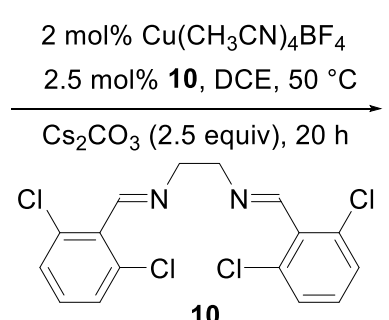

10

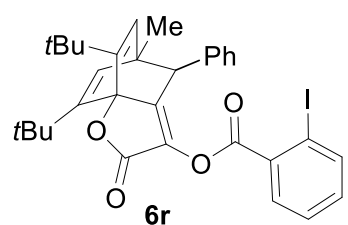

\begin{tabular}{ccc}
\hline Entry & $\mathbf{T}$ & Yield (\%) \\
\hline 1 & $\mathrm{RT}$ & 88 \\
2 & $35^{\circ} \mathrm{C}$ & 87 \\
3 & $50^{\circ} \mathrm{C}$ & 88 \\
\hline
\end{tabular}

\section{d) Screening of equivalents of $\mathrm{Cs}_{2} \mathrm{CO}_{3}$}

A flame dried $5 \mathrm{~mL}$ microwave vial was charged under nitrogen with $\mathrm{Cu}\left(\mathrm{CH}_{3} \mathrm{CN}\right)_{4} \mathrm{BF}_{4}(1.0 \mathrm{mg}, 3.0 \mu \mathrm{mol}$, 0.02 equiv), ligand 10 (1.4 mg, $3.8 \mu \mathrm{mol}, 0.025$ equiv) and dry DCE ( $1 \mathrm{~mL})$. The resulting solution was stirred at $30^{\circ} \mathrm{C}$ for $1 \mathrm{~h}$ and then added to a mixture of 1-[phenylethynyl]-1,2-benziodoxol-3(1H)-one (9b) (0.15 mmol, 1.0 equiv) and 2,6-di-tert-butyl-4-methylphenyl 2-diazoacetate (8a) $(0.30 \mathrm{mmol}, 2.0$ equiv) in dry DCE $(2 \mathrm{~mL})$ in $5 \mathrm{~mL}$ microwave vial over $2 \mathrm{~min}$ and the resulting reaction mixture was stirred at 50 ${ }^{\circ} \mathrm{C}$ for $14 \mathrm{~h}$. Next, $\mathrm{Cs}_{2} \mathrm{CO}_{3}$ (x equiv) was added and the reaction mixture stirred at room temperature. After $20 \mathrm{~h}$, the reaction mixture was filtered, evaporated under reduced pressure and the crude product was purified by flash column chromatography $\left(\mathrm{Et}_{2} \mathrm{O}\right.$ :pentane, 1:20 v/v) directly without any further work-up.<smiles>Cc1cc(Br)c(OC(=O)C(=N)Br)c(C(C)(C)C)c1</smiles>

$8 \mathbf{a}$<smiles>O=C1OI(C#Cc2ccccc2)c2ccccc21</smiles>

$9 b$

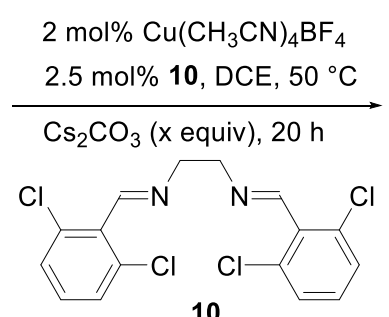

10

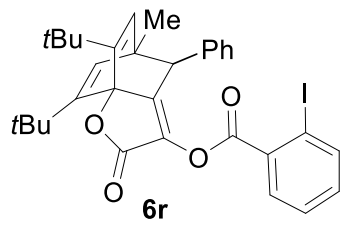

\begin{tabular}{ccc}
\hline Entry & $\mathrm{Cs}_{2} \mathrm{CO}_{3}$ (x equiv) & Yield (\%) \\
\hline 1 & 2.5 & 88 \\
2 & 2 & 87 \\
3 & 1.1 & 87 \\
\hline
\end{tabular}




\section{e) Screening of concentration}

A flame dried $5 \mathrm{~mL}$ microwave vial was charged under nitrogen with $\mathrm{Cu}\left(\mathrm{CH}_{3} \mathrm{CN}\right)_{4} \mathrm{BF}_{4}(1.0 \mathrm{mg}, 3.0 \mu \mathrm{mol}$, 0.02 equiv), ligand 10 (1.4 mg, $3.8 \mu \mathrm{mol}, 0.025$ equiv) and dry DCE ( $1 \mathrm{~mL})$. The resulting solution was stirred at $30^{\circ} \mathrm{C}$ for $1 \mathrm{~h}$ and then added to a mixture of 1-[phenylethynyl]-1,2-benziodoxol-3(1H)-one (9b) (0.15 mmol, 1.0 equiv), 2,6-di-tert-butyl-4-methylphenyl 2-diazoacetate (8a) ( $0.30 \mathrm{mmol}, 2.0$ equiv) and dry DCE (x M) over 2 min and the resulting reaction mixture was stirred at $50{ }^{\circ} \mathrm{C}$ for $14 \mathrm{~h}$. Next, $\mathrm{Cs}_{2} \mathrm{CO}_{3}$ ( $0.165 \mathrm{mmol}, 1.10$ equiv) was added and the reaction mixture stirred at room temperature. After $20 \mathrm{~h}$, the reaction mixture was filtered, evaporated under reduced pressure and the crude product was purified by flash column chromatography $\left(\mathrm{Et}_{2} \mathrm{O}\right.$ :pentane, 1:20 v/v) directly without any further work-up.<smiles>Cc1cc(C(=O)C=[W])c(OC(=O)C(C)(C)C)c(C(C)(C)C)c1</smiles>

$8 a$<smiles>O=C1OI(C#Cc2ccccc2)c2ccccc21</smiles>

9b
$2 \mathrm{~mol} \% \mathrm{Cu}\left(\mathrm{CH}_{3} \mathrm{CN}\right)_{4} \mathrm{BF}_{4}$ $2.5 \mathrm{~mol} \% 10$, DCE (xM), $50^{\circ} \mathrm{C}$ $\mathrm{Cs}_{2} \mathrm{CO}_{3}$ (1.1 equiv), $20 \mathrm{~h}$<smiles>Clc1cccc(Cl)c1/C=N/CC/N=C/c1c(Cl)cccc1Cl</smiles>

10

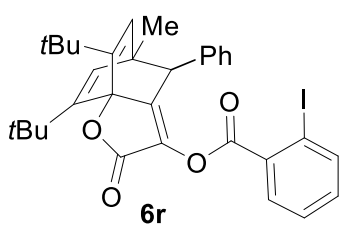

O $6 r$

\begin{tabular}{|c|c|c|}
\hline Entry & Concentration (x M) & Yield (\%) \\
\hline 1 & 0.1 & 82 \\
\hline 2 & 0.05 & 87 \\
\hline 3 & 0.025 & 92 \\
\hline
\end{tabular}




\section{General procedure A}<smiles>[R]c1cc(C(=O)O)c(OC(=O)C=[W])c(C(C)(C)C)c1</smiles>

8

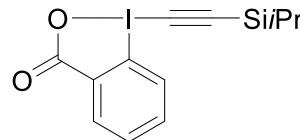

9a

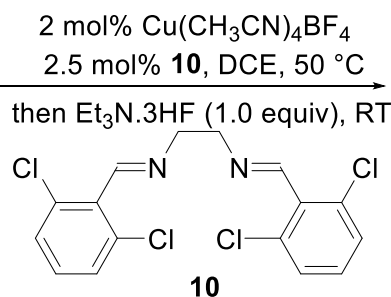

10

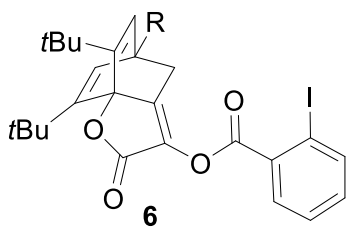

A flame dried $5 \mathrm{~mL}$ microwave vial was charged under nitrogen with $\mathrm{Cu}\left(\mathrm{CH}_{3} \mathrm{CN}\right)_{4} \mathrm{BF}_{4}(1.0 \mathrm{mg}, 3.0 \mu \mathrm{mol}$, 0.02 equiv), ligand 10 (1.4 mg, $3.8 \mu \mathrm{mol}, 0.025$ equiv) and dry DCE ( $1 \mathrm{~mL})$. The resulting solution was stirred at $30{ }^{\circ} \mathrm{C}$ for $1 \mathrm{~h}$ and then added to a mixture of 1-[(triiso-propylsilyl)ethynyl]-1,2-benziodoxol$3(1 \mathrm{H})$-one (9a) (0.15 mmol, 1.0 equiv), diazo compound 8 ( $0.18 \mathrm{mmol}, 1.2$ equiv) and dry DCE $(5 \mathrm{~mL})$ in $20 \mathrm{~mL}$ microwave vial over $2 \mathrm{~min}$ and the resulting reaction mixture was stirred at $50{ }^{\circ} \mathrm{C}$. Next, the reaction mixture was cooled down to room temperature and triethylamine trihydrofluoride $(24 \mu \mathrm{L}, 0.15$ mmol, 1.0 equiv) was added and the reaction mixture was stirred. After the reaction was completed (monitored by TLC, EtOAc:pentane or $\mathrm{Et}_{2} \mathrm{O}$ :pentane), the solvent was evaporated under reduced pressure and the crude product was purified by flash column chromatography (EtOAc:pentane or $\mathrm{Et}_{2} \mathrm{O}$ :pentane) directly without any further work-up.

\section{General procedure B}<smiles>[R]c1cc([R])c(OC(=O)C=[W])c([R])c1</smiles>

8

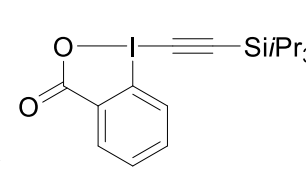

9a

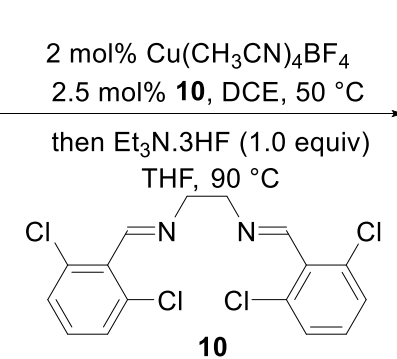

10

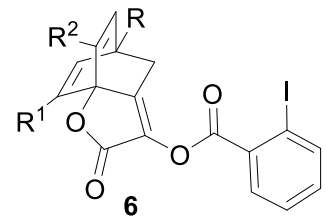

A flame dried $5 \mathrm{~mL}$ microwave vial was charged under nitrogen with $\mathrm{Cu}\left(\mathrm{CH}_{3} \mathrm{CN}\right)_{4} \mathrm{BF}_{4}(1.0 \mathrm{mg}, 3.0 \mu \mathrm{mol}$, 0.02 equiv), ligand 10 (1.4 mg, $3.8 \mu \mathrm{mol}, 0.025$ equiv) and dry DCE ( $1 \mathrm{~mL})$. The resulting solution was stirred at $30{ }^{\circ} \mathrm{C}$ for $1 \mathrm{~h}$ and then added to a mixture of 1-[(triiso-propylsilyl)ethynyl]-1,2-benziodoxol$3(1 H)$-one (9a) (0.15 mmol, 1.0 equiv), diazo compound 8 (0.18 mmol, 1.2 equiv) and dry DCE (5 mL) in $20 \mathrm{~mL}$ microwave vial over $2 \mathrm{~min}$ and the resulting reaction mixture was stirred at $50^{\circ} \mathrm{C}$. The solvent was evaporated and the residue was filtered through a small plug of silica gel using $\mathrm{Et}_{2} \mathrm{O}$ ( $c a 15 \mathrm{~mL}$ ). The $\mathrm{Et}_{2} \mathrm{O}$ was evaporated and the crude redissolved in THF $(6 \mathrm{~mL})$ in a $20 \mathrm{~mL}$ microwave vial. Next, triethylamine trihydrofluoride ( $24 \mu \mathrm{L}, 0.15 \mathrm{mmol}, 1.0$ equiv) was added and the reaction mixture stirred at $90{ }^{\circ} \mathrm{C}$. After the reaction was completed (monitored by TLC, EtOAc:pentane or $\mathrm{Et}_{2} \mathrm{O}$ :pentane), the 
solvent was evaporated under reduced pressure and the crude product was purified by flash column chromatography (EtOAc:pentane or $\mathrm{Et}_{2} \mathrm{O}$ :pentane) directly without any further work-up.

\section{General procedure C}<smiles>[R]c1cc(C(=O)O)c(OC(=O)C=[W])c(C(C)(C)C)c1</smiles>

8<smiles>O=C1OI(C#CBr)c2ccccc21</smiles>

$9 b$

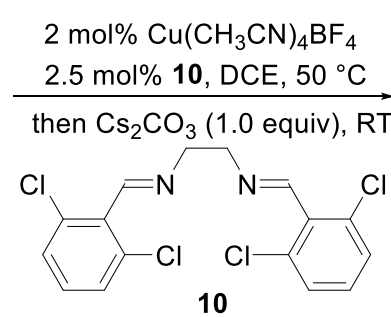

10

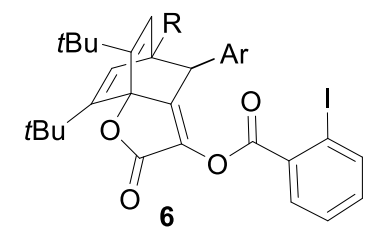

O 6

A flame dried $5 \mathrm{~mL}$ microwave vial was charged under nitrogen with $\mathrm{Cu}\left(\mathrm{CH}_{3} \mathrm{CN}\right)_{4} \mathrm{BF}_{4}(1.0 \mathrm{mg}, 3.0 \mu \mathrm{mol}$, 0.02 equiv), ligand 10 (1.4 mg, $3.8 \mu \mathrm{mol}, 0.025$ equiv) and dry DCE (1 mL). The resulting solution was stirred at $30{ }^{\circ} \mathrm{C}$ for $1 \mathrm{~h}$ and then added to a mixture of Ph-EBX (9b) (0.15 mmol, 1.0 equiv), diazo compound 8 (0.18 mmol, 1.2 equiv) and dry DCE ( $5 \mathrm{~mL}$ ) in $20 \mathrm{~mL}$ microwave vial over 2 min and the resulting reaction mixture was stirred at $50{ }^{\circ} \mathrm{C}$. Next, the reaction mixture was cooled down to room temperature and $\mathrm{Cs}_{2} \mathrm{CO}_{3}(54.0 \mathrm{mg}, 0.165 \mathrm{mmol}, 1.10$ equiv) was added and the reaction mixture was stirred. After the reaction was completed (monitored by TLC, EtOAc:pentane or Et ${ }_{2} \mathrm{O}:$ pentane), the solvent was evaporated under reduced pressure and the crude product was purified by flash column chromatography (EtOAc:pentane or $\mathrm{Et}_{2} \mathrm{O}$ :pentane) directly without any further work-up.

\section{General procedure D}

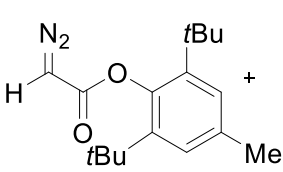

$8 \mathbf{a}$

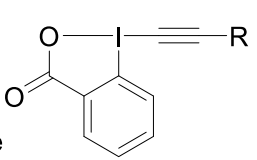

9

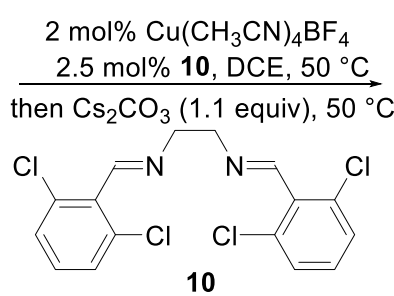

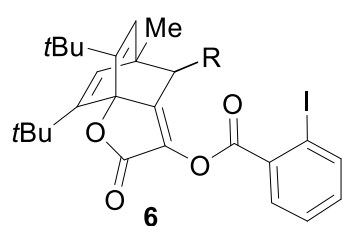

A flame dried $5 \mathrm{~mL}$ microwave vial was charged under nitrogen with $\mathrm{Cu}\left(\mathrm{CH}_{3} \mathrm{CN}\right)_{4} \mathrm{BF}_{4}(1.0 \mathrm{mg}, 3.0 \mu \mathrm{mol}$, 0.02 equiv), ligand 10 (1.4 mg, $3.8 \mu \mathrm{mol}, 0.025$ equiv) and dry DCE ( $1 \mathrm{~mL})$. The resulting solution was stirred at $30{ }^{\circ} \mathrm{C}$ for $1 \mathrm{~h}$ and then added to a mixture of R-EBX (9) (0.15 mmol, 1.0 equiv), 2,6-di-tert-butyl4-methylphenyl 2-diazoacetate (8a) $(0.18 \mathrm{mmol}, 1.2$ equiv) and dry DCE (5 mL) in $20 \mathrm{~mL}$ microwave vial over $2 \mathrm{~min}$ and the resulting reaction mixture was stirred at $50{ }^{\circ} \mathrm{C}$. Next, $\mathrm{Cs}_{2} \mathrm{CO}_{3}(54.0 \mathrm{mg}, 0.165 \mathrm{mmol}$, 1.10 equiv) was added and the reaction mixture was stirred at $50{ }^{\circ} \mathrm{C}$. After the reaction was completed (monitored by TLC, EtOAc:pentane or $\mathrm{Et}_{2} \mathrm{O}$ :pentane), the solvent was evaporated under reduced pressure and the crude product was purified by flash column chromatography (EtOAc:pentane or $\mathrm{Et}_{2} \mathrm{O}$ :pentane) directly without any further work-up. 
7,8-Di-tert-butyl-5-methyl-2-oxo-4,5-dihydro-2H-5,7a-ethenobenzofuran-3-yl 2-iodobenzoate (6a)

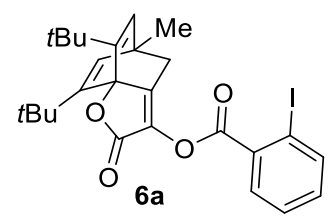

Following general procedure A, 1-[(triiso-propylsilyl)ethynyl]-1,2-benziodoxol-3(1H)-one (9a) $(64.0 \mathrm{mg}$, $0.150 \mathrm{mmol}, 1.00$ equiv) and 2,6-di-tert-butyl-4-methylphenyl 2-diazoacetate (8a) (52 mg, $0.18 \mathrm{mmol}$, 1.2 equiv) were stirred for $12 \mathrm{~h}$. Next, triethylamine trihydrofluoride ( $24 \mu \mathrm{L}, 0.15 \mathrm{mmol}, 1.0$ equiv) was added and the reaction mixture further stirred for $24 \mathrm{~h}$. The crude reaction mixture was concentrated in vacuo and purified by flash chromatography using $\mathrm{Et}_{2} \mathrm{O}$ :pentane 1:20 as mobile phase to afford $6 \mathrm{a}$ as a white solid (75.0 mg, $0.141 \mathrm{mmol}, 94 \%) . \mathrm{Mp}: 162.3-162.7^{\circ} \mathrm{C}$; TLC (Et $2 \mathrm{O}$ :pentane, 1:10 v/v): $\mathrm{R}_{\mathrm{f}}=0.37$, $\mathrm{KMnO}_{4} ;{ }^{1} \mathrm{H}$ NMR $\left(400 \mathrm{MHz}, \mathrm{CDCl}_{3}\right): \delta 8.06-8.02(\mathrm{~m}, 2 \mathrm{H}, \mathrm{ArH}), 7.44(\mathrm{td}, J=7.6,1.2 \mathrm{~Hz}, 1 \mathrm{H}, \mathrm{ArH}), 7.21(\mathrm{td}$, $J=7.6,1.7 \mathrm{~Hz}, 1 \mathrm{H}, \mathrm{ArH}), 5.81(\mathrm{~s}, 2 \mathrm{H}, 2 \times t \mathrm{BuCCH}), 2.36\left(\mathrm{~s}, 2 \mathrm{H}, \mathrm{CH}_{3} \mathrm{CCH}_{2}\right), 1.62\left(\mathrm{~s}, 3 \mathrm{H}, \mathrm{CHCCH}_{3}\right), 1.16$ (s, $18 \mathrm{H}, 2 \times t \mathrm{Bu}) ;{ }^{13} \mathrm{C}$ NMR $\left(100 \mathrm{MHz}, \mathrm{CDCl}_{3}\right): \delta 169.1,162.1,157.8,151.3,141.7,133.7,132.5,132.2,132.2$, 129.4, 128.1, 95.0, 92.9, 41.6, 38.6, 35.2, 29.1, 22.2; IR v 3058 (w), 2961 (w), $2871(w), 1783$ (s), 1758 (m), $1718(w), 1692(w), 1583(w), 1472(w), 1365(w), 1333(w), 1292(w), 1233(s), 1155(m), 1086(s)$, 1057 (m), 1004 (s), 923 (w); HRMS (ESI) calcd. for $\mathrm{C}_{26} \mathrm{H}_{30} \mathrm{IO}_{4}{ }^{+}[\mathrm{M}+\mathrm{H}]^{+}$533.1183; found 533.1191.

Large scale procedure: Following general procedure A, 1-[(triiso-propylsilyl)ethynyl]-1,2-benziodoxol3(1H)-one (9a) (860 mg, $2.00 \mathrm{mmol}, 1.00$ equiv) and 2,6-di-tert-butyl-4-methylphenyl 2-diazoacetate (8a) $(692 \mathrm{mg}, 2.40 \mathrm{mmol}, 1.20$ equiv) were stirred for $12 \mathrm{~h}$. Next, triethylamine trihydrofluoride (0.33 $\mathrm{mL}, 2.0 \mathrm{mmol}, 1.0$ equiv) was added and the reaction mixture further stirred for $24 \mathrm{~h}$. The crude reaction mixture was concentrated in vacuo and purified by flash chromatography using $\mathrm{Et}_{2} \mathrm{O}$ :pentane 1:20 as mobile phase to afford $6 \mathrm{a}$ as a white solid $(1.00 \mathrm{~g}, 1.88 \mathrm{mmol}, 94 \%)$.

\section{7,8-Di-tert-butyl-5-ethyl-2-oxo-4,5-dihydro-2H-5,7a-ethenobenzofuran-3-yl 2-iodobenzoate (6b)}

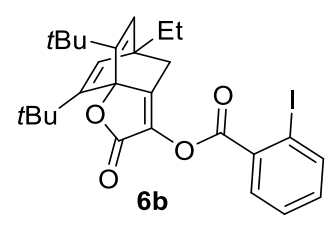

Following general procedure A, 1-[(triiso-propylsilyl)ethynyl]-1,2-benziodoxol-3(1H)-one (9a) $(64.0 \mathrm{mg}$, $0.150 \mathrm{mmol}, 1.00$ equiv) and 2,6-di-tert-butyl-4-ethylphenyl 2-diazoacetate (8b) (54.4 mg, $0.180 \mathrm{mmol}$, 1.20 equiv) were stirred for $12 \mathrm{~h}$. Next, triethylamine trihydrofluoride ( $24 \mu \mathrm{L}, 0.15 \mathrm{mmol}, 1.0$ equiv) was added and the reaction mixture was further stirred for $24 \mathrm{~h}$. The crude reaction mixture was concentrated in vacuo and purified by flash chromatography using $\mathrm{Et}_{2} \mathrm{O}$ :pentane 1:20 as mobile phase to afford $\mathbf{6 b}$ as a white solid (79.0 $\mathrm{mg}, 0.145 \mathrm{mmol}, 96 \%) . \mathrm{Mp}$ : $164.0-166.5^{\circ} \mathrm{C}$; TLC (Et ${ }_{2} \mathrm{O}$ :pentane, 1:10 
$\mathrm{v} / \mathrm{v}): \mathrm{R}_{\mathrm{f}}=0.39, \mathrm{KMnO}_{4} ;{ }^{1} \mathrm{H} \mathrm{NMR}\left(400 \mathrm{MHz}, \mathrm{CDCl}_{3}\right): \delta 8.05-8.02(\mathrm{~m}, 2 \mathrm{H}, \mathrm{ArH}), 7.44(\mathrm{td}, J=7.7,1.2 \mathrm{~Hz}, 1 \mathrm{H}$, $\operatorname{ArH}), 7.20(\mathrm{td}, J=7.7,1.7 \mathrm{~Hz}, 1 \mathrm{H}, \mathrm{ArH}), 5.88(\mathrm{~s}, 2 \mathrm{H}, 2 \times t \mathrm{BuCCH}), 2.34\left(\mathrm{~s}, 2 \mathrm{H}, \mathrm{EtCCH}_{2}\right), 1.97$ (q, J $=7.5 \mathrm{~Hz}$, $\left.2 \mathrm{H}, \mathrm{CH}_{2} \mathrm{CH}_{3}\right), 1.20-1.12\left(\mathrm{~m}, 21 \mathrm{H}, 2 \times t \mathrm{Bu}\right.$ and $\left.\mathrm{CH}_{2} \mathrm{CH}_{3}\right) ;{ }^{13} \mathrm{C} \mathrm{NMR}\left(100 \mathrm{MHz}, \mathrm{CDCl}_{3}\right): \delta 169.0,162.1,157.8$, $151.5,141.7,133.6,132.6,132.2,130.2,129.7,128.1,94.9,92.7,46.1,36.1,35.4,29.2$, 28.1, 9.6; IR v $3063(w), 2962(m), 2871(w), 2255(w), 1778(s), 1710(w), 1583(w), 1464(m), 1429(w), 1363(w), 1273$ (m), 1236 (s), 1191 (m), 1088 (s), 1008 (s), 913 (m); HRMS (ESI) calcd. for $\mathrm{C}_{27} \mathrm{H}_{31} \mathrm{INaO}_{4}{ }^{+}[\mathrm{M}+\mathrm{Na}]^{+}$569.1159; found 569.1173 .

\section{5,7,8-Tri-tert-butyl-2-oxo-4,5-dihydro-2H-5,7a-ethenobenzofuran-3-yl 2-iodobenzoate (6c)}

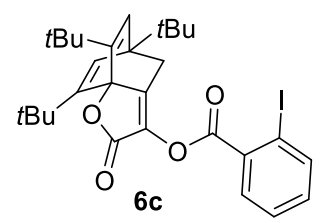

Following general procedure A, 1-[(triiso-propylsilyl)ethynyl]-1,2-benziodoxol-3(1H)-one (9a) $(64.0 \mathrm{mg}$, $0.150 \mathrm{mmol}, 1.00$ equiv) and 2,4,6-tri-tert-butylphenyl 2-diazoacetate (8c) $(59.5 \mathrm{mg}, 0.180 \mathrm{mmol}, 1.20$ equiv) were stirred for $12 \mathrm{~h}$. Next, triethylamine trihydrofluoride ( $24 \mu \mathrm{L}, 0.15 \mathrm{mmol}, 1.0$ equiv) was added and the reaction mixture further stirred for $24 \mathrm{~h}$ at $50{ }^{\circ} \mathrm{C}$. The crude reaction mixture was concentrated in vacuo and purified by flash chromatography using $\mathrm{Et}_{2} \mathrm{O}$ :pentane 1:20 as mobile phase to afford $6 \mathrm{c}$ as a white solid $(72.0 \mathrm{mg}, 0.125 \mathrm{mmol}, 84 \%)$. Mp: 183.0-187.5 ${ }^{\circ} \mathrm{C}$; $\mathrm{TLC}\left(\mathrm{Et}_{2} \mathrm{O}\right.$ :pentane, 1:10 $\mathrm{v} / \mathrm{v}$ ): $\mathrm{R}_{\mathrm{f}}=0.4, \mathrm{KMnO}_{4} ;{ }^{1} \mathrm{H} \mathrm{NMR}\left(400 \mathrm{MHz}, \mathrm{CDCl}_{3}\right): \delta 8.04$ (ddd, $\left.J=7.9,3.7,1.4 \mathrm{~Hz}, 2 \mathrm{H}, \mathrm{ArH}\right), 7.44(\mathrm{td}, J=$ 7.6, 1.2 Hz, 1H, ArH), $7.20(\mathrm{td}, J=7.6,1.7 \mathrm{~Hz}, 1 \mathrm{H}, \mathrm{ArH}), 6.04(\mathrm{~s}, 2 \mathrm{H}, 2 \times t \mathrm{BuCCH}), 2.39\left(\mathrm{~s}, 2 \mathrm{H}, \mathrm{EtCCH}_{2}\right), 1.17$ (s, 18H, $2 \times t \mathrm{Bu}), 1.14$ (s, 9H, tBu); ${ }^{13} \mathrm{C} \mathrm{NMR} \mathrm{(100} \mathrm{MHz,} \mathrm{CDCl} 3$ ): $\delta 169.1,162.2,158.6,151.3,141.7,133.6$, 132.6, 132.2, 129.7, 128.3, 128.1, 94.9, 92.2, 52.6, 35.5, 32.5, 31.9, 29.2, 26.4; IR v 3081 (w), 2961 (m), $2871(w), 2255$ (w), 1782 (s), $1711(w), 1584(w), 1467$ (w), $1430(w), 1359$ (w), $1274(w), 1234$ (s), 1190 $(\mathrm{m}), 1141(\mathrm{~m}), 1084(\mathrm{~s}), 1035(\mathrm{w}), 1008(\mathrm{~m}), 911(\mathrm{~s}), 832(\mathrm{w})$; HRMS (ESI) calcd. for $\mathrm{C}_{29} \mathrm{H}_{36} \mathrm{IO}_{4}{ }^{+}[\mathrm{M}+\mathrm{H}]^{+}$ 575.1653 ; found 575.1660 .

\section{7,8-Di-tert-butyl-5-methoxy-2-oxo-4,5-dihydro-2H-5,7a-ethenobenzofuran-3-yl 2-iodobenzoate (6d)}

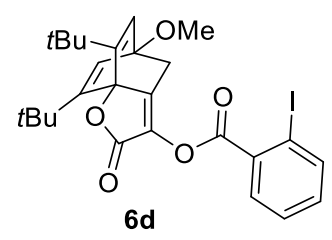

Following general procedure A, 1-[(triiso-propylsilyl)ethynyl]-1,2-benziodoxol-3(1H)-one (9a) $(64.0 \mathrm{mg}$, $0.150 \mathrm{mmol}, 1.00$ equiv) and 2,6-di-tert-butyl-4-methoxyphenyl 2-diazoacetate (8d) (59 mg, $0.18 \mathrm{mmol}$, 1.2 equiv) were stirred for $12 \mathrm{~h}$. Next, triethylamine trihydrofluoride ( $24 \mu \mathrm{L}, 0.15 \mathrm{mmol}, 1.0$ equiv) was added and further stirred for $24 \mathrm{~h}$. The crude reaction mixture was concentrated in vacuo and purified 
by flash chromatography using $\mathrm{Et}_{2} \mathrm{O}$ :pentane $1: 10$ as mobile phase to afford $\mathbf{6} \mathbf{d}$ as a white solid $(70.0$ $\mathrm{mg}, 0.128 \mathrm{mmol}, 85 \%)$. Mp: $159.5-160.8{ }^{\circ} \mathrm{C} ; \mathrm{TLC}\left(\mathrm{Et}_{2} \mathrm{O}\right.$ :pentane, $\left.1: 10 \mathrm{v} / \mathrm{v}\right): \mathrm{R}_{\mathrm{f}}=0.23, \mathrm{KMnO}_{4} ;{ }^{1} \mathrm{H} \mathrm{NMR}$ (400 MHz, $\left.\mathrm{CDCl}_{3}\right): 8.06-8.01(\mathrm{~m}, 2 \mathrm{H}, \mathrm{ArH}), 7.44(\mathrm{td}, J=7.6,1.2 \mathrm{~Hz}, 1 \mathrm{H}, \mathrm{ArH}), 7.21(\mathrm{td}, J=7.7,1.7 \mathrm{~Hz}, 1 \mathrm{H}$, $\operatorname{ArH}), 6.18(\mathrm{~s}, 2 \mathrm{H}, 2 \times t \mathrm{BuCCH}), 3.61\left(\mathrm{~s}, 3 \mathrm{H}, \mathrm{OCH}_{3}\right), 2.67\left(\mathrm{~s}, 2 \mathrm{H}, \mathrm{OCH}_{3} \mathrm{CCH}_{2}\right), 1.18(\mathrm{~s}, 18 \mathrm{H}, 2 \times t \mathrm{Bu}) ;{ }^{13} \mathrm{C} \mathrm{NMR}$ $\left(100 \mathrm{MHz}, \mathrm{CDCl}_{3}\right): \delta 168.6,162.1,154.2,149.7,141.7,133.7,132.5,132.8,129.6,128.2,128.1,94.9$, 91.3, 82.6, 53.4, 35.7, 35.4, 29.0; IR $v 3060$ (w), 2996 (w), 2960 (m), $2870(w), 2835$ (w), 1767 (s), 1706 $(m), 1635(w), 1584(w), 1563(w), 1469(w), 1427(w), 1392(w), 1363(w), 1310(m), 1273(m), 1240(s)$, $1191(\mathrm{~m}), 1137(\mathrm{~m}), 1089$ (s), 1029 (m), 1008 (m), 966 (w), 932 (w); HRMS (ESI) calcd. for $\mathrm{C}_{26} \mathrm{H}_{30} \mathrm{OO}_{5}{ }^{+}$ $[\mathrm{M}+\mathrm{H}]^{+}$549.1132; found 549.1139.

\section{5-Bromo-7,8-di-tert-butyl-2-oxo-4,5-dihydro-2H-5,7a-ethenobenzofuran-3-yl 2-iodobenzoate (6e)}

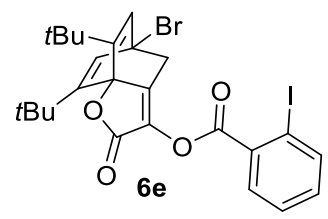

Following general procedure A, 1-[(triiso-propylsilyl)ethynyl]-1,2-benziodoxol-3(1H)-one (9a) $(64.0 \mathrm{mg}$, $0.150 \mathrm{mmol}, 1.00$ equiv) and 4-bromo-2,6-di-tert-butylphenyl 2-diazoacetate (8e) $(64 \mathrm{mg}, 0.18 \mathrm{mmol}$, 1.2 equiv) were stirred for $12 \mathrm{~h}$. Next, triethylamine trihydrofluoride ( $24 \mu \mathrm{L}, 0.15 \mathrm{mmol}, 1.0$ equiv) was added and the reaction mixture further stirred for $24 \mathrm{~h}$. The crude reaction mixture was concentrated in vacuo and purified by flash chromatography using $\mathrm{Et}_{2} \mathrm{O}$ :pentane 1:20 as mobile phase to afford $6 \mathrm{e}$ as a white solid (74.0 mg, $0.124 \mathrm{mmol}, 83 \%)$. Mp: 146.5-147.5 ${ }^{\circ} \mathrm{C}$; TLC (Et $2 \mathrm{O}$ :pentane, 1:20 v/v): $\mathrm{R}_{\mathrm{f}}=0.28$, $\mathrm{KMnO}_{4} ;{ }^{1} \mathrm{H}$ NMR (400 MHz, CDCl 3 ): $\delta 8.04$ (ddd, $\left.J=7.8,3.0,1.4 \mathrm{~Hz}, 2 \mathrm{H}, \mathrm{ArH}\right), 7.45(\mathrm{td}, J=7.6,1.2 \mathrm{~Hz}, 1 \mathrm{H}$, $\operatorname{ArH}), 7.22(\mathrm{td}, J=7.7,1.7 \mathrm{~Hz}, 1 \mathrm{H}, \operatorname{ArH}), 6.21(\mathrm{~s}, 2 \mathrm{H}, 2 \times t \mathrm{BuCCH}), 3.04\left(\mathrm{~s}, 2 \mathrm{H}, \mathrm{BrCCH}_{2}\right), 1.18(\mathrm{~s}, 18 \mathrm{H}, 2 \mathrm{x}$ $t \mathrm{Bu}) ;{ }^{13} \mathrm{C}$ NMR $\left(100 \mathrm{MHz}, \mathrm{CDCl}_{3}\right): \delta 168.1,161.9,153.7,151.1,141.8,133.9,132.2,132.2,132.1,128.8$, 128.1, 95.1, 90.8, 53.9, 43.1, 35.4, 28.9; IR v 2997 (w), 2963 (w), 2869 (w), 2259 (w), 1789 (s), $1766(\mathrm{~m})$, 1705 (w), 1583 (w), 1466 (w), 1365 (w), 1275 (w), 1236 (s), 1189 (w), $1124(m), 1081$ (s), 1035 (w), 1007 (m), 911 (m); HRMS (ESI) calcd. for $\mathrm{C}_{25} \mathrm{H}_{26} \mathrm{BrINaO}_{4}{ }^{+}[\mathrm{M}+\mathrm{Na}]^{+}$618.9951; found 618.9958.

\section{7,8-Di-tert-butyl-2-oxo-4,5-dihydro-2H-5,7a-ethenobenzofuran-3-yl 2-iodobenzoate (6f)}

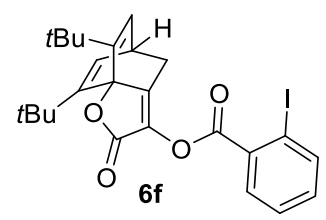

Following general procedure A, 1-[(triiso-propylsilyl)ethynyl]-1,2-benziodoxol-3(1H)-one (9a) $(64.0 \mathrm{mg}$, $0.150 \mathrm{mmol}, 1.00$ equiv) and 2,6-di-tert-butylphenyl 2-diazoacetate (8f) (50 mg, $0.18 \mathrm{mmol}, 1.2$ equiv) were stirred for $12 \mathrm{~h}$. Next, triethylamine trihydrofluoride ( $24 \mu \mathrm{L}, 0.15 \mathrm{mmol}, 1.0$ equiv) was added and 
the reaction mixture further stirred for $24 \mathrm{~h}$. The crude reaction mixture was concentrated in vacuo and purified by flash chromatography using $\mathrm{Et}_{2} \mathrm{O}$ :pentane 1:15 as mobile phase to afford $\mathbf{6} \mathbf{f}$ as a white solid (72.0 mg, $0.138 \mathrm{mmol}, 92 \%)$. Mp: $146.5-147.8{ }^{\circ} \mathrm{C}$; TLC (Et $2 \mathrm{O}$ :pentane, $\left.1: 10 \mathrm{v} / \mathrm{v}\right): \mathrm{R}_{\mathrm{f}}=0.31, \mathrm{KMnO}_{4} ;{ }^{1} \mathrm{H}$ $\operatorname{NMR}\left(400 \mathrm{MHz}, \mathrm{CDCl}_{3}\right): \delta 8.04$ (ddd, $\left.J=8.1,6.8,1.4 \mathrm{~Hz}, 2 \mathrm{H}, \mathrm{ArH}\right), 7.44(\mathrm{td}, J=7.6,1.2 \mathrm{~Hz}, 1 \mathrm{H}, \mathrm{ArH}), 7.21$ $(\mathrm{td}, J=7.7,1.7 \mathrm{~Hz}, 1 \mathrm{H}, \mathrm{ArH}), 6.10(\mathrm{~d}, J=6.5 \mathrm{~Hz}, 2 \mathrm{H}, 2 \times t \mathrm{BuCCH}), 3.88-3.83\left(\mathrm{~m}, 1 \mathrm{H}, \mathrm{CHCHCH}_{2}\right.$ ), 2.48 (d, $\left.J=2.6 \mathrm{~Hz}, 2 \mathrm{H}, \mathrm{CHCH}_{2}\right), 1.17(\mathrm{~s}, 18 \mathrm{H}, 2 \times t \mathrm{Bu}) ;{ }^{13} \mathrm{C} \mathrm{NMR}\left(100 \mathrm{MHz}, \mathrm{CDCl}_{3}\right): \delta 169.0,162.1,156.2,151.4$, 141.7, 133.6, 132.7, 132.2, 130.4, 128.1, 126.6, 94.9, 92.7, 36.4, 35.4, 31.6, 29.2; IR v 3070 (w), 2961 (w), $2870(w), 1779(s), 1710(w), 1584(w), 1465(w), 1428(w), 1363(w), 1269(m), 1233(s), 1174(m), 1128$ (s), 1075 (s), $1030(\mathrm{~m}), 1008$ (s), $966(\mathrm{w})$; HRMS (ESI) calcd. for $\mathrm{C}_{25} \mathrm{H}_{28} \mathrm{IO}_{4}{ }^{+}[\mathrm{M}+\mathrm{H}]^{+}$519.1027; found 519.1044 .

\section{7,8-Diisopropyl-2-oxo-4,5-dihydro-2H-5,7a-ethenobenzofuran-3-yl 2-iodobenzoate (6g)}

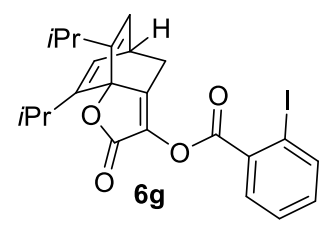

Following general procedure B, 1-[(triiso-propylsilyl)ethynyl]-1,2-benziodoxol-3(1H)-one (9a) $(64.0 \mathrm{mg}$, $0.150 \mathrm{mmol}, 1.00$ equiv) and 2,6-diisopropylphenyl 2-diazoacetate $(8 \mathrm{~g})(44 \mathrm{mg}, 0.18 \mathrm{mmol}, 1.2$ equiv) were stirred for $12 \mathrm{~h}$. Next, triethylamine trihydrofluoride ( $24 \mu \mathrm{L}, 0.15 \mathrm{mmol}, 1.0$ equiv) was added and the reaction mixture further stirred for $24 \mathrm{~h}$. The crude reaction mixture was concentrated in vacuo and purified by flash chromatography using $\mathrm{Et}_{2} \mathrm{O}$ :pentane $1: 15$ as mobile phase to afford $\mathbf{6 g}$ as a white solid (66.0 mg, $0.135 \mathrm{mmol}, 90 \%) . \mathrm{Mp}: 99.1-100.3{ }^{\circ} \mathrm{C}$; TLC (Et $2 \mathrm{O}$ :pentane, 1:15 v/v): $\mathrm{R}_{\mathrm{f}}=0.3, \mathrm{KMnO}_{4} ;{ }^{1} \mathrm{H}$ NMR (400 MHz, $\left.\mathrm{CDCl}_{3}\right): \delta 8.06-8.02(\mathrm{~m}, 2 \mathrm{H}, \mathrm{ArH}), 7.44(\mathrm{td}, J=7.6,1.2 \mathrm{~Hz}, 1 \mathrm{H}, \operatorname{ArH}), 7.21(\mathrm{td}, J=7.7,1.7 \mathrm{~Hz}$, $1 \mathrm{H}, \mathrm{ArH}), 6.05(\mathrm{dd}, J=6.3,1.4 \mathrm{~Hz}, 2 \mathrm{H}, 2 \times \mathrm{iPrCCH}), 3.92\left(\mathrm{tt}, J=6.3,2.6 \mathrm{~Hz}, 1 \mathrm{H}, \mathrm{CHCHCH}_{2}\right), 2.62-2.55(\mathrm{~m}$, $2 \mathrm{H}, \mathrm{CH}_{3} \mathrm{CHCH}_{3}$ ), 2.46 (d, J = 2.6 Hz, 2H, CHCH ), 1.10 (d, J = 6.9 Hz, 6H, $i \mathrm{Pr}$ ), 1.03 (d, J = 6.7 Hz, 6H, iPr); ${ }^{13} \mathrm{C} \mathrm{NMR}\left(100 \mathrm{MHz}, \mathrm{CDCl}_{3}\right): \delta$ 169.1, 162.0, 154.0, 149.9, 141.7, 133.7, 132.4, 132.2, 129.5, 128.1, 125.7, 95.0, 90.5, 36.8, 32.2, 27.9, 21.9, 21.4; IR v 3063 (w), 2964 (m), 2931 (w), $2872(w), 1779$ (s), $1709(w)$, $1583(w), 1465(w), 1430(w), 1270(m), 1235(s), 1174(m), 1098(s), 1071(s), 1009(m), 957(w), 916$ (w); HRMS (ESI) calcd. for $\mathrm{C}_{23} \mathrm{H}_{24} \mathrm{OO}_{4}{ }^{+}[\mathrm{M}+\mathrm{H}]^{+}$491.0714; found 491.0718. Three carbons were resolved from two iPr groups at $100 \mathrm{MHz}$. 


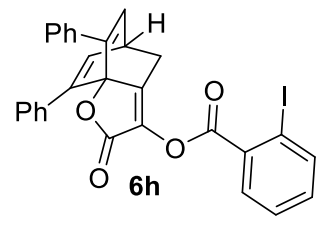

Following general procedure B, 1-[(triiso-propylsilyl)ethynyl]-1,2-benziodoxol-3(1H)-one (9a) $(64.0 \mathrm{mg}$, $0.150 \mathrm{mmol}, 1.00$ equiv) and [1,1':3',1'-terphenyl]-2'-yl 2-diazoacetate $(8 \mathrm{~h})(57 \mathrm{mg}, 0.18 \mathrm{mmol}, 1.2$ equiv) were stirred for $12 \mathrm{~h}$. Next, triethylamine trihydrofluoride ( $24 \mu \mathrm{L}, 0.15 \mathrm{mmol}, 1.0$ equiv) was added and the reaction mixture further stirred for $30 \mathrm{~h}$. The crude reaction mixture was concentrated in vacuo and purified by flash chromatography using $\mathrm{Et}_{2} \mathrm{O}$ :pentane $1: 4$ as mobile phase to afford $6 \mathrm{~h}$ as a white solid (60.0 mg, $0.107 \mathrm{mmol}, 71 \%)$. Mp: 172.5-175.6 ${ }^{\circ} \mathrm{C}$; $\operatorname{TLC}\left(\mathrm{Et}_{2} \mathrm{O}\right.$ :pentane, 1:2 v/v): $\mathrm{R}_{\mathrm{f}}=0.4$, $\mathrm{KMnO}_{4} ;{ }^{1} \mathrm{H} \mathrm{NMR}\left(400 \mathrm{MHz}, \mathrm{CDCl}_{3}\right): \delta 7.95(\mathrm{dd}, J=4.2,1.4 \mathrm{~Hz}, 1 \mathrm{H}, \mathrm{ArH}), 7.93(\mathrm{dd}, J=4.1,1.4 \mathrm{~Hz}, 1 \mathrm{H}, \mathrm{ArH})$, $7.38-7.19(\mathrm{~m}, 11 \mathrm{H}, \mathrm{ArH}), 7.12(\mathrm{td}, J=7.7,1.7 \mathrm{~Hz}, 1 \mathrm{H}, \operatorname{ArH}), 6.54(\mathrm{~d}, J=6.3 \mathrm{~Hz}, 2 \mathrm{H}, 2 \times \mathrm{PhCCH}), 4.12$ (tt, $\left.J=6.4,2.6 \mathrm{~Hz}, 1 \mathrm{H}, \mathrm{CHCHCH}_{2}\right), 2.72\left(\mathrm{~d}, J=2.6 \mathrm{~Hz}, 2 \mathrm{H}, \mathrm{CHCH}_{2}\right) ;{ }^{13} \mathrm{C} \mathrm{NMR}\left(100 \mathrm{MHz}, \mathrm{CDCl}_{3}\right): \delta 167.9,161.8$, 152.3, 144.2, 141.8, 133.8, 133.6, 132.2, 132.1, 131.5, 130.3, 128.4, 128.2, 128.1, 95.1, 88.6, 37.9, 31.9; IR v 3056 (w), 2954 (w), 2919 (m), 2854 (w), 2249 (w), 1946 (w), 1780 (s), 1760 (s), 1713 (w), 1582 (w), $1492(w), 1465(w), 1427(w), 1264(m), 1234(s), 1183(m), 1097(s), 1031(w), 1008(m), 960(w), 911$ (m); HRMS (ESI) calcd. for $\mathrm{C}_{29} \mathrm{H}_{19} \mathrm{INaO}_{4}{ }^{+}[\mathrm{M}+\mathrm{Na}]^{+}$581.0220; found 581.0224.

\section{7,8-Dimethyl-2-oxo-4,5-dihydro-2H-5,7a-ethenobenzofuran-3-yl 2-iodobenzoate (6i)}

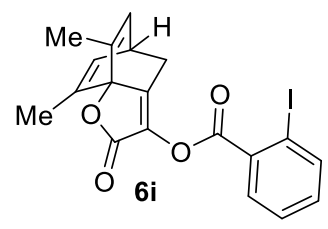

Following general procedure B, 1-[(triiso-propylsilyl)ethynyl]-1,2-benziodoxol-3(1H)-one (9a) $(64.0 \mathrm{mg}$, $0.150 \mathrm{mmol}, 1.00$ equiv) and 2,6-dimethylphenyl 2-diazoacetate ( $8 \mathrm{i})(34.5 \mathrm{mg}, 0.180 \mathrm{mmol}, 1.20$ equiv) were stirred for $12 \mathrm{~h}$. Next, triethylamine trihydrofluoride ( $24 \mu \mathrm{L}, 0.15 \mathrm{mmol}, 1.0$ equiv) was added and the reaction mixture further stirred for $30 \mathrm{~h}$. The crude reaction mixture was concentrated in vacuo and purified by flash chromatography using $\mathrm{Et}_{2} \mathrm{O}$ :pentane $1: 10$ as mobile phase to afford $\mathbf{6} \mathbf{i}$ as a white solid (55.0 mg, $0.127 \mathrm{mmol}, 84 \%)$. Mp: $127.6-128.9^{\circ} \mathrm{C} ; \mathrm{TLC}\left(\mathrm{Et}_{2} \mathrm{O}\right.$ :pentane, 1:5 v/v): $\mathrm{R}_{\mathrm{f}}=0.37, \mathrm{KMnO}_{4} ;{ }^{1} \mathrm{H} \mathrm{NMR}$ $\left(400 \mathrm{MHz}, \mathrm{CDCl}_{3}\right): \delta 8.06$ (dd, J = 5.2, 1.6 Hz, 1H, $\mathrm{ArH}$ ), 8.04 (dd, J = 5.3, 1.7 Hz, 1H, ArH), 7.45 (td, J = 7.7, $1.2 \mathrm{~Hz}, 1 \mathrm{H}, \mathrm{ArH}), 7.22(\mathrm{td}, J=7.7,1.7 \mathrm{~Hz}, 1 \mathrm{H}, \mathrm{ArH}), 6.09\left(\mathrm{dq}, J=6.2,1.7 \mathrm{~Hz}, 2 \mathrm{H}, 2 \times \mathrm{CH}_{3} \mathrm{CCH}\right), 3.85(\mathrm{tt}, J=$ $\left.6.2,2.6 \mathrm{~Hz}, 1 \mathrm{H}, \mathrm{CHCHCH}_{2}\right), 2.47\left(\mathrm{~d}, J=2.6 \mathrm{~Hz}, 2 \mathrm{H}, \mathrm{CHCH}_{2}\right.$ ), $1.85\left(\mathrm{~d}, J=1.7 \mathrm{~Hz}, 6 \mathrm{H}, 2 \times \mathrm{CH}_{3} \mathrm{CCH}\right.$ ); ${ }^{13} \mathrm{C} \mathrm{NMR}$ (100 MHz, $\left.\mathrm{CDCl}_{3}\right): \delta 169.0,162.0,152.2,141.8,139.5,133.8,132.2,129.4,128.6,128.1,95.1,89.9,37.5$, 32.5, 14.4; IR v 3051 (w), $2977(w), 2944(w), 2916(w), 2257(w), 1779(s), 1757(s), 1708(m), 1582(w)$, 
$1562(w), 1467(w), 1437(w), 1283(m), 1234(s), 1205(m), 1172(s), 1128(m), 1086(s), 1029(m), 1012$ (s), 912 (m); HRMS (ESI) calcd. for $\mathrm{C}_{19} \mathrm{H}_{16} \mathrm{OO}_{4}{ }^{+}[\mathrm{M}+\mathrm{H}]^{+}$435.0088; found 435.0081. One carbon was not resolved at $100 \mathrm{MHz}$.

\section{7-(Tert-butyl)-2-oxo-4,5-dihydro-2H-5,7a-ethenobenzofuran-3-yl 2-iodobenzoate (6j)}

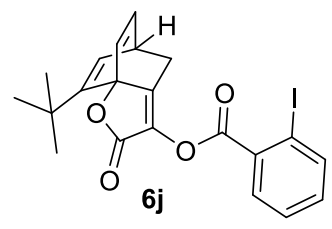

Following general procedure B, 1-[(triiso-propylsilyl)ethynyl]-1,2-benziodoxol-3(1H)-one (9a) $(64.0 \mathrm{mg}$, $0.150 \mathrm{mmol}, 1.00$ equiv) and 2-(tert-butyl)phenyl 2-diazoacetate ( $8 \mathrm{j})(39.5 \mathrm{mg}, 0.180 \mathrm{mmol}, 1.20$ equiv) were stirred for $12 \mathrm{~h}$. Next, triethylamine trihydrofluoride ( $24 \mu \mathrm{L}, 0.15 \mathrm{mmol}, 1.0$ equiv) was added and the reaction mixture further stirred for $30 \mathrm{~h}$. The crude reaction mixture was concentrated in vacuo and purified by flash chromatography using $\mathrm{Et}_{2} \mathrm{O}$ :pentane $1: 10$ as mobile phase to afford $\mathbf{6} \mathbf{j}$ as a white solid (63.0 mg, $0.136 \mathrm{mmol}$, 91\%). Mp: 145.3-147.3 ${ }^{\circ} \mathrm{C} ; \mathrm{TLC}\left(\mathrm{Et}_{2} \mathrm{O}\right.$ :pentane, 1:5 v/v): $\mathrm{R}_{\mathrm{f}}=0.38, \mathrm{KMnO}_{4} ;{ }^{1} \mathrm{H} \mathrm{NMR}$ (400 MHz, $\left.\mathrm{CDCl}_{3}\right): \delta 8.06-8.02(\mathrm{~m}, 2 \mathrm{H}, \mathrm{ArH}), 7.44(\mathrm{td}, J=7.6,1.2 \mathrm{~Hz}, 1 \mathrm{H}, \operatorname{ArH}), 7.21(\mathrm{td}, J=7.7,1.7 \mathrm{~Hz}$, $1 \mathrm{H}, \mathrm{ArH}), 6.51-6.44(\mathrm{~m}, 2 \mathrm{H}, \mathrm{tBuCCH}$ and $\mathrm{OCCHCH}), 6.09(\mathrm{~d}, J=6.5 \mathrm{~Hz}, 1 \mathrm{H}, \mathrm{OCCHCH}), 4.02-3.97(\mathrm{~m}, 1 \mathrm{H}$, $\left.\mathrm{CHCHCH}_{2}\right), 2.58-2.44\left(\mathrm{~m}, 2 \mathrm{H}, \mathrm{CHCH}_{2}\right), 1.15(\mathrm{~s}, 9 \mathrm{H}, \mathrm{tBu}) ;{ }^{13} \mathrm{C} \mathrm{NMR}\left(100 \mathrm{MHz}, \mathrm{CDCl}_{3}\right): \delta 168.8,162.0,153.5$, $151.4,141.7,135.1,133.7,132.4,132.2,130.2,128.1$, 125.5, 95.0, 89.8, 38.1, 34.9, 31.6, 28.4; IR v 3068 (w), $2961(w), 2870(w), 1781(s), 1710(w), 1583(w), 1465(w), 1429(w), 1363(w), 1333(w), 1271(m)$, 1236 (s), 1183 (m), 1136 (m), 1099 (s), 1059 (m), 1029 (w), 1008 (m), 951 (w); HRMS (ESI) calcd. for $\mathrm{C}_{21} \mathrm{H}_{20} \mathrm{OO}_{4}{ }^{+}[\mathrm{M}+\mathrm{H}]^{+} 463.0401$; found 463.0401 . One carbon was not resolved at $100 \mathrm{MHz}$.

\section{7-Methyl-2-oxo-4,5-dihydro-2H-5,7a-ethenobenzofuran-3-yl 2-iodobenzoate (6k)}

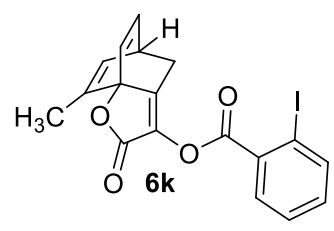

Following general procedure B, 1-[(triiso-propylsilyl)ethynyl]-1,2-benziodoxol-3(1H)-one (9a) $(64.0 \mathrm{mg}$, $0.150 \mathrm{mmol}, 1.00$ equiv) and o-tolyl 2-diazoacetate (8k) (32 $\mathrm{mg}, 0.18 \mathrm{mmol}, 1.2$ equiv) were stirred for $12 \mathrm{~h}$. Next, triethylamine trihydrofluoride ( $24 \mu \mathrm{L}, 0.15 \mathrm{mmol}, 1.0$ equiv) was added and the reaction mixture further stirred for $36 \mathrm{~h}$. The crude reaction mixture was concentrated in vacuo and purified by flash chromatography using $\mathrm{Et}_{2} \mathrm{O}$ :pentane $1: 7$ as mobile phase to afford $\mathbf{6} \mathbf{k}$ as a colorless thick gel (35.0 $\mathrm{mg}, 0.083 \mathrm{mmol}, 55 \%)$. TLC (Et $2 \mathrm{O}$ :pentane, 1:5 v/v): $\mathrm{R}_{\mathrm{f}}=0.25, \mathrm{KMnO}_{4} ;{ }^{1} \mathrm{H} \mathrm{NMR}\left(400 \mathrm{MHz}, \mathrm{CDCl}_{3}\right) ; \delta 8.10$ $-8.01(\mathrm{~m}, 2 \mathrm{H}, \operatorname{ArH}), 7.45(\mathrm{t}, J=7.6 \mathrm{~Hz}, 1 \mathrm{H}, \operatorname{ArH}), 7.22(\mathrm{td}, J=7.7,1.7 \mathrm{~Hz}, 1 \mathrm{H}, \operatorname{ArH}), 6.57-6.42(\mathrm{~m}, 2 \mathrm{H}$, $\mathrm{OCCHCH}$ and $\left.\mathrm{CH}_{3} \mathrm{CCH}\right), 6.09$ (d, $J=5.7 \mathrm{~Hz}, 1 \mathrm{H}, \mathrm{OCCHCH}$ ), 3.99 (tt, $J=5.9,2.6 \mathrm{~Hz}, 1 \mathrm{H}, \mathrm{CHCH}_{2}$ ), $2.62-2.40$ 
$\left(\mathrm{m}, 2 \mathrm{H}, \mathrm{CHCH}_{2}\right), 1.86\left(\mathrm{~d}, J=1.6 \mathrm{~Hz}, 3 \mathrm{H}, \mathrm{CH}_{3}\right) ;{ }^{13} \mathrm{C} \mathrm{NMR}\left(100 \mathrm{MHz}, \mathrm{CDCl}_{3}\right): \delta 168.9,162.0,151.7,141.8$, $140.0,135.2,133.8,132.2,132.2,131.0,129.7,128.1,127.8,95.1,88.5,38.5,32.1,14.3$; IR v $3063(w)$, 2917 (w), 1782 (s), 1759 (s), $1710(w), 1584(w), 1563$ (w), 1466 (w), $1435(w), 1336(w), 1286(m), 1236$ (s), $1203(\mathrm{~m}), 1175(\mathrm{~m}), 1150(\mathrm{~m}), 1096(\mathrm{~s}), 1064(\mathrm{~m}), 1029(\mathrm{~m}), 1009$ (m); HRMS (ESI) calcd. for $\mathrm{C}_{18} \mathrm{H}_{14} \mathrm{IO}_{4}{ }^{+}$ $[\mathrm{M}+\mathrm{H}]^{+}$420.9931; found 420.9937 .

5-Methoxy-2-oxo-4,5-dihydro-2H-5,7a-ethenobenzofuran-3-yl 2-iodobenzoate (8I)

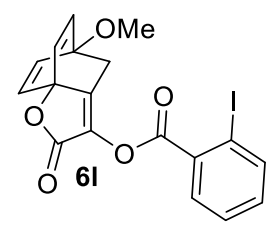

Following general procedure B, 1-[(triiso-propylsilyl)ethynyl]-1,2-benziodoxol-3(1H)-one (9a) $(64.0 \mathrm{mg}$, $0.150 \mathrm{mmol}, 1.00$ equiv) and 4-methoxyphenyl 2-diazoacetate ( $8 \mathrm{I})$ (35 $\mathrm{mg}, 0.18 \mathrm{mmol}, 1.2$ equiv) were stirred for $12 \mathrm{~h}$. Next, triethylamine trihydrofluoride ( $24 \mu \mathrm{L}, 0.15 \mathrm{mmol}, 1.0$ equiv) was added and the reaction mixture further stirred for $36 \mathrm{~h}$. The crude reaction mixture was concentrated in vacuo and purified by flash chromatography using $\mathrm{Et}_{2} \mathrm{O}$ :pentane $1: 5$ as mobile phase to afford $6 \mathrm{I}$ as a colorless thick

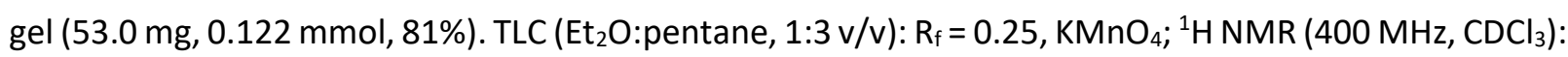
$\delta 8.05(\mathrm{dd}, J=3.3,1.4 \mathrm{~Hz}, 1 \mathrm{H}, \mathrm{ArH}), 8.03(\mathrm{dd}, J=3.2,1.5 \mathrm{~Hz}, 1 \mathrm{H}, \operatorname{ArH}), 7.45(\mathrm{td}, J=7.6,1.2 \mathrm{~Hz}, 1 \mathrm{H}, \operatorname{ArH})$, $7.22(\mathrm{td}, J=7.7,1.7 \mathrm{~Hz}, 1 \mathrm{H}, \operatorname{ArH}), 6.62\left(\mathrm{~d}, J=7.8 \mathrm{~Hz}, 2 \mathrm{H}, 2 \times \mathrm{CH}_{3} \mathrm{OCCH}\right), 6.46(\mathrm{~d}, J=7.8 \mathrm{~Hz}, 2 \mathrm{H}, 2 \mathrm{x}$ $\left.\mathrm{CH}_{3} \mathrm{OCCHCH}\right), 3.64\left(\mathrm{~s}, 3 \mathrm{H}, \mathrm{OCH}_{3}\right), 2.71\left(\mathrm{~s}, 2 \mathrm{H}, \mathrm{OCH}_{3} \mathrm{CCH}_{2}\right) ;{ }^{13} \mathrm{C} \mathrm{NMR}\left(100 \mathrm{MHz}, \mathrm{CDCl}_{3}\right): \delta$ 168.4, 161.9, $149.4,141.9,136.1,133.9,132.2,132.0,129.5,129.4,128.2,95.2,85.7,85.2,54.0,36.2$; IR v 3071 (w), $2942(w), 2836(w), 1788(s), 1760(m), 1581(w), 1564(w), 1504(w), 1465(w), 1429(w), 1352(m), 1314$ (w), $1276(\mathrm{~m}), 1237(\mathrm{~s}), 1198(\mathrm{~m}), 1168(\mathrm{~m}), 1095(\mathrm{~s}), 1010(\mathrm{~m}), 913(\mathrm{w})$; HRMS (ESI) calcd. for $\mathrm{C}_{18} \mathrm{H}_{14} \mathrm{IO}_{5}{ }^{+}$ $[\mathrm{M}+\mathrm{H}]^{+}$436.9880; found 436.9881 .

\section{5-Methyl-2-oxo-4,5-dihydro-2H-5,7a-ethenobenzofuran-3-yl 2-iodobenzoate $(6 \mathrm{~m})$}

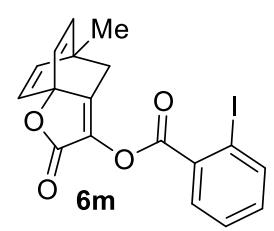

Following general procedure B, 1-[(triiso-propylsilyl)ethynyl]-1,2-benziodoxol-3(1H)-one (9a) $(64.0 \mathrm{mg}$, $0.150 \mathrm{mmol}, 1.00$ equiv) and $p$-tolyl 2-diazoacetate $(8 \mathrm{~m})(32 \mathrm{mg}, 0.18 \mathrm{mmol}, 1.2$ equiv) were stirred for $12 \mathrm{~h}$. Next, triethylamine trihydrofluoride ( $24 \mu \mathrm{L}, 0.15 \mathrm{mmol}, 1.0$ equiv) was added and further stirred for $36 \mathrm{~h}$. The crude reaction mixture was concentrated in vacuo and purified by flash chromatography using EtOAc:pentane 1:9 as mobile phase to afford $6 \mathrm{~m}$ as a white solid (26.0 mg, $62.0 \mu \mathrm{mol}, 41 \%)$. Mp: 128-130 ${ }^{\circ} \mathrm{C}$; TLC (EtOAc:pentane, 1:9 v/v): Rf $=0.35, \mathrm{KMnO} 4 ;{ }^{1} \mathrm{H} \mathrm{NMR}\left(400 \mathrm{MHz}, \mathrm{CDCl}_{3}\right): \delta 8.04(\mathrm{dt}, J=$ 
7.8, 1.3 Hz, 2H, ArH), 7.45 (td, J = 7.6, 1.2 Hz, 1H, ArH), 7.22 (td, J = 7.7, 1.7 Hz, 1H, ArH), 6.48 (d, J = 7.4 $\mathrm{Hz}, 2 \mathrm{H}, 2 \times \mathrm{OCCH}), 6.24\left(\mathrm{~d}, J=7.4 \mathrm{~Hz}, 2 \mathrm{H}, 2 \times \mathrm{H}_{3} \mathrm{CCCH}\right), 2.41\left(\mathrm{~s}, 2 \mathrm{H}, \mathrm{CH}_{3} \mathrm{CCH}_{2}\right), 1.72\left(\mathrm{~s}, 3 \mathrm{H}, \mathrm{CH}_{3}\right) ;{ }^{13} \mathrm{C} \mathrm{NMR}$ $\left(100 \mathrm{MHz}, \mathrm{CDCl}_{3}\right): \delta 169.3,162.3,152.9,144.6,142.0,133.9,132.4,132.4,129.1,128.3,124.3,95.2$, 87.3, 50.3, 31.1, 19.7; IR v 2988 (s), $2904(\mathrm{~m}), 2114(\mathrm{~s}), 1707$ (m), 1370 (s), $1216(\mathrm{~m}), 1077$ (m), 1049 (s); HRMS (ESI) calcd. for $\mathrm{C}_{18} \mathrm{H}_{14} \mathrm{IO}_{4}{ }^{+}[\mathrm{M}+\mathrm{H}]^{+}$420.9931; found 420.9927 .

\section{2-Oxo-4,5-dihydro-2H-5,7a-ethenobenzofuran-3-yl 2-iodobenzoate (6n)}

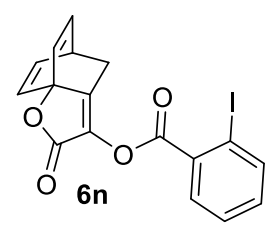

Following general procedure B, 1-[(triiso-propylsilyl)ethynyl]-1,2-benziodoxol-3(1H)-one (9a) $(64.0 \mathrm{mg}$, $0.150 \mathrm{mmol}, 1.00$ equiv) and phenyl 2-diazoacetate $(8 \mathrm{n})(30 \mathrm{mg}, 0.18 \mathrm{mmol}, 1.2$ equiv) were stirred for $12 \mathrm{~h}$. Next, triethylamine trihydrofluoride ( $24 \mu \mathrm{L}, 0.15 \mathrm{mmol}, 1.0$ equiv) was added and the reaction mixture further stirred for $48 \mathrm{~h}$. The crude reaction mixture was concentrated in vacuo and purified by flash chromatography using $\mathrm{Et}_{2} \mathrm{O}$ :pentane $1: 4$ as mobile phase to afford $\mathbf{6 n}$ as a colorless thick gel (20.0 $\mathrm{mg}, 0.049 \mathrm{mmol}, 33 \%)$. TLC (Et $2 \mathrm{O}$ :pentane, $1: 2 \mathrm{v} / \mathrm{v}): \mathrm{R}_{\mathrm{f}}=0.5, \mathrm{KMnO}_{4} ;{ }^{1} \mathrm{H} \mathrm{NMR}\left(400 \mathrm{MHz}, \mathrm{CDCl}_{3}\right): \delta 8.06-$ $8.02(\mathrm{~m}, 2 \mathrm{H}, \mathrm{ArH}), 7.45(\mathrm{td}, J=7.6,1.2 \mathrm{~Hz}, 1 \mathrm{H}, \mathrm{ArH}), 7.22(\mathrm{td}, J=7.7,1.8 \mathrm{~Hz}, 1 \mathrm{H}, \mathrm{ArH}), 6.54-6.49(\mathrm{~m}, 4 \mathrm{H}$, $4 x$ vinyl $\mathrm{CH}$ ), $4.13\left(\mathrm{p}, J=3.5 \mathrm{~Hz}, 1 \mathrm{H}, \mathrm{CHCHCH}_{2}\right), 2.52\left(\mathrm{~d}, J=2.6 \mathrm{~Hz}, 2 \mathrm{H}, \mathrm{CHCHCH}_{2}\right) ;{ }^{13} \mathrm{C} \mathrm{NMR}(100 \mathrm{MHz}$, $\left.\mathrm{CDCl}_{3}\right): \delta 168.8,162.0,151.2,141.8,134.5,133.8,132.2,132.2,131.5,130.0,128.2,95.1,87.1,39.3$, 31.8; IR v 3060 (w), $2953(w), 2924(w), 2856$ (w), 1783 (s), 1760 (s), $1583(w), 1492$ (w), 1465 (w), 1428 (w), $1344(w), 1286(m), 1270(m), 1238(s), 1192(m), 1128(m), 1109(s), 1079(m), 1071(w), 1054(w)$, $1010(\mathrm{~m}), 938$ (w); HRMS (ESI) calcd. for $\mathrm{C}_{17} \mathrm{H}_{12} \mathrm{IO}_{4}{ }^{+}[\mathrm{M}+\mathrm{H}]^{+}$406.9775; found 406.9779.

\section{6,9-Dimethyl-2-oxo-4,5-dihydro-2H-5,7a-ethenobenzofuran-3-yl 2-iodobenzoate (6o)}

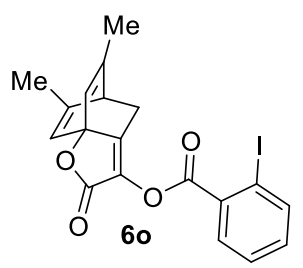

Following general procedure B, 1-[(triiso-propylsilyl)ethynyl]-1,2-benziodoxol-3(1H)-one (9a) $(64.0 \mathrm{mg}$, $0.150 \mathrm{mmol}, 1.00$ equiv) and 3,5-dimethylphenyl 2-diazoacetate ( 80$)(34 \mathrm{mg}, 0.18 \mathrm{mmol}, 1.2$ equiv) were stirred for $12 \mathrm{~h}$. Next, triethylamine trihydrofluoride ( $24 \mu \mathrm{L}, 0.15 \mathrm{mmol}, 1.0$ equiv) was added and the reaction mixture was further stirred for $36 \mathrm{~h}$. The crude reaction mixture was concentrated in vacuo and purified by flash chromatography using EtOAc:pentane 1:9 as mobile phase to afford 60 as a white solid (37.0 mg, $85.0 \mu \mathrm{mol}, 57 \%) . \mathrm{Mp}: 169-171{ }^{\circ} \mathrm{C}$; TLC (EtOAc:pentane, 1:9 v/v): $\mathrm{R}_{\mathrm{f}}=0.33, \mathrm{KMnO}_{4} ;{ }^{1} \mathrm{H} \mathrm{NMR}$ 
(400 MHz, $\mathrm{CDCl}_{3}$ ): $\delta 8.05$ (ddd, J = 7.9, 2.2, 1.4 Hz, 2H, ArH), 7.45 (td, J = 7.6, 1.2 Hz, 1H, ArH), 7.22 (td, J $=7.7,1.7 \mathrm{~Hz}, 1 \mathrm{H}, \mathrm{ArH}), 6.02(\mathrm{p}, J=1.8 \mathrm{~Hz}, 2 \mathrm{H}, 2 \times \mathrm{OCCH}), 3.48\left(\mathrm{~h}, J=2.4 \mathrm{~Hz}, 1 \mathrm{H}, \mathrm{CHCH}_{2}\right), 2.51(\mathrm{~d}, J=2.6$ $\mathrm{Hz}, 2 \mathrm{H}, \mathrm{CH}_{2}$ ), 1.91 (d, $\left.J=1.6 \mathrm{~Hz}, 6 \mathrm{H}, 2 \times \mathrm{CH}_{3}\right) ;{ }^{13} \mathrm{C} \mathrm{NMR}\left(100 \mathrm{MHz}, \mathrm{CDCl}_{3}\right): \delta 169.3,162.3,152.9,144.6$, 142.0, 133.9, 132.4, 132.4, 129.1, 128.3, 124.3, 95.2, 87.3, 50.3, 31.1, 19.7; IR v 2988 (s), 2924 (s), 2114 (s), 1378 (s), 1215 (m), 1074 (s), 1048 (s); HRMS (ESI) calcd. for $\mathrm{C}_{19} \mathrm{H}_{16} \mathrm{IO}_{4}{ }^{+}[\mathrm{M}+\mathrm{H}]^{+}$435.0088; found 435.0080 .

(-)-(5S,7aR)-6,8-Dimethyl-2-oxo-4,5-dihydro-2H-5,7a-ethenobenzofuran-3-yl 2-iodobenzoate (-)-(6p) and (+)-(5R,7aS)-6,8-Dimethyl-2-oxo-4,5-dihydro-2H-5,7a-ethenobenzofuran-3-yl 2-iodobenzoate (+)(6p).

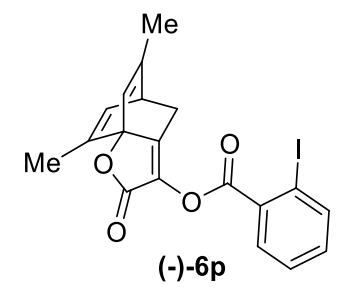

and

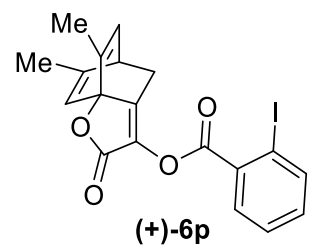

Following general procedure B, 1-[(triiso-propylsilyl)ethynyl]-1,2-benziodoxol-3(1H)-one (15a) $64.0 \mathrm{mg}$, $0.150 \mathrm{mmol}, 1.00$ equiv) and 2,5-dimethylphenyl 2-diazoacetate $(8 \mathrm{p})(34 \mathrm{mg}, 0.18 \mathrm{mmol}, 1.2$ equiv) were stirred for $12 \mathrm{~h}$. Next, triethylamine trihydrofluoride ( $24 \mu \mathrm{L}, 0.15 \mathrm{mmol}, 1.0$ equiv) was added and the reaction mixture was further stirred for $36 \mathrm{~h}$. The crude reaction mixture was concentrated in vacuo and purified by flash chromatography using $\mathrm{Et}_{2} \mathrm{O}$ :pentane $1: 9$ as mobile phase to afford $6 \mathrm{p}$ as a white solid (28.0 mg, $64.0 \mu \mathrm{mol}, 42 \%)$. The obtained racemic mixture was resolved by preparative chiral HPLC, Chiralpak IB, iPOH/hexane 3.5:96.5, $18 \mathrm{~mL} / \mathrm{min}, \operatorname{tr}(+)=14.9 \mathrm{~min}$. and $\operatorname{tr}(-)=16.4 \mathrm{~min} . \lambda=254 \mathrm{~cm}^{-1}$. Mp: $125-126{ }^{\circ} \mathrm{C} ; \operatorname{TLC}\left(\mathrm{Et}_{2} \mathrm{O}\right.$ :pentane, $\left.1: 9 \mathrm{v} / \mathrm{v}\right): \mathrm{R}_{\mathrm{f}}=0.27, \mathrm{KMnO}_{4} ;[\alpha]_{\mathrm{D}}{ }^{20}=+7.78\left(\mathrm{c}=0.3, \mathrm{CH}_{2} \mathrm{Cl}_{2}\right) ;{ }^{1} \mathrm{H}$ NMR (400 $\mathrm{MHz}, \mathrm{CDCl}_{3}$ ): $\delta 8.04$ (ddd, J = 7.9, 3.6, $\left.1.4 \mathrm{~Hz}, 2 \mathrm{H}, \operatorname{ArH}\right), 7.45$ (td, J= 7.6, 1.2 Hz, 1H, $\left.\operatorname{ArH}\right), 7.21$ (td, J = 7.7, $1.7 \mathrm{~Hz}, 1 \mathrm{H}, \mathrm{ArH}), 6.08\left(\mathrm{dt}, J=6.1,1.7 \mathrm{~Hz}, 1 \mathrm{H}, \mathrm{CH}_{3} \mathrm{C}=\mathrm{CH}\right), 5.99(\mathrm{p}, J=1.8 \mathrm{~Hz}, 1 \mathrm{H}, \mathrm{OCCH}), 3.65(\mathrm{dq}, J=6.1$, $2.4 \mathrm{~Hz}, 1 \mathrm{H}, \mathrm{CHCH}_{2}$ ), 2.49 (d, J=2.6 Hz, $\left.2 \mathrm{H}, \mathrm{CH}_{2}\right), 1.89$ (d, J=1.7 Hz, $\left.3 \mathrm{H}, \mathrm{CH}_{3}\right), 1.84$ (d, J=1.7 Hz, 3H, $\mathrm{CH}_{3}$ ); ${ }^{13} \mathrm{C} \mathrm{NMR}\left(100 \mathrm{MHz}, \mathrm{CDCl}_{3}\right): \delta$ 169.2, 162.2, 152.6, 145.7, 142.0, 140.5, 133.9, 132.4, 132.4, 129.3, 128.3, 127.6, 123.3, 95.2, 88.7, 44.0, 31.8, 19.5, 14.4.; IR v 2987 (w), 2965 (w), 2359 (w), 2341 (w), 1757 (s), $1705(\mathrm{~m}), 1428(\mathrm{~m}), 1228(\mathrm{~s}), 1128(\mathrm{~s}), 1114(\mathrm{~m}), 1102(\mathrm{~s}), 1052(\mathrm{~s}), 1006(\mathrm{~s}), 818(\mathrm{~m}), 767(\mathrm{~m}), 727(\mathrm{~s})$; HRMS (ESI) calcd. for $\mathrm{C}_{19} \mathrm{H}_{16} \mathrm{IO}_{4}{ }^{+}[\mathrm{M}+\mathrm{H}]^{+} 435.0088$; found 435.0083. The crystal structure of (+)-6p has been deposited at the Cambridge Crystallographic Data Centre and allocated the deposition number: CCDC 2027173. $[\alpha]_{D}^{20}$ of $(-)-6 p$ was not determined. 


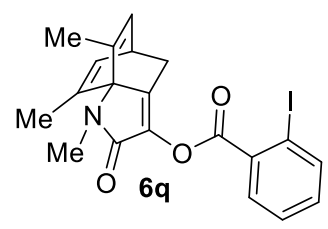

Following general procedure B, 1-[(triiso-propylsilyl)ethynyl]-1,2-benziodoxol-3(1H)-one (9a) $(64.0 \mathrm{mg}$, $0.150 \mathrm{mmol}, 1.00$ equiv) and 2-diazo- $N$-(2,6-dimethylphenyl)- $N$-methylacetamide (6q) (37 mg, 0.18 mmol, 1.2 equiv) were stirred for $12 \mathrm{~h}$. Next, triethylamine trihydrofluoride ( $48 \mu \mathrm{L}, 0.30 \mathrm{mmol}, 2.0$ equiv) was added and the reaction mixture further stirred for $36 \mathrm{~h}$. The crude reaction mixture was concentrated in vacuo and purified by flash chromatography using EtOAc:pentane 3:7 as mobile phase to afford $\mathbf{6 q}$ as a white solid $(27.0 \mathrm{mg}, 60.0 \mu \mathrm{mol}, 40 \%)$. Mp: 149-151 ${ }^{\circ} \mathrm{C}$; TLC (EtOAc:pentane, 1:3 v/v): $\mathrm{Rf}=0.23, \mathrm{KMnO}_{4} ;{ }^{1} \mathrm{H} \mathrm{NMR}\left(400 \mathrm{MHz}, \mathrm{CDCl}_{3}\right): \delta 8.04(\mathrm{~m}, 2 \mathrm{H}, \mathrm{ArH}), 7.43(\mathrm{td}, J=7.6,1.2 \mathrm{~Hz}, 1 \mathrm{H}, \mathrm{ArH}), 7.19$ $(\mathrm{td}, J=7.7,1.7 \mathrm{~Hz}, 1 \mathrm{H}, \mathrm{ArH}), 6.13\left(\mathrm{dq}, J=6.2,1.6 \mathrm{~Hz}, 2 \mathrm{H}, 2 \times \mathrm{CH}_{3} \mathrm{C}=\mathrm{CH}\right), 3.79(\mathrm{tt}, J=6.3,2.6 \mathrm{~Hz}, 1 \mathrm{H}$, $\mathrm{CHCH}_{2}$ ), $3.36\left(\mathrm{~s}, 3 \mathrm{H}, \mathrm{NCH}_{3}\right), 2.31\left(\mathrm{~d}, J=2.6 \mathrm{~Hz}, 2 \mathrm{H}, \mathrm{CH}_{2}\right), 1.84\left(\mathrm{~d}, J=1.6 \mathrm{~Hz}, 6 \mathrm{H}, 2 \times \mathrm{CH}_{3}\right) ;{ }^{13} \mathrm{C} \mathrm{NMR}(100$ $\left.\mathrm{MHz}, \mathrm{CDCl}_{3}\right): \delta 168.0,162.7,143.2,141.7,139.4,134.3,133.5,133.2,132.4,130.2,128.2,95.1,75.3$, 37.8, 31.8, 31.2, 16.4; IR $\vee 2990$ (s), 2922 (s), 2114 (s), 1702 (m), 1372 (s), 1215 (s), 1075 (s), 1050 (s); HRMS (ESI) calcd. for $\mathrm{C}_{20} \mathrm{H}_{19} \mathrm{INO}_{3}+[\mathrm{M}+\mathrm{H}]^{+}$448.0404; found 448.0416 .

7,8-Di-tert-butyl-5-methyl-2-oxo-4-phenyl-4,5-dihydro-2H-5,7a-ethenobenzofuran-3-yl iodobenzoate $(6 r)$

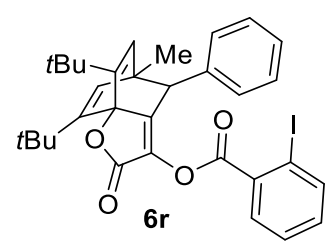

Following general procedure C, 1-[phenylethynyl]-1,2-benziodoxol-3(1H)-one (9b) (52.5 mg, 0.150 mmol, 1.00 equiv) and 2,6-di-tert-butyl-4-methylphenyl 2-diazoacetate (8a) $(65.0 \mathrm{mg}, 0.225 \mathrm{mmol}, 1.50$ equiv) were stirred for $12 \mathrm{~h}$. Next, $\mathrm{Cs}_{2} \mathrm{CO}_{3}(54.0 \mathrm{mg}, 0.165 \mathrm{mmol}, 1.10$ equiv) was added and further stirred for $20 \mathrm{~h}$. The crude reaction mixture was concentrated in vacuo and purified by flash chromatography using $\mathrm{Et}_{2} \mathrm{O}$ :pentane $1: 20$ as mobile phase to afford $6 \mathrm{r}$ as a white solid $(83.0 \mathrm{mg}, 0.137$ mmol, 91\%). Mp: 190.0-191.5 ${ }^{\circ} \mathrm{C}$; TLC (Et $2 \mathrm{O}:$ pentane, 1:10 v/v): $\mathrm{R}_{\mathrm{f}}=0.37, \mathrm{KMnO}_{4} ;{ }^{1} \mathrm{H}$ NMR (400 MHz, $\left.\mathrm{CDCl}_{3}\right): \delta 7.88(\mathrm{dd}, J=7.9,1.1 \mathrm{~Hz}, 1 \mathrm{H}, \mathrm{ArH}), 7.25-7.13(\mathrm{~m}, 5 \mathrm{H}, \mathrm{ArH}), 7.06(\mathrm{td}, J=7.6,1.9 \mathrm{~Hz}, 1 \mathrm{H}, \mathrm{ArH})$, $7.00(\mathrm{dd}, J=7.2,2.3 \mathrm{~Hz}, 2 \mathrm{H}, \operatorname{Ar} H), 5.93(\mathrm{~s}, 1 \mathrm{H}, t \mathrm{BuCCH}), 5.63(\mathrm{~s}, 1 \mathrm{H}, t \mathrm{BuCCH}), 3.63(\mathrm{~s}, 1 \mathrm{H}, \operatorname{ArCH}), 1.31(\mathrm{~s}$, $\left.3 \mathrm{H}, \mathrm{CHCCH}_{3}\right), 1.29(\mathrm{~s}, 9 \mathrm{H}, \mathrm{tBu}), 1.22(\mathrm{~s}, 9 \mathrm{H}, t \mathrm{Bu}) ;{ }^{13} \mathrm{C} \mathrm{NMR}\left(100 \mathrm{MHz}, \mathrm{CDCl}_{3}\right): \delta 168.8,162.0,159.1,152.3$, $150.1,141.3,136.8,133.5,133.2,132.4,131.7,130.7,130.4,129.4,128.2$, 127.6, 127.4, 94.4, 92.7, 53.6, 46.6, 35.4, 35.3, 29.2, 29.1, 20.2; IR v 3063 (w), 2962 (m), $2871(w), 2256(w), 1777(s), 1703$ (w), 1582 
(w), $1463(w), 1363(w), 1236$ (s), $1091(s), 1007$ (m), 910 (m); HRMS (ESI) calcd. for $\mathrm{C}_{32} \mathrm{H}_{33} \mathrm{INaO}_{4}{ }^{+}[\mathrm{M}+\mathrm{Na}]^{+}$ 631.1316; found 631.1325 .

Large scale procedure: Following general procedure C, 1-[phenylethynyl]-1,2-benziodoxol-3(1H)-one (9b) (670 mg, $2.00 \mathrm{mmol}, 1.00$ equiv) and 2,6-di-tert-butyl-4-methylphenyl 2-diazoacetate (8a) (865 mg, $3.00 \mathrm{mmol}, 1.50$ equiv) were stirred for $12 \mathrm{~h}$. Next, $\mathrm{Cs}_{2} \mathrm{CO}_{3}(720 \mathrm{mg}, 2.20 \mathrm{mmol}, 1.10$ equiv) was added and further stirred for $20 \mathrm{~h}$. The crude reaction mixture was concentrated in vacuo and purified by flash chromatography using $\mathrm{Et}_{2} \mathrm{O}$ :pentane 1:20 as mobile phase to afford $6 \mathrm{r}$ as a white solid $(1.10 \mathrm{~g}, 1.80$ $\mathrm{mmol}, 90 \%)$.

7,8-Di-tert-butyl-5-ethyl-2-oxo-4-phenyl-4,5-dihydro-2H-5,7a-ethenobenzofuran-3-yl 2-iodobenzoate (6s)

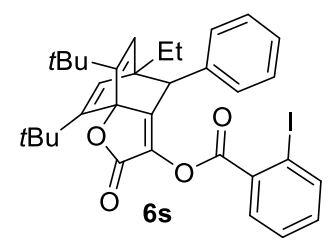

Following general procedure C, 1-[phenylethynyl]-1,2-benziodoxol-3(1H)-one (9b) (52.5 mg, 0.150 mmol, 1.00 equiv) and 2,6-di-tert-butyl-4-ethylphenyl 2-diazoacetate (8b) (68.0 mg, $0.225 \mathrm{mmol}, 1.50$ equiv) were stirred for $12 \mathrm{~h}$. Next, $\mathrm{Cs}_{2} \mathrm{CO}_{3}(54.0 \mathrm{mg}, 0.165 \mathrm{mmol}, 1.10$ equiv) was added and the reaction mixture further stirred for $20 \mathrm{~h}$. The crude reaction mixture was concentrated in vacuo and purified by flash chromatography using $\mathrm{Et}_{2} \mathrm{O}$ :pentane 1:20 as mobile phase to afford $6 \mathrm{~s}$ as a white solid $(90.0 \mathrm{mg}$, $0.145 \mathrm{mmol}, 96 \%)$. Mp: 68.0-74.5 ${ }^{\circ} \mathrm{C} ; \mathrm{TLC}\left(\mathrm{Et}_{2} \mathrm{O}\right.$ :pentane, $\left.1: 15 \mathrm{v} / \mathrm{v}\right): \mathrm{R}_{\mathrm{f}}=0.32, \mathrm{KMnO}_{4} ;{ }^{1} \mathrm{H} \mathrm{NMR}(400 \mathrm{MHz}$, $\left.\mathrm{CDCl}_{3}\right): \delta 7.88(\mathrm{~d}, J=7.8 \mathrm{~Hz}, 1 \mathrm{H}, \operatorname{ArH}), 7.22-7.13(\mathrm{~m}, 5 \mathrm{H}, \operatorname{ArH}), 7.10-6.94(\mathrm{~m}, 3 \mathrm{H}, \operatorname{ArH}), 6.04(\mathrm{~s}, 1 \mathrm{H}$, $t$ BuCCH), $5.74(\mathrm{~s}, 1 \mathrm{H}, t \mathrm{BuCCH}), 3.66(\mathrm{~s}, 1 \mathrm{H}, \mathrm{ArCH}), 1.68-1.50\left(\mathrm{~m}, 2 \mathrm{H}, \mathrm{CH}_{2} \mathrm{CH}_{3}\right), 1.29(\mathrm{~s}, 9 \mathrm{H}, t \mathrm{Bu}), 1.23(\mathrm{~s}$, $9 \mathrm{H}, t \mathrm{Bu}), 1.04\left(\mathrm{t}, J=7.4 \mathrm{~Hz}, 3 \mathrm{H}, \mathrm{CH}_{2} \mathrm{CH}_{3}\right) ;{ }^{13} \mathrm{C} \mathrm{NMR}\left(100 \mathrm{MHz}, \mathrm{CDCl}_{3}\right): \delta 168.8,161.9,160.0,152.5,150.2$, $141.3,136.9,133.2,132.3,131.7,130.7,130.6,129.3,128.8,128.2,127.6,127.4,94.5,92.5,52.5,51.1$, 35.6, 35.5, 29.2, 29.1, 25.8, 9.6; IR $v 3063(w), 2962(m), 2871(w), 2255(w), 1777(s), 1700(w), 1583$ (w), 1463 (w), $1364(w), 1272(w), 1236$ (s), $1184(m), 1130$ (w), 1091 (s), $1036(m), 1007$ (s), $911(m)$; HRMS (ESI) calcd. for $\mathrm{C}_{33} \mathrm{H}_{36} \mathrm{IO}_{4}{ }^{+}[\mathrm{M}+\mathrm{H}]^{+}$623.1653; found 623.1655 . 


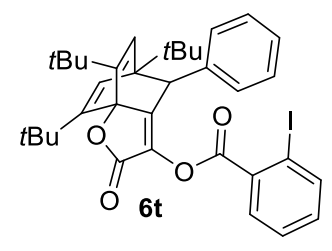

Following general procedure C, 1-[phenylethynyl]-1,2-benziodoxol-3(1H)-one (9b) (52.5 mg, 0.150 mmol, 1.00 equiv) and 2,4,6-tri-tert-butylphenyl 2-diazoacetate (8c) $(74.5 \mathrm{mg}, 0.225 \mathrm{mmol}, 1.50$ equiv) were stirred for $12 \mathrm{~h}$. Next, $\mathrm{Cs}_{2} \mathrm{CO}_{3}(54.0 \mathrm{mg}, 0.165 \mathrm{mmol}, 1.10$ equiv) was added and further stirred for $20 \mathrm{~h}$. The crude reaction mixture was concentrated in vacuo and purified by flash chromatography using $\mathrm{Et}_{2} \mathrm{O}$ :pentane 1:20 as mobile phase to afford $6 \mathrm{t}$ as a white solid $(96.0 \mathrm{mg}, 0.148 \mathrm{mmol}, 98 \%)$. Mp: 84.5$89.5^{\circ} \mathrm{C}$; TLC (Et $2 \mathrm{O}$ :pentane, 1:15 v/v): $\mathrm{R}_{\mathrm{f}}=0.35, \mathrm{KMnO}_{4} ;{ }^{1} \mathrm{H}$ NMR $\left(400 \mathrm{MHz}, \mathrm{CDCl}_{3}\right): \delta 7.91$ (dd, J = 7.9, $1.3 \mathrm{~Hz}, 1 \mathrm{H}, \mathrm{ArH}), 7.21-7.04$ (m, 5H, ArH), $7.03-6.95$ (m, 3H, ArH), 6.18 (s, 2H, $2 \times t \mathrm{BuCCH}), 3.82(\mathrm{~s}, 1 \mathrm{H}$, $\operatorname{ArCH}), 1.32(\mathrm{~s}, 9 \mathrm{H}, t \mathrm{Bu}), 1.23(\mathrm{~s}, 9 \mathrm{H}, t \mathrm{Bu}), 0.88(\mathrm{~s}, 9 \mathrm{H}, t \mathrm{Bu}) ;{ }^{13} \mathrm{C} \mathrm{NMR}\left(100 \mathrm{MHz}, \mathrm{CDCl}_{3}\right): \delta$ 169.0, 161.7, $161.5,151.6,150.0,141.5,139.0,133.3,132.0,131.7,131.6,130.7,131.0,129.0,128.4,127.5,127.3$, 127.2, 126.9, 95.0, 91.7, 57.5, 50.8, 35.7, 35.6, 33.9, 29.2, 29.1, 27.0; IR $v 3085$ (w), $2961(\mathrm{~m}), 2872(w)$, $2255(w), 1778(s), 1694(w), 1583(w), 1467(m), 1431(w), 1397(w), 1367(w), 1271(w), 1236(s), 1184$ $(\mathrm{m}), 1136(\mathrm{~m}), 1082(\mathrm{~s}), 1040(\mathrm{~m}), 1009(\mathrm{~m}), 912(\mathrm{~m})$; HRMS (ESI) calcd. for $\mathrm{C}_{35} \mathrm{H}_{39} \mathrm{INaO}_{4}{ }^{+}[\mathrm{M}+\mathrm{Na}]^{+}$ 673.1785; found 673.1788. All six carbons of phenyl group are different due to adjacent $t$ Bu group.

7,8-Di-tert-butyl-5-methoxy-2-oxo-4-phenyl-4,5-dihydro-2H-5,7a-ethenobenzofuran-3-yl iodobenzoate $(6 u)$

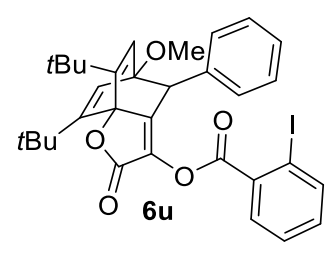

Following general procedure C, 1-[phenylethynyl]-1,2-benziodoxol-3(1H)-one (9b) (52.5 mg, 0.150 mmol, 1.00 equiv) and 2,6-di-tert-butyl-4-methoxyphenyl 2-diazoacetate (8d) $(68.5 \mathrm{mg}, 0.225 \mathrm{mmol}$, 1.50 equiv) were stirred for $12 \mathrm{~h}$. Next, $\mathrm{Cs}_{2} \mathrm{CO}_{3}(54.0 \mathrm{mg}, 0.165 \mathrm{mmol}, 1.10$ equiv) was added and the reaction mixture further stirred for $20 \mathrm{~h}$. The crude reaction mixture was concentrated in vacuo and purified by flash chromatography using $\mathrm{Et}_{2} \mathrm{O}$ :pentane 1:15 as mobile phase to afford $\mathbf{6 u}$ as a white solid (91.0 mg, $0.146 \mathrm{mmol}, 97 \%$ ). Mp: 153.9-157.8 ${ }^{\circ} \mathrm{C}$; TLC (Et $2 \mathrm{O}:$ pentane, 1:15 v/v): $\mathrm{R}_{\mathrm{f}}=0.13, \mathrm{KMnO}_{4} ;{ }^{1} \mathrm{H}$ $\operatorname{NMR}\left(400 \mathrm{MHz}, \mathrm{CDCl}_{3}\right): \delta 7.88(\mathrm{dd}, J=7.9,1.2 \mathrm{~Hz}, 1 \mathrm{H}, \mathrm{ArH}), 7.31-7.26(\mathrm{~m}, 1 \mathrm{H}, \mathrm{ArH}), 7.24-7.14(\mathrm{~m}, 4 \mathrm{H}$, $\operatorname{ArH}), 7.10-7.04(\mathrm{~m}, 3 \mathrm{H}, \mathrm{ArH}), 6.33(\mathrm{~d}, J=1.3 \mathrm{~Hz}, 1 \mathrm{H}, t \mathrm{BuCCH}), 5.98(\mathrm{~d}, J=1.2 \mathrm{~Hz}, 1 \mathrm{H}, t \mathrm{BuCCH}), 4.05$ (s, $1 \mathrm{H}, \mathrm{ArCH}), 3.51\left(\mathrm{~s}, 3 \mathrm{H}, \mathrm{OCH}_{3}\right), 1.29(\mathrm{~s}, 9 \mathrm{H}, t \mathrm{Bu}), 1.24(\mathrm{~s}, 9 \mathrm{H}, t \mathrm{Bu}) ;{ }^{13} \mathrm{C} \mathrm{NMR}\left(100 \mathrm{MHz}, \mathrm{CDCl}_{3}\right): \delta$ 168.4, $161.9,156.4,150.9,148.1,141.6,135.8,133.3$, 132.4, 131.7, 130.7, 129.7, 128.5, 128.1, 127.7, 127.6, 
126.9, 94.4, 91.3, 85.6, 53.8, 52.1, 35.7, 35.5, 29.1, 29.0; IR $\vee 3063$ (w), 2961 (m), $2253(w), 1783(s)$, $1706(w), 1583(w), 1465(w), 1430(w), 1364(w), 1307(m), 1270(m), 1236(m), 1187(m), 1130(m)$, 1090 (s), 1036 (w), 1007 (m); HRMS (ESI) calcd. for $\mathrm{C}_{32} \mathrm{H}_{33} \mathrm{INaO}_{5}{ }^{+}[\mathrm{M}+\mathrm{Na}]^{+}$647.1265; found 647.1265.

5-Bromo-7,8-di-tert-butyl-2-oxo-4-phenyl-4,5-dihydro-2H-5,7a-ethenobenzofuran-3-yl iodobenzoate $(6 \mathrm{v})$

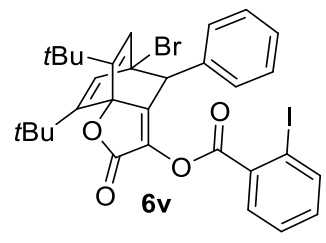

Following general procedure C, 1-[phenylethynyl]-1,2-benziodoxol-3(1H)-one (9b) (52.5 mg, 0.150 mmol, 1.00 equiv) and 4-bromo-2,6-di-tert-butylphenyl 2-diazoacetate $(8 e)(79.0 \mathrm{mg}, 0.225 \mathrm{mmol}, 1.50$ equiv) were stirred for $12 \mathrm{~h}$. Next, $\mathrm{Cs}_{2} \mathrm{CO}_{3}(54.0 \mathrm{mg}, 0.165 \mathrm{mmol}, 1.10$ equiv) was added and the reaction mixture further stirred for $20 \mathrm{~h}$. The crude reaction mixture was concentrated in vacuo and purified by flash chromatography using $\mathrm{Et}_{2} \mathrm{O}$ :pentane 1:20 as mobile phase to afford $\mathbf{6 v}$ as a white solid $(100 \mathrm{mg}$, $0.149 \mathrm{mmol}, 99 \%)$. Mp: $178.6-180.1^{\circ} \mathrm{C}$; TLC (Et $2 \mathrm{O}$ :pentane, 1:20 v/v): $\mathrm{R}_{\mathrm{f}}=0.28, \mathrm{KMnO}_{4} ;{ }^{1} \mathrm{H}$ NMR (400 $\left.\mathrm{MHz}, \mathrm{CDCl}_{3}\right): \delta 7.89(\mathrm{dd}, \mathrm{J}=7.9,1.2 \mathrm{~Hz}, 1 \mathrm{H}, \mathrm{ArH}), 7.27-7.17(\mathrm{~m}, 5 \mathrm{H}, \mathrm{ArH}), 7.13-7.05(\mathrm{~m}, 3 \mathrm{H}, \mathrm{ArH}), 6.37$ (s, $1 \mathrm{H}, t \mathrm{BuCCH}), 6.01(\mathrm{~s}, 1 \mathrm{H}, t \mathrm{BuCCH}), 4.10(\mathrm{~s}, 1 \mathrm{H}, \mathrm{ArCH}), 1.30$ (s, 9H, tBu), $1.24(\mathrm{~s}, 9 \mathrm{H}, t \mathrm{Bu}) ;{ }^{13} \mathrm{C}$ NMR (100 $\left.\mathrm{MHz}, \mathrm{CDCl}_{3}\right): \delta 167.9,162.0,155.1,152.1,149.9,141.5,135.5,133.8,133.5,131.9,131.7,130.3,130.2$, 130.1, 128.2, 128.1, 127.7, 94.6, 90.9, 61.3, 56.0, 35.6, 35.5, 29.0, 28.9; IR v 3064 (w), 2962 (m), 2871 (w), $2255(w), 1785(s), 1702(w), 1650(w), 1606(w), 1584(w), 1464(w), 1430(w), 1365(w), 1235(s)$, $1184(\mathrm{~m}), 1123(\mathrm{~m}), 1080$ (s), $1033(\mathrm{~m}), 1005$ (s), 911 (s); HRMS (ESI) calcd. for $\mathrm{C}_{31} \mathrm{H}_{31} \mathrm{BrIO}_{4}{ }^{+}[\mathrm{M}+\mathrm{H}]^{+}$ 673.0445; found 673.0451.

\section{7,8-Di-tert-butyl-2-oxo-4-phenyl-4,5-dihydro-2H-5,7a-ethenobenzofuran-3-yl-2-iodobenzoate (6w)}

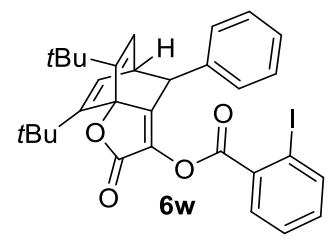

Following general procedure C, 1-[phenylethynyl]-1,2-benziodoxol-3(1H)-one (9b) (52.5 mg, 0.150 mmol, 1.00 equiv) and 2,6-di-tert-butylphenyl 2-diazoacetate (8f) $(62.0 \mathrm{mg}, 0.225 \mathrm{mmol}, 1.50$ equiv) were stirred for $12 \mathrm{~h}$. Next, $\mathrm{Cs}_{2} \mathrm{CO}_{3}(54.0 \mathrm{mg}, 0.165 \mathrm{mmol}, 1.10$ equiv) was added and the reaction mixture further stirred for $20 \mathrm{~h}$. The crude reaction mixture was concentrated in vacuo and purified by flash chromatography using $\mathrm{Et}_{2} \mathrm{O}$ :pentane $1: 15$ as mobile phase to afford $\mathbf{6} \mathbf{w}$ as a white solid $(85.0 \mathrm{mg}$, $0.143 \mathrm{mmol}, 95 \%)$. Mp: $159.5-162.3{ }^{\circ} \mathrm{C} ; \mathrm{TLC}\left(\mathrm{Et}_{2} \mathrm{O}\right.$ :pentane, $\left.1: 15 \mathrm{v} / \mathrm{v}\right): \mathrm{R}_{\mathrm{f}}=0.25, \mathrm{KMnO}_{4} ;{ }^{1} \mathrm{H}$ NMR (400 $\left.\mathrm{MHz}, \mathrm{CDCl}_{3}\right): \delta 7.88(\mathrm{dd}, J=8.0,1.2 \mathrm{~Hz}, 1 \mathrm{H}, \operatorname{ArH}), 7.47(\mathrm{dd}, J=7.9,1.7 \mathrm{~Hz}, 1 \mathrm{H}, \operatorname{ArH}), 7.25-7.14(\mathrm{~m}, 4 \mathrm{H}$, 
$\operatorname{Ar} H), 7.11-7.03(\mathrm{~m}, 3 \mathrm{H}, \operatorname{ArH}), 6.24(\mathrm{~d}, J=6.5 \mathrm{~Hz}, 1 \mathrm{H}, t \mathrm{BuCCH}), 5.86(\mathrm{~d}, J=6.3 \mathrm{~Hz}, 1 \mathrm{H}, t \mathrm{BuCCH}), 4.00(\mathrm{~d}$, $J=2.4 \mathrm{~Hz}, 1 \mathrm{H}, \mathrm{ArCH}$ ), 3.80 (td, $J=6.4,2.5 \mathrm{~Hz}, 1 \mathrm{H}, \mathrm{ArCHCH}), 1.26(\mathrm{~s}, 9 \mathrm{H}, t \mathrm{Bu}), 1.23(\mathrm{~s}, 9 \mathrm{H}, t \mathrm{Bu}) ;{ }^{13} \mathrm{C} \mathrm{NMR}$ (100 MHz, $\mathrm{CDCl}_{3}$ ): $\delta$ 168.7, 162.1, 156.4, 152.3, 150.4, 141.3, 139.0, 133.3, 132.6, 131.8, 131.7, 128.5, $128.1,127.7,127.3,127.2,125.0,94.4,92.9,48.8,45.4,35.5,35.4,29.2,29.1$; IR v 3068 (w), $2960(\mathrm{~m})$, $2870(w), 2255(w), 1777(s), 1706(w), 1583(w), 1466(w), 1430(w), 1363(w), 1272(m), 1241(m), 1170$ (m), 1127 (s), 1083 (s), 1032 (m), 1008 (s), 912 (m); HRMS (ESI) calcd. for $\mathrm{C}_{31} \mathrm{H}_{31} \mathrm{INaO}_{4}{ }^{+}[\mathrm{M}+\mathrm{Na}]^{+}$617.1159; found 617.1172 .

7,8-Di-tert-butyl-5-methyl-2-oxo-4-(4-pentylphenyl)-4,5-dihydro-2 $\mathrm{H}-5,7 a-e t h e n o b e n z o f u r a n-3-y l \quad 2-$ iodobenzoate $(6 \mathrm{x})$

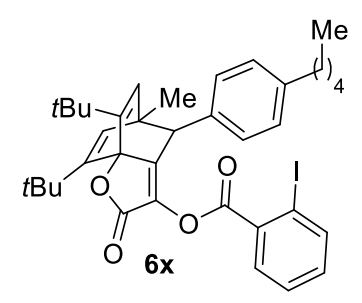

Following general procedure C, 1-[4-pentylphenylethynyl]-1,2-benziodoxol-3(1H)-one (9c) $(63.0 \mathrm{mg}$, $0.150 \mathrm{mmol}, 1.00$ equiv) and 2,6-di-tert-butyl-4-methylphenyl 2-diazoacetate (8a) (65.0 mg, 0.225 mmol, 1.50 equiv) were stirred for $12 \mathrm{~h}$. Next, $\mathrm{Cs}_{2} \mathrm{CO}_{3}(54.0 \mathrm{mg}, 0.165 \mathrm{mmol}, 1.10$ equiv) was added and the reaction mixture further stirred for $20 \mathrm{~h}$. The crude reaction mixture was concentrated in vacuo and purified by flash chromatography using $\mathrm{Et}_{2} \mathrm{O}$ :pentane 1:25 as mobile phase to afford $\mathbf{6 x}$ as a white solid (93.0 mg, $0.137 \mathrm{mmol}, 91 \%)$. Mp: 189.6-192.5 ${ }^{\circ} \mathrm{C}$; TLC (Et $2 \mathrm{O}$ :pentane, 1:15 v/v): $\mathrm{R}_{\mathrm{f}}=0.38, \mathrm{KMnO}_{4} ;{ }^{1} \mathrm{H}$ $\operatorname{NMR}\left(400 \mathrm{MHz}, \mathrm{CDCl}_{3}\right): \delta 7.87$ (dd, J = 7.9, $\left.1.2 \mathrm{~Hz}, 1 \mathrm{H}, \mathrm{ArH}\right), 7.23-7.12(\mathrm{~m}, 2 \mathrm{H}, \mathrm{ArH}), 7.05$ (td, J = 7.6, 2.0 $\mathrm{Hz}, 1 \mathrm{H}, \mathrm{ArH}), 6.98(\mathrm{~d}, J=8.0 \mathrm{~Hz}, 2 \mathrm{H}, \mathrm{ArH}), 6.89(\mathrm{~d}, J=8.1 \mathrm{~Hz}, 2 \mathrm{H}, \mathrm{ArH}), 5.91(\mathrm{~s}, 1 \mathrm{H}, t \mathrm{BuCCH}), 5.64(\mathrm{~s}, 1 \mathrm{H}$, $t$ BuCCH), $3.58(\mathrm{~s}, 1 \mathrm{H}, \mathrm{ArCH}), 2.51-2.44\left(\mathrm{~m}, 2 \mathrm{H}, \mathrm{ArCH}_{2}\right), 1.47\left(\mathrm{p}, J=7.6 \mathrm{~Hz}, 2 \mathrm{H}, \mathrm{ArCH}_{2} \mathrm{CH}_{2}\right), 1.40-1.08$ (m, $25 \mathrm{H}, \mathrm{CHCCH}_{3}, 2 \times t \mathrm{Bu}$, and $\left.\mathrm{CH}_{2} \mathrm{CH}_{2} \mathrm{CH}_{3}\right), 0.85\left(\mathrm{t}, J=7.1 \mathrm{~Hz}, 3 \mathrm{H}, \mathrm{CH}_{2} \mathrm{CH}_{2} \mathrm{CH}_{3}\right) ;{ }^{13} \mathrm{CNMR}\left(100 \mathrm{MHz}, \mathrm{CDCl}_{3}\right)$ : $\delta$ 168.8, 161.9, 159.4, 152.2, 150.0, 142.2, 141.3, 133.8, 133.5, 133.1, 132.5, 131.6, 130.6, 130.5, 129.2, 128.2, 127.5, 94.4, 92.7, 53.3, 46.7, 35.4, 35.3, 31.5, 31.1, 29.2, 29.1, 22.5, 20.2, 14.0; IR v 2959 (w), 2930 (w), $2867(w), 1782(s), 1703(w), 1584(w), 1464(w), 1363(w), 1237(m), 1188(w), 1146(w), 1092(s)$, 1007 (m), 911 (w), $848(w)$; HRMS (ESI) calcd. for $\mathrm{C}_{37} \mathrm{H}_{44} \mathrm{O}_{4}{ }^{+}[\mathrm{M}+\mathrm{H}]^{+}$679.2279; found 679.2282. One carbon was not resolved at $100 \mathrm{MHz}$. 

iodobenzoate (6y)

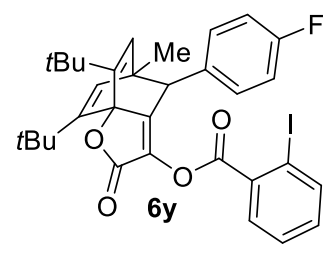

Following general procedure C, 1-[4-fluorophenylethynyl]-1,2-benziodoxol-3(1H)-one (9d) (55.0 mg, $0.150 \mathrm{mmol}, 1.00$ equiv) and 2,6-di-tert-butyl-4-methylphenyl 2-diazoacetate (8a) (65.0 mg, 0.225 mmol, 1.50 equiv) were stirred for $12 \mathrm{~h}$. Next, $\mathrm{Cs}_{2} \mathrm{CO}_{3}(54.0 \mathrm{mg}, 0.165 \mathrm{mmol}, 1.10$ equiv) was added and the reaction mixture further stirred for $20 \mathrm{~h}$. The crude reaction mixture was concentrated in vacuo and purified by flash chromatography using $\mathrm{Et}_{2} \mathrm{O}$ :pentane 1:25 as mobile phase to afford $6 y$ as a white solid (90.0 mg, $0.144 \mathrm{mmol}$, 96\%). Mp: 197.3-198.7 ${ }^{\circ} \mathrm{C}$; TLC (Et ${ }_{2} \mathrm{O}:$ pentane, 1:10 v/v): $\mathrm{R}_{\mathrm{f}}=0.36, \mathrm{KMnO}_{4} ;{ }^{1} \mathrm{H}$ $\operatorname{NMR}\left(400 \mathrm{MHz}, \mathrm{CDCl}_{3}\right.$ ): $\delta 7.91(\mathrm{dd}, J=7.9,1.2 \mathrm{~Hz}, 1 \mathrm{H}, \mathrm{ArH}), 7.39(\mathrm{dd}, J=7.9,1.7 \mathrm{~Hz}, 1 \mathrm{H}, \mathrm{ArH}), 7.26-7.21$ $(\mathrm{m}, 1 \mathrm{H}, \mathrm{ArH}), 7.10(\mathrm{td}, J=7.6,1.7 \mathrm{~Hz}, 1 \mathrm{H}, \mathrm{ArH}), 7.01-6.95(\mathrm{~m}, 2 \mathrm{H}, \mathrm{ArH}), 6.88(\mathrm{t}, J=8.7 \mathrm{~Hz}, 2 \mathrm{H}, \operatorname{ArH}), 5.92$ (s, 1H, tBuCCH), 5.61 (s, 1H, tBuCCH), 3.63 (s, 1H, ArCH), 1.30 (s, 3H, CHCCH $)_{3}, 1.28$ (s, 9H, tBu), $1.22(\mathrm{~s}$, $9 \mathrm{H}, t \mathrm{Bu}) ;{ }^{13} \mathrm{C}$ NMR (100 MHz, $\left.\mathrm{CDCl}_{3}\right): \delta 168.7,162.2$ (d, $\left.J=246.6 \mathrm{~Hz}\right), 161.8,158.8,152.3,150.4,141.5$, 133.5, 133.4, 132.6 (d, $J=3.3 \mathrm{~Hz}), 132.1,131.7,130.8(\mathrm{~d}, J=6.1 \mathrm{~Hz}), 130.2,127.8,115.1(\mathrm{~d}, J=21.3 \mathrm{~Hz})$, 94.6, 92.6, 52.8, 46.5, 35.5, 35.4, 29.2, 29.1, 20.2; IR v3063 (w), 2961 (w), 2931 (w), 2871 (w), 2256 (w), 1779 (s), 1702 (w), 1604 (w), 1584 (w), 1509 (m), $1471(w), 1431$ (w), $1364(w), 1273(w), 1234(s), 1187$ (w), $1146(w), 1093$ (s), $1033(w), 1006$ (m), 912 (m), 900 (w); HRMS (ESI) calcd. for $\mathrm{C}_{32} \mathrm{H}_{32} \mathrm{FINaO}_{4}{ }^{+}[\mathrm{M}+\mathrm{Na}]^{+}$ 649.1222; found 649.1229. One carbon was not resolved at $100 \mathrm{MHz}$.

4-(4-Bromophenyl)-7,8-di-tert-butyl-5-methyl-2-oxo-4,5-dihydro-2H-5,7a-ethenobenzofuran-3-yl 2iodobenzoate (6z)

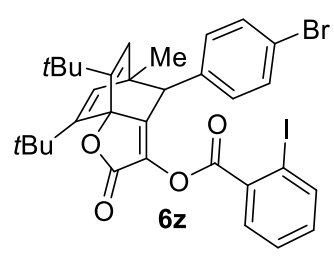

Following general procedure C, 1-[4-bromophenylethynyl]-1,2-benziodoxol-3(1H)-one (9e) (64.0 mg, $0.150 \mathrm{mmol}, 1.00$ equiv) and 2,6-di-tert-butyl-4-methylphenyl 2-diazoacetate (8a) (65.0 mg, 0.225 mmol, 1.50 equiv) were stirred for $12 \mathrm{~h}$. Next, $\mathrm{Cs}_{2} \mathrm{CO}_{3}(54.0 \mathrm{mg}, 0.165 \mathrm{mmol}, 1.10$ equiv) was added and the reaction mixture further stirred for $20 \mathrm{~h}$. The crude reaction mixture was concentrated in vacuo and purified by flash chromatography using $\mathrm{Et}_{2} \mathrm{O}$ :pentane 1:20 as mobile phase to afford $\mathbf{6 z}$ as a white solid (102 mg, $0.149 \mathrm{mmol}, 99 \%) . \mathrm{Mp}: 196.5-199.3{ }^{\circ} \mathrm{C}$; TLC (Et $2 \mathrm{O}:$ pentane, 1:10 v/v): $\mathrm{R}_{\mathrm{f}}=0.37, \mathrm{KMnO}_{4} ;{ }^{1} \mathrm{H}$ NMR (400 MHz, CDCl $)$ ): $\delta 7.91(\mathrm{dd}, J=8.0,1.2 \mathrm{~Hz}, 1 \mathrm{H}, \operatorname{ArH}), 7.39-7.30(\mathrm{~m}, 3 \mathrm{H}, \operatorname{ArH}), 7.29-7.23(\mathrm{~m}, 1 \mathrm{H}$, 
$\operatorname{ArH}), 7.11(\mathrm{td}, J=7.6,1.8 \mathrm{~Hz}, 1 \mathrm{H}, \operatorname{ArH}), 6.88(\mathrm{~d}, J=8.4 \mathrm{~Hz}, 2 \mathrm{H}, \operatorname{ArH}), 5.91(\mathrm{~s}, 1 \mathrm{H}, t \mathrm{BuCCH}), 5.60(\mathrm{~s}, 1 \mathrm{H}$, $t \mathrm{BuCCH}), 3.60(\mathrm{~s}, 1 \mathrm{H}, \mathrm{ArCH}), 1.30\left(\mathrm{~s}, 3 \mathrm{H}, \mathrm{CHCCH}_{3}\right), 1.27(\mathrm{~s}, 9 \mathrm{H}, t \mathrm{Bu}), 1.21(\mathrm{~s}, 9 \mathrm{H}, t \mathrm{Bu}) ;{ }^{13} \mathrm{C} \mathrm{NMR}(100 \mathrm{MHz}$, $\left.\mathrm{CDCl}_{3}\right): \delta 168.6,162.0,158.4,152.5,151.0,141.5,135.9,133.5,133.3,132.2,131.7,131.4,130.9,130.9$, 130.1, 127.8, 121.6, 94.5, 92.6, 53.0, 46.5, 35.5, 35.4, 29.2, 29.1, 20.2; IR v 3062 (w), 2961 (m), $2930(w)$, $2871(w), 2255(w), 1779(s), 1704(w), 1585(w), 1484(w), 1464(w), 1431(w), 1363(w), 1272(w), 1236$ (s), $1183(w), 1146(w), 1091(s), 1034(w), 1008(m), 911(m), 850(w), 737$ (s); HRMS (ESI) calcd. for $\mathrm{C}_{32} \mathrm{H}_{32} \mathrm{BrINaO}_{4}^{+}[\mathrm{M}+\mathrm{Na}]^{+}$709.0421; found 709.0433.

7,8-Di-tert-butyl-5-methyl-2-oxo-4-(4-(trifluoromethyl)phenyl)-4,5-dihydro-2H-5,7aethenobenzofuran-3-yl 2-iodobenzoate (6aa)

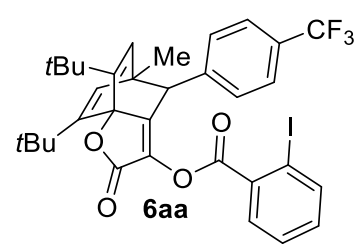

Following general procedure C, 1-[4-trifluoromethylphenylethynyl]-1,2-benziodoxol-3(1H)-one (9f) (62.5 mg, $0.150 \mathrm{mmol}, 1.00$ equiv) and 2,6-di-tert-butyl-4-methylphenyl 2-diazoacetate (8a) $(65.0 \mathrm{mg}$, $0.225 \mathrm{mmol}, 1.50$ equiv) were stirred for $12 \mathrm{~h} . \mathrm{Next}, \mathrm{Cs}_{2} \mathrm{CO}_{3}(54.0 \mathrm{mg}, 0.165 \mathrm{mmol}, 1.10$ equiv) was added and the reaction mixture further stirred for $20 \mathrm{~h}$. The crude reaction mixture was concentrated in vacuo and purified by flash chromatography using $\mathrm{Et}_{2} \mathrm{O}$ :pentane 1:20 as mobile phase to afford 6 aa as a white solid (92.0 mg, $0.136 \mathrm{mmol}, 91 \%)$. Mp: 190.0-191.5 ${ }^{\circ} \mathrm{C}$; TLC (Et $2 \mathrm{O}$ :pentane, 1:10 v/v): $\mathrm{R}_{\mathrm{f}}=0.35, \mathrm{KMnO}_{4} ;{ }^{1} \mathrm{H}$ $\operatorname{NMR}\left(400 \mathrm{MHz}, \mathrm{CDCl}_{3}\right): \delta 7.89$ (dd, J = 7.9, $\left.1.2 \mathrm{~Hz}, 1 \mathrm{H}, \mathrm{ArH}\right), 7.47(\mathrm{~d}, J=8.1 \mathrm{~Hz}, 2 \mathrm{H}, \mathrm{ArH}), 7.30-7.24(\mathrm{~m}$, $1 \mathrm{H}, \operatorname{ArH}), 7.20(\mathrm{td}, J=7.6,1.2 \mathrm{~Hz}, 1 \mathrm{H}, \mathrm{ArH}), 7.14(\mathrm{~d}, J=8.0 \mathrm{~Hz}, 2 \mathrm{H}, \operatorname{ArH}), 7.08(\mathrm{td}, J=7.6,1.8 \mathrm{~Hz}, 1 \mathrm{H}, \operatorname{ArH})$, $5.93(\mathrm{~s}, 1 \mathrm{H}, t \mathrm{BuCCH}), 5.61(\mathrm{~s}, 1 \mathrm{H}, t \mathrm{BuCCH}), 3.70(\mathrm{~s}, 1 \mathrm{H}, \mathrm{ArCH}), 1.32\left(\mathrm{~s}, 3 \mathrm{H}, \mathrm{CHCCH}_{3}\right), 1.29(\mathrm{~s}, 9 \mathrm{H}, t \mathrm{Bu}), 1.22$ $(\mathrm{s}, 9 \mathrm{H}, \mathrm{tBu}) ;{ }^{13} \mathrm{C}$ NMR $\left(100 \mathrm{MHz}, \mathrm{CDCl}_{3}\right): \delta 168.4,161.9,158.0,152.7,150.9,141.5,141.0,133.5,133.2$, 132.1, 131.6, 131.0, 130.0, 129.8 (q, $J=32.3 \mathrm{~Hz}$ ), 129.6 (q, $J=2.0 \mathrm{~Hz}$ ), 127.7, 125.2 (q, J = 3.0 Hz), 123.9 $(q, J=272.7 \mathrm{~Hz}), 94.4,92.5,53.3,46.5,35.5,35.4,29.2,29.1,20.2 ; \mathrm{IR} \vee 3061(w), 2963(\mathrm{~m}), 2872(w)$, $2257(w), 1781(s), 1703(w), 1619(w), 1584(w), 1465(w), 1425(w), 1364(w), 1326(s), 1272(w), 1236$ (m), $1168(\mathrm{~m}), 1129$ (s), $1092(\mathrm{~s}), 1006(\mathrm{~m}), 912(\mathrm{~m})$; HRMS (ESI) calcd. for $\mathrm{C}_{33} \mathrm{H}_{32} \mathrm{~F}_{3} \mathrm{INaO}_{4}{ }^{+}[\mathrm{M}+\mathrm{Na}]^{+}$ 699.1190; found 699.1195. 
7,8-Di-tert-butyl-4-(4-formylphenyl)-5-methyl-2-oxo-4,5-dihydro-2H-5,7a-ethenobenzofuran-3-yl 2iodobenzoate (6ab)

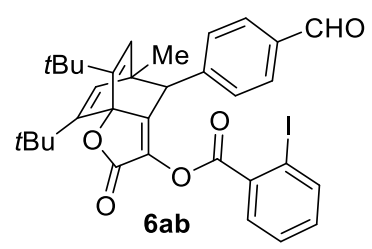

Following general procedure C, 1-((4-formylphenyl)ethynyl)-1,2-benziodoxol-3(1H)-one (9g) $(56.5 \mathrm{mg}$, $0.150 \mathrm{mmol}, 1.00$ equiv) and 2,6-di-tert-butyl-4-methylphenyl 2-diazoacetate (8a) (65.0 mg, 0.225 mmol, 1.50 equiv) were stirred for $12 \mathrm{~h}$. Next, $\mathrm{Cs}_{2} \mathrm{CO}_{3}(54.0 \mathrm{mg}, 0.165 \mathrm{mmol}, 1.10$ equiv) was added and the reaction mixture further stirred for $20 \mathrm{~h}$. The crude reaction mixture was concentrated in vacuo and purified by flash chromatography using $\mathrm{Et}_{2} \mathrm{O}$ :pentane 1:5 as mobile phase to afford 6 ab as a white solid (57 mg, $0.09 \mathrm{mmol}, 60 \%) . \mathrm{Mp}: 99.0-103.4{ }^{\circ} \mathrm{C}$; TLC (Et $2 \mathrm{O}$ :pentane, 1:4 v/v): $\mathrm{R}_{\mathrm{f}}=0.19, \mathrm{KMnO}_{4} ;{ }^{1} \mathrm{H}$ NMR (400 $\left.\mathrm{MHz}, \mathrm{CDCl}_{3}\right): \delta 9.94(\mathrm{~s}, 1 \mathrm{H}, \mathrm{CHO}), 7.92-7.85(\mathrm{~m}, 1 \mathrm{H}, \mathrm{ArH}), 7.75(\mathrm{~d}, J=8.2 \mathrm{~Hz}, 2 \mathrm{H}, \mathrm{ArH}), 7.47(\mathrm{dd}, J=7.8$, $1.7 \mathrm{~Hz}, 1 \mathrm{H}, \operatorname{ArH}), 7.25-7.22(\mathrm{~m}, 3 \mathrm{H}, \mathrm{ArH}), 7.10(\mathrm{td}, J=7.7,1.7 \mathrm{~Hz}, 1 \mathrm{H}, \operatorname{ArH}), 5.97(\mathrm{~s}, 1 \mathrm{H}, t \mathrm{BuCCH}), 5.63$ $(\mathrm{s}, 1 \mathrm{H}, t \mathrm{BuCCH}), 3.78(\mathrm{~s}, 1 \mathrm{H}, \mathrm{ArCH}), 1.35\left(\mathrm{~s}, 3 \mathrm{H}, \mathrm{CHCCH}_{3}\right), 1.32(\mathrm{~s}, 9 \mathrm{H}, t \mathrm{Bu}), 1.25(\mathrm{~s}, 9 \mathrm{H}, t \mathrm{Bu}) ;{ }^{13} \mathrm{C} \mathrm{NMR}(100$ $\left.\mathrm{MHz}, \mathrm{CDCl}_{3}\right): \delta 191.6,168.4,161.7,157.9,152.8,150.9,143.9,141.6,135.6,133.6,133.3,133.1,131.8$, 131.8, 131.0, 130.0, 129.6, 127.8, 94.7, 92.6, 53.6, 46.7, 35.5, 35.4, 29.2, 29.1, 20.3; IR v 3060 (w), 2962 $(m), 2871(w), 2256(w), 1777(s), 1702(m), 1607(w), 1582(w), 1465(w), 1428(w), 1364(w), 1269(m)$, 1235 (s), 1186 (m), 1090 (s), 1032 (w), 1006 (m); HRMS (ESI) calcd. for $\mathrm{C}_{33} \mathrm{H}_{33} \mathrm{INaO}_{5}{ }^{+}[\mathrm{M}+\mathrm{Na}]^{+}$659.1265; found 659.1268 .

7,8-Di-tert-butyl-4-(3-fluorophenyl)-5-methyl-2-oxo-4,5-dihydro-2H-5,7a-ethenobenzofuran-3-yl 2iodobenzoate (6ac)

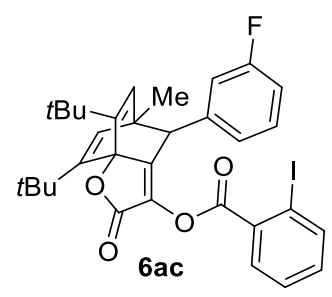

Following general procedure C, 1-[3-fluorophenylethynyl]-1,2-benziodoxol-3(1H)-one (9h) $(55.0 \mathrm{mg}$, $0.150 \mathrm{mmol}, 1.00$ equiv) and 2,6-di-tert-butyl-4-methylphenyl 2-diazoacetate (8a) (65.0 mg, 0.225 mmol, 1.50 equiv) were stirred for $12 \mathrm{~h}$. Next, $\mathrm{Cs}_{2} \mathrm{CO}_{3}(54.0 \mathrm{mg}, 0.165 \mathrm{mmol}, 1.10$ equiv) was added and the reaction mixture further stirred for $20 \mathrm{~h}$. The crude reaction mixture was concentrated in vacuo and purified by flash chromatography using $\mathrm{Et}_{2} \mathrm{O}$ :pentane 1:25 as mobile phase to afford 6 ac as a white solid (78.0 mg, $0.125 \mathrm{mmol}, 83 \%$ ). Mp: $175.5-177.8{ }^{\circ} \mathrm{C}$; TLC (Et $2 \mathrm{O}$ :pentane, 1:10 v/v): $\mathrm{R}_{\mathrm{f}}=0.36, \mathrm{KMnO}_{4} ;{ }^{1} \mathrm{H}$ $\operatorname{NMR}\left(400 \mathrm{MHz}, \mathrm{CDCl}_{3}\right): \delta 7.90(\mathrm{dd}, J=7.9,1.2 \mathrm{~Hz}, 1 \mathrm{H}, \operatorname{ArH}), 7.44(\mathrm{dd}, J=7.8,1.7 \mathrm{~Hz}, 1 \mathrm{H}, \operatorname{ArH}), 7.26-7.21$ 
(m, 1H, ArH), $7.19-7.06(\mathrm{~m}, 2 \mathrm{H}, \operatorname{ArH}), 6.87$ (tdd, J = 8.4, 2.6, 1.0 Hz, 1H, ArH), 6.81 (d, J = 7.7, 1.6 Hz, $1 \mathrm{H}$, $\operatorname{ArH}), 6.72(\mathrm{dt}, J=10.1,2.1 \mathrm{~Hz}, 1 \mathrm{H}, \operatorname{ArH}), 5.92(\mathrm{~s}, 1 \mathrm{H}, t \mathrm{BuCCH}), 5.63(\mathrm{~s}, 1 \mathrm{H}, t \mathrm{BuCCH}), 3.65(\mathrm{~s}, 1 \mathrm{H}, \operatorname{ArCH})$, $1.32\left(\mathrm{~s}, 3 \mathrm{H}, \mathrm{CHCCH}_{3}\right), 1.29(\mathrm{~s}, 9 \mathrm{H}, \mathrm{tBu}), 1.22(\mathrm{~s}, 9 \mathrm{H}, t \mathrm{Bu}) ;{ }^{13} \mathrm{C} \mathrm{NMR}\left(100 \mathrm{MHz}, \mathrm{CDCl}_{3}\right): \delta$ 168.6, $162.4(\mathrm{~d}, J$ $=246.2 \mathrm{~Hz}$ ), 161.8, 158.3, 152.6, 150.5, 141.5, 139.4 (d, J = $7.1 \mathrm{~Hz}$ ), 133.5, 133.3, 132.1, 131.8, 130.8, 130.3, 129.6 (d, J = 8.3 Hz), 127.8, $125.2(\mathrm{~d}, J=2.1 \mathrm{~Hz}), 116.1(\mathrm{~d}, J=22.1 \mathrm{~Hz}), 114.5(\mathrm{~d}, J=21.0 \mathrm{~Hz}), 94.6$, 92.6, 53.3, 46.5, 35.5, 35.4, 29.2, 29.1, 20.2; IR v3062 (w), 2961 (m), 2871 (w), 2255 (w), 1777 (s), 1702 (w), $1614(w), 1587(m), 1485(m), 1440(w), 1390(w), 1364(w), 1266(m), 1235(s), 1191(w), 1152(m)$, 1091 (s), 1034 (w), 1006 (m), 959 (w), 912 (m); HRMS (ESI) calcd. for $\mathrm{C}_{32} \mathrm{H}_{32} \mathrm{FINaO}_{4}{ }^{+}[\mathrm{M}+\mathrm{Na}]^{+}$649.1222; found 649.1229 .

7,8-Di-tert-butyl-5-methyl-2-oxo-4-(o-tolyl)-4,5-dihydro-2H-5,7a-ethenobenzofuran-3-yl iodobenzoate (6ad)

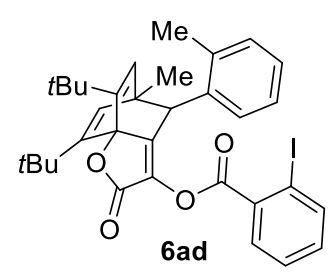

Following general procedure C, 1-[o-tolylethynyl]-1,2-benziodoxol-3(1H)-one (9i) $(54.5 \mathrm{mg}, 0.150 \mathrm{mmol}$, 1.00 equiv) and 2,6-di-tert-butyl-4-methylphenyl 2-diazoacetate (8a) $(65.0 \mathrm{mg}, 0.225 \mathrm{mmol}, 1.50$ equiv) were stirred for $12 \mathrm{~h}$. Next, $\mathrm{Cs}_{2} \mathrm{CO}_{3}(54.0 \mathrm{mg}, 0.165 \mathrm{mmol}, 1.10$ equiv) was added and the reaction mixture further stirred for $20 \mathrm{~h}$. The crude reaction mixture was concentrated in vacuo and purified by flash chromatography using $\mathrm{Et}_{2} \mathrm{O}$ :pentane $1: 20$ as mobile phase to afford 6 ad as a white solid $(82.0 \mathrm{mg}$, $0.132 \mathrm{mmol}, 88 \%)$. Mp: 200.0-202.5 ${ }^{\circ} \mathrm{C}$; TLC (Et $2 \mathrm{O}$ :pentane, 1:10 v/v): $\mathrm{R}_{\mathrm{f}}=0.38, \mathrm{KMnO}_{4} ;{ }^{1} \mathrm{H}$ NMR (400 $\left.\mathrm{MHz}, \mathrm{CDCl}_{3}\right): \delta 7.88(\mathrm{dd}, J=7.9,1.2 \mathrm{~Hz}, 1 \mathrm{H}, \mathrm{ArH}), 7.20-6.96(\mathrm{~m}, 6 \mathrm{H}, \mathrm{ArH}), 6.80-6.70(\mathrm{~m}, 1 \mathrm{H}, \mathrm{ArH}), 5.95$ (s, $1 \mathrm{H}, t \mathrm{BuCCH}), 5.67(\mathrm{~s}, 1 \mathrm{H}, t \mathrm{BuCCH}), 3.95(\mathrm{~s}, 1 \mathrm{H}, \mathrm{ArCH}), 2.36\left(\mathrm{~s}, 3 \mathrm{H}, \mathrm{ArCH}_{3}\right), 1.32\left(\mathrm{~s}, 3 \mathrm{H}, \mathrm{CHCCH}_{3}\right), 1.30$ (s, 9H, tBu), 1.24 (s, 9H, tBu); $\left.{ }^{13} \mathrm{C} \mathrm{NMR} \mathrm{(100} \mathrm{MHz,} \mathrm{CDCl}_{3}\right): \delta$ 168.9, 161.9, 160.2, 152.4, 149.8, 141.3, 138.0, 135.3, 133.8, 133.2, 132.3, 131.7, 131.0, 130.4, 130.3, 127.6, 127.6, 127.3, 125.9, 94.4, 92.8, 48.5, 47.5, 35.5, 35.3, 29.1, 29.1, 20.8, 19.4; IR v 3060 (w), 2961 (m), 2931 (w), $2872(w), 2254(w), 1776(s)$, 1697 (w), 1584 (w), 1465 (m), 1364 (w), 1232 (s), $1188(\mathrm{~m}), 1147$ (m), 1091 (s), 1006 (m), 912 (m); HRMS (ESI) calcd. for $\mathrm{C}_{33} \mathrm{H}_{35} \mathrm{INaO}_{4}{ }^{+}[\mathrm{M}+\mathrm{Na}]^{+}$645.1472; found 645.1481 . 

iodobenzoate (6ae)

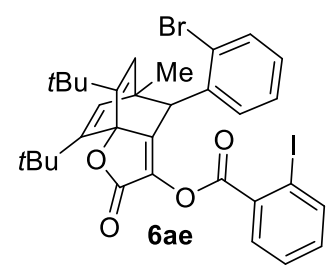

Following general procedure C, 1-[2-bromophenylethynyl]-1,2-benziodoxol-3(1H)-one (9j) $(64.0 \mathrm{mg}$, $0.150 \mathrm{mmol}, 1.00$ equiv) and 2,6-di-tert-butyl-4-methylphenyl 2-diazoacetate (8a) (65.0 mg, 0.225 mmol, 1.50 equiv) were stirred for $12 \mathrm{~h}$. Next, $\mathrm{Cs}_{2} \mathrm{CO}_{3}(54.0 \mathrm{mg}, 0.165 \mathrm{mmol}, 1.10$ equiv) was added and the reaction mixture further stirred for $20 \mathrm{~h}$. The crude reaction mixture was concentrated in vacuo and purified by flash chromatography using $\mathrm{Et}_{2} \mathrm{O}$ :pentane 1:20 as mobile phase to afford 6 ae as a white solid (94.0 mg, $0.137 \mathrm{mmol}, 91 \%)$. Mp: 212.5-214.0 ${ }^{\circ} \mathrm{C}$; TLC (Et $2 \mathrm{O}$ :pentane, $\left.1: 10 \mathrm{v} / \mathrm{v}\right): \mathrm{R}_{\mathrm{f}}=0.37, \mathrm{KMnO}_{4} ;{ }^{1} \mathrm{H}$ NMR (400 MHz, CDCl $)$ : $\delta 7.88$ (d, J = 7.9 Hz, 1H, ArH), 7.46 (dd, J = 8.0, 1.3 Hz, 1H, ArH), 7.35 (dd, J = 7.8, $1.7 \mathrm{~Hz}, 1 \mathrm{H}, \operatorname{ArH}), 7.22$ (td, J = 7.6, 1.2 Hz, 1H, ArH), 7.16 (td, J = 7.6, 1.3 Hz, 1H, ArH), 7.08 (td, J = 7.6, 1.7 $\mathrm{Hz}, 1 \mathrm{H}, \operatorname{ArH}), 7.02(\mathrm{td}, J=7.6,1.7 \mathrm{~Hz}, 1 \mathrm{H}, \operatorname{ArH}), 6.85(\mathrm{dd}, J=7.8,1.7 \mathrm{~Hz}, 1 \mathrm{H}, \operatorname{ArH}), 5.96(\mathrm{~s}, 1 \mathrm{H}, t \mathrm{BuCCH})$, $5.63(\mathrm{~s}, 1 \mathrm{H}, t \mathrm{BuCCH}), 4.36(\mathrm{~s}, 1 \mathrm{H}, \mathrm{ArCH}), 1.42\left(\mathrm{~s}, 3 \mathrm{H}, \mathrm{CHCCH}_{3}\right), 1.30(\mathrm{~s}, 9 \mathrm{H}, t \mathrm{Bu}), 1.23(\mathrm{~s}, 9 \mathrm{H}, t \mathrm{Bu}) ;{ }^{13} \mathrm{C} \mathrm{NMR}$ $\left(100 \mathrm{MHz}, \mathrm{CDCl}_{3}\right): \delta$ 168.5, 161.9, 159.2, 152.6, 150.5, 141.4, 136.6, 133.5, 133.3, 132.9, 132.5, 131.7, $130.9,130.6,129.3,129.0,127.6,127.5,127.1,94.4,92.7,50.9,47.6,35.5,35.4,29.2,29.1,19.4$; IR v $3062(w), 2961(m), 2871(w), 2255(w), 1779(s), 1707$ (w), $1584(w), 1565(w), 1467(m), 1435(w), 1390$ $(w), 1364(w), 1313(w), 1272(w), 1234(s), 1187(m), 1146(m), 1089(s), 1029(m), 1005$ (s), $911(s)$; HRMS (ESI) calcd. for $\mathrm{C}_{32} \mathrm{H}_{32} \mathrm{BrINaO}_{4}^{+}[\mathrm{M}+\mathrm{Na}]^{+}$709.0421; found 709.0423 .

\section{7,8-Di-tert-butyl-4,5-dimethyl-2-oxo-4,5-dihydro-2H-5,7a-ethenobenzofuran-3-yl 2-iodobenzoate} (6af)

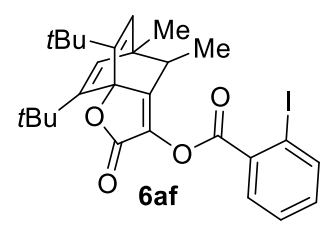

Following general procedure $\mathbf{D}$, propynyl-1,2-benziodoxol-3(1H)-one $(\mathbf{9 k})(43.0 \mathrm{mg}, 0.150 \mathrm{mmol}, 1.00$ equiv) and 2,6-di-tert-butyl-4-methylphenyl 2-diazoacetate (8a) $(65.0 \mathrm{mg}, 0.225 \mathrm{mmol}, 1.50$ equiv) were stirred for $12 \mathrm{~h}$. Next, $\mathrm{Cs}_{2} \mathrm{CO}_{3}(54.0 \mathrm{mg}, 0.165 \mathrm{mmol}, 1.10$ equiv) was added and the reaction mixture further stirred for $20 \mathrm{~h}$. The crude reaction mixture was concentrated in vacuo and purified by flash chromatography using $\mathrm{Et}_{2} \mathrm{O}$ :pentane 1:30 as mobile phase to afford 6 af as a white solid $(43.0 \mathrm{mg}, 0.079$ mmol, 53\%). Mp: $170.5-174.8{ }^{\circ} \mathrm{C}$; $\mathrm{TLC}\left(\mathrm{Et}_{2} \mathrm{O}\right.$ :pentane, 1:15 v/v): $\mathrm{R}_{\mathrm{f}}=0.27, \mathrm{KMnO}_{4} ;{ }^{1} \mathrm{H} \mathrm{NMR}(400 \mathrm{MHz}$, $\mathrm{CDCl}_{3}$ ): $\delta 8.04(\mathrm{ddd}, J=8.0,3.2,1.4 \mathrm{~Hz}, 2 \mathrm{H}, \mathrm{ArH}), 7.45(\mathrm{td}, J=7.7,1.2 \mathrm{~Hz}, 1 \mathrm{H}, \operatorname{ArH}), 7.21(\mathrm{td}, J=7.7,1.7$ 
$\mathrm{Hz}, 1 \mathrm{H}, \operatorname{Ar} H), 5.80(\mathrm{~s}, 1 \mathrm{H}, t \mathrm{BuCCH}), 5.70(\mathrm{~s}, 1 \mathrm{H}, t \mathrm{BuCCH}), 2.56$ (q, $\left.J=7.0 \mathrm{~Hz}, 1 \mathrm{H}, \mathrm{CHCH}_{3}\right), 1.51(\mathrm{~s}, 3 \mathrm{H}$, $\left.\mathrm{CHCCH}_{3}\right), 1.18(\mathrm{~s}, 9 \mathrm{H}, t \mathrm{Bu}), 1.17(\mathrm{~s}, 9 \mathrm{H}, t \mathrm{Bu}), 1.04\left(\mathrm{~d}, J=7.0 \mathrm{~Hz}, 3 \mathrm{H}, \mathrm{CHCH}_{3}\right) ;{ }^{13} \mathrm{C} \mathrm{NMR}\left(100 \mathrm{MHz}, \mathrm{CDCl}_{3}\right): \delta$ 169.0, 162.4, 161.5, 151.5, 150.4, 141.7, 133.6, 132.9, 132.6, 132.2, 130.0, 129.9, 128.1, 94.9, 92.5, 44.9, 42.5, 35.2, 35.2, 29.2, 29.1, 19.5, 15.3; IR v 3059 (w), 2962 (m), 2872 (w), 2255 (w), 1778 (s), $1704(w)$, $1583(w), 1469(w), 1430(w), 1390(w), 1365(w), 1271(m), 1235(s), 1154(m), 1091(s), 1043(m), 1008$ (m), $958(w), 912(m)$; HRMS (ESI) calcd. for $\mathrm{C}_{27} \mathrm{H}_{31} \mathrm{INaO}_{4}{ }^{+}[\mathrm{M}+\mathrm{Na}]^{+}$569.1159; found 569.1161.

7,8-Di-tert-butyl-5-methyl-2-oxo-4-tetradecyl-4,5-dihydro-2H-5,7a-ethenobenzofuran-3-yl 2iodobenzoate (6ag)

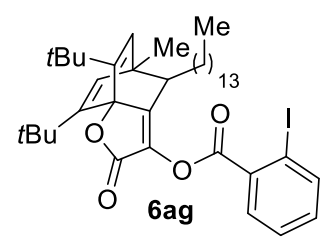

Following general procedure $\mathbf{D}$, hexadecynyl-1,2-benziodoxol-3(1H)-one (9I) $(70.5 \mathrm{mg}, 0.150 \mathrm{mmol}, 1.00$ equiv) and 2,6-di-tert-butyl-4-methylphenyl 2-diazoacetate (8a) $(65.0 \mathrm{mg}, 0.225 \mathrm{mmol}, 1.50$ equiv) were stirred for $12 \mathrm{~h}$. Next, $\mathrm{Cs}_{2} \mathrm{CO}_{3}(54.0 \mathrm{mg}, 0.165 \mathrm{mmol}, 1.10$ equiv) was added and the reaction mixture further stirred for $20 \mathrm{~h}$. The crude reaction mixture was concentrated in vacuo and purified by flash chromatography using $\mathrm{Et}_{2} \mathrm{O}$ :pentane 1:50 as mobile phase to afford $6 \mathrm{ag}$ ( $86.0 \mathrm{mg}, 0.118 \mathrm{mmol}, 79 \%$ ) as a colourless oil. TLC (Et $t_{2} \mathrm{O}$ :pentane, 1:15 v/v): $\mathrm{R}_{\mathrm{f}}=0.34, \mathrm{KMnO}_{4} ;{ }^{1} \mathrm{H} \mathrm{NMR}\left(400 \mathrm{MHz}, \mathrm{CDCl}_{3}\right): \delta 8.10$ (dd, J $=7.9,1.7 \mathrm{~Hz}, 1 \mathrm{H}, \operatorname{ArH}), 8.05(\mathrm{dd}, J=8.0,1.2 \mathrm{~Hz}, 1 \mathrm{H}, \operatorname{ArH}), 7.44(\mathrm{td}, J=7.6,1.2 \mathrm{~Hz}, 1 \mathrm{H}, \operatorname{ArH}), 7.21(\mathrm{td}, J=$ 7.7, $1.7 \mathrm{~Hz}, 1 \mathrm{H}, \mathrm{ArH}), 5.79(\mathrm{~s}, 1 \mathrm{H}, t \mathrm{BuCCH}), 5.70(\mathrm{~s}, 1 \mathrm{H}, t \mathrm{BuCCH}), 2.50$ (dd, $J=6.2,4.3 \mathrm{~Hz}, 1 \mathrm{H}, \mathrm{CHCH}_{2}$ ), $1.62-1.54\left(\mathrm{~m}, 4 \mathrm{H}, \mathrm{CHCH}^{a}{ }_{2}\right.$ and $\left.\mathrm{CHCCH}_{3}\right), 1.31-1.09\left(\mathrm{~m}, 43 \mathrm{H}, \mathrm{CHCH}^{b}{ }_{2}, 12 \times \mathrm{CH}_{2}\right.$, and $\left.2 \times t \mathrm{Bu}\right), 0.88(\mathrm{t}, J=$ $\left.6.8 \mathrm{~Hz}, 3 \mathrm{H}, \mathrm{CH}_{2} \mathrm{CH}_{3}\right) ;{ }^{13} \mathrm{CNMR}\left(100 \mathrm{MHz}, \mathrm{CDCl}_{3}\right): \delta 169.1,162.0,161.4,152.0,149.6,142.0,133.7,133.5$, 132.5, 132.0, 130.8, 130.0, 128.0, 95.3, 92.8, 48.0, 45.2, 35.2, 35.2, 31.9, 31.2, 30.1, 29.7, 29.7, 29.6, 29.5, 29.4, 29.4, 29.2, 29.1, 28.7, 22.7, 20.2, 14.1; IR $v 3057$ (w), 2957 (m), 2924 (s), $2854(\mathrm{~m}), 1781$ (s), $1698(w), 1583(w), 1464(m), 1433(w), 1389(w), 1363(w), 1270(w), 1234(s), 1154(w), 1089(s), 1035$ (w), 1006 (m); HRMS (ESI) calcd. for $\mathrm{C}_{40} \mathrm{H}_{57} \mathrm{NNaO}_{4}{ }^{+}[\mathrm{M}+\mathrm{Na}]^{+} 751.3194$; found 751.3200. Two carbons were not resolved at $100 \mathrm{MHz}$. 

iodobenzoate (6ah)

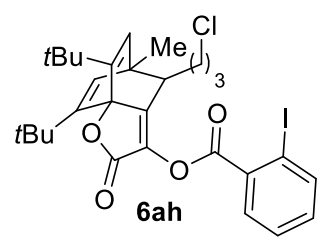

Following general procedure $\mathbf{D}$, (5-chloropent-1-ynyl)-1,2-benziodoxol-3(1H)-one (9m) (52.5 mg, 0.150 mmol, 1.00 equiv) and 2,6-di-tert-butyl-4-methylphenyl 2-diazoacetate (8a) $(65.0 \mathrm{mg}, 0.225 \mathrm{mmol}, 1.50$ equiv) were stirred for $12 \mathrm{~h}$. Next, $\mathrm{Cs}_{2} \mathrm{CO}_{3}(54.0 \mathrm{mg}, 0.165 \mathrm{mmol}, 1.10$ equiv) was added and the reaction mixture further stirred for $20 \mathrm{~h}$. The crude reaction mixture was concentrated in vacuo and purified by flash chromatography using $\mathrm{Et}_{2} \mathrm{O}$ :pentane $1: 30$ as mobile phase to afford 6 ah as a white solid $(66.0 \mathrm{mg}$, $0.108 \mathrm{mmol}, 72 \%)$. Mp: $124.0-128.2^{\circ} \mathrm{C}$; TLC (Et ${ }_{2} \mathrm{O}$ :pentane, 1:10 v/v): $\mathrm{R}_{\mathrm{f}}=0.29, \mathrm{KMnO}_{4} ;{ }^{1} \mathrm{H}$ NMR (400 $\mathrm{MHz}, \mathrm{CDCl}_{3}$ ): $\delta 8.10(\mathrm{dd}, J=7.8,1.7 \mathrm{~Hz}, 1 \mathrm{H}, \mathrm{ArH}), 8.05(\mathrm{dd}, J=7.9,1.2 \mathrm{~Hz}, 1 \mathrm{H}, \mathrm{ArH}), 7.45(\mathrm{td}, J=7.6,1.2$ $\mathrm{Hz}, 1 \mathrm{H}, \mathrm{ArH}), 7.22(\mathrm{td}, J=7.7,1.7 \mathrm{~Hz}, 1 \mathrm{H}, \mathrm{ArH}), 5.80(\mathrm{~s}, 1 \mathrm{H}, t \mathrm{BuCCH}), 5.72(\mathrm{~s}, 1 \mathrm{H}, t \mathrm{BuCCH}), 3.46-3.37(\mathrm{~m}$, $\left.2 \mathrm{H}, \mathrm{ClCH}_{2} \mathrm{CH}_{2}\right), 2.62-2.49\left(\mathrm{~m}, 1 \mathrm{H}, \mathrm{CHCH}_{2}\right), 1.85-1.66\left(\mathrm{~m}, 3 \mathrm{H}, \mathrm{ClCH}_{2} \mathrm{CH}_{2}\right.$ and $\left.\mathrm{ClCH}_{2} \mathrm{CH}_{2} \mathrm{CH}^{a}{ }_{2}\right), 1.61-1.49$ (m, $4 \mathrm{H}, \mathrm{ClCH}_{2} \mathrm{CH}_{2} \mathrm{CH}^{b}$ and $\left.\mathrm{CHCCH}_{3}\right), 1.18$ (s, 9H,tBu), $1.16(\mathrm{~s}, 9 \mathrm{H}, t \mathrm{Bu}) ;{ }^{13} \mathrm{C} \mathrm{NMR}\left(100 \mathrm{MHz}, \mathrm{CDCl}_{3}\right): \delta$ $168.8,162.3,160.2$, 152.2, 150.1, 141.9, 133.9, 133.4, 132.5, 131.9, 130.6, 130.3, 128.2, 95.2, 92.7, 47.2, 45.1, 45.0, 35.3, 35.2, 31.1, 29.1, 29.1, 28.1, 20.2; IR v 3060 (w), 2960 (m), $2870(w), 2254(w), 1778(s)$, $1698(w), 1583(w), 1464(w), 1390(w), 1364(w), 1274(w), 1235(s), 1192(w), 1154(w), 1128(w), 1093$ (s), $1034(\mathrm{w}), 1007(\mathrm{~m}), 913(\mathrm{~m})$; HRMS (ESI) calcd. for $\mathrm{C}_{29} \mathrm{H}_{34} \mathrm{ClINaO}_{4}{ }^{+}[\mathrm{M}+\mathrm{Na}]^{+}$631.1083; found 631.1090 .

7,8-Di-tert-butyl-5-methyl-2-oxo-4-(6-(trimethylsilyl)hex-5-yn-1-yl)-4,5-dihydro-2H-5,7aethenobenzofuran-3-yl 2-iodobenzoate (6ag)

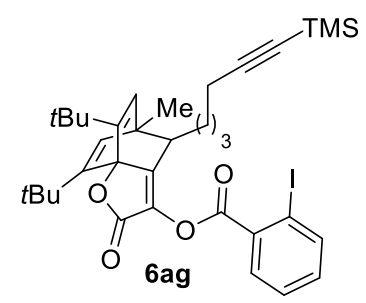

Following general procedure D, 8-(trimethylsilyl)octa-1,7-diyn-1-yl-1,2-benziodoxol-3(1H)-one (9n) (64.0 mg, $0.150 \mathrm{mmol}, 1.00$ equiv) and 2,6-di-tert-butyl-4-methylphenyl 2-diazoacetate (8a) $(65.0 \mathrm{mg}$, $0.225 \mathrm{mmol}, 1.50$ equiv) were stirred for $12 \mathrm{~h}$. Next, $\mathrm{Cs}_{2} \mathrm{CO}_{3}(54.0 \mathrm{mg}, 0.165 \mathrm{mmol}, 1.10$ equiv) was added and the reaction mixture further stirred for $20 \mathrm{~h}$. The crude reaction mixture was concentrated in vacuo and purified by flash chromatography using $\mathrm{Et}_{2} \mathrm{O}$ :pentane $1: 35$ as mobile phase to afford $6 \mathrm{ag}$ as a yellow thick oil (73.0 mg, $0.107 \mathrm{mmol}, 71 \%)$. TLC (Et $2 \mathrm{O}$ :pentane, 1:15 v/v): $\mathrm{R}_{\mathrm{f}}=0.27, \mathrm{KMnO}_{4} ;{ }^{1} \mathrm{H} \mathrm{NMR}(400 \mathrm{MHz}$, 
$\left.\mathrm{CDCl}_{3}\right): \delta 8.09$ (dd, J= 7.8, 1.7 Hz, 1H, ArH), $8.05(\mathrm{~d}, J=7.9 \mathrm{~Hz}, 1 \mathrm{H}, \mathrm{ArH}), 7.45(\mathrm{td}, J=7.7,1.2 \mathrm{~Hz}, 1 \mathrm{H}, \mathrm{ArH})$, $7.22(\mathrm{td}, J=7.7,1.7 \mathrm{~Hz}, 1 \mathrm{H}, \mathrm{ArH}), 5.79(\mathrm{~s}, 1 \mathrm{H}, t \mathrm{BuCCH}), 5.71(\mathrm{~s}, 1 \mathrm{H}, t \mathrm{BuCCH}), 2.54\left(\mathrm{t}, J=5.0 \mathrm{~Hz}, 1 \mathrm{H}, \mathrm{CHCH}_{2}\right)$, $2.08\left(\mathrm{t}, J=6.4 \mathrm{~Hz}, 2 \mathrm{H}, \mathrm{CCCH}_{2}\right), 1.61-1.55\left(\mathrm{~m}, 4 \mathrm{H}, \mathrm{CHCH}^{a}{ }_{2}\right.$ and $\left.\mathrm{CHCCH}_{3}\right), 1.44-1.31\left(\mathrm{~m}, 5 \mathrm{H}, \mathrm{CHCH}^{b}{ }_{2}\right.$, $\mathrm{CHCH}_{2} \mathrm{CH}_{2} \mathrm{CH}_{2} \mathrm{CH}_{2} \mathrm{CC}$ ), 1.18 (s, 9H, tBu), 1.16 (s, 9H, tBu), 0.11 (s, 9H, TMS); ${ }^{13} \mathrm{C} \mathrm{NMR} \mathrm{(100} \mathrm{MHz,} \mathrm{CDCl} 3$ ): $\delta$ 168.9, 162.2, 160.8, 152.1, 149.6, 141.9, 133.8, 133.4, 132.4, 132.1, 130.8, 130.1, 128.1, 107.0, 95.2, 92.8, 84.7, 47.8, 45.1, 35.2, 35.2, 30.3, 29.1, 29.1, 28.9, 27.4, 20.2, 19.6, 0.2; IR v 3058 (w), 2960 (m), $2870(w), 2173(w), 1781(s), 1700(w), 1578(w), 1465(w), 1430(w), 1392(w), 1364(w), 1270(w), 1235$ (s), 1190 (w), 1154 (w), 1092 (s), 1034 (w), 1007 (m); HRMS (ESI) calcd. for $\mathrm{C}_{35} \mathrm{H}_{45} \mathrm{INaO}_{4} \mathrm{Si}^{+}$[M+Na] 707.2024; found 707.2043.

7,8-Di-tert-butyl-4-cyclopropyl-5-methyl-2-oxo-4,5-dihydro-2H-5,7a-ethenobenzofuran-3-yl iodobenzoate (6aj)

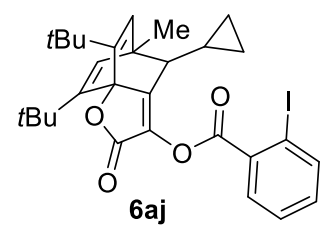

Following general procedure D, 2-cyclopropylethynyl-1,2-benziodoxol-3(1H)-one (9o) (47.0 mg, 0.150 mmol, 1.00 equiv) and 2,6-di-tert-butyl-4-methylphenyl 2-diazoacetate (8a) $(65.0 \mathrm{mg}, 0.225 \mathrm{mmol}, 1.50$ equiv) were stirred for $12 \mathrm{~h}$. Next, $\mathrm{Cs}_{2} \mathrm{CO}_{3}(54.0 \mathrm{mg}, 0.165 \mathrm{mmol}, 1.10$ equiv) was added and the reaction mixture further stirred for $20 \mathrm{~h}$. The crude reaction mixture was concentrated in vacuo and purified by flash chromatography using $\mathrm{Et}_{2} \mathrm{O}$ :pentane $1: 35$ as mobile phase to afford 6 aj as a white solid $(80.0 \mathrm{mg}$, $0.140 \mathrm{mmol}, 93 \%) . \mathrm{Mp}: 185.4-188.5^{\circ} \mathrm{C} ; \mathrm{TLC}\left(\mathrm{Et}_{2} \mathrm{O}\right.$ :pentane, $\left.1: 10 \mathrm{v} / \mathrm{v}\right): \mathrm{R}_{\mathrm{f}}=0.37, \mathrm{KMnO}_{4} ;{ }^{1} \mathrm{H}$ NMR (400 $\mathrm{MHz}, \mathrm{CDCl}_{3}$ ): $\delta 8.15$ (dd, $\left.J=7.9,1.7 \mathrm{~Hz}, 1 \mathrm{H}, \operatorname{ArH}\right), 8.07$ (dd, $\left.J=8.0,1.2 \mathrm{~Hz}, 1 \mathrm{H}, \operatorname{ArH}\right), 7.45(\mathrm{td}, J=7.6,1.2$ $\mathrm{Hz}, 1 \mathrm{H}, \mathrm{ArH}), 7.21(\mathrm{td}, J=7.7,1.7 \mathrm{~Hz}, 1 \mathrm{H}, \mathrm{ArH}), 5.82(\mathrm{~s}, 1 \mathrm{H}, t \mathrm{BuCCH}), 5.76(\mathrm{~s}, 1 \mathrm{H}, t \mathrm{BuCCH}), 1.71(\mathrm{~d}, J=9.5$ $\left.\mathrm{Hz}, 1 \mathrm{H}, \mathrm{CHCCH}_{3}\right), 1.64\left(\mathrm{~s}, 3 \mathrm{H}, \mathrm{CHCCH}_{3}\right), 1.21(\mathrm{~s}, 9 \mathrm{H}, t \mathrm{Bu}), 1.16(\mathrm{~s}, 9 \mathrm{H}, t \mathrm{Bu}), 0.66-0.52$ (m, 1H, cyclopropyl$\mathrm{CH}), 0.47-0.28\left(\mathrm{~m}, 3 \mathrm{H}\right.$, cyclopropyl- $\mathrm{CH}_{2}$ and $\left.\mathrm{CH}^{a}{ }_{2}\right), 0.22-0.10\left(\mathrm{~m}, 1 \mathrm{H}\right.$, cyclopropyl-CH$\left.{ }^{b}\right) ;{ }^{13} \mathrm{C}$ NMR (100 $\left.\mathrm{MHz}, \mathrm{CDCl}_{3}\right): \delta 169.1,162.2,160.3,151.5,150.3,142.1,133.8,132.9,132.6,131.8,130.7,130.6,128.1$, 95.4, 92.4, 52.9, 46.4, 35.2, 35.2, 29.3, 29.1, 20.9, 12.9, 5.6, 3.0; IR v 3061 (w), 2997 (w), 2960 (m), 2931 (w), $2871(w), 2254(w), 1773(s), 1701(w), 1583(w), 1467(w), 1429(w), 1389(w), 1364(w), 1318(w)$, $1272(w), 1235$ (s), 1192 (w), 1156 (w), 1091 (s), 1033 (m), 1007 (m), 962 (w), 912 (m); HRMS (ESI) calcd. for $\mathrm{C}_{29} \mathrm{H}_{33} \mathrm{INaO}_{4}{ }^{+}[\mathrm{M}+\mathrm{Na}]^{+}$595.1316; found 595.1325. 

iodobenzoate (6ak)

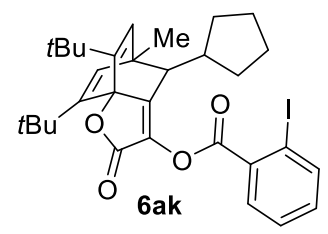

Following general procedure D, 2-cyclopentylethynyl-1,2-benziodoxol-3(1H)-one (9p) (51.0 mg, 0.150 mmol, 1.00 equiv) and 2,6-di-tert-butyl-4-methylphenyl 2-diazoacetate (8a) (65.0 mg, 0.225 mmol, 1.50 equiv) were stirred for $12 \mathrm{~h}$. Next, $\mathrm{Cs}_{2} \mathrm{CO}_{3}(54.0 \mathrm{mg}, 0.165 \mathrm{mmol}, 1.10$ equiv) was added and the reaction mixture further stirred for $20 \mathrm{~h}$. The crude reaction mixture was concentrated in vacuo and purified by flash chromatography using $\mathrm{Et}_{2} \mathrm{O}$ :pentane 1:35 as mobile phase to afford 6ak as a white solid (83.0 mg, $0.138 \mathrm{mmol}, 92 \%)$. Mp: 169.0-171.2 ${ }^{\circ} \mathrm{C}$; $\mathrm{TLC}_{(\mathrm{Et}} \mathrm{O}$ :pentane, 1:15 v/v): $\mathrm{R}_{\mathrm{f}}=0.27, \mathrm{KMnO}_{4} ;{ }^{1} \mathrm{H} \mathrm{NMR}(400$ $\mathrm{MHz}_{\mathrm{CDCl}}$ ): $\delta 8.06(\mathrm{td}, J=7.4,6.8,1.4 \mathrm{~Hz}, 2 \mathrm{H}, \mathrm{ArH}), 7.44(\mathrm{td}, J=7.6,1.2 \mathrm{~Hz}, 1 \mathrm{H}, \operatorname{ArH}), 7.21(\mathrm{td}, J=7.7$, $1.7 \mathrm{~Hz}, 1 \mathrm{H}, \mathrm{ArH}), 5.80(\mathrm{~s}, 1 \mathrm{H}, \mathrm{tBuCCH}), 5.69(\mathrm{~s}, 1 \mathrm{H}, \mathrm{tBuCCH}), 2.75\left(\mathrm{~d}, \mathrm{~J}=2.9 \mathrm{~Hz}, 1 \mathrm{H}, \mathrm{CHCCH}_{3}\right), 2.15-2.02$ (m, $1 \mathrm{H}$, cyclopentyl-H), 1.77 (dt, $J=11.0,7.3 \mathrm{~Hz}, 1 \mathrm{H}$, cyclopentyl-H), $1.62-1.56$ (m, 4H, cyclopentyl-H and $\left.\mathrm{CHCCH}_{3}\right), 1.49-1.31\left(\mathrm{~m}, 6 \mathrm{H}\right.$, cyclopentyl-H), $1.18(\mathrm{~s}, 9 \mathrm{H}, t \mathrm{Bu}), 1.16(\mathrm{~s}, 9 \mathrm{H}, t \mathrm{Bu}) ;{ }^{13} \mathrm{C} \mathrm{NMR}(100 \mathrm{MHz}$, $\left.\mathrm{CDCl}_{3}\right): \delta 169.0,162.2,159.1,152.2,148.8,142.0,134.1,133.7,132.4,132.1,131.1,130.9,128.1,95.3$, 93.2, 51.3, 45.5, 41.1, 35.2, 35.1, 33.0, 30.1, 29.2, 29.1, 25.1, 23.9, 21.1; IR v 3059 (w), 2956 (m), 2866 (w), 2254 (w), 1775 (s), 1690 (w), 1583 (w), 1464 (w), 1431 (w), $1390(w), 1363(w), 1272(w), 1234(s)$, 1186 (m), 1153 (w), 1094 (s), 1034 (w), 1005 (m), 912 (m); HRMS (ESI) calcd. for $\mathrm{C}_{31} \mathrm{H}_{38} \mathrm{IO}_{4}{ }^{+}[\mathrm{M}+\mathrm{H}]^{+}$ 601.1809; found 601.1818.

7,8-Di-tert-butyl-4-cyclohexyl-5-methyl-2-oxo-4,5-dihydro-2H-5,7a-ethenobenzofuran-3-yl 2iodobenzoate (6al)

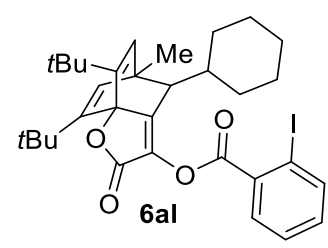

Following general procedure D, 2-cyclohexylethynyl-1,2-benziodoxol-3(1H)-one (9q) (53.0 mg, 0.150 mmol, 1.00 equiv) and 2,6-di-tert-butyl-4-methylphenyl 2-diazoacetate (8a) (65.0 mg, 0.225 mmol, 1.50 equiv) were stirred for $12 \mathrm{~h}$. Next, $\mathrm{Cs}_{2} \mathrm{CO}_{3}(54.0 \mathrm{mg}, 0.165 \mathrm{mmol}, 1.10$ equiv) was added and the reaction mixture further stirred for $20 \mathrm{~h}$. The crude reaction mixture was concentrated in vacuo and purified by flash chromatography using $\mathrm{Et}_{2} \mathrm{O}$ :pentane 1:35 as mobile phase to afford 6 al as a white solid (55.0 mg, $0.089 \mathrm{mmol}, 60 \%)$. Mp: 185.0-190.5 ${ }^{\circ} \mathrm{C}$; $\mathrm{TLC}\left(\mathrm{Et}_{2} \mathrm{O}\right.$ :pentane, 1:15 v/v): $\mathrm{R}_{\mathrm{f}}=0.27, \mathrm{KMnO}_{4} ;{ }^{1} \mathrm{H} \mathrm{NMR}(400$ $\mathrm{MHz}_{\mathrm{CDCl}}$ ): $\delta 8.11$ (dd, $\left.J=7.9,1.7 \mathrm{~Hz}, 1 \mathrm{H}, \mathrm{ArH}\right), 8.06(\mathrm{dd}, J=7.9,1.2 \mathrm{~Hz}, 1 \mathrm{H}, \operatorname{ArH}), 7.45(\mathrm{td}, J=7.6,1.2$ 
$\mathrm{Hz}, 1 \mathrm{H}, \mathrm{ArH}), 7.22(\mathrm{td}, J=7.7,1.7 \mathrm{~Hz}, 1 \mathrm{H}, \mathrm{ArH}), 5.78(\mathrm{~s}, 1 \mathrm{H}, t \mathrm{BuCCH}), 5.72(\mathrm{~s}, 1 \mathrm{H}, t \mathrm{BuCCH}), 2.45$ (d, $J=2.0$ $\left.\mathrm{Hz}, 1 \mathrm{H}, \mathrm{CHCCH}_{3}\right), 1.75-1.54\left(\mathrm{~m}, 8 \mathrm{H}\right.$, cyclohexyl-H and $\left.\mathrm{CHCCH}_{3}\right), 1.47-1.43$ (m, $1 \mathrm{H}$, cyclohexyl- $\left.H\right)$, 1.34 - $1.22\left(\mathrm{~m}, 2 \mathrm{H}\right.$, cyclohexyl-H), $1.17(\mathrm{~s}, 9 \mathrm{H}, t \mathrm{Bu}), 1.16(\mathrm{~s}, 9 \mathrm{H}, t \mathrm{Bu}), 1.11-0.93(\mathrm{~m}, 3 \mathrm{H}$, cyclohexyl- $H) ;{ }^{13} \mathrm{C}$ NMR (100 MHz, $\left.\mathrm{CDCl}_{3}\right): \delta$ 169.0, 162.1, 159.4, 152.6, 148.8, 142.0, 134.4, 133.7, 132.4, 132.2, 131.0, 130.6, 128.1, 95.2, 93.1, 54.4, 45.5, 39.1, 35.2, 35.1, 34.3, 31.2, 29.2, 29.1, 27.2, 26.9, 26.1, 21.2; IR v $3060(w), 2967(w), 2958(m), 2929(m), 2855(w), 2255(w), 1774(s), 1689(w), 1583(w), 1464(w), 1390$ (w), 1364 (w), 1271 (w), 1234 (s), 1187 (m), 1093 (s), 1034 (w), 1006 (m), 912 (m); HRMS (ESI) calcd. for $\mathrm{C}_{32} \mathrm{H}_{39} \mathrm{INaO}_{4}^{+}[\mathrm{M}+\mathrm{Na}]^{+}$637.1785; found 637.1789.

\section{3-0xo-5,6-dihydro-1H,3H-6,8a-epoxyisochromen-4-yl 2-iodobenzoate (13)}

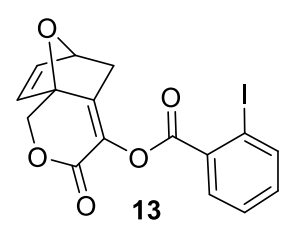

Following general procedure B, 1-[(triiso-propylsilyl)ethynyl]-1,2-benziodoxol-3(1H)-one (9a) $(64.0 \mathrm{mg}$, $0.150 \mathrm{mmol}, 1.00$ equiv) and furan-2-ylmethyl 2-diazoacetate (12) (30 mg, $0.18 \mathrm{mmol}, 1.2$ equiv) were stirred for $12 \mathrm{~h}$. Next, triethylamine trihydrofluoride ( $24 \mu \mathrm{L}, 0.15 \mathrm{mmol}, 1.0$ equiv) was added and the reaction mixture further stirred for $36 \mathrm{~h}$. The crude reaction mixture was concentrated in vacuo and purified by flash chromatography using EtOAc:pentane 1:3 as mobile phase to afford $\mathbf{1 3}$ as a white solid (51.0 mg, $0.124 \mathrm{mmol}, 83 \%$ ). Mp: 203.5-205.5 ${ }^{\circ} \mathrm{C}$; TLC (EtOAc:pentane, 1:3 v/v): $\mathrm{R}_{\mathrm{f}}=0.3, \mathrm{KMnO}_{4} ;{ }^{1} \mathrm{H}$ NMR (400 MHz, CDCl 3 ): $\delta 8.03$ (dd, $J=7.7,1.7 \mathrm{~Hz}, 2 \mathrm{H}, \mathrm{ArH}), 7.45$ (td, $J=7.6,1.2 \mathrm{~Hz}, 1 \mathrm{H}, \mathrm{ArH}), 7.21$ (td, $J=7.7$, $1.7 \mathrm{~Hz}, 1 \mathrm{H}, \mathrm{ArH}), 6.67(\mathrm{dt}, J=5.9,1.4 \mathrm{~Hz}, 1 \mathrm{H}, \mathrm{OCHCH}), 6.63(\mathrm{~d}, J=5.7 \mathrm{~Hz}, 1 \mathrm{H}, \mathrm{OCCH}), 5.28(\mathrm{dd}, J=4.3,1.7$ $\mathrm{Hz}, 1 \mathrm{H}, \mathrm{OCH}), 4.90\left(\mathrm{~d}, J=11.3 \mathrm{~Hz}, 1 \mathrm{H}, \mathrm{OCCH}^{a}{ }_{2}\right), 4.80\left(\mathrm{~d}, J=11.2 \mathrm{~Hz}, 1 \mathrm{H}, \mathrm{OCCH}^{b}{ }_{2}\right), 2.88(\mathrm{dd}, J=16.1,4.2$ $\left.\mathrm{Hz}, 1 \mathrm{H}, \mathrm{OCHCH}^{a}{ }_{2}\right), 2.35\left(\mathrm{~d}, J=16.2 \mathrm{~Hz}, 1 \mathrm{H}, \mathrm{OCHCH}^{b}{ }_{2}\right) ;{ }^{13} \mathrm{C} \mathrm{NMR}\left(100 \mathrm{MHz}, \mathrm{CDCl}_{3}\right): \delta 163.3,158.8,144.5$, 141.6, 140.2, 133.6, 132.8, 132.1, 132.0, 130.6, 128.1, 94.8, 83.0, 79.4, 67.7, 33.1; IR 22952 (w), 2366 (w), $1738(s), 1623(w), 1583(w), 1563(w), 1467(w), 1429(w), 1401(w), 1331(w), 1275(m), 1239(s)$, $1209(\mathrm{~m}), 1149$ (s), $1130(\mathrm{~m}), 1104$ (s), $1074(\mathrm{~m}), 1039$ (m), 1014 (m), 988 (w), 952 (w), 912 (w); HRMS (ESI) calcd. for $\mathrm{C}_{16} \mathrm{H}_{11} \mathrm{INaO}_{5}^{+}[\mathrm{M}+\mathrm{Na}]^{+} 432.9543$; found 432.9547 . 
7,8-Di-tert-butyl-3-hydroxy-5-methyl-4-phenyl-4,5-dihydro-2H-5,7a-ethenobenzofuran-2-one (19a)<smiles>Cc1cc(C)c(C(C)(C)C)c(C(=O)OC(C)(C)C)c1</smiles>

$8 \mathbf{a}$<smiles>O=C1OI(C#Cc2ccccc2)c2ccccc21</smiles>

$9 b$

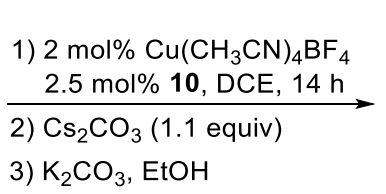

3) $\mathrm{K}_{2} \mathrm{CO}_{3}$, $\mathrm{EtOH}$

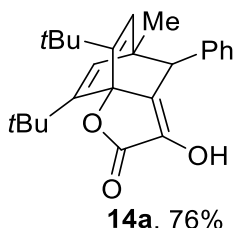

A flame dried $20 \mathrm{~mL}$ microwave vial was charged under nitrogen with $\mathrm{Cu}\left(\mathrm{CH}_{3} \mathrm{CN}\right)_{4} \mathrm{BF}_{4}(25 \mathrm{mg}, 0.08 \mathrm{mmol}$, 0.02 equiv), ligand 10 ( $37 \mathrm{mg}, 0.10 \mathrm{mmol}, 0.025$ equiv) and dry DCE (10 mL). The resulting solution was stirred at $30^{\circ} \mathrm{C}$ for $1 \mathrm{~h}$ and then added to a mixture of Ph-EBX (9b) (1.4 g, $4.0 \mathrm{mmol}, 1.0$ equiv), 2,6-ditert-butyl-4-methylphenyl 2-diazoacetate (8a) $(1.73 \mathrm{~g}, 6.00 \mathrm{mmol}, 1.50$ equiv) and dry DCE $(150 \mathrm{~mL})$ in $250 \mathrm{~mL}$ round-bottom flask over $2 \mathrm{~min}$ and the resulting reaction mixture was stirred at $50^{\circ} \mathrm{C}$ for $14 \mathrm{~h}$. Next, the reaction mixture was cooled down to room temperature and $\mathrm{Cs}_{2} \mathrm{CO}_{3}(1.44 \mathrm{~g}, 4.40 \mathrm{mmol}, 1.10$ equiv) was added and the reaction mixture stirred. After $20 \mathrm{~h}$, the reaction mixture was filtered and the filtrate was evaporated under reduced pressure. The crude residue was dissolved in EtOH $(80 \mathrm{~mL})$ and $\mathrm{K}_{2} \mathrm{CO}_{3}(0.83 \mathrm{~g}, 6.0 \mathrm{mmol}, 1.5$ equiv) was added and the reaction mixture stirred at room temperature for $20 \mathrm{~h}$. The solvent was evaporated under reduced pressure and the crude product was purified by flash chromatography using EtOAc:pentane 1:10 as mobile phase to afford 14a as a white solid $(1.15 \mathrm{~g}, 3.04$ mmol, 76\%). Mp: $178.5-182.3{ }^{\circ} \mathrm{C}$; TLC (EtOAc:pentane, 1:6 v/v): $\mathrm{R}_{\mathrm{f}}=0.44, \mathrm{KMnO}_{4} ;{ }^{1} \mathrm{H} \mathrm{NMR}(400 \mathrm{MHz}$, $\mathrm{CDCl}_{3}$ ): $\delta 7.27(\mathrm{dd}, J=5.0,1.9 \mathrm{~Hz}, 3 \mathrm{H}, \mathrm{ArH}), 7.05-6.98(\mathrm{~m}, 2 \mathrm{H}, \mathrm{ArH}), 5.84(\mathrm{~d}, J=0.8 \mathrm{~Hz}, 1 \mathrm{H}, t \mathrm{BuCCH})$, $5.50(\mathrm{~d}, J=0.8 \mathrm{~Hz}, 1 \mathrm{H}, t \mathrm{BuCCH}), 4.80(\mathrm{~s}, 1 \mathrm{H}, \mathrm{OH}), 3.46(\mathrm{~s}, 1 \mathrm{H}, \mathrm{ArCH}), 1.30\left(\mathrm{~s}, 3 \mathrm{H}, \mathrm{CHCCH}_{3}\right), 1.22(\mathrm{~s}, 9 \mathrm{H}$, $t \mathrm{Bu}), 1.15(\mathrm{~s}, 9 \mathrm{H}, \mathrm{tBu}) ;{ }^{13} \mathrm{C} \mathrm{NMR}\left(100 \mathrm{MHz}, \mathrm{CDCl}_{3}\right): \delta 171.8,152.8,150.8,142.3,137.3,133.4,133.0$, 129.6, 129.1, 128.1, 127.4, 92.5, 51.5, 46.5, 35.2, 35.2, 29.2, 29.1, 20.5; IR v 3350 (w), 3060 (w), 2962 (m), $2872(w), 2255(w), 1747(s), 1735(m), 1603(w), 1458(w), 1387(w), 1365(m), 1313(w), 1242(w)$, $1200(m), 1150(w), 1101$ (s), $1046(w), 912(m)$; HRMS (ESI) calcd. for $\mathrm{C}_{25} \mathrm{H}_{31} \mathrm{O}_{3}{ }^{+}[\mathrm{M}+\mathrm{H}]^{+}$379.2268; found 379.2273.

7,8-Di-tert-butyl-3-hydroxy-5-methyl-4-phenyl-4,5-dihydro-2H-5,7a-ethenobenzofuran-2-one (14b)<smiles>Cc1cc(C(=O)OCC(=O)C=[W])c(C(C)(C)C)c(C(C)(C)C)c1</smiles>

$8 \mathbf{a}$<smiles></smiles>

9a

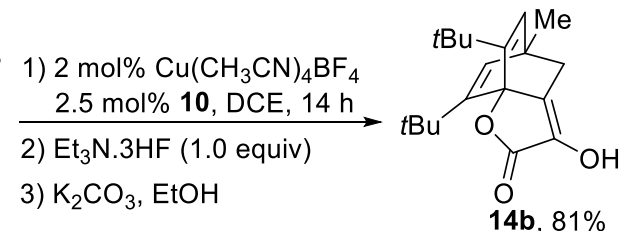

A flame dried $20 \mathrm{~mL}$ microwave vial was charged under nitrogen with $\mathrm{Cu}\left(\mathrm{CH}_{3} \mathrm{CN}\right)_{4} \mathrm{BF}_{4}(25 \mathrm{mg}, 0.08 \mathrm{mmol}$, 0.02 equiv), ligand 10 ( $37 \mathrm{mg}, 0.10 \mathrm{mmol}, 0.025$ equiv) and dry DCE (10 mL). The resulting solution was stirred at $30^{\circ} \mathrm{C}$ for $1 \mathrm{~h}$ and then added to a mixture of TIPS-EBX (9a) (1.72 g, $4.00 \mathrm{mmol}, 1.00$ equiv), 2,6- 
di-tert-butyl-4-methylphenyl 2-diazoacetate (8a) (1.4 g, $4.8 \mathrm{mmol}, 1.2$ equiv) and dry DCE (150 mL) in $250 \mathrm{~mL}$ round-bottom flask over $2 \mathrm{~min}$ and the resulting reaction mixture was stirred at $50{ }^{\circ} \mathrm{C}$ for $14 \mathrm{~h}$. Next, the reaction mixture was cooled down to room temperature and triethylamine trihydrofluoride ( $0.67 \mathrm{~mL}, 4.0 \mathrm{mmol}, 1.0$ equiv) was added and the reaction mixture stirred. After $24 \mathrm{~h}$, the solvent was evaporated under reduced pressure. The crude residue was dissolved in $\mathrm{EtOH}(80 \mathrm{~mL})$ and $\mathrm{K}_{2} \mathrm{CO}_{3}(0.83$ g, $6.0 \mathrm{mmol}, 1.5$ equiv) was added and the reaction mixture stirred at room temperature. After $20 \mathrm{~h}$, the solvent was evaporated under reduced pressure and the crude product was purified by flash column chromatography using EtOAc:pentane 1:10 as mobile phase to afford $14 \mathrm{~b}$ as a white solid $(0.980 \mathrm{~g}, 3.24$ mmol, 81\%). Mp: 189.0-190.3 ${ }^{\circ} \mathrm{C}$; TLC (EtOAc:pentane, 1:6 v/v): $\mathrm{R}_{\mathrm{f}}=0.43, \mathrm{KMnO}_{4} ;{ }^{1} \mathrm{H}$ NMR $(400 \mathrm{MHz}$, $\left.\mathrm{CDCl}_{3}\right): \delta 5.72(\mathrm{~s}, 2 \mathrm{H}, 2 \times t \mathrm{BuCCH}), 5.04$ (brs, $\left.1 \mathrm{H}, \mathrm{OH}\right), 2.18\left(\mathrm{~s}, 2 \mathrm{H}, \mathrm{CH}_{3} \mathrm{CCH}_{2}\right), 1.60$ (s, 3H, $\left.\mathrm{CHCCH}_{3}\right), 1.10$ (s, $18 \mathrm{H}, 2 \times t \mathrm{Bu}) ;{ }^{13} \mathrm{C} \mathrm{NMR}\left(100 \mathrm{MHz}, \mathrm{CDCl}_{3}\right): \delta 172.3,151.8,140.8,132.4,131.6,92.7,41.5,36.0,35.0,29.2$, 22.5; IR v $3348(\mathrm{~m}), 3298(w), 3054(w), 2958(w), 2929(w), 2866(w), 1747(s), 1711(s), 1461(w), 1384$ (m), $1376(\mathrm{~m}), 1328$ (w), 1241 (m), 1221 (m), 1202 (m), 1160 (m), 1104 (s), 1046 (w), 900 (w); HRMS (ESI) calcd. for $\mathrm{C}_{19} \mathrm{H}_{26} \mathrm{NaO}_{3}{ }^{+}[\mathrm{M}+\mathrm{Na}]^{+}$325.1774; found 325.1786.

\section{3-Bromo-7,8-di-tert-butyl-5-methyl-4-phenyl-4,5-dihydro-2H-5,7a-ethenobenzofuran-2,3(3aH)-dione} (15)
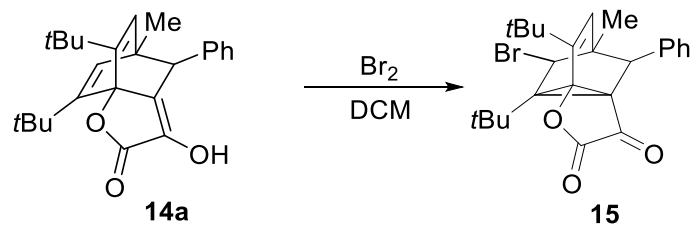

A solution of bromine (16 mg, $0.10 \mathrm{mmol}, 2.0$ equiv) in dry $\mathrm{CH}_{2} \mathrm{Cl}_{2}(1 \mathrm{~mL})$ was slowly added to a vigorously stirred solution of $14 \mathrm{a}$ (19 mg, $0.05 \mathrm{mmol}, 1.0$ equiv) in dry $\mathrm{CH}_{2} \mathrm{Cl}_{2}(1 \mathrm{~mL})$ at $0{ }^{\circ} \mathrm{C}$ under nitrogen. The reaction mixture was allowed to warm to room temperature and stirred for $14 \mathrm{~h}$. Next, an aqueous solution of $\mathrm{Na}_{2} \mathrm{SO}_{3}(5 \mathrm{~mL})$ was added to the reaction mixture and extracted with $\mathrm{CH}_{2} \mathrm{Cl}_{2}(3 \times 10 \mathrm{~mL})$. The organic layers were combined, dried over $\mathrm{MgSO}_{4}$, filtered, and concentrated under reduced pressure. The crude product was purified by flash column chromatography using 1:15 EtOAc:pentane as mobile phase to afford 15 as a pale yellow solid (20.0 mg, $0.044 \mathrm{mmol}, 87 \%$ ). Mp: 201.5-205.3 ${ }^{\circ} \mathrm{C}$; TLC (EtOAc:pentane, 1:15 v/v): $\mathrm{R}_{\mathrm{f}}=0.35, \mathrm{KMnO}_{4} ;{ }^{1} \mathrm{H} \mathrm{NMR}\left(400 \mathrm{MHz}, \mathrm{CDCl}_{3}\right): \delta 7.24-7.15(\mathrm{~m}, 3 \mathrm{H}, \mathrm{ArH}), 6.74$ $-6.68(\mathrm{~m}, 2 \mathrm{H}, \mathrm{ArH}), 4.92(\mathrm{~d}, J=1.1 \mathrm{~Hz}, 1 \mathrm{H}, t \mathrm{BuCCH}), 4.17(\mathrm{~d}, J=1.2 \mathrm{~Hz}, 1 \mathrm{H}, t \mathrm{BuCCHBr}), 3.39(\mathrm{~s}, 1 \mathrm{H}, \operatorname{ArCH})$, $1.35(\mathrm{~s}, 9 \mathrm{H}, t \mathrm{Bu}), 1.34(\mathrm{~s}, 9 \mathrm{H}, \mathrm{tBu}), 1.25\left(\mathrm{~s}, 3 \mathrm{H}, \mathrm{CHCCH}_{3}\right) ;{ }^{13} \mathrm{C} \mathrm{NMR}\left(100 \mathrm{MHz}, \mathrm{CDCl}_{3}\right): \delta 186.2,161.8,141.4$, 133.6, 128.9, 128.0, 127.7, 123.4, 63.9, 62.9, 49.6, 46.6, 46.1, 35.5, 33.9, 32.1, 29.1, 19.9; IR v 2967 (m), $2932(\mathrm{~m}), 2875(\mathrm{~m}), 1806(\mathrm{~s}), 1751$ (s), 1601 (w), $1492(\mathrm{w}), 1457(\mathrm{w}), 1370(\mathrm{~m}), 1325(\mathrm{~m}), 1265$ (m), 1235 $(\mathrm{m}), 1173(\mathrm{w}), 1147(\mathrm{~m}), 1090(\mathrm{~m}), 1062(\mathrm{~m}), 1032(\mathrm{w}), 946(\mathrm{w})$; HRMS (ESI) calcd. for $\mathrm{C}_{25} \mathrm{H}_{30} \mathrm{BrO}_{3}{ }^{+}[\mathrm{M}+\mathrm{H}]^{+}$ 457.1373; found 457.1373. One carbon was not resolved at $100 \mathrm{MHz}$. 


\section{7,8-Di-tert-butyl-5-methyl-2-oxo-4-phenyl-4,5-dihydro-2H-5,7a-ethenobenzofuran-3-yl}

\section{trifluoromethanesulfonate (16)}
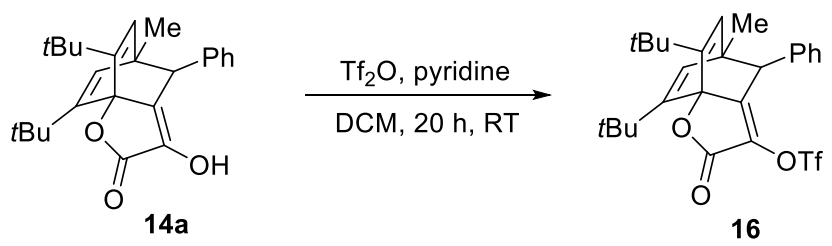

To a solution of 14a (303 mg, $0.800 \mathrm{mmol}, 1.00$ equiv.) and pyridine ( $0.129 \mathrm{~mL}, 1.60 \mathrm{mmol}, 2.00$ equiv.) in $\mathrm{CH}_{2} \mathrm{Cl}_{2}(40 \mathrm{~mL})$ was added triflic anhydride $\left(2.4 \mathrm{~mL}, 1.0 \mathrm{M}, 2.4 \mathrm{mmol}, 3.0\right.$ equiv) at $0{ }^{\circ} \mathrm{C}$ in $10 \mathrm{~min}$. The mixture was allowed to warm to room temperature and stirred for $20 \mathrm{~h}$. Next, the reaction mixture was quenched with water $(30 \mathrm{~mL})$ and the layers were separated. The aqueous layer was extracted with DCM $\left(3 \times 20 \mathrm{~mL}\right.$ ). The combined organic layers were washed with brine $(40 \mathrm{~mL})$, dried over $\mathrm{MgSO}_{4}$, and concentrated under reduced pressure. The crude product was purified by flash column chromatography using 1:40 EtOAc:pentane as mobile phase to afford $\mathbf{1 6}$ as a white solid (408 mg, $0.800 \mathrm{mmol}$, quant.). Mp: 187.5-191.5 ${ }^{\circ} \mathrm{C} ; \mathrm{TLC}($ EtOAc:pentane, $1: 40 \mathrm{v} / \mathrm{v}): \mathrm{R}_{\mathrm{f}}=0.5, \mathrm{KMnO}_{4} ;{ }^{1} \mathrm{H} \mathrm{NMR}\left(400 \mathrm{MHz}, \mathrm{CDCl}_{3}\right): \delta 7.32-$ $7.28(\mathrm{~m}, 3 \mathrm{H}, \mathrm{ArH}), 7.01-6.98(\mathrm{~m}, 2 \mathrm{H}, \mathrm{ArH}), 5.95(\mathrm{~s}, 1 \mathrm{H}, t \mathrm{BuCCH}), 5.67(\mathrm{~m}, 1 \mathrm{H}, t \mathrm{BuCCH}), 3.65(\mathrm{~s}, 1 \mathrm{H}$, $\operatorname{ArCH}), 1.32\left(\mathrm{~s}, 3 \mathrm{H}, \mathrm{CHCCH}_{3}\right), 1.24(\mathrm{~s}, 9 \mathrm{H}, t \mathrm{Bu}), 1.17(\mathrm{~s}, 9 \mathrm{H}, t \mathrm{Bu}) ;{ }^{13} \mathrm{C} \mathrm{NMR}\left(100 \mathrm{MHz}, \mathrm{CDCl}_{3}\right): 166.2,162.8$, 151.6, 149.1, 135.3, 134.2, 131.1, 130.5, 129.1, 128.4, 128.1, 118.0 (q, $J=321.2 \mathrm{~Hz}$ ), 92.6, 53.7, 46.7, 35.4, 35.3, 29.0, 28.9, 20.0; IR v 3064 (w), $2964(\mathrm{~m}), 2874(w), 1788$ (s), $1697(w), 1603(w), 1432(\mathrm{~s})$, 1392 (w), 1365 (w), 1316 (w), 1214 (s), 1182 (m), 1138 (s), 1072 (s), 1035 (w); HRMS (ESI) calcd. for $\mathrm{C}_{26} \mathrm{H}_{30} \mathrm{~F}_{3} \mathrm{O}_{5} \mathrm{~S}^{+}[\mathrm{M}+\mathrm{H}]^{+}$511.1761; found 511.1765 .

7,8-Di-tert-butyl-5-methyl-4-phenyl-4,5-dihydro-2H-5,7a-ethenobenzofuran-2-one (17)
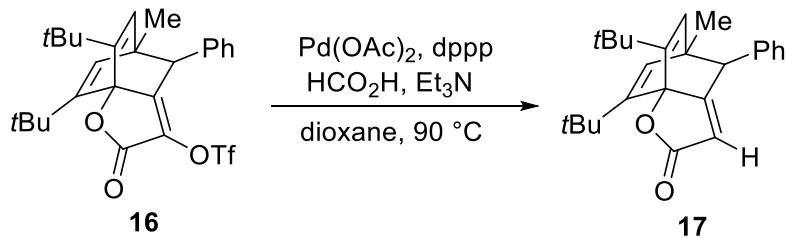

A mixture of 16 (51 mg, 0.10 mmol, 1.0 equiv), $\mathrm{Pd}(\mathrm{OAc})_{2}(5.6 \mathrm{mg}, 25 \mu \mathrm{mol}, 0.25$ equiv), dppp ( $25 \mathrm{mg}$, $0.06 \mathrm{mmol}, 0.60$ equiv), and dioxane $(1.0 \mathrm{~mL})$ was placed in a $2 \mathrm{~mL}$ microwave vial under nitrogen. Formic acid ( $15 \mu \mathrm{L}, 0.40 \mathrm{mmol}, 4.0$ equiv.) and triethylamine ( $55 \mu \mathrm{L}, 0.40 \mathrm{mmol}, 4.0$ equiv.) were added to the reaction mixture. The resulting mixture was stirred at $90{ }^{\circ} \mathrm{C}$ for $18 \mathrm{~h}$ and then quenched with water $(5$ $\mathrm{mL})$. The layers were separated and the aqueous layer was extracted with EtOAc $(3 \times 10 \mathrm{~mL})$. The combined organic layers were washed with brine $(20 \mathrm{~mL})$, dried over $\mathrm{MgSO}_{4}$, and concentrated under reduced pressure. The crude product was purified by flash column chromatography using 1:30 $\mathrm{Et}_{2} \mathrm{O}$ :pentane as mobile phase to afford 17 as a colorless semi solid ( $32.0 \mathrm{mg}, 0.088 \mathrm{mmol}, 88 \%$ ). TLC 
$\left(\mathrm{Et}_{2} \mathrm{O}\right.$ :pentane, $\left.1: 20 \mathrm{v} / \mathrm{v}\right): \mathrm{R}_{\mathrm{f}}=0.28, \mathrm{KMnO}_{4} ;{ }^{1} \mathrm{H} \mathrm{NMR}\left(400 \mathrm{MHz}, \mathrm{CDCl}_{3}\right): \delta 7.32-7.20(\mathrm{~m}, 3 \mathrm{H}, \mathrm{ArH}), 7.03-$ $6.99(\mathrm{~m}, 2 \mathrm{H}, \mathrm{ArH}), 5.84(\mathrm{~s}, 1 \mathrm{H}, t \mathrm{BuCCH}), 5.54-5.51(\mathrm{~m}, 2 \mathrm{H}, t \mathrm{BuCCH}$ and $\mathrm{C}(\mathrm{O}) \mathrm{CH}), 3.47(\mathrm{~d}, J=1.9 \mathrm{~Hz}, 1 \mathrm{H}$, $\operatorname{ArCH}), 1.29\left(\mathrm{~s}, 3 \mathrm{H}, \mathrm{CHCCH}_{3}\right), 1.24(\mathrm{~s}, 9 \mathrm{H}, \mathrm{tBu}), 1.17(\mathrm{~s}, 9 \mathrm{H}, t \mathrm{Bu}) ;{ }^{13} \mathrm{CNMR}\left(100 \mathrm{MHz}, \mathrm{CDCl}_{3}\right): \delta 179.0,175.4$, 152.4, 150.0, 139.1, 132.6, 129.3, 129.2, 128.2, 127.4, 109.7, 96.6, 52.9, 46.4, 35.4, 35.4, 29.1, 29.1, 20.5; IR v $2961(m), 2872(w), 1797(w), 1762(s), 1652(w), 1457(w), 1390(w), 1363(w), 1314(w), 1247(w)$, $1218(w), 1128(w), 1097(w), 1047(w)$; HRMS (ESI) calcd. for $\mathrm{C}_{25} \mathrm{H}_{31} \mathrm{O}_{2}{ }^{+}[\mathrm{M}+\mathrm{H}]^{+}$363.2319; found 363.2316 .

\section{7,8-Di-tert-butyl-5-methyl-4-phenyl-3-((3-phenylprop-2-yn-1-yl)oxy)-4,5-dihydro-2H-5,7a-} ethenobenzofuran-2-one (18)
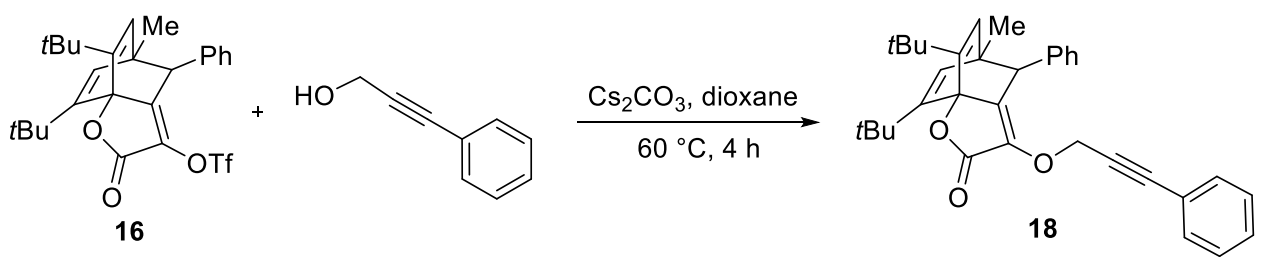

A mixture of 16 (51 mg, $0.10 \mathrm{mmol}, 1.0$ equiv), $\mathrm{Cs}_{2} \mathrm{CO}_{3}(65.5 \mathrm{mg}, 0.200 \mathrm{mmol}, 2.00$ equiv), and dioxane $(1.0 \mathrm{~mL})$ was placed in a $2 \mathrm{~mL}$ microwave vial under nitrogen. 3-Phenylprop-2-yn-1-ol $(66 \mathrm{mg}, 0.50 \mathrm{mmol}$, 5.0 equiv.) was added slowly to the reaction mixture over $5 \mathrm{~min}$ and it was stirred at $60^{\circ} \mathrm{C}$ for $4 \mathrm{~h}$. The reaction mixture was quenched with water $(10 \mathrm{~mL})$ and transferred to a separating funnel. The layers were separated and the aqueous layer was extracted with EtOAc $(3 \times 10 \mathrm{~mL})$. The combined organic layers were washed with brine $(20 \mathrm{~mL})$, dried over $\mathrm{MgSO}_{4}$, and concentrated under reduced pressure. The crude product was purified by flash column chromatography using 1:15 $\mathrm{Et}_{2} \mathrm{O}$ :pentane as mobile phase to afford 18 as a pale yellow thick gel $(44.5 \mathrm{mg}, 0.090 \mathrm{mmol}, 90 \%)$. TLC (Et $2 \mathrm{O}$ :pentane, 1:15 v/v): $\mathrm{R}_{\mathrm{f}}=0.33, \mathrm{KMnO}_{4} ;{ }^{1} \mathrm{H}$ NMR $\left(400 \mathrm{MHz}, \mathrm{CDCl}_{3}\right): \delta 7.38-7.26(\mathrm{~m}, 8 \mathrm{H}, \mathrm{ArH}), 7.38-7.26(\mathrm{~m}, 2 \mathrm{H}, \mathrm{ArH}), 5.82(\mathrm{~s}$, $1 \mathrm{H}, t \mathrm{BuCCH}), 5.48(\mathrm{~s}, 1 \mathrm{H}, t \mathrm{BuCCH}), 4.53\left(\mathrm{~d}, J=15.9 \mathrm{~Hz}, 1 \mathrm{H}, \mathrm{OCH}^{a}{ }_{2}\right), 4.37\left(\mathrm{~d}, J=15.9 \mathrm{~Hz}, 1 \mathrm{H}, \mathrm{OCH}^{b}{ }_{2}\right), 3.74$ $(\mathrm{s}, 1 \mathrm{H}, \mathrm{ArCH}), 1.30\left(\mathrm{~s}, 3 \mathrm{H}, \mathrm{CHCCH}_{3}\right), 1.23(\mathrm{~s}, 9 \mathrm{H}, t \mathrm{Bu}), 1.11(\mathrm{~s}, 9 \mathrm{H}, t \mathrm{Bu}) ;{ }^{13} \mathrm{CNMR}\left(100 \mathrm{MHz}, \mathrm{CDCl}_{3}\right): \delta 170.5$, 153.3, 150.7, 148.3, 139.1, 135.9, 132.8, 131.7, 129.5, 129.1, 128.8, 128.3, 128.2, 127.5, 122.1, 92.2, 87.6, 84.1, 58.6, 52.7, 46.4, 35.3, 35.2, 29.2, 29.1, 20.8; IR v 3061 (w), 2961 (m), $2871(w), 2252$ (w), 1769 (s), $1684(w), 1601(w), 1491(w), 1453(w), 1389(w), 1366(w), 1316(w), 1244(w), 1191(w), 1148(w)$, 1099 (s), 1034 (w), 988 (w), $954(w), 913(m)$; HRMS (ESI) calcd. for $\mathrm{C}_{34} \mathrm{H}_{37} \mathrm{O}_{3}{ }^{+}[\mathrm{M}+\mathrm{H}]^{+}$493.2737; found 493.2741.

7,8-Di-tert-butyl-5-methyl-2-oxo-4-phenyl-4,5-dihydro-2H-5,7a-ethenobenzofuran-3-yl

diethyl phosphate (19) 


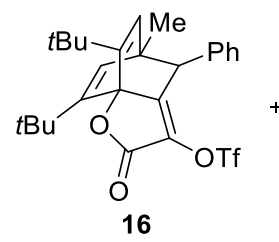

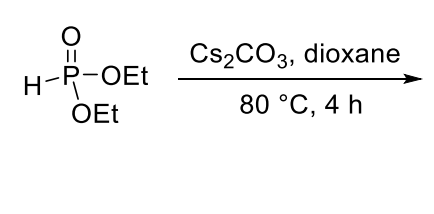

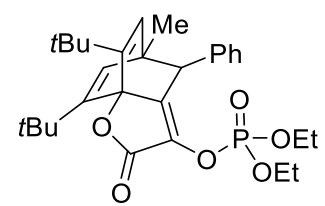

$19,66 \%$

A mixture of 16 (51 mg, $0.10 \mathrm{mmol}, 1.0$ equiv), $\mathrm{Cs}_{2} \mathrm{CO}_{3}(65.5 \mathrm{mg}, 0.200 \mathrm{mmol}, 2.00$ equiv), and dioxane $(1.0 \mathrm{~mL})$ was placed in a $2 \mathrm{~mL}$ microwave vial under nitrogen. Diethyl phosphonate $(69 \mathrm{mg}, 0.50 \mathrm{mmol}$, 5.0 equiv.) was added slowly to the reaction mixture over $5 \mathrm{~min}$ and the reaction mixture stirred at 80 ${ }^{\circ} \mathrm{C}$ for $4 \mathrm{~h}$. The reaction mixture was quenched with water $(10 \mathrm{~mL})$ and transferred to a separating funnel. The layers were separated and the aqueous layer was extracted with EtOAc $(3 \times 10 \mathrm{~mL})$. The combined organic layers were washed with brine $(20 \mathrm{~mL})$, dried over $\mathrm{MgSO}_{4}$, and concentrated under reduced pressure. The crude product was purified by flash column chromatography using 1:10 EtOAc:pentane as mobile phase to afford 19 as a colorless thick gel $(34.0 \mathrm{mg}, 0.066 \mathrm{mmol}, 66 \%)$. TLC (EtOAc:pentane, 1:6 $\mathrm{v} / \mathrm{v}): \mathrm{R}_{\mathrm{f}}=0.25, \mathrm{KMnO}_{4} ;{ }^{1} \mathrm{H}$ NMR $\left(400 \mathrm{MHz}, \mathrm{CDCl}_{3}\right): \delta 7.24-7.11(\mathrm{~m}, 3 \mathrm{H}, \mathrm{ArH}), 7.02-6.91(\mathrm{~m}, 2 \mathrm{H}, \mathrm{ArH})$, $5.80(\mathrm{~s}, 1 \mathrm{H}, t \mathrm{BuCCH}), 5.47(\mathrm{~s}, 1 \mathrm{H}, t \mathrm{BuCCH}), 4.09-3.80\left(\mathrm{~m}, 2 \mathrm{H}, \mathrm{OCH}_{2} \mathrm{CH}_{3}\right), 3.73(\mathrm{~d}, J=3.4 \mathrm{~Hz}, 1 \mathrm{H}, \operatorname{ArCH})$, $3.49-3.26\left(\mathrm{~m}, 2 \mathrm{H}, \mathrm{OCH}_{2} \mathrm{CH}_{3}\right), 1.23\left(\mathrm{~s}, 3 \mathrm{H}, \mathrm{CHCCH}_{3}\right), 1.19-1.04\left(\mathrm{~m}, 12 \mathrm{H}, \mathrm{tBu}\right.$ and $\left.\mathrm{OCH}_{2} \mathrm{CH}_{3}\right), 1.10(\mathrm{~s}, 9 \mathrm{H}$, $t \mathrm{Bu}), 0.90\left(\mathrm{td}, J=7.1,1.2 \mathrm{~Hz}, 3 \mathrm{H}, \mathrm{OCH}_{2} \mathrm{CH}_{3}\right) ;{ }^{13} \mathrm{C} \mathrm{NMR}\left(100 \mathrm{MHz}, \mathrm{CDCl}_{3}\right): \delta 169.2$ (d, J=3.1 Hz), 157.0 (d, $J=4.8 \mathrm{~Hz}$ ), 152.0, 149.9, 137.4, 133.5, 130.6 (d, $J=7.5 \mathrm{~Hz}), 130.2,129.6,127.9,127.2,92.2,64.9(\mathrm{~d}, J=$ $6.6 \mathrm{~Hz}$ ), 64.3 (d, J = 6.2 Hz), 52.6, 46.4, 35.3, 35.2, 29.1, 29.0, 20.3, 15.9 (d, J = 7.3 Hz), 15.7 (d, J = 7.1 Hz); IR v $2962(m), 2872(w), 2246(w), 1779(s), 1703(w), 1601(w), 1481(w), 1456(w), 1393(w), 1365(w)$, $1295(\mathrm{~m}), 1265(\mathrm{w}), 1189(\mathrm{w}), 1149(\mathrm{w}), 1099(\mathrm{~m}), 1056$ (s), 1033 (s), 967 (w), 918 (m); HRMS (ESI) calcd. for $\mathrm{C}_{29} \mathrm{H}_{39} \mathrm{NaO}_{6} \mathrm{P}^{+}[\mathrm{M}+\mathrm{Na}]^{+}$537.2376; found 537.2390.

\section{Preparation of $[\mathrm{RhCl}(6 \mathrm{~m})]_{2}(20 \mathrm{a})$}

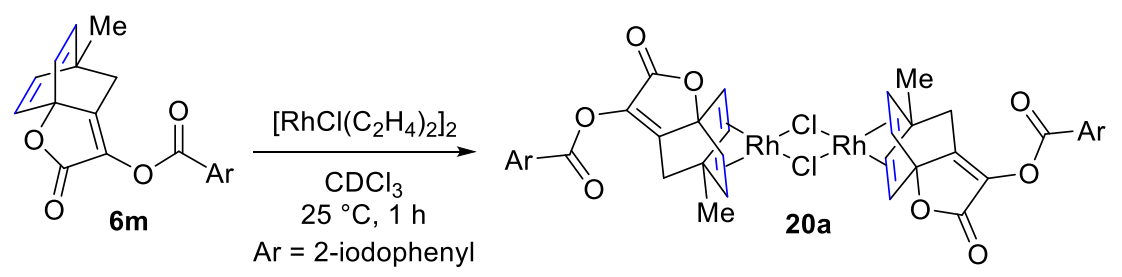

Under inert atmosphere, $\left[\mathrm{RhCl}\left(\mathrm{C}_{2} \mathrm{H}_{4}\right)_{2}\right]_{2}(6.5 \mathrm{mg}, 17 \mu \mathrm{mol}, 1.0$ equiv) and 5-methyl-2-oxo-4,5-dihydro$2 \mathrm{H}-5$,7a-ethenobenzofuran-3-yl 2-iodobenzoate $6 \mathrm{~m}$ (14.1 mg, $33.0 \mu \mathrm{mol}, 2.0$ equiv) were stirred in $\mathrm{CDCl}_{3}$ $(1.7 \mathrm{~mL})$ at $25^{\circ} \mathrm{C}$. Within $1 \mathrm{~h},\left[\mathrm{RhCl}\left(\mathrm{C}_{2} \mathrm{H}_{4}\right)_{2}\right]_{2}$ was fully converted into $[\mathrm{RhCl}(6 \mathrm{~m})]_{2}(20 \mathrm{a}) .{ }^{1} \mathrm{H} \mathrm{NMR}(400 \mathrm{MHz}$, $\left.\mathrm{CDCl}_{3}\right) \delta 8.05(\mathrm{td}, J=7.5,1.4 \mathrm{~Hz}, 4 \mathrm{H}, \mathrm{ArH}), 7.47(\mathrm{td}, J=7.6,1.2 \mathrm{~Hz}, 2 \mathrm{H}, \mathrm{ArH}), 7.28-7.20(\mathrm{~m}, 2 \mathrm{H}, \mathrm{ArH})$, $3.77(\mathrm{dd}, J=5.5,1.9 \mathrm{~Hz}, 4 \mathrm{H}, 2 \times \mathrm{OCCH}), 3.54\left(\mathrm{dd}, J=5.9,1.9 \mathrm{~Hz}, 4 \mathrm{H}, 2 \times \mathrm{H}_{3} \mathrm{CCCH}\right), 2.30\left(\mathrm{~s}, 4 \mathrm{H}, \mathrm{CHCH}_{2}\right.$ ), $2.25\left(\mathrm{~s}, 6 \mathrm{H}, \mathrm{CH}_{3}\right) ;{ }^{13} \mathrm{C} \mathrm{NMR}\left(101 \mathrm{MHz}, \mathrm{CDCl}_{3}\right) \delta 166.4,161.6,149.2,142.1,134.2,132.5,131.8,128.9$, 128.4, 95.5, $88.8(\mathrm{~d}, J=3.9 \mathrm{~Hz}), 56.3(\mathrm{~d}, J=10.8 \mathrm{~Hz}), 49.2(\mathrm{~d}, J=11.0 \mathrm{~Hz}), 47.5(\mathrm{~d}, J=2.5 \mathrm{~Hz}), 39.2,21.4$. The complex can be isolated by precipitation in $\mathrm{Et}_{2} \mathrm{O}$ to furnish $20 \mathrm{a}$ as a yellow solid $(18.6 \mathrm{mg}, 17.0 \mu \mathrm{mol}$, 
100\%). The crystal structure of 20a has been deposited at the Cambridge Crystallographic Data Centre and allocated the deposition number: CCDC 1945514.

\section{Preparation of $[\mathrm{RhCl}((+)-6 p)]_{2}(-)-(20 b)$}

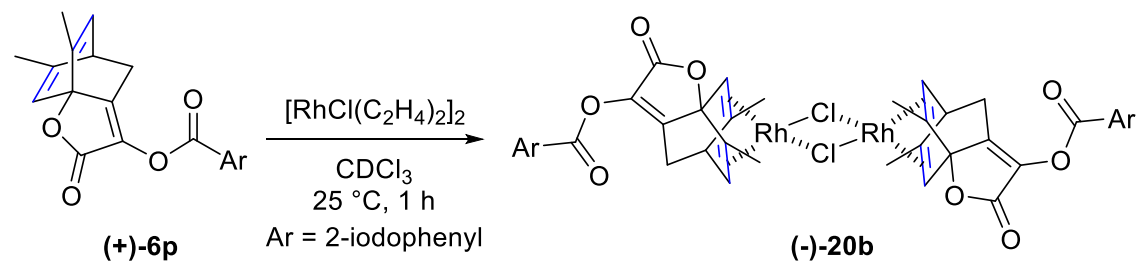

Under inert atmosphere, $\left[\mathrm{RhCl}\left(\mathrm{C}_{2} \mathrm{H}_{4}\right)_{2}\right]_{2}(15.9 \mathrm{mg}, 41.0 \mu \mathrm{mol}, 1.0$ equiv) and (+)-(5R,7aS)-6,8-dimethyl-2oxo-4,5-dihydro-2H-5,7a-ethenobenzofuran-3-yl 2-iodobenzoate (+)-(6p) (35.6 mg, $82.0 \mu \mathrm{mol}, 2.00$ equiv) were stirred in $\mathrm{CDCl}_{3}(4.1 \mathrm{~mL})$ at $25{ }^{\circ} \mathrm{C}$ for $1 \mathrm{~h}$. After complete complexation (monitored by ${ }^{1} \mathrm{H}$ NMR), the reaction mixture was directly loaded and purified by flash column chromatography using EtOAc:pentane 1:2 as eluent to furnish (-)-20b as a yellow solid (41.0 mg, $36.0 \mu \mathrm{mol}, 87 \%)$. TLC (EtOAc:pentane, 1:1 v/v): $\mathrm{R}_{\mathrm{f}}=0.45 ;[\alpha]_{\mathrm{D}}{ }^{20}=-26.11\left(\mathrm{c}=0.3, \mathrm{CH}_{2} \mathrm{Cl}_{2}\right) ;{ }^{1} \mathrm{H} \mathrm{NMR}\left(400 \mathrm{MHz}, \mathrm{CDCl}_{3}\right) \delta 8.06$ (dd, $J=7.8,1.4 \mathrm{~Hz}, 4 \mathrm{H}, \mathrm{ArH}), 7.47(\mathrm{td}, J=7.6,1.2 \mathrm{~Hz}, 2 \mathrm{H}, \mathrm{ArH}), 7.28-7.21(\mathrm{~m}, 2 \mathrm{H}, \mathrm{ArH}), 4.42(\mathrm{~s}, 2 \mathrm{H}, \mathrm{OCCH}=\mathrm{C})$, $3.50\left(\mathrm{~d}, J=5.3 \mathrm{~Hz}, 2 \mathrm{H}, \mathrm{CHCH}_{2}\right), 3.39\left(\mathrm{~s}, 2 \mathrm{H}, \mathrm{CH}_{3} \mathrm{C}=\mathrm{CHCH}\right), 2.45-2.26\left(\mathrm{~m}, 4 \mathrm{H}, \mathrm{CH}_{2}\right), 1.62\left(\mathrm{~s}, 6 \mathrm{H}, \mathrm{CH}_{3}\right), 1.51$ (s, 6H, $\left.\mathrm{CH}_{3}\right) ;{ }^{13} \mathrm{C}$ NMR $\left(101 \mathrm{MHz}, \mathrm{CDCl}_{3}\right) \delta$ 166.5, 161.7, 147.9 (br s), 142.1, 134.2, 132.5, 131.9, 129.2, 128.4, 95.4, $91.4(\mathrm{~d}, J=4.2 \mathrm{~Hz}), 64.4(\mathrm{~d}, J=9.3 \mathrm{~Hz}), 61.7(\mathrm{~d}, J=12.3 \mathrm{~Hz}), 47.6(\mathrm{~d}, J=10.8 \mathrm{~Hz}), 47.4(\mathrm{~d}, J=$ 3.6 Hz), $46.0(\mathrm{~d}, J=11.1 \mathrm{~Hz}), 31.7(\mathrm{~d}, J=1.7 \mathrm{~Hz}), 21.4,15.7$. The crystal structure of $(-)-20 \mathrm{~b}$ has been deposited at the Cambridge Crystallographic Data Centre and allocated the deposition number: CCDC 2027174. The complex (-)-20b decomposed in the mass spectrometer and therefore the accurate mass was not obtained.

\section{1,4-Addition of boronic acid 21 to enone 22 catalyzed by $[\mathrm{RhCl}(6 \mathrm{~m})]_{2}(20 \mathrm{a})$.}

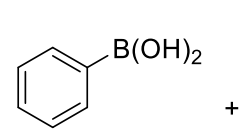

21<smiles>O=C1C=CCCC1</smiles>

22

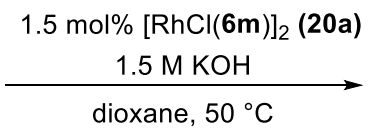

dioxane, $50^{\circ} \mathrm{C}$

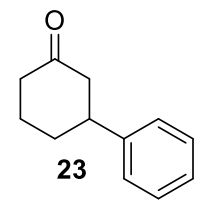

An oven-dried $10 \mathrm{~mL}$ microwave vial was successively charged with $[\mathrm{RhCl}(6 \mathrm{~m})]_{2} 20 \mathrm{a}(8.4 \mathrm{mg}, 7.5 \mu \mathrm{mol}$, 0.015 equiv), degassed dioxane $(2.0 \mathrm{~mL})$ and a $1.5 \mathrm{M}$ degassed solution of $\mathrm{KOH}$ in water $(167 \mu \mathrm{L}, 0.250$ mmol, 0.50 equiv) and the resulting mixture was stirred for a further 10 minutes at room temperature. Subsequently, phenylboronic acid (21) (122 mg, $1.00 \mathrm{mmol}, 2.00$ equiv) and 2-cyclohexenone (22) (48.5 $\mu \mathrm{L}, 0.50 \mathrm{mmol}, 1.00$ equiv) was added to this solution. After stirring at $50{ }^{\circ} \mathrm{C}$ for $3 \mathrm{~h}$, the reaction mixture was quenched with saturated $\mathrm{NH}_{4} \mathrm{Cl}$ in water $(5 \mathrm{~mL})$ and extracted with $\mathrm{Et}_{2} \mathrm{O}(3 \times 15 \mathrm{~mL})$. The combined organic layers were dried over $\mathrm{MgSO}_{4}$, filtered and concentrated under reduced pressure. The crude product was purified by column chromatography using Et ${ }_{2} \mathrm{O}$ :pentane 1:20 as mobile phase to afford 3- 
phenylcyclohexanone (23) as a colorless oil $(67.0 \mathrm{mg}, 0.385 \mathrm{mmol}, 77 \%) .{ }^{1} \mathrm{H} \mathrm{NMR}\left(400 \mathrm{MHz}, \mathrm{CDCl}_{3}\right): \delta$ $7.37-7.30(\mathrm{~m}, 2 \mathrm{H}), 7.27-7.20(\mathrm{~m}, 3 \mathrm{H}), 3.02(\mathrm{tt}, J=11.6,4.0 \mathrm{~Hz}, 1 \mathrm{H}), 2.65-2.33(\mathrm{~m}, 4 \mathrm{H}), 2.21-2.04$ (m, 2H), $\left.1.94-1.69(\mathrm{~m}, 2 \mathrm{H}) ;{ }^{13} \mathrm{C} \mathrm{NMR} \mathrm{(101} \mathrm{MHz,} \mathrm{CDCl}\right)$ ) $211.2,144.5,128.8,126.8,126.7,49.1,44.9$, $41.3,32.9,25.7$. The value of the NMR spectra are in accordance with reported literature data. ${ }^{27}$

\section{Enantioselective Rh-catalyzed 1,4-addition of boronic acid 21 to enone 22.}

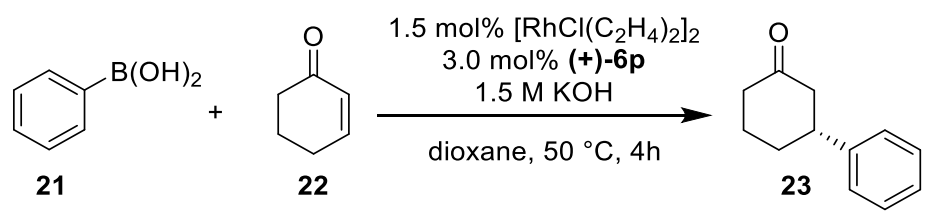

An oven-dried $10 \mathrm{~mL}$ microwave vial was charged with $\left[\mathrm{RhCl}\left(\mathrm{C}_{2} \mathrm{H}_{4}\right)_{2}\right]_{2}(1.6 \mathrm{mg}, 4.1 \mu \mathrm{mol}, 0.015$ equiv) and (+)-(5S,7aR)-6,8-dimethyl-2-oxo-4,5-dihydro-2H-5,7a-ethenobenzofuran-3-yl 2-iodobenzoate (6p) (3.6 $\mathrm{mg}, 8.2 \mu \mathrm{mol}, 0.030$ equiv) and degassed dioxane $(1.1 \mathrm{~mL})$ under inert atmosphere. After stirring $1 \mathrm{~h}$ at room temperature, a $1.5 \mathrm{M}$ degassed solution of $\mathrm{KOH}$ in water ( $91 \mu \mathrm{L}, 0.14 \mathrm{mmol}, 0.50$ equiv) was added and the reaction mixture was stirred for further 10 minutes at room temperature. Subsequently, phenylboronic acid (21) (67 mg, $0.55 \mathrm{mmol}, 2.00$ equiv) and 2-cyclohexenone (22) (26 $\mu \mathrm{L}, 0.27 \mathrm{mmol}$, 1.00 equiv) were added to this solution. After stirring at $50^{\circ} \mathrm{C}$ for $4 \mathrm{~h}$, the reaction mixture was quenched with saturated $\mathrm{NH}_{4} \mathrm{Cl}$ in water $(5 \mathrm{~mL})$ and extracted with $\mathrm{Et}_{2} \mathrm{O}(3 \times 15 \mathrm{~mL})$. The combined organic layers were dried over $\mathrm{MgSO}_{4}$, filtered and concentrated under reduced pressure. The crude product was purified by column chromatography using $\mathrm{Et}_{2} \mathrm{O}$ :pentane $1: 20$ as mobile phase to afford 3phenylcyclohexanone (23) as a colorless oil $(36.0 \mathrm{mg}, 0.207 \mathrm{mmol}, 75 \%) .[\alpha]_{\mathrm{D}}{ }^{20}=+17.00\left(\mathrm{c}=0.5, \mathrm{CH}_{2} \mathrm{Cl}_{2}\right)$; ${ }^{1} \mathrm{H} \mathrm{NMR}\left(400 \mathrm{MHz}, \mathrm{CDCl}_{3}\right): \delta 7.37-7.30(\mathrm{~m}, 2 \mathrm{H}, \mathrm{ArH}), 7.27-7.20(\mathrm{~m}, 3 \mathrm{H}, \mathrm{ArH}), 3.02(\mathrm{tt}, J=11.6,4.0 \mathrm{~Hz}$, $1 \mathrm{H}, \mathrm{CHPh}), 2.65-2.33\left(\mathrm{~m}, 4 \mathrm{H}, 2 \times \mathrm{COCH}_{2}\right), 2.21-2.04\left(\mathrm{~m}, 2 \mathrm{H}, \mathrm{CH}_{2}\right), 1.94-1.69\left(\mathrm{~m}, 2 \mathrm{H}, \mathrm{CH}_{2}\right) ;{ }^{13} \mathrm{C} \mathrm{NMR}$ $\left(101 \mathrm{MHz}, \mathrm{CDCl}_{3}\right) \delta$ 211.2, 144.5, 128.8, 126.8, 126.7, 49.1, 44.9, 41.3, 32.9, 25.7; Chiral HPLC conditions: ee $=87 \%$, Chiralpak IA 95:5, Hexane/iPrOH, $0.8 \mathrm{~mL} / \mathrm{min}, 30 \mathrm{~min}$. $\operatorname{tr}$ (minor) = $7.7 \mathrm{~min}$. and tr (major) = $8.5 \mathrm{~min}, \lambda=254 \mathrm{~nm}$. The value of the NMR spectra are in accordance with reported literature data. ${ }^{27}$ Absolute configuration of the major enantiomer (drawn) was determined by comparison with $[\alpha]_{D}$ given in the literature. ${ }^{28}$

\footnotetext{
${ }^{27}$ Y. Takaya, M. Ogasawara, T. Hayashi, M. Sakai, N. Miyaura, J. Am. Chem. Soc. 1998, 120, 5579.

${ }^{28}$ M. Pucheault, S. Darses, J.-P. Genet, Tetrahedron Lett. 2002, 43, 6155.
} 


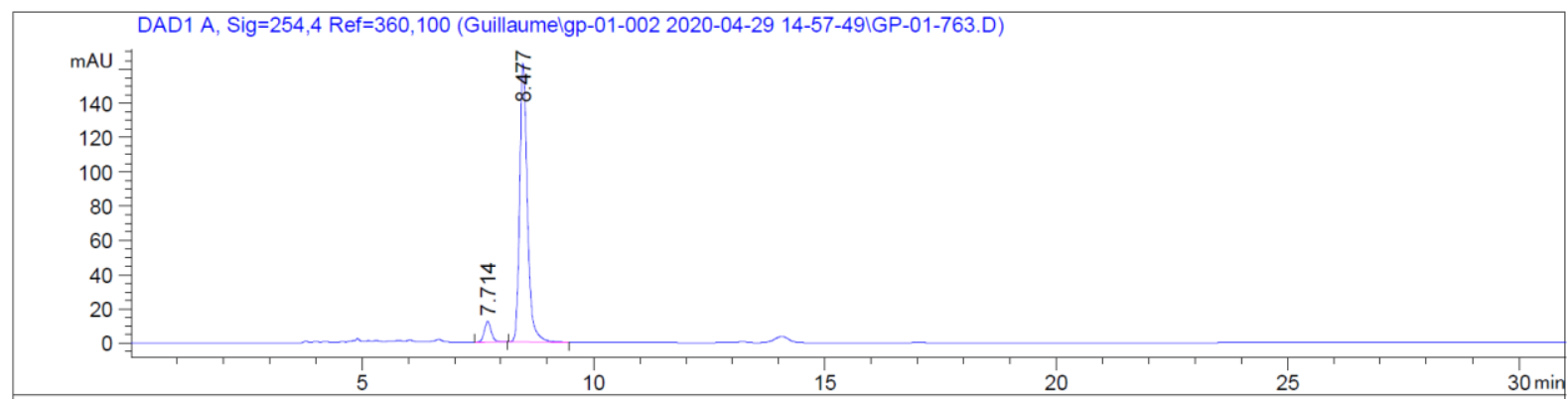

Signal 1: DAD1 A, Sig=254,4 Ref $=360,100$

\begin{tabular}{|c|c|c|c|c|c|c|}
\hline eak & $\begin{array}{c}\text { RetTime } \\
\text { [min] }\end{array}$ & Type & $\begin{array}{l}\text { Width } \\
\text { [min] }\end{array}$ & $\begin{array}{c}\text { Area } \\
{\left[\mathrm{mAU}^{*} \mathrm{~s}\right]}\end{array}$ & $\begin{array}{l}\text { Height } \\
\text { [mAU] }\end{array}$ & $\begin{array}{c}\text { Area } \\
\%\end{array}$ \\
\hline & & & & - & $-\ldots$ & \\
\hline 1 & & $R$ & & 128. & 813 & 6. \\
\hline & 8.477 & B & 59 & 1895.54675 & 753 & 93.6646 \\
\hline
\end{tabular}

$\begin{array}{ll}\text { Totals : } & 2023.75929 \quad 175.03567\end{array}$

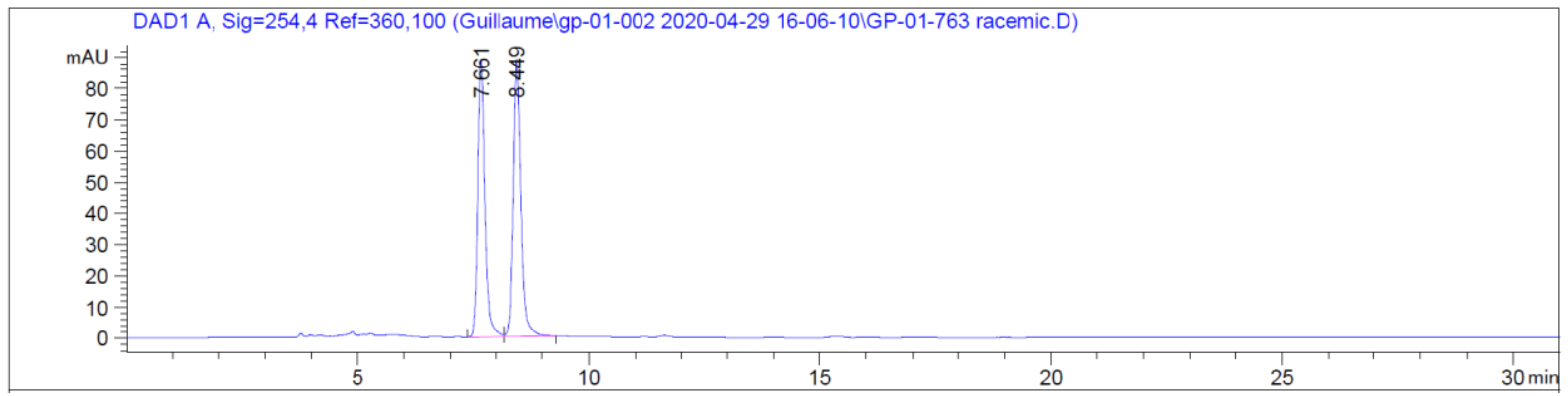

Signal 1: DAD1 A, Sig=254,4 Ref $=360,100$

\begin{tabular}{cccccc}
$\begin{array}{c}\text { Peak RetTime Type } \\
\text { Width } \\
{[\mathrm{min}]}\end{array}$ & $\begin{array}{c}\text { Area } \\
{[\mathrm{min}]}\end{array}$ & $\begin{array}{c}\text { Height } \\
{[\mathrm{mAU} \text { s }]}\end{array}$ & $\begin{array}{c}\text { Area } \\
{[\mathrm{mAU}]}\end{array}$ & $\%$ \\
\hline 1 & 7.661 BV & 0.1597 & 943.93439 & 89.04942 & 47.9240 \\
2 & 8.449 VB & 0.1745 & 1025.71448 & 89.00008 & 52.0760 \\
& & & & & \\
Totals : & & 1969.64886 & 178.04950
\end{tabular}




\section{Control experiments}

\section{Isolation of the reaction intermediates}<smiles>CC(C)c1cccc(C(C)C)c1OC(=O)C=[W]</smiles>

$8 \mathrm{~g}$

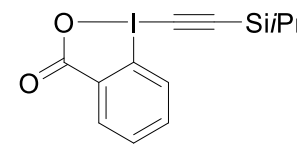

9a

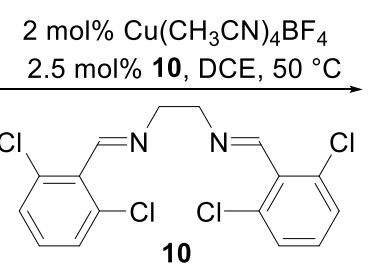

$\frac{\mathrm{THF}}{90^{\circ} \mathrm{C}}$

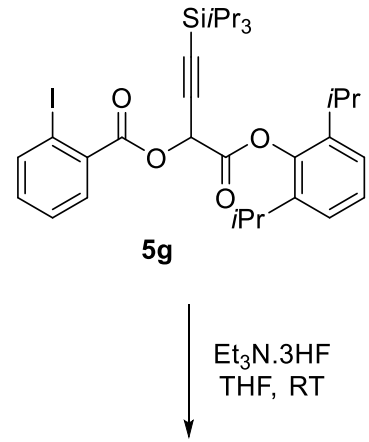<smiles>C=IC(OC(=O)c1ccccc1I)C(=O)Oc1c(C(C)C)cccc1C(C)C</smiles>

A flame dried $5 \mathrm{~mL}$ microwave vial was charged under nitrogen with $\mathrm{Cu}\left(\mathrm{CH}_{3} \mathrm{CN}\right)_{4} \mathrm{BF}_{4}(1.9 \mathrm{mg}, 6.0 \mu \mathrm{mol}$, 0.02 equiv), ligand 10 ( $2.8 \mathrm{mg}, 7.5 \mu \mathrm{mol}, 0.025$ equiv) and dry DCE $(2 \mathrm{~mL})$. The resulting solution was stirred at $30{ }^{\circ} \mathrm{C}$ for $1 \mathrm{~h}$ and then added to a mixture of 1-[(triiso-propylsilyl)ethynyl]-1,2-benziodoxol3(1H)-one (9a) (129 mg, $0.300 \mathrm{mmol}, 1.00$ equiv), 2,6-diisopropylphenyl 2-diazoacetate (8g) (89,0 mg, $0.180 \mathrm{mmol}, 1.20$ equiv) and dry DCE $(10 \mathrm{~mL})$ in $20 \mathrm{~mL}$ microwave vial over $2 \mathrm{~min}$ and the resulting reaction mixture was stirred at $50^{\circ} \mathrm{C}$ for $4 \mathrm{~h}$. After this time, the solvent was evaporated under reduced pressure and the crude product was purified by flash column chromatography using EtOAc:pentane 1:50 as eluent to afford $\mathbf{5 g}$ as a colorless oil (185 $\mathrm{mg}, 0.286 \mathrm{mmol}, 95 \%)$. TLC (EtOAc:pentane, 1:30 v/v): $R_{\mathrm{f}}=$ 0.53, $\mathrm{KMnO}_{4} ;{ }^{1} \mathrm{H}$ NMR $\left(400 \mathrm{MHz}, \mathrm{CDCl}_{3}\right): \delta 8.05-7.96(\mathrm{~m}, 2 \mathrm{H}, \mathrm{ArH}), 7.44(\mathrm{td}, J=7.6,1.2 \mathrm{~Hz}, 1 \mathrm{H}, \mathrm{ArH})$, $7.25-7.13(\mathrm{~m}, 4 \mathrm{H}, \mathrm{ArH}), 6.31(\mathrm{~s}, 1 \mathrm{H}, \mathrm{OCH}), 3.11$ (hept, $\left.\mathrm{J}=6.8 \mathrm{~Hz}, 2 \mathrm{H}, 2 \times \mathrm{CH}\left(\mathrm{CH}_{3}\right)_{2}\right), 1.30-1.15(\mathrm{~m}, 12 \mathrm{H}$, $\left.2 \times \mathrm{CH}\left(\mathrm{CH}_{3}\right)_{2}\right), 1.16-1.08(\mathrm{~m}, 21 \mathrm{H}, \mathrm{TIPS}) ;{ }^{13} \mathrm{C} \mathrm{NMR}\left(100 \mathrm{MHz}, \mathrm{CDCl}_{3}\right): \delta 165.1,164.4,145.1,141.7,140.7$, 133.5, 133.4, 132.0, 128.2, 127.2, 124.2, 96.9, 94.6, 91.7, 64.0, 27.2, 23.7 (br), 18.7, 11.3; IR v 3685 (m), $3662(\mathrm{~m}), 2970(\mathrm{~s}), 2901(\mathrm{~s}), 1781(\mathrm{~m}), 1740(\mathrm{~m}), 1464(\mathrm{~m}), 1407(\mathrm{~m}), 1393(\mathrm{~m}), 1384(\mathrm{~m}), 1241(\mathrm{~s}), 1066$ (s), $1016(\mathrm{~s}), 882(\mathrm{~m}), 791(\mathrm{~m}), 740(\mathrm{~m}), 679(\mathrm{~m})$; HRMS (ESI) calcd. for $\mathrm{C}_{32} \mathrm{H}_{43} \mathrm{INaO}_{4} \mathrm{Si}^{+}[\mathrm{M}+\mathrm{Na}]^{+}$669.1868; Found 669.1875.

In a flame dried $20 \mathrm{~mL}$ microwave vial, 1-(2,6-diisopropylphenoxy)-1-oxo-4-(triisopropylsilyl)but-3-yn-2yl 2-iodobenzoate $(\mathbf{5 g})(129 \mathrm{mg}, 0.200 \mathrm{mmol}, 1.00$ equiv) was dissolved in THF ( $8 \mathrm{~mL})$ under nitrogen. Then, triethylamine trihydrofluoride ( $33 \mu \mathrm{L}, 0.200 \mathrm{mmol}, 1.00$ equiv) was added and the reaction mixture was stirred at room temperature for $16 \mathrm{~h}$. After this time, the solvent was evaporated and the crude product was purified by flash column chromatography using EtOAc:pentane 1:30 as eluent to afford $11 \mathrm{~g}$ as a colorless oil (100 mg, $0.204 \mathrm{mmol}, 100 \%)$. TLC (EtOAc:pentane, 1:30 v/v): $R_{f}=0.29$, 
$\mathrm{KMnO}_{4} ;{ }^{1} \mathrm{H} \mathrm{NMR}\left(400 \mathrm{MHz}, \mathrm{CDCl}_{3}\right): \delta 8.04$ (ddd, $\left.J=7.9,3.6,1.4 \mathrm{~Hz}, 2 \mathrm{H}, \mathrm{ArH}\right), 7.43(\mathrm{td}, J=7.6,1.2 \mathrm{~Hz}, 1 \mathrm{H}$, $\operatorname{ArH}), 7.25-7.14(\mathrm{~m}, 4 \mathrm{H}, \mathrm{ArH}), 5.94\left(\mathrm{~s}, 2 \mathrm{H}, \mathrm{CCH}_{2}\right), 3.02$ (hept, $\left.J=6.9 \mathrm{~Hz}, 2 \mathrm{H}, 2 \times \mathrm{CH}\left(\mathrm{CH}_{3}\right)_{2}\right), 1.21(\mathrm{~d}, J=6.9$ $\left.\mathrm{Hz}, 12 \mathrm{H}, 2 \times \mathrm{CH}\left(\mathrm{CH}_{3}\right)_{2}\right) ;{ }^{13} \mathrm{C} \mathrm{NMR}\left(100 \mathrm{MHz}, \mathrm{CDCl}_{3}\right): \delta 207.6,163.9,161.1,145.5,141.8,140.6,133.6$, 133.3, 132.1, 128.2, 126.9, 124.2, 116.2, 95.0, 90.7, 27.7, 24.0 (br), 22.9 (br); IR v 3661 (m), $2970(\mathrm{~s})$, 2901 (s), $1739(\mathrm{~s}), 1465(\mathrm{~m}), 1384(\mathrm{~m}), 1276(\mathrm{~m}), 1246(\mathrm{~m}), 1225(\mathrm{~s}), 1085$ (s), 1065 (s), $1011(\mathrm{~s}), 880(\mathrm{~m})$, 794 (m), 738 (s); HRMS (ESI) calcd. for $\mathrm{C}_{23} \mathrm{H}_{23} \mathrm{INaO}_{4}{ }^{+}[\mathrm{M}+\mathrm{Na}]^{+}$513.0533; Found 513.0538.

In a flame dried $20 \mathrm{~mL}$ microwave vial, THF (6 mL) was added to 1-(2,6-diisopropylphenoxy)-1-oxobuta2,3-dien-2-yl 2-iodobenzoate (11g) (73 $\mathrm{mg}, 0.15 \mathrm{mmol}, 1.00$ equiv) under nitrogen. The resulting reaction mixture was stirred at $90^{\circ} \mathrm{C}$ for $12 \mathrm{~h}$. After this time, the solvent was evaporated under reduced pressure and the crude product was purified by flash chromatography using $\mathrm{Et}_{2} \mathrm{O}$ :pentane 1:9 as eluent to furnish $6 \mathrm{~g}$ as a white solid (67 $\mathrm{mg}, 0.137 \mathrm{mmol}, 91 \%$ ).

The oxyalkynylated and allene intermediates were successfully isolated and submitted to the next reaction step. It confirms the role of the copper catalyst for the oxyalkynylation of the diazo compound, the role of $\mathrm{Et}_{3} \mathrm{~N} \cdot 3 \mathrm{HF}$ for the desilylation/allene formation step and the need of thermal activation for the cycloaddition.

\section{Racemization of the intermediate product}

Enantioenriched (81\% ee) $(\mathbf{5 r})$ was prepared according to a procedure of our previously reported work. ${ }^{1}$

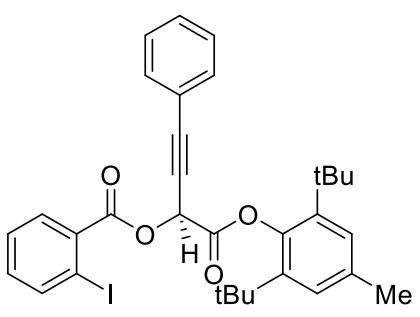

5 r, $81 \%$ ee

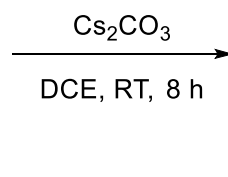

In a flame dried $20 \mathrm{~mL}$ microwave vial, $\mathrm{Cs}_{2} \mathrm{CO}_{3}(54.0 \mathrm{mg}, 0.165 \mathrm{mmol}, 1.10$ equiv) was added to a solution of of (S)-1-(2,6-di-tert-butyl-4-methylphenoxy)-1-oxo-4-phenylbut-3-yn-2-yl 2-iodobenzoate (81\% ee, 5r) $(91 \mathrm{mg}, 0.15 \mathrm{mmol}, 1.00$ equiv) in DCE $(5 \mathrm{~mL})$ and the reaction mixture was stirred at room temperature for $8 \mathrm{~h}$. After this time, the solvent was evaporated under reduced pressure and the crude product was purified by flash column chromatography using $\mathrm{Et}_{2} \mathrm{O}$ :pentane 1:20 as mobile phase to afford $6 \mathrm{r}$ as a white solid (83.0 mg, $0.137 \mathrm{mmol}$, 91\%). Chiral HPLC conditions: ee $=0 \%$; Chiralpak IB 99.75:0.25 Hexane/iPrOH, $1 \mathrm{~mL} / \mathrm{min}, 60 \mathrm{~min} . \operatorname{tr}(1)=20.1 \mathrm{~min}$. and $\operatorname{tr}(2)=42.0 \mathrm{~min} . \lambda=254 \mathrm{~cm}^{-1}$. 


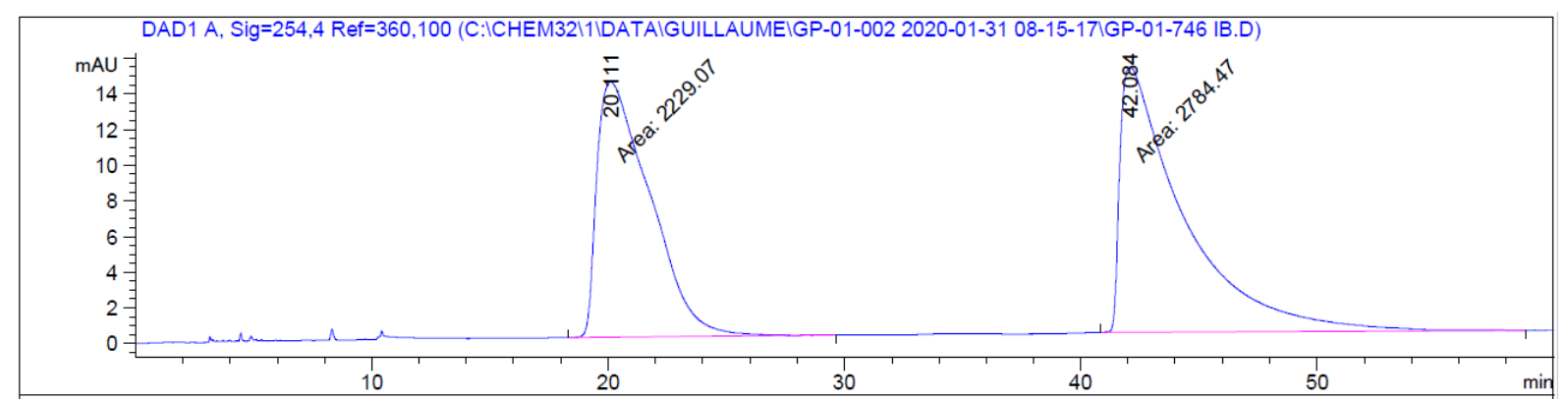

Signal 1: DAD1 A, Sig=254,4 Ref $=360,100$

\begin{tabular}{cccccc}
$\begin{array}{c}\text { Peak RetTime Type } \\
\text { W }\end{array}$ [min] & $\begin{array}{c}\text { Width } \\
{[\mathrm{min}]}\end{array}$ & $\begin{array}{c}\text { Area } \\
{[\mathrm{mAU} \text { s }]}\end{array}$ & $\begin{array}{c}\text { Height } \\
{[\mathrm{mAU}]}\end{array}$ & $\begin{array}{c}\text { Area } \\
\%\end{array}$ \\
\hline 1 & $20.111 \mathrm{MM}$ & 2.5997 & 2229.07227 & 14.29075 & 44.4611 \\
2 & $42.084 \mathrm{MM}$ & 3.1237 & 2784.46704 & 14.85644 & 55.5389 \\
& & & & & \\
Totals : & & 5013.53931 & 29.14719
\end{tabular}

When an enantioenriched sample of $\mathbf{5} \boldsymbol{r}$ was submitted to the cycloaddition reaction, a racemic mixture of the cycloadduct $6 r$ was obtained. It supports the formation of a racemic allene intermediate. 


\section{Crystal structures}

Bragg-intensities of $\mathbf{6 a}, \mathbf{6 p}, \mathbf{2 0 a}$ and $\mathbf{2 0 b}$ were collected at low temperature using MoK $\alpha / \mathrm{CuK} \alpha$ radiation. A Rigaku SuperNova dual system diffractometer with an Atlas CCD detector was used for compound $\mathbf{6 p}$ and one equipped with an Atlas S2 CCD detector for compounds 6a, 20a and 20b. The datasets were reduced and corrected for absorption, with the help of a set of faces enclosing the crystal as snugly as possible, with the latest available version of CrysAlis ${ }^{\text {Pro }}{ }^{1}$

Bragg intensities of $\mathbf{6 r}$ and $\mathbf{1 5}$ were measured, at low temperature using MoKa radiation, on a Bruker APEX II CCD diffractometer equipped with a k-geometry goniometer. The datasets were reduced by EvalCCD ${ }^{2}$ and then corrected for absorption. ${ }^{3}$

The solutions and refinements of the structures were performed by the latest available version of SheIXT ${ }^{4}$ and SheIXL. ${ }^{5} \mathrm{All}$ non-hydrogen atoms were refined anisotropically using full-matrix least-squares based on $|F|^{2}$. The hydrogen atoms were placed at calculated positions by means of the "riding" model in which each $\mathrm{H}$-atom was assigned a fixed isotropic displacement parameter with a value equal to $1.2 U_{\text {eq }}$ of its parent C-atom (1.5 $U_{\text {eq }}$ for the methyl groups). Crystallographic and refinement data are summarized in Tables below.

\section{Citations}

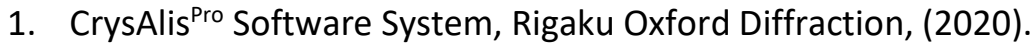

2. Duisenberg, A. J. M.; Kroon-Batenburg, L. M. J.; Schreurs, A. M. M. J. Appl. Crystallogr. 2003, 36, 220-229.

3. Blessing, R. H. Acta Crystallogr. A $1995,51,33-38$.

4. Sheldrick, G.M., ShelXT-Integrated space-group and crystal-structure determination, Acta Cryst., (2015), A71, 3-8.

5. Sheldrick, G.M., Crystal structure refinement with ShelXL, Acta Cryst., (2015), C71, 3-8. 


\section{CCDC 1848760}
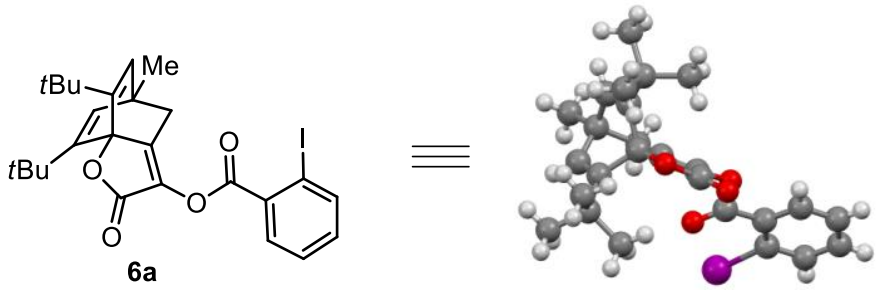

Empirical formula

Formula weight

Temperature

Wavelength

Crystal system

Space group

Unit cell dimensions

Volume

Z

Density (calculated)

Absorption coefficient

$\mathrm{F}(000)$

Crystal size

$\Theta$ range for data collection

Index ranges

Reflections collected

Independent reflections

Completeness to $\Theta=25.242^{\circ}$

Absorption correction

Max. and min. transmission

Refinement method

Data / restraints / parameters

Goodness-of-fit on $F^{2}$

Final $R$ indices $[I>2 \sigma(I)]$

$R$ indices (all data)

Largest diff. peak and hole
$\mathrm{C}_{26} \mathrm{H}_{29} \mathrm{IO}_{4}$

532.39

292(2) K

$0.71073 \AA$

Triclinic

$P \overline{1}$

$a=8.7662(4) \AA \quad \alpha=94.559(3)^{\circ}$.

$b=11.9386(6) \AA \quad \beta=98.326(3)^{\circ}$.

$c=12.1637(4) \AA \quad \gamma=106.805(4)^{\circ}$.

$1195.86(9) \AA^{3}$

2

$1.479 \mathrm{Mg} / \mathrm{m}^{3}$

$1.368 \mathrm{~mm}^{-1}$

540

$0.412 \times 0.276 \times 0.145 \mathrm{~mm}^{3}$

2.570 to $29.772^{\circ}$.

$-11 \leq h \leq 12,-12 \leq k \leq 16,-16 \leq \mathrm{I} \leq 16$

9791

$5617\left[R_{\text {int }}=0.0224\right]$

$99.9 \%$

Gaussian

0.855 and 0.730

Full-matrix least-squares on $F^{2}$

5617 / 0 / 287

1.030

$R_{1}=0.0366, w R_{2}=0.0751$

$R_{1}=0.0515, w R_{2}=0.0825$

0.501 and -0.675 e. $\AA^{-3}$ 
CCDC 2027173

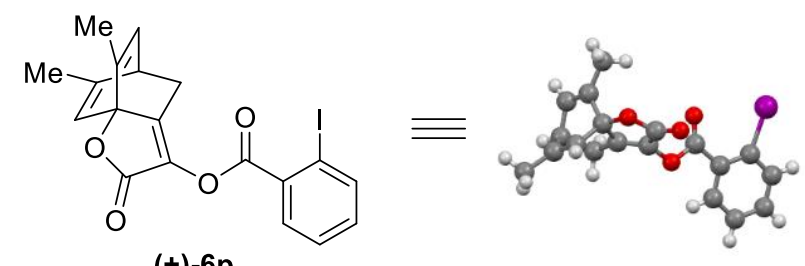

$(+)-6 p$

Empirical formula

Formula weight

Colour

Shape

Temperature

Wavelength

Radiation type

Crystal system

Flack Parameter

Hooft Parameter

Space group

Unit cell dimensions

Volume

Z

$Z^{\prime}$

Density (calculated)

Absorption coefficient

Crystal size

$\Theta$ range for data collection

Mesured reflections

Independent reflections

Refl's $\mid \geq 2 \sigma(I)$

$R_{\text {int }}$

Parameters / restraints

Goodness-of-fit on $F^{2}$

Final $R$ indices $[I>2 \sigma(I)]$

$R$ indices (all data)

Largest diff. peak and hole
$\mathrm{C}_{19} \mathrm{H}_{15} \mathrm{IO}_{4}$

434.21

Colourless

Needle

140.00(10) K

$0.71073 \AA$

MoKa

Orthorhombic

$-0.015(15)$

$-0.006(14)$

$P 2{ }_{1} 2_{1} 2_{1}$

$a=7.4295(3) \AA$ $\alpha=90^{\circ}$.

$\mathrm{b}=14.3717(5) \AA$ $\beta=90^{\circ}$.

$c=31.6622(12) \AA$ $\gamma=90^{\circ}$.

$3380.7(2) \AA^{3}$

8

2

$1.706 \mathrm{~g} / \mathrm{cm}^{3}$

$1.914 \mathrm{~mm}^{-1}$

$0.53 \times 0.06 \times 0.03 \mathrm{~mm}^{3}$

3.029 to $29.429^{\circ}$.

36614

8423

6816

0.0357

437 / 0

1.064

$R_{1}=0.0333, w R_{2}=0.0670$

$R_{1}=0.0493, w R_{2}=0.0742$

0.616 and -0.674 e. $\AA^{-3}$ 
CCDC 1848773
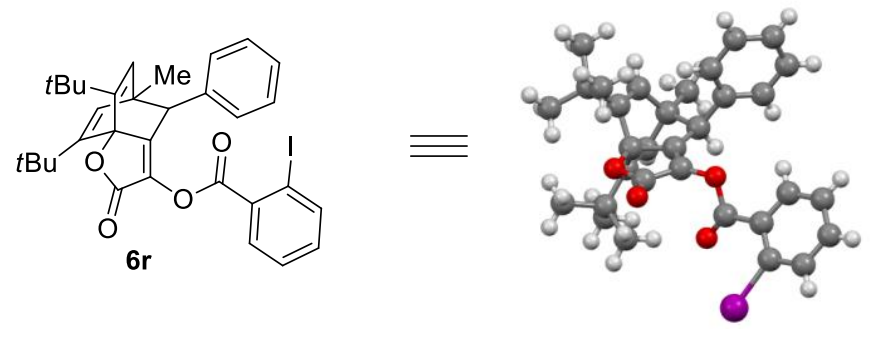

Empirical formula

Formula weight

Temperature

Wavelength

Crystal system

Space group

Unit cell dimensions

Volume

Z

Density (calculated)

Absorption coefficient

$F(000)$

Crystal size

Theta range for data collection

Index ranges

Reflections collected

Independent reflections

Completeness to $\Theta=25.242^{\circ}$

Absorption correction

Max. and min. transmission

Refinement method

Data / restraints / parameters

Goodness-of-fit on $F^{2}$

Final $R$ indices $[I>2 \sigma(I)]$

$R$ indices (all data)

Largest diff. peak and hole
$\mathrm{C}_{32} \mathrm{H}_{33} \mathrm{IO}_{4}$

608.48

120(2) K

$0.71073 \AA$

Triclinic

$P \overline{1}$

$a=9.3288(15) \AA$

$\alpha=65.569(4)^{\circ}$.

$b=12.5347(10) \AA$

$\beta=87.392(9)^{\circ}$.

$c=13.9206(11) \AA$ $\gamma=69.207(9)^{\circ}$.

$1375.7(3) \AA^{3}$

2

$1.469 \mathrm{Mg} / \mathrm{m}^{3}$

$1.199 \mathrm{~mm}^{-1}$

620

$0.520 \times 0.441 \times 0.206 \mathrm{~mm}^{3}$

2.980 to $34.999^{\circ}$.

$-15 \leq h \leq 15,-20 \leq k \leq 20,-21 \leq \mathrm{I} \leq 22$

32700

$11876\left[R_{\text {int }}=0.0225\right]$

$98.2 \%$

Semi-empirical from equivalents

0.7469 and 0.5376

Full-matrix least-squares on $\mathrm{F}^{2}$

11876 / 0 / 351

1.093

$R_{1}=0.0361, w R_{2}=0.0799$

$R_{1}=0.0485, w R_{2}=0.0885$

2.927 and -2.092 e. $\AA^{-3}$ 


\section{CCDC 1850113}
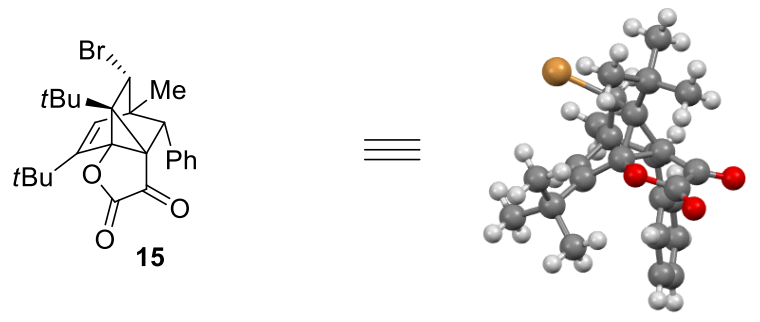

Empirical formula

Formula weight

Temperature

Wavelength

Crystal system

Space group

Unit cell dimensions

Volume

Z

Density (calculated)

Absorption coefficient

$\mathrm{F}(000)$

Crystal size

Theta range for data collection

Index ranges

Reflections collected

Independent reflections

Completeness to $\Theta=25.242^{\circ}$

Absorption correction

Max. and min. transmission

Refinement method

Data / restraints / parameters

Goodness-of-fit on $F^{2}$

Final R indices [I $>2 \sigma(\mathrm{I})]$

$R$ indices (all data)

Largest diff. peak and hole
$\mathrm{C}_{25} \mathrm{H}_{29} \mathrm{BrO}_{3}$

457.39

120(2) K

$0.71073 \AA$

Monoclinic

$P 2_{1} / c$

$\mathrm{a}=15.6484(15) \AA \quad \alpha=90^{\circ}$.

$\mathrm{b}=9.8378(7) \AA \quad \beta=112.228(8)^{\circ}$.

c $=15.4117(12) \AA \quad \gamma=90^{\circ}$.

2196.3(3) $\AA^{3}$

4

$1.383 \mathrm{Mg} / \mathrm{m}^{3}$

$1.895 \mathrm{~mm}^{-1}$

952

$0.365 \times 0.363 \times 0.360 \mathrm{~mm}^{3}$

1.406 to $34.998^{\circ}$.

$-25 \leq h \leq 25,-15 \leq k \leq 11,-24 \leq \mathrm{I} \leq 24$

45712

$9569\left[R_{\text {int }}=0.0416\right]$

$99.6 \%$

Semi-empirical from equivalents

0.7469 and 0.6329

Full-matrix least-squares on $\mathrm{F}^{2}$

9569 / 0 / 269

1.148

$R_{1}=0.0406, w R_{2}=0.0686$

$R_{1}=0.0870, w R_{2}=0.0856$

0.573 and -0.542 e. $\AA^{-3}$ 
CCDC 1945514

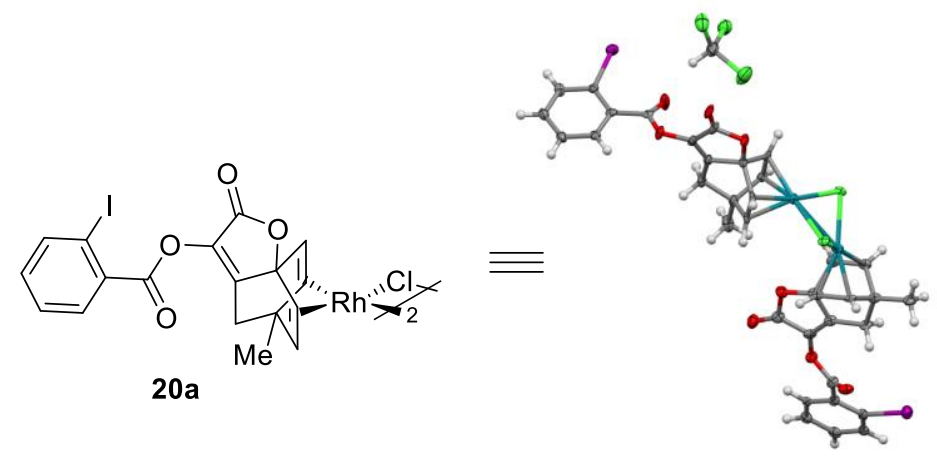

Empirical formula

Formula weight

Temperature

Wavelength

Crystal system

Space group

Unit cell dimensions

Volume

Z

Density (calculated)

Absorption coefficient

$\mathrm{F}(000)$

Crystal size

$\Theta$ range for data collection

Index ranges

Reflections collected

Independent reflections

Completeness to $\Theta=25.242^{\circ}$

Absorption correction

Max. and min. transmission

Refinement method

Data / restraints / parameters

Goodness-of-fit on $F^{2}$

Final $R$ indices $[I>2 \sigma(I)]$

$R$ indices (all data)
$\mathrm{C}_{37} \mathrm{H}_{27} \mathrm{Cl}_{5} \mathrm{I}_{2} \mathrm{O}_{8} \mathrm{Rh}_{2}$

1236.45

100.00(10) K

$0.71073 \AA$

Triclinic

$P \overline{1}$

$a=7.9093(11) \AA \quad \alpha=108.577(12)^{\circ}$.

$\mathrm{b}=13.7923(19) \AA \quad \beta=92.892(11)^{\circ}$.

$c=19.266(3) \AA \quad \gamma=91.997(12)^{\circ}$.

$1986.8(5) \AA^{3}$

2

$2.067 \mathrm{Mg} / \mathrm{m}^{3}$

$2.772 \mathrm{~mm}^{-1}$

1188

$0.220 \times 0.097 \times 0.068 \mathrm{~mm}^{3}$

2.582 to $26.372^{\circ}$.

$-9 \leq h \leq 9,-17 \leq k \leq 13,-24 \leq \mathrm{I} \leq 23$

8493

8493

$98.6 \%$

Gaussian

1.000 and 0.588

Full-matrix least-squares on $\mathrm{F}^{2}$

8493 / 737 / 491

0.933

$R_{1}=0.0697, w R_{2}=0.1388$

$R_{1}=0.1395, w R_{2}=0.1508$ 
CCDC 2027174

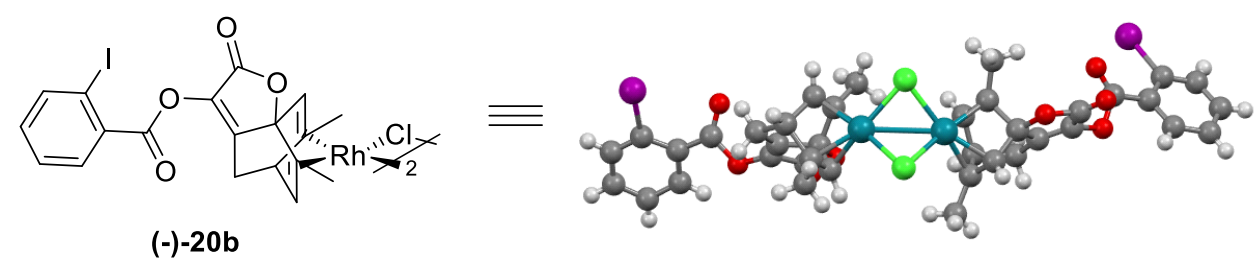

The structure was determined as a twin with three molecules of $\mathrm{CH}_{2} \mathrm{Cl}_{2}$. One unit of (-)-20b, as well as, the three molecules of $\mathrm{CH}_{2} \mathrm{Cl}_{2}$ were removed from the above representation for clarity reason.

Empirical formula

Formula weight

Colour

Shape

Temperature

Wavelength

Radiation type

Crystal system

Flack Parameter

Space group

Unit cell dimensions

Volume

Z

$Z^{\prime}$

Density (calculated)

Absorption coefficient

Crystal size

$\Theta$ range for data collection

Mesured reflections

Independent reflections

Refl's $I \geq 2 \sigma(I)$

$R_{\text {int }}$

Parameters / restraints
$\mathrm{C}_{39.5} \mathrm{H}_{33} \mathrm{Cl}_{5} \mathrm{I}_{2} \mathrm{O}_{8} \mathrm{Rh}_{2}$

1272.53

Clear intense yellow

Needle

$140.00(10) \mathrm{K}$

$1.54184 \AA$

CuKa

Triclinic

$-0.016(7)$

P1

$$
\begin{array}{ll}
a=8.0196(2) \AA & \alpha=93.373(5)^{\circ} . \\
b=15.8266(11) \AA & \beta=97.318(3)^{\circ} . \\
c=17.0926(9) \AA & \gamma=96.178(4)^{\circ} .
\end{array}
$$

2133.47(19) $\AA^{3}$

2

2

$1.981 \mathrm{~g} / \mathrm{cm}^{3}$

$20.924 \mathrm{~mm}^{-1}$

$0.37 \times 0.02 \times 0.02 \mathrm{~mm}^{3}$

2.816 to $72.429^{\circ}$.

10540

10540

8334

n/a

992 / 1052 
Goodness-of-fit on $F^{2}$

Final $R$ indices $[I>2 \sigma(I)]$

$R$ indices (all data)

Largest diff. peak and hole
1.151

$R_{1}=0.0635, w R_{2}=0.1680$

$R_{1}=0.0842, w R_{2}=0.1890$

2.128 and -2.547 e. $\AA^{-3}$

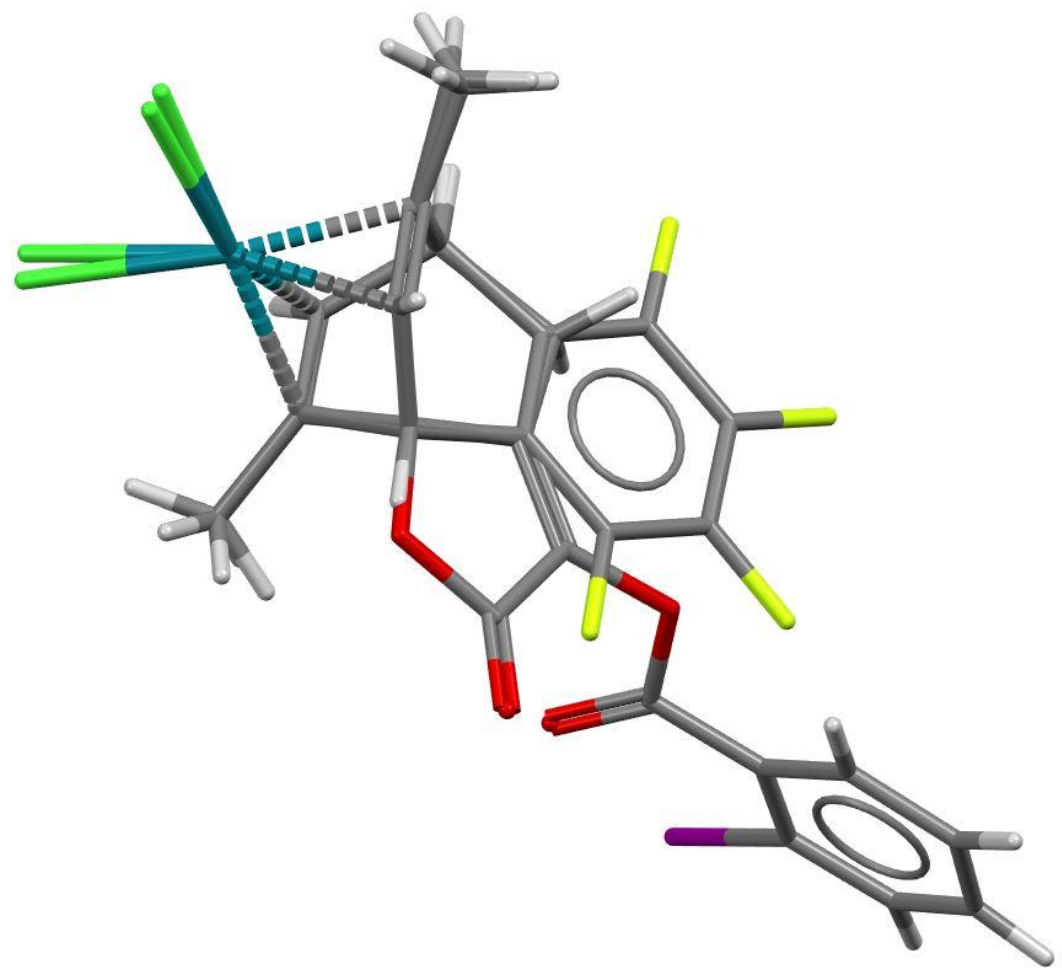

Figure S1. Overlay of the crystal structures of $\mathbf{2 0 b}$ and $\mathbf{2 0 c}$. The mirror image of the reported structure for $\mathbf{2 0 c}$ was used in order to have the same absolute configuration. 


\section{Computational details}

The geometries of all structures were optimized using the M06-2X $X^{29,30}$ density functional in tandem with the def2-SVP basis set ${ }^{31}$ using the "ultrafine" integration grid and the SMD implicit solvent model $^{32}$ (in tetrahydrofuran) as implemented in Gaussian09. ${ }^{33}$ Refined energy estaimtes were obtained on the M06-2X/def2-SVP geometries through single point energy computations using the PBEO ${ }^{34,35}$ density functional appended with a density dependent dispersion correction ${ }^{36}$ (-dDSC) and the TZ2P basis set as implementd in ADF ${ }^{37}$ Reported free energies include PBEO-dDsC/TZ2P electronic energies, M06/def2-SVP uncorrected free energy corrections, and solvation correction (at the PBE0-dDsC/TZ2P level) using COSMO-RS. ${ }^{38}$

\footnotetext{
${ }^{29}$ Y. Zhao, D. G. Truhlar, Acc. Chem. Res. 2008, 41, 157.

${ }^{30}$ Y. Zhao, D. G. Truhlar, Theor. Chem. Acc. 2008, 120, 215.

${ }^{31}$ F. Weigend, R. Ahlrichs, Phys. Chem. Chem. Phys. 2005, 7, 3297.

${ }^{32}$ A. V. Marenich, C. J. Cramer, D. G. Truhlar, J. Phys. Chem. B 2009, 113, 6378.

${ }^{33}$ Gaussian 09, Revision D.01, M. J. Frisch, G. W. Trucks, H. B. Schlegel, G. E. Scuseria, M. A. Robb, J. R. Cheeseman, G. Scalmani, V. Barone, G. A. Petersson, H. Nakatsuji, X. Li, M. Caricato, A. Marenich, J. Bloino, B. G. Janesko, R. Gomperts, B. Mennucci, H. P. Hratchian, J. V. Ortiz, A. F. Izmaylov, J. L. Sonnenberg, D. WilliamsYoung, F. Ding, F. Lipparini, F. Egidi, J. Goings, B. Peng, A. Petrone, T. Henderson, D. Ranasinghe, V. G. Zakrzewski, J. Gao, N. Rega, G. Zheng, W. Liang, M. Hada, M. Ehara, K. Toyota, R. Fukuda, J. Hasegawa, M. Ishida, T. Nakajima, Y. Honda, O. Kitao, H. Nakai, T. Vreven, K. Throssell, J. A. Montgomery, Jr., J. E. Peralta, F. Ogliaro, M. Bearpark, J. J. Heyd, E. Brothers, K. N. Kudin, V. N. Staroverov, T. Keith, R. Kobayashi, J. Normand, K. Raghavachari, A. Rendell, J. C. Burant, S. S. Iyengar, J. Tomasi, M. Cossi, J. M. Millam, M. Klene, C. Adamo, R. Cammi, J. W. Ochterski, R. L. Martin, K. Morokuma, O. Farkas, J. B. Foresman, and D. J. Fox, Gaussian, Inc., Wallingford CT, 2016.

34 J. P. Perdew, K. Burke, M. Ernzerhof, Phys. Rev. Lett. 1996, 77, 3865.

${ }^{35}$ C. Adamo, V. Barone, J. Chem. Phys. 1999, 110, 6158.

36 a) S. N. Steinmann, C. Corminboeuf, J. Chem. Theory Comput. 2010, 6, 1990; b) S. N. Steinmann, C. Corminboeuf, Chimia 2011, 65, 240; c) S. N. Steinmann, C. Corminboeuf, J. Chem. Phys. 2011, 134, 044117; d) S. N. Steinmann, C. Corminboeuf, J. Chem. Theory Comput. 2011, 7, 3567.

37 a) C. Fonseca Guerra, J. G. Snijders, G. te Velde, E. J. Baerends, Theor. Chem. Acc. 1998, 99, 391; b) G. te Velde, F. M. Bickelhaupt, S. J. A. van Gisbergen, C. Fonseca Guerra, E. J. Barends, J. G. Snijders, T. Ziegler, J. Comput. Chem. 2001, 22, 931.
}

${ }^{38}$ A. Klamt, WIREs Comput. Mol. Sci. 2011, 1, 699. 
<smiles>C=CC(=O)Oc1ccccc1</smiles>

$\mathrm{C}_{1}$<smiles>C=C(C)C(=O)Oc1ccccc1</smiles>

$\mathrm{C}_{4}$<smiles>C=C(OC(=O)c1ccccc1I)C(=O)Oc1ccccc1</smiles><smiles>C=CC(=O)Oc1c(C)cccc1C</smiles>

$\mathrm{C}_{2}$<smiles>C=C(C)C(=O)Oc1c(C)cccc1C</smiles>

$\mathrm{C}_{5}$<smiles>C=C(OC(=O)c1ccccc1I)C(=O)Oc1c(C)cccc1C(C)(C)C</smiles><smiles>C=CC(=O)Oc1c(Br)cccc1Br</smiles>

$\mathrm{C}_{3}$<smiles>C=C(C)C(=O)Oc1c(Br)cccc1C(C)(C)C</smiles>

$\mathrm{C}_{6}$<smiles>C=C(OC(=O)c1ccccc1I)C(=O)Oc1c(Br)cccc1C(C)(C)C</smiles>

Figure S2. Schematic depiction of relevant compounds. 
Table S1. Computed free energies for reactant, transition state, and product of C1 - C9 relevant to the reactant. Values in $\mathrm{kcal} / \mathrm{mol}$.

\begin{tabular}{|l|c|c|c|}
\hline Compound & Reactant & Transition State & Product \\
\hline C1 & 0.00 & 25.29 & -36.07 \\
\hline C2 & 0.00 & 25.28 & -37.15 \\
\hline C3 & 0.00 & 18.30 & -41.38 \\
\hline C4 & 0.00 & 23.25 & -36.32 \\
\hline C5 & 0.00 & 22.15 & -38.71 \\
\hline C6 & 0.00 & 16.25 & -41.31 \\
\hline C7 & 0.00 & 22.07 & -33.96 \\
\hline C8 & 0.00 & 20.29 & -36.51 \\
\hline C9 & 0.00 & 14.68 & -40.71 \\
\hline
\end{tabular}

Table S2. Computed energies, free energies and solvation corrections (in hartree) of relevant compounds.

\begin{tabular}{|l|c|c|c|c|}
\hline Compound & $\begin{array}{c}\text { M06-2X/def2- } \\
\text { SVP Electronic } \\
\text { Energy }\end{array}$ & $\begin{array}{c}\text { M06-2X/def2- } \\
\text { SVP Free Energy } \\
\text { Correction }\end{array}$ & $\begin{array}{c}\text { PBE0- } \\
\text { dDsC/TZ2P//M06- } \\
\text { 2X/def2-SVP } \\
\text { Electronic Energy }\end{array}$ & $\begin{array}{c}\text { Solvation } \\
\text { Correction }\end{array}$ \\
\hline C1 - Reactant & -535.660485 & 0.115453 & -5.882364 & -0.014746 \\
\hline C1 - TS & -535.617528 & 0.119650 & -5.846487 & -0.014519 \\
\hline C1 - Product & -535.680127 & 0.124302 & -5.907232 & -0.015909 \\
\hline C2 - Reactant & -614.199300 & 0.165579 & -7.351969 & -0.015602 \\
\hline C2 - TS & -614.157995 & 0.171586 & -7.317906 & -0.015381 \\
\hline C2 - Product & -614.223114 & 0.176433 & -7.382658 & -0.014683 \\
\hline C3 - Reactant & -849.772979 & 0.331232 & -11.711835 & -0.018823 \\
\hline C3 - TS & -849.738859 & 0.333412 & -11.684717 & -0.018951 \\
\hline C3 - Product & -849.808169 & 0.337372 & -11.761901 & -0.011665 \\
\hline C4 - Reactant & -574.928934 & 0.141236 & -6.615322 & -0.014856 \\
\hline C4 - TS & -574.887718 & 0.144938 & -6.581929 & -0.014908 \\
\hline C4 - Product & -574.951522 & 0.150158 & -6.644298 & -0.015631 \\
\hline C5 - Reactant & -653.467394 & 0.193920 & -8.084606 & -0.015760 \\
\hline C5 - TS & -653.428103 & 0.197060 & -8.052369 & -0.015832 \\
\hline
\end{tabular}




\begin{tabular}{|l|c|c|c|c|}
\hline C5 - Product & -653.494318 & 0.201848 & -8.118429 & -0.016245 \\
\hline C6 - Reactant & -889.040804 & 0.356440 & -12.444611 & -0.019038 \\
\hline C6 - TS & -889.008836 & 0.358190 & -12.428794 & -0.010703 \\
\hline C6 - Product & -889.079516 & 0.363561 & -12.490830 & -0.019871 \\
\hline C7- Reactant & -1251.829112 & 0.187822 & -9.901926 & -0.026683 \\
\hline C7 - TS & -1251.788131 & 0.190415 & -9.867835 & -0.028202 \\
\hline C7 - Product & -1251.849800 & 0.197190 & -9.928381 & -0.028557 \\
\hline C8- Reactant & -1330.367868 & 0.239743 & -11.370473 & -0.028151 \\
\hline C8- TS & -1330.329533 & 0.241703 & -11.339615 & -0.028642 \\
\hline C8- Product & -1330.393078 & 0.246804 & -11.402967 & -0.028571 \\
\hline C9 - Reactant & -1565.940676 & 0.402229 & -15.729831 & -0.031708 \\
\hline C9 - TS & -1565.910105 & 0.403203 & -15.707217 & -0.031909 \\
\hline C9 - Product & -1565.978305 & 0.407324 & -15.776023 & -0.032103 \\
\hline
\end{tabular}




\section{Cartesian Coordinates}

20

Compound 1 - Reactant
$\begin{array}{llll}\text { C } & -2.89486 & 0.36350 & -0.13603\end{array}$
$\begin{array}{llll}\text { C } & -0.18102 & 0.90589 & -0.11991\end{array}$
$\begin{array}{llll}\text { C } & -2.22251 & 0.59221 & -1.33864\end{array}$
$\begin{array}{llll}\text { C } & -2.20738 & 0.44544 & 1.07684\end{array}$
$\begin{array}{llll}\text { C } & -0.84272 & 0.72517 & 1.09136\end{array}$
$\begin{array}{llll}\text { C } & -0.85802 & 0.87270 & -1.33625\end{array}$
$\begin{array}{llll}\text { O } & 1.17364 & 1.16571 & -0.10951\end{array}$
$\begin{array}{llll}\text { C } & 2.10779 & 0.19874 & -0.26412\end{array}$
$\begin{array}{llll}0 & 3.26090 & 0.52300 & -0.28960\end{array}$
$\begin{array}{llll}\text { C } & 1.71526 & -1.23493 & -0.38924\end{array}$
$\begin{array}{llll}\text { C } & 0.53184 & -1.81259 & -0.35051\end{array}$
$\begin{array}{llll}\text { C } & -0.58800 & -2.48032 & -0.32620\end{array}$
$\begin{array}{llll}H & -0.99768 & -2.84832 & 0.61967\end{array}$
$\begin{array}{llll}H & -3.96248 & 0.13850 & -0.14310\end{array}$
$\begin{array}{llll}H & -2.76389 & 0.54922 & -2.28519\end{array}$
$\begin{array}{llll}\text { H } & -2.73630 & 0.28630 & 2.01801\end{array}$
$\begin{array}{llll}H & -0.27877 & 0.78171 & 2.02370\end{array}$
$\begin{array}{llll}H & -0.30676 & 1.04398 & -2.26241\end{array}$
H $2.59436 \quad-1.87367 \quad-0.52005$
H $\quad-1.14747 \quad-2.66727 \quad-1.24825$

20

Compound 1 - TS
$\begin{array}{llll}\text { C } & -2.49347 & -0.24107 & -0.16806\end{array}$
$\begin{array}{llll}\text { C } & -0.05845 & 0.79404 & -0.15977\end{array}$
$\begin{array}{llll}\text { C } & -2.06100 & 0.41335 & -1.36600\end{array}$
$\begin{array}{llll}\text { C } & -2.00085 & 0.25209 & 1.08271\end{array}$
$\begin{array}{llll}\text { C } & -0.75133 & 0.79518 & 1.09462\end{array}$
$\begin{array}{llll}\text { C } & -0.81180 & 0.95734 & -1.36779\end{array}$
$\begin{array}{llll}\text { O } & 1.26722 & 1.16361 & -0.16781\end{array}$
$\begin{array}{llll}\text { C } & 2.16260 & 0.13621 & -0.25649\end{array}$
$\begin{array}{llll}\text { O } & 3.33657 & 0.35473 & -0.27017\end{array}$ 


$$
\begin{array}{lrrr}
\text { C } & 1.49842 & -1.18817 & -0.32754 \\
\text { C } & 0.17425 & -1.24078 & -0.29966 \\
\text { C } & -1.02544 & -1.89652 & -0.31347 \\
\text { H } & -1.35746 & -2.41267 & 0.58981 \\
\text { H } & -3.45354 & -0.76056 & -0.17870 \\
\text { H } & -2.66647 & 0.36167 & -2.27221 \\
\text { H } & -2.56143 & 0.08013 & 2.00285 \\
\text { H } & -0.22228 & 1.08890 & 2.00236 \\
\text { H } & -0.32682 & 1.36912 & -2.25402 \\
\text { H } & 2.15015 & -2.06124 & -0.40062 \\
\text { H } & -1.40295 & -2.29041 & -1.25947
\end{array}
$$

20

Compound 1 - Product
$\begin{array}{llll}\text { C } & -0.90998 & 2.06559 & -0.30677\end{array}$
$\begin{array}{llll}\text { C } & -0.42740 & -0.41316 & -0.02548\end{array}$
$\begin{array}{llll}\text { C } & -1.58854 & 1.43835 & 0.90040\end{array}$
$\begin{array}{llll}\text { C } & -1.24166 & 1.22978 & -1.53256\end{array}$
C $\quad-0.98481-0.07270 \quad-1.39405$
$\begin{array}{llll}\text { C } & -1.33440 & 0.13749 & 1.05791\end{array}$
$\begin{array}{llll}0 & -0.02364 & -1.74593 & 0.14633\end{array}$
$\begin{array}{llll}\text { C } & 1.32989 & -1.80456 & 0.34422\end{array}$
$\begin{array}{llll}\text { O } & 1.89390 & -2.84541 & 0.51394\end{array}$
$\begin{array}{llll}\text { C } & 1.87026 & -0.42539 & 0.30311\end{array}$
$\begin{array}{llll}\text { C } & 0.85331 & 0.41405 & 0.08619\end{array}$
$\begin{array}{llll}\text { C } & 0.63405 & 1.88154 & -0.07085\end{array}$
H $\quad 1.20497 \quad 2.27290 \quad-0.92429$
$\begin{array}{llll}\text { H } & -1.15877 & 3.12337 & -0.43292\end{array}$
$\begin{array}{llll}\text { H } & -2.19788 & 2.03208 & 1.58321\end{array}$
$\begin{array}{llll}H & -1.62331 & 1.68661 & -2.44672\end{array}$
$\begin{array}{llll}\text { H } & -1.09818 & -0.84834 & -2.15246\end{array}$
$\begin{array}{llll}\text { H } & -1.67218 & -0.50322 & 1.87341\end{array}$
$\begin{array}{llll}H & 2.92876 & -0.21248 & 0.43577\end{array}$
$\begin{array}{llll}H & 0.95488 & 2.42323 & 0.82976\end{array}$ 
Compound 2 - Reactant
$\begin{array}{llll}\text { C } & -2.88706 & 0.44791 & -0.10467\end{array}$
$\begin{array}{llll}\text { C } & -0.16699 & 0.84175 & -0.02346\end{array}$
$\begin{array}{llll}\text { C } & -2.18947 & 0.71214 & -1.28348\end{array}$
C $\quad-2.21793 \quad 0.41336 \quad 1.11890$
$\begin{array}{llll}\text { C } & -0.83711 & 0.61700 & 1.18278\end{array}$
$\begin{array}{llll}\text { C } & -0.80813 & 0.92122 & -1.26329\end{array}$
$\begin{array}{llll}\text { O } & 1.20027 & 1.04784 & 0.01836\end{array}$
$\begin{array}{llll}\text { C } & 2.09692 & 0.04160 & -0.09613\end{array}$
$\begin{array}{llll}\text { O } & 3.26401 & 0.31079 & -0.04892\end{array}$
$\begin{array}{llll}\text { C } & 1.64650 & -1.36942 & -0.27674\end{array}$
$\begin{array}{llll}\text { C } & 0.43637 & -1.88515 & -0.35560\end{array}$
$\begin{array}{llll}\text { C } & -0.70958 & -2.50155 & -0.44625\end{array}$
$\begin{array}{llll}\text { H } & -1.21717 & -2.87167 & 0.45007\end{array}$
$\begin{array}{llll}H & -3.96531 & 0.28238 & -0.13802\end{array}$
$\begin{array}{llll}H & -2.71957 & 0.75396 & -2.23739\end{array}$
$\begin{array}{llll}H & -2.77029 & 0.22186 & 2.04135\end{array}$
$\begin{array}{llll}\text { C } & -0.06698 & 0.55467 & 2.47134\end{array}$
$\begin{array}{llll}\text { C } & -0.00796 & 1.17403 & -2.50956\end{array}$
H $\quad 2.50058 \quad-2.04984 \quad-0.35078$
H $\quad-1.19411-2.63968-1.41794$
$\begin{array}{llll}H & -0.66558 & 1.25458 & -3.38417\end{array}$
H $\quad 0.57886 \quad 2.10033 \quad-2.42402$
$\begin{array}{llll}H & 0.70639 & 0.35539 & -2.69419\end{array}$
$\begin{array}{llll}H & -0.74509 & 0.42067 & 3.32348\end{array}$
$\begin{array}{llll}H & 0.64514 & -0.28640 & 2.46661\end{array}$
$\begin{array}{llll}\text { H } & 0.51907 & 1.47198 & 2.62883\end{array}$

26

Compound 2 - TS
$\begin{array}{llll}\text { C } & -2.53028 & -0.24167 & -0.18656\end{array}$
$\begin{array}{llll}\text { C } & -0.03714 & 0.59318 & -0.05294\end{array}$
$\begin{array}{llll}\text { C } & -2.01123 & 0.43365 & -1.33345\end{array}$
$\begin{array}{llll}\text { C } & -2.04047 & 0.13112 & 1.10261\end{array}$ 

$\begin{array}{llll}C & -0.75302 & 0.57879 & 1.19585\end{array}$
$\begin{array}{llll}\text { C } & -0.72325 & 0.88676 & -1.28390\end{array}$
$\begin{array}{llll}0 & 1.31039 & 0.88439 & -0.00060\end{array}$
$\begin{array}{llll}\text { C } & 2.14342 & -0.19152 & -0.12433\end{array}$
$\begin{array}{llll}0 & 3.32908 & -0.04830 & -0.09239\end{array}$
C $\quad \begin{array}{llll}.39777 & -1.46185 & -0.29102\end{array}$
$\begin{array}{llll}\text { C } & 0.07088 & -1.42658 & -0.30258\end{array}$
$\begin{array}{llll}\text { C } & -1.15946 & -2.01715 & -0.39043\end{array}$
$\begin{array}{llll}\mathrm{H} & -1.55322 & -2.55782 & 0.47254\end{array}$
H $\quad-3.52392 \quad-0.68914 \quad-0.25406$
$\begin{array}{llll}\mathrm{H} & -2.58372 & 0.46507 & -2.26289\end{array}$
H $\quad-2.63486 \quad-0.06405 \quad 1.99771$
$\begin{array}{llll}\text { C } & -0.02189 & 0.83807 & 2.47803\end{array}$
$\begin{array}{llll}\text { C } & 0.03723 & 1.44965 & -2.44605\end{array}$
H $1.99243 \quad-2.37146 \quad-0.39686$
H $\quad-1.53138 \quad-2.32940 \quad-1.36832$
H $\quad-0.63486 \quad 1.62718 \quad-3.29534$
$\begin{array}{llll}\mathrm{H} & 0.53259 & 2.39490 & -2.18028\end{array}$
H $0.826640 .75300 \quad-2.77256$
$\begin{array}{llll}H & -0.71441 & 0.80449 & 3.32879\end{array}$
$\begin{array}{llll}H & 0.76155 & 0.08033 & 2.64281\end{array}$
$\begin{array}{llll}\text { H } & 0.47691 & 1.81811 & 2.46333\end{array}$

26

Compound 2 - Product
C $0.53816 \quad 2.17931$
0.70877
$\begin{array}{llll}\text { C } & -0.19579 & -0.11239 & -0.07201\end{array}$
$\begin{array}{llll}\text { C } & -0.48637 & 1.52037 & 1.61725\end{array}$
$\begin{array}{llll}\text { C } & 0.00520 & 2.15724 & -0.71414\end{array}$
$\begin{array}{llll}\text { C } & -0.38190 & 0.95273 & -1.14880\end{array}$
$\begin{array}{llll}\text { C } & -0.88252 & 0.30414 & 1.22550\end{array}$
$\begin{array}{llll}0 & -0.46996 & -1.42524 & -0.48845\end{array}$
$\begin{array}{llll}\text { C } & 0.67540 & -2.17823 & -0.45266\end{array}$
$\begin{array}{llll}0 & 0.67631 & -3.33201 & -0.76761\end{array}$
$\begin{array}{llll}\text { C } & 1.78469 & -1.31664 & 0.01663\end{array}$ 

$\begin{array}{llll}C & 1.29470 & -0.09353 & 0.24742\end{array}$
$\begin{array}{llll}\text { C } & 1.79175 & 1.23412 & 0.71489\end{array}$
H $\quad 2.57355 \quad 1.616340 .04358$
$\begin{array}{llll}H & 0.81187 & 3.18532 & 1.04130\end{array}$
$\begin{array}{llll}H & -0.83340 & 2.00150 & 2.53369\end{array}$
H $\quad-0.01845 \quad 3.05733 \quad-1.33142$
$\begin{array}{llll}\text { C } & -0.87125 & 0.55882 & -2.50281\end{array}$
C $\quad-1.80266 \quad-0.64790 \quad 1.91464$
H $2.80061 \quad-1.68904 \quad 0.12912$
$\begin{array}{llll}\text { H } & 2.21912 & 1.15716 & 1.72454\end{array}$
$\begin{array}{llll}H & -2.19912 & -0.20463 & 2.83746\end{array}$
$\begin{array}{llll}H & -2.64371 & -0.92684 & 1.26174\end{array}$
$\begin{array}{llll}H & -1.27572 & -1.58040 & 2.17133\end{array}$
$\begin{array}{llll}\text { H } & -0.93410 & 1.43432 & -3.16223\end{array}$
$\begin{array}{llll}\text { H } & -0.19345 & -0.17824 & -2.96156\end{array}$
$\begin{array}{llll}\text { H } & -1.86279 & 0.08490 & -2.44196\end{array}$

44

Compound 3 - Reactant
$\begin{array}{llll}\text { C } & -0.16779 & 2.80949 & -0.17375\end{array}$
$\begin{array}{llll}\text { C } & -0.49197 & 0.09111 & -0.35084\end{array}$
$\begin{array}{llll}\text { C } & -1.07223 & 2.16775 & 0.66641\end{array}$
C $0.48253 \quad 2.10265 \quad-1.18033$
C $0.31965 \quad 0.71942 \quad-1.31794$
$\begin{array}{llll}\text { C } & -1.28372 & 0.78655 & 0.58631\end{array}$
$\begin{array}{llll}\mathrm{O} & -0.57146 & -1.29245 & -0.36889\end{array}$
$\begin{array}{llll}\text { C } & 0.25055 & -2.08953 & 0.35153\end{array}$
$\begin{array}{llll}0 & 0.09972 & -3.27710 & 0.26672\end{array}$
C $\quad 1.31246-1.51646 \quad 1.22603$
C $\quad \begin{array}{lll}1.64437 & -0.26386 & 1.46010\end{array}$
$\begin{array}{llll}\text { C } & 2.05529 & 0.93619 & 1.76313\end{array}$
$\begin{array}{llll}\mathrm{H} & 2.83028 & 1.42824 & 1.16685\end{array}$
$\begin{array}{llll}H & -0.00818 & 3.88487 & -0.07725\end{array}$
$\begin{array}{llll}H & -1.62056 & 2.76416 & 1.39308\end{array}$
H $1.12473 \quad 2.64926 \quad-1.86825$ 

$\begin{array}{llll}C & 0.94852 & -0.04135 & -2.50354\end{array}$
$\begin{array}{llll}\text { C } & -2.37060 & 0.09772 & 1.43734\end{array}$
H $\quad \begin{array}{lll}1.87718 & -2.30622 & 1.73121\end{array}$
H $\quad 1.61747 \quad 1.48111 \quad 2.60549$
$\begin{array}{llll}\text { C } & -3.16693 & 1.13444 & 2.24181\end{array}$
$\begin{array}{llll}\text { C } & -3.36342 & -0.62293 & 0.50795\end{array}$
$\begin{array}{llll}\text { C } & -1.79312 & -0.90468 & 2.45243\end{array}$
$\begin{array}{llll}\text { C } & 1.64059 & 0.93284 & -3.46688\end{array}$
$\begin{array}{llll}\text { C } & 2.01215 & -1.06354 & -2.06472\end{array}$
$\begin{array}{llll}\text { C } & -0.16087 & -0.75781 & -3.29396\end{array}$
$\begin{array}{llll}H & -3.97571 & 0.62056 & 2.78108\end{array}$
$\begin{array}{llll}H & -2.54134 & 1.64503 & 2.98912\end{array}$
$\begin{array}{llll}H & -3.62623 & 1.89457 & 1.59316\end{array}$
$\begin{array}{llll}H & -4.16212 & -1.08478 & 1.10897\end{array}$
$\begin{array}{llll}H & -3.83094 & 0.09027 & -0.18797\end{array}$
$\begin{array}{llll}H & -2.87796 & -1.41374 & -0.07802\end{array}$
$\begin{array}{llll}H & -2.58997 & -1.20536 & 3.15004\end{array}$
$\begin{array}{llll}H & -1.42520 & -1.82744 & 1.98650\end{array}$
H $\quad-0.98034 \quad-0.45625 \quad 3.04350$
$\begin{array}{llll}\text { H } & 2.01590 & 0.36923 & -4.33320\end{array}$
H $0.94976 \quad 1.70242 \quad-3.84108$
H $\quad 2.50084 \quad 1.43395 \quad-2.99848$
H $\quad 2.55311-1.41999-2.95487$
H $2.74806 \quad-0.61122 \quad-1.38282$
H $\quad 1.58447-1.95315 \quad-1.58559$
H $\quad 0.27884-1.27241 \quad-4.16246$
H $\quad-0.68266 \quad-1.50588 \quad-2.68361$
$\begin{array}{llll}H & -0.90099 & -0.03341 & -3.66682\end{array}$

44

Compound 3 - TS
$\begin{array}{llll}\text { C } & 0.33392 & 2.54468 & 0.25885\end{array}$
$\begin{array}{llll}\text { C } & -0.22691 & -0.00026 & -0.12472\end{array}$
$\begin{array}{llll}\text { C } & -0.84514 & 2.04082 & 0.88094\end{array}$
$\begin{array}{llll}\text { C } & 0.72601 & 1.97622 & -0.98780\end{array}$ 


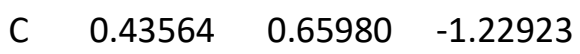
$\begin{array}{llll}\text { C } & -1.17763 & 0.72615 & 0.68963\end{array}$
$\begin{array}{llll}0 & -0.35275 & -1.37372 & -0.18296\end{array}$
$\begin{array}{llll}\text { C } & 0.52126 & -2.09529 & 0.57789\end{array}$
$\begin{array}{llll}0 & 0.47102 & -3.29024 & 0.57776\end{array}$
$\begin{array}{llll}\text { C } & 1.46126 & -1.24344 & 1.33861\end{array}$
$\begin{array}{llll}\text { C } & 1.37678 & 0.07384 & 1.22127\end{array}$
C $\quad 1.75634 \quad 1.35314 \quad 1.49606$
H $2.65680 \quad 1.75429 \quad 1.02644$
$\begin{array}{llll}\text { H } & 0.64021 & 3.56879 & 0.48096\end{array}$
$\begin{array}{llll}H & -1.39558 & 2.67727 & 1.57279\end{array}$
$\begin{array}{llll}\text { H } & 1.33399 & 2.56501 & -1.67365\end{array}$
$\begin{array}{llll}\text { C } & 0.85205 & -0.08204 & -2.50352\end{array}$
$\begin{array}{llll}\text { C } & -2.38581 & 0.05119 & 1.34713\end{array}$
$\begin{array}{llll}\text { H } & 2.18820 & -1.76103 & 1.96811\end{array}$
H $1.46325 \quad 1.80338 \quad 2.44668$
$\begin{array}{llll}\text { C } & -3.24420 & 1.09534 & 2.07052\end{array}$
$\begin{array}{llll}\text { C } & -3.25444 & -0.60960 & 0.26350\end{array}$
$\begin{array}{llll}\text { C } & -1.96205 & -1.00018 & 2.38885\end{array}$
$\begin{array}{llll}\text { C } & 1.45236 & 0.90199 & -3.51431\end{array}$
$\begin{array}{llll}\text { C } & 1.91451 & -1.15991 & -2.22151\end{array}$
$\begin{array}{llll}\text { C } & -0.38679 & -0.72735 & -3.14714\end{array}$
$\begin{array}{llll}H & -4.14998 & 0.60908 & 2.46150\end{array}$
$\begin{array}{llll}\mathrm{H} & -2.71251 & 1.54403 & 2.92295\end{array}$
$\begin{array}{llll}H & -3.56000 & 1.90312 & 1.39382\end{array}$
H $\quad-4.13563 \quad-1.07942 \quad 0.72755$
$\begin{array}{llll}H & -3.60968 & 0.14010 & -0.46019\end{array}$
H $\quad-2.70175 \quad-1.38625 \quad-0.28127$
$\begin{array}{llll}H & -2.84900 & -1.32784 & 2.95346\end{array}$
$\begin{array}{llll}\text { H } & -1.52473 & -1.89893 & 1.93488\end{array}$
$\begin{array}{llll}H & -1.24209 & -0.58053 & 3.10822\end{array}$
H $\quad 1.66430 \quad 0.36981 \quad-4.45326$
H $0.75973 \quad 1.72572 \quad-3.74207$
H $2.39868 \quad 1.33303 \quad-3.15467$
H $\quad 2.30602 \quad-1.54071 \quad-3.17782$ 


$\begin{array}{llll}H & 2.76128 & -0.74543 & -1.65305 \\ H & 1.51221 & -2.02371 & -1.67647 \\ H & -0.09728 & -1.24677 & -4.07393 \\ H & -0.85572 & -1.46074 & -2.47803 \\ H & -1.13397 & 0.03885 & -3.40529\end{array}$

44

Compound 3 - Product
$\begin{array}{llll}\text { C } & 1.32383 & 2.24756 & -0.34417\end{array}$
$\begin{array}{llll}\text { C } & 0.35641 & -0.06483 & 0.04313\end{array}$
$\begin{array}{llll}\text { C } & 0.39808 & 2.16113 & 0.85254\end{array}$
$\begin{array}{llll}\text { C } & 0.60016 & 1.67482 & -1.54620\end{array}$
$\begin{array}{llll}\text { C } & 0.08083 & 0.45075 & -1.38039\end{array}$
$\begin{array}{llll}\text { C } & -0.12748 & 0.95199 & 1.09198\end{array}$
$\begin{array}{llll}0 & -0.01085 & -1.40205 & 0.28330\end{array}$
$\begin{array}{llll}\text { C } & 1.09716 & -2.16904 & 0.53222\end{array}$
$\begin{array}{llll}\text { O } & 1.00327 & -3.34013 & 0.76171\end{array}$
$\begin{array}{llll}\text { C } & 2.28853 & -1.30115 & 0.45660\end{array}$
$\begin{array}{llll}\text { C } & 1.88022 & -0.05990 & 0.17052\end{array}$
$\begin{array}{llll}\text { C } & 2.51117 & 1.27256 & -0.04648\end{array}$
H $\quad 3.21440 \quad 1.23793 \quad-0.89071$
H $1.68950 \quad 3.26392 \quad-0.51942$
$\begin{array}{llll}\text { H } & 0.21363 & 3.03772 & 1.47343\end{array}$
$\begin{array}{llll}H & 0.54659 & 2.23648 & -2.47873\end{array}$
$\begin{array}{llll}\text { C } & -0.63474 & -0.37862 & -2.43600\end{array}$
$\begin{array}{llll}\text { C } & -1.03010 & 0.57268 & 2.25628\end{array}$
$\begin{array}{llll}\text { H } & 3.29628 & -1.67727 & 0.61776\end{array}$
$\begin{array}{llll}H & 3.06807 & 1.59015 & 0.84654\end{array}$
$\begin{array}{llll}\text { C } & -1.35889 & 1.81821 & 3.08491\end{array}$
$\begin{array}{llll}\text { C } & -2.34470 & -0.02635 & 1.73277\end{array}$
$\begin{array}{llll}\text { C } & -0.32718 & -0.44021 & 3.17838\end{array}$
$\begin{array}{llll}\text { C } & -0.78551 & 0.43806 & -3.72299\end{array}$
$\begin{array}{llll}\text { C } & 0.17402 & -1.64573 & -2.76867\end{array}$
$\begin{array}{llll}\text { C } & -2.03513 & -0.77124 & -1.94015\end{array}$
$\begin{array}{llll}\text { H } & -2.03502 & 1.54240 & 3.90774\end{array}$ 


$\begin{array}{lrrr}\mathrm{H} & -0.45380 & 2.26094 & 3.52694 \\ \mathrm{H} & -1.85974 & 2.58683 & 2.47769 \\ \mathrm{H} & -3.01086 & -0.25572 & 2.57920 \\ \mathrm{H} & -2.86469 & 0.68610 & 1.07375 \\ \mathrm{H} & -2.16845 & -0.95616 & 1.17750 \\ \mathrm{H} & -0.94771 & -0.61256 & 4.07172 \\ \mathrm{H} & -0.17638 & -1.41321 & 2.69287 \\ \mathrm{H} & 0.64892 & -0.05666 & 3.51342 \\ \mathrm{H} & -1.32916 & -0.15647 & -4.47216 \\ \mathrm{H} & -1.35227 & 1.36487 & -3.54933 \\ \mathrm{H} & 0.19274 & 0.70477 & -4.15019 \\ \mathrm{H} & -0.30011 & -2.17034 & -3.61295 \\ \mathrm{H} & 1.20320 & -1.38988 & -3.06441 \\ \mathrm{H} & 0.21318 & -2.34977 & -1.92725 \\ \mathrm{H} & -2.56367 & -1.33174 & -2.72711 \\ \mathrm{H} & -1.98066 & -1.40769 & -1.04801 \\ \mathrm{H} & -2.63089 & 0.12320 & -1.70078\end{array}$

23

Compound 4 - Reactant
$\begin{array}{llll}\text { C } & -2.95559 & 0.77248 & -0.26280\end{array}$
$\begin{array}{llll}\text { C } & -0.20858 & 0.67814 & 0.14799\end{array}$
C $\quad-2.08105 \quad 0.88040 \quad-1.34490$
C $\quad-2.44395 \quad 0.63436 \quad 1.02895$
$\begin{array}{llll}\text { C } & -1.06783 & 0.58606 & 1.24080\end{array}$
$\begin{array}{llll}\text { C } & -0.70144 & 0.84511 & -1.14563\end{array}$
$\begin{array}{llll}0 & 1.14437 & 0.66876 & 0.39846\end{array}$
$\begin{array}{llll}\text { C } & 2.04555 & 0.01426 & -0.38267\end{array}$
$\begin{array}{llll}0 & 3.12475 & 0.50359 & -0.55347\end{array}$
C $\quad 1.68989-1.33206 \quad-0.92904$
$\begin{array}{llll}\text { C } & 0.68839 & -2.02549 & -0.42598\end{array}$
$\begin{array}{llll}\text { C } & -0.31345 & -2.71088 & 0.04992\end{array}$
$\begin{array}{llll}H & -0.19009 & -3.36576 & 0.91833\end{array}$
$\begin{array}{llll}H & -4.03382 & 0.80546 & -0.42497\end{array}$
$\begin{array}{llll}\text { H } & -2.47265 & 1.00406 & -2.35604\end{array}$ 


$$
\begin{array}{llll}
\mathrm{H} & -3.12156 & 0.55921 & 1.88108 \\
\mathrm{H} & -0.64578 & 0.46650 & 2.23939 \\
\mathrm{H} & -0.01079 & 0.94461 & -1.98559 \\
\mathrm{C} & 2.62284 & -1.86359 & -1.98611 \\
\mathrm{H} & -1.30668 & -2.63012 & -0.40593 \\
\mathrm{H} & 2.29795 & -2.85318 & -2.32793 \\
\mathrm{H} & 2.65514 & -1.17945 & -2.84670 \\
\mathrm{H} & 3.64404 & -1.93770 & -1.58628
\end{array}
$$

\section{3}

Compound 4 - TS
$\begin{array}{llll}\text { C } & -2.45371 & -0.23068 & -0.08173\end{array}$
$\begin{array}{llll}\text { C } & -0.04078 & 0.85171 & -0.18616\end{array}$
$\begin{array}{llll}\text { C } & -2.16605 & 0.60924 & -1.20332\end{array}$
$\begin{array}{llll}\text { C } & -1.82077 & 0.06807 & 1.16579\end{array}$
$\begin{array}{llll}\text { C } & -0.58317 & 0.63751 & 1.12236\end{array}$
$\begin{array}{llll}\text { C } & -0.93032 & 1.18160 & -1.25956\end{array}$
$\begin{array}{llll}0 & 1.26952 & 1.26480 & -0.28277\end{array}$
$\begin{array}{llll}\text { C } & 2.15971 & 0.29551 & -0.63373\end{array}$
$\begin{array}{llll}\text { O } & 3.32273 & 0.54809 & -0.74535\end{array}$
$\begin{array}{llll}\text { C } & 1.52530 & -1.03700 & -0.84573\end{array}$
$\begin{array}{llll}\text { C } & 0.21050 & -1.11754 & -0.67262\end{array}$
$\begin{array}{llll}\text { C } & -0.96728 & -1.81255 & -0.65974\end{array}$
H $\begin{array}{llll}-1.19532 & -2.46724 & 0.18442\end{array}$
H $\quad-3.40157 \quad-0.77219 \quad-0.06728$
$\begin{array}{llll}H & -2.87136 & 0.68236 & -2.03264\end{array}$
$\begin{array}{llll}H & -2.26842 & -0.26263 & 2.10431\end{array}$
$\begin{array}{llll}\text { H } & 0.04531 & 0.79963 & 1.99926\end{array}$
$\begin{array}{llll}H & -0.55478 & 1.74013 & -2.11818\end{array}$
$\begin{array}{llll}\text { C } & 2.44948 & -2.15483 & -1.23570\end{array}$
H $\quad-1.45616 \quad-2.05840 \quad-1.60514$
H $\quad 1.89443 \quad-3.09074 \quad-1.36958$
H $\quad 2.97240 \quad-1.90945 \quad-2.17193$
H $\quad 3.21994 \quad-2.30063 \quad-0.46410$ 
Compound 4 - Product
$\begin{array}{llll}\text { C } & -0.63965 & 2.29621 & -0.41051\end{array}$
$\begin{array}{llll}\text { C } & -0.74440 & -0.24054 & -0.35272\end{array}$
$\begin{array}{llll}\text { C } & -1.78092 & 1.74531 & 0.42947\end{array}$
C $\quad-0.70053 \quad 1.65024 \quad-1.78549$
$\begin{array}{llll}\text { C } & -0.75128 & 0.31649 & -1.76292\end{array}$
$\begin{array}{llll}\text { C } & -1.83948 & 0.41225 & 0.46806\end{array}$
$\begin{array}{llll}0 & -0.67432 & -1.64073 & -0.25845\end{array}$
$\begin{array}{llll}\text { C } & 0.50268 & -2.00445 & 0.33122\end{array}$
$\begin{array}{llll}0 & 0.78963 & -3.15119 & 0.52031\end{array}$
$\begin{array}{llll}\text { C } & 1.28299 & -0.78129 & 0.65935\end{array}$
$\begin{array}{llll}\text { C } & 0.55789 & 0.27032 & 0.26057\end{array}$
$\begin{array}{llll}\text { C } & 0.68026 & 1.75792 & 0.25641\end{array}$
$\begin{array}{llll}H & 1.56043 & 2.08010 & -0.31830\end{array}$
$\begin{array}{llll}H & -0.63365 & 3.38936 & -0.45450\end{array}$
$\begin{array}{llll}\text { H } & -2.45921 & 2.40572 & 0.97165\end{array}$
$\begin{array}{llll}H & -0.66955 & 2.24823 & -2.69742\end{array}$
$\begin{array}{llll}\mathrm{H} & -0.75354 & -0.35387 & -2.62339\end{array}$
$\begin{array}{llll}\mathrm{H} & -2.54060 & -0.19662 & 1.04035\end{array}$
$\begin{array}{llll}\text { C } & 2.61861 & -0.87294 & 1.31464\end{array}$
$\begin{array}{llll}\mathrm{H} & 0.78127 & 2.14867 & 1.27910\end{array}$
$\begin{array}{llll}H & 3.04548 & 0.12437 & 1.48130\end{array}$
$\begin{array}{llll}\mathrm{H} & 2.54124 & -1.38917 & 2.28321\end{array}$
$\begin{array}{llll}\text { H } & 3.31625 & -1.45532 & 0.69436\end{array}$

29

Compound 5 - Reactant
$\begin{array}{llll}\text { C } & -2.95648 & 0.67824 & -0.27325\end{array}$
$\begin{array}{llll}\text { C } & -0.21346 & 0.75918 & 0.01880\end{array}$
$\begin{array}{llll}\text { C } & -2.14443 & 0.89459 & -1.38433\end{array}$
$\begin{array}{llll}\text { C } & -2.38582 & 0.52543 & 0.99093\end{array}$
$\begin{array}{llll}\text { C } & -1.00029 & 0.56698 & 1.15988\end{array}$
$\begin{array}{llll}\text { C } & -0.75143 & 0.95255 & -1.25851\end{array}$
$\begin{array}{llll}\text { O } & 1.15419 & 0.84962 & 0.20865\end{array}$ 

$\begin{array}{llll}C & 2.06589 & 0.05368 & -0.40299\end{array}$
$\begin{array}{llll}0 & 3.18228 & 0.46481 & -0.54476\end{array}$
$\begin{array}{llll}\text { C } & 1.67721 & -1.32673 & -0.83437\end{array}$
$\begin{array}{llll}\text { C } & 0.66108 & -1.96606 & -0.29086\end{array}$
$\begin{array}{llll}\text { C } & -0.33394 & -2.63067 & 0.22894\end{array}$
$\begin{array}{llll}\mathrm{H} & -0.20124 & -3.22214 & 1.14061\end{array}$
$\begin{array}{llll}H & -4.04080 & 0.64108 & -0.39029\end{array}$
$\begin{array}{llll}H & -2.59048 & 1.03681 & -2.37106\end{array}$
H $\quad-3.02113 \quad 0.36700 \quad 1.86505$
$\begin{array}{llll}\text { C } & -0.34294 & 0.37103 & 2.49496\end{array}$
$\begin{array}{llll}\text { C } & 0.14263 & 1.21862 & -2.43761\end{array}$
$\begin{array}{llll}\text { C } & 2.61122 & -1.96513 & -1.83186\end{array}$
$\begin{array}{llll}\mathrm{H} & -1.32863 & -2.59363 & -0.22844\end{array}$
$\begin{array}{llll}\text { H } & 2.25858 & -2.96566 & -2.10796\end{array}$
$\begin{array}{llll}\mathrm{H} & 2.68493 & -1.34772 & -2.73940\end{array}$
$\begin{array}{llll}\text { H } & 3.62125 & -2.04382 & -1.40556\end{array}$
$\begin{array}{llll}\text { H } & -0.44349 & 1.58192 & -3.29128\end{array}$
$\begin{array}{llll}H & 0.90707 & 1.97144 & -2.19457\end{array}$
$\begin{array}{llll}\text { H } & 0.67085 & 0.30796 & -2.76378\end{array}$
$\begin{array}{llll}H & -1.09421 & 0.23127 & 3.28241\end{array}$
$\begin{array}{llll}H & 0.31362 & -0.51369 & 2.47822\end{array}$
$\begin{array}{llll}\text { H } & 0.28744 & 1.23254 & 2.75986\end{array}$

29

Compound 5 - TS
$\begin{array}{llll}\text { C } & -2.49002 & -0.31014 & -0.19444\end{array}$
$\begin{array}{llll}\text { C } & -0.05285 & 0.68770 & -0.15907\end{array}$
$\begin{array}{llll}\text { C } & -2.10084 & 0.48812 & -1.31155\end{array}$
$\begin{array}{llll}\text { C } & -1.92858 & -0.01751 & 1.08453\end{array}$
$\begin{array}{llll}\text { C } & -0.67100 & 0.51624 & 1.12918\end{array}$
$\begin{array}{llll}\text { C } & -0.84630 & 1.03083 & -1.30962\end{array}$
$\begin{array}{llll}0 & 1.27020 & 1.08238 & -0.17097\end{array}$
$\begin{array}{llll}\text { C } & 2.16422 & 0.09023 & -0.44385\end{array}$
$\begin{array}{llll}0 & 3.33743 & 0.31914 & -0.47919\end{array}$
$\begin{array}{llll}\text { C } & 1.51677 & -1.23095 & -0.67643\end{array}$ 


$\begin{array}{llll}\text { C } & 0.19006 & -1.27974 & -0.59167 \\ \text { C } & -0.98981 & -1.96915 & -0.65254 \\ \text { H } & -1.28945 & -2.60181 & 0.18578 \\ \text { H } & -3.45185 & -0.82553 & -0.23404 \\ \text { H } & -2.74123 & 0.55248 & -2.19386 \\ \text { H } & -2.43996 & -0.33182 & 1.99690 \\ \text { C } & 0.13484 & 0.71822 & 2.37638 \\ \text { C } & -0.21320 & 1.74018 & -2.46794 \\ \text { C } & 2.43654 & -2.37753 & -0.98431 \\ \text { H } & -1.41917 & -2.21941 & -1.62509 \\ \text { H } & 1.86644 & -3.30122 & -1.13918 \\ \text { H } & 3.02712 & -2.16429 & -1.88768 \\ \text { H } & 3.14980 & -2.52959 & -0.16063 \\ \text { H } & -0.95299 & 1.92423 & -3.25740 \\ \text { H } & 0.22466 & 2.70076 & -2.15942 \\ \text { H } & 0.60387 & 1.13771 & -2.89745 \\ \text { H } & -0.48423 & 0.54746 & 3.26633 \\ \text { H } & 0.98565 & 0.01825 & 2.41115 \\ \text { H } & 0.55333 & 1.73423 & 2.42350\end{array}$

29

Compound 5 - Product
$\begin{array}{llll}\text { C } & -0.34403 & 2.40131 & 0.06523\end{array}$
$\begin{array}{llll}\text { C } & -0.45489 & -0.12169 & -0.06591\end{array}$
$\begin{array}{llll}\text { C } & -1.16746 & 1.76477 & 1.17254\end{array}$
C $\quad-0.84599 \quad 1.87756 \quad-1.27012$
$\begin{array}{llll}\text { C } & -0.90399 & 0.54420 & -1.36238\end{array}$
$\begin{array}{llll}\text { C } & -1.23157 & 0.42933 & 1.12539\end{array}$
$\begin{array}{lllll}0 & -0.38013 & -1.52487 & -0.12085\end{array}$
$\begin{array}{llll}\text { C } & 0.91932 & -1.92248 & 0.03195\end{array}$
$\begin{array}{llll}0 & 1.23460 & -3.07740 & 0.02026\end{array}$
$\begin{array}{llll}\text { C } & 1.77806 & -0.72071 & 0.20050\end{array}$
$\begin{array}{llll}\text { C } & 0.97741 & 0.35151 & 0.14453\end{array}$
$\begin{array}{llll}\text { C } & 1.11329 & 1.83617 & 0.23095\end{array}$
H $\quad 1.77102 \quad 2.21799 \quad-0.56319$ 


$$
\begin{array}{lrrr}
\text { H } & -0.34301 & 3.49457 & 0.11585 \\
\text { H } & -1.62943 & 2.36337 & 1.96002 \\
\text { H } & -1.09604 & 2.55051 & -2.09259 \\
\text { C } & -1.26010 & -0.29609 & -2.54356 \\
\text { C } & -1.87080 & -0.51020 & 2.09324 \\
\text { C } & 3.25108 & -0.85080 & 0.38866 \\
\text { H } & 1.53905 & 2.13663 & 1.19919 \\
\text { H } & 3.72598 & 0.13289 & 0.49437 \\
\text { H } & 3.47561 & -1.44805 & 1.28501 \\
\text { H } & 3.70620 & -1.37117 & -0.46727 \\
\text { H } & -2.36177 & 0.04341 & 2.90421 \\
\text { H } & -2.61575 & -1.14783 & 1.59352 \\
\text { H } & -1.11857 & -1.18390 & 2.53335 \\
\text { H } & -1.53177 & 0.33454 & -3.40013 \\
\hline H & -0.41154 & -0.93577 & -2.83371 \\
\hline H & -2.10095 & -0.96773 & -2.31311
\end{array}
$$

\section{7}

Compound 6 - Reactant
$\begin{array}{llll}\text { C } & -0.17544 & 2.83554 & -0.19123\end{array}$
$\begin{array}{llll}\text { C } & -0.59310 & 0.12670 & -0.30105\end{array}$
$\begin{array}{llll}\text { C } & -1.14440 & 2.25465 & 0.62088\end{array}$
$\begin{array}{llll}\text { C } & 0.49591 & 2.07321 & -1.14201\end{array}$
C $0.28790 \quad 0.69322-1.24509$
$\begin{array}{llll}\text { C } & -1.40350 & 0.88029 & 0.57282\end{array}$
O $\quad-0.73391 \quad-1.25071 \quad-0.29031$
$\begin{array}{llll}\text { C } & 0.00030 & -2.08584 & 0.47871\end{array}$
$\begin{array}{llll}0 & -0.22500 & -3.26202 & 0.39020\end{array}$
$\begin{array}{llll}\text { C } & 1.06034 & -1.58059 & 1.41303\end{array}$
$\begin{array}{llll}\text { C } & 1.40654 & -0.32153 & 1.60570\end{array}$
$\begin{array}{llll}\text { C } & 1.84822 & 0.87306 & 1.89389\end{array}$
$\begin{array}{llll}\text { H } & 2.66744 & 1.32192 & 1.32262\end{array}$
$\begin{array}{llll}H & 0.02030 & 3.90694 & -0.11937\end{array}$
H $\quad-1.70485 \quad 2.89365 \quad 1.30058$
$\begin{array}{llll}\text { H } & 1.19200 & 2.57321 & -1.81274\end{array}$ 

$\begin{array}{llll}\text { C } & 0.94711 & -0.12759 & -2.37245\end{array}$
$\begin{array}{llll}\text { C } & -2.55443 & 0.25969 & 1.39102\end{array}$
$\begin{array}{llll}\text { C } & 1.75222 & -2.69022 & 2.17084\end{array}$
H $\quad 1.39058 \quad 1.46297 \quad 2.69484$
$\begin{array}{llll}\text { C } & -3.35243 & 1.35161 & 2.11704\end{array}$
$\begin{array}{llll}\text { C } & -3.52683 & -0.46249 & 0.44137\end{array}$
$\begin{array}{llll}\text { C } & -2.06032 & -0.72107 & 2.46929\end{array}$
$\begin{array}{llll}\text { C } & 1.71716 & 0.79098 & -3.33133\end{array}$
C $1.95436-1.16539-1.84599$
$\begin{array}{llll}\text { C } & -0.14362 & -0.83634 & -3.19522\end{array}$
$\begin{array}{llll}\text { H } & -4.20592 & 0.88583 & 2.63035\end{array}$
$\begin{array}{llll}H & -2.74806 & 1.86790 & 2.87773\end{array}$
$\begin{array}{llll}\text { H } & -3.74949 & 2.10339 & 1.41944\end{array}$
$\begin{array}{llll}\text { H } & -4.37092 & -0.87002 & 1.01915\end{array}$
$\begin{array}{llll}\text { H } & -3.93148 & 0.23793 & -0.30516\end{array}$
$\begin{array}{llll}H & -3.04362 & -1.29367 & -0.08749\end{array}$
$\begin{array}{llll}\text { H } & -2.89794 & -0.96824 & 3.13985\end{array}$
$\begin{array}{llll}\text { H } & -1.70319 & -1.67304 & 2.05619\end{array}$
H $\quad-1.26005 \quad-0.27663 \quad 3.08031$
H $2.112920 .18709 \quad-4.16053$
H $\quad 1.07144 \quad 1.57031 \quad-3.76164$
$\begin{array}{llll}H & 2.57088 & 1.27963 & -2.83853\end{array}$
H $\quad 2.52954 \quad-1.56871 \quad-2.69384$
H $2.66746 \quad-0.71170-1.14108$
$\begin{array}{llll}\text { H } & 1.47481 & -2.02487 & -1.36040\end{array}$
H $\quad 0.32260 \quad-1.38894 \quad-4.02570$
H $\quad-0.71595 \quad-1.55064-2.59005$
H $\quad-0.84344-0.10300-3.62426$
$\begin{array}{llll}\text { H } & 2.51750 & -2.28189 & 2.84096\end{array}$
$\begin{array}{llll}\text { H } & 1.02075 & -3.25988 & 2.76203\end{array}$
$\begin{array}{llll}H & 2.22407 & -3.39279 & 1.46883\end{array}$

47

Compound 6 - TS

$\begin{array}{llll}\text { C } & 0.34716 & 2.48197 & 0.33135\end{array}$ 

$\begin{array}{llll}\text { C } & -0.37677 & -0.01735 & -0.08494\end{array}$
$\begin{array}{llll}\text { C } & -0.89234 & 2.06522 & 0.89386\end{array}$
$\begin{array}{llll}\text { C } & 0.76681 & 1.88165 & -0.88930\end{array}$
$\begin{array}{llll}\text { C } & 0.39207 & 0.58972 & -1.15006\end{array}$
$\begin{array}{llll}\text { C } & -1.31178 & 0.77824 & 0.68116\end{array}$
$\begin{array}{llll}0 & -0.60939 & -1.37728 & -0.16139\end{array}$
$\begin{array}{llll}\text { C } & 0.16312 & -2.16277 & 0.63826\end{array}$
$\begin{array}{llll}0 & 0.02356 & -3.35175 & 0.63080\end{array}$
C $\quad 1.13612-1.40221 \quad 1.46530$
$\begin{array}{llll}\text { C } & 1.14599 & -0.08023 & 1.33839\end{array}$
$\begin{array}{llll}\text { C } & 1.61899 & 1.15888 & 1.65092\end{array}$
$\begin{array}{llll}H & 2.56556 & 1.49868 & 1.22515\end{array}$
$\begin{array}{llll}\text { H } & 0.71995 & 3.47864 & 0.57561\end{array}$
H $\quad-1.42725 \quad 2.74104 \quad 1.56025$
$\begin{array}{llll}\text { H } & 1.45541 & 2.42210 & -1.53789\end{array}$
$\begin{array}{llll}\text { C } & 0.82400 & -0.18308 & -2.40033\end{array}$
$\begin{array}{llll}\text { C } & -2.59731 & 0.19545 & 1.27677\end{array}$
$\begin{array}{llll}\text { C } & 2.01556 & -2.21984 & 2.36775\end{array}$
$\begin{array}{llll}\mathrm{H} & 1.30451 & 1.63822 & 2.58047\end{array}$
$\begin{array}{llll}\text { C } & -3.40968 & 1.30000 & 1.96275\end{array}$
$\begin{array}{llll}\text { C } & -3.46126 & -0.39469 & 0.14952\end{array}$
$\begin{array}{llll}\text { C } & -2.30436 & -0.88562 & 2.33323\end{array}$
$\begin{array}{llll}\text { C } & 1.55436 & 0.75079 & -3.37244\end{array}$
C $1.78402-1.33796-2.06085$
$\begin{array}{llll}\text { C } & -0.42096 & -0.73104 & -3.11809\end{array}$
$\begin{array}{llll}\text { H } & -4.36409 & 0.88032 & 2.31292\end{array}$
$\begin{array}{llll}H & -2.88587 & 1.71219 & 2.83803\end{array}$
$\begin{array}{llll}H & -3.63577 & 2.12615 & 1.27241\end{array}$
$\begin{array}{llll}H & -4.39906 & -0.79217 & 0.56787\end{array}$
$\begin{array}{llll}\text { H } & -3.71842 & 0.38153 & -0.58745\end{array}$
$\begin{array}{llll}\text { H } & -2.94685 & -1.21261 & -0.37138\end{array}$
$\begin{array}{llll}\text { H } & -3.24115 & -1.15245 & 2.84694\end{array}$
$\begin{array}{llll}\text { H } & -1.90617 & -1.81164 & 1.89857\end{array}$
H $\quad-1.59714 \quad-0.51752 \quad 3.09252$
H $\quad 1.78508 \quad 0.20001 \quad-4.29605$ 


$\begin{array}{llll}\mathrm{H} & 0.93660 & 1.62029 & -3.64178 \\ \mathrm{H} & 2.50498 & 1.11575 & -2.95588 \\ \mathrm{H} & 2.19382 & -1.75383 & -2.99453 \\ \mathrm{H} & 2.62932 & -0.98512 & -1.44998 \\ \mathrm{H} & 1.28916 & -2.16514 & -1.53559 \\ \mathrm{H} & -0.11907 & -1.26561 & -4.03220 \\ \mathrm{H} & -0.98131 & -1.43010 & -2.48385 \\ \mathrm{H} & -1.09251 & 0.09103 & -3.40964 \\ \mathrm{H} & 2.69644 & -1.57428 & 2.93493 \\ \mathrm{H} & 1.40390 & -2.80436 & 3.07123 \\ \mathrm{H} & 2.60647 & -2.93729 & 1.77888\end{array}$

47

Compound 6 - Product
$\begin{array}{llll}\text { C } & 1.03776 & 2.34623 & 0.49846\end{array}$
$\begin{array}{llll}\text { C } & 0.14818 & 0.02547 & 0.00114\end{array}$
$\begin{array}{llll}\text { C } & 0.25992 & 1.72786 & 1.64281\end{array}$
$\begin{array}{llll}\text { C } & 0.18499 & 2.26978 & -0.75211\end{array}$
$\begin{array}{llll}\text { C } & -0.29900 & 1.05609 & -1.04959\end{array}$
$\begin{array}{llll}\text { C } & -0.22192 & 0.49789 & 1.41747\end{array}$
$\begin{array}{llll}0 & -0.17638 & -1.31383 & -0.29170\end{array}$
$\begin{array}{llll}\text { C } & 0.96214 & -2.04269 & -0.49208\end{array}$
$\begin{array}{llll}0 & 0.92277 & -3.21099 & -0.75527\end{array}$
$\begin{array}{llll}\text { C } & 2.13869 & -1.15791 & -0.32878\end{array}$
$\begin{array}{llll}\text { C } & 1.67570 & 0.06463 & -0.03773\end{array}$
$\begin{array}{llll}\text { C } & 2.26405 & 1.40463 & 0.24704\end{array}$
$\begin{array}{llll}\text { H } & 2.86276 & 1.76058 & -0.60401\end{array}$
$\begin{array}{llll}H & 1.36807 & 3.36590 & 0.71885\end{array}$
$\begin{array}{llll}H & 0.14269 & 2.26317 & 2.58489\end{array}$
H $0.01912 \quad 3.15663 \quad-1.36350$
$\begin{array}{llll}\text { C } & -1.12120 & 0.68619 & -2.27506\end{array}$
$\begin{array}{llll}\text { C } & -0.97465 & -0.37424 & 2.41115\end{array}$
$\begin{array}{llll}\text { C } & 3.52627 & -1.67787 & -0.48983\end{array}$
H $2.91705 \quad 1.36799 \quad 1.13116$
$\begin{array}{llll}\text { C } & -1.20993 & 0.40234 & 3.71057\end{array}$ 

$\begin{array}{llll}\text { C } & -2.33859 & -0.77940 & 1.83151\end{array}$
$\begin{array}{llll}\text { C } & -0.15941 & -1.63536 & 2.75184\end{array}$
$\begin{array}{llll}\text { C } & -1.42394 & 1.94317 & -3.09680\end{array}$
C $\quad-0.34431 \quad-0.29364 \quad-3.17369$
$\begin{array}{llll}\text { C } & -2.45303 & 0.05166 & -1.84604\end{array}$
H $\quad-1.77662 \quad-0.22482 \quad 4.41482$
$\begin{array}{llll}H & -0.26146 & 0.67899 & 4.19490\end{array}$
$\begin{array}{llll}H & -1.78872 & 1.32107 & 3.53303\end{array}$
$\begin{array}{llll}H & -2.89463 & -1.37560 & 2.57187\end{array}$
$\begin{array}{llll}H & -2.94062 & 0.11018 & 1.59020\end{array}$
$\begin{array}{llll}H & -2.22537 & -1.38501 & 0.92338\end{array}$
$\begin{array}{llll}\text { H } & -0.66353 & -2.18876 & 3.55968\end{array}$
$\begin{array}{llll}H & -0.06689 & -2.31845 & 1.89727\end{array}$
$\begin{array}{llll}\text { H } & 0.84961 & -1.36921 & 3.10305\end{array}$
$\begin{array}{llll}\text { H } & -2.03989 & 1.67240 & -3.96728\end{array}$
$\begin{array}{llll}\text { H } & -1.97914 & 2.68760 & -2.50675\end{array}$
H $\quad-0.50273 \quad 2.41485 \quad-3.47042$
H $\quad-0.90300 \quad-0.45203 \quad-4.10952$
$\begin{array}{llll}\text { H } & 0.64530 & 0.11193 & -3.43539\end{array}$
H $\quad-0.20983 \quad-1.27686 \quad-2.70399$
$\begin{array}{llll}H & -3.06014 & -0.17558 & -2.73629\end{array}$
H $\quad-2.29336 \quad-0.88423 \quad-1.29568$
$\begin{array}{llll}H & -3.02795 & 0.74206 & -1.20978\end{array}$
$\begin{array}{llll}\text { H } & 4.26683 & -0.88319 & -0.33322\end{array}$
$\begin{array}{llll}\text { H } & 3.72189 & -2.48821 & 0.22832\end{array}$
$\begin{array}{llll}\text { H } & 3.66791 & -2.09792 & -1.49687\end{array}$

33

Compound 7 - Reactant
$\begin{array}{llll}\text { C } & -4.67498 & 2.36696 & -0.46680\end{array}$
$\begin{array}{llll}\text { C } & -3.38403 & 0.04816 & 0.33502\end{array}$
$\begin{array}{llll}\text { C } & -5.10646 & 1.68445 & 0.67164\end{array}$
$\begin{array}{llll}\text { C } & -3.60054 & 1.87116 & -1.20761\end{array}$
$\begin{array}{llll}\text { C } & -2.95132 & 0.70047 & -0.81809\end{array}$
$\begin{array}{llll}\text { C } & -4.46126 & 0.51822 & 1.07986\end{array}$ 

$\begin{array}{llll}0 & -2.79764 & -1.13524 & 0.74571\end{array}$
$\begin{array}{llll}\text { C } & -1.46791 & -1.34305 & 0.76586\end{array}$
$\begin{array}{llll}0 & -1.02608 & -2.44456 & 0.62244\end{array}$
$\begin{array}{llll}\text { C } & -0.56653 & -0.17937 & 1.05900\end{array}$
$\begin{array}{llll}\text { C } & -0.92848 & 0.91589 & 1.68857\end{array}$
$\begin{array}{llll}\text { C } & -1.32342 & 1.99439 & 2.30225\end{array}$
$\begin{array}{llll}H & -1.65978 & 2.86461 & 1.72708\end{array}$
$\begin{array}{llll}H & -5.18017 & 3.28135 & -0.78102\end{array}$
$\begin{array}{llll}H & -5.95095 & 2.06215 & 1.25047\end{array}$
H $\quad-3.26445 \quad 2.39470 \quad-2.10413$
H $\quad-2.105320 .30543 \quad-1.38471$
H $\quad-4.77472 \quad-0.02910 \quad 1.96972$
$\begin{array}{llll}0 & 0.76067 & -0.42626 & 0.76317\end{array}$
$\begin{array}{llll}\mathrm{H} & -1.33208 & 2.05226 & 3.39550\end{array}$
$\begin{array}{llll}\text { C } & 1.03638 & -0.68662 & -0.53935\end{array}$
$\begin{array}{llll}\text { C } & 2.42315 & -1.21134 & -0.69952\end{array}$
O $0.23263 \quad-0.51946-1.41164$
$\begin{array}{llll}\text { C } & 2.92328 & -2.04309 & 0.31329\end{array}$
$\begin{array}{llll}\text { C } & 4.18014 & -2.62668 & 0.20192\end{array}$
$\begin{array}{llll}\text { C } & 4.96010 & -2.36742 & -0.92319\end{array}$
$\begin{array}{llll}\text { C } & 3.21594 & -0.95830 & -1.83019\end{array}$
$\begin{array}{llll}\text { C } & 4.48411 & -1.53158 & -1.93234\end{array}$
$\begin{array}{llll}H & 2.29807 & -2.24089 & 1.18422\end{array}$
H $4.54890 \quad-3.28135 \quad 0.99219$
H $\quad 5.95095 \quad-2.81358-1.02276$
I $2.632920 .33000-3.39550$
H $\quad 5.10505 \quad-1.32301 \quad-2.80403$

33

Compound 7 - TS
$\begin{array}{llll}\text { C } & -3.87578 & 2.47352 & 0.72474\end{array}$
$\begin{array}{llll}\text { C } & -3.44509 & -0.06475 & 0.11392\end{array}$
$\begin{array}{llll}\text { C } & -4.16927 & 1.50178 & 1.73345\end{array}$
$\begin{array}{llll}\text { C } & -4.03981 & 2.09501 & -0.64593\end{array}$
$\begin{array}{llll}\text { C } & -3.83198 & 0.78754 & -0.96919\end{array}$ 

$\begin{array}{llll}\text { C } & -3.96288 & 0.19067 & 1.42428\end{array}$
$\begin{array}{llll}0 & -3.05433 & -1.35747 & -0.18580\end{array}$
$\begin{array}{llll}\text { C } & -1.71827 & -1.57421 & -0.14147\end{array}$
$\begin{array}{llll}0 & -1.24076 & -2.64900 & -0.34137\end{array}$
$\begin{array}{llll}\text { C } & -0.96248 & -0.33136 & 0.18637\end{array}$
$\begin{array}{llll}\text { C } & -1.60471 & 0.79670 & 0.42472\end{array}$
$\begin{array}{llll}\text { C } & -1.68526 & 2.12057 & 0.74928\end{array}$
H $\quad-1.45761 \quad 2.86898 \quad-0.01286$
$\begin{array}{llll}H & -3.95092 & 3.53111 & 0.98403\end{array}$
$\begin{array}{llll}\text { H } & -4.43149 & 1.81861 & 2.74395\end{array}$
H $\quad-4.20240 \quad 2.85550 \quad-1.41112$
$\begin{array}{llll}H & -3.80311 & 0.40863 & -1.99163\end{array}$
$\begin{array}{llll}H & -4.03546 & -0.62465 & 2.14539\end{array}$
$\begin{array}{llll}0 & 0.40423 & -0.49758 & 0.26046\end{array}$
$\begin{array}{llll}\text { H } & -1.52710 & 2.42305 & 1.78710\end{array}$
$\begin{array}{llll}\text { C } & 1.03815 & -0.75489 & -0.91435\end{array}$
$\begin{array}{llll}\text { C } & 2.44098 & -1.20858 & -0.67331\end{array}$
$\begin{array}{llll}0 & 0.50294 & -0.62830 & -1.97577\end{array}$
$\begin{array}{llll}\text { C } & 2.68952 & -1.98360 & 0.46917\end{array}$
$\begin{array}{llll}\text { C } & 3.95624 & -2.49627 & 0.72479\end{array}$
$\begin{array}{llll}\text { C } & 4.99895 & -2.22195 & -0.15782\end{array}$
$\begin{array}{llll}\text { C } & 3.49854 & -0.94048 & -1.55663\end{array}$
C $4.77361-1.44165 \quad-1.29066$
H $\quad \begin{array}{lll}1.86295 & -2.19238 & 1.14841\end{array}$
H $4.12783 \quad-3.10709 \quad 1.61175$
$\begin{array}{llll}H & 6.00007 & -2.61285 & 0.03165\end{array}$
$\begin{array}{llll}\text { I } & 3.30507 & 0.26445 & -3.27702\end{array}$
H $\quad 5.59579-1.21972 \quad-1.97150$

33

Compound 7 - Product
$\begin{array}{llll}\text { C } & -3.59976 & 2.69424 & 2.10716\end{array}$
$\begin{array}{llll}\text { C } & -3.83255 & 0.41053 & 1.02117\end{array}$
$\begin{array}{llll}\text { C } & -4.42589 & 1.70667 & 2.91528\end{array}$
$\begin{array}{llll}\text { C } & -4.15099 & 2.73685 & 0.69094\end{array}$ 

$\begin{array}{llll}C & -4.27207 & 1.54078 & 0.11122\end{array}$
$\begin{array}{llll}\text { C } & -4.55029 & 0.50241 & 2.35321\end{array}$
$\begin{array}{llll}0 & -3.82867 & -0.87112 & 0.42846\end{array}$
$\begin{array}{llll}\text { C } & -2.56046 & -1.35371 & 0.37250\end{array}$
$\begin{array}{llll}0 & -2.28133 & -2.43416 & -0.05252\end{array}$
$\begin{array}{llll}\text { C } & -1.65976 & -0.31801 & 0.94078\end{array}$
$\begin{array}{llll}\text { C } & -2.37390 & 0.73067 & 1.34317\end{array}$
$\begin{array}{llll}\text { C } & -2.16561 & 2.05659 & 1.98742\end{array}$
$\begin{array}{llll}H & -1.50773 & 2.69037 & 1.37652\end{array}$
$\begin{array}{llll}H & -3.54373 & 3.68241 & 2.57256\end{array}$
$\begin{array}{llll}\text { H } & -4.84281 & 1.97534 & 3.88679\end{array}$
$\begin{array}{llll}\text { H } & -4.38485 & 3.68231 & 0.19981\end{array}$
$\begin{array}{llll}H & -4.59597 & 1.33498 & -0.90961\end{array}$
$\begin{array}{llll}\text { H } & -5.05726 & -0.36824 & 2.77106\end{array}$
$\begin{array}{llll}\text { O } & -0.31991 & -0.55088 & 1.04316\end{array}$
$\begin{array}{llll}\text { H } & -1.70712 & 1.94118 & 2.97962\end{array}$
$\begin{array}{llll}\text { C } & 0.35606 & -0.69893 & -0.13327\end{array}$
$\begin{array}{llll}\text { C } & 1.73793 & -1.21005 & 0.10692\end{array}$
$\begin{array}{llll}0 & -0.13988 & -0.43935 & -1.18817\end{array}$
$\begin{array}{llll}\text { C } & 1.94787 & -2.04736 & 1.21321\end{array}$
$\begin{array}{llll}\text { C } & 3.19507 & -2.60882 & 1.46091\end{array}$
$\begin{array}{llll}\text { C } & 4.25827 & -2.32312 & 0.60693\end{array}$
$\begin{array}{llll}\text { C } & 2.81732 & -0.92883 & -0.74719\end{array}$
$\begin{array}{llll}\text { C } & 4.07259 & -1.48148 & -0.48835\end{array}$
H $\quad 1.10780 \quad-2.26543 \quad 1.87238$
H $3.33529 \quad-3.26685 \quad 2.31911$
H $\quad 5.24453 \quad-2.75296 \quad 0.78987$
$\begin{array}{llll}\text { I } & 2.69592 & 0.36512 & -2.40868\end{array}$
H $4.91132 \quad-1.25102 \quad-1.14572$

39

Compound 8 - Reactant
$\begin{array}{llll}\text { C } & -5.19880 & 2.35815 & 0.42296\end{array}$
$\begin{array}{llll}\text { C } & -3.78648 & 0.01919 & 0.15401\end{array}$
$\begin{array}{llll}\text { C } & -5.08703 & 1.48781 & 1.50766\end{array}$ 

$\begin{array}{llll}C & -4.62492 & 2.03283 & -0.80602\end{array}$
$\begin{array}{llll}\text { C } & -3.90986 & 0.84268 & -0.96899\end{array}$
$\begin{array}{llll}\text { C } & -4.37750 & 0.29029 & 1.39018\end{array}$
$\begin{array}{llll}0 & -3.07469 & -1.16645 & 0.02643\end{array}$
$\begin{array}{llll}\text { C } & -1.73573 & -1.22830 & 0.08695\end{array}$
$\begin{array}{llll}0 & -1.18116 & -2.26909 & -0.12057\end{array}$
$\begin{array}{llll}\text { C } & -0.93204 & 0.00136 & 0.42136\end{array}$
$\begin{array}{llll}\text { C } & -1.33110 & 1.17674 & 0.86229\end{array}$
$\begin{array}{llll}\text { C } & -1.63668 & 2.35958 & 1.31569\end{array}$
$\begin{array}{llll}H & -1.84552 & 3.18469 & 0.62647\end{array}$
$\begin{array}{llll}H & -5.75173 & 3.29273 & 0.53222\end{array}$
$\begin{array}{llll}\text { H } & -5.55018 & 1.73971 & 2.46394\end{array}$
$\begin{array}{llll}\text { H } & -4.73031 & 2.70841 & -1.65748\end{array}$
$\begin{array}{llll}\text { C } & -3.26174 & 0.45626 & -2.26858\end{array}$
$\begin{array}{llll}\text { C } & -4.18366 & -0.65372 & 2.54244\end{array}$
$\begin{array}{llll}0 & 0.42813 & -0.24578 & 0.31357\end{array}$
$\begin{array}{llll}H & -1.70330 & 2.54655 & 2.39261\end{array}$
$\begin{array}{llll}\text { C } & 0.89640 & -0.45284 & -0.94276\end{array}$
$\begin{array}{llll}\text { C } & 2.27419 & -1.02671 & -0.90859\end{array}$
O $0.25295 \quad-0.20733 \quad-1.92160$
$\begin{array}{llll}\text { C } & 2.56882 & -1.94294 & 0.11160\end{array}$
$\begin{array}{llll}\text { C } & 3.80677 & -2.57319 & 0.16929\end{array}$
$\begin{array}{llll}\text { C } & 4.77351 & -2.27716 & -0.78961\end{array}$
$\begin{array}{llll}\text { C } & 3.25414 & -0.73723 & -1.87044\end{array}$
$\begin{array}{llll}\text { C } & 4.50186 & -1.35828 & -1.80224\end{array}$
$\begin{array}{llll}\text { H } & 1.79808 & -2.16685 & 0.84932\end{array}$
$\begin{array}{llll}H & 4.01529 & -3.29273 & 0.96183\end{array}$
$\begin{array}{llll}\text { H } & 5.75173 & -2.75951 & -0.75447\end{array}$
$\begin{array}{llll}\text { I } & 2.98426 & 0.67390 & -3.41456\end{array}$
$\begin{array}{llll}\text { H } & 5.26593 & -1.12105 & -2.54284\end{array}$
$\begin{array}{llll}\text { H } & -4.76411 & -0.32750 & 3.41456\end{array}$
$\begin{array}{llll}\text { H } & -4.49085 & -1.67560 & 2.27720\end{array}$
$\begin{array}{llll}H & -3.12244 & -0.70203 & 2.83688\end{array}$
$\begin{array}{llll}H & -3.50511 & 1.18470 & -3.05223\end{array}$
$\begin{array}{llll}\text { H } & -2.16477 & 0.40857 & -2.17390\end{array}$ 


\section{9}

Compound 8 - TS
$\begin{array}{llll}\text { C } & -4.12784 & 2.53774 & 0.74571\end{array}$
$\begin{array}{llll}\text { C } & -3.64625 & 0.02478 & 0.12778\end{array}$
$\begin{array}{llll}\text { C } & -4.39150 & 1.55980 & 1.75199\end{array}$
$\begin{array}{llll}\text { C } & -4.27537 & 2.16665 & -0.62560\end{array}$
$\begin{array}{llll}\text { C } & -4.04268 & 0.86525 & -0.97083\end{array}$
$\begin{array}{llll}\text { C } & -4.16538 & 0.24610 & 1.45112\end{array}$
$\begin{array}{llll}0 & -3.25499 & -1.26892 & -0.18378\end{array}$
$\begin{array}{llll}\text { C } & -1.91542 & -1.46943 & -0.18255\end{array}$
$\begin{array}{llll}0 & -1.42967 & -2.53421 & -0.41656\end{array}$
$\begin{array}{llll}\text { C } & -1.17233 & -0.22170 & 0.14898\end{array}$
$\begin{array}{llll}\text { C } & -1.82816 & 0.89320 & 0.41919\end{array}$
$\begin{array}{llll}\text { C } & -1.89705 & 2.21447 & 0.75984\end{array}$
$\begin{array}{llll}H & -1.68712 & 2.97258 & 0.00267\end{array}$
H $\quad-4.220113 .59289 \quad 1.01029$
$\begin{array}{llll}H & -4.64281 & 1.86835 & 2.76884\end{array}$
$\begin{array}{llll}H & -4.43324 & 2.93057 & -1.38966\end{array}$
$\begin{array}{llll}\text { C } & -3.94374 & 0.35165 & -2.37474\end{array}$
$\begin{array}{llll}\text { C } & -4.21872 & -0.88221 & 2.43563\end{array}$
$\begin{array}{llll}0 & 0.19896 & -0.36425 & 0.18455\end{array}$
H $\quad-1.72958 \quad 2.50545 \quad 1.79930$
C $\quad 0.80913 \quad-0.56344 \quad-1.01223$
$\begin{array}{llll}\text { C } & 2.23237 & -0.97451 & -0.82000\end{array}$
$\begin{array}{llll}0 & 0.24484 & -0.42625 & -2.05775\end{array}$
$\begin{array}{llll}\text { C } & 2.52810 & -1.81190 & 0.26551\end{array}$
$\begin{array}{llll}\text { C } & 3.81757 & -2.29041 & 0.46885\end{array}$
$\begin{array}{llll}\text { C } & 4.83434 & -1.91840 & -0.40833\end{array}$
$\begin{array}{llll}\text { C } & 3.26386 & -0.60690 & -1.69763\end{array}$
$\begin{array}{llll}\text { C } & 4.56134 & -1.07401 & -1.48334\end{array}$
H $\quad 1.72107-2.09695 \quad 0.94065$
H $4.02699 \quad-2.95099 \quad 1.31091$
H $\quad 5.85267 \quad-2.28126 \quad-0.25913$
$\begin{array}{llll}\text { I } & 2.99190 & 0.70956 & -3.32269\end{array}$ 


$$
\begin{array}{llll}
H & 5.36378 & -0.77516 & -2.15839 \\
H & -4.64308 & -0.53942 & 3.38772 \\
H & -4.82472 & -1.71761 & 2.05609 \\
H & -3.20951 & -1.27865 & 2.63344 \\
H & -4.28878 & 1.11222 & -3.08648 \\
H & -2.89845 & 0.10042 & -2.61964 \\
H & -4.53842 & -0.56289 & -2.51260
\end{array}
$$

39

Compound 8 - Product
$\begin{array}{llll}\text { C } & -1.85289 & 2.43873 & 3.41862\end{array}$
$\begin{array}{llll}\text { C } & -2.84323 & 0.58433 & 2.01410\end{array}$
$\begin{array}{llll}\text { C } & -2.65923 & 1.42656 & 4.21399\end{array}$
$\begin{array}{llll}\text { C } & -2.70285 & 2.93358 & 2.26007\end{array}$
$\begin{array}{llll}\text { C } & -3.22762 & 1.96811 & 1.49740\end{array}$
$\begin{array}{llll}\text { C } & -3.18895 & 0.43382 & 3.49017\end{array}$
$\begin{array}{llll}0 & -3.27723 & -0.48261 & 1.19553\end{array}$
$\begin{array}{llll}\text { C } & -2.20478 & -1.11314 & 0.64918\end{array}$
$\begin{array}{llll}0 & -2.28850 & -2.05850 & -0.07627\end{array}$
$\begin{array}{llll}\text { C } & -0.98440 & -0.42185 & 1.13352\end{array}$
$\begin{array}{llll}\text { C } & -1.32043 & 0.57440 & 1.95129\end{array}$
$\begin{array}{llll}\text { C } & -0.66765 & 1.63706 & 2.76658\end{array}$
H $\quad-0.05086 \quad 2.29175 \quad 2.13499$
H $\quad-1.46838 \quad 3.25375 \quad 4.03911$
$\begin{array}{llll}H & -2.75967 & 1.49992 & 5.29842\end{array}$
$\begin{array}{llll}H & -2.82158 & 3.99807 & 2.04994\end{array}$
$\begin{array}{llll}\text { C } & -3.99819 & 2.09032 & 0.22542\end{array}$
C $\quad-3.96271 \quad-0.75456 \quad 3.95606$
$\begin{array}{llll}\text { O } & 0.24570 & -0.87173 & 0.75175\end{array}$
H $\quad-0.02006 \quad 1.19536 \quad 3.53708$
$\begin{array}{llll}\text { C } & 0.54679 & -0.73082 & -0.57144\end{array}$
$\begin{array}{llll}\text { C } & 1.75883 & -1.52546 & -0.92716\end{array}$
$\begin{array}{llll}0 & -0.10995 & -0.05911 & -1.30915\end{array}$
$\begin{array}{llll}\text { C } & 1.93336 & -2.76621 & -0.29689\end{array}$
$\begin{array}{llll}\text { C } & 2.99905 & -3.59392 & -0.63173\end{array}$ 


$$
\begin{array}{llll}
\text { C } & 3.91577 & -3.17724 & -1.59482 \\
\text { C } & 2.68791 & -1.11557 & -1.89619 \\
\text { C } & 3.76615 & -1.94008 & -2.21969 \\
\text { H } & 1.20503 & -3.08088 & 0.45080 \\
\text { H } & 3.11282 & -4.56097 & -0.14073 \\
\text { H } & 4.76008 & -3.81367 & -1.86500 \\
\text { I } & 2.60514 & 0.75486 & -2.86624 \\
\text { H } & 4.49469 & -1.61358 & -2.96233 \\
\text { H } & -4.10942 & -0.71804 & 5.04330 \\
\text { H } & -4.94612 & -0.80380 & 3.46441 \\
\text { H } & -3.43288 & -1.68702 & 3.70510 \\
\text { H } & -4.17826 & 3.14535 & -0.01812 \\
\text { H } & -3.43913 & 1.63029 & -0.60552 \\
\text { H } & -4.96356 & 1.56668 & 0.29205
\end{array}
$$

\section{7}

Compound 9 - Reactant
$\begin{array}{llll}\text { C } & -5.01536 & 1.07666 & 2.38753\end{array}$
$\begin{array}{llll}\text { C } & -3.68021 & 0.00736 & 0.24779\end{array}$
$\begin{array}{llll}\text { C } & -4.65592 & -0.26736 & 2.40270\end{array}$
$\begin{array}{llll}\text { C } & -4.81016 & 1.84890 & 1.24851\end{array}$
$\begin{array}{llll}\text { C } & -4.15687 & 1.32841 & 0.12533\end{array}$
$\begin{array}{llll}\text { C } & -3.99593 & -0.85395 & 1.31748\end{array}$
$\begin{array}{llll}0 & -2.90253 & -0.50310 & -0.78610\end{array}$
$\begin{array}{llll}\text { C } & -1.56710 & -0.37661 & -0.83455\end{array}$
$\begin{array}{llll}0 & -0.97332 & -0.81154 & -1.78094\end{array}$
$\begin{array}{llll}\text { C } & -0.81775 & 0.31445 & 0.27234\end{array}$
$\begin{array}{llll}\text { C } & -1.25822 & 0.82358 & 1.40437\end{array}$
$\begin{array}{llll}\text { C } & -1.59535 & 1.37074 & 2.53809\end{array}$
$\begin{array}{llll}H & -1.86506 & 2.43093 & 2.58868\end{array}$
$\begin{array}{llll}\text { H } & -5.51123 & 1.51456 & 3.25563\end{array}$
$\begin{array}{llll}H & -4.89806 & -0.86238 & 3.28118\end{array}$
$\begin{array}{llll}H & -5.17348 & 2.87464 & 1.24302\end{array}$
$\begin{array}{llll}\text { C } & -4.03443 & 2.15168 & -1.17428\end{array}$
$\begin{array}{llll}\text { C } & -3.68257 & -2.36315 & 1.29739\end{array}$ 

$\begin{array}{llll}0 & 0.52436 & 0.45001 & -0.04880\end{array}$
$\begin{array}{llll}H & -1.62661 & 0.77825 & 3.45854\end{array}$
$\begin{array}{llll}\text { C } & 1.27523 & -0.68168 & -0.01976\end{array}$
$\begin{array}{llll}\text { C } & 2.58103 & -0.46662 & -0.71305\end{array}$
$\begin{array}{llll}0 & 0.90301 & -1.69395 & 0.49533\end{array}$
$\begin{array}{llll}\text { C } & 2.58832 & 0.36489 & -1.84250\end{array}$
$\begin{array}{llll}\text { C } & 3.74963 & 0.55590 & -2.58271\end{array}$
$\begin{array}{llll}\text { C } & 4.92729 & -0.07521 & -2.18729\end{array}$
$\begin{array}{llll}\text { C } & 3.77268 & -1.09804 & -0.32458\end{array}$
$\begin{array}{llll}\text { C } & 4.94170 & -0.89376 & -1.05890\end{array}$
H $\quad \begin{array}{lll}1.65676 & 0.84568 & -2.14100\end{array}$
H $3.73380 \quad 1.19583 \quad-3.46559$
$\begin{array}{llll}\text { H } & 5.84805 & 0.06734 & -2.75536\end{array}$
$\begin{array}{llll}\text { I } & 3.93809 & -2.31474 & 1.39127\end{array}$
$\begin{array}{llll}\text { H } & 5.86887 & -1.37555 & -0.74744\end{array}$
$\begin{array}{llll}\text { C } & -4.26739 & -3.05388 & 2.53635\end{array}$
$\begin{array}{llll}\text { C } & -4.33795 & -3.00578 & 0.06217\end{array}$
$\begin{array}{llll}\text { C } & -2.17158 & -2.65047 & 1.29383\end{array}$
$\begin{array}{llll}\text { C } & -4.81002 & 3.47074 & -1.05158\end{array}$
C $\quad-2.57983 \quad 2.52284 \quad-1.51505$
$\begin{array}{llll}\text { C } & -4.65558 & 1.36455 & -2.34177\end{array}$
H $\quad-2.00875 \quad-3.72182 \quad 1.48894$
$\begin{array}{llll}\mathrm{H} & -1.68624 & -2.43469 & 0.33464\end{array}$
$\begin{array}{llll}H & -1.64863 & -2.08342 & 2.07820\end{array}$
H $\quad-4.08748 \quad-4.13567 \quad 2.45681$
H $\quad-3.79277 \quad-2.70484 \quad 3.46559$
$\begin{array}{llll}H & -5.35314 & -2.89980 & 2.62056\end{array}$
$\begin{array}{llll}\text { H } & -4.13620 & -4.08815 & 0.06028\end{array}$
$\begin{array}{llll}H & -5.42932 & -2.86397 & 0.08286\end{array}$
H $\quad-3.94993 \quad-2.58709 \quad-0.87508$
$\begin{array}{llll}\text { H } & -2.58222 & 3.27635 & -2.31750\end{array}$
$\begin{array}{llll}\mathrm{H} & -2.06042 & 2.95736 & -0.64761\end{array}$
$\begin{array}{llll}H & -1.99229 & 1.67562 & -1.89167\end{array}$
H $\quad-4.76772 \quad 3.99814 \quad-2.01540$
$\begin{array}{llll}H & -5.86887 & 3.30289 & -0.80640\end{array}$ 


$\begin{array}{llll}H & -4.37690 & 4.13567 & -0.28970 \\ H & -4.59864 & 1.96652 & -3.26189 \\ H & -4.13534 & 0.41588 & -2.52434 \\ H & -5.71609 & 1.14805 & -2.14200\end{array}$

57

Compound 9 - TS

$\begin{array}{llll}\text { C } & -3.78298 & -0.93523 & 2.33787\end{array}$

$\begin{array}{llll}\text { C } & -2.99499 & -0.18312 & -0.06033\end{array}$

$\begin{array}{llll}\text { C } & -3.49066 & -1.96461 & 1.39768\end{array}$

$\begin{array}{llll}\text { C } & -4.29569 & 0.29855 & 1.84387\end{array}$

$\begin{array}{llll}\text { C } & -3.92503 & 0.71268 & 0.59171\end{array}$

$\begin{array}{llll}\text { C } & -3.09732 & -1.61226 & 0.13348\end{array}$

$\begin{array}{llll}0 & -2.39172 & 0.26252 & -1.22789\end{array}$

$\begin{array}{llll}\text { C } & -1.12312 & 0.71498 & -1.09937\end{array}$

$\begin{array}{llll}0 & -0.51244 & 1.15152 & -2.02899\end{array}$

$\begin{array}{llll}\text { C } & -0.62078 & 0.61278 & 0.29655\end{array}$

$\begin{array}{llll}\text { C } & -1.39021 & 0.13182 & 1.25443\end{array}$

$\begin{array}{llll}\text { C } & -1.67815 & -0.22238 & 2.53630\end{array}$

$\begin{array}{llll}H & -1.89934 & 0.55577 & 3.27000\end{array}$

H $\quad-4.01819 \quad-1.22101 \quad 3.36486$

H $\quad-3.48525 \quad-3.00185 \quad 1.73036$

H $\quad-4.88656 \quad 0.93095 \quad 2.50543$

$\begin{array}{llll}\text { C } & -4.37012 & 2.04084 & -0.02966\end{array}$

$\begin{array}{llll}\text { C } & -2.69752 & -2.62309 & -0.94550\end{array}$

$\begin{array}{llll}0 & 0.64802 & 1.12405 & 0.48008\end{array}$

H $\quad-1.29204 \quad-1.16572 \quad 2.92841$

$\begin{array}{llll}\text { C } & 1.66717 & 0.44218 & -0.10311\end{array}$

C $2.91350 \quad 1.26608-0.12560$

O $\quad 1.54135 \quad-0.66565 \quad-0.53492$

$\begin{array}{llll}\text { C } & 2.77744 & 2.64740 & -0.32679\end{array}$

$\begin{array}{llll}\text { C } & 3.89429 & 3.46891 & -0.43045\end{array}$

$\begin{array}{llll}\text { C } & 5.16741 & 2.91449 & -0.31509\end{array}$

$\begin{array}{llll}\text { C } & 4.20064 & 0.71838 & -0.01259\end{array}$

$\begin{array}{llll}\text { C } & 5.32120 & 1.54576 & -0.09977\end{array}$ 


$$
\begin{array}{llll}
\mathrm{H} & 1.77474 & 3.06513 & -0.41776 \\
\mathrm{H} & 3.76966 & 4.53893 & -0.60010 \\
\mathrm{H} & 6.05395 & 3.54646 & -0.38894 \\
\mathrm{I} & 4.56508 & -1.32402 & 0.36779 \\
\mathrm{H} & 6.31939 & 1.11920 & 0.00288 \\
\mathrm{C} & -2.99090 & -4.04926 & -0.46535 \\
\mathrm{C} & -3.52696 & -2.37218 & -2.21610 \\
\mathrm{C} & -1.19581 & -2.54199 & -1.27274 \\
\mathrm{C} & -5.40926 & 2.71939 & 0.87056 \\
\mathrm{C} & -3.19609 & 3.02239 & -0.20311 \\
\mathrm{C} & -5.02928 & 1.76990 & -1.39252 \\
\mathrm{H} & -0.91732 & -3.40032 & -1.90404 \\
\mathrm{H} & -0.92478 & -1.63644 & -1.83029 \\
\mathrm{H} & -0.58202 & -2.57851 & -0.36072 \\
\mathrm{H} & -2.77742 & -4.75381 & -1.28234 \\
\mathrm{H} & -2.35991 & -4.33145 & 0.39051 \\
\mathrm{H} & -4.04531 & -4.17434 & -0.17716 \\
\mathrm{H} & -3.25398 & -3.10812 & -2.98817 \\
\mathrm{H} & -4.60229 & -2.48014 & -2.00636 \\
\mathrm{H} & -3.35165 & -1.36953 & -2.62776 \\
\mathrm{H} & -3.59287 & 4.01578 & -0.46383 \\
\mathrm{H} & -2.61923 & 3.12461 & 0.72901 \\
\mathrm{H} & -2.51327 & 2.73356 & -1.01293 \\
\mathrm{H} & -5.78007 & 3.62645 & 0.37145 \\
\mathrm{H} & -6.27052 & 2.06291 & 1.06366 \\
\mathrm{H} & -4.97932 & 3.02219 & 1.83681 \\
\hline & -5.37008 & 2.71830 & -1.83614 \\
\hline & -4.33139 & 1.29759 & -2.09626 \\
\hline
\end{array}
$$

\section{7}

Compound 9 - Product
$\begin{array}{llll}\text { C } & -2.04702 & 3.36676 & 0.31099\end{array}$
$\begin{array}{llll}\text { C } & -2.50694 & 0.90754 & -0.09882\end{array}$
$\begin{array}{llll}\text { C } & -2.45352 & 2.60131 & 1.55402\end{array}$ 

$\begin{array}{llll}C & -3.07731 & 3.10345 & -0.76826\end{array}$
$\begin{array}{llll}\text { C } & -3.34455 & 1.81392 & -1.01601\end{array}$
$\begin{array}{llll}\text { C } & -2.69906 & 1.29578 & 1.37837\end{array}$
O $\quad-2.59951 \quad-0.47781 \quad-0.37395$
$\begin{array}{llll}\text { C } & -1.40160 & -0.96283 & -0.79306\end{array}$
O $\quad-1.22956-2.10066-1.11620$
$\begin{array}{llll}\text { C } & -0.43879 & 0.16010 & -0.78109\end{array}$
$\begin{array}{llll}C & -1.05373 & 1.27668 & -0.39467\end{array}$
$\begin{array}{llll}\text { C } & -0.71404 & 2.70920 & -0.18549\end{array}$
$\begin{array}{llll}\text { H } & -0.37105 & 3.16869 & -1.12350\end{array}$
$\begin{array}{llll}\text { H } & -1.90310 & 4.43415 & 0.50245\end{array}$
$\begin{array}{llll}H & -2.49910 & 3.10253 & 2.52047\end{array}$
$\begin{array}{llll}H & -3.53504 & 3.93185 & -1.30837\end{array}$
$\begin{array}{llll}\text { C } & -4.28255 & 1.27317 & -2.08470\end{array}$
$\begin{array}{llll}\text { C } & -3.04146 & 0.28475 & 2.46190\end{array}$
$\begin{array}{llll}0 & 0.84982 & -0.02738 & -1.18773\end{array}$
$\begin{array}{llll}H & 0.08424 & 2.81829 & 0.56216\end{array}$
$\begin{array}{llll}\text { C } & 1.60455 & -0.86707 & -0.42214\end{array}$
$\begin{array}{llll}\text { C } & 2.88558 & -1.20460 & -1.10974\end{array}$
$\begin{array}{llll}0 & 1.24223 & -1.25651 & 0.64734\end{array}$
$\begin{array}{llll}\text { C } & 2.86738 & -1.32742 & -2.50710\end{array}$
$\begin{array}{llll}\text { C } & 4.00843 & -1.70334 & -3.20674\end{array}$
$\begin{array}{llll}\text { C } & 5.19194 & -1.94389 & -2.51177\end{array}$
$\begin{array}{llll}\text { C } & 4.08320 & -1.45044 & -0.41955\end{array}$
$\begin{array}{llll}\text { C } & 5.23198 & -1.81150 & -1.12473\end{array}$

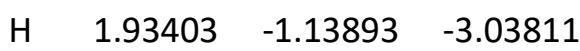
$\begin{array}{llll}\text { H } & 3.97259 & -1.80667 & -4.29174\end{array}$
$\begin{array}{llll}\text { H } & 6.09743 & -2.23464 & -3.04694\end{array}$
$\begin{array}{llll}\text { I } & 4.29217 & -1.23513 & 1.66812\end{array}$
$\begin{array}{llll}\text { H } & 6.16390 & -1.98843 & -0.58709\end{array}$
$\begin{array}{llll}\text { C } & -3.17913 & 0.99926 & 3.80998\end{array}$
$\begin{array}{llll}\text { C } & -4.37518 & -0.40645 & 2.13927\end{array}$
$\begin{array}{llll}\text { C } & -1.92390 & -0.76702 & 2.59336\end{array}$
$\begin{array}{llll}\text { C } & -4.99875 & 2.43440 & -2.78142\end{array}$
$\begin{array}{llll}\text { C } & -3.49145 & 0.49313 & -3.15052\end{array}$ 


$\begin{array}{llll}\mathrm{C} & -5.34182 & 0.35960 & -1.44887 \\ \mathrm{H} & -2.12505 & -1.40217 & 3.47026 \\ \mathrm{H} & -1.86090 & -1.42939 & 1.72042 \\ \mathrm{H} & -0.94340 & -0.28928 & 2.73876 \\ \mathrm{H} & -3.46010 & 0.26886 & 4.58308 \\ \mathrm{H} & -2.23247 & 1.46824 & 4.11697 \\ \mathrm{H} & -3.95724 & 1.77635 & 3.77779 \\ \mathrm{H} & -4.62894 & -1.11406 & 2.94399 \\ \mathrm{H} & -5.19023 & 0.33005 & 2.06523 \\ \mathrm{H} & -4.32253 & -0.96895 & 1.19816 \\ \mathrm{H} & -4.16848 & 0.20255 & -3.96891 \\ \mathrm{H} & -2.69026 & 1.11523 & -3.57862 \\ \mathrm{H} & -3.04720 & -0.42887 & -2.75290 \\ \mathrm{H} & -5.69342 & 2.03591 & -3.53565 \\ \mathrm{H} & -5.58148 & 3.03497 & -2.06722 \\ \mathrm{H} & -4.28838 & 3.09903 & -3.29539 \\ \mathrm{H} & -6.04091 & 0.00885 & -2.22401 \\ \mathrm{H} & -4.88682 & -0.52205 & -0.97976 \\ \mathrm{H} & -5.92239 & 0.90426 & -0.68846\end{array}$


10. Spectra for new compounds

${ }^{1} \mathrm{H}$-NMR (400 MHz, $\mathrm{CDCl}_{3}$ ) of compound 28

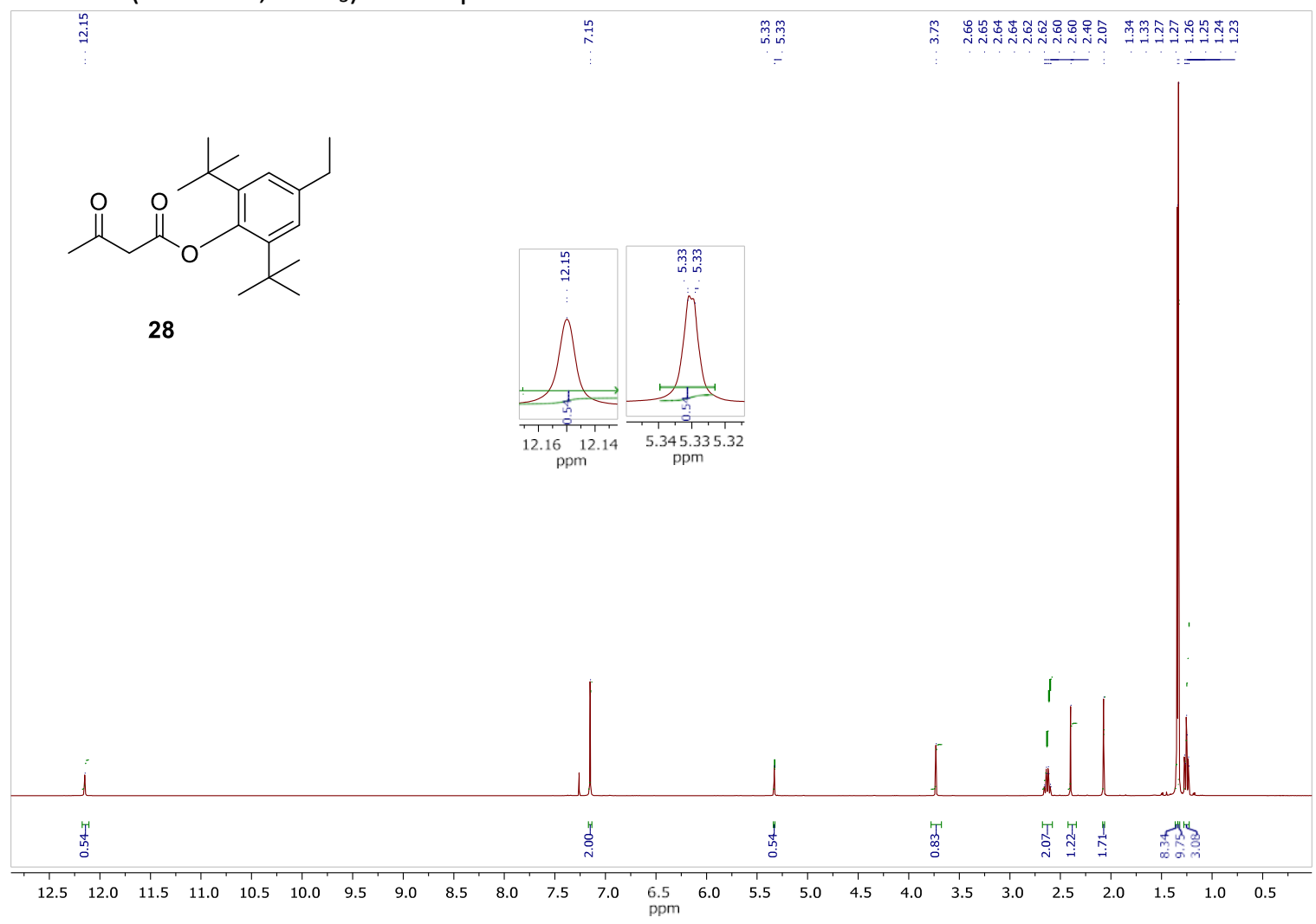

${ }^{13}$ C-NMR $\left(100 \mathrm{MHz}, \mathrm{CDCl}_{3}\right)$ of compound 28

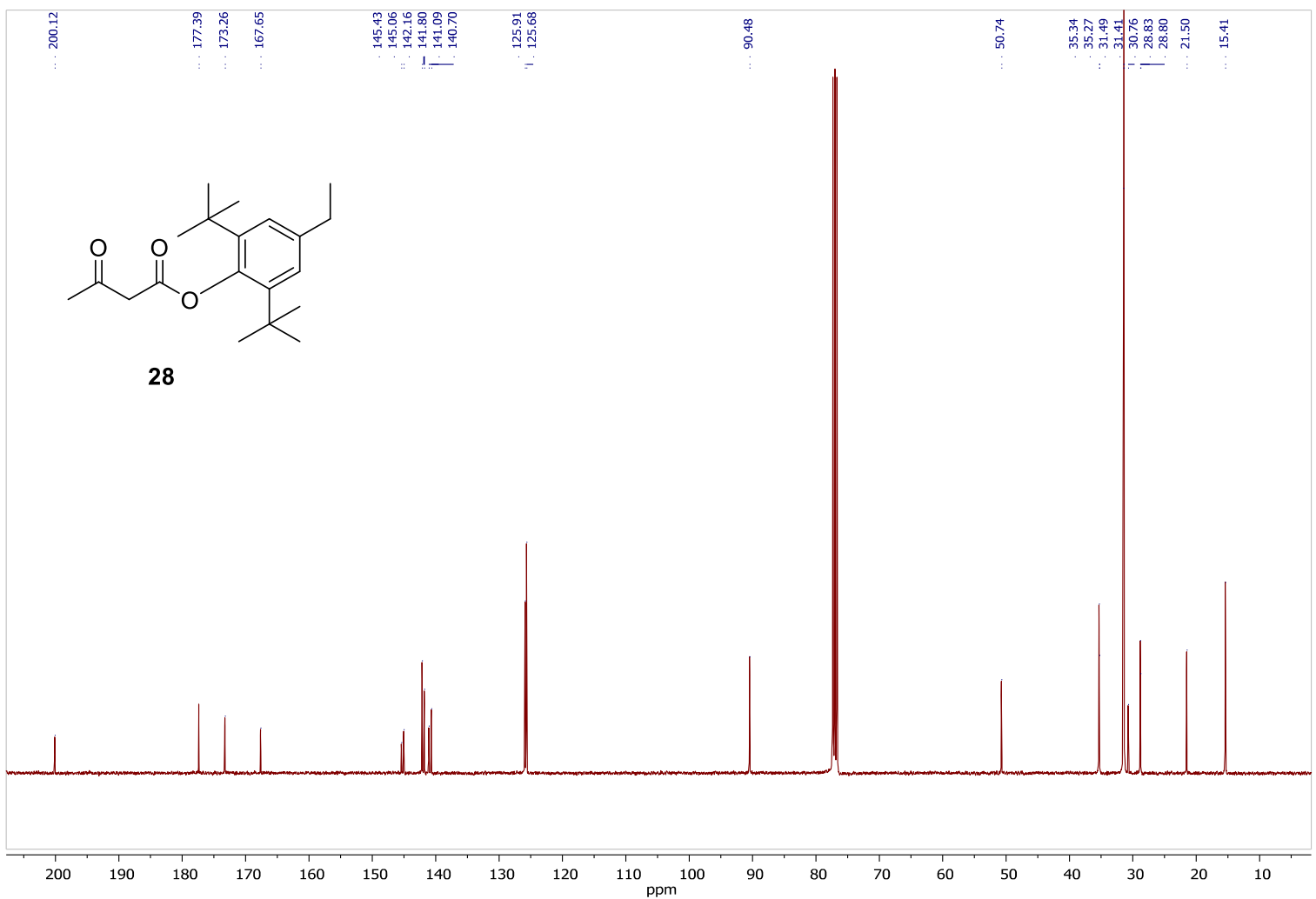


IR of compound $\mathbf{2 8}$

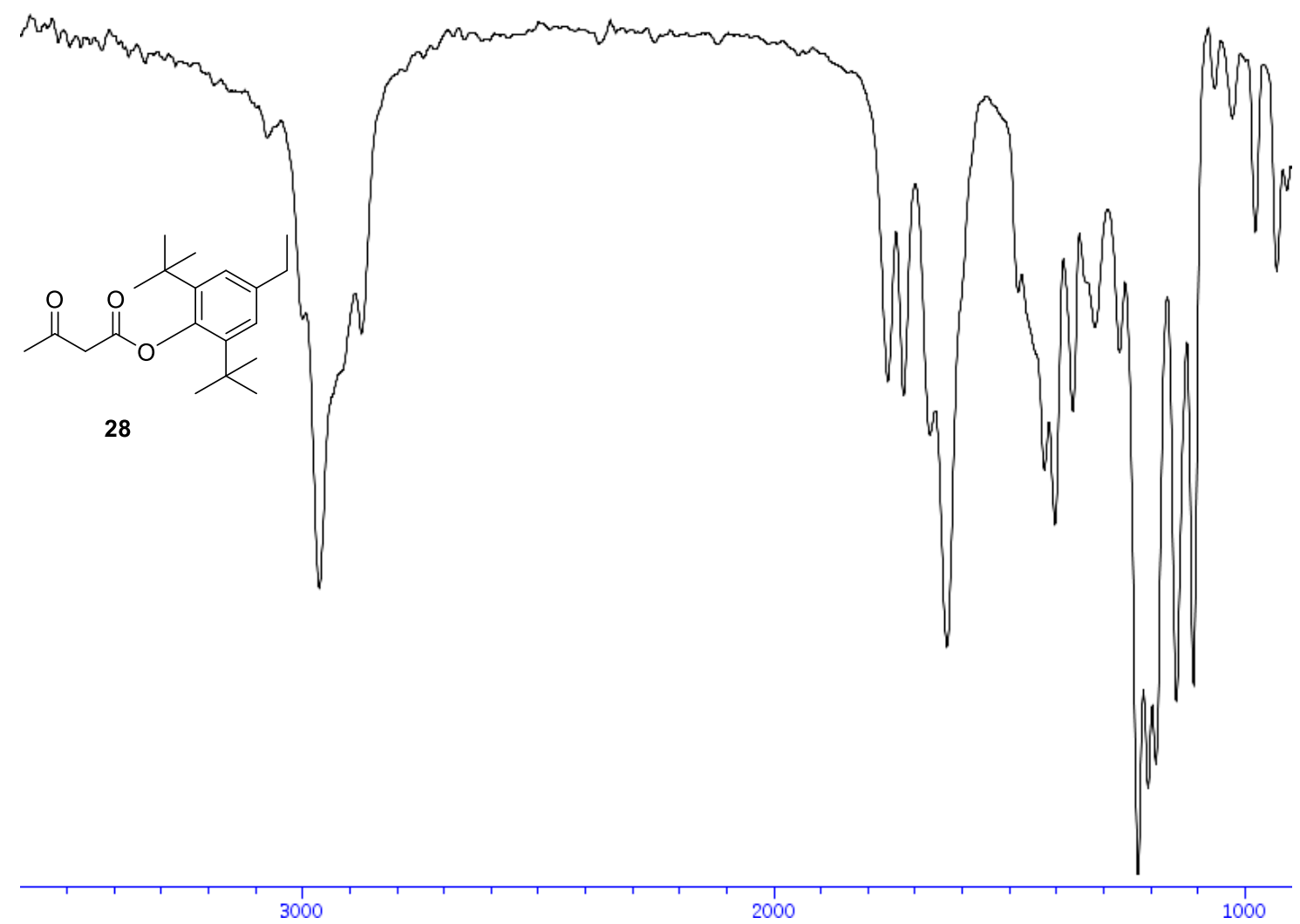


${ }^{1} \mathbf{H}$-NMR (400 MHz, $\mathrm{CDCl}_{3}$ ) of compound $\mathbf{8 b}$

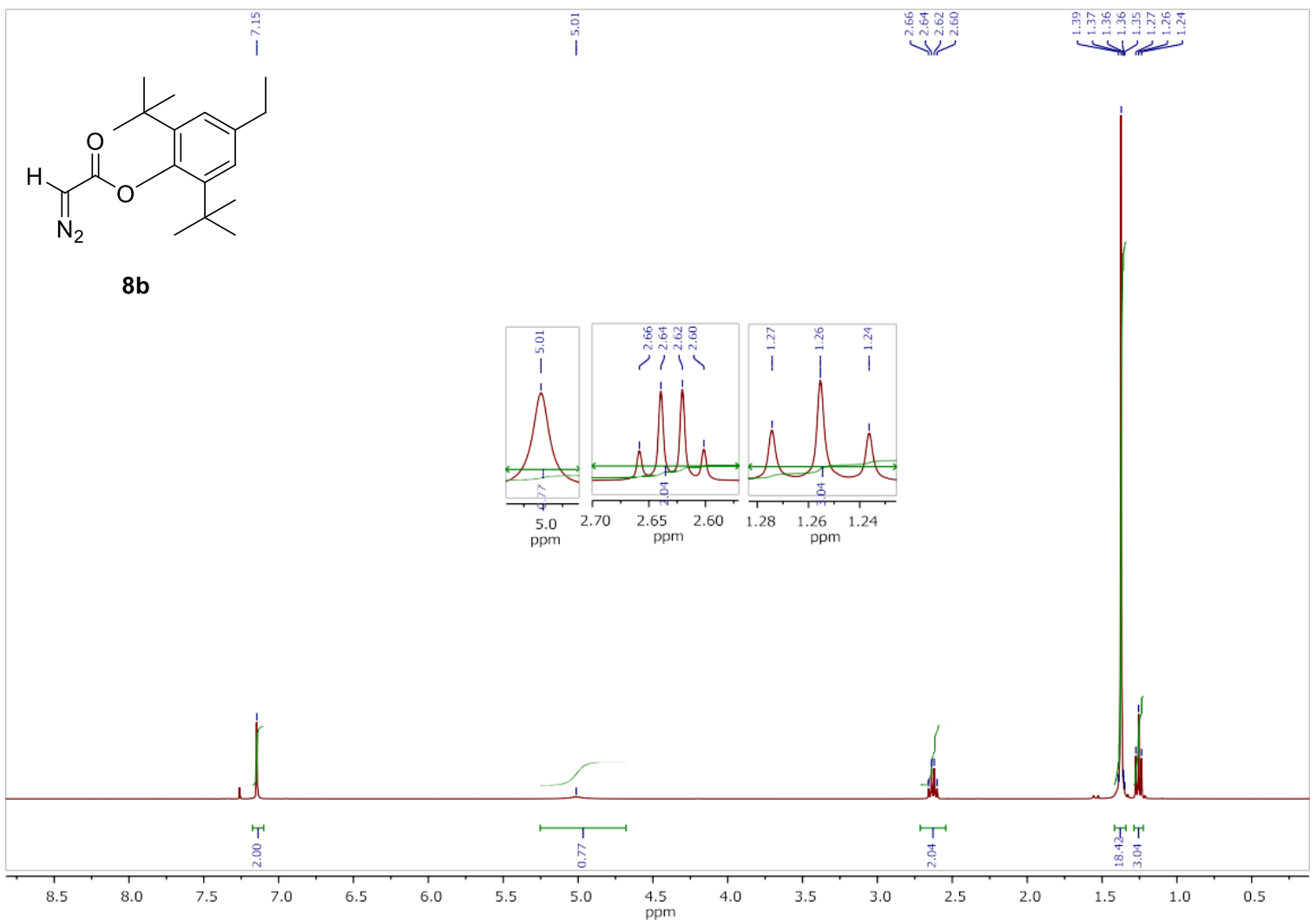

${ }^{13} \mathrm{C}-\mathrm{NMR}\left(100 \mathrm{MHz}, \mathrm{CDCl}_{3}\right)$ of compound $\mathbf{8 b}$

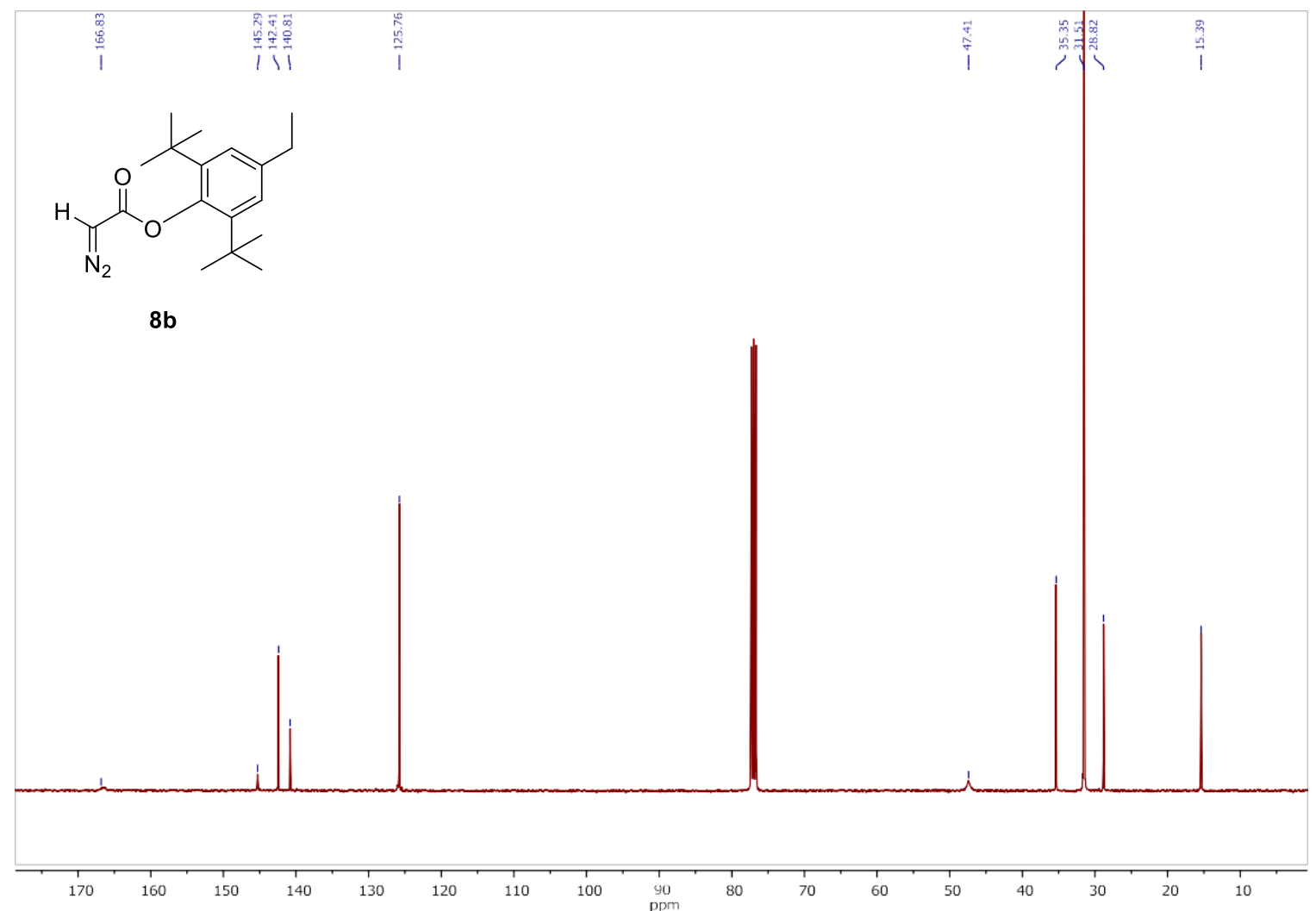




\section{IR of compound $\mathbf{8 b}$}

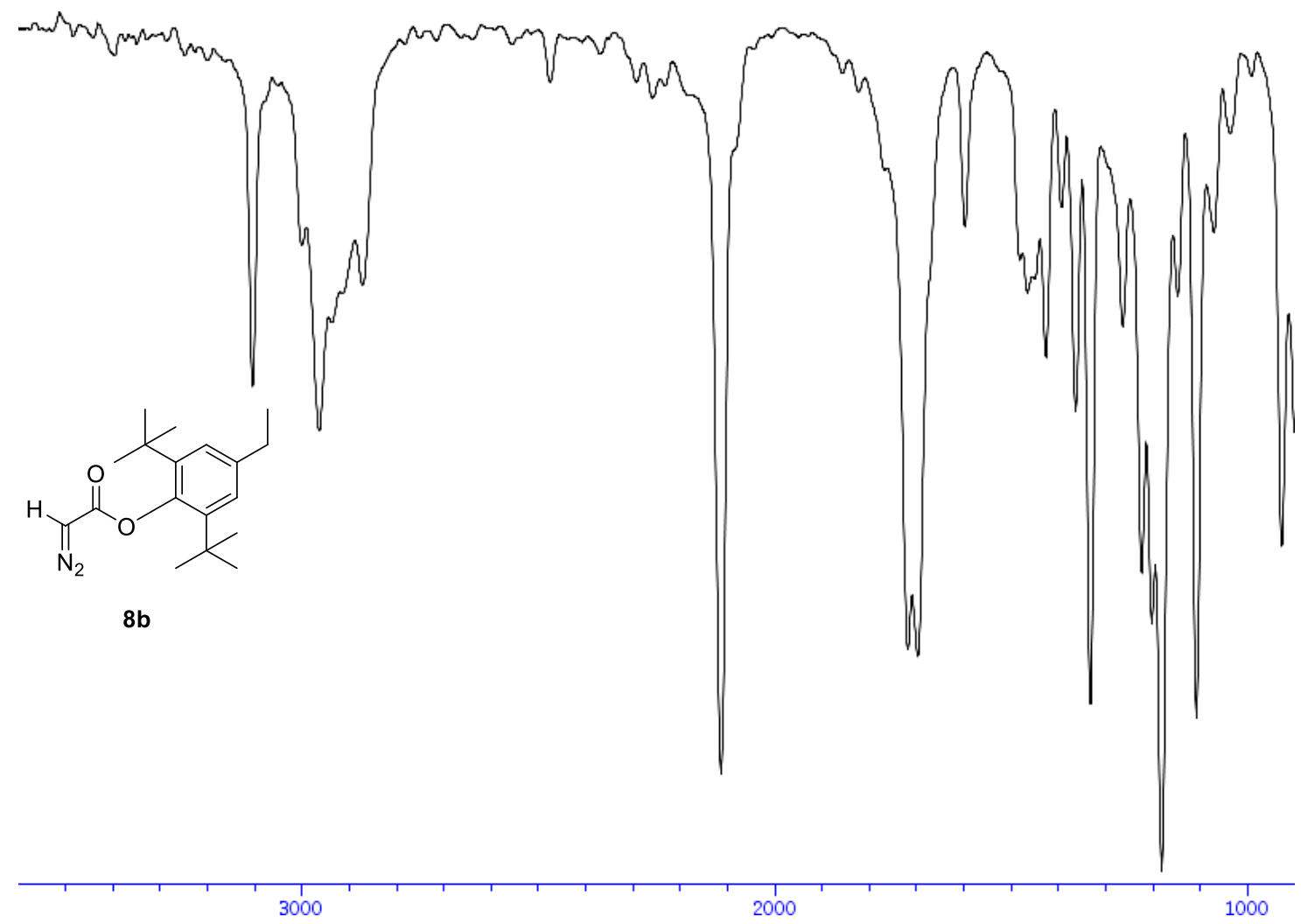


${ }^{1} \mathrm{H}$-NMR (400 MHz, $\mathrm{CDCl}_{3}$ ) of compound 30

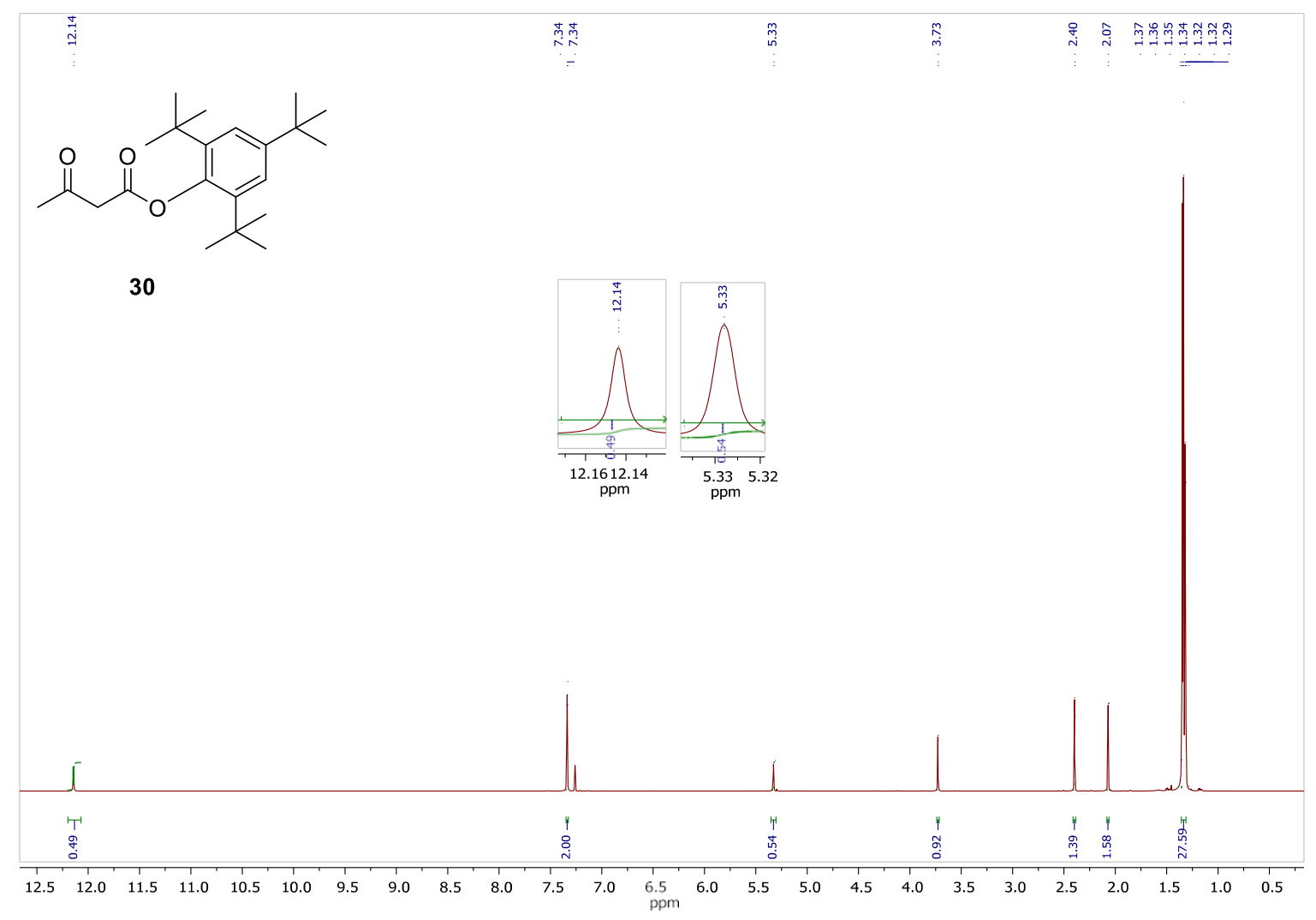

${ }^{13} \mathrm{C}$-NMR (100 MHz, $\mathrm{CDCl}_{3}$ ) of compound $\mathbf{3 0}$

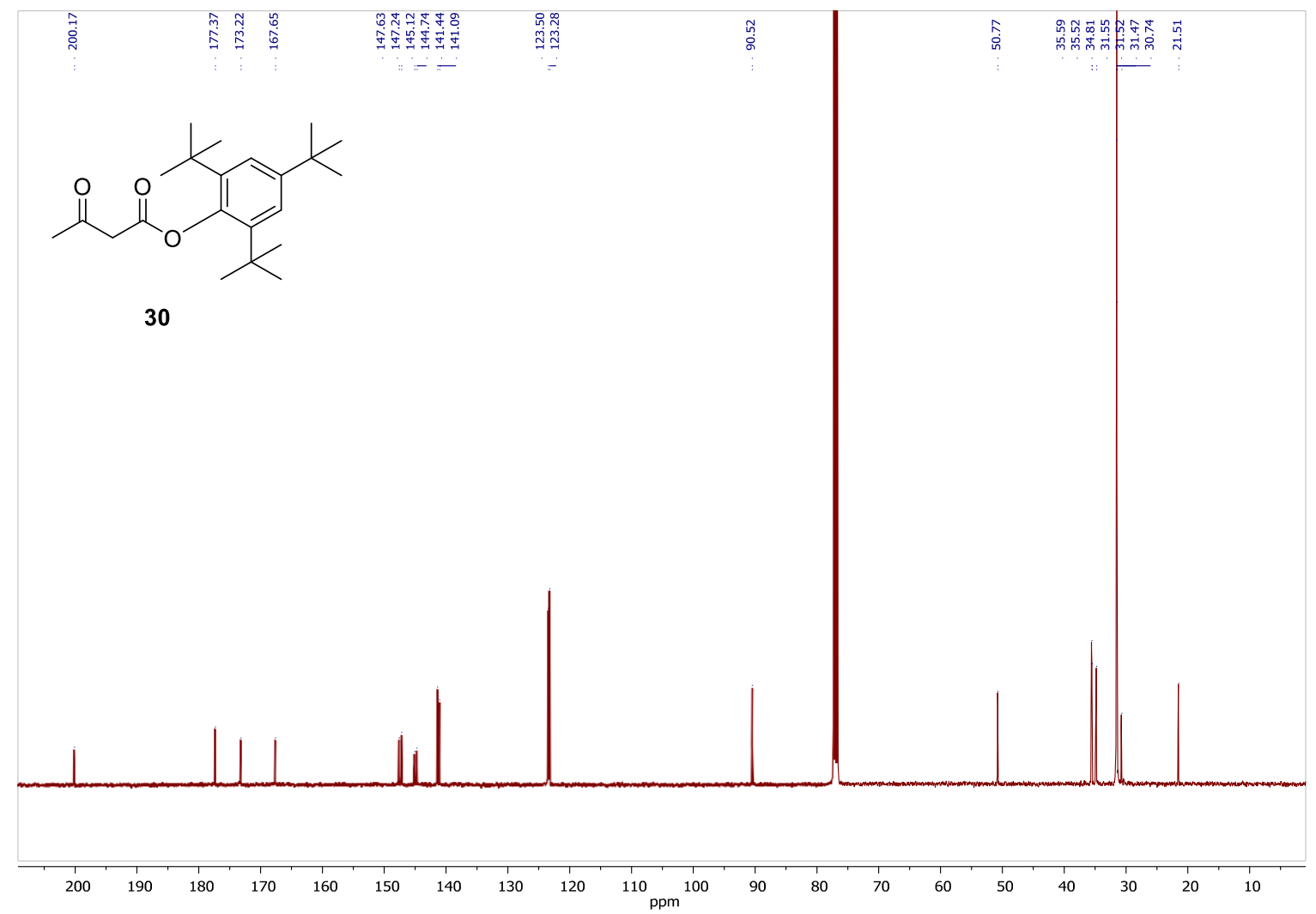


IR of compound $\mathbf{3 0}$

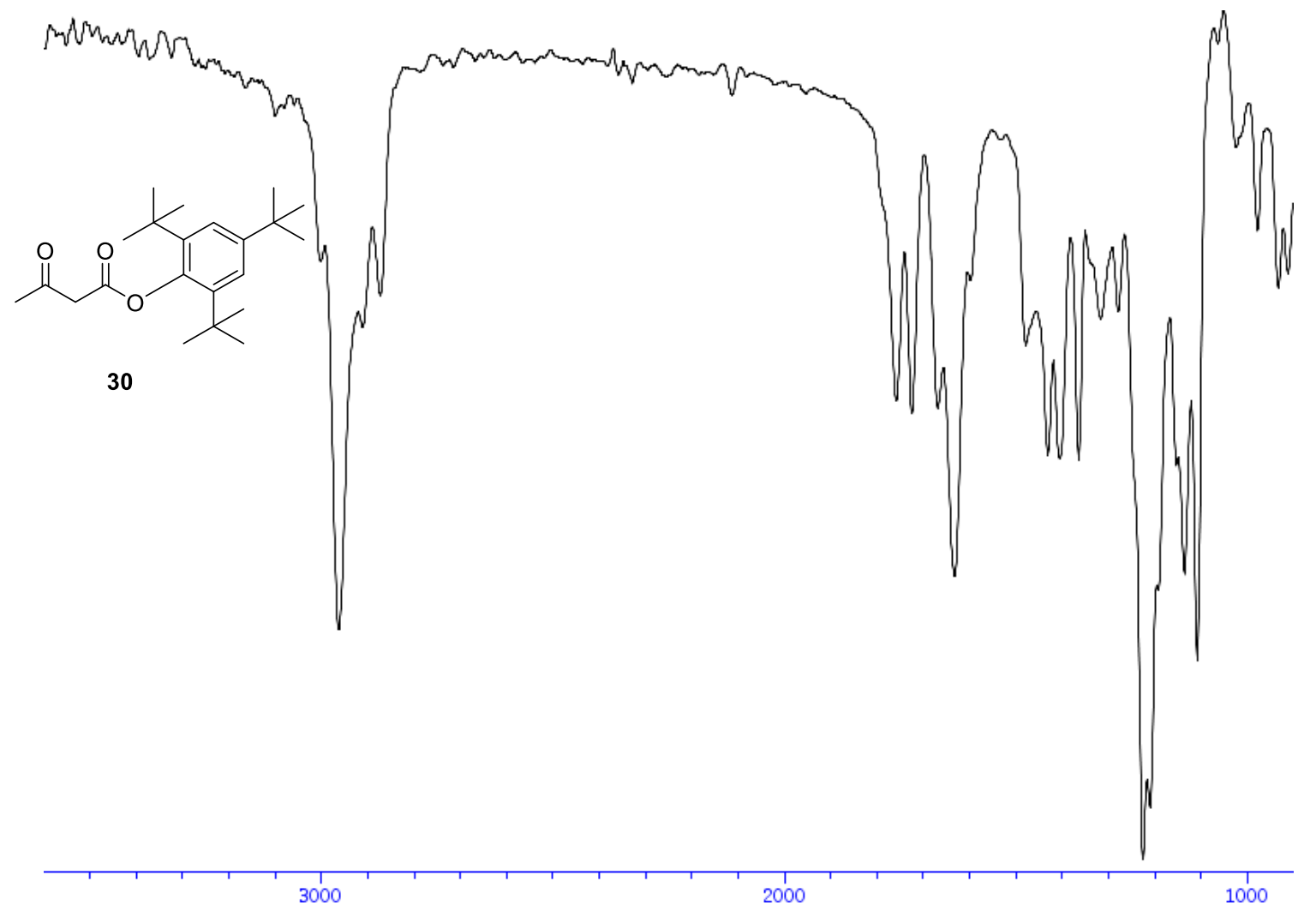


${ }^{1} \mathbf{H}-\mathrm{NMR}\left(400 \mathrm{MHz}, \mathrm{CDCl}_{3}\right.$ ) of compound $8 \mathrm{C}$

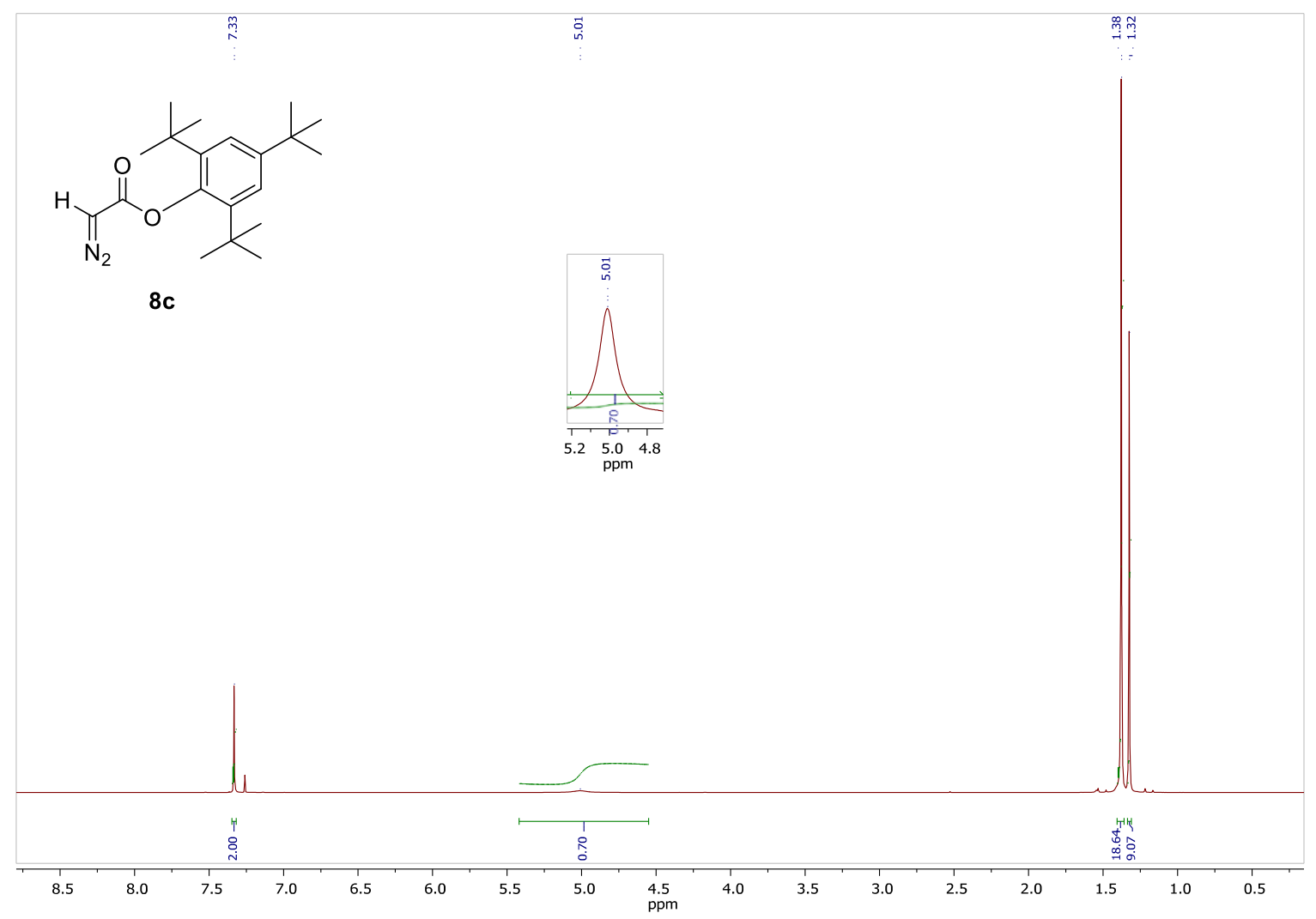

${ }^{13} \mathrm{C}$-NMR (100 MHz, $\mathrm{CDCl}_{3}$ ) of compound $8 \mathrm{c}$

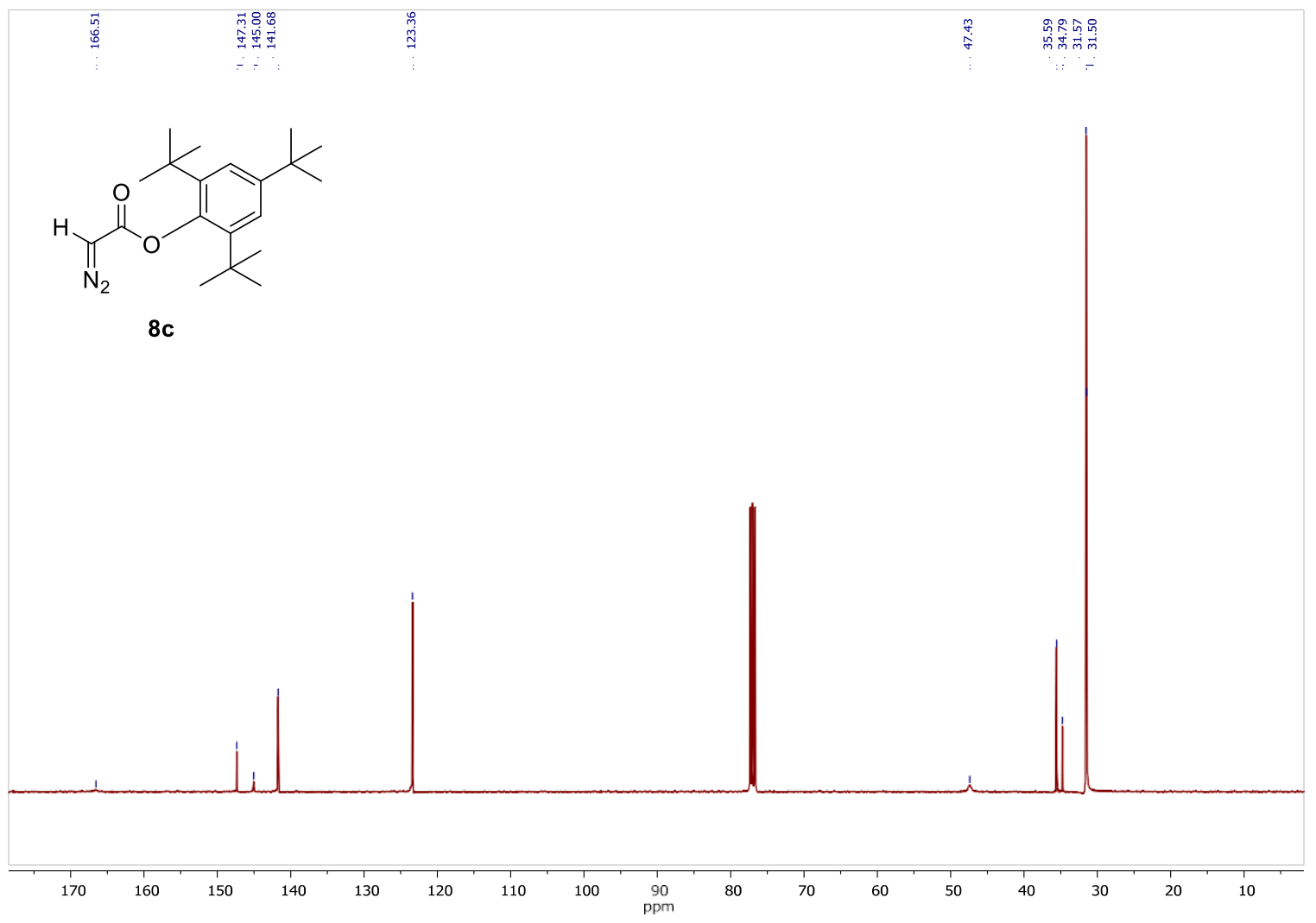

S113 
IR of compound 8c

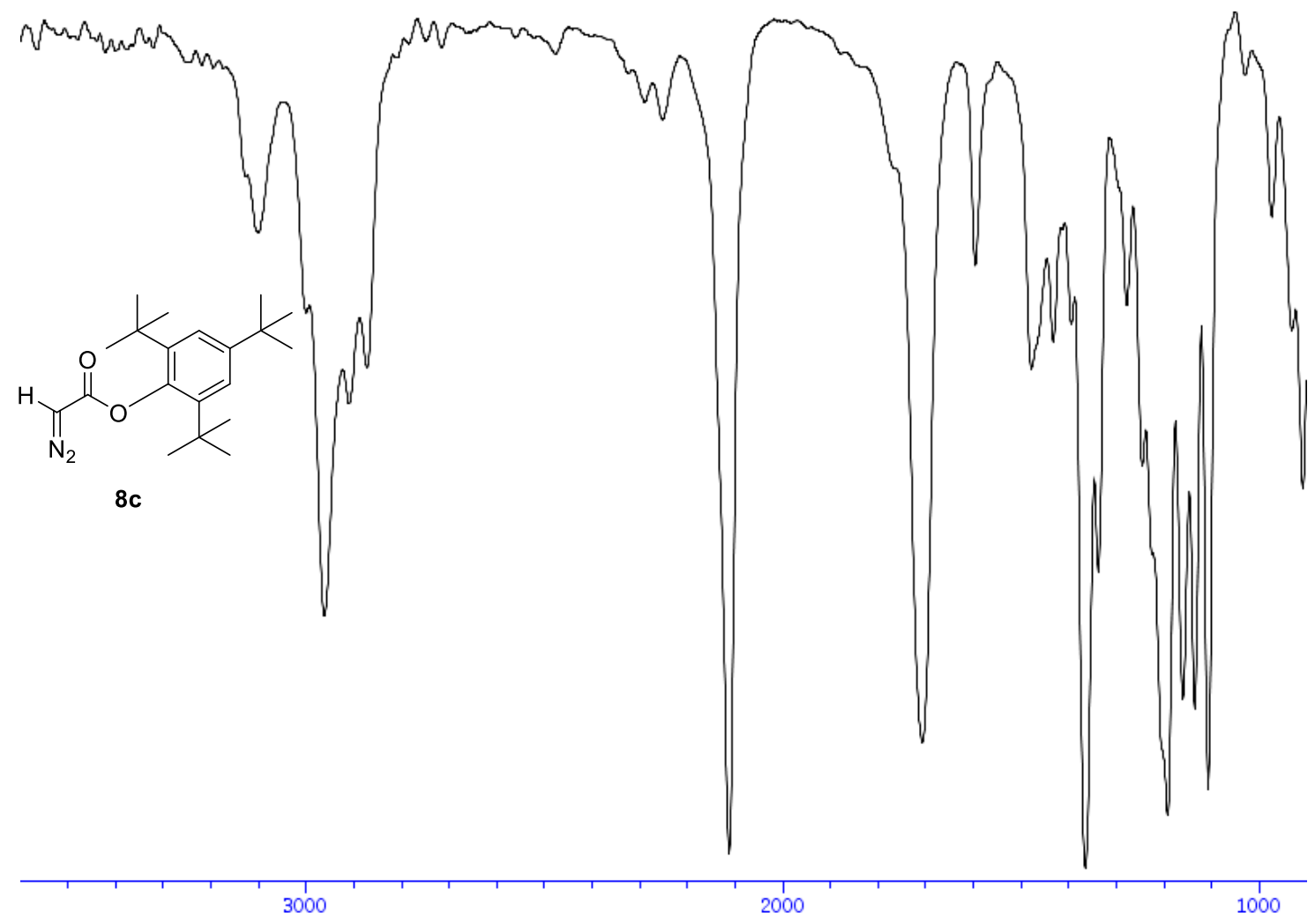


${ }^{1} \mathrm{H}$-NMR (400 MHz, $\mathrm{CDCl}_{3}$ ) of compound 34

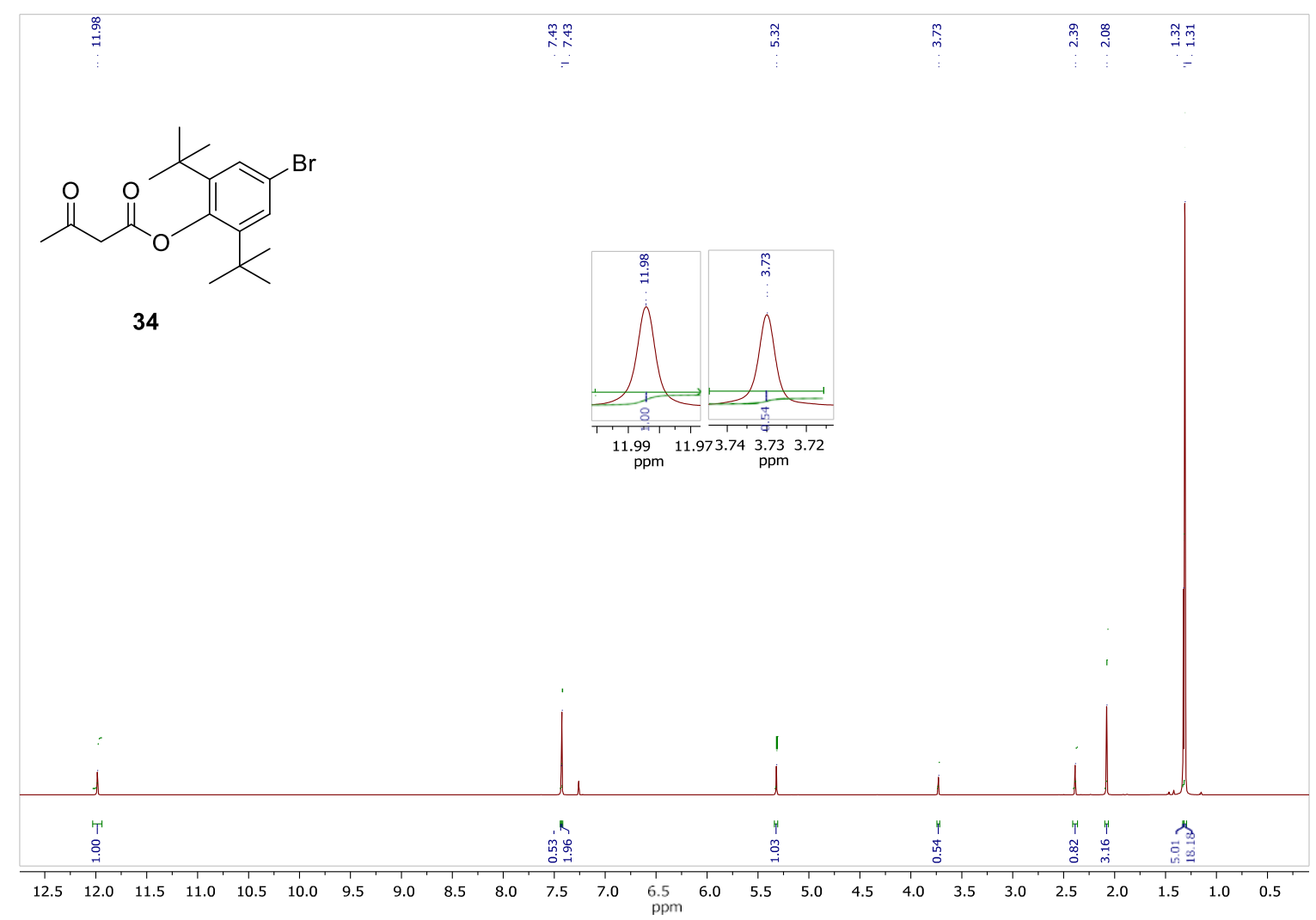

${ }^{13}$ C-NMR (100 MHz, $\mathrm{CDCl}_{3}$ ) of compound 34

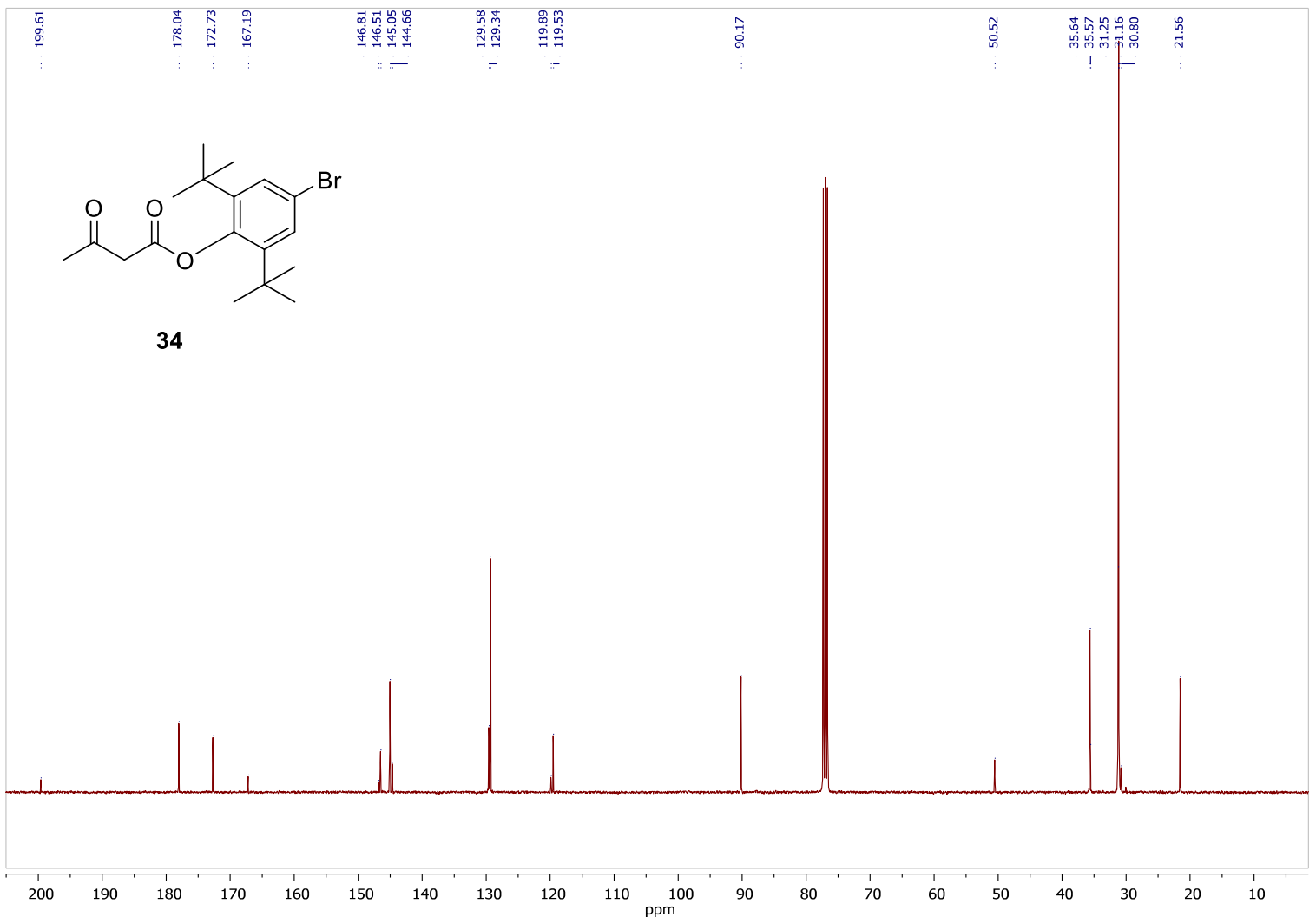


IR of compound $\mathbf{3 4}$

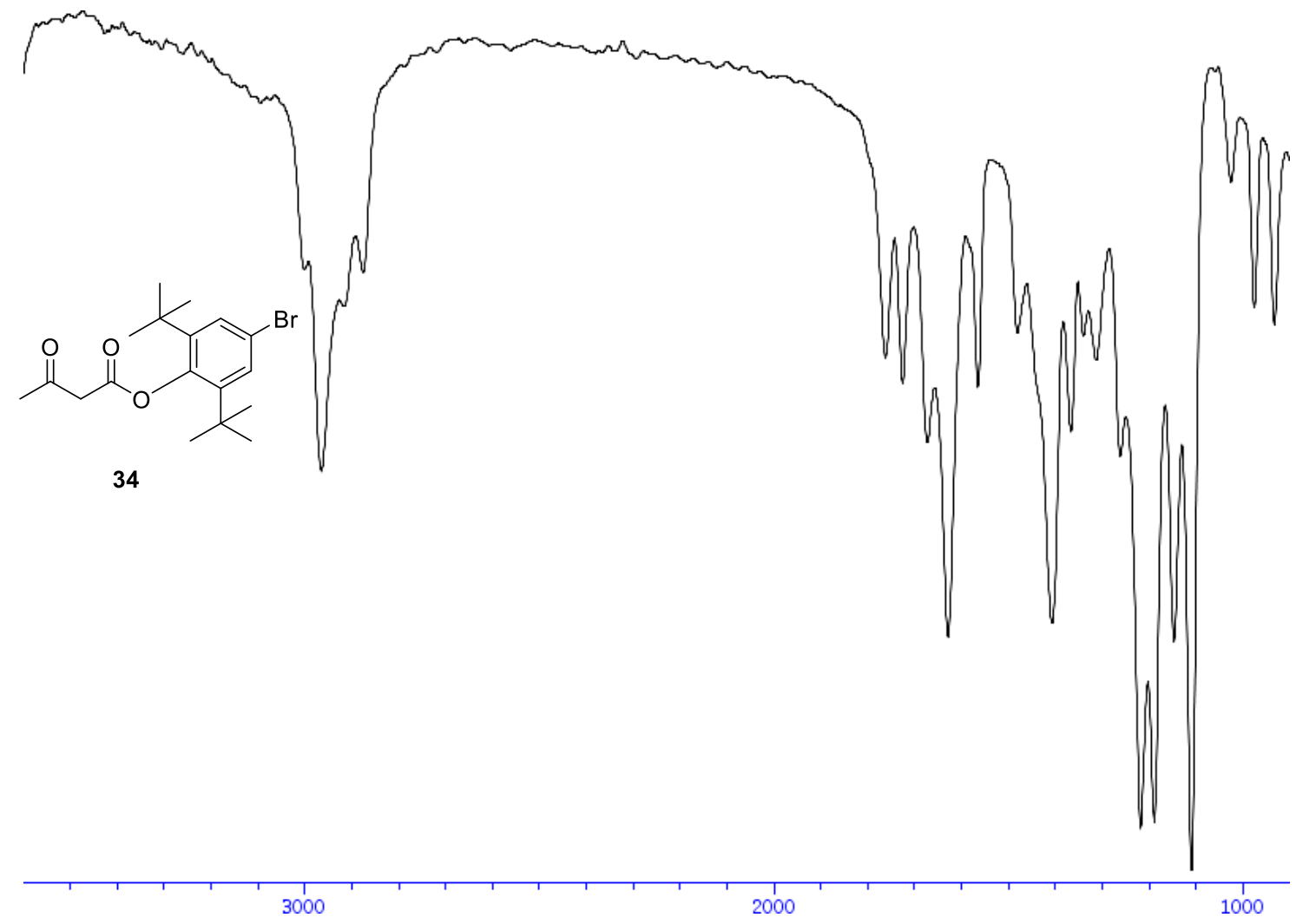


${ }^{1} \mathbf{H}$-NMR (400 MHz, $\mathrm{CDCl}_{3}$ ) of compound $8 \mathbf{e}$

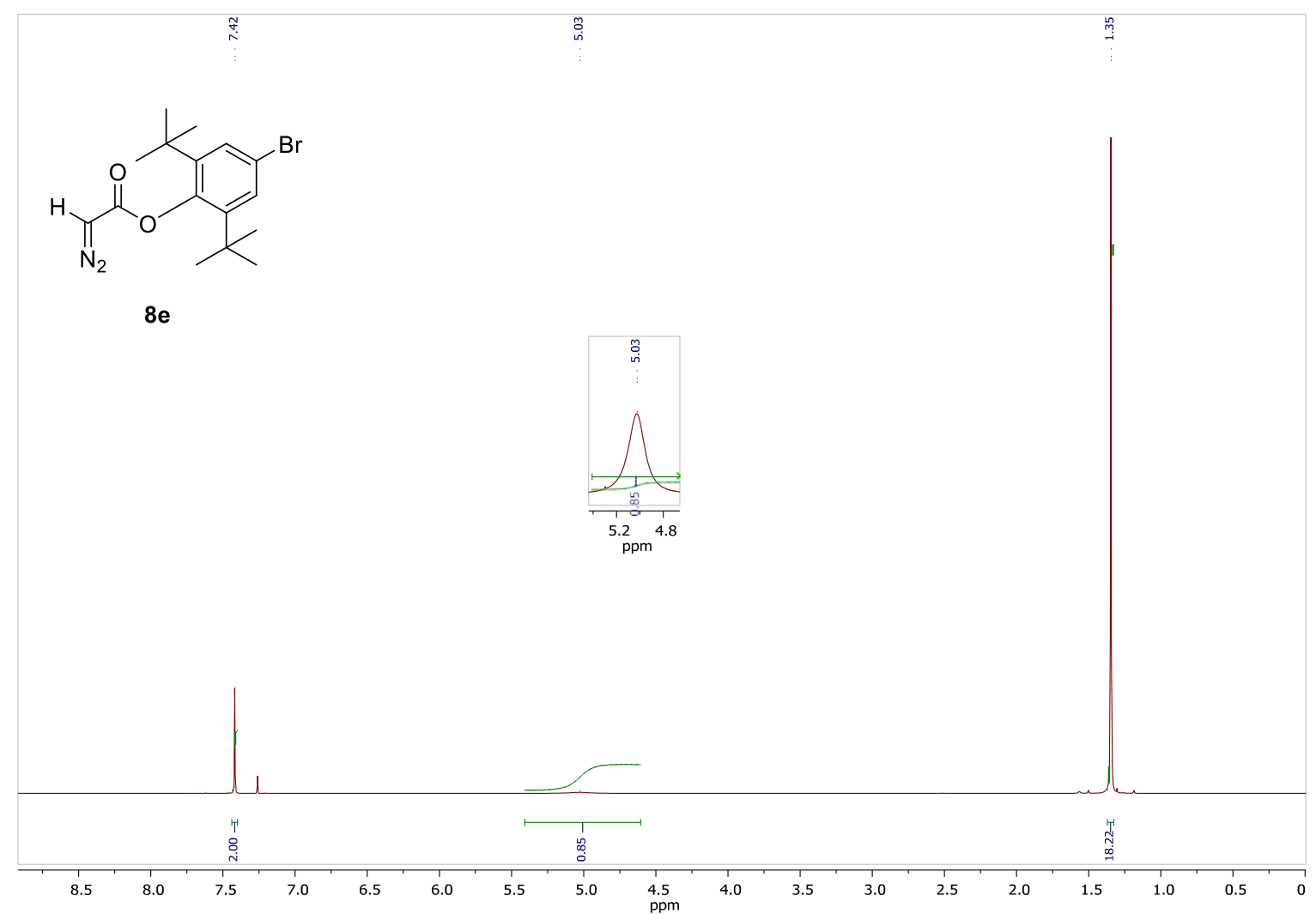

${ }^{13} \mathrm{C}-\mathrm{NMR}\left(100 \mathrm{MHz}, \mathrm{CDCl}_{3}\right)$ of compound $8 \mathrm{e}$

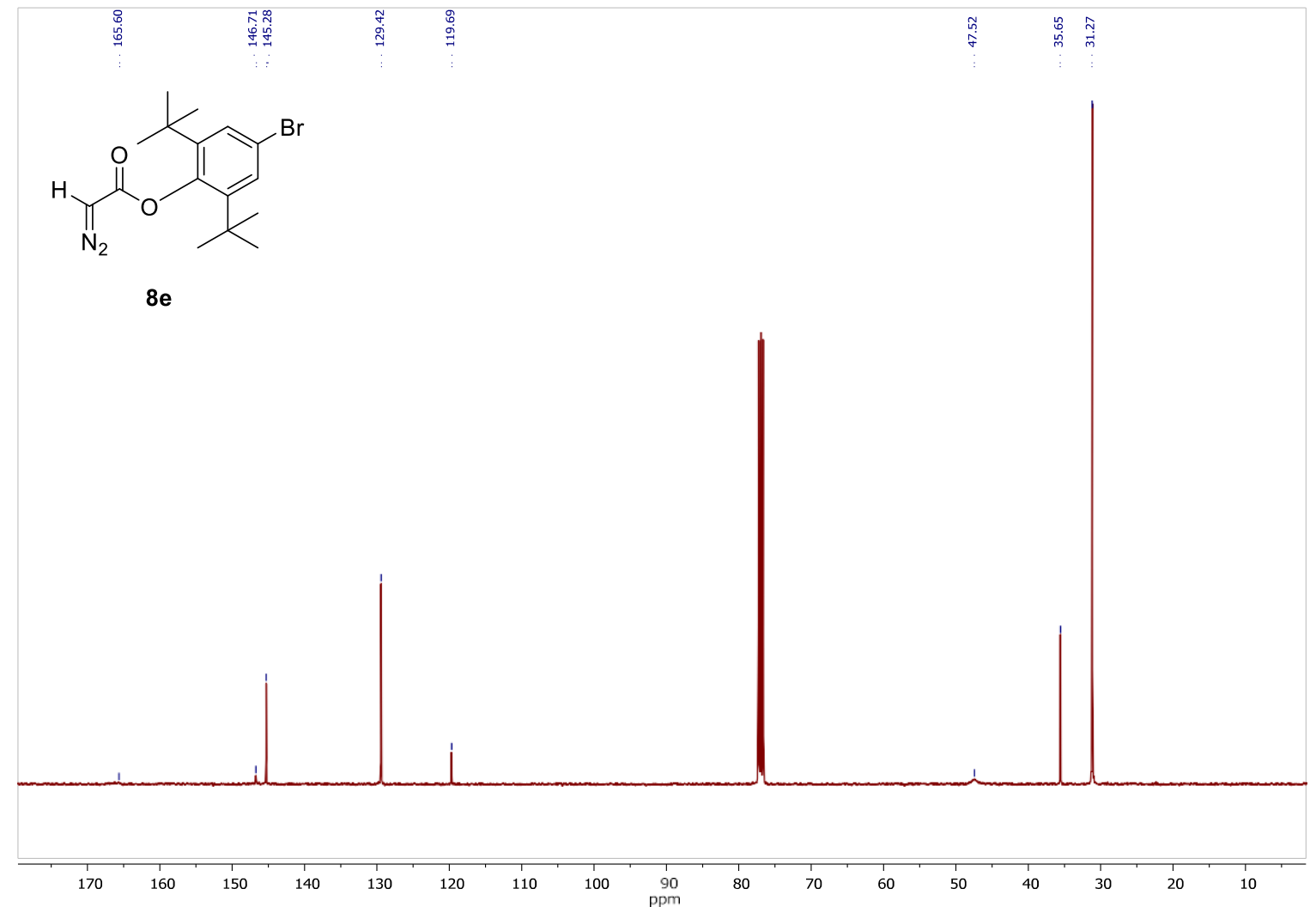


IR of compound $8 \mathbf{e}$

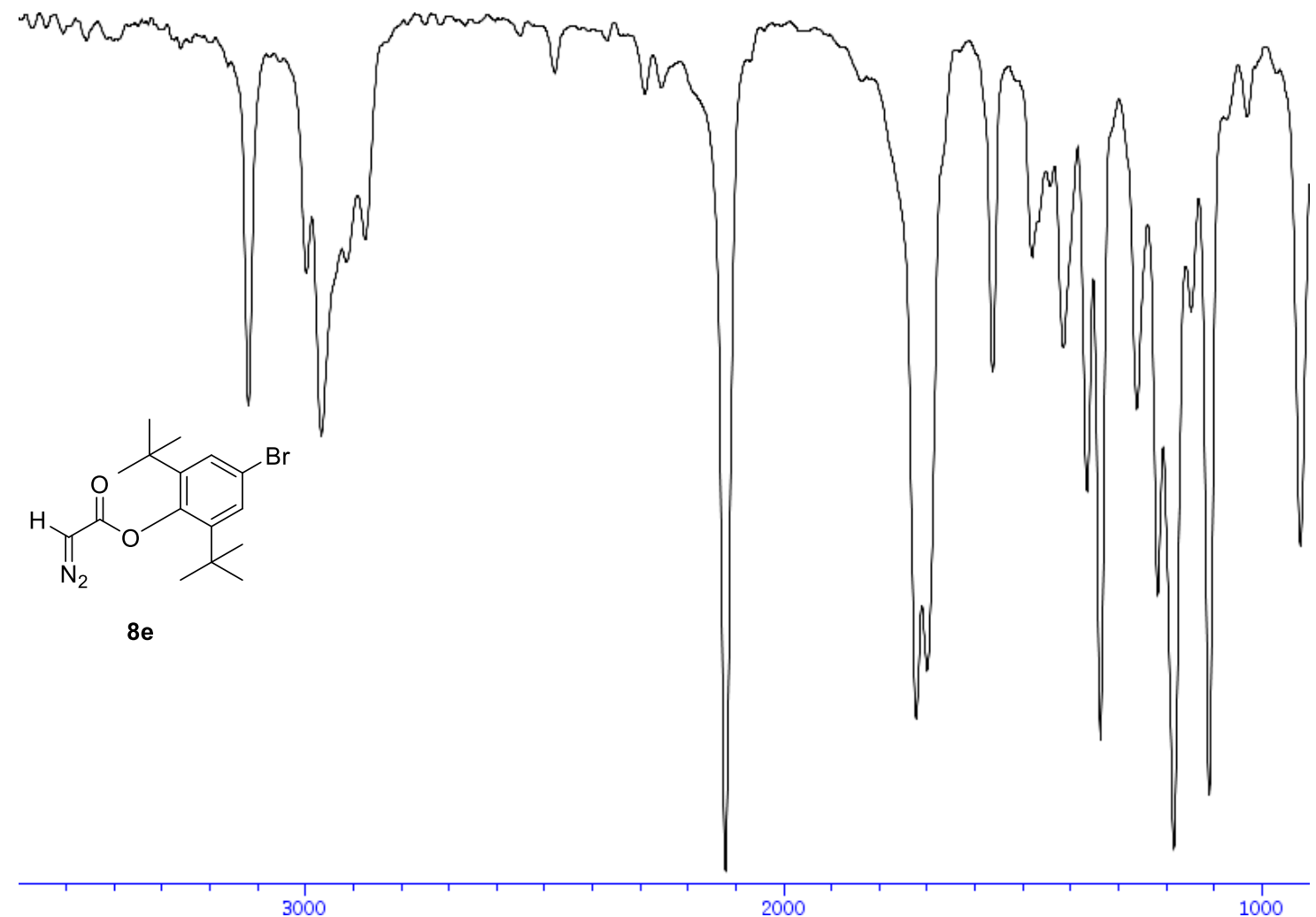


${ }^{1} \mathrm{H}$-NMR (400 MHz, $\mathrm{CDCl}_{3}$ ) of compound 36

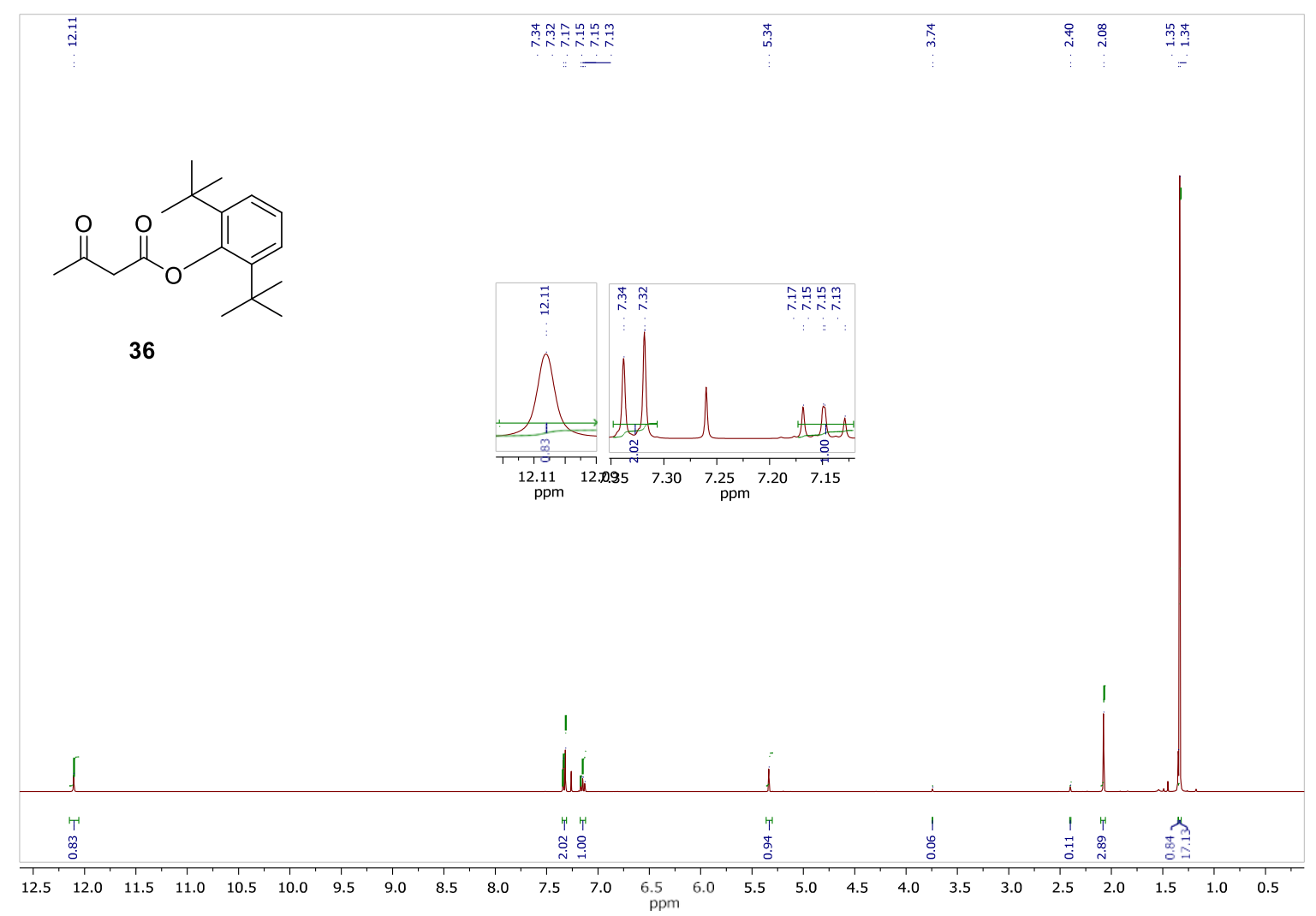

${ }^{13}$ C-NMR (100 MHz, $\mathrm{CDCl}_{3}$ ) of compound 36

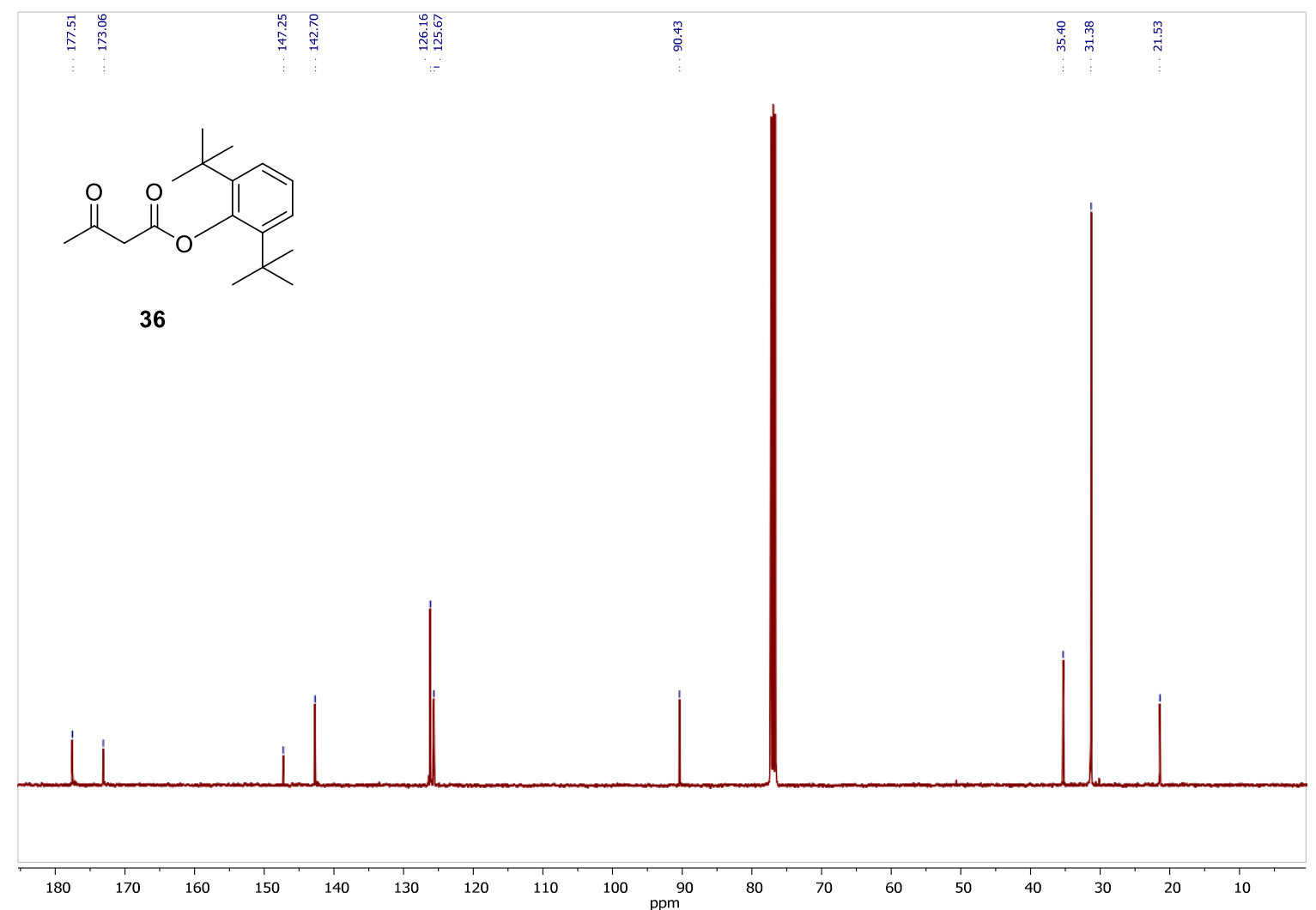


IR of compound $\mathbf{3 6}$

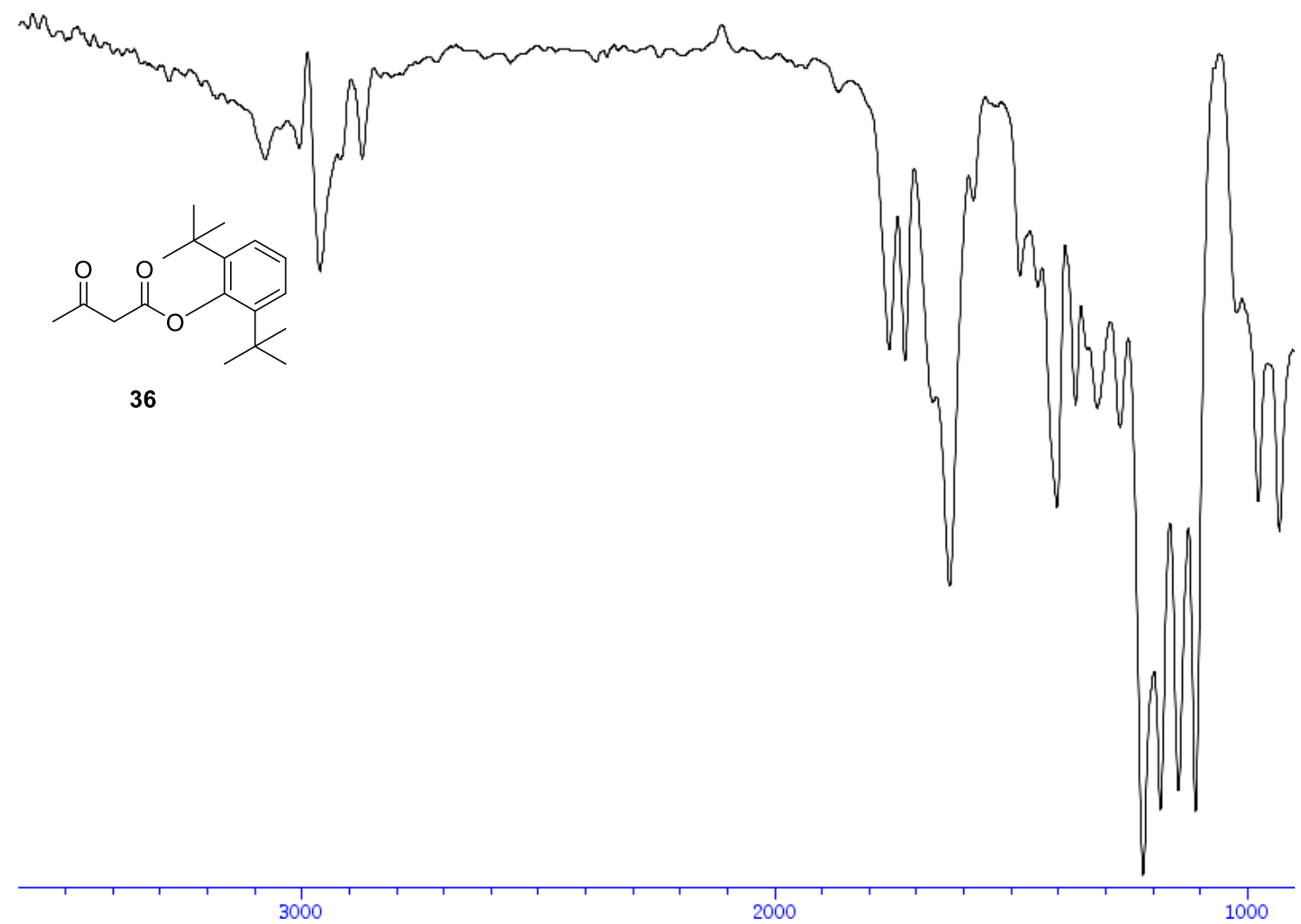


${ }^{1} \mathbf{H}$-NMR (400 MHz, $\mathrm{CDCl}_{3}$ ) of compound $8 \mathbf{f}$

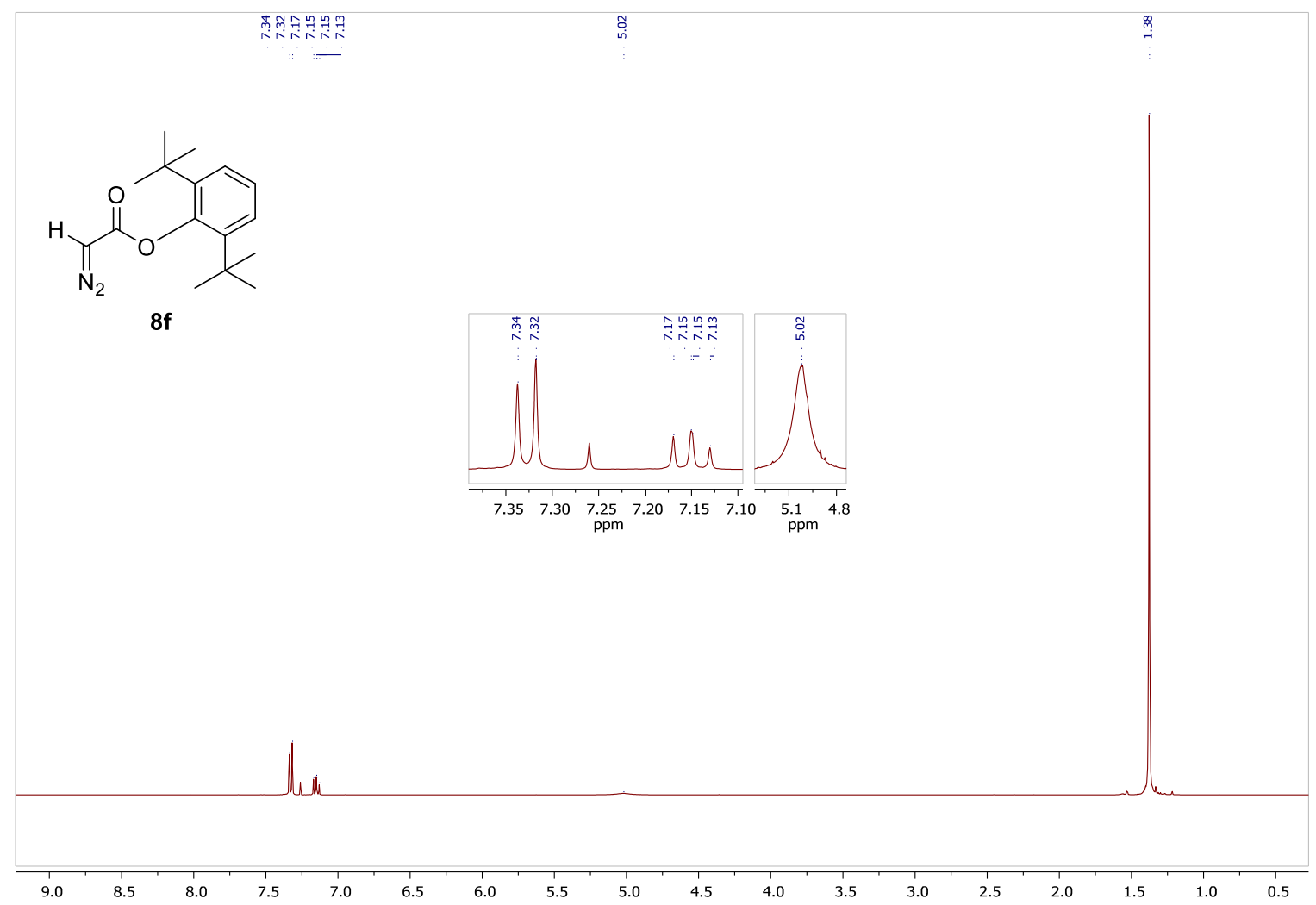

${ }^{13} \mathrm{C}-\mathrm{NMR}\left(100 \mathrm{MHz}, \mathrm{CDCl}_{3}\right)$ of compound $8 \mathrm{f}$

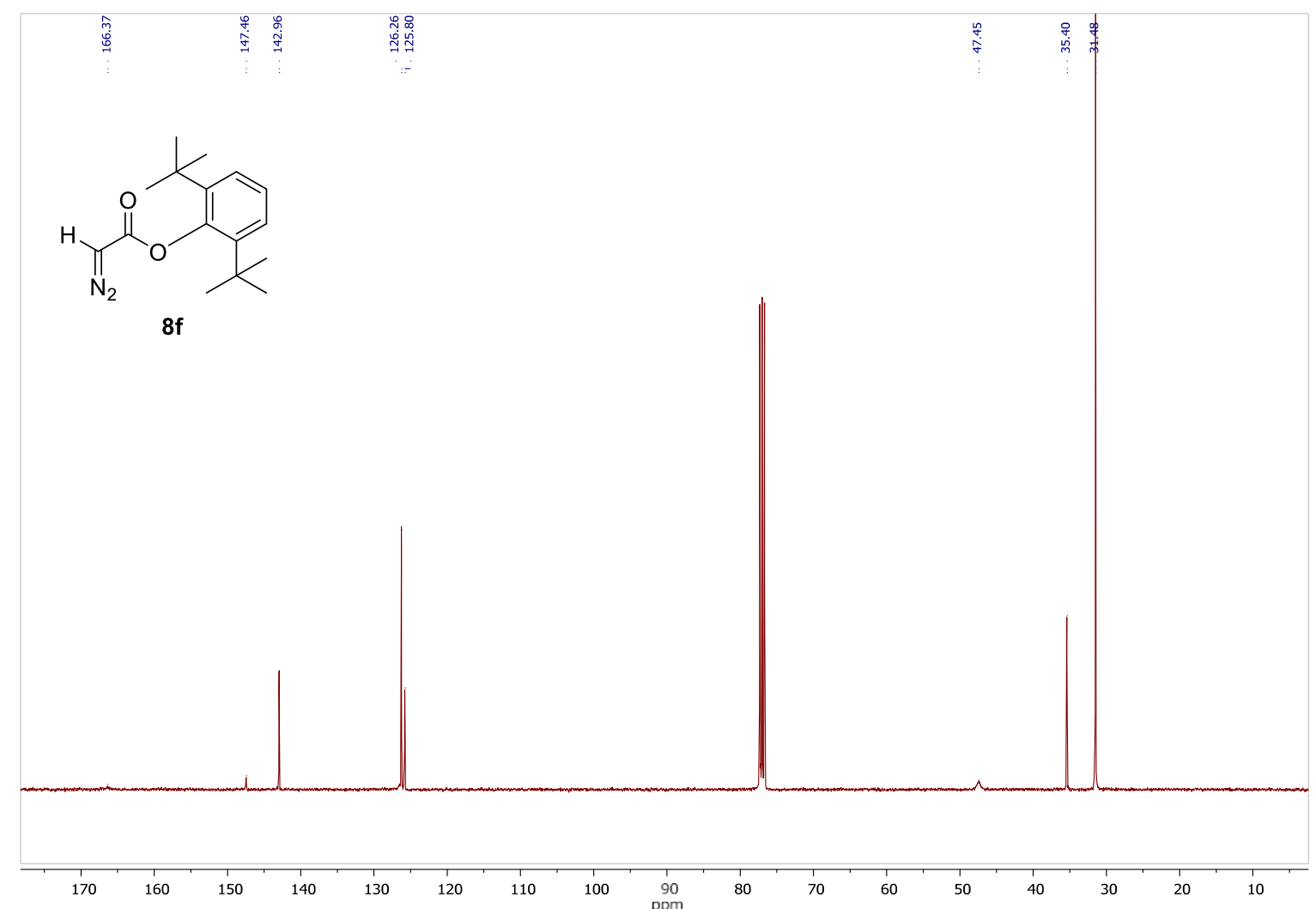


IR of compound $\mathbf{8 f}$

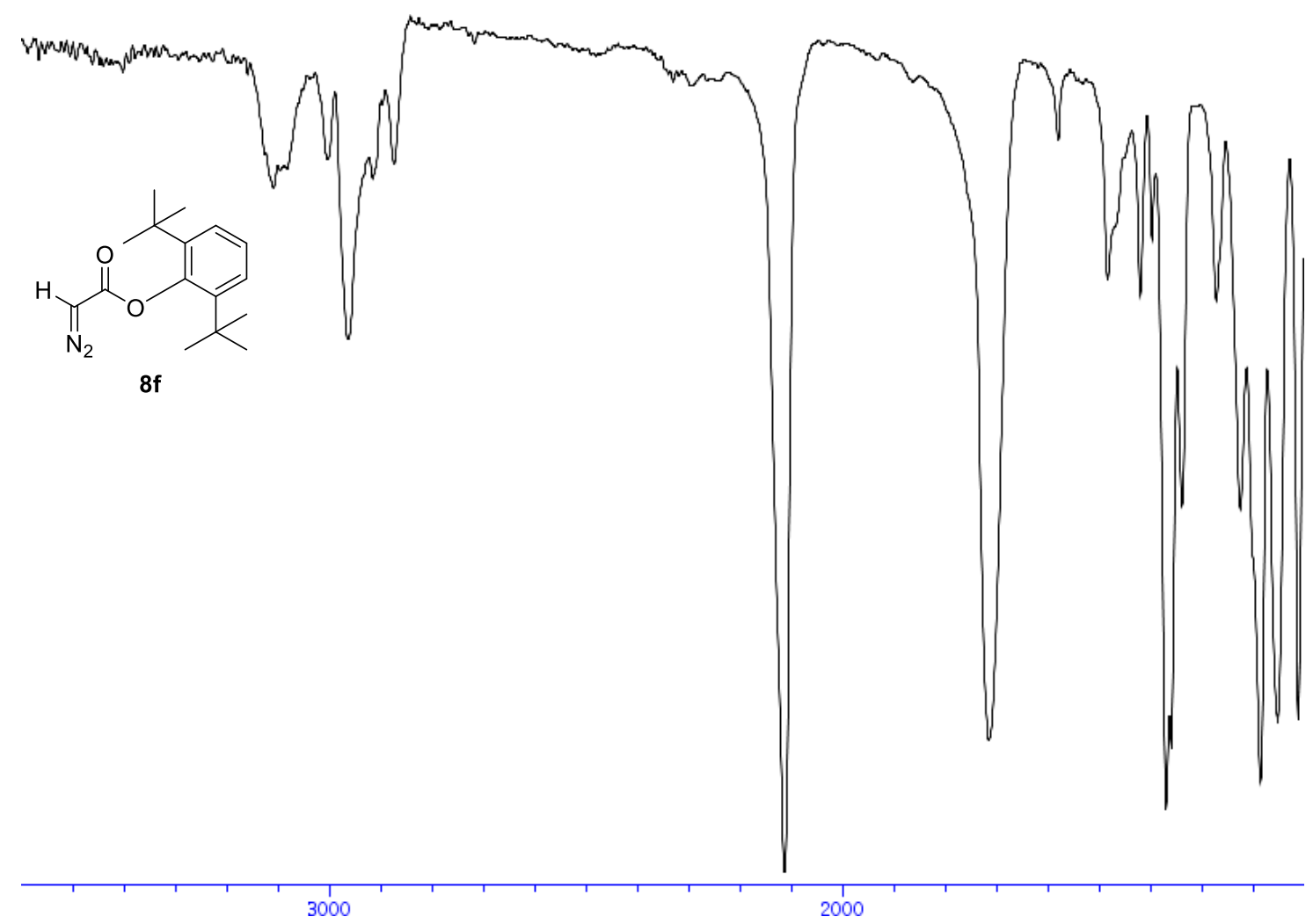


${ }^{1} \mathrm{H}$-NMR (400 MHz, $\mathrm{CDCl}_{3}$ ) of compound 40

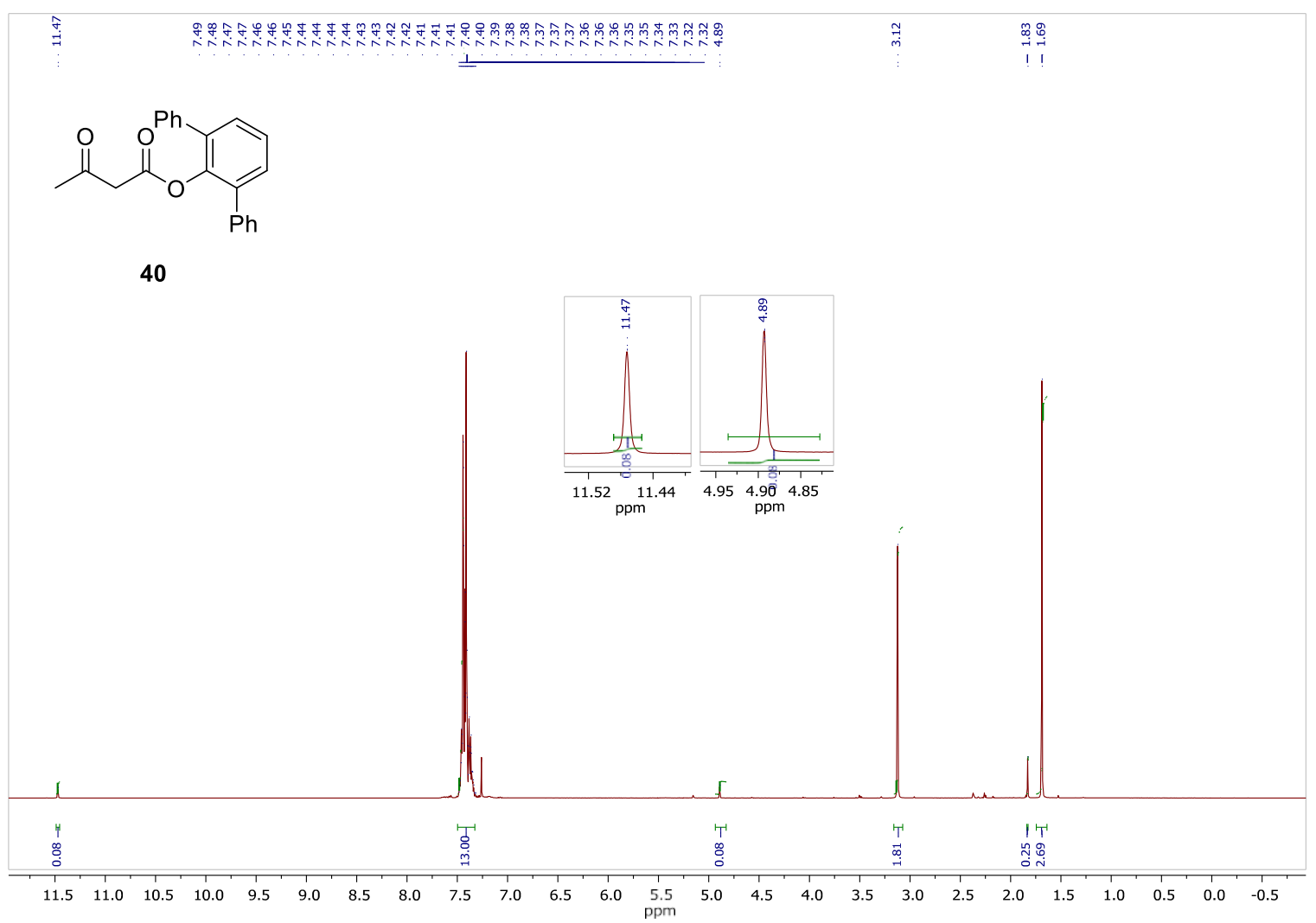

${ }^{13}$ C-NMR (100 MHz, $\left.\mathrm{CDCl}_{3}\right)$ of compound 40

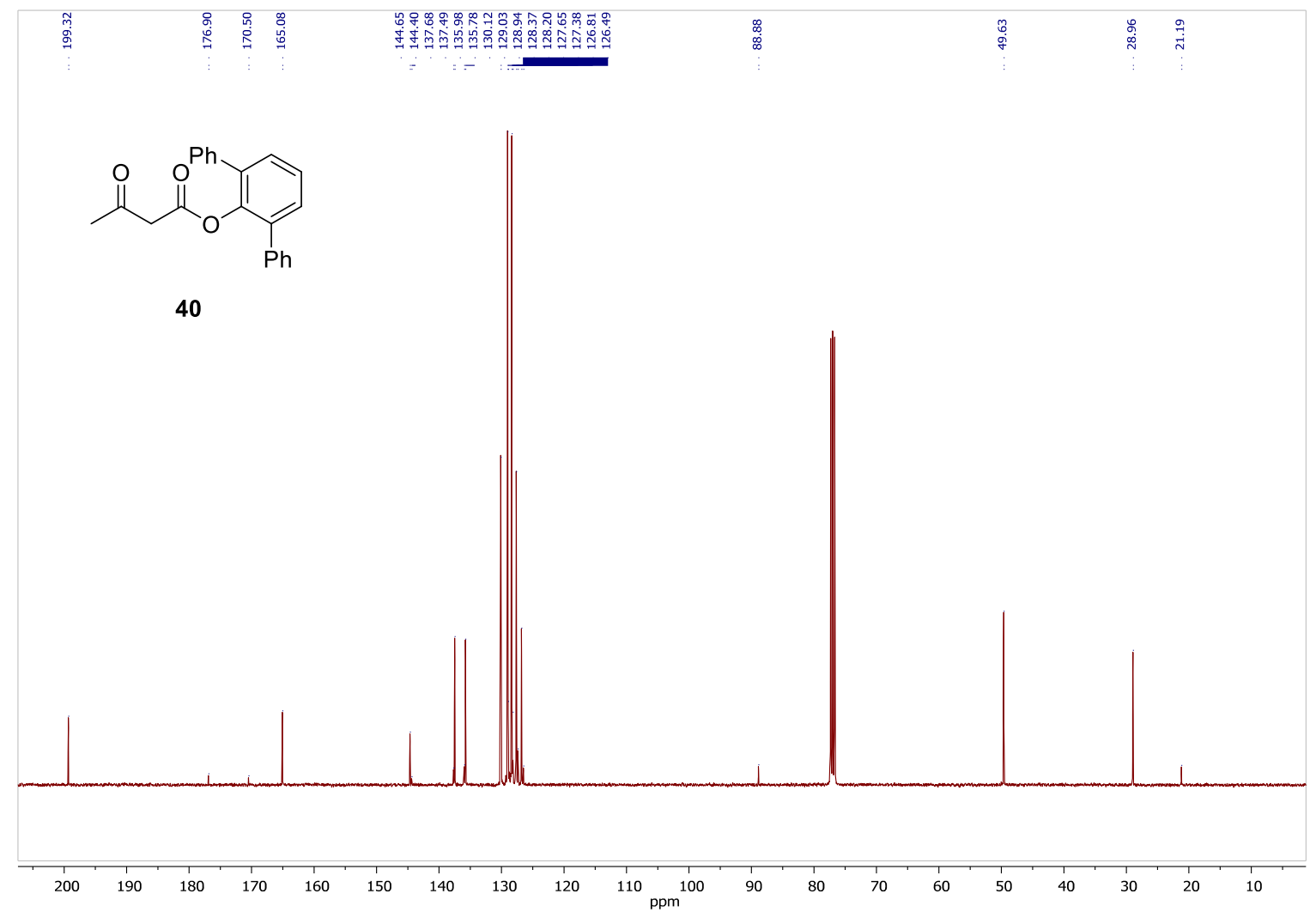


IR of compound $\mathbf{4 0}$

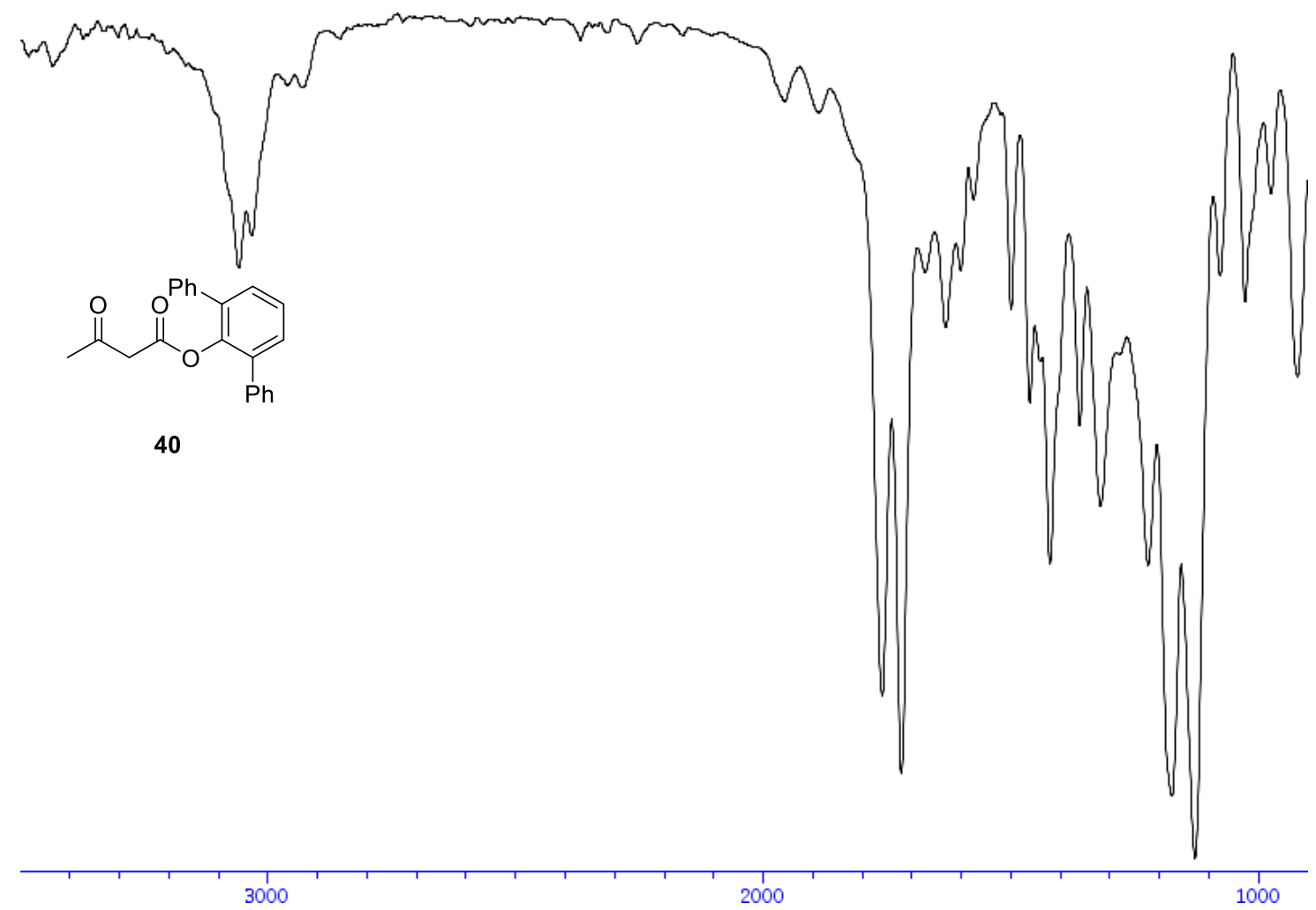


${ }^{1} \mathbf{H}$-NMR (400 MHz, $\mathrm{CDCl}_{3}$ ) of compound $\mathbf{8 h}$

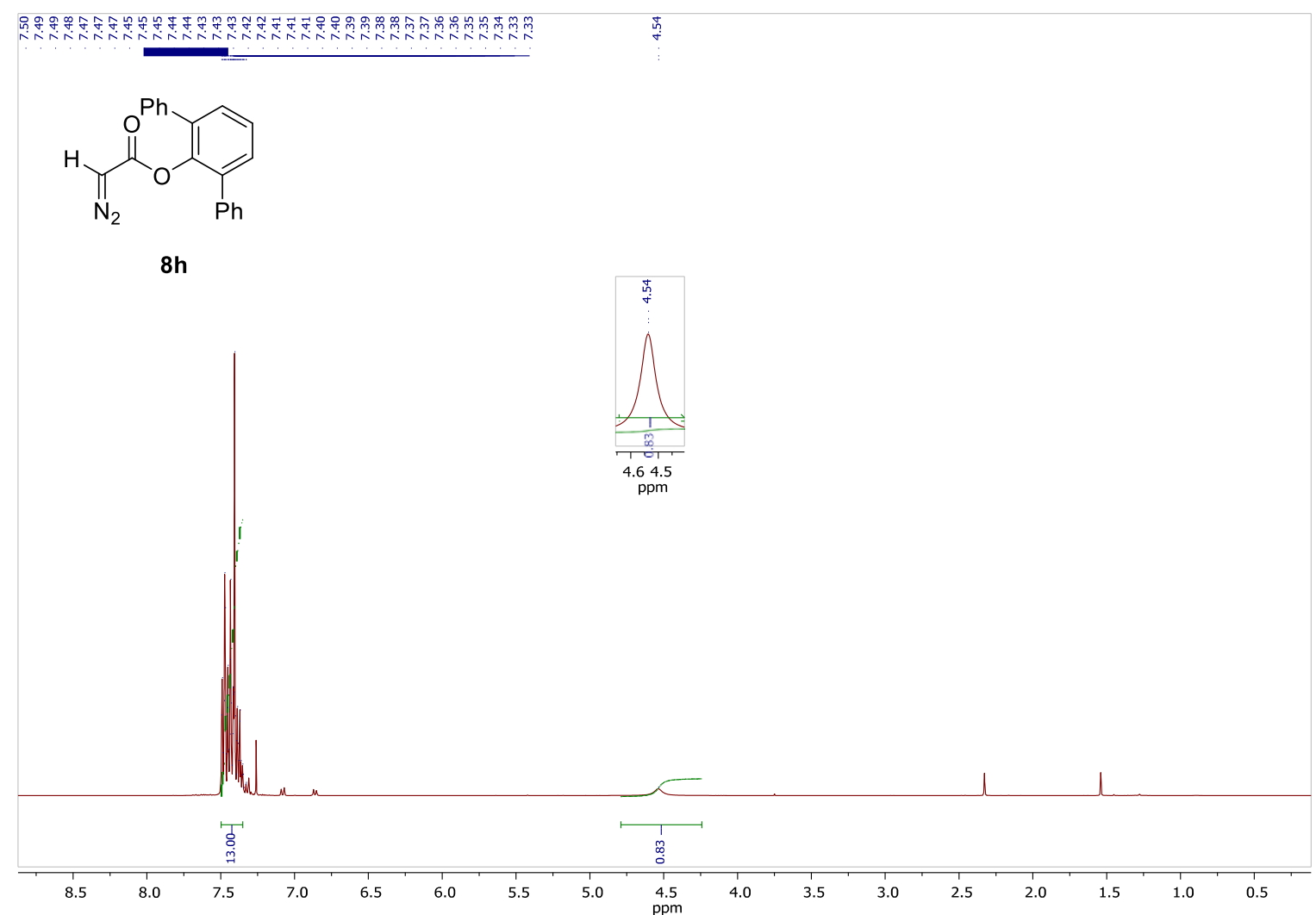

${ }^{13} \mathrm{C}-\mathrm{NMR}\left(100 \mathrm{MHz}, \mathrm{CDCl}_{3}\right)$ of compound $8 \mathrm{~h}$

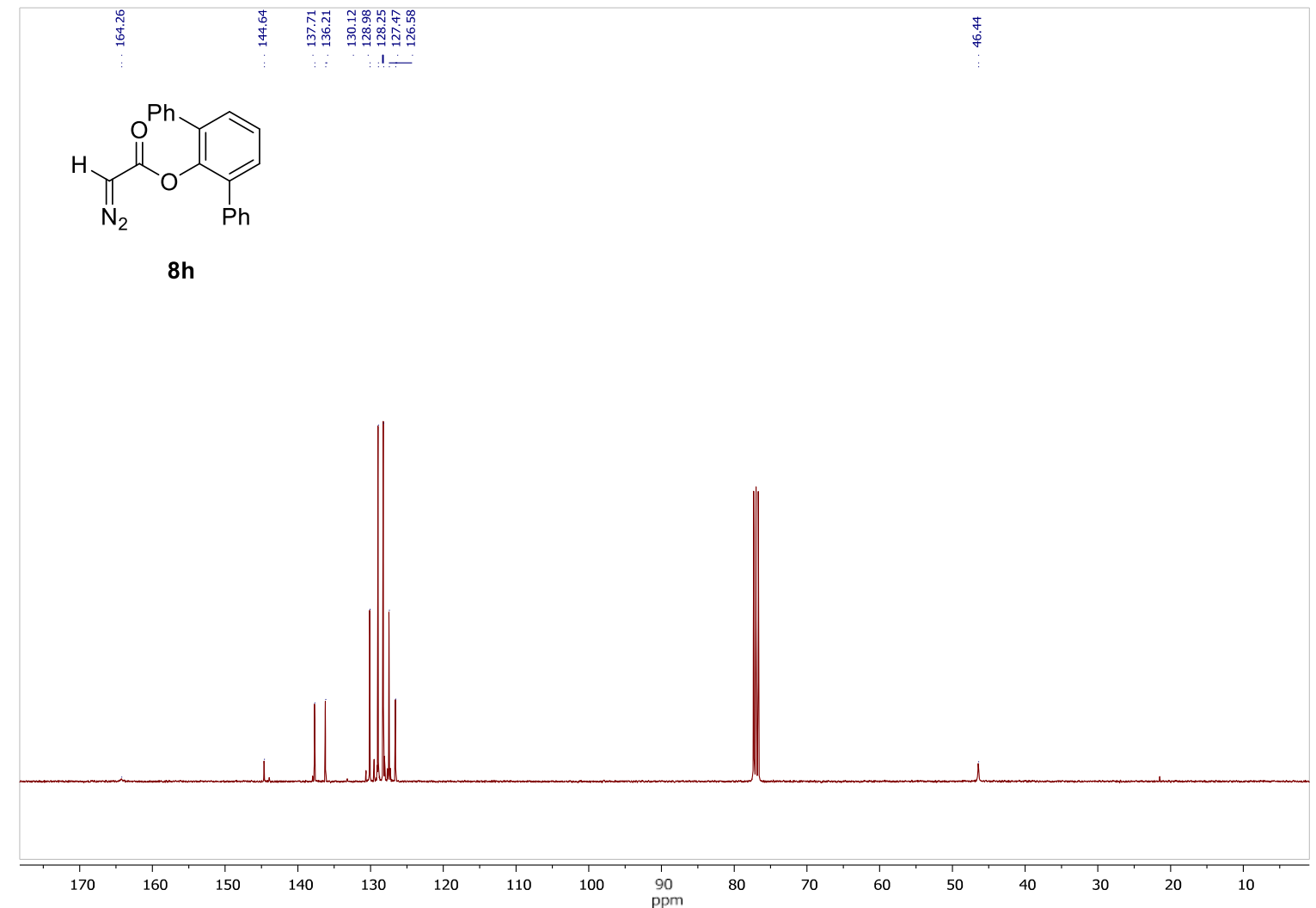


IR of compound $\mathbf{8 h}$

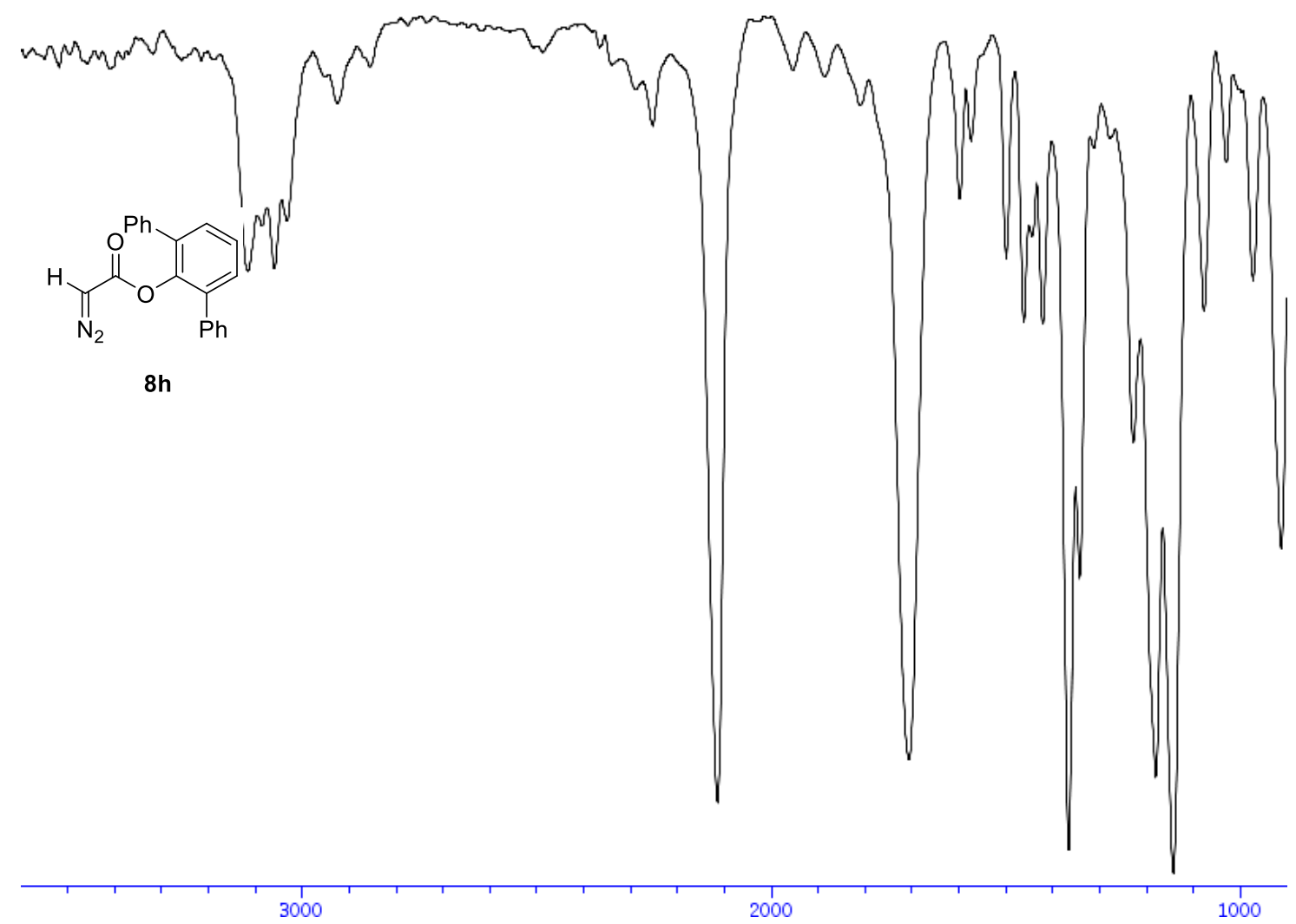


${ }^{1} \mathrm{H}$-NMR (400 MHz, $\mathrm{CDCl}_{3}$ ) of compound 42

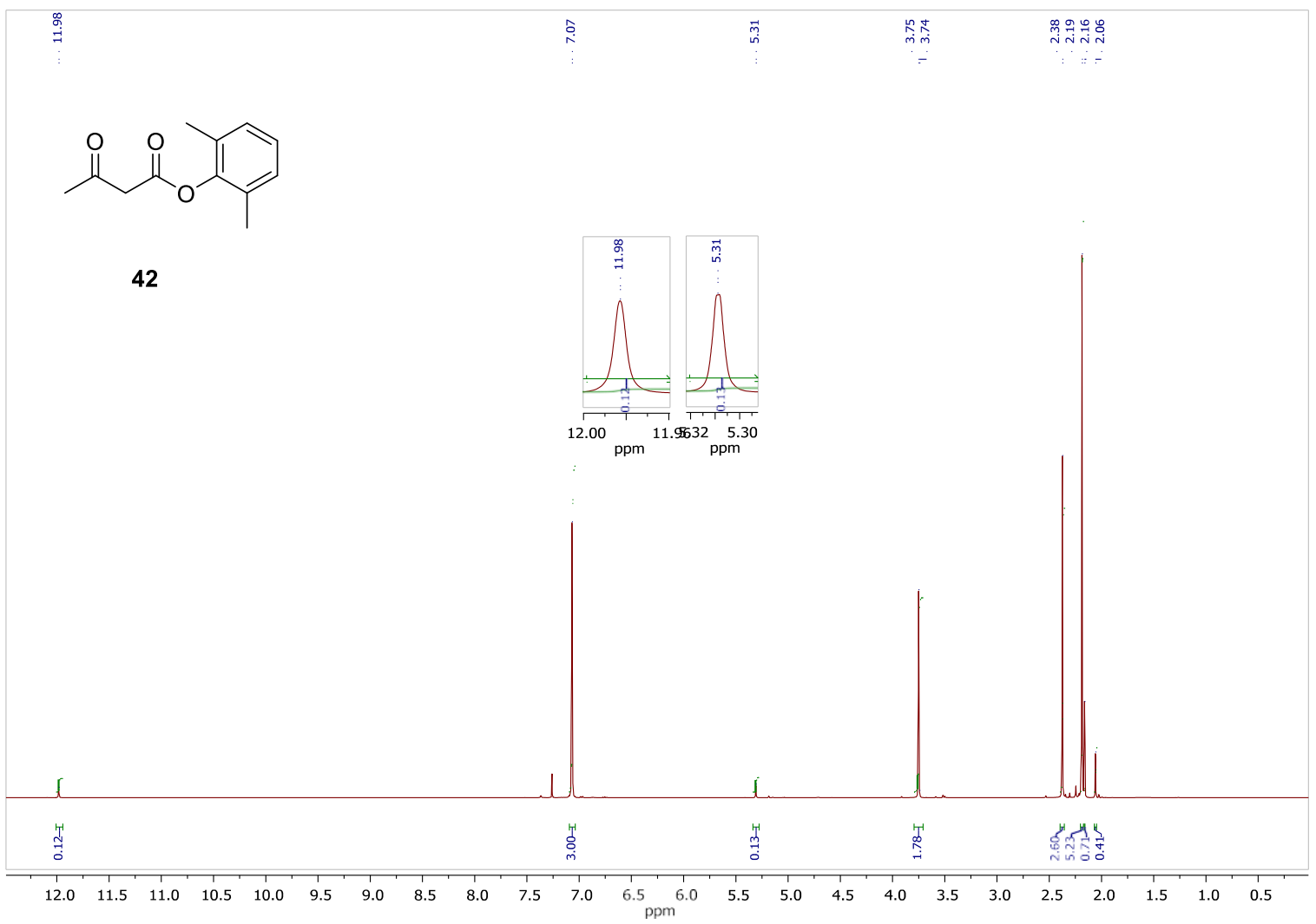

${ }^{13}$ C-NMR (100 MHz, $\mathrm{CDCl}_{3}$ ) of compound 42

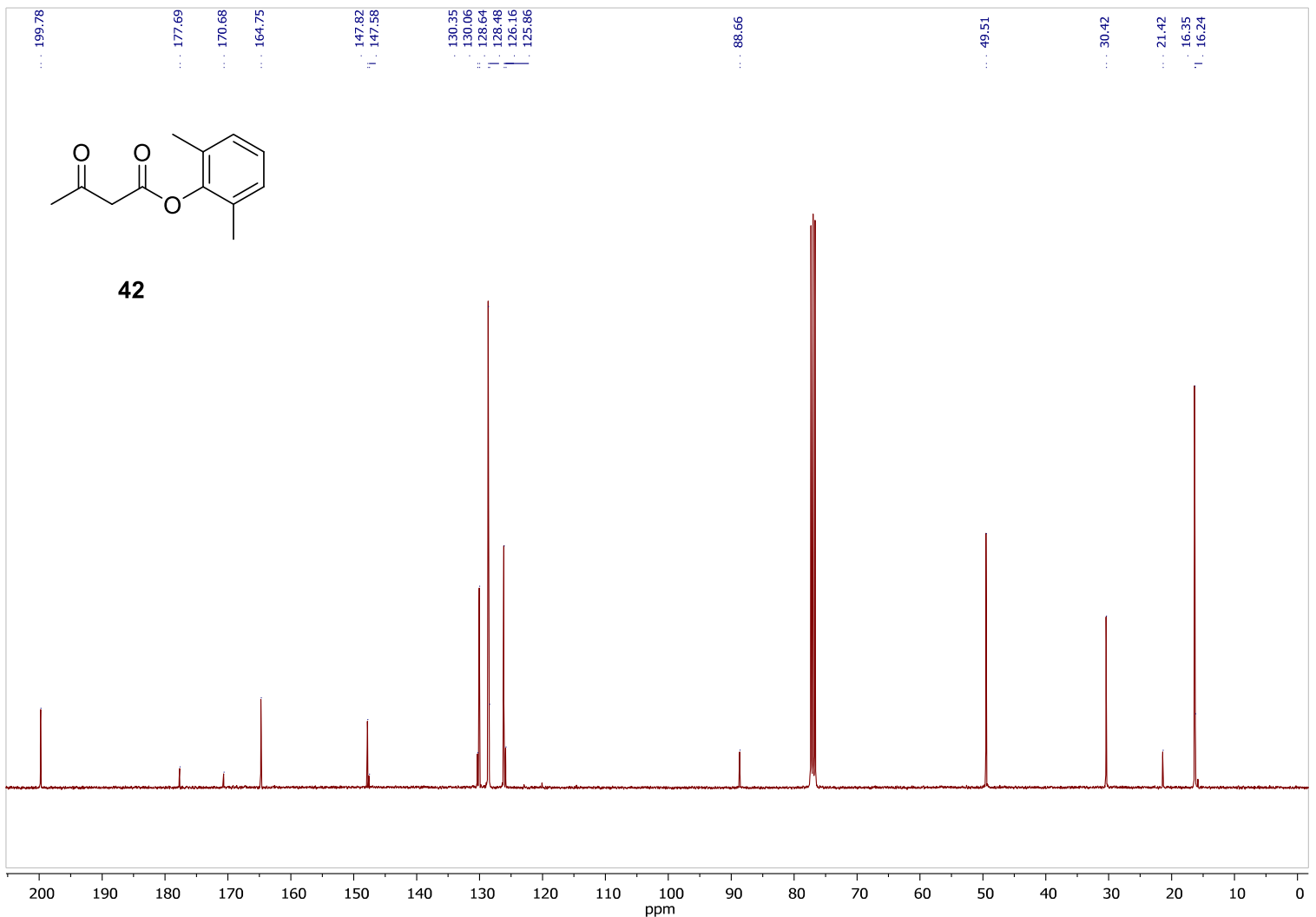


IR of compound $\mathbf{4 2}$

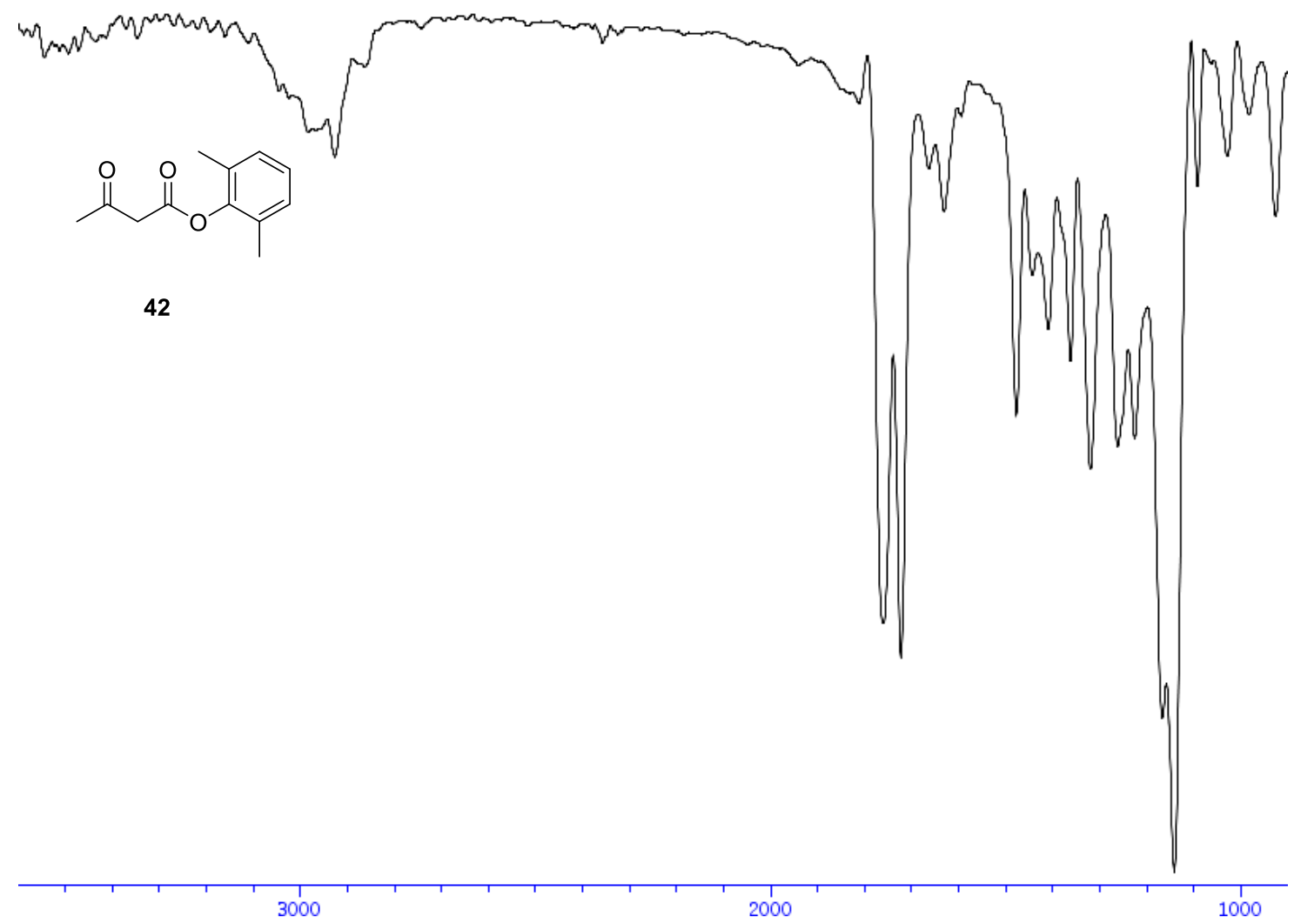


${ }^{1} \mathrm{H}$-NMR (400 MHz, $\mathrm{CDCl}_{3}$ ) of compound $\mathbf{4 4}$

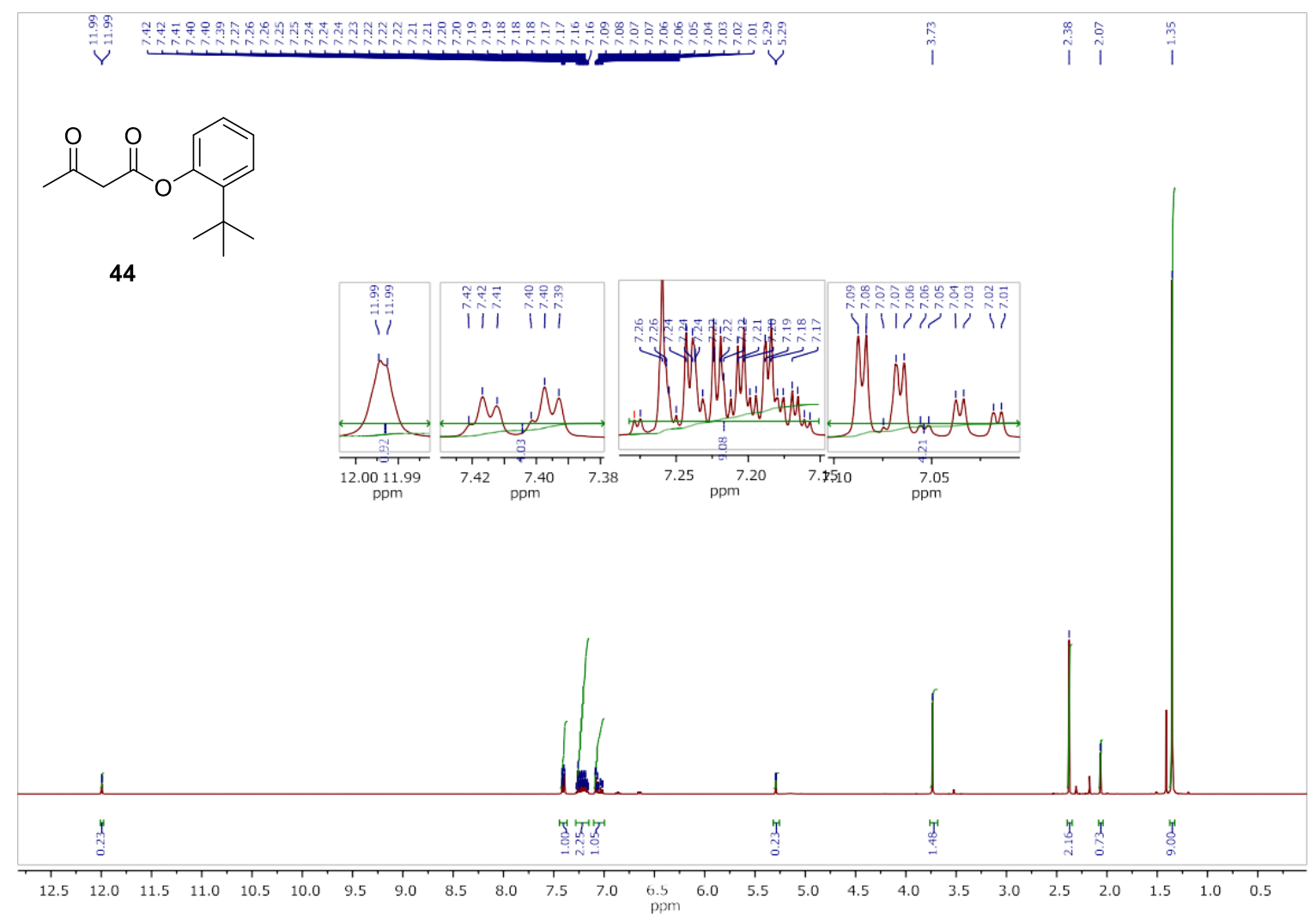

${ }^{13}$ C-NMR (100 MHz, $\mathrm{CDCl}_{3}$ ) of compound 44

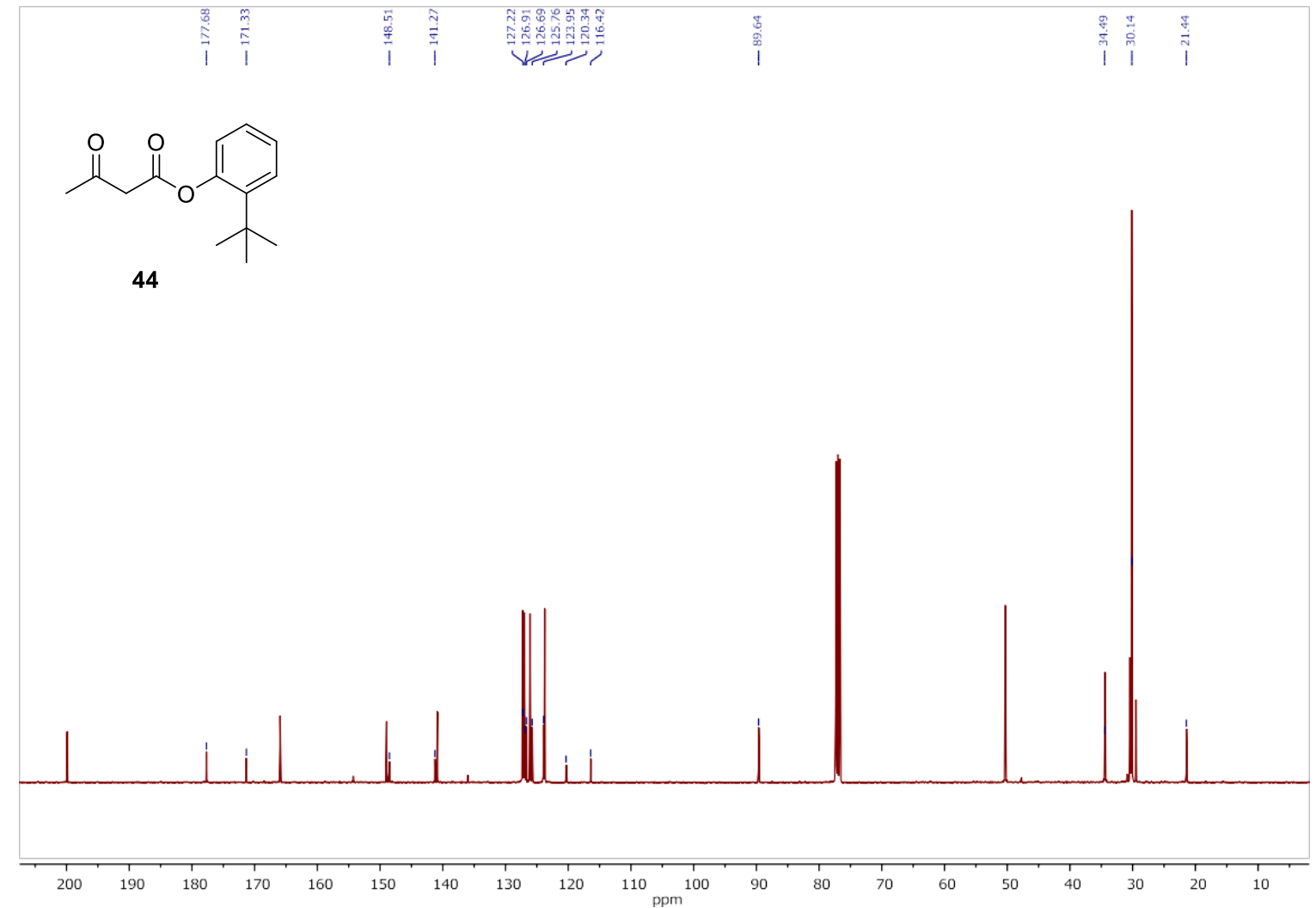


IR of compound $\mathbf{4 4}$

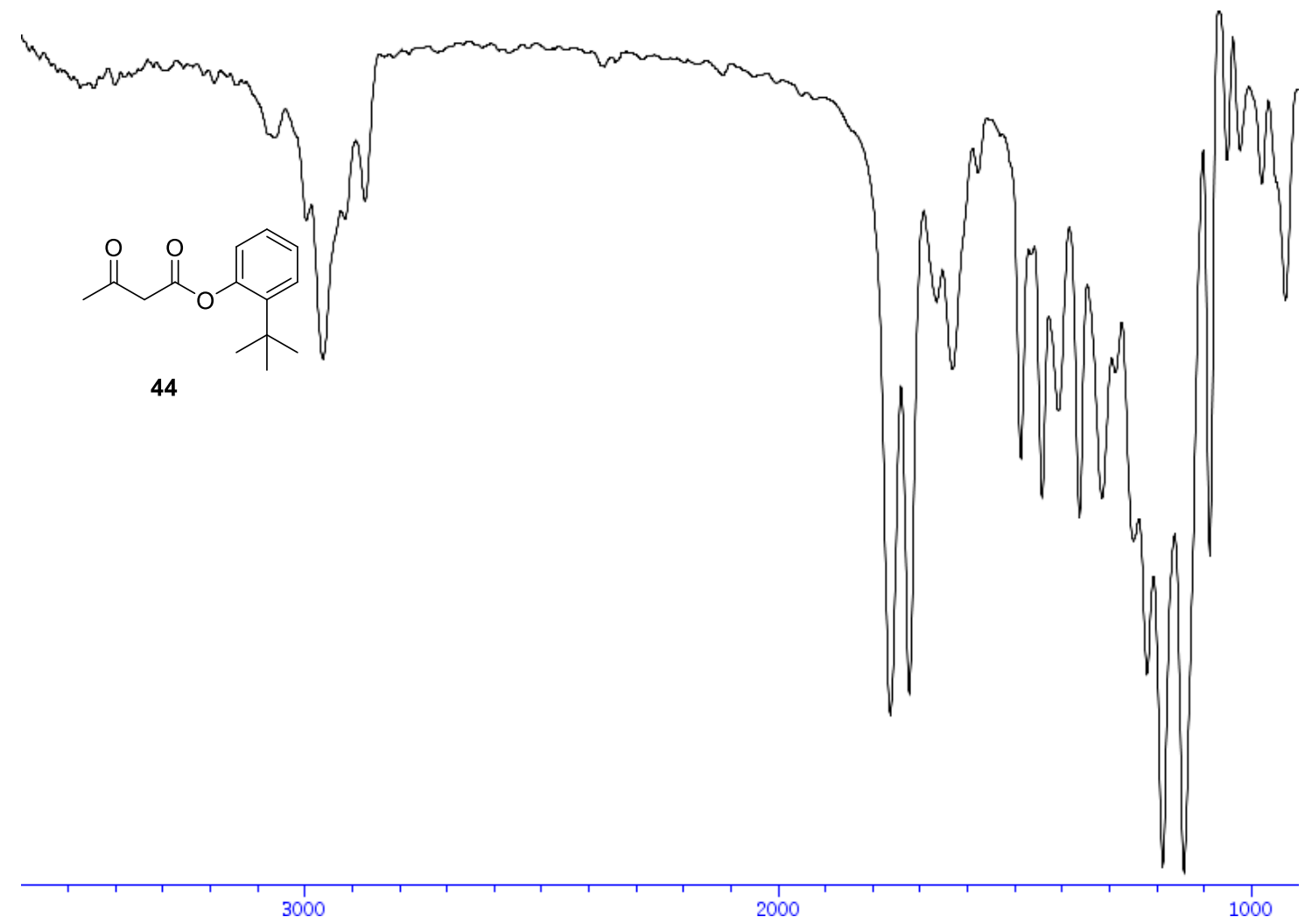


${ }^{1} \mathbf{H}-\mathbf{N M R}\left(400 \mathrm{MHz}, \mathrm{CDCl}_{3}\right.$ ) of compound $\mathbf{8 j}$

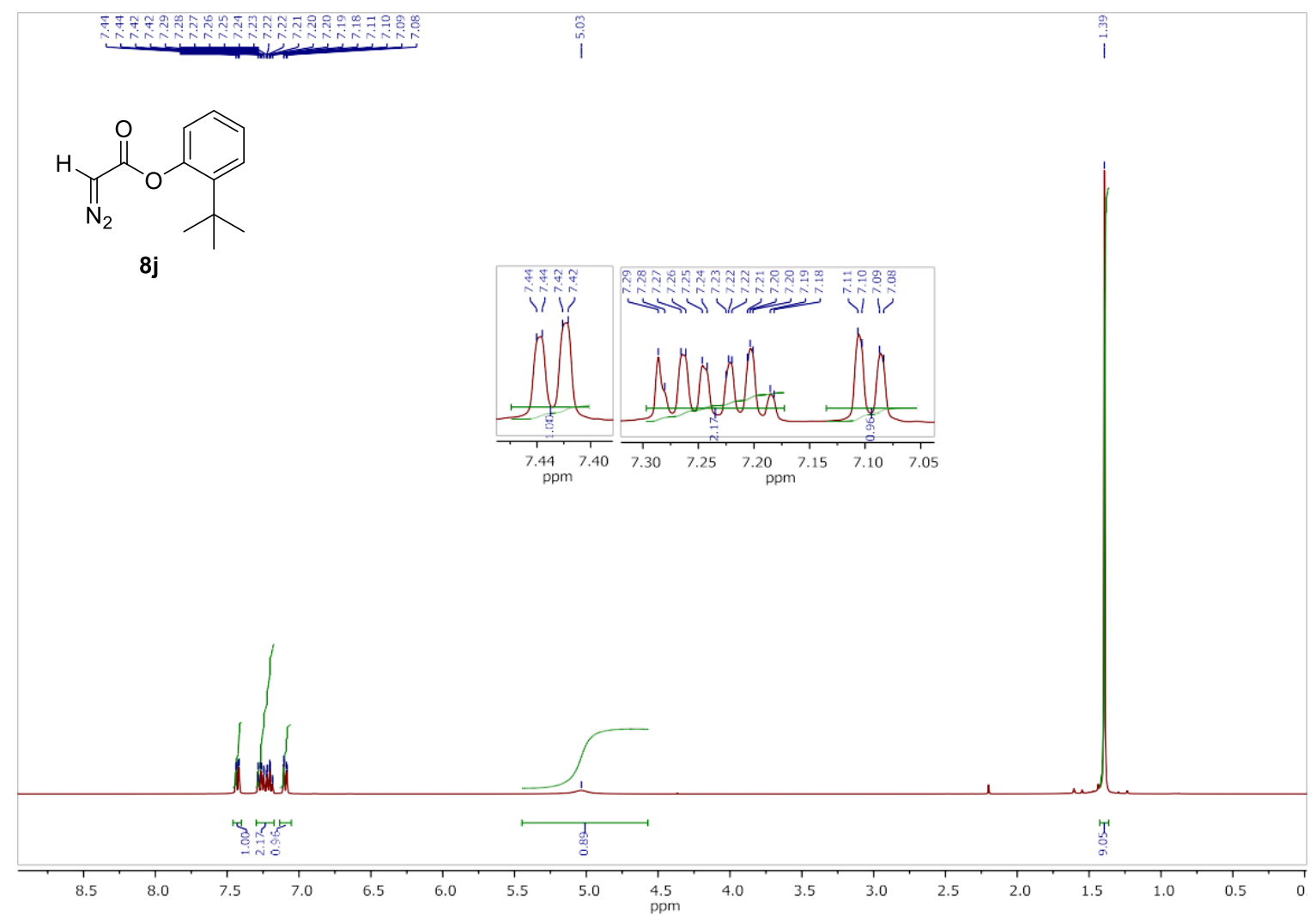

${ }^{13} \mathrm{C}-\mathrm{NMR}\left(100 \mathrm{MHz}, \mathrm{CDCl}_{3}\right.$ ) of compound 8j

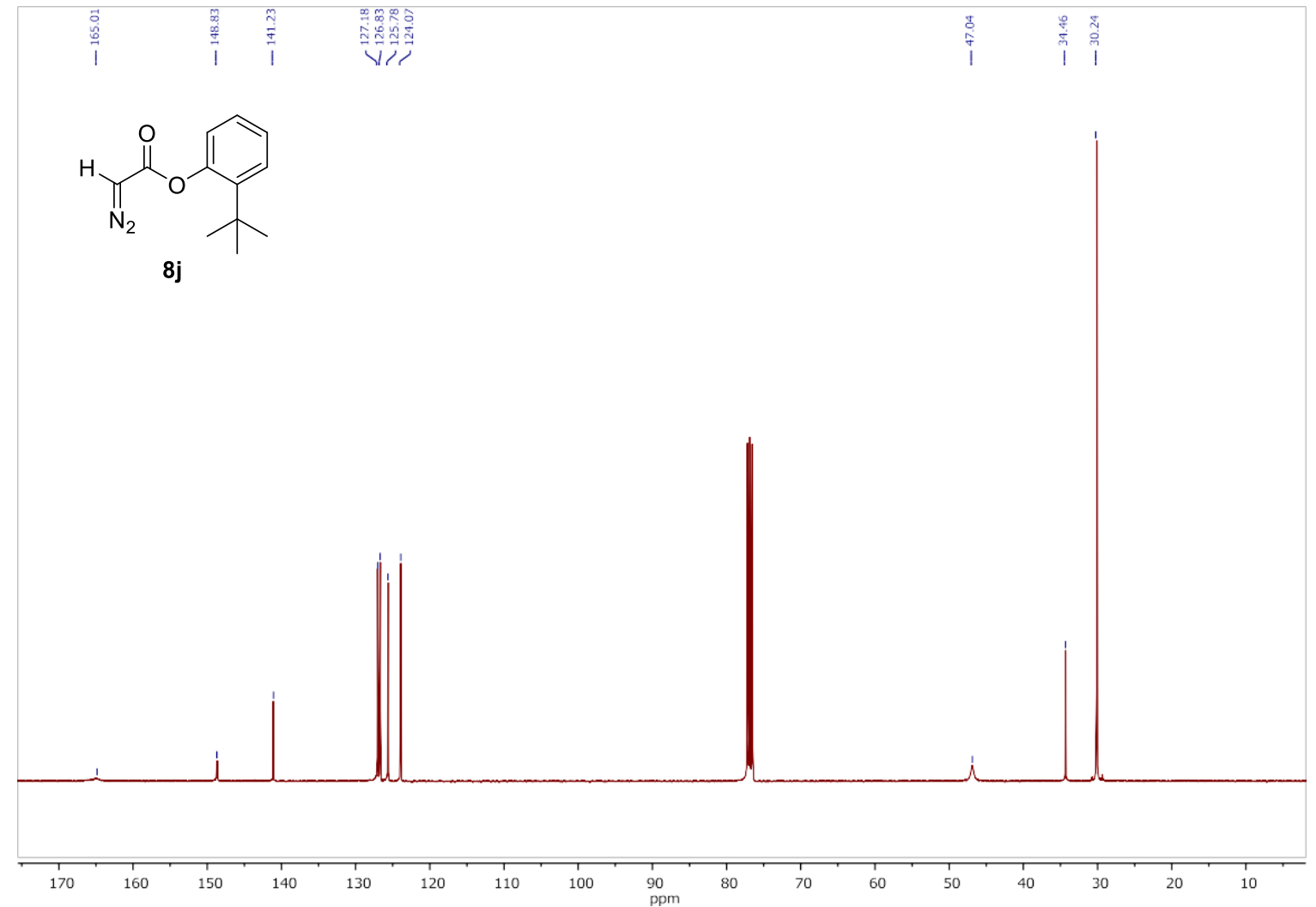


IR of compound $\mathbf{8 j}$

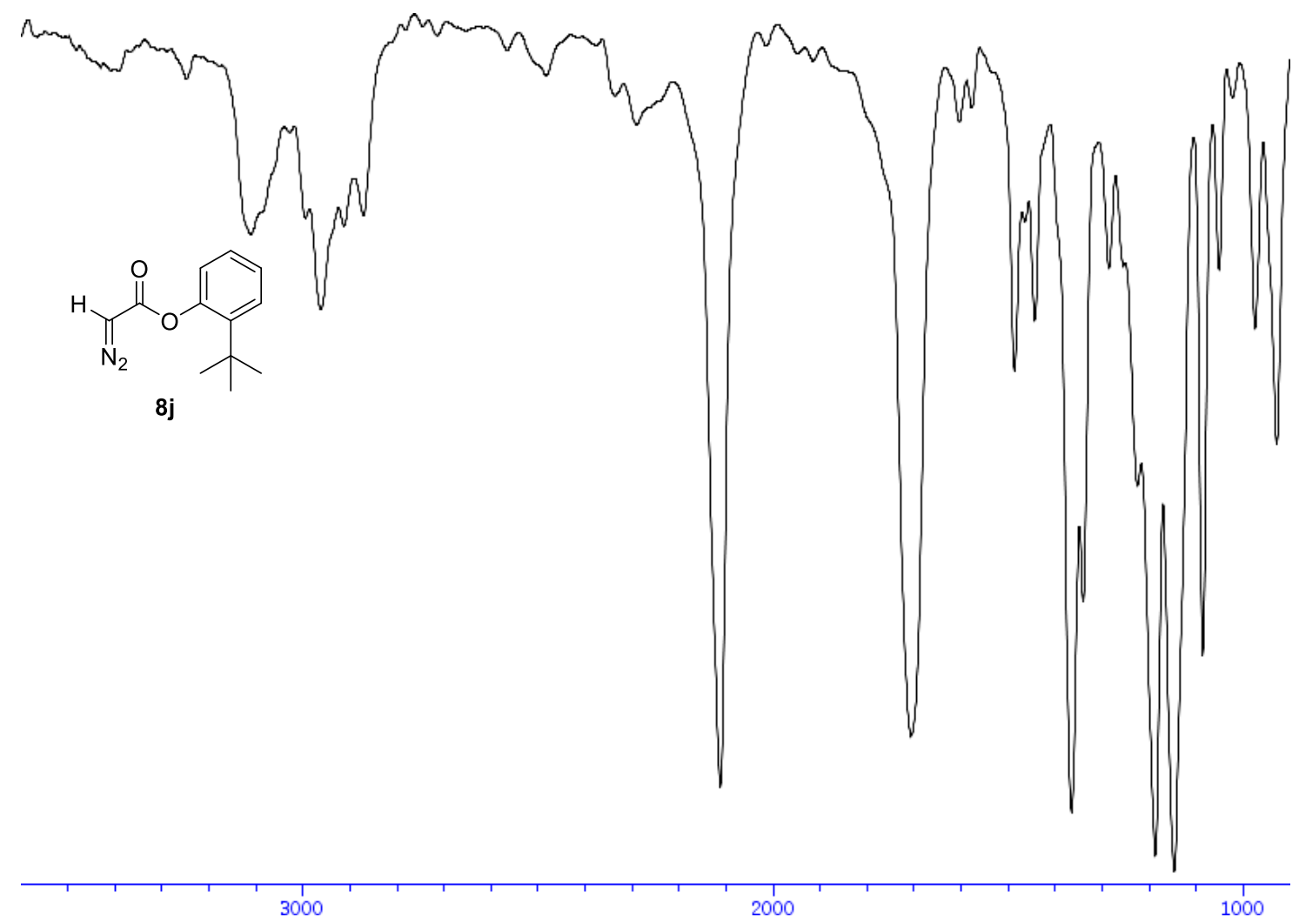


${ }^{1} \mathbf{H}-\mathrm{NMR}$ (400 MHz, $\mathrm{CDCl}_{3}$ ) of compound 47

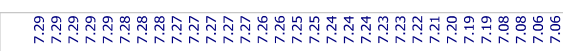

$\stackrel{\circ}{+}$

$\stackrel{\text { N }}{2}$

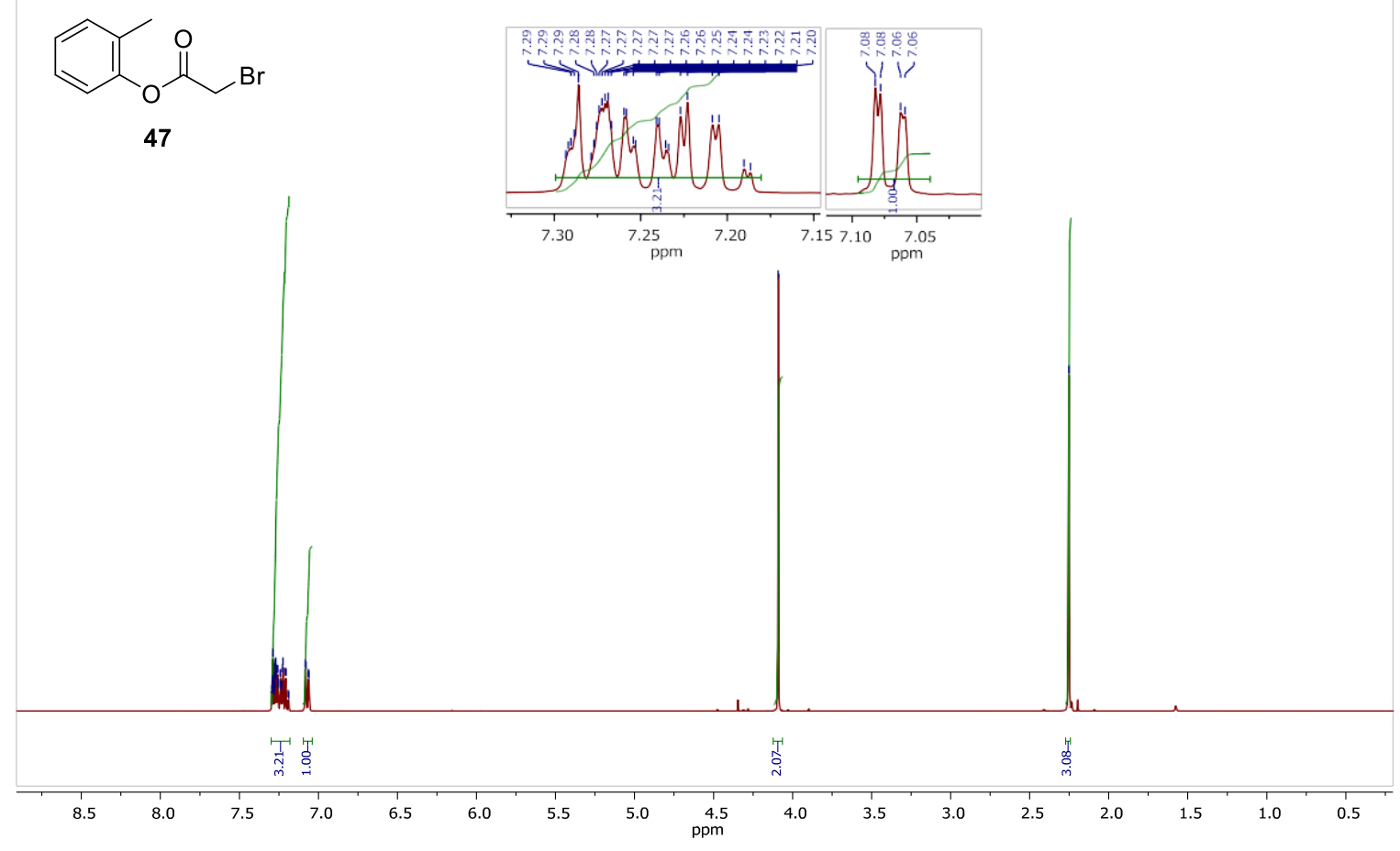

${ }^{13}$ C-NMR (100 MHz, $\mathrm{CDCl}_{3}$ ) of compound 47

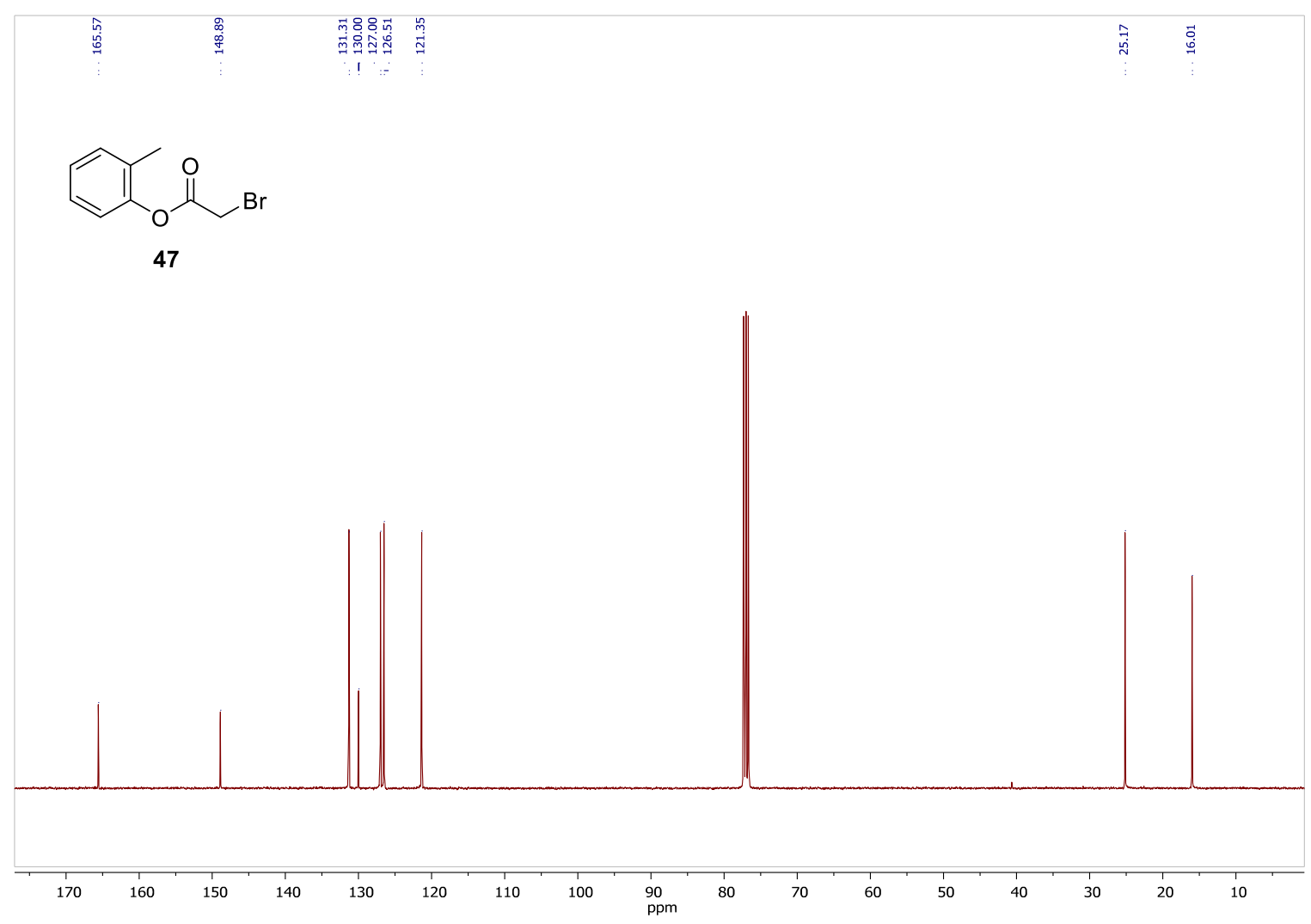

S133 
IR of compound $\mathbf{4 7}$

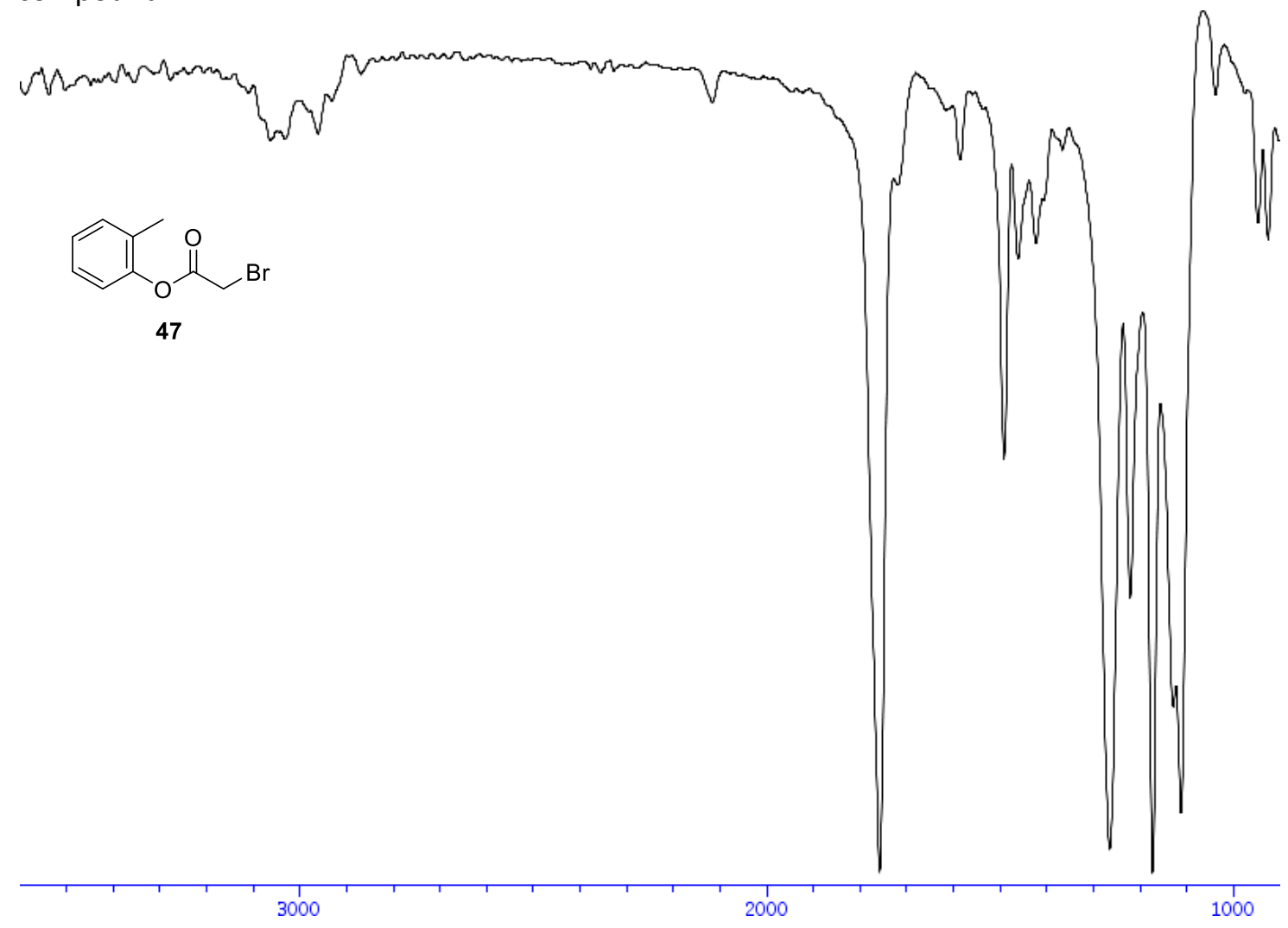


${ }^{1} \mathbf{H}-\mathbf{N M R}\left(400 \mathrm{MHz}, \mathrm{CDCl}_{3}\right.$ ) of compound $\mathbf{8 k}$

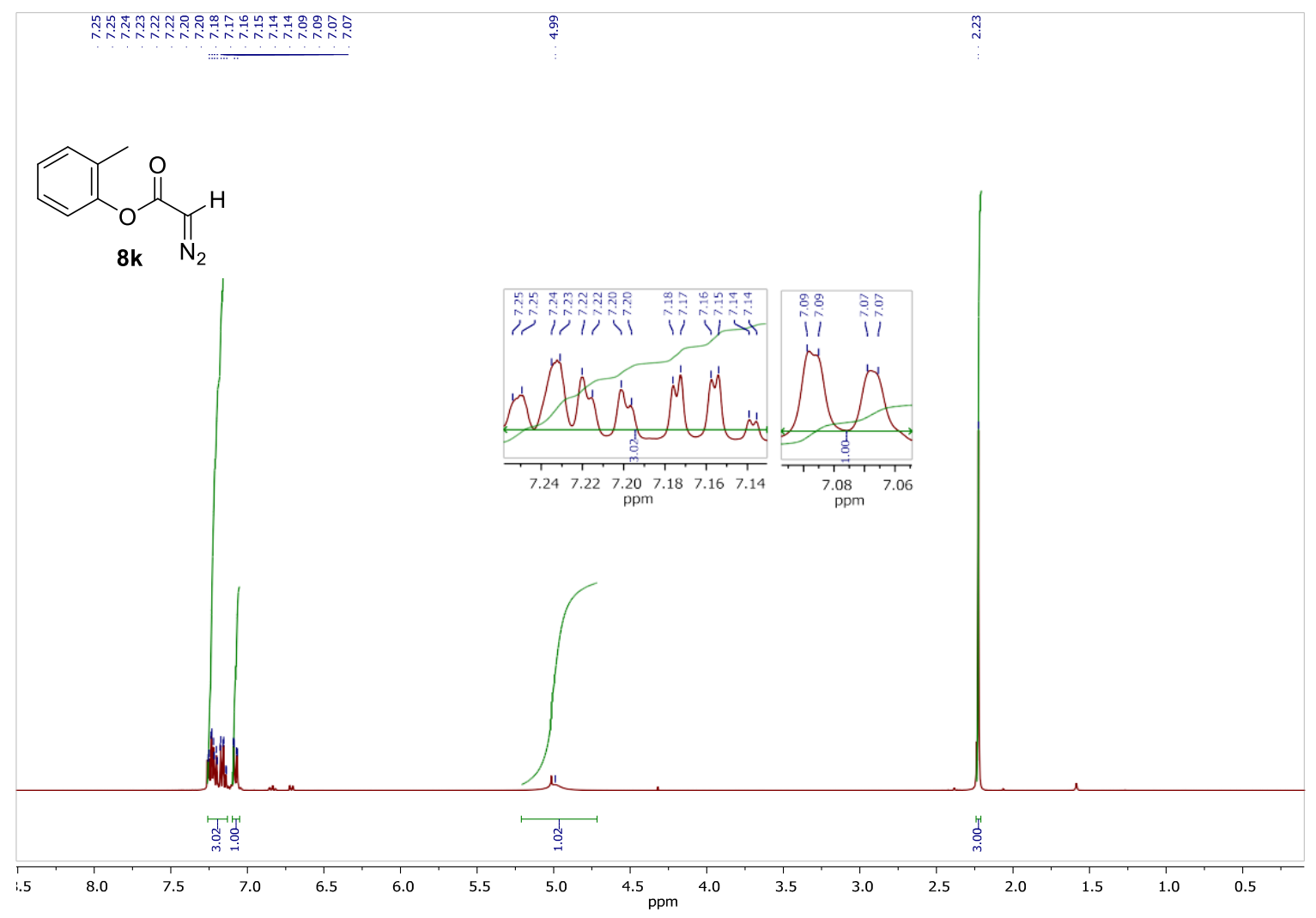

${ }^{13} \mathrm{C}$-NMR (100 MHz, $\mathrm{CDCl}_{3}$ ) of compound $\mathbf{8 k}$

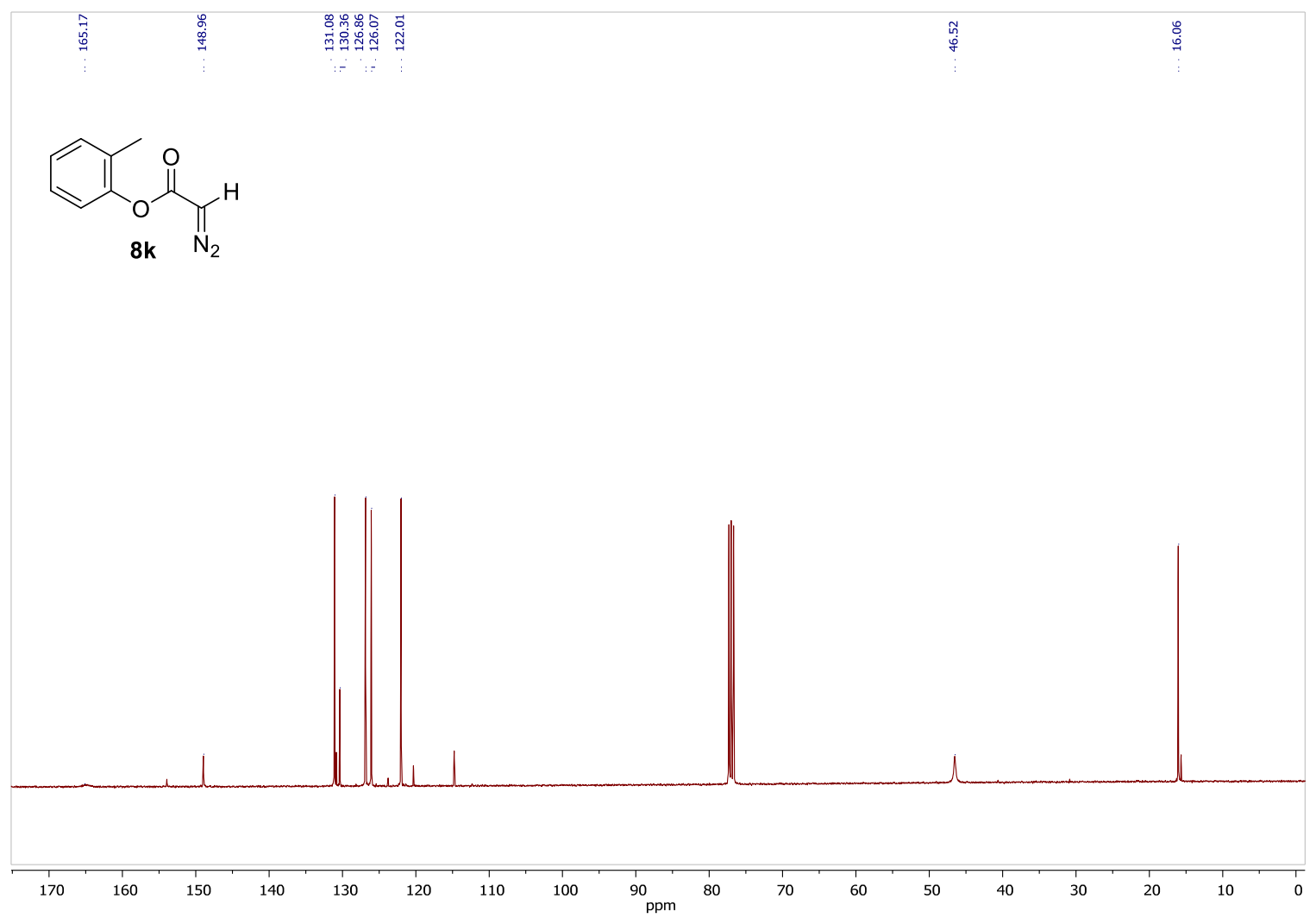

S135 
IR of compound 8k

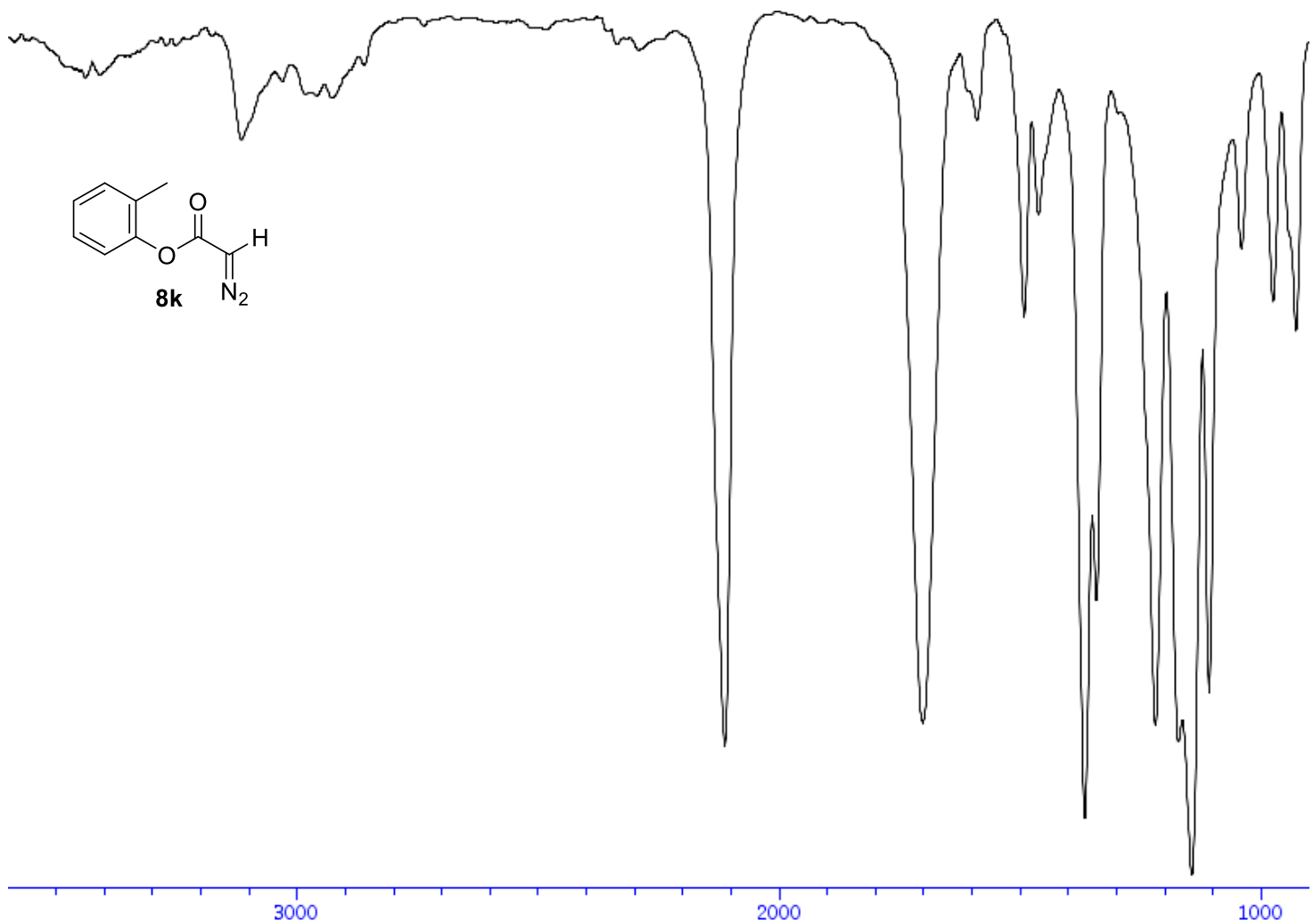


${ }^{1} \mathbf{H}-\mathbf{N M R}\left(400 \mathrm{MHz}, \mathrm{CDCl}_{3}\right.$ ) of compound $8 \mathbf{m}$

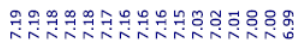

号
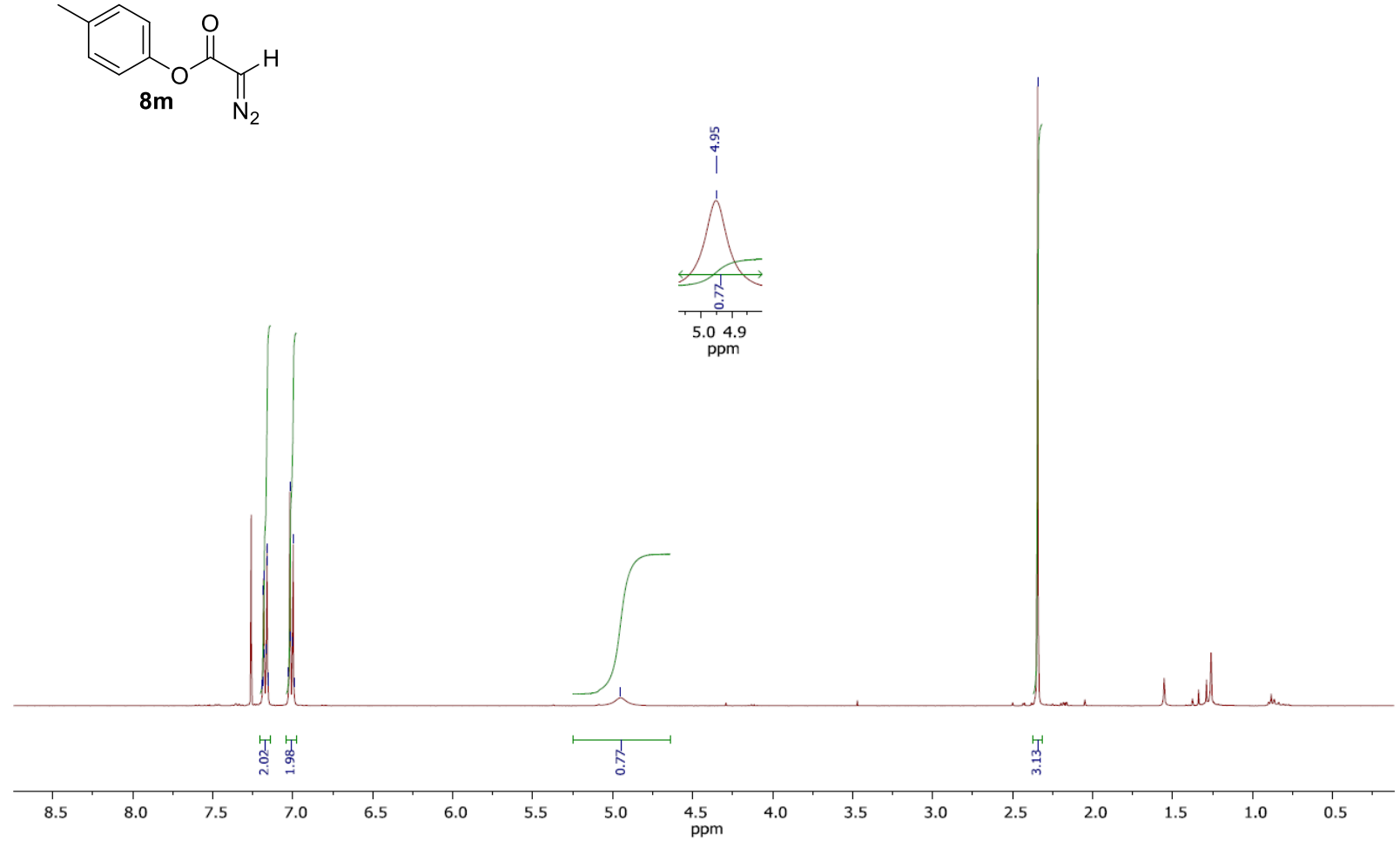

${ }^{13} \mathrm{C}-\mathrm{NMR}\left(100 \mathrm{MHz}, \mathrm{CDCl}_{3}\right)$ of compound $8 \mathrm{~m}$

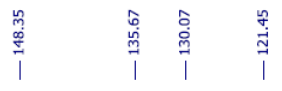<smiles>Cc1ccc(OC(=O)C=[W])cc1</smiles>
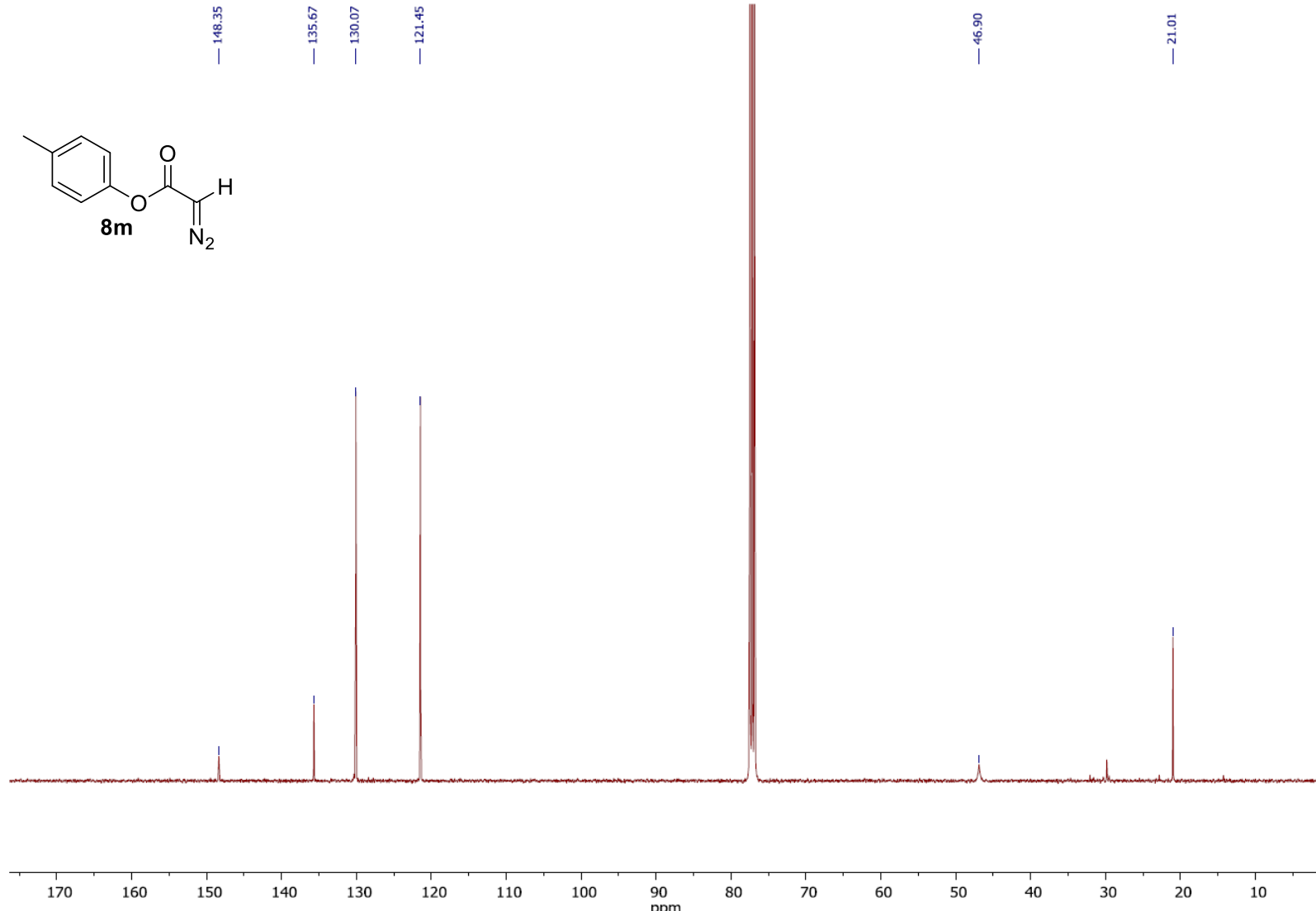
${ }^{1} \mathrm{H}$-NMR (400 MHz, $\mathrm{CDCl}_{3}$ ) of compound 80

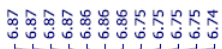

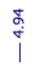
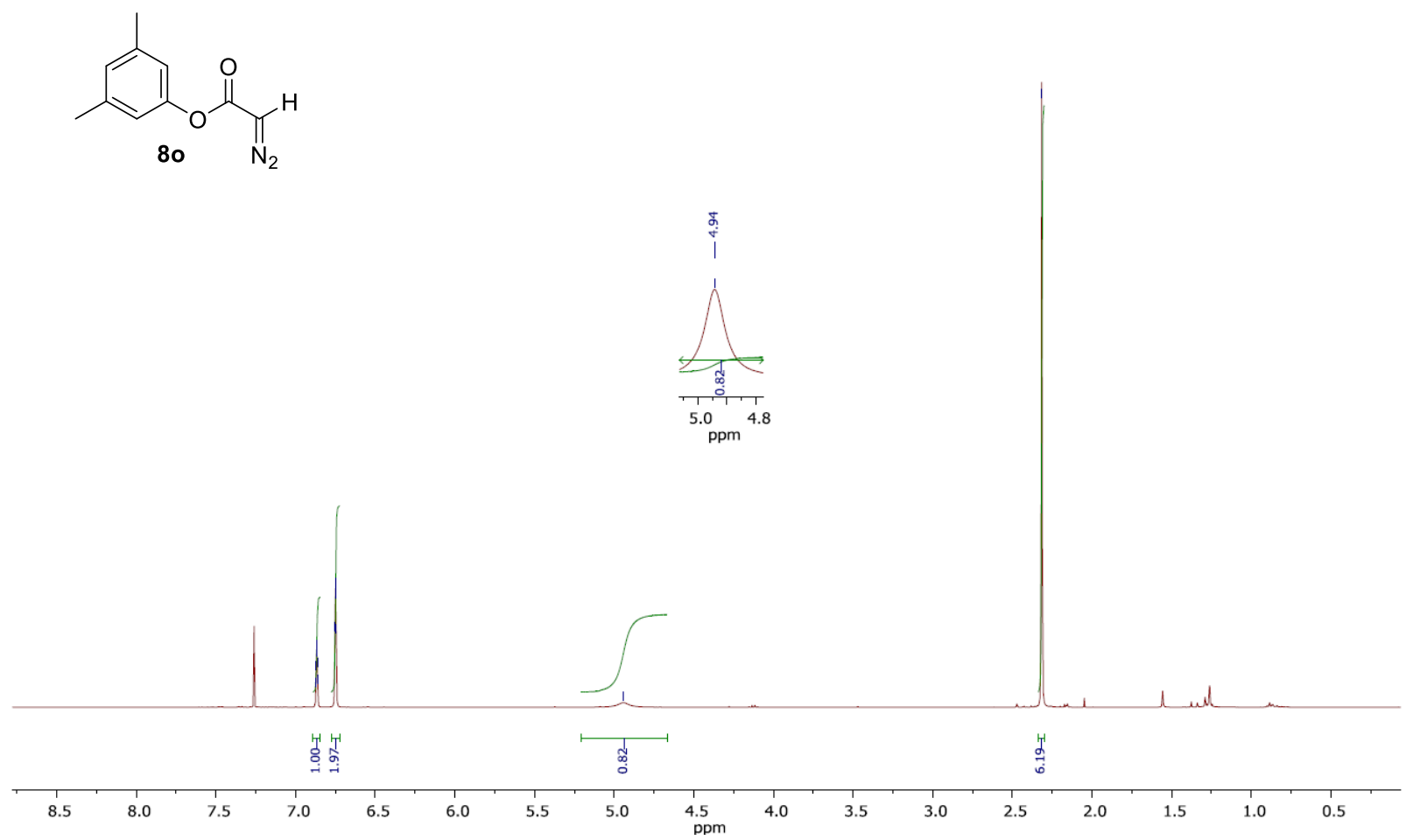

${ }^{13}$ C-NMR (100 MHz, CDCl $)$ of compound 80 弯<smiles>Cc1cc(C)cc(OC(=O)C=[W])c1</smiles>

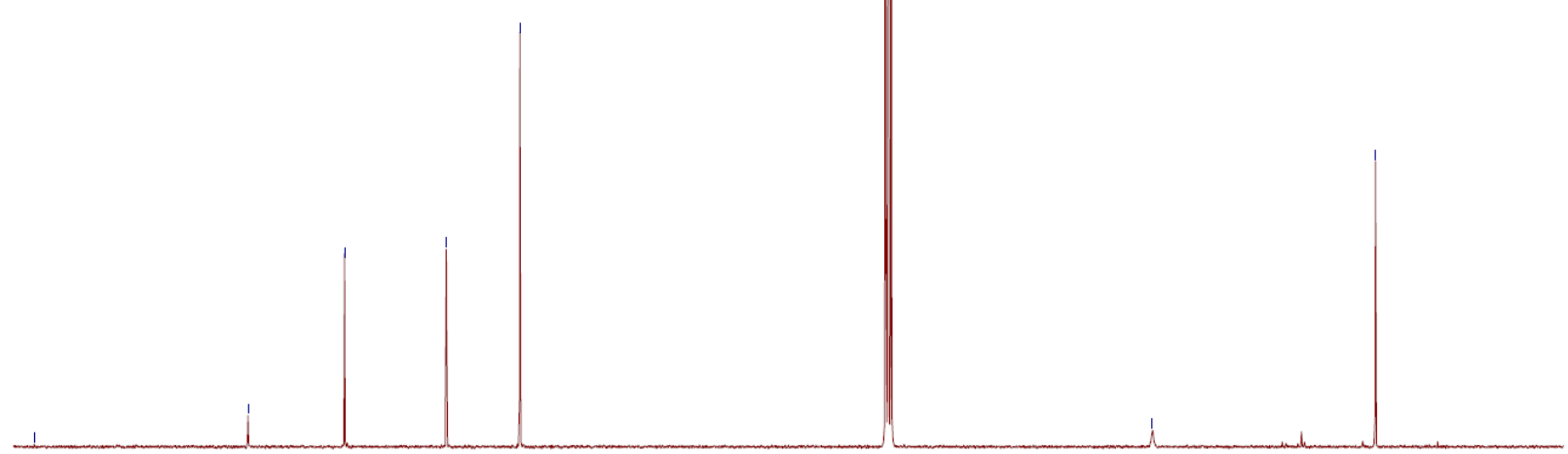


${ }^{1} \mathbf{H}-\mathrm{NMR}\left(400 \mathrm{MHz}, \mathrm{CDCl}_{3}\right.$ ) of compound 8p

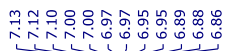
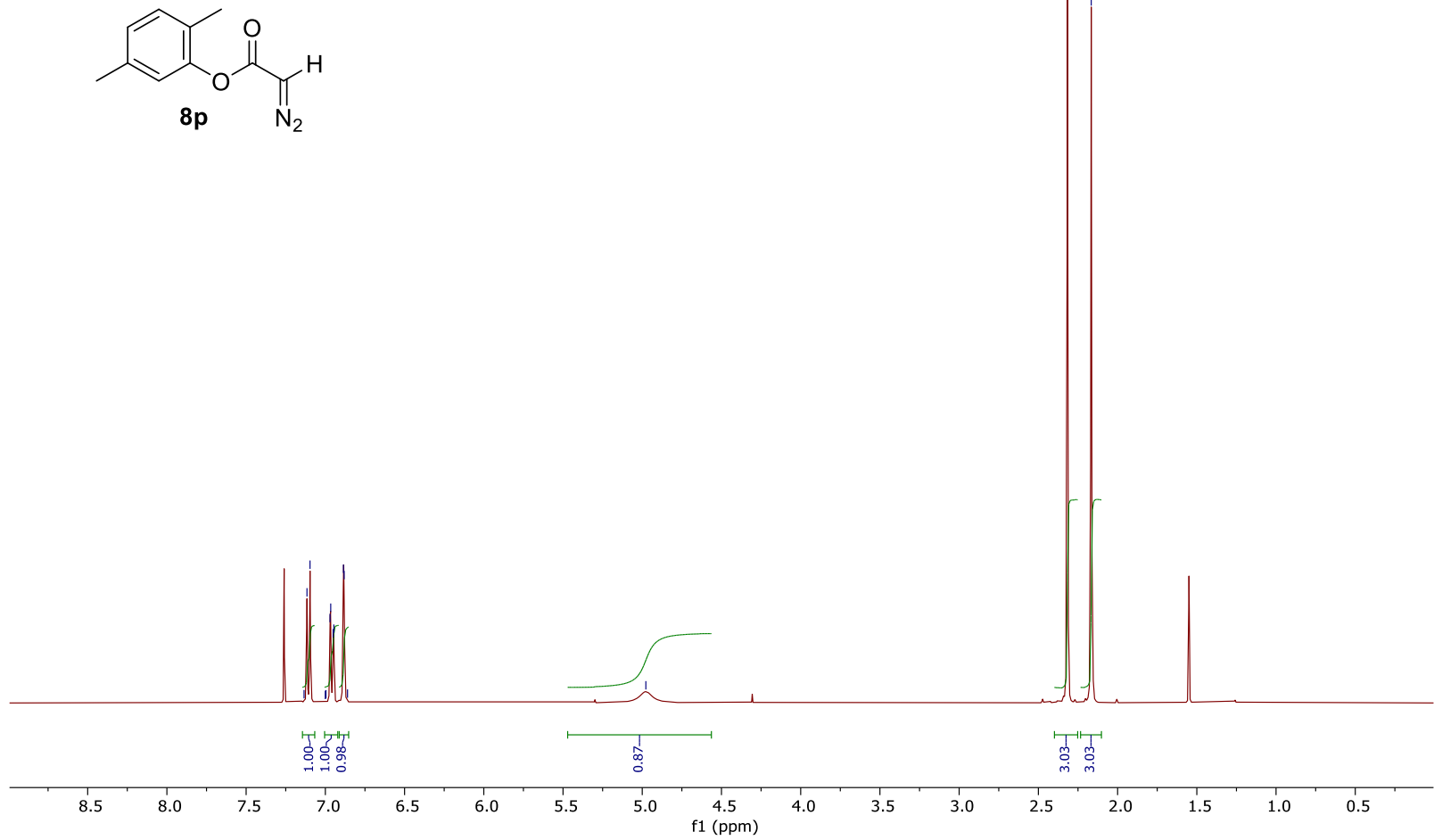

${ }^{13} \mathrm{C}-\mathrm{NMR}\left(100 \mathrm{MHz}, \mathrm{CDCl}_{3}\right.$ ) of compound 80

$$
\text { 年 }
$$
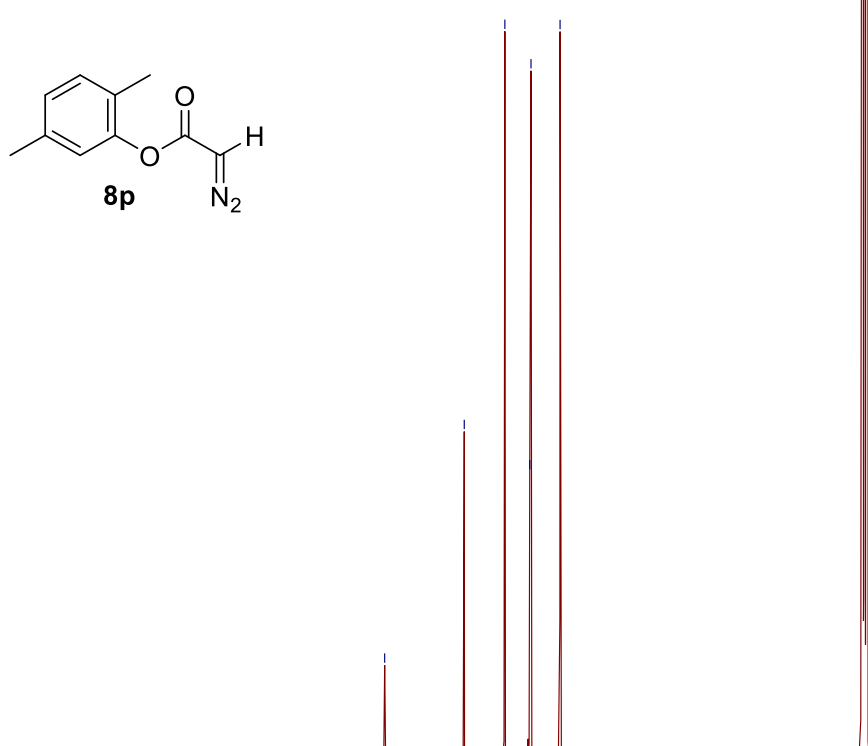

$\begin{array}{lllllll}210 & 200 & 190 & 180 & 170 & 160 & 150\end{array}$
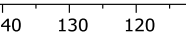
${ }^{1} \mathbf{H}$-NMR (400 MHz, $\mathrm{CDCl}_{3}$ ) of compound 8q

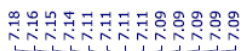

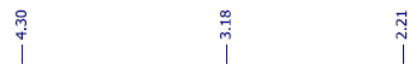<smiles>Cc1cccc(C)c1NC(=O)C=[W]</smiles>
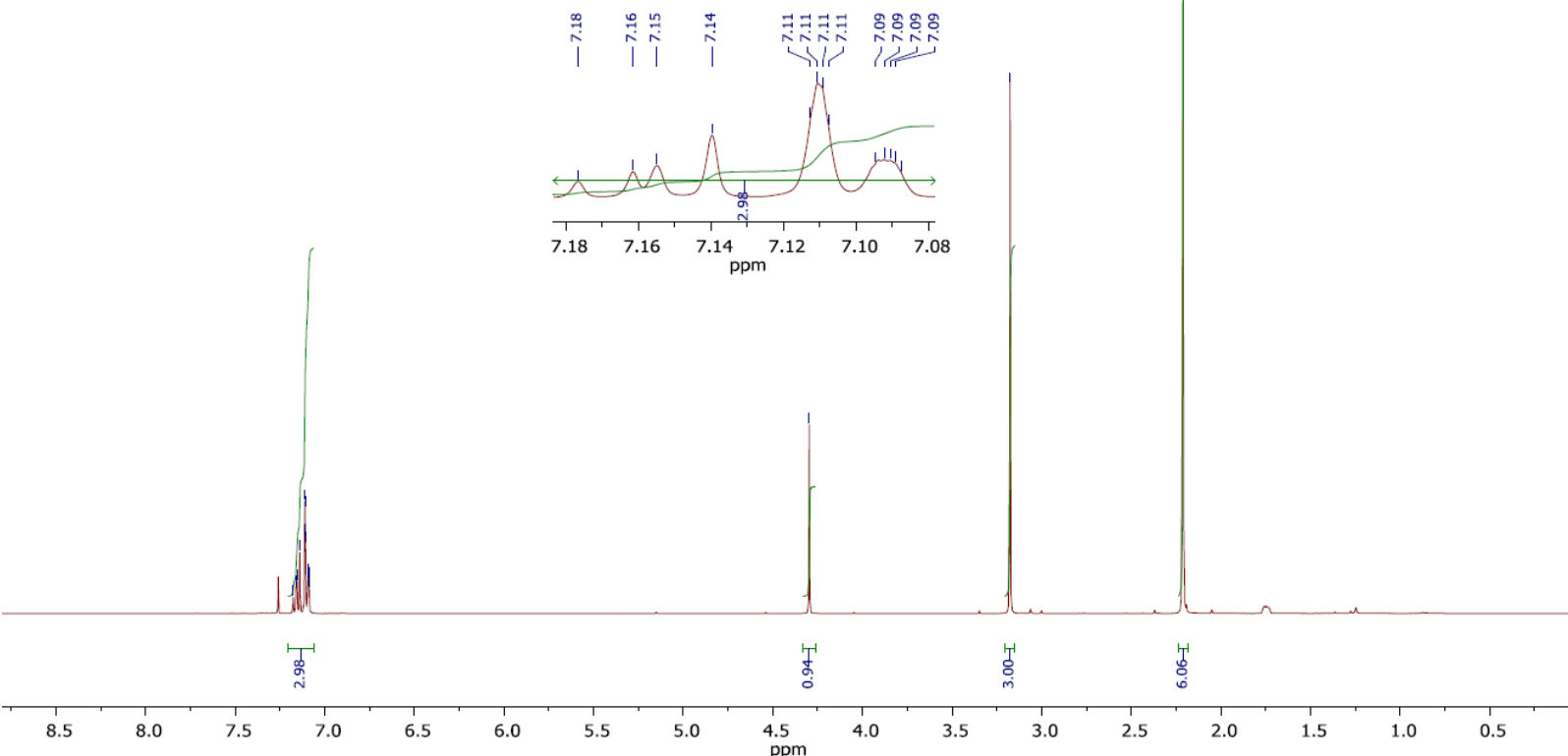

${ }^{13}$ C-NMR (100 MHz, $\mathrm{CDCl}_{3}$ ) of compound 8q
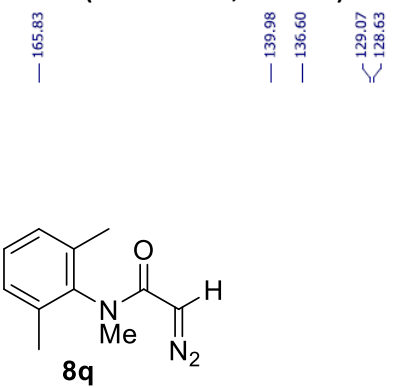

赵

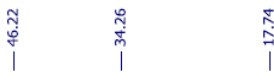

89

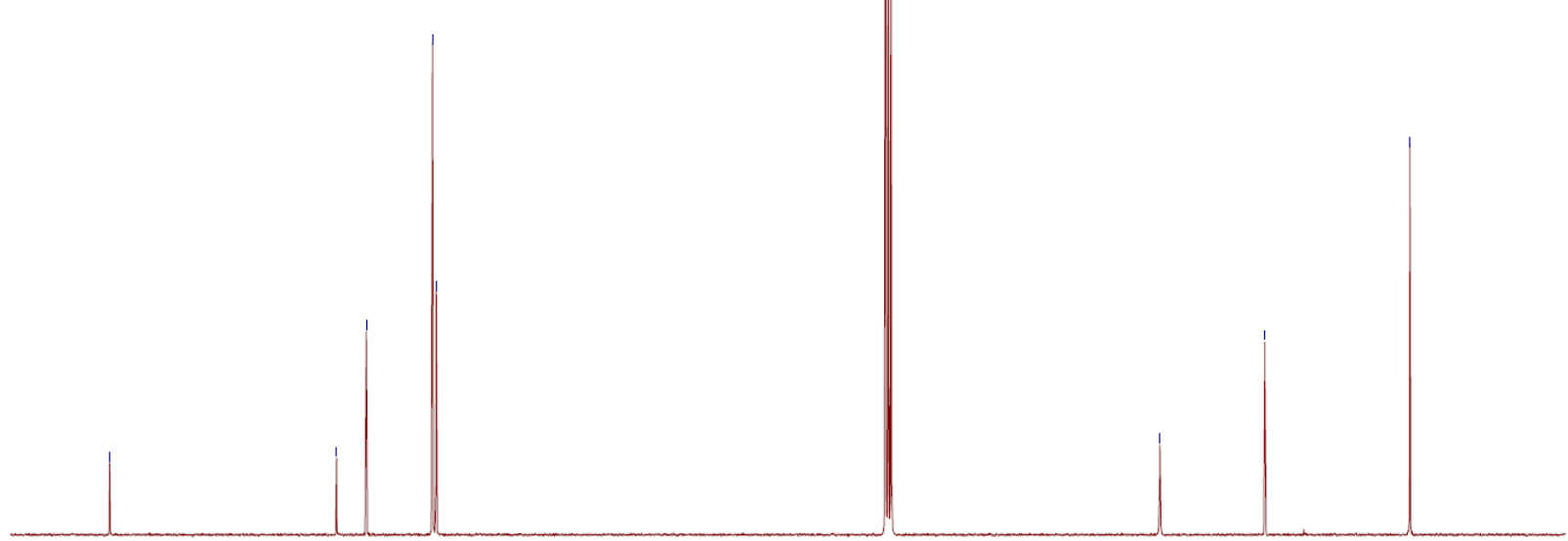

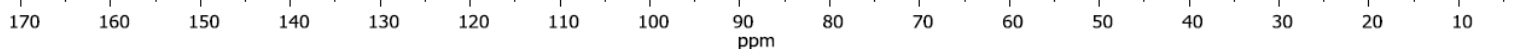


${ }^{1} \mathrm{H}$-NMR (400 MHz, $\mathrm{CDCl}_{3}$ ) of compound 12

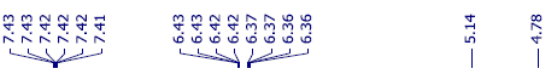<smiles>N=C(P)C(=O)OCc1ccco1</smiles>

12
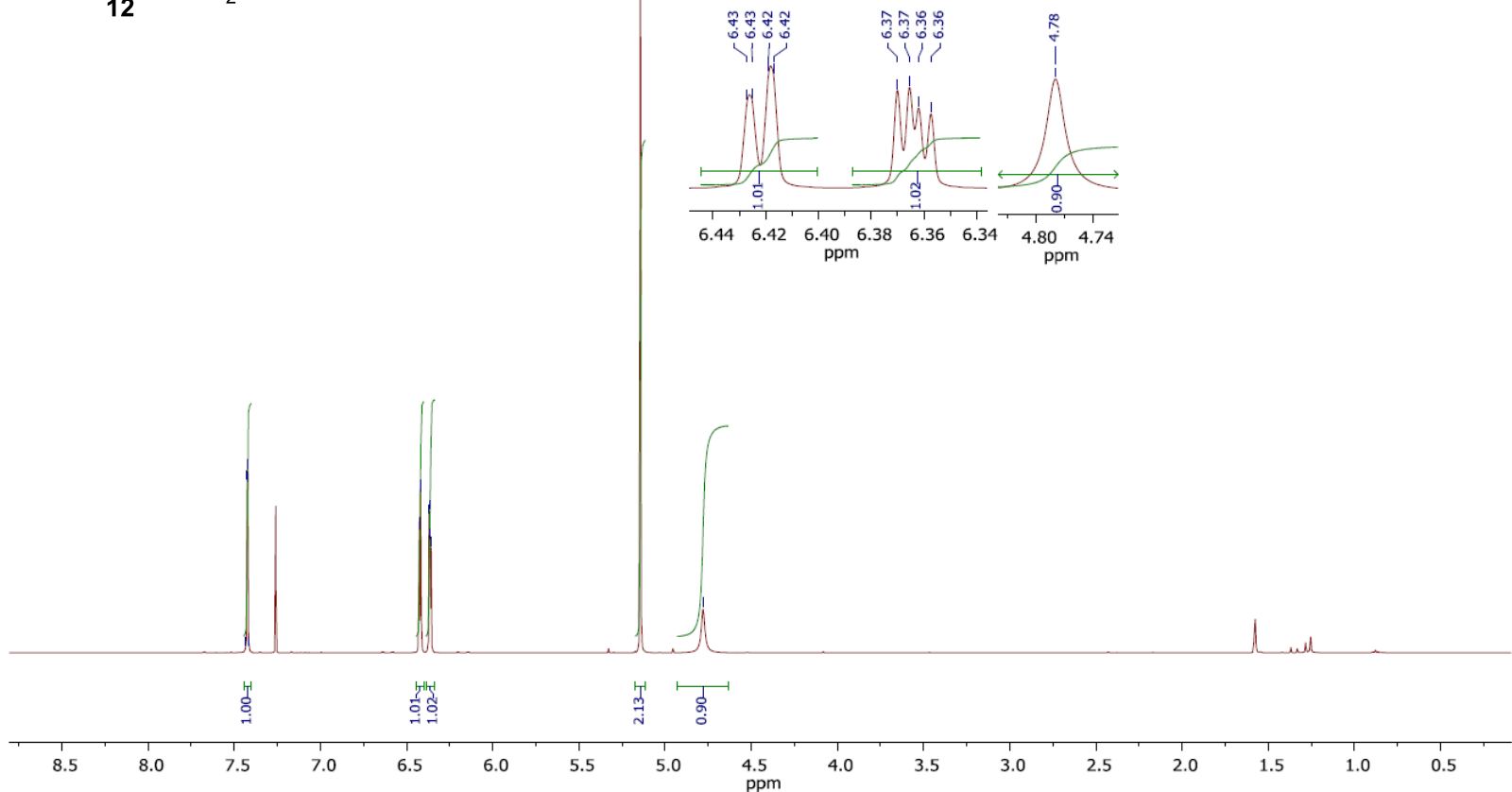

${ }^{13}$ C-NMR (100 MHz, $\mathrm{CDCl}_{3}$ ) of compound 12

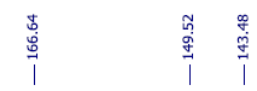<smiles>N#CC(=O)OCc1ccco1</smiles>

12

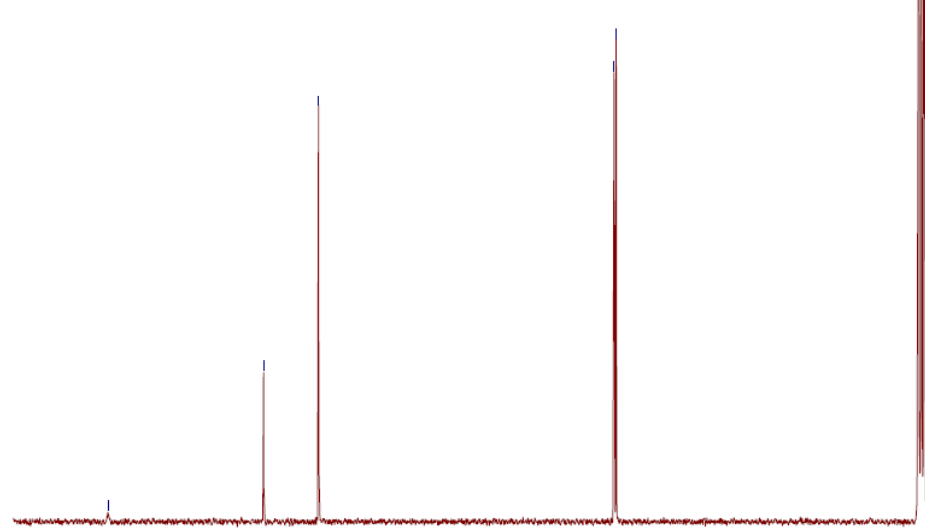

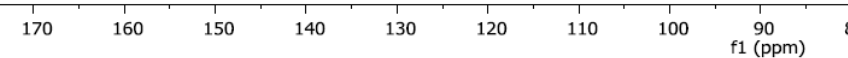


${ }^{1} \mathrm{H}-\mathrm{NMR}\left(400 \mathrm{MHz}, \mathrm{CDCl}_{3}\right)$ of compound $\mathbf{9 p}$

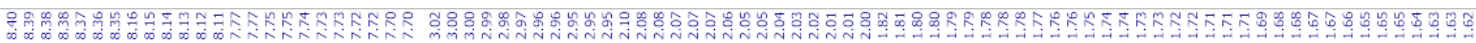<smiles>O=C1OI(C#CC2CCCC2)c2ccccc21</smiles>

$9 p$

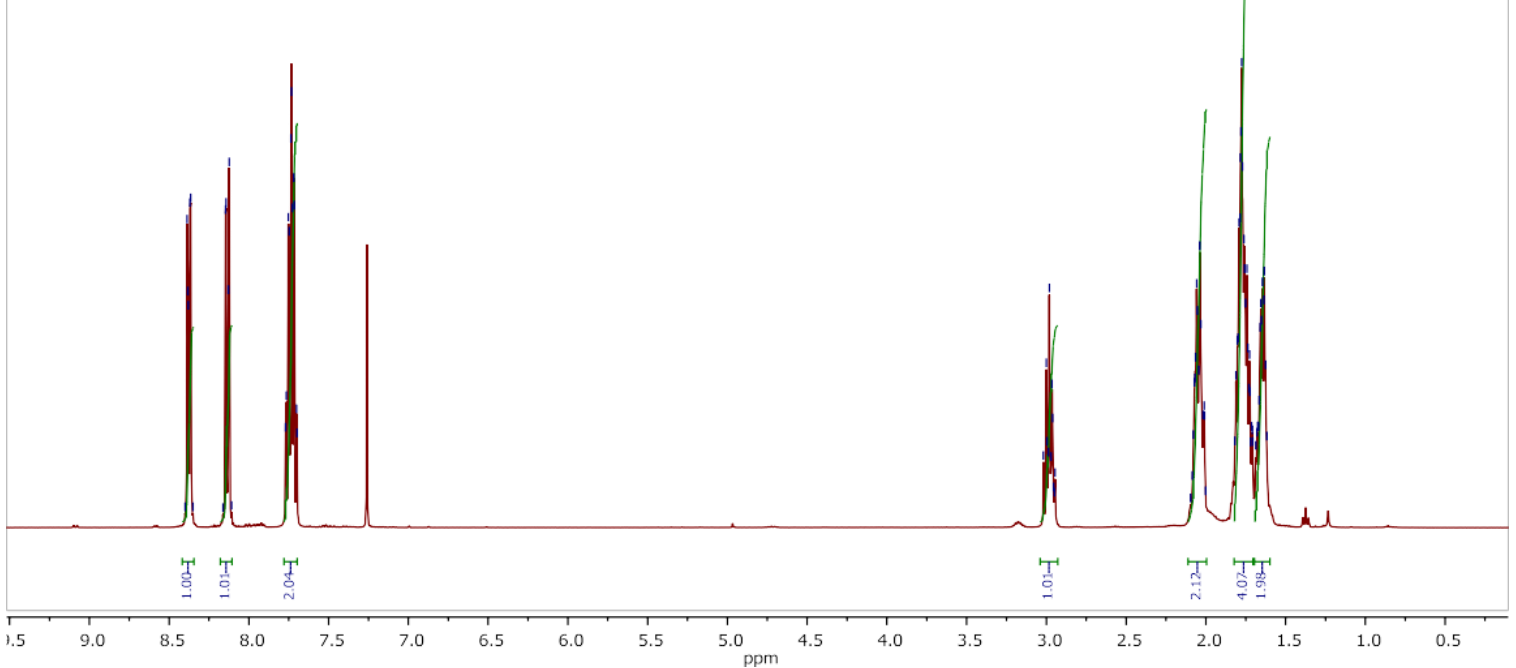

${ }^{13} \mathrm{C}-\mathrm{NMR}\left(100 \mathrm{MHz}, \mathrm{CDCl}_{3}\right)$ of compound 9p
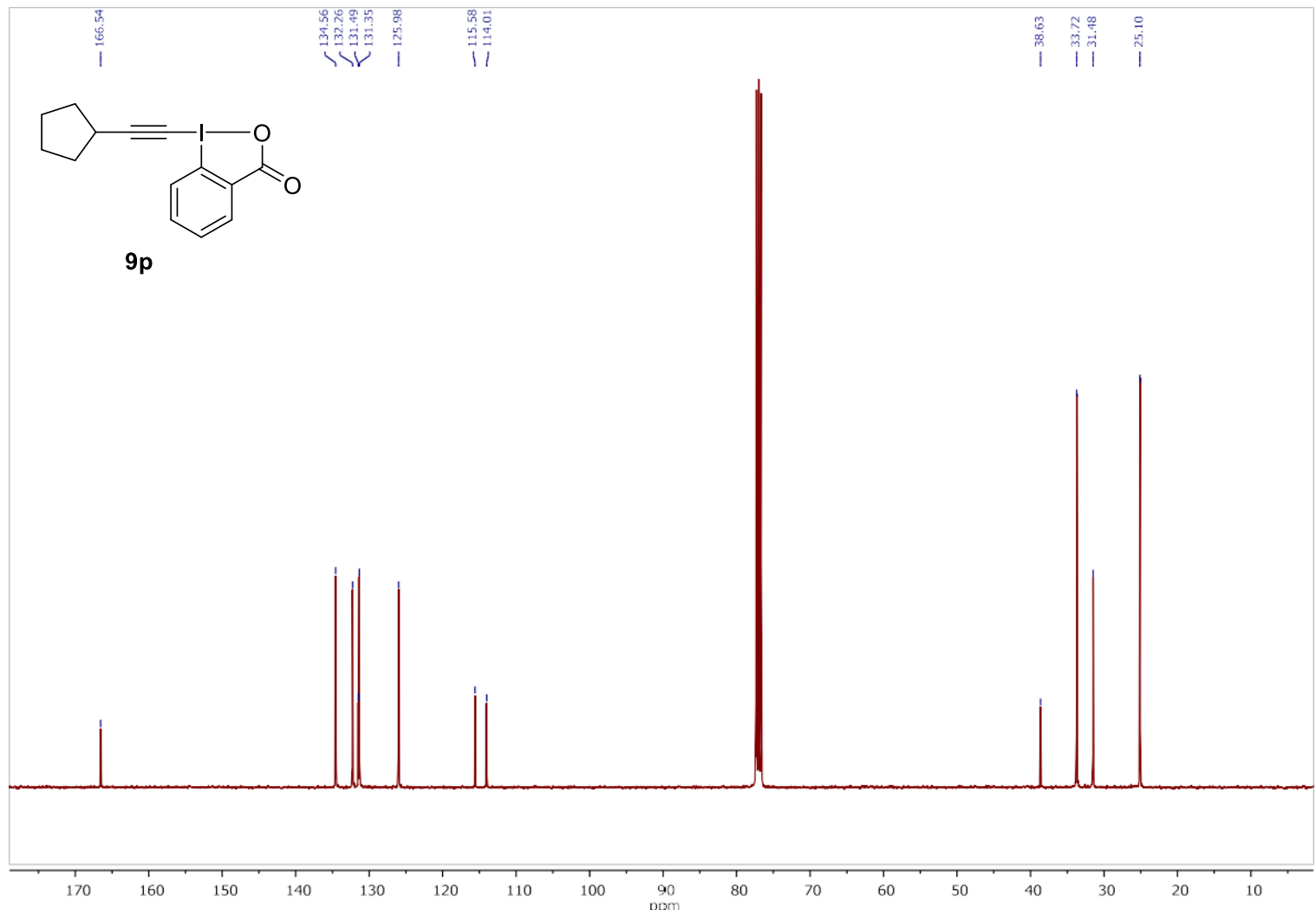
IR of compound $9 p$

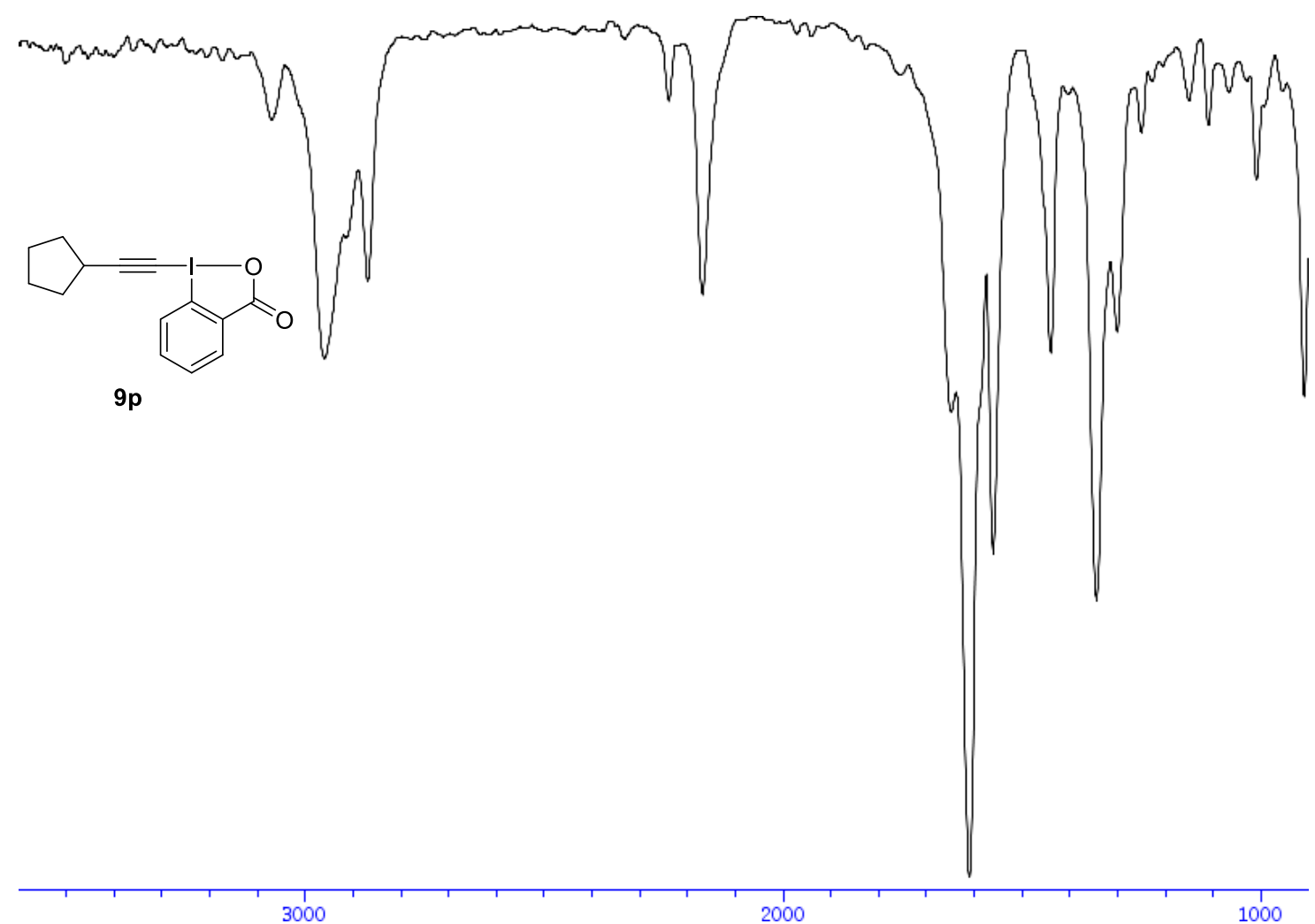


${ }^{1} \mathbf{H}-\mathrm{NMR}\left(400 \mathrm{MHz}, \mathrm{CDCl}_{3}\right.$ ) of compound $\mathbf{6 a}$

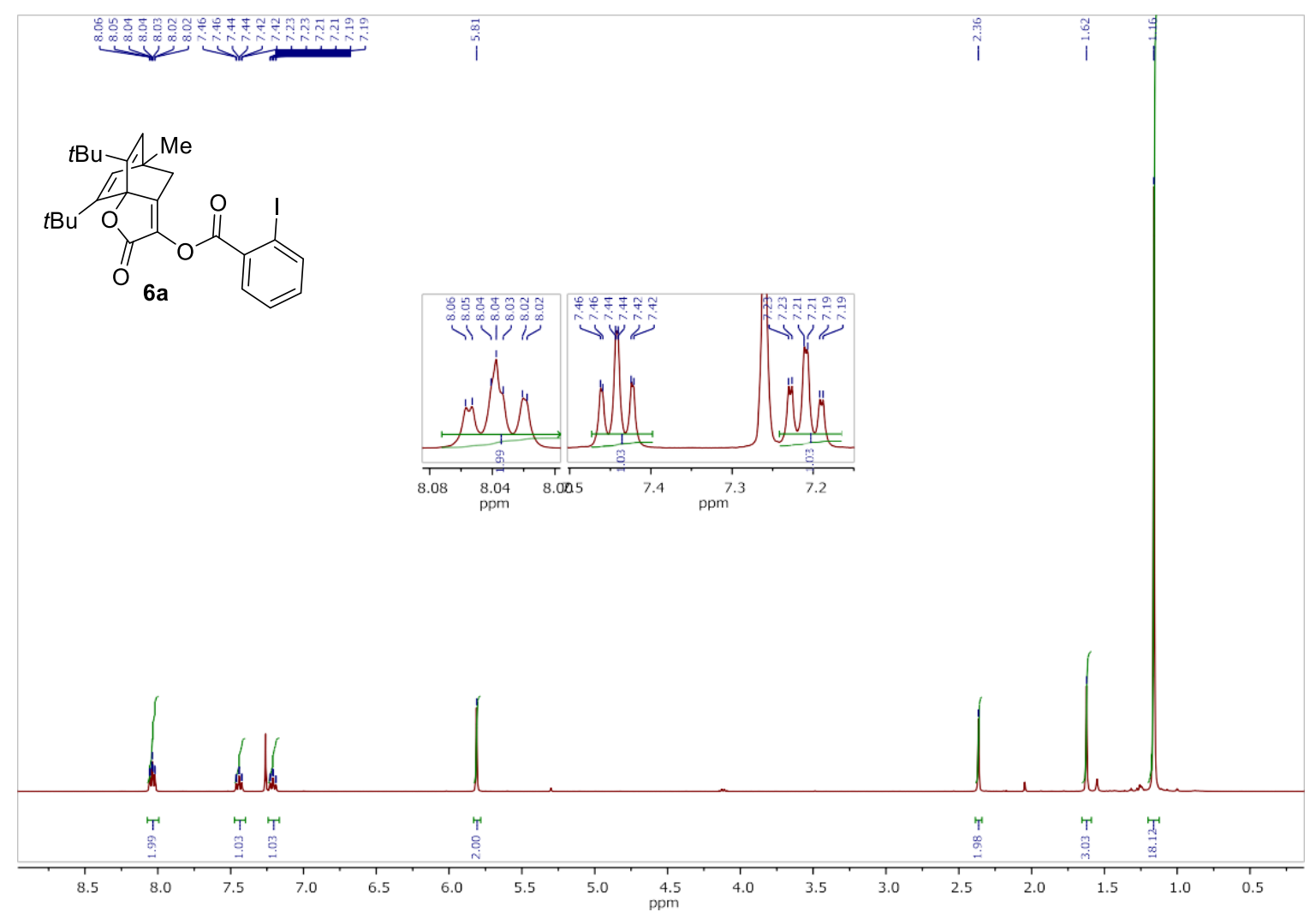

${ }^{13}$ C-NMR (100 MHz, $\mathrm{CDCl}_{3}$ ) of compound $\mathbf{6 a}$

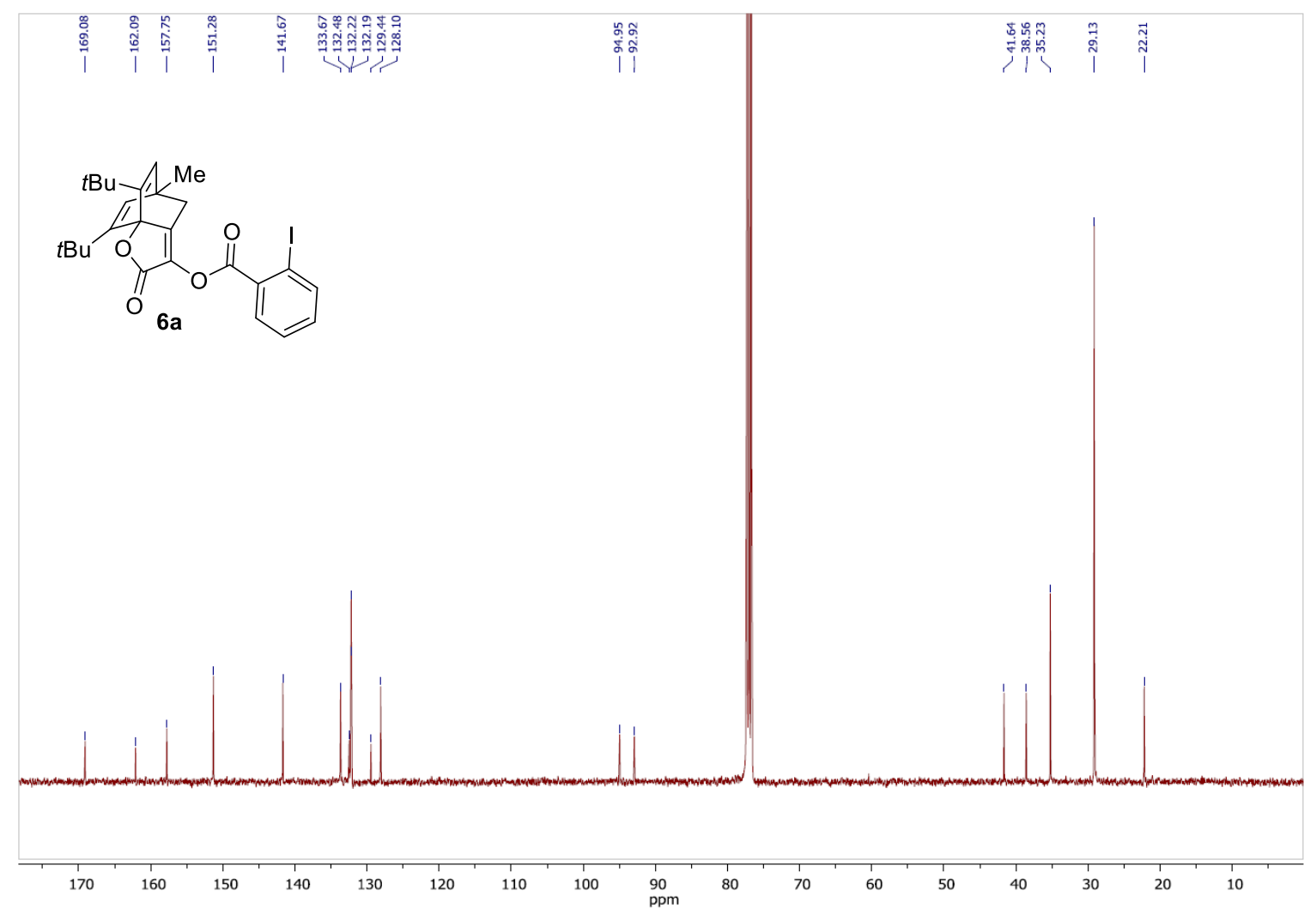

S144 
IR of compound $\mathbf{6 a}$

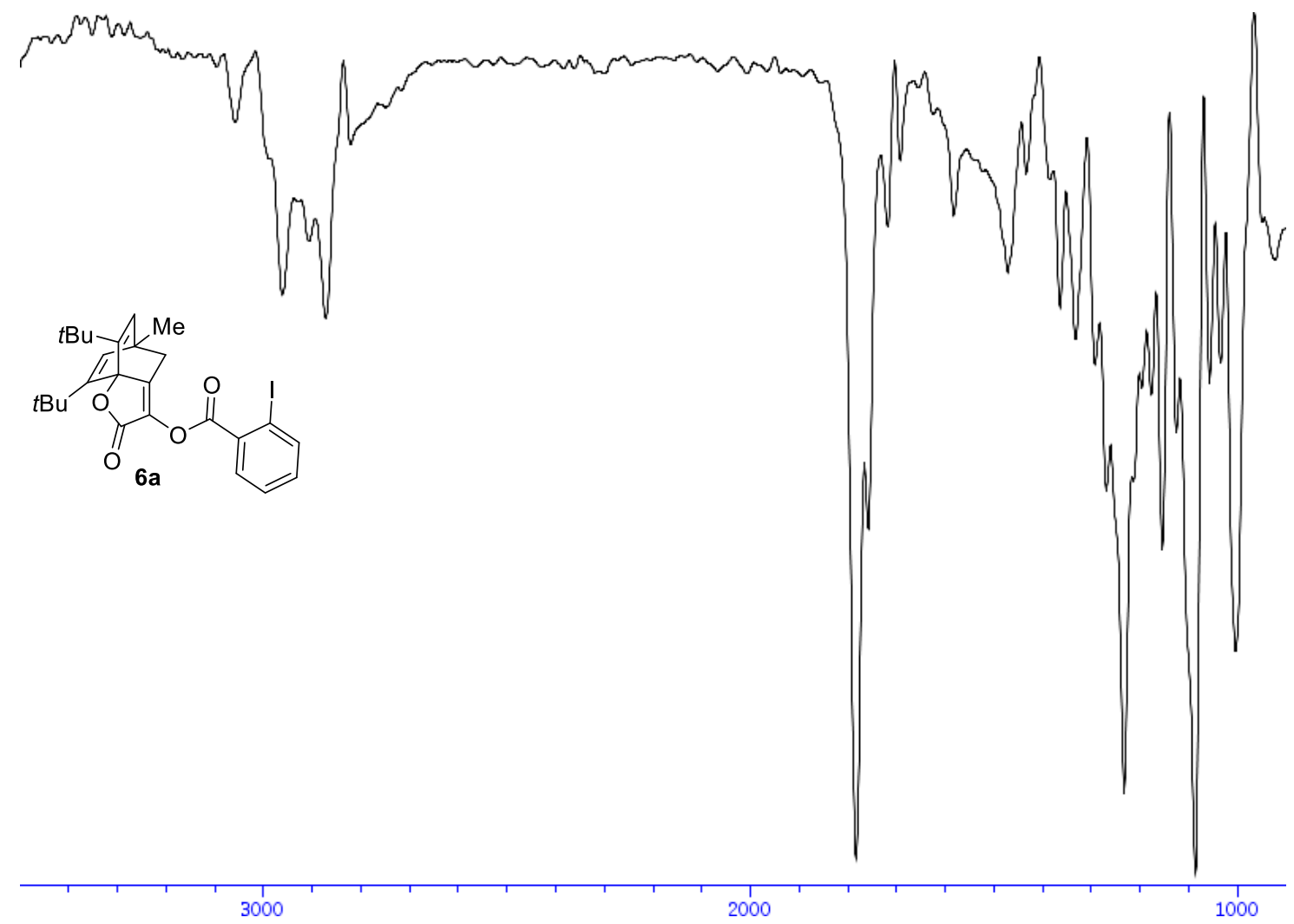


${ }^{1} \mathbf{H}$-NMR (400 MHz, $\mathrm{CDCl}_{3}$ ) of compound $\mathbf{6 b}$

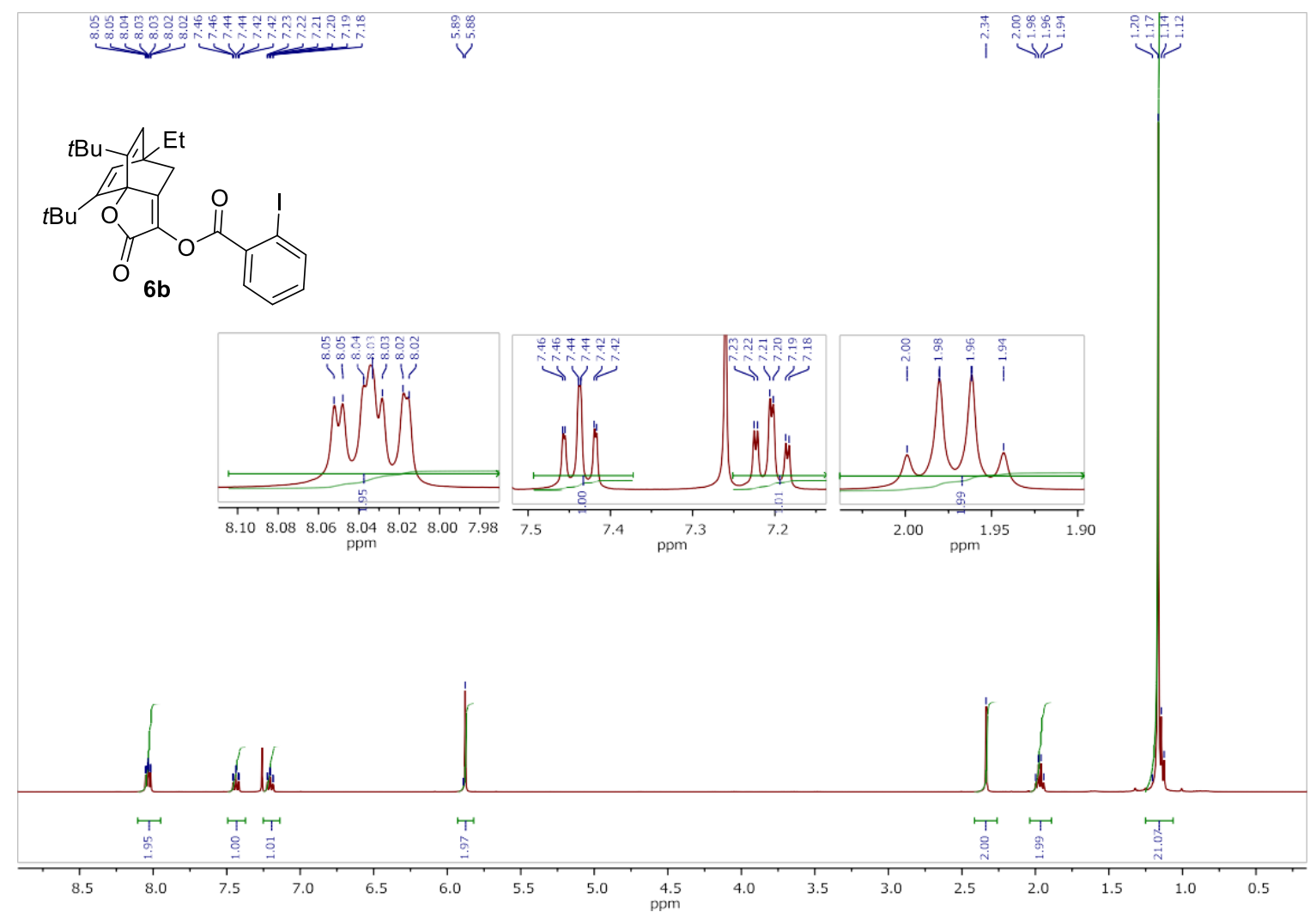

${ }^{13}$ C-NMR $\left(100 \mathrm{MHz}, \mathrm{CDCl}_{3}\right)$ of compound $\mathbf{6 b}$

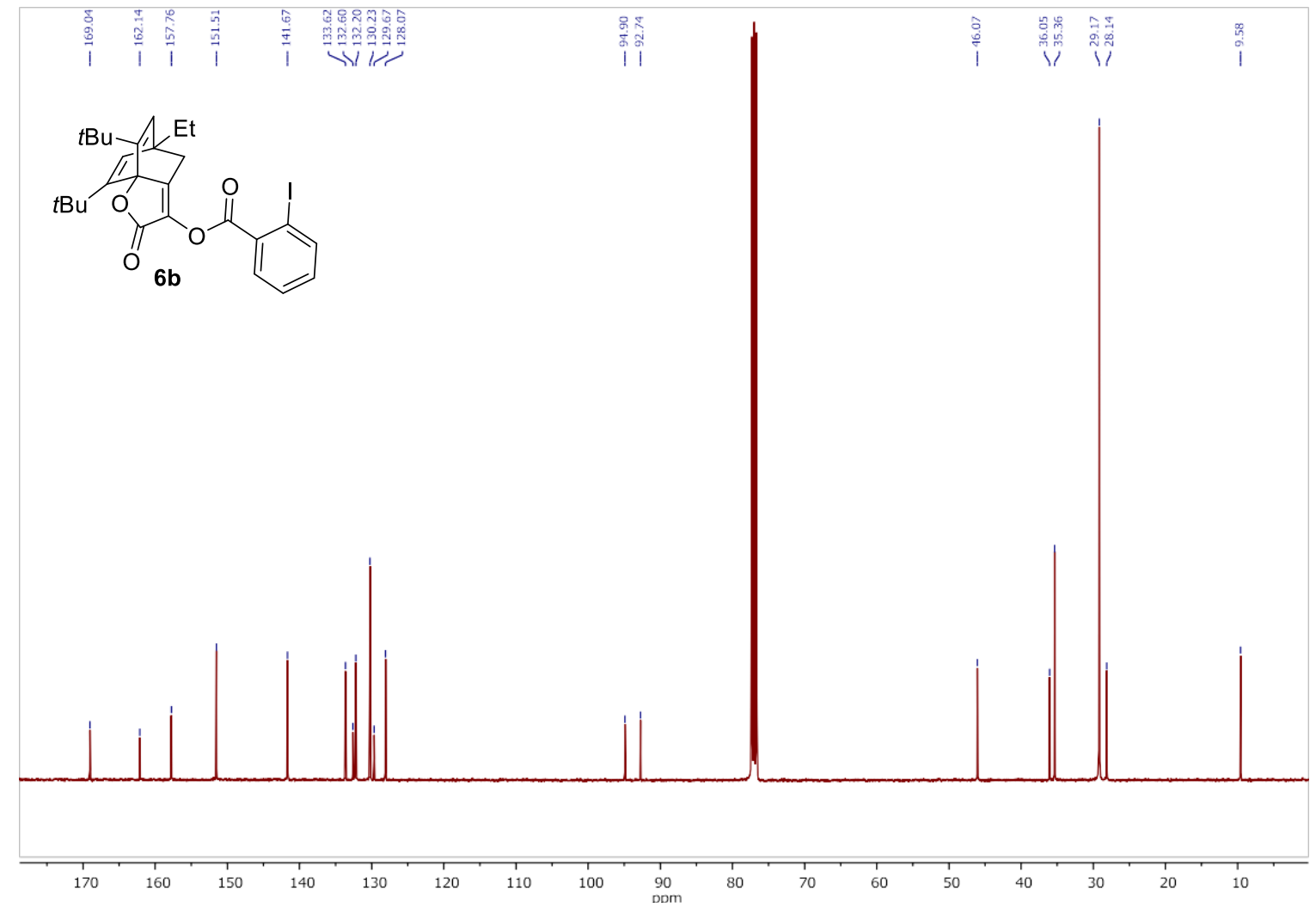


IR of compound $\mathbf{6 b}$

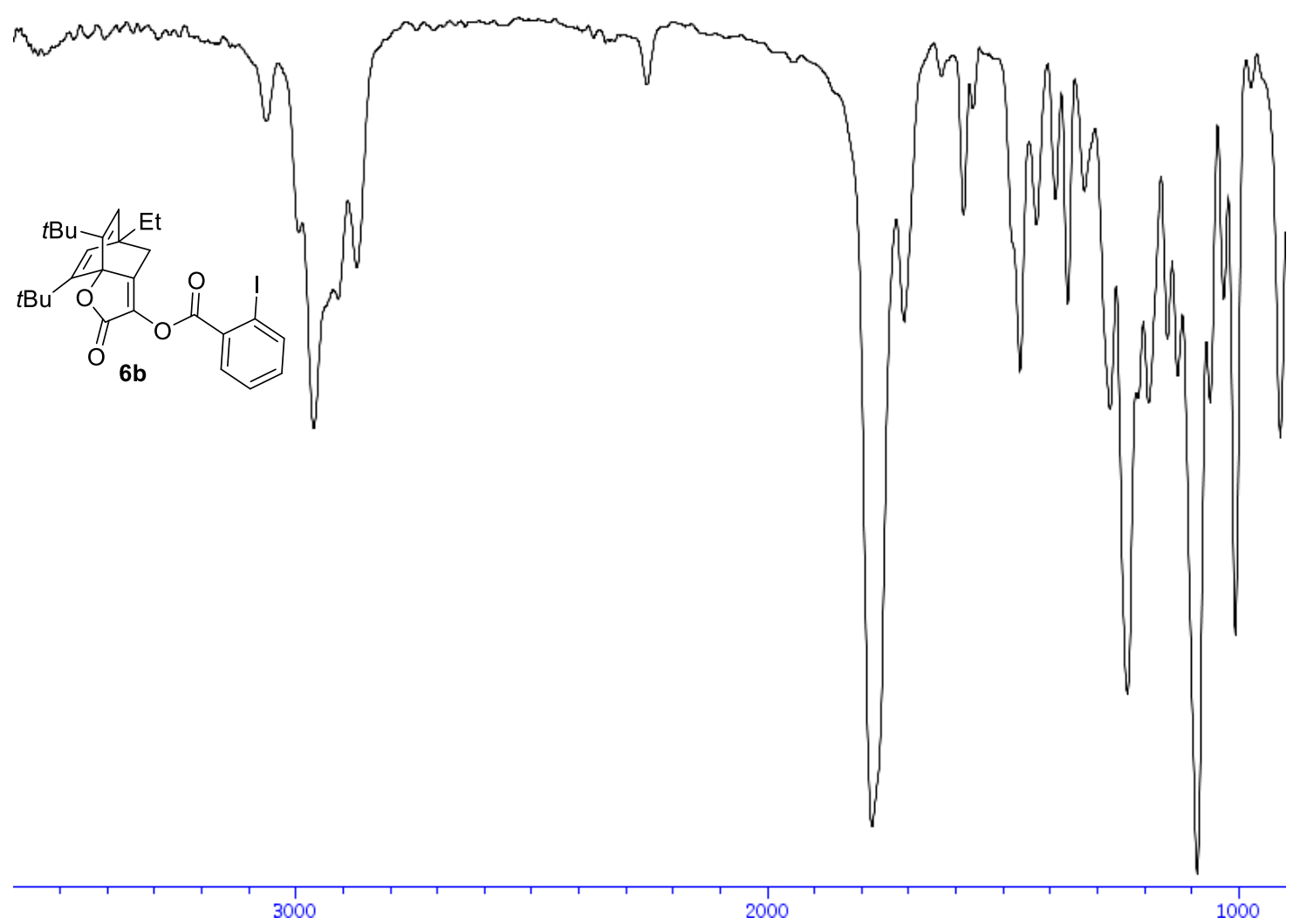


${ }^{1} \mathbf{H}$-NMR (400 MHz, $\mathrm{CDCl}_{3}$ ) of compound $\mathbf{6 c}$

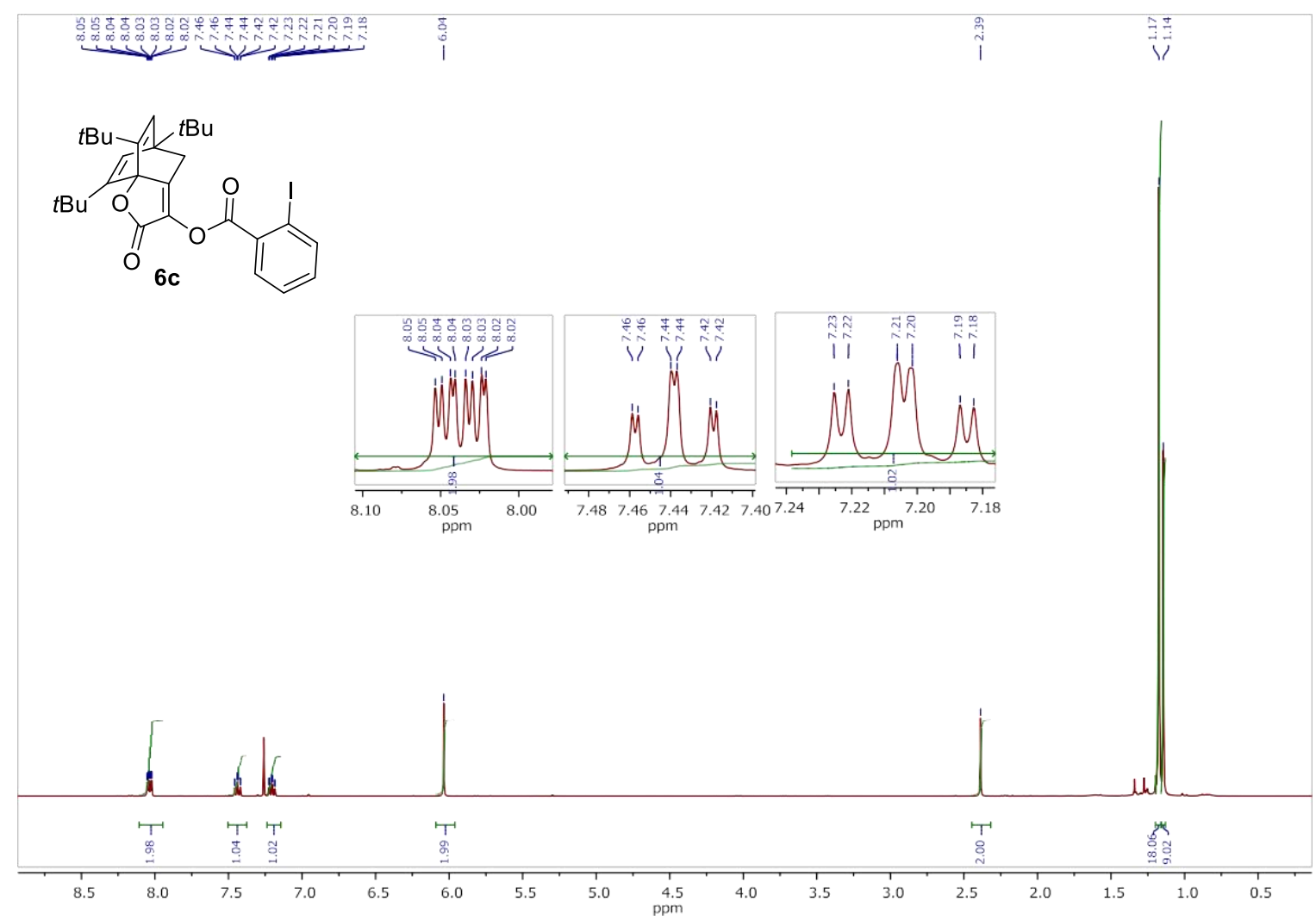

${ }^{13} \mathrm{C}-\mathrm{NMR}\left(100 \mathrm{MHz}, \mathrm{CDCl}_{3}\right)$ of compound $6 \mathrm{c}$

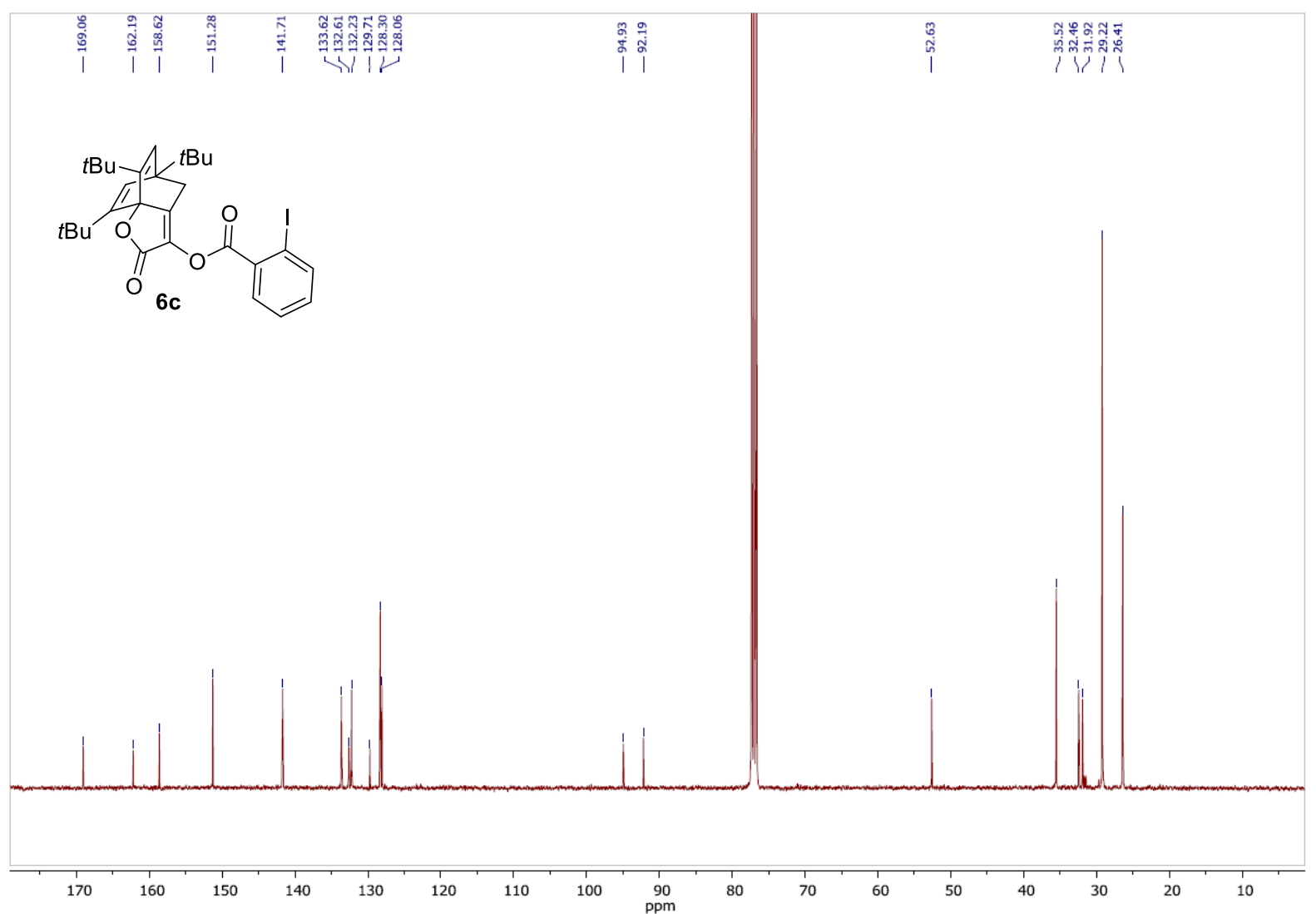


IR of compound $\mathbf{6 c}$

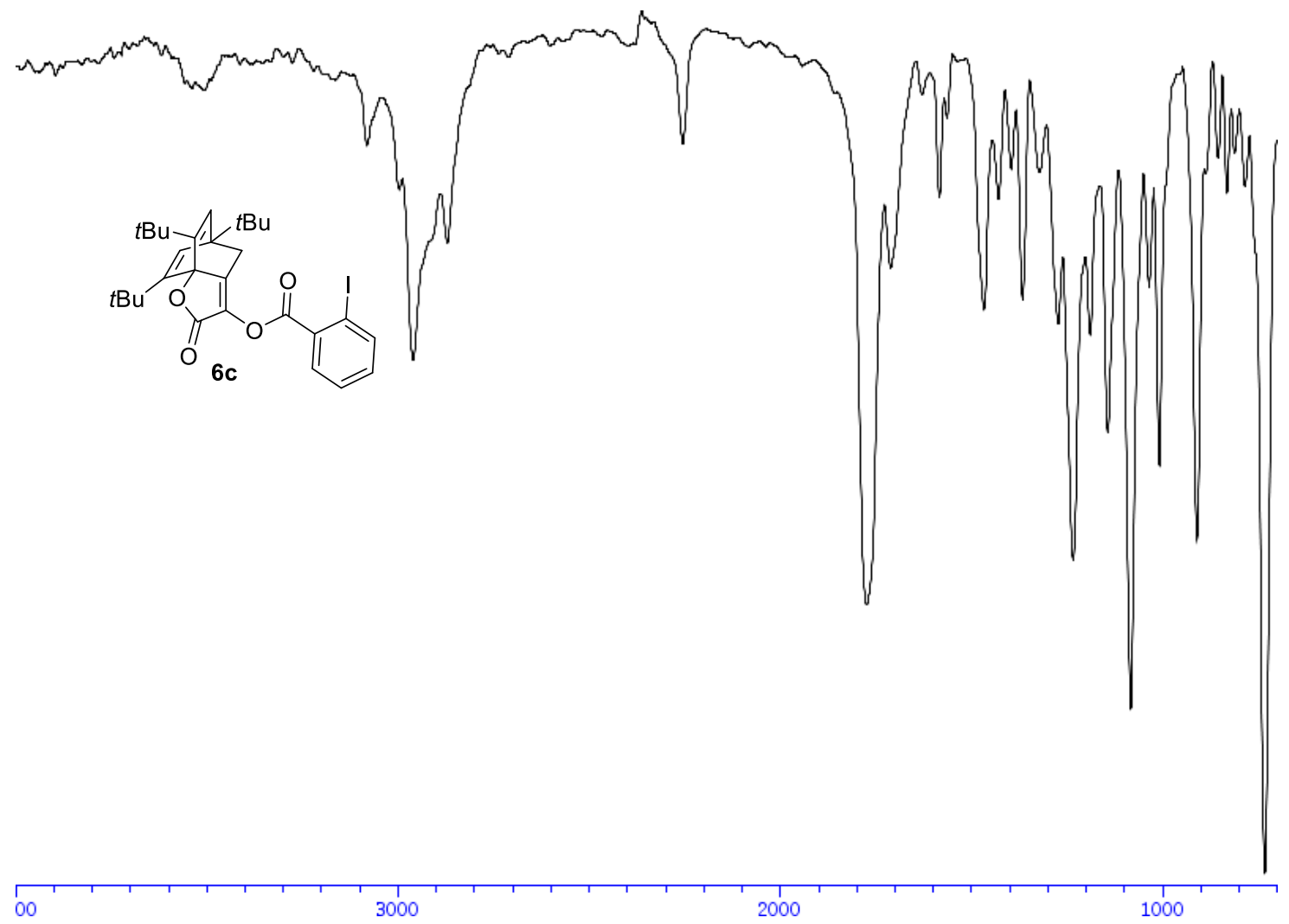


${ }^{1} \mathbf{H}$-NMR (400 MHz, $\mathrm{CDCl}_{3}$ ) of compound $\mathbf{6 d}$

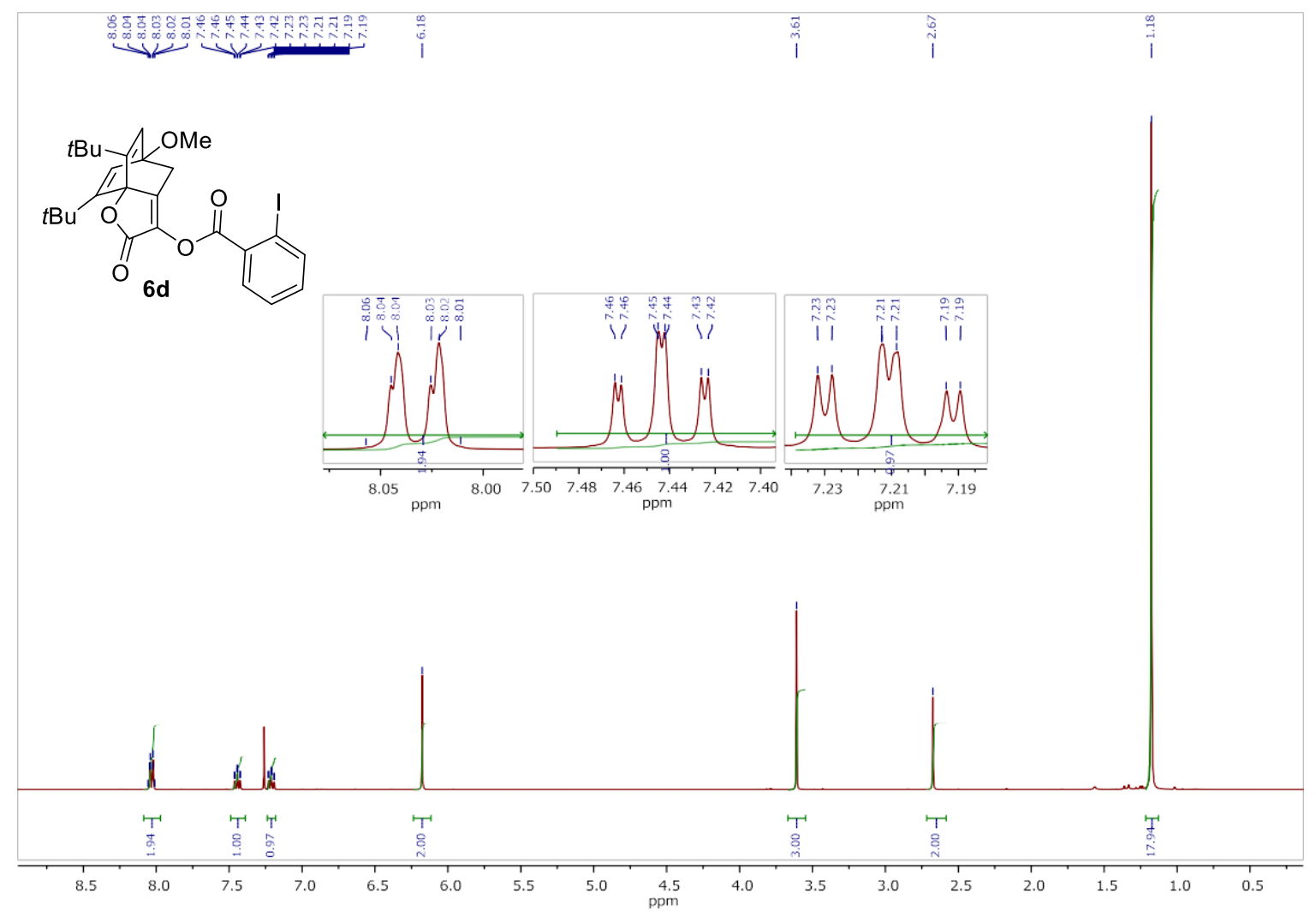

${ }^{13} \mathrm{C}-\mathrm{NMR}\left(100 \mathrm{MHz}, \mathrm{CDCl}_{3}\right)$ of compound $\mathbf{6 d}$

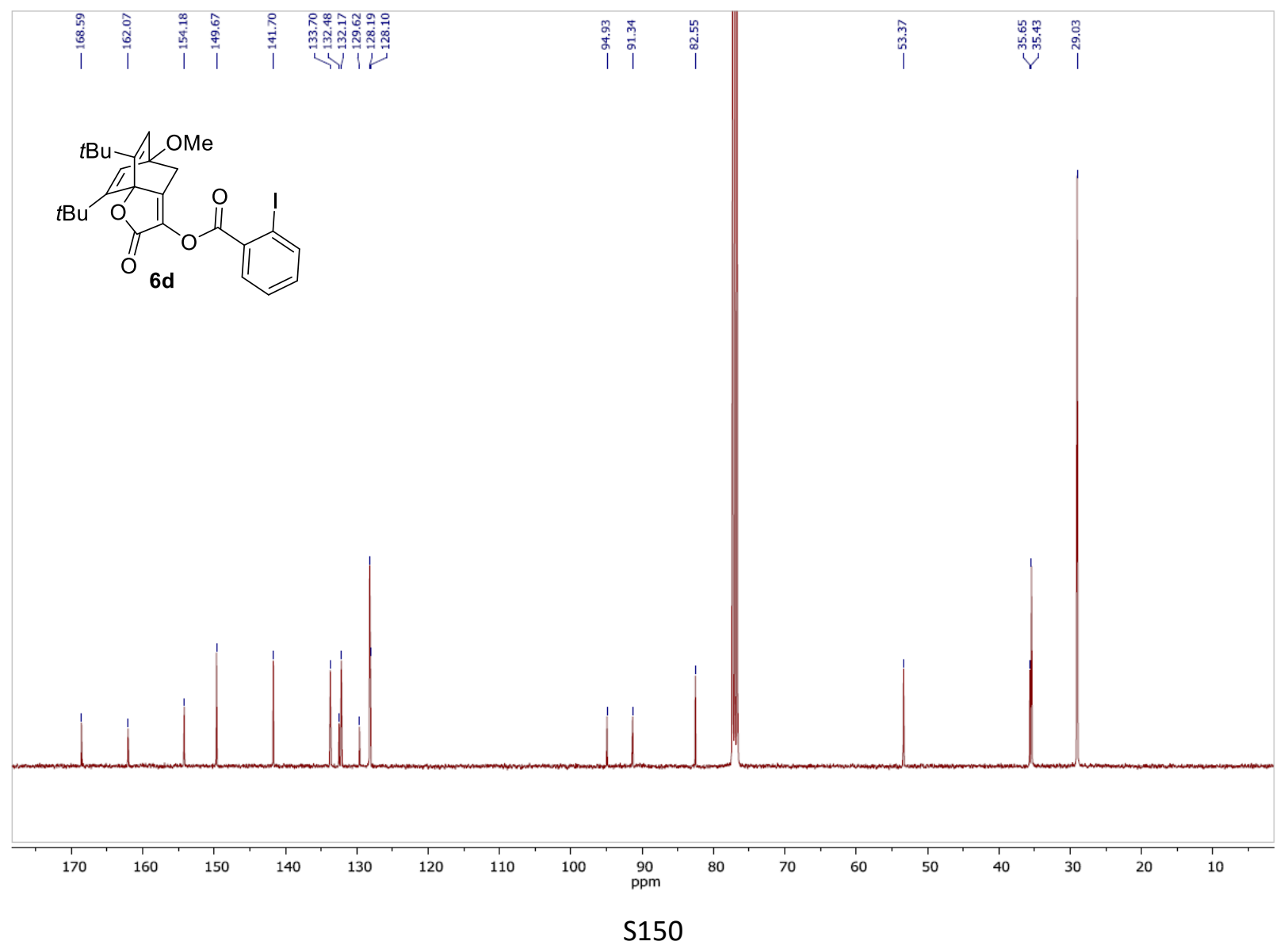


IR of compound $\mathbf{6 d}$

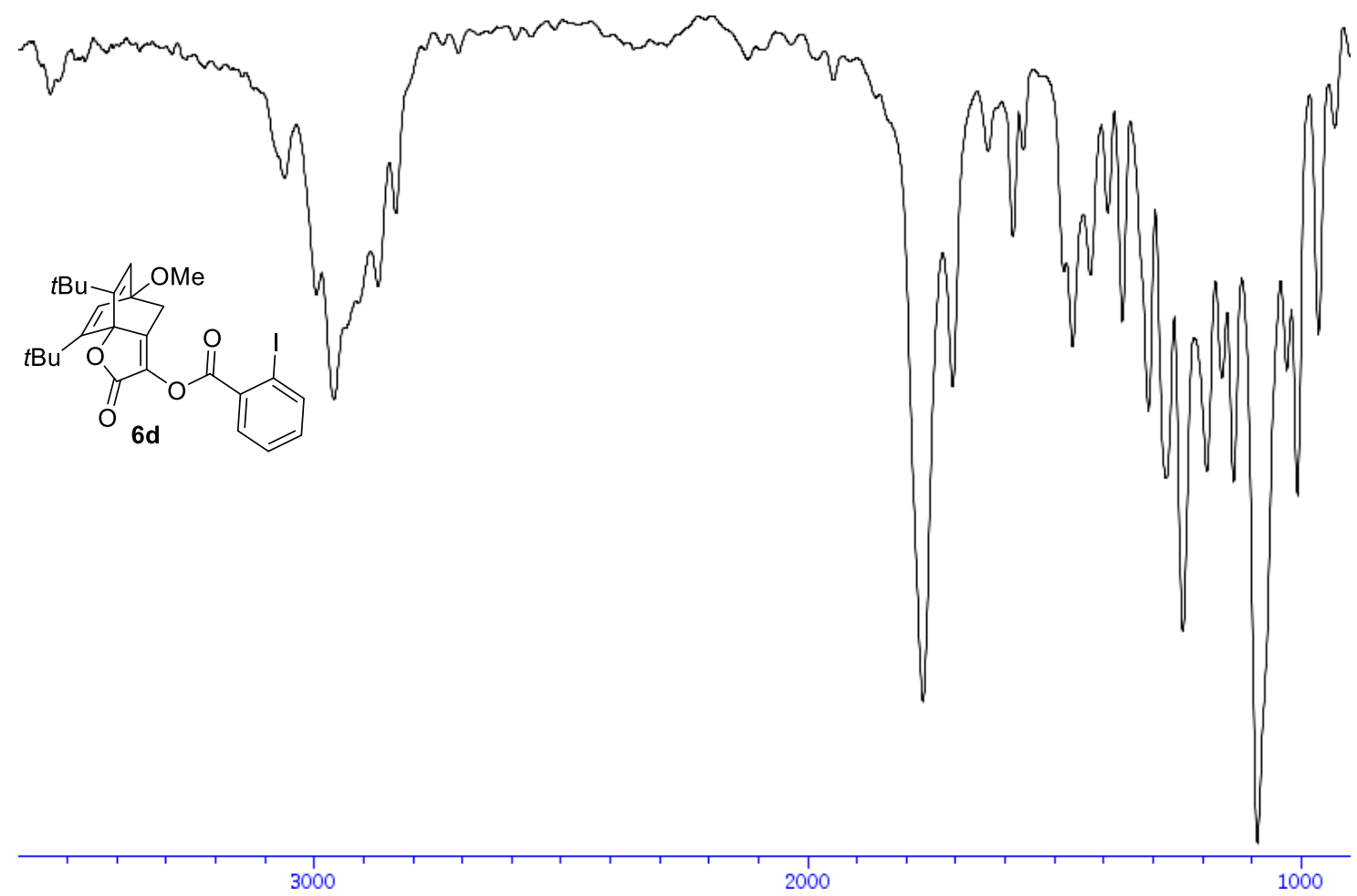


${ }^{1} \mathbf{H}-\mathrm{NMR}\left(400 \mathrm{MHz}, \mathrm{CDCl}_{3}\right.$ ) of compound $\mathbf{6 e}$

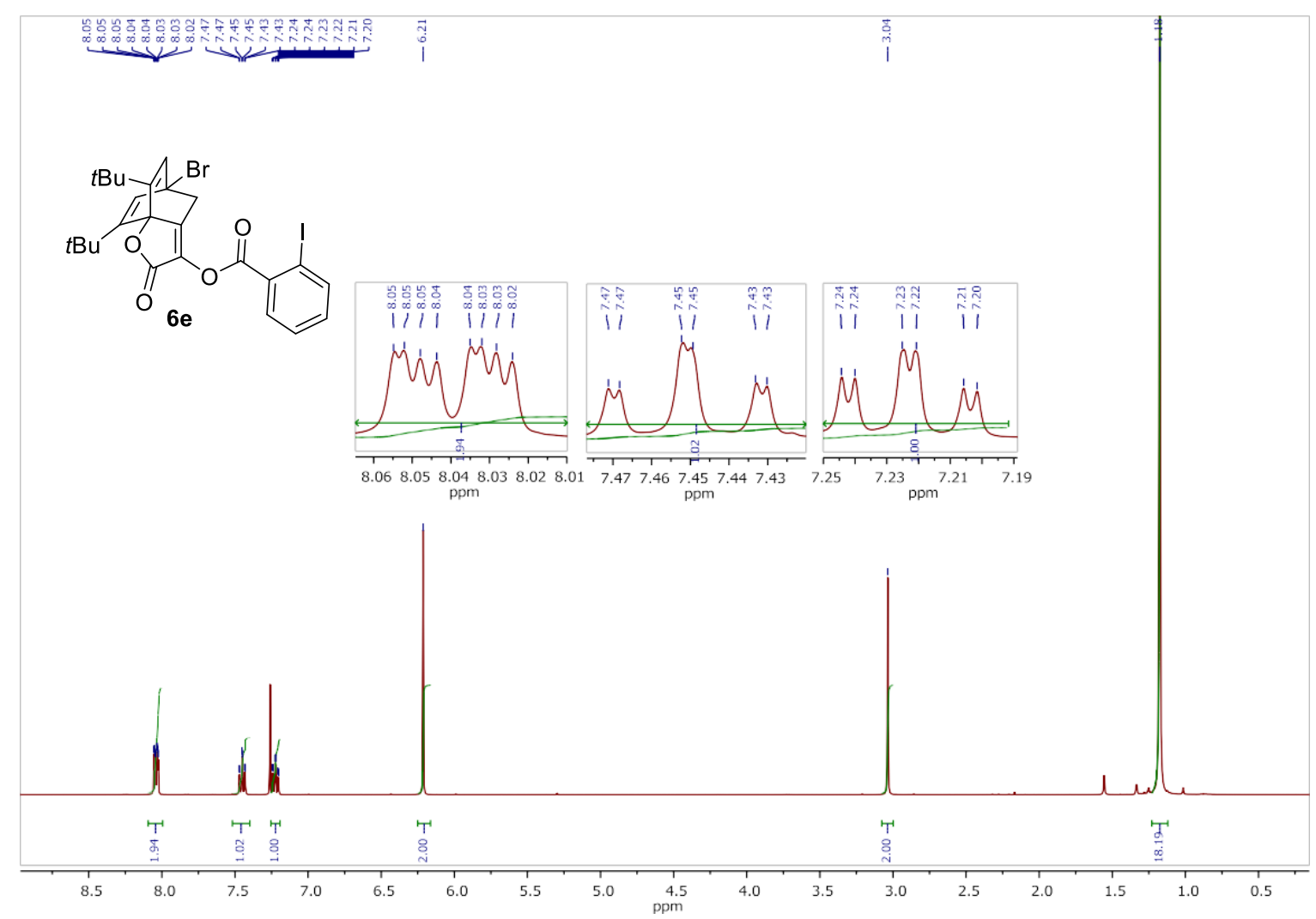

${ }^{13} \mathrm{C}-\mathrm{NMR}\left(100 \mathrm{MHz}, \mathrm{CDCl}_{3}\right)$ of compound $6 \mathrm{e}$

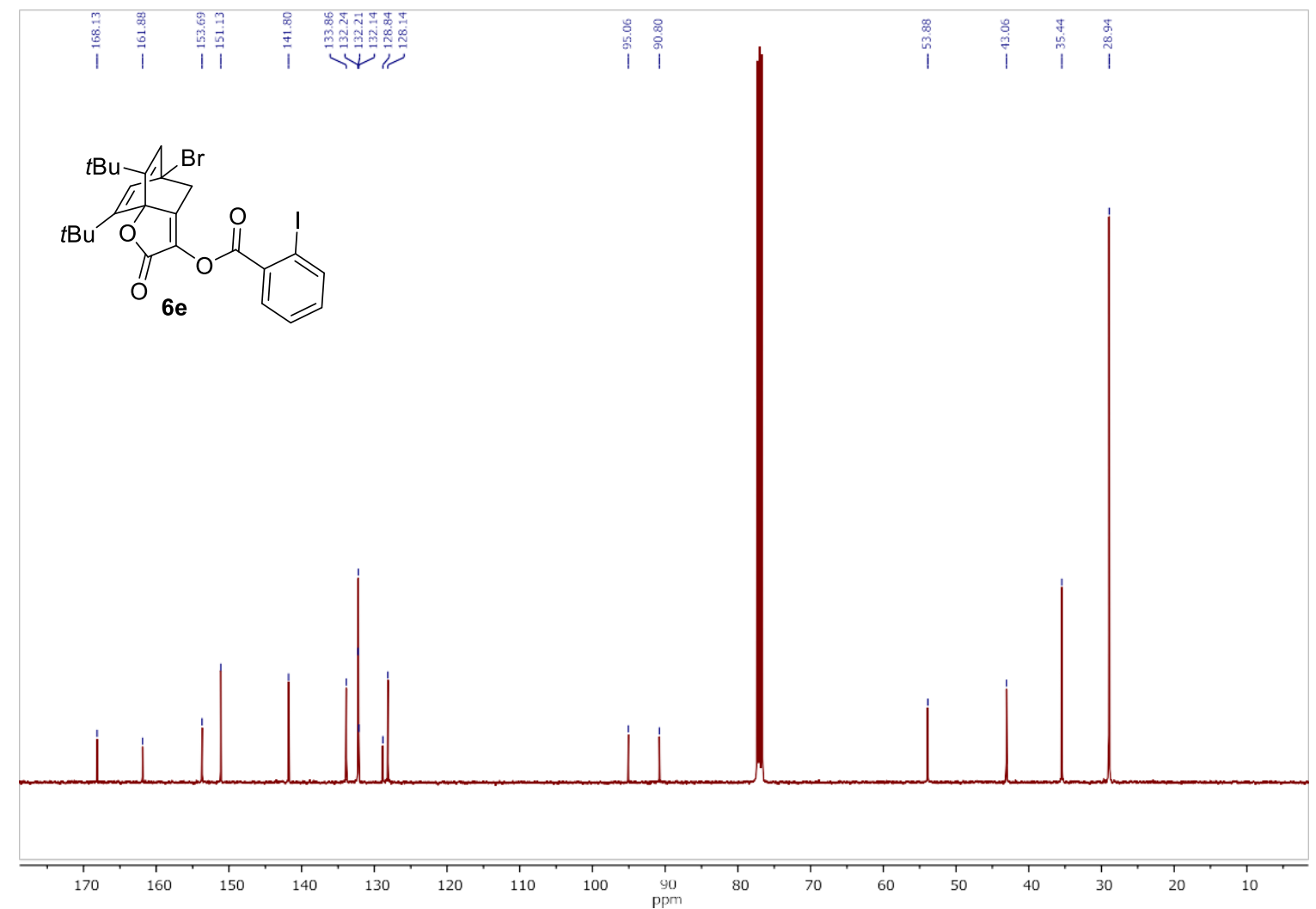


IR of compound $\mathbf{6 e}$

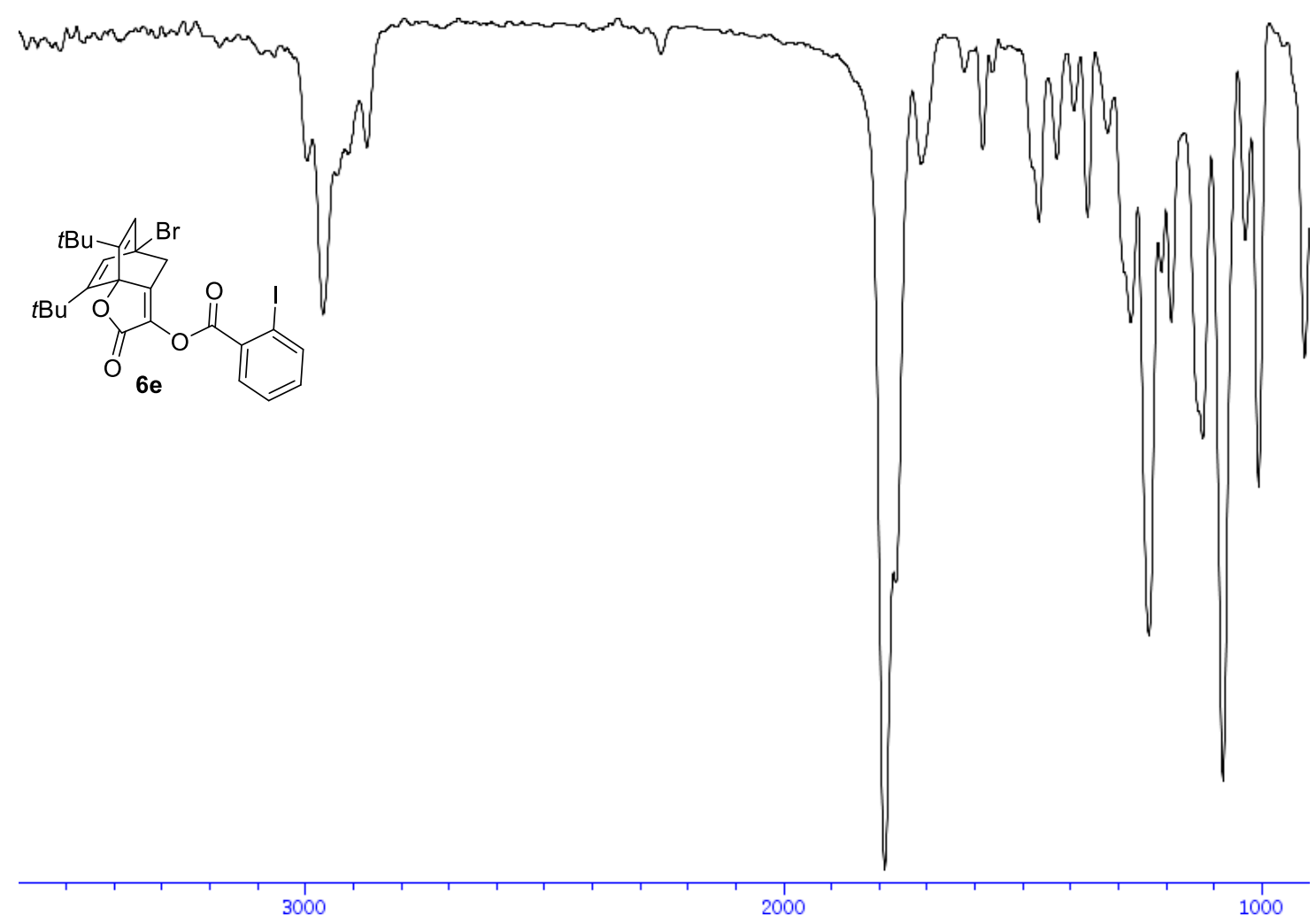


${ }^{1} \mathbf{H}-\mathrm{NMR}\left(400 \mathrm{MHz}, \mathrm{CDCl}_{3}\right.$ ) of compound $\mathbf{6 f}$

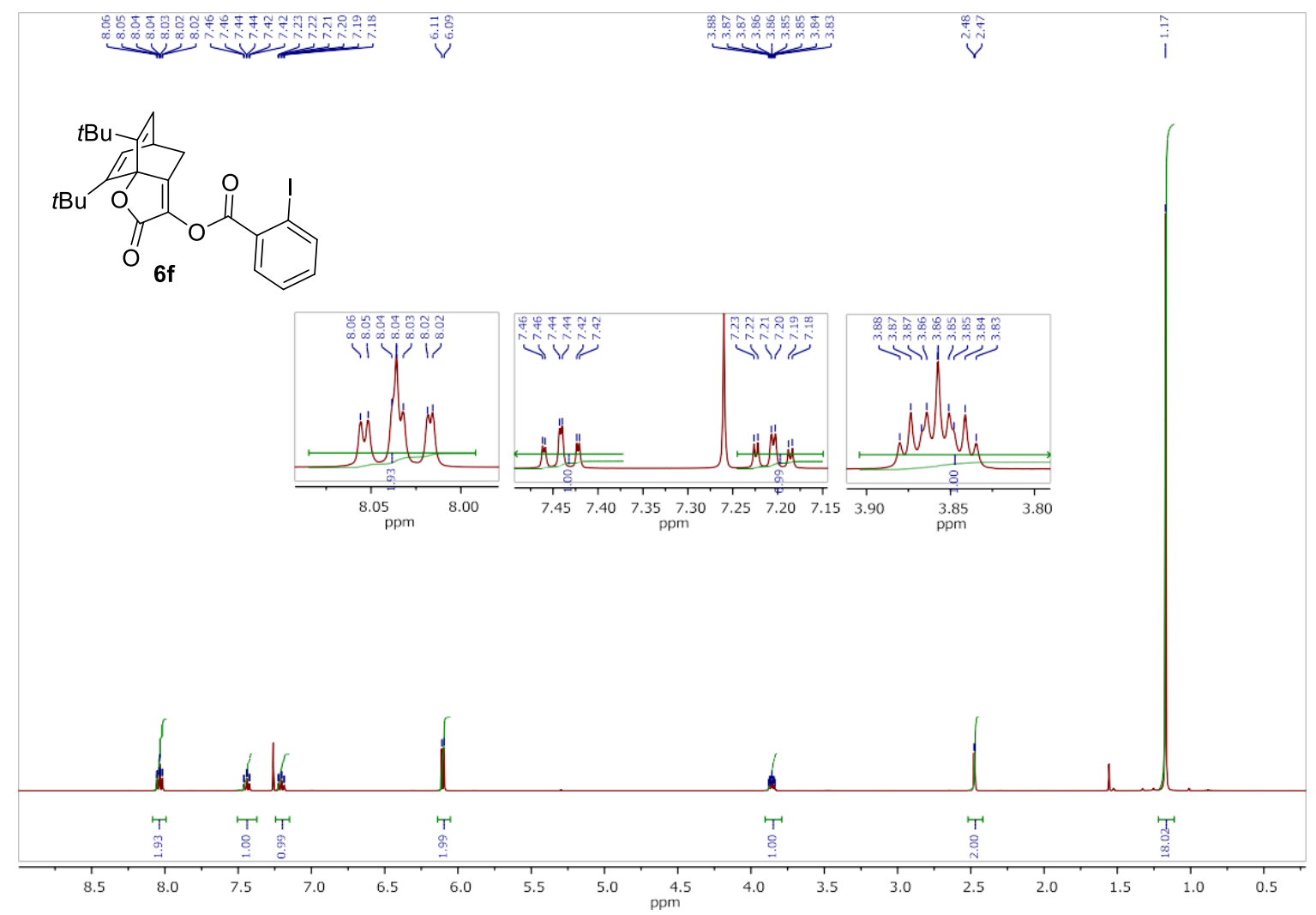

${ }^{13} \mathrm{C}$-NMR (100 MHz, $\mathrm{CDCl}_{3}$ ) of compound $6 f$

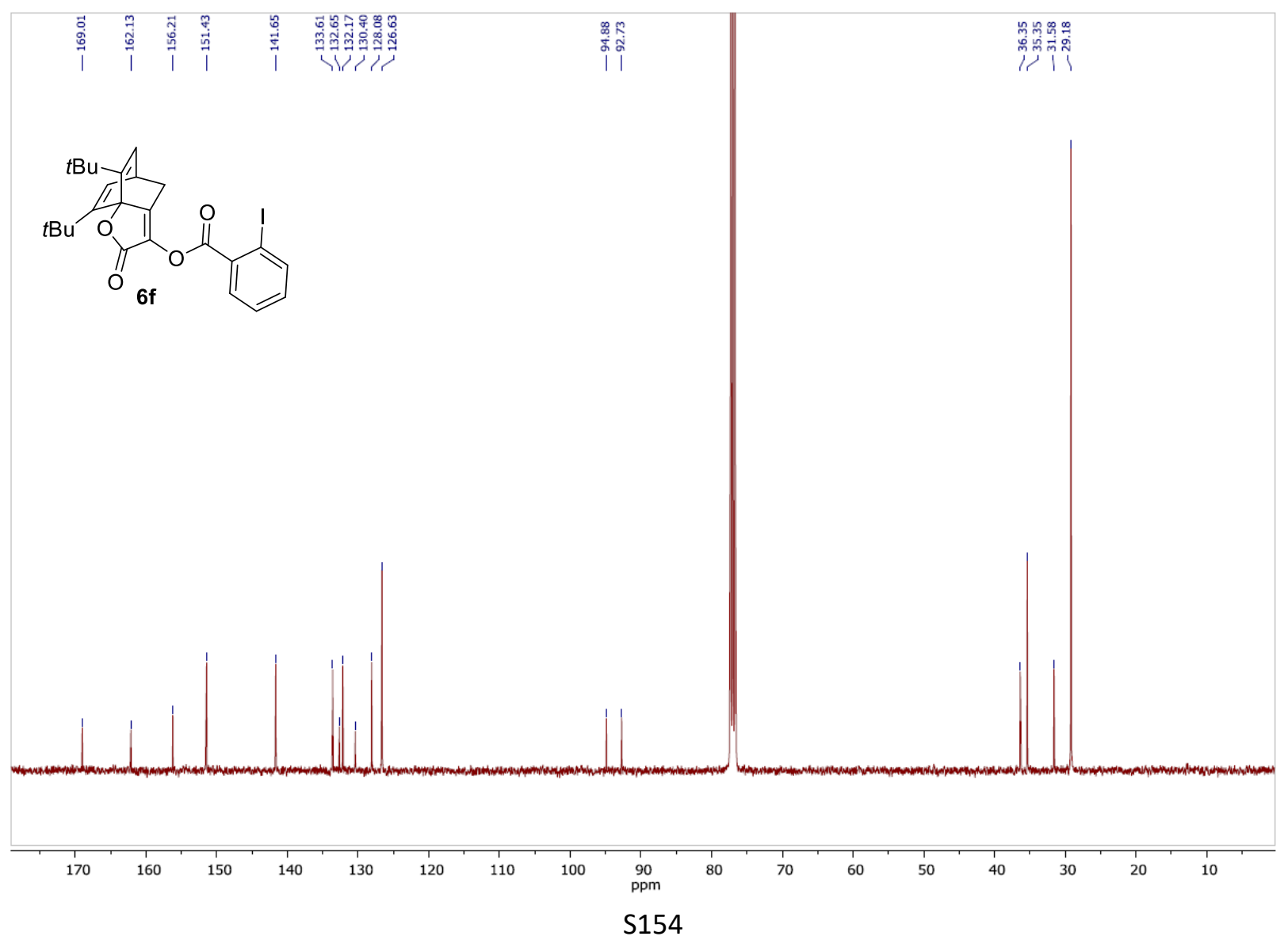


IR of compound $\mathbf{6 f}$

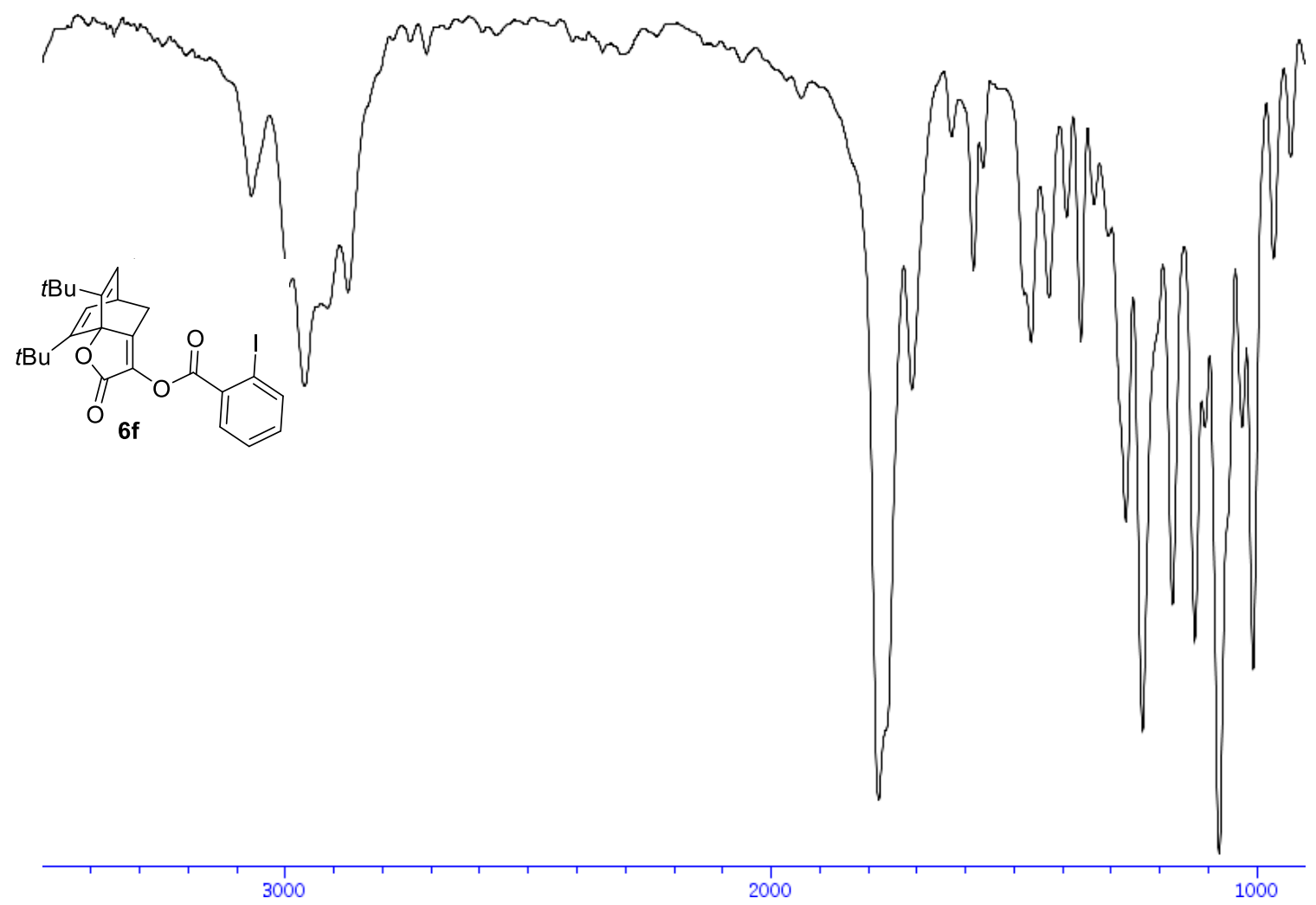


${ }^{1} \mathbf{H}$-NMR (400 MHz, $\mathrm{CDCl}_{3}$ ) of compound $\mathbf{6 g}$

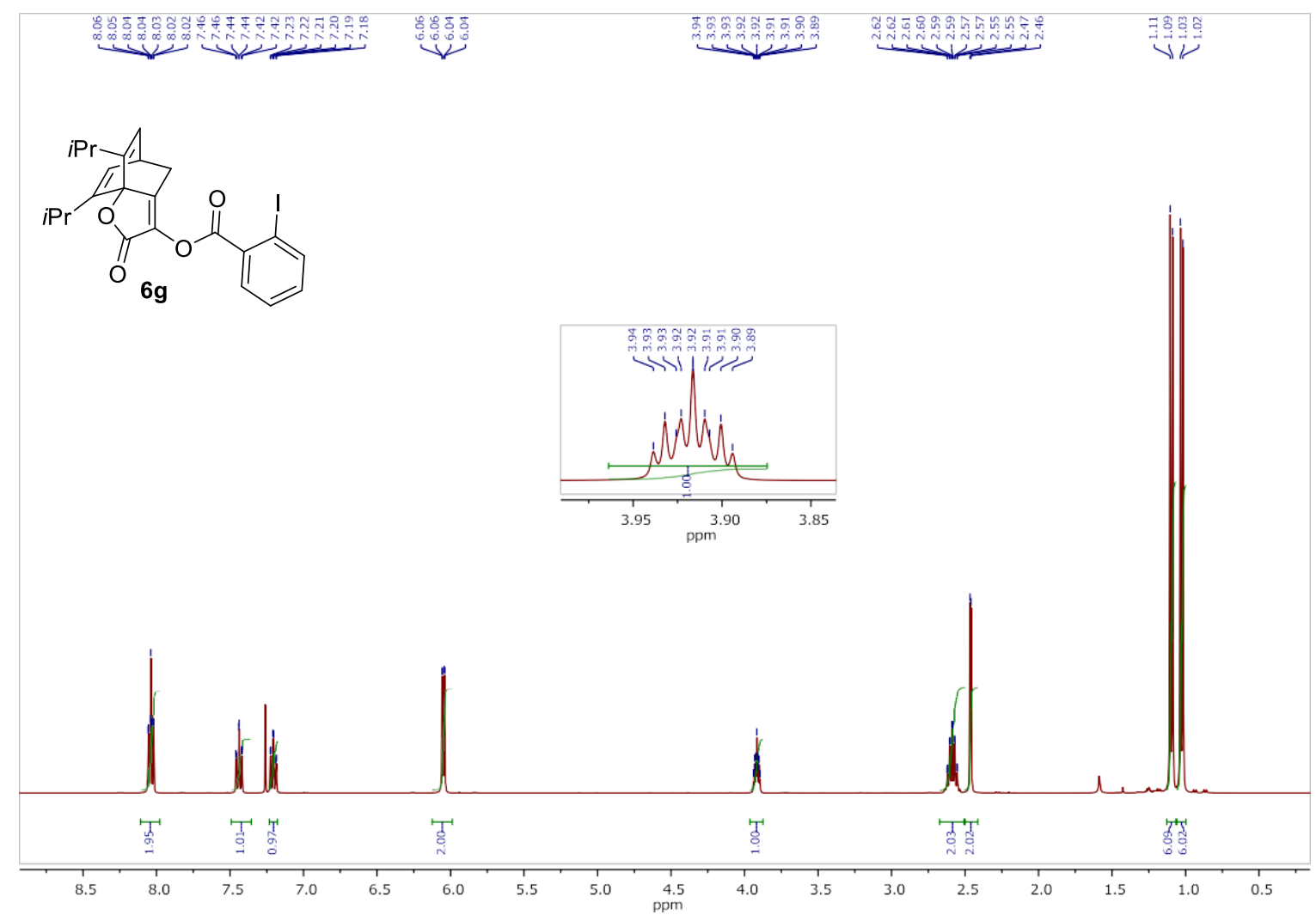

${ }^{13} \mathrm{C}$-NMR (100 MHz, $\mathrm{CDCl}_{3}$ ) of compound $6 \mathrm{~g}$
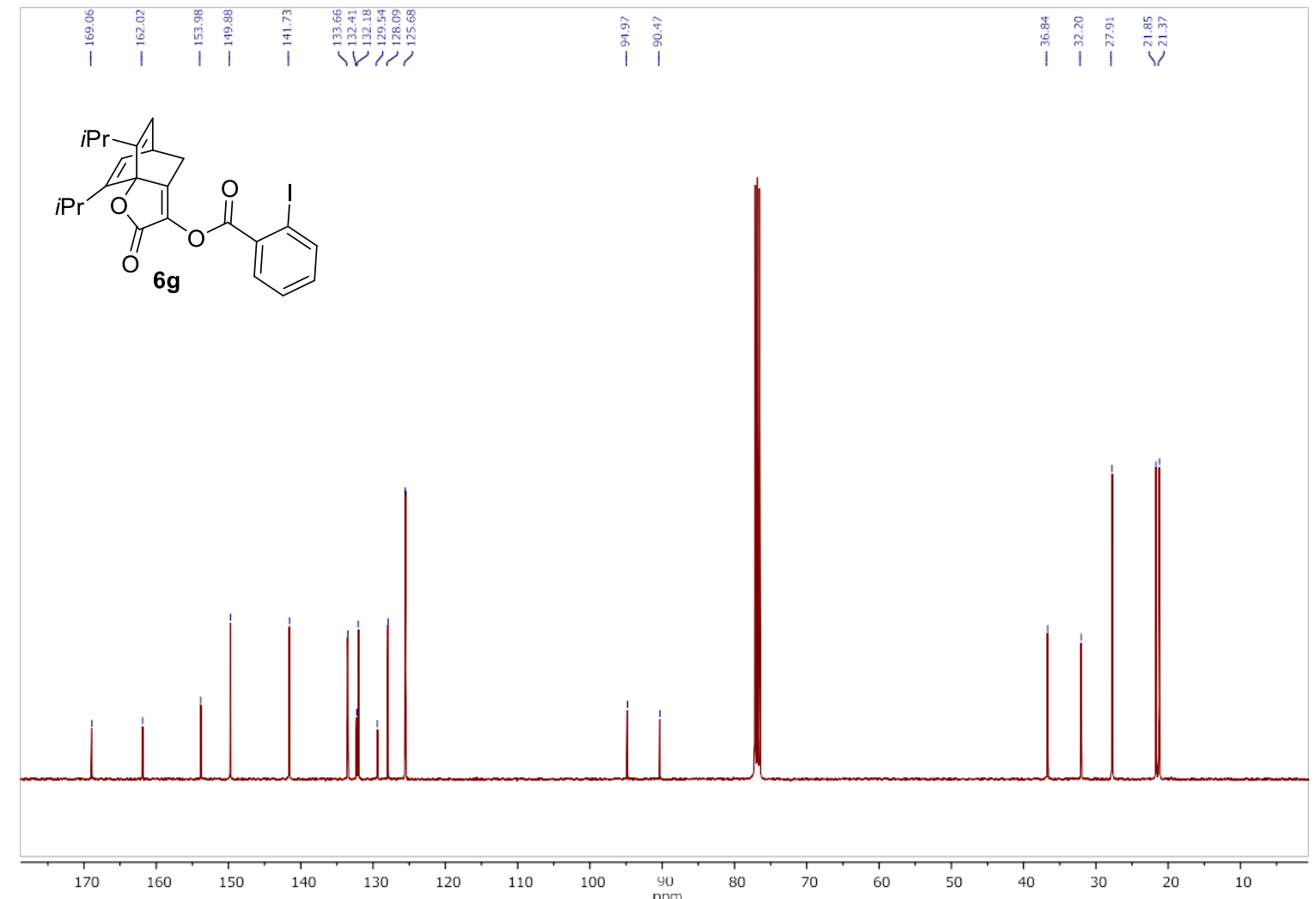
IR of compound $6 \mathrm{~g}$

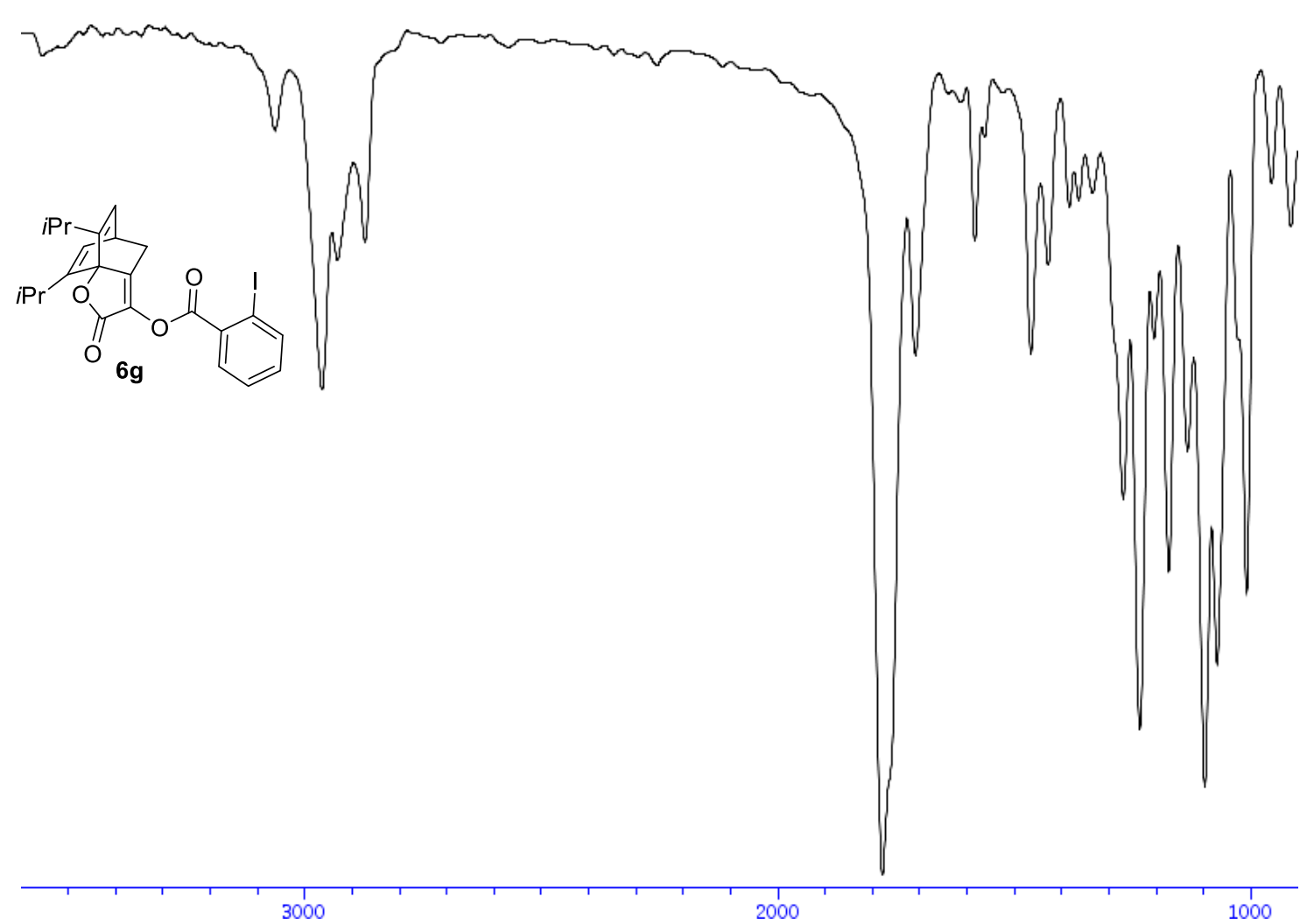


${ }^{1} \mathbf{H}$-NMR (400 MHz, $\mathrm{CDCl}_{3}$ ) of compound $\mathbf{6 h}$

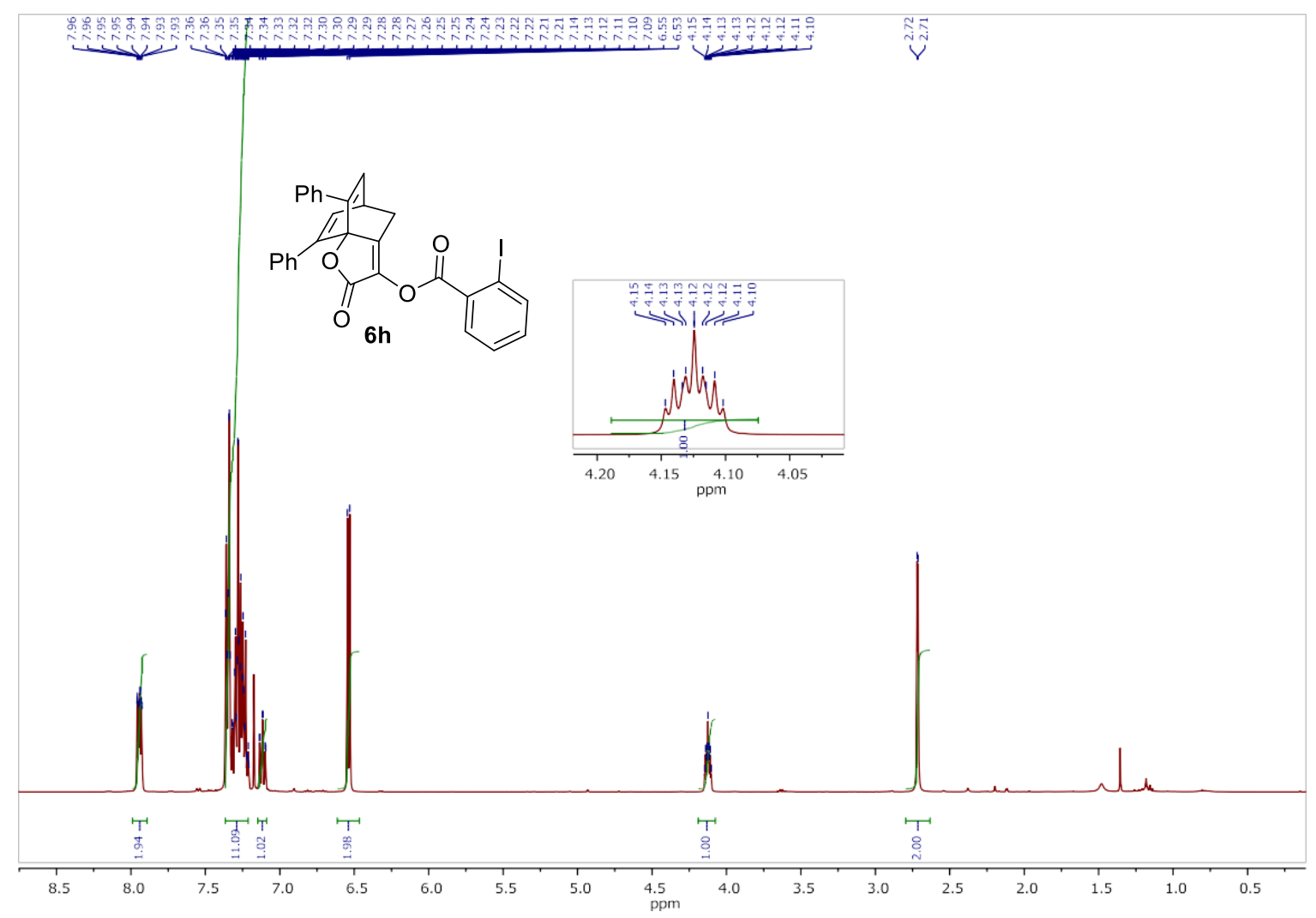

${ }^{13} \mathrm{C}-\mathrm{NMR}\left(100 \mathrm{MHz}, \mathrm{CDCl}_{3}\right)$ of compound $\mathbf{6 h}$

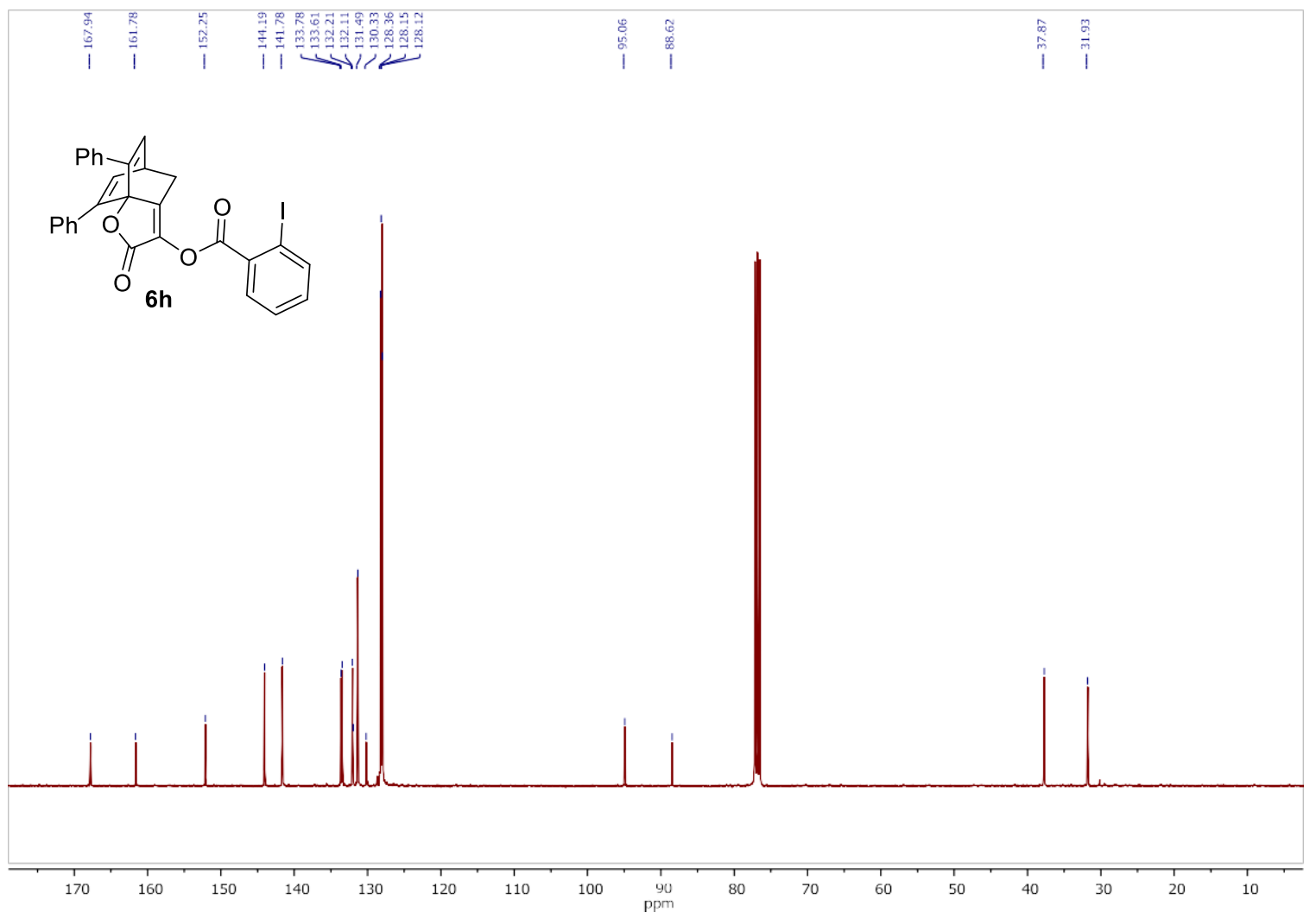

S158 
IR of compound $\mathbf{6 h}$

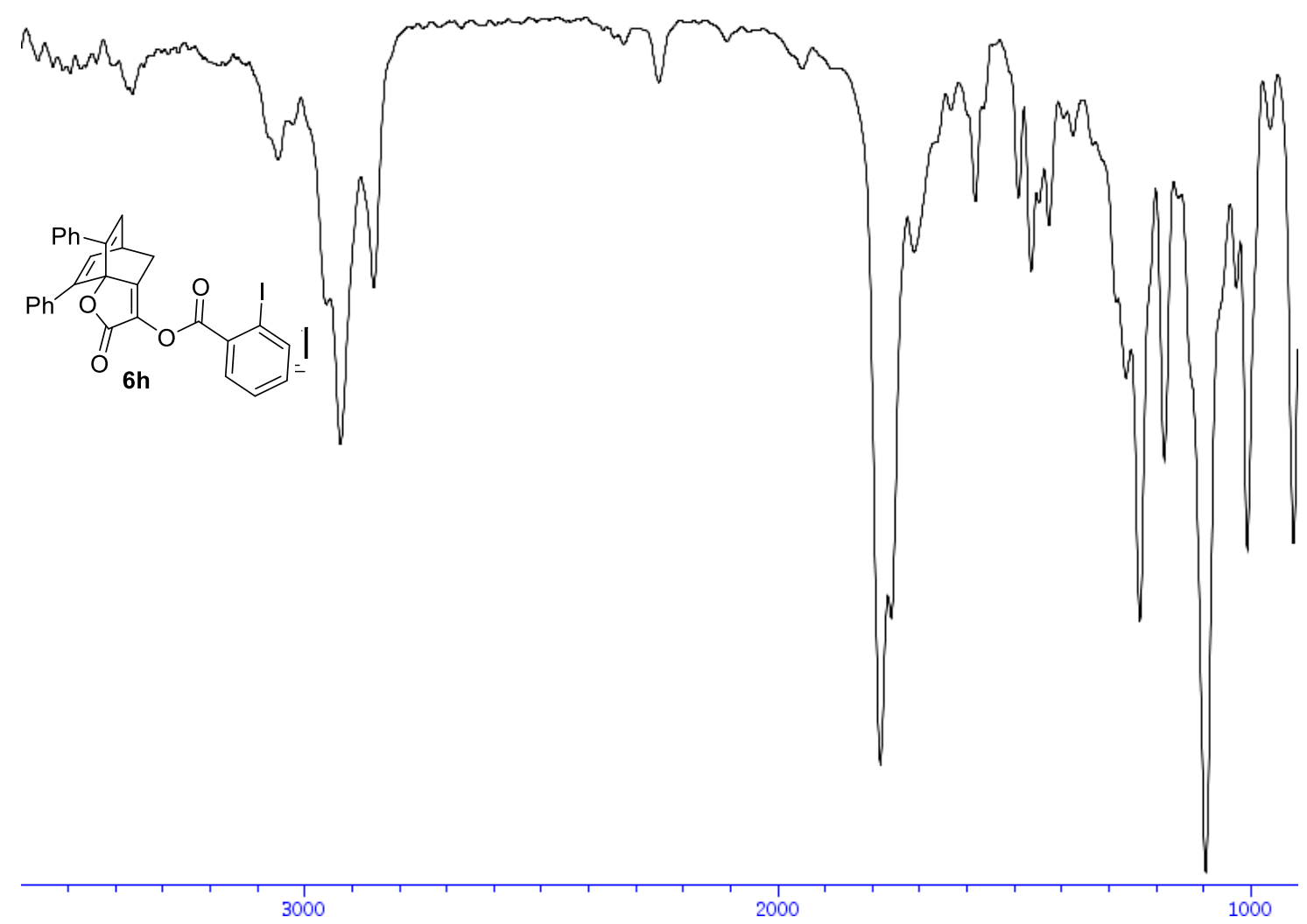


${ }^{1} \mathbf{H}$-NMR (400 MHz, $\mathrm{CDCl}_{3}$ ) of compound $\mathbf{6 i}$

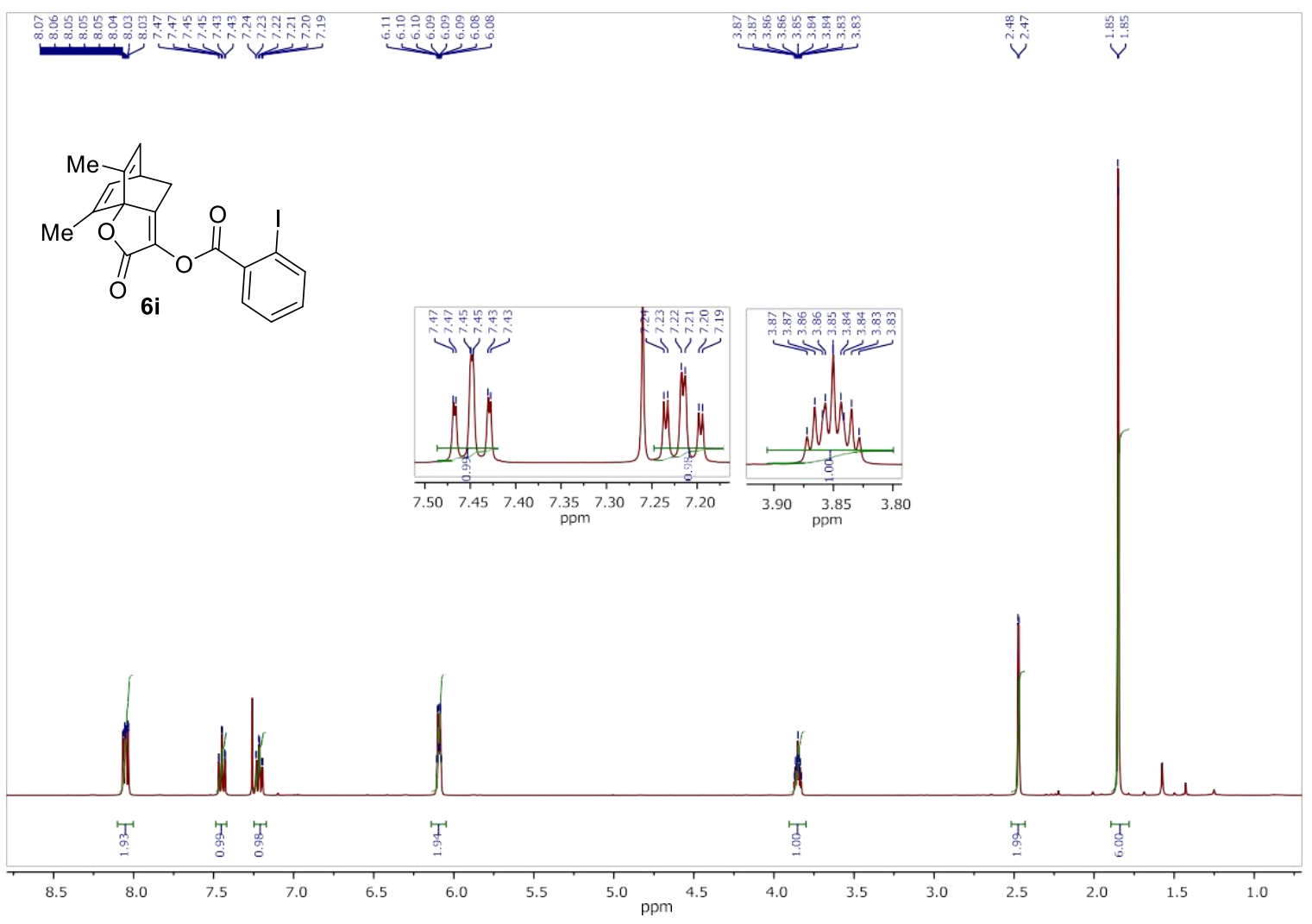

${ }^{13} \mathrm{C}$-NMR $\left(100 \mathrm{MHz}, \mathrm{CDCl}_{3}\right)$ of compound $\mathbf{6 i}$

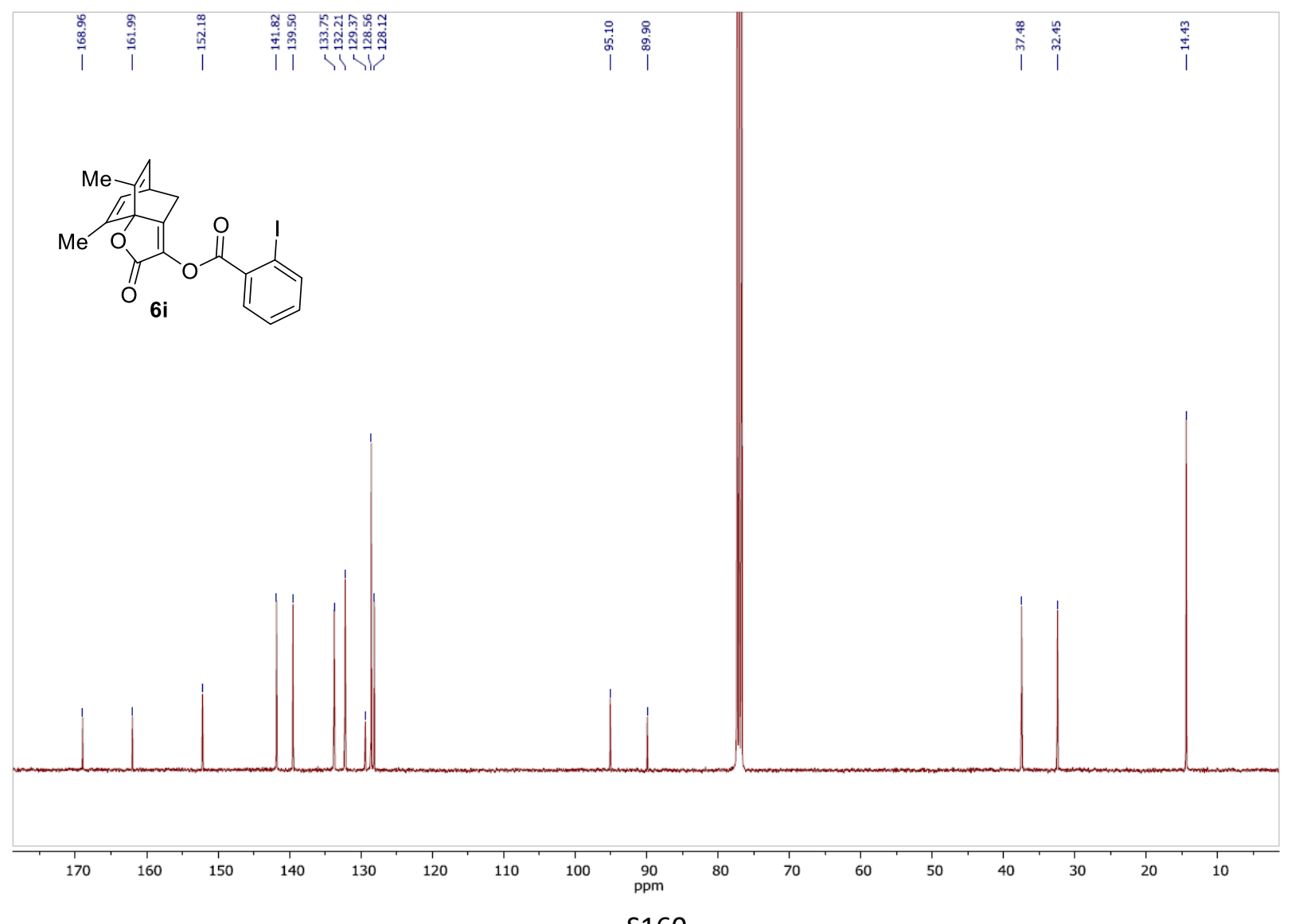

S160 
IR of compound $\mathbf{6 i}$

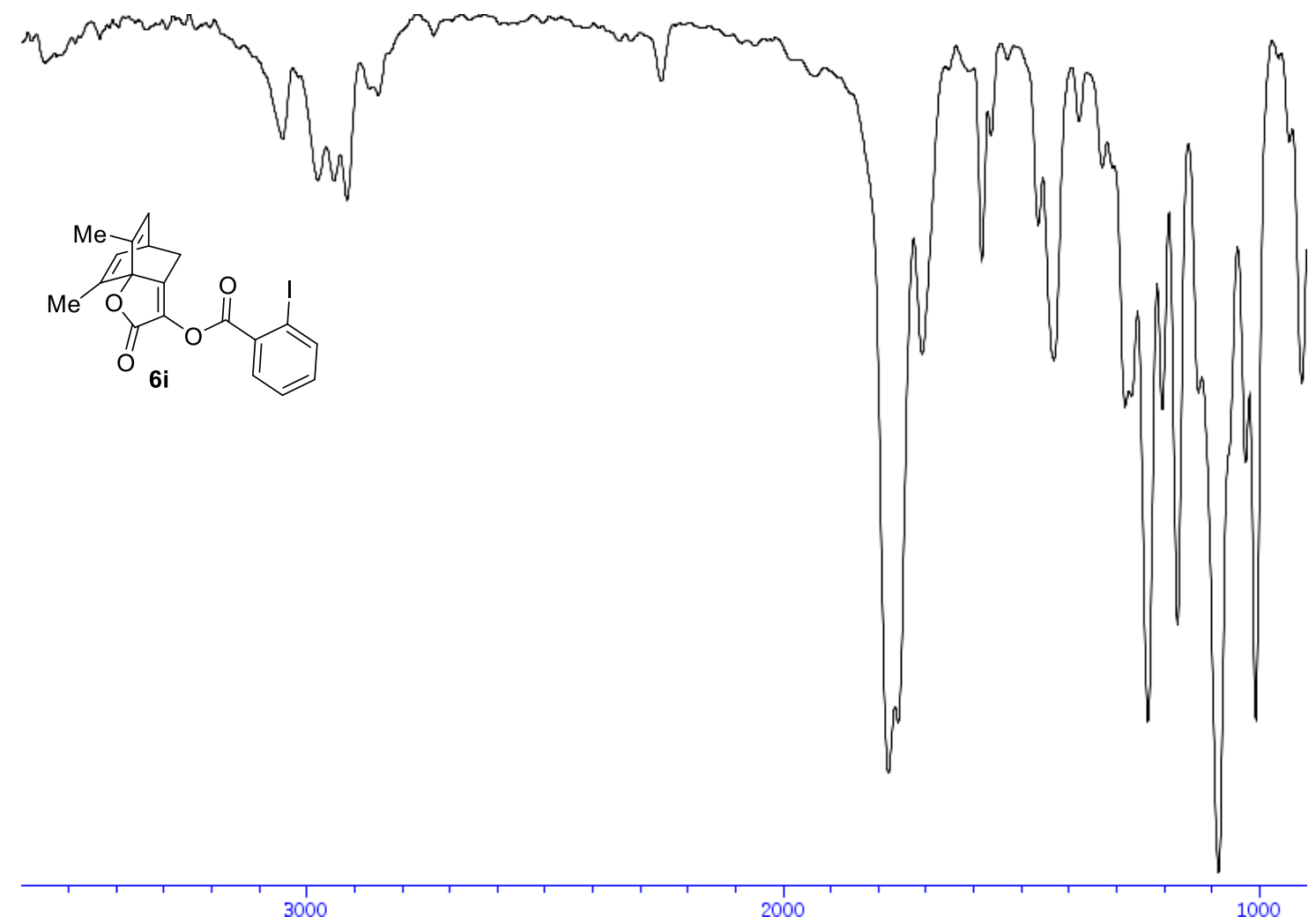


${ }^{1} \mathbf{H}-\mathrm{NMR}\left(400 \mathrm{MHz}, \mathrm{CDCl}_{3}\right)$ of compound $\mathbf{6 j}$

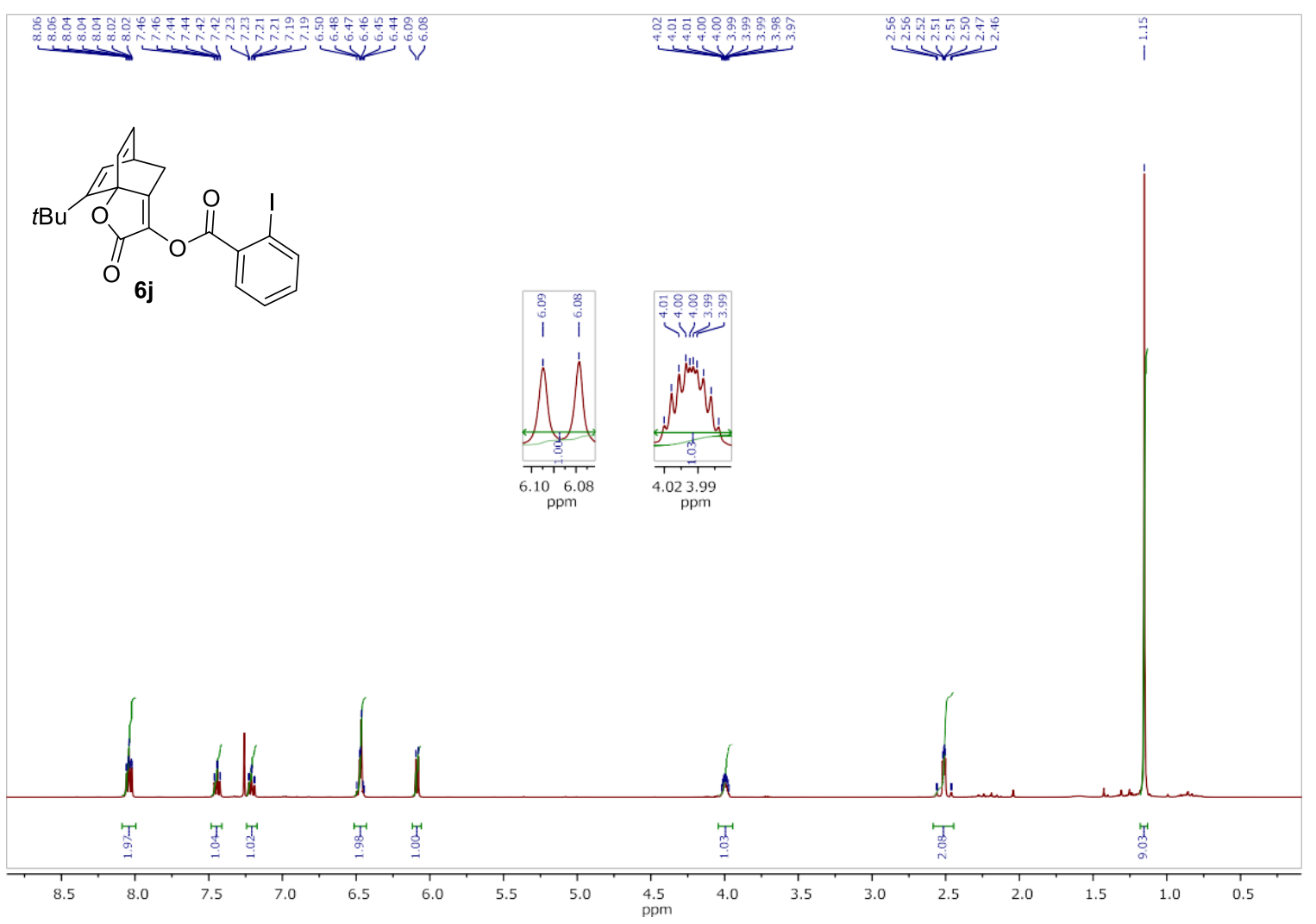

${ }^{13} \mathrm{C}$-NMR (100 MHz, $\mathrm{CDCl}_{3}$ ) of compound $\mathbf{6 j}$

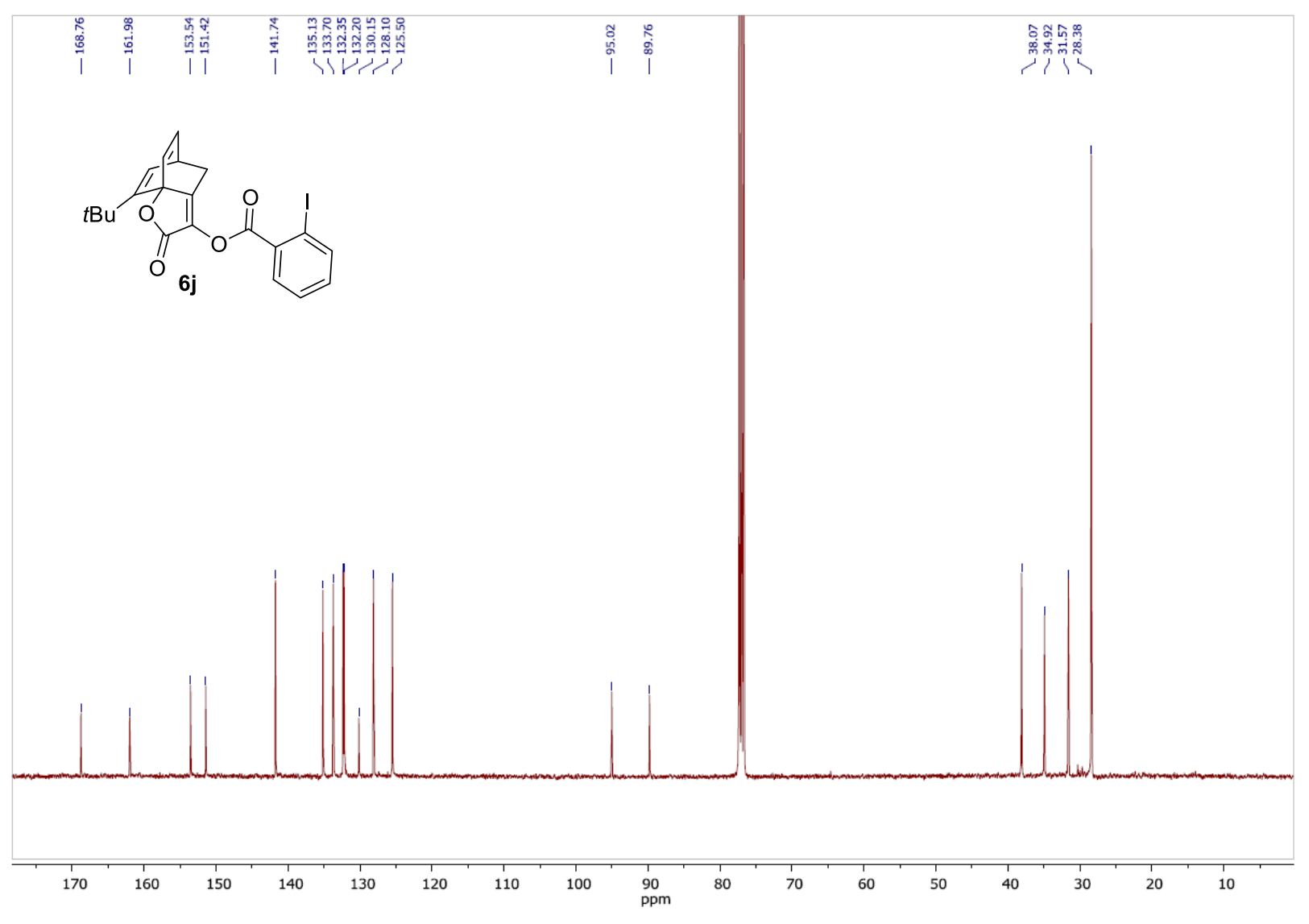

S161 
IR of compound $\mathbf{6 j}$

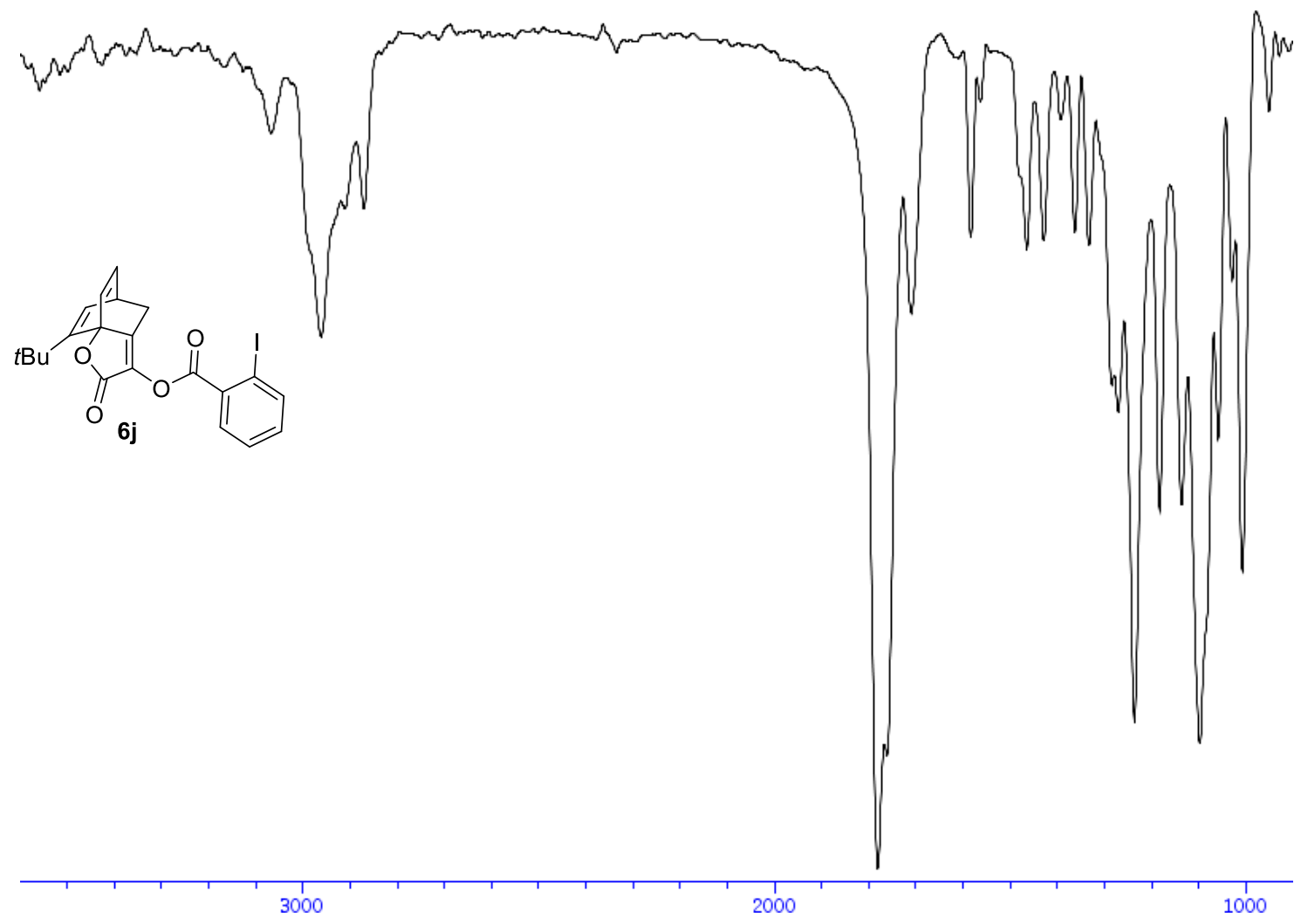


${ }^{1} \mathbf{H}-\mathrm{NMR}\left(400 \mathrm{MHz}, \mathrm{CDCl}_{3}\right.$ ) of compound $\mathbf{6 k}$

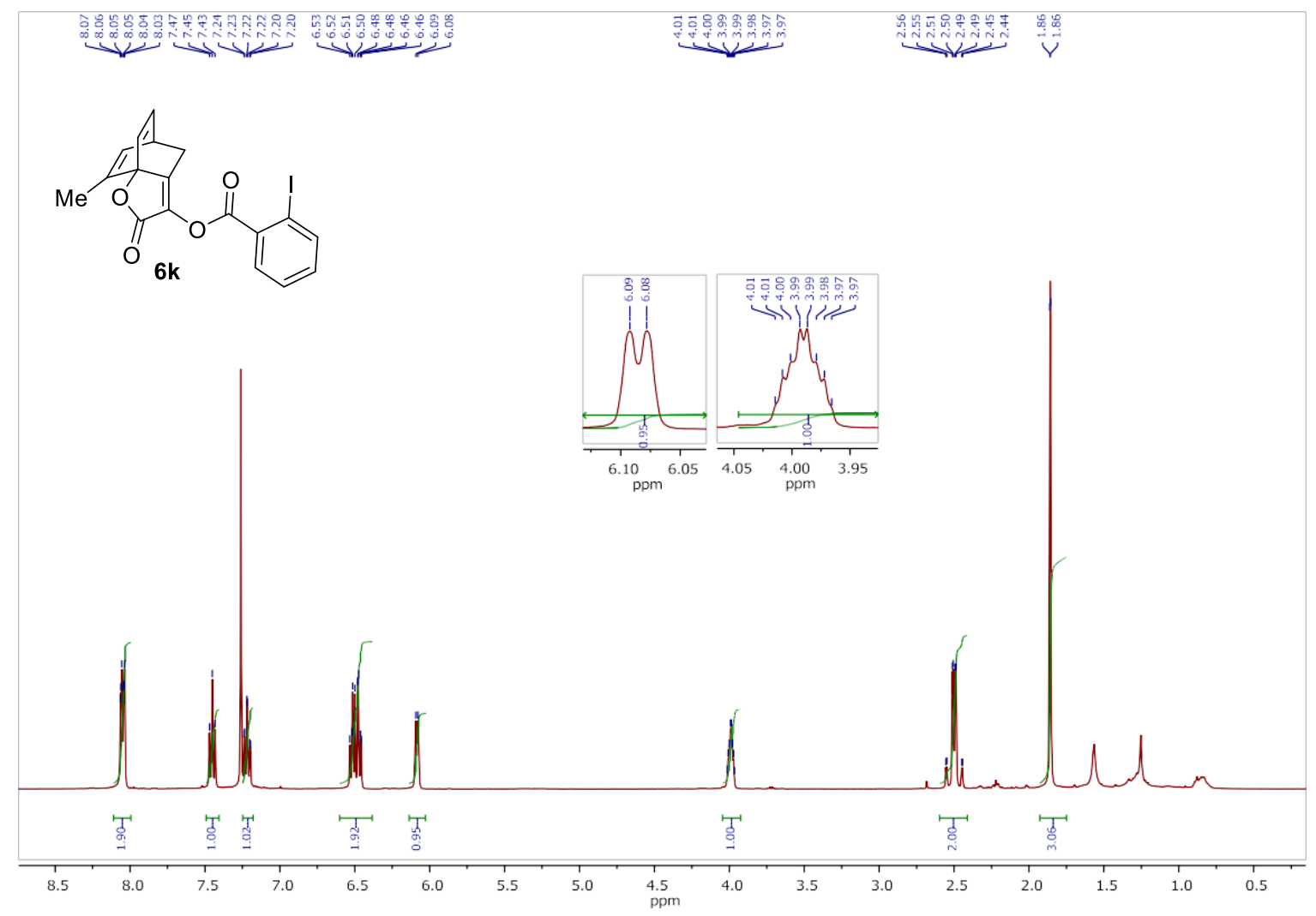

${ }^{13} \mathrm{C}-\mathrm{NMR}\left(100 \mathrm{MHz}, \mathrm{CDCl}_{3}\right)$ of compound $\mathbf{6 k}$

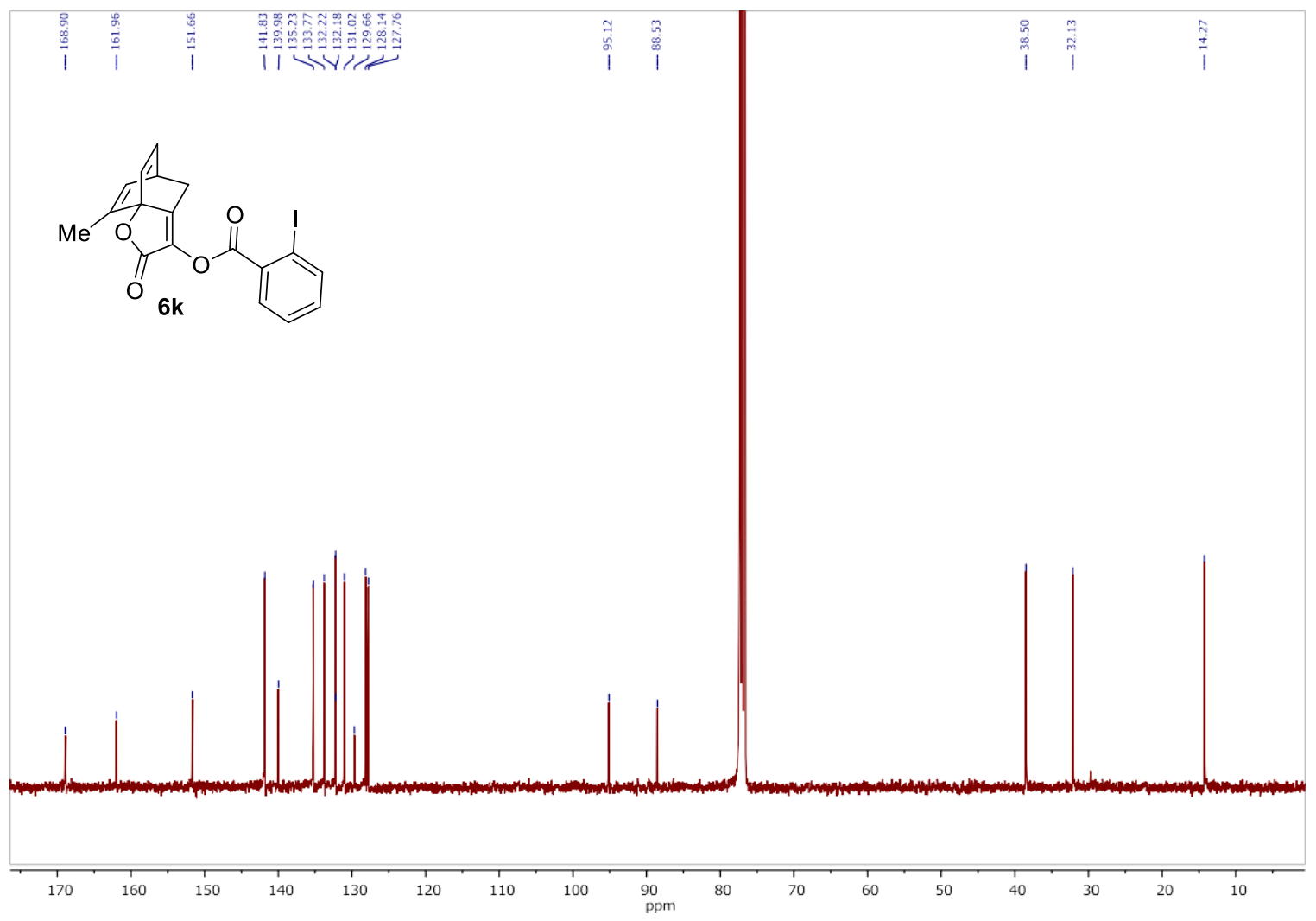

S163 
IR of compound $\mathbf{6 k}$

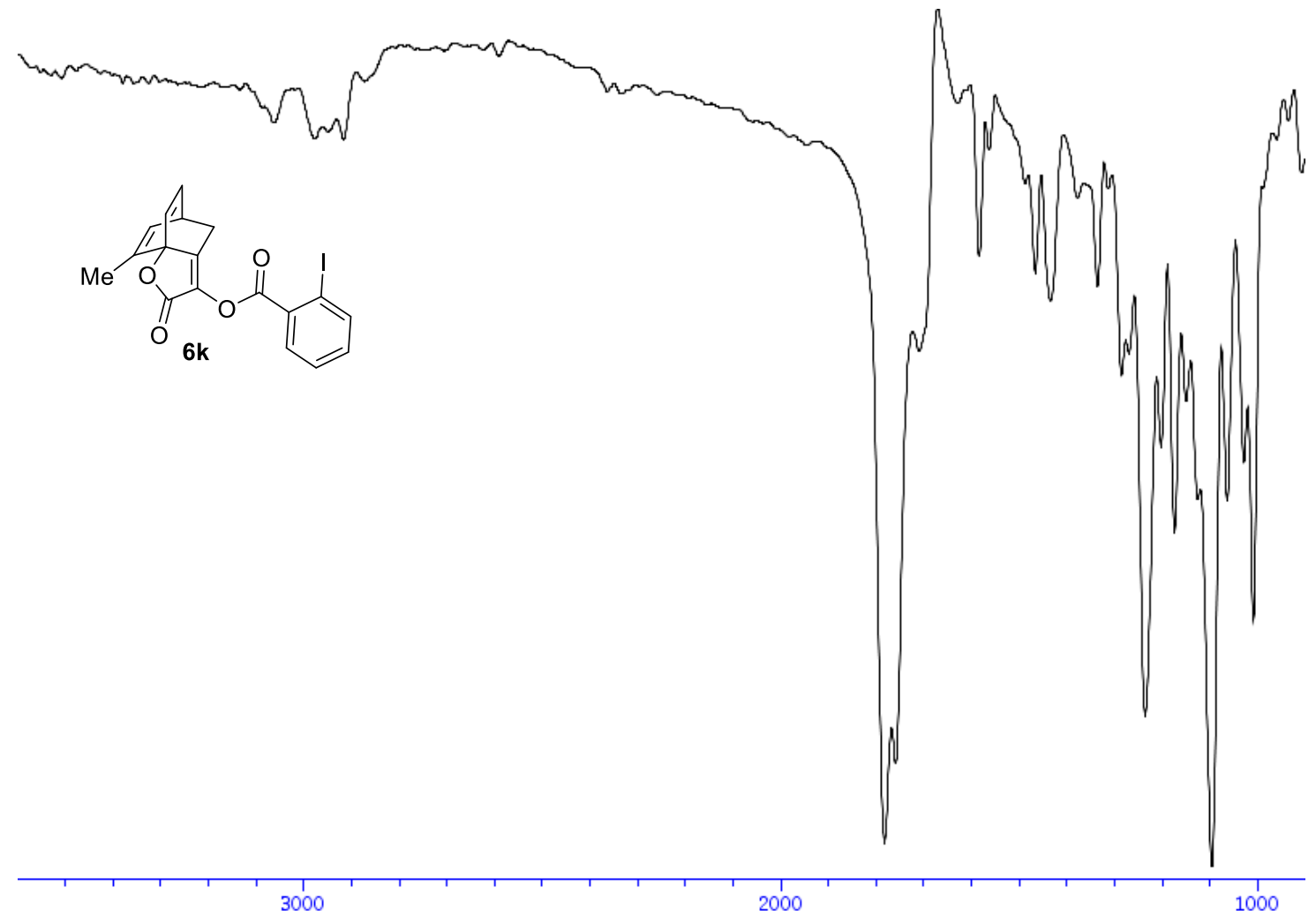


${ }^{1} \mathbf{H}-\mathrm{NMR}\left(400 \mathrm{MHz}, \mathrm{CDCl}_{3}\right.$ ) of compound $\mathbf{6 I}$

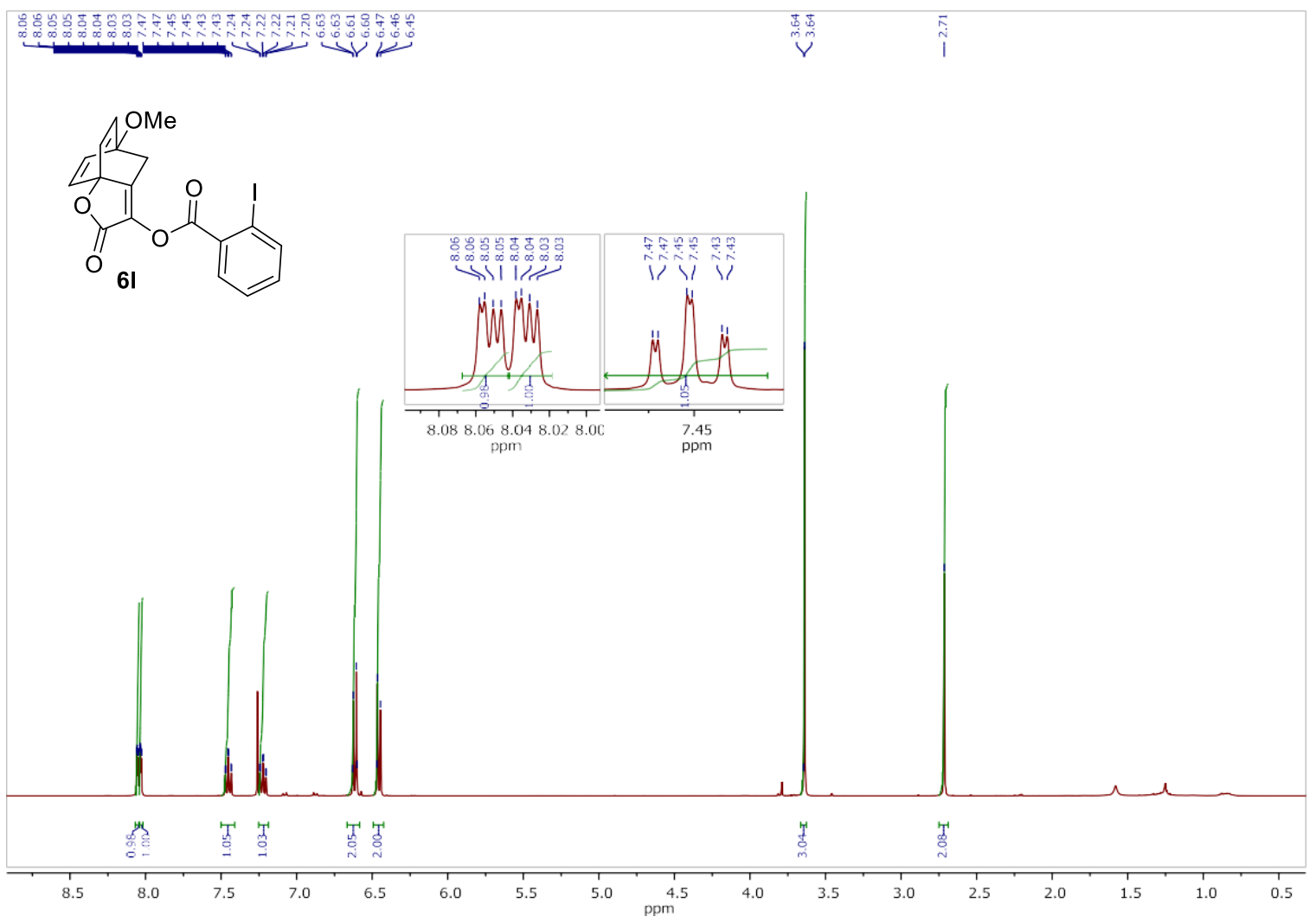

${ }^{13} \mathrm{C}$-NMR (100 MHz, $\left.\mathrm{CDCl}_{3}\right)$ of compound 6 I

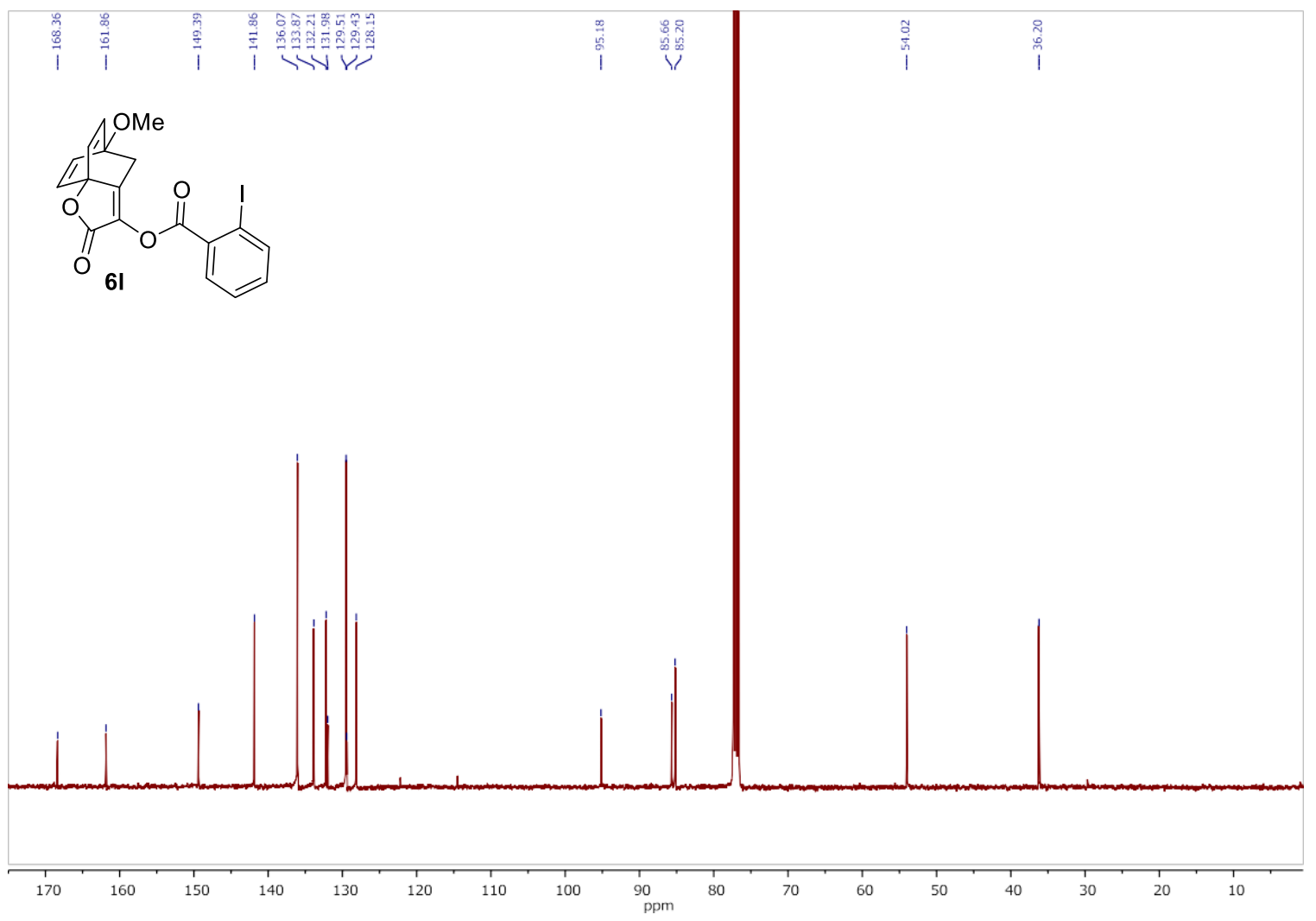

S165 
IR of compound $\mathbf{6 I}$

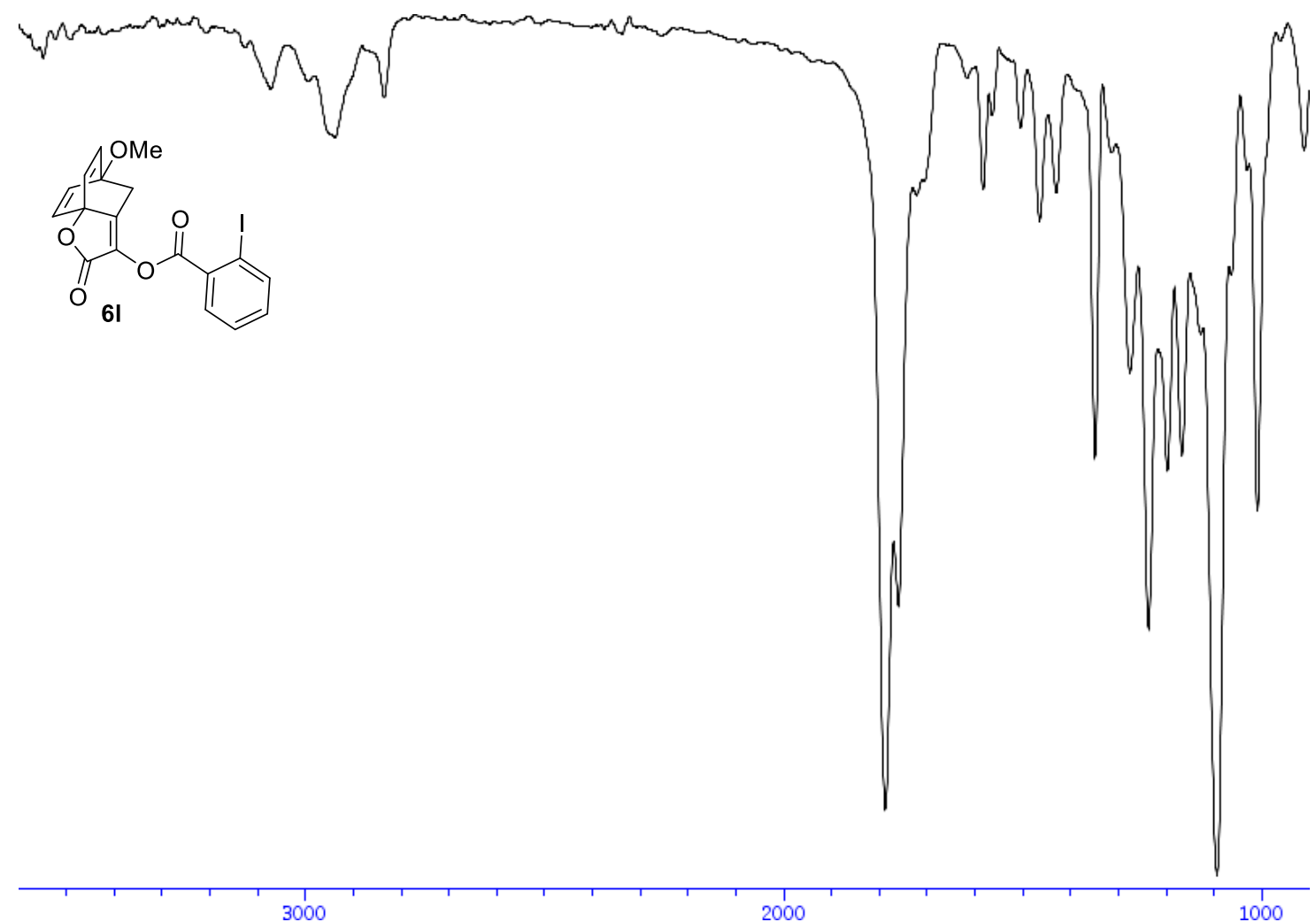


${ }^{1} \mathbf{H}$-NMR (400 MHz, $\mathrm{CDCl}_{3}$ ) of compound $\mathbf{6 m}$
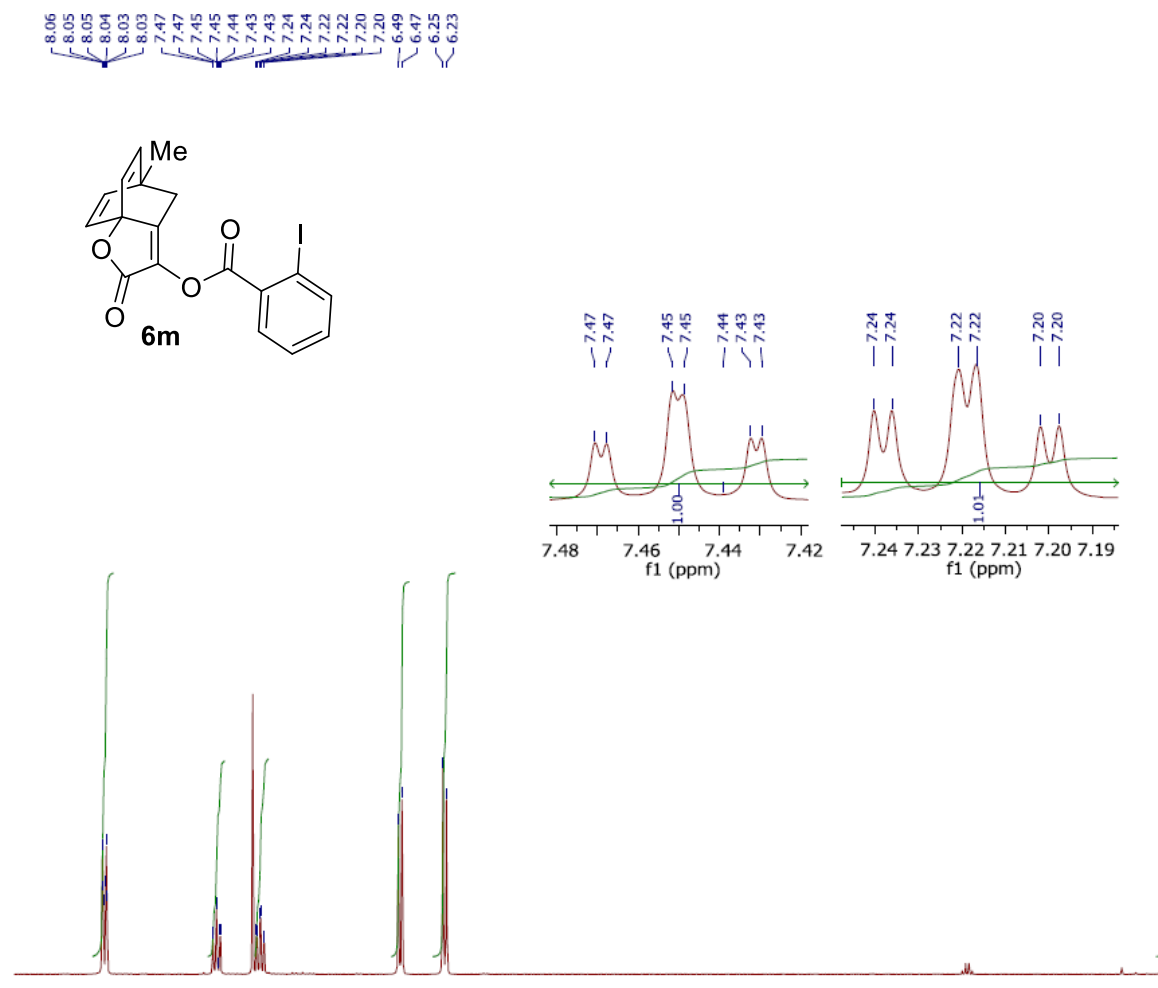

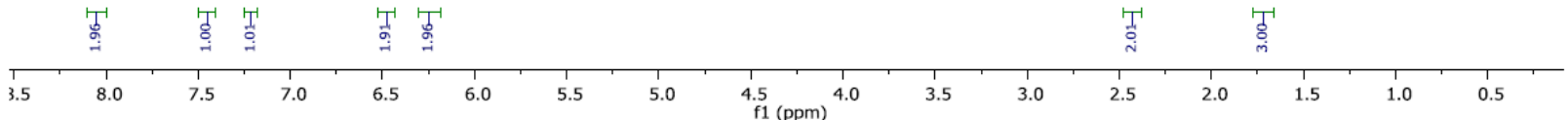

${ }^{13} \mathrm{C}-\mathrm{NMR}\left(100 \mathrm{MHz}, \mathrm{CDCl}_{3}\right)$ of compound $6 \mathrm{~m}$

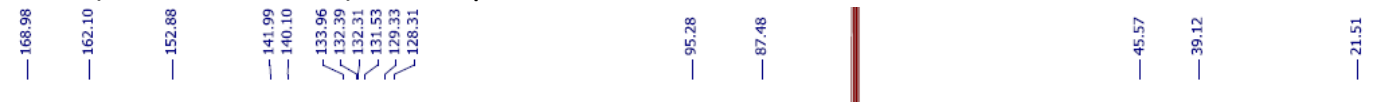<smiles>CC1(C)C2CCC1C(OC(=O)c1ccccc1I)C(=O)O2</smiles>

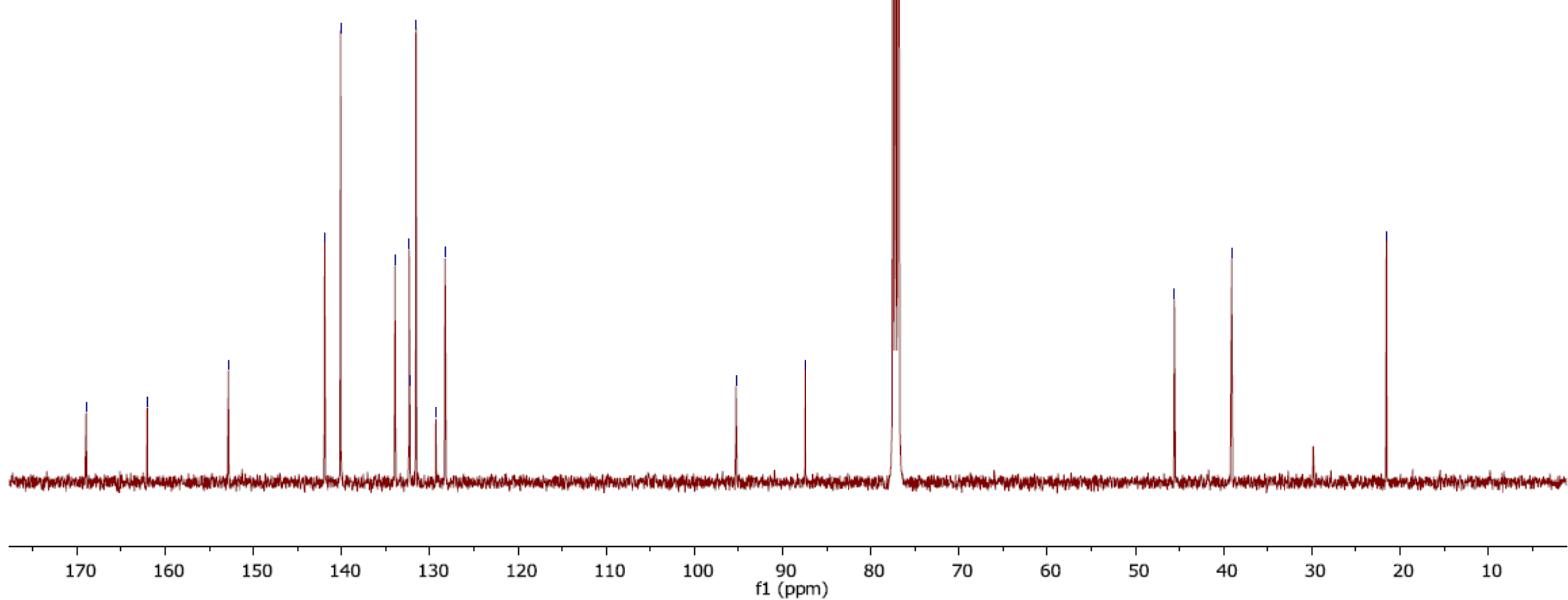


${ }^{1} \mathbf{H}$-NMR (400 MHz, $\mathrm{CDCl}_{3}$ ) of compound $\mathbf{6 n}$

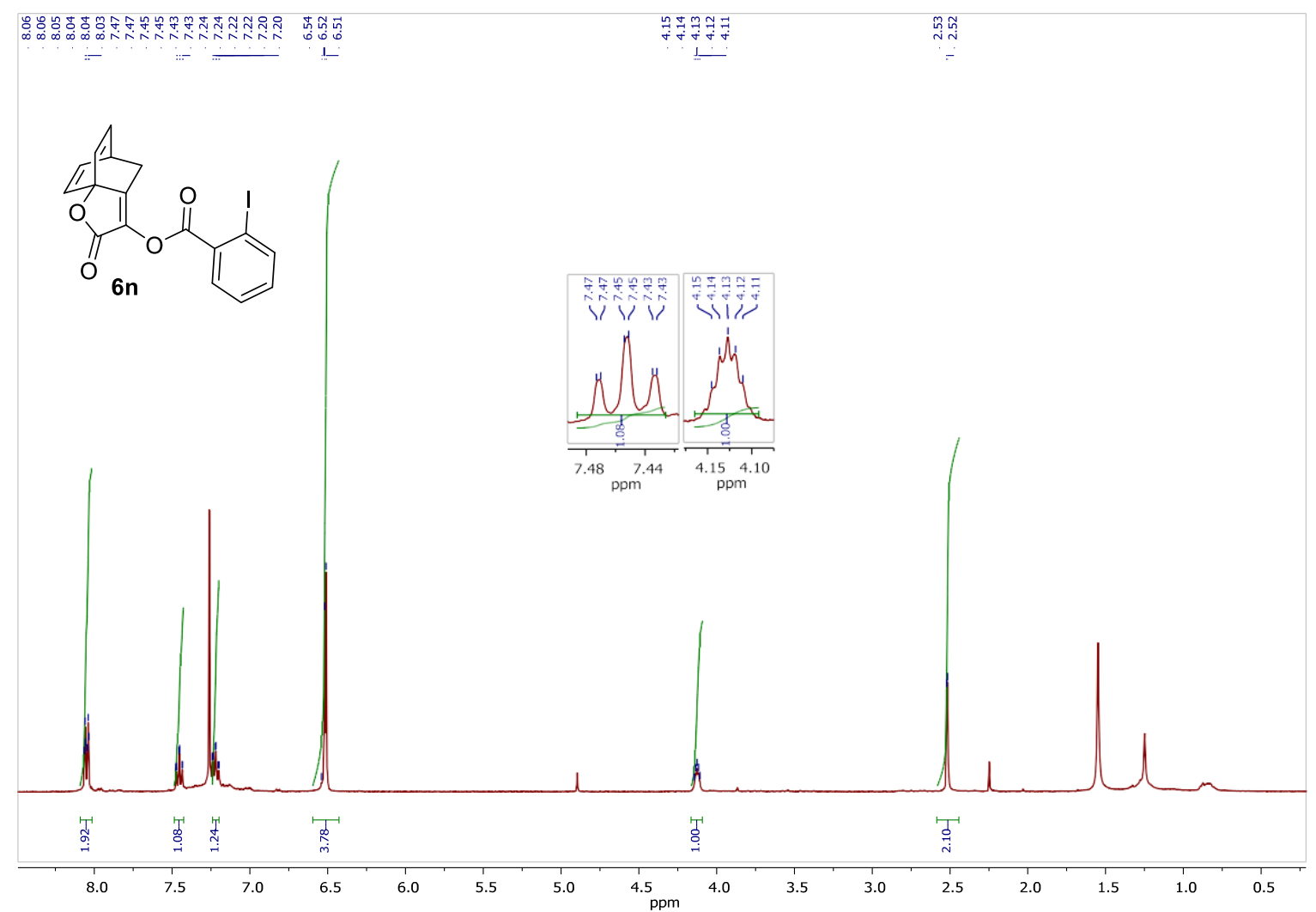

${ }^{13} \mathrm{C}-\mathrm{NMR}\left(100 \mathrm{MHz}, \mathrm{CDCl}_{3}\right)$ of compound $\mathbf{6 n}$

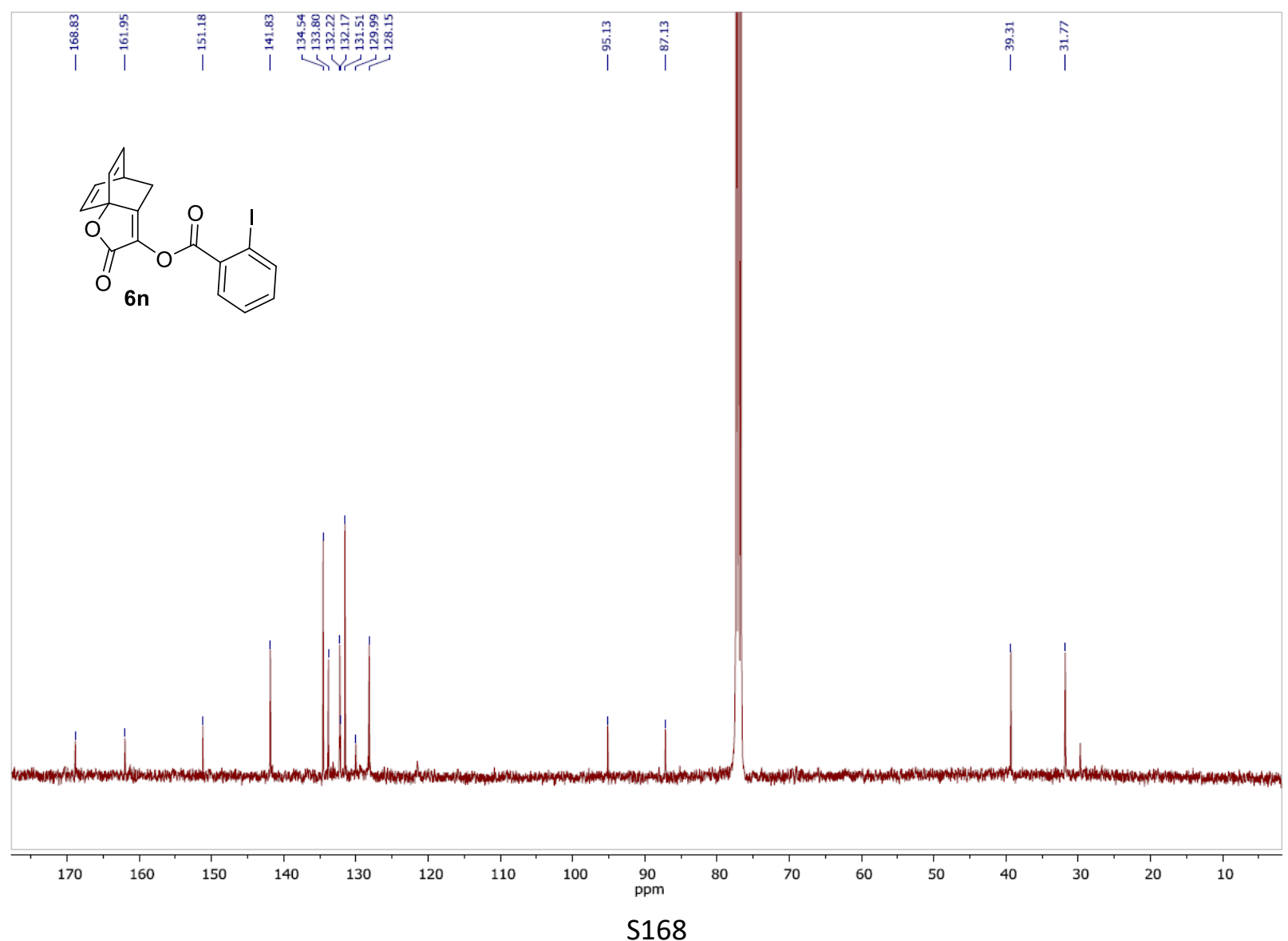


${ }^{1} \mathbf{H}-\mathrm{NMR}\left(400 \mathrm{MHz}, \mathrm{CDCl}_{3}\right.$ ) of compound $\mathbf{6 0}$

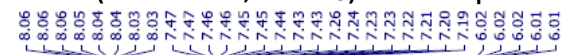

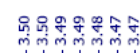

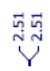

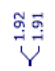
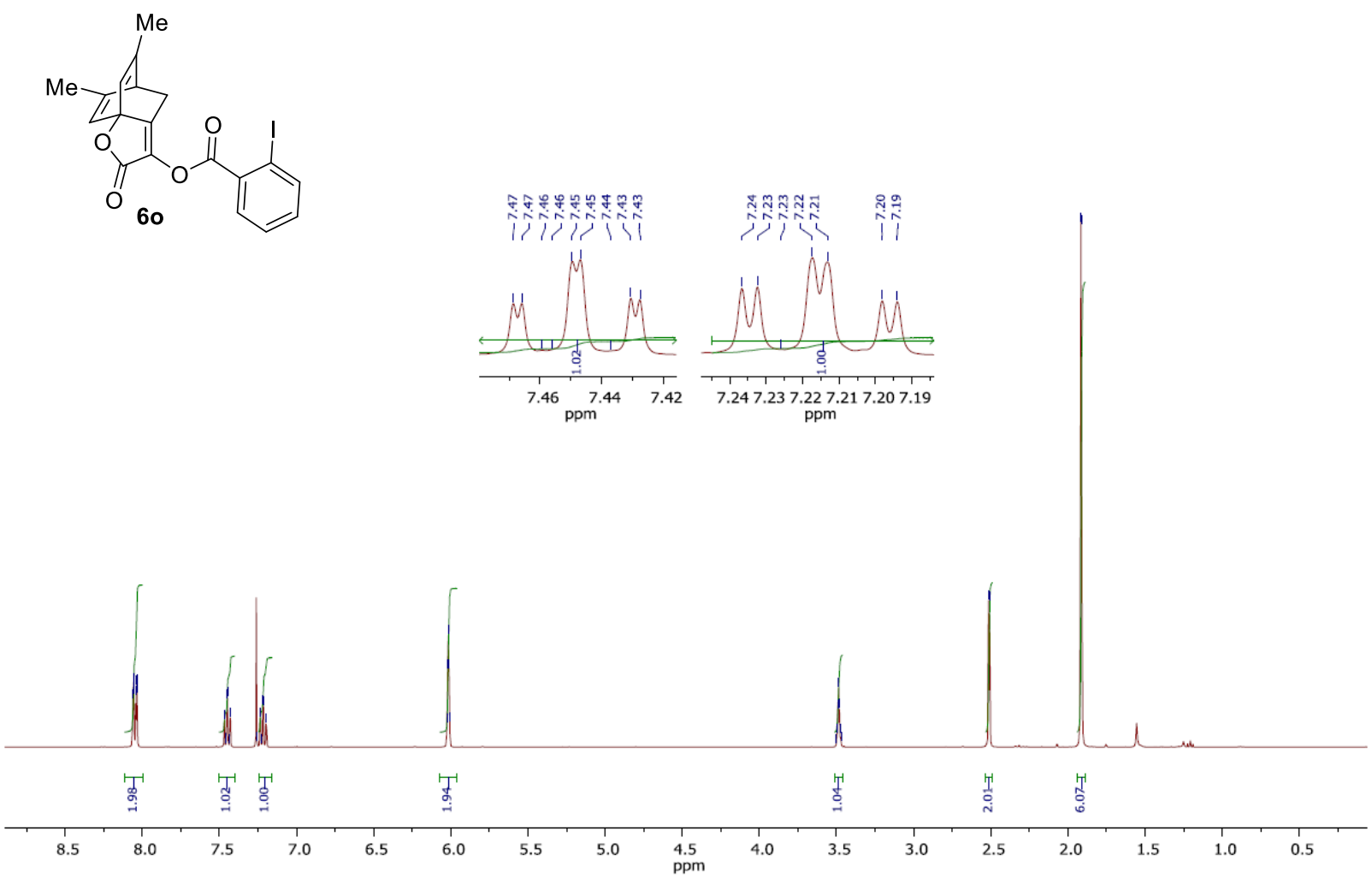

${ }^{13} \mathrm{C}$-NMR (100 MHz, $\mathrm{CDCl}_{3}$ ) of compound 60

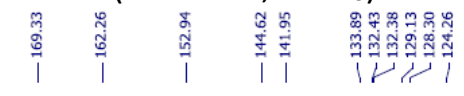
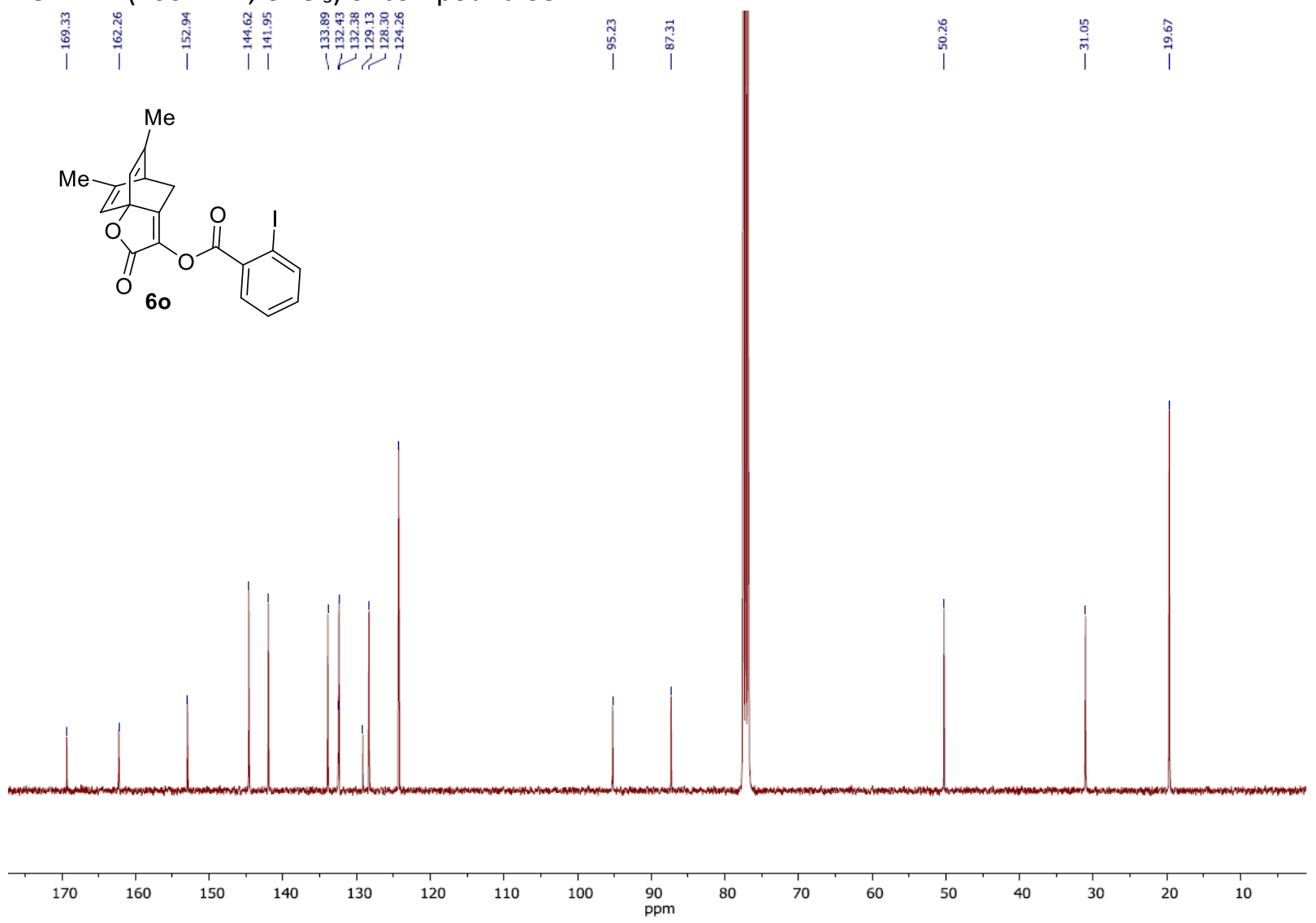

S170 
${ }^{1} \mathbf{H}-\mathrm{NMR}\left(400 \mathrm{MHz}, \mathrm{CDCl}_{3}\right.$ ) of compound $\mathbf{6 p}$

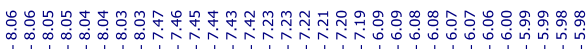

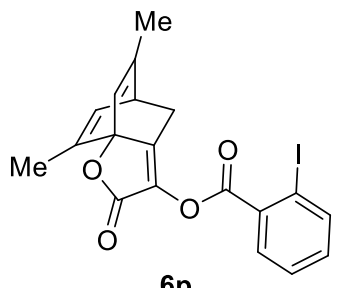

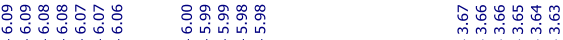

$6 p$

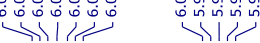

111111
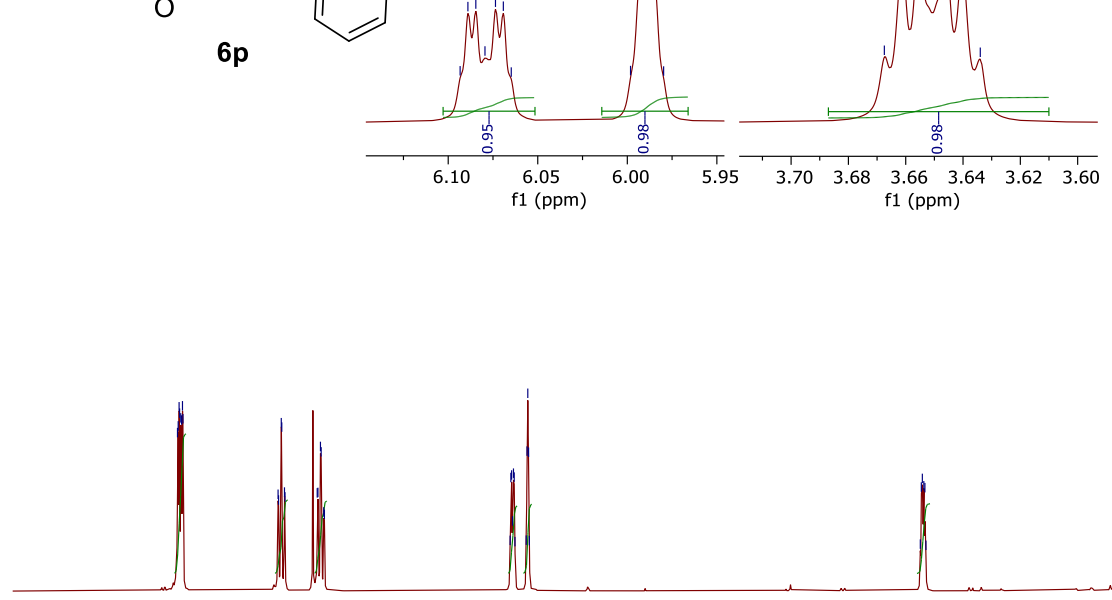

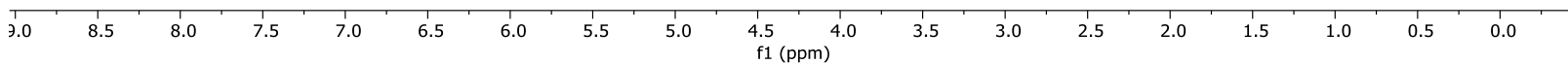

${ }^{13}$ C-NMR (100 MHz, $\mathrm{CDCl}_{3}$ ) of compound $\mathbf{6 p}$

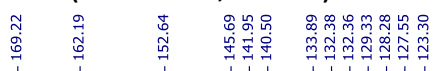

YI/
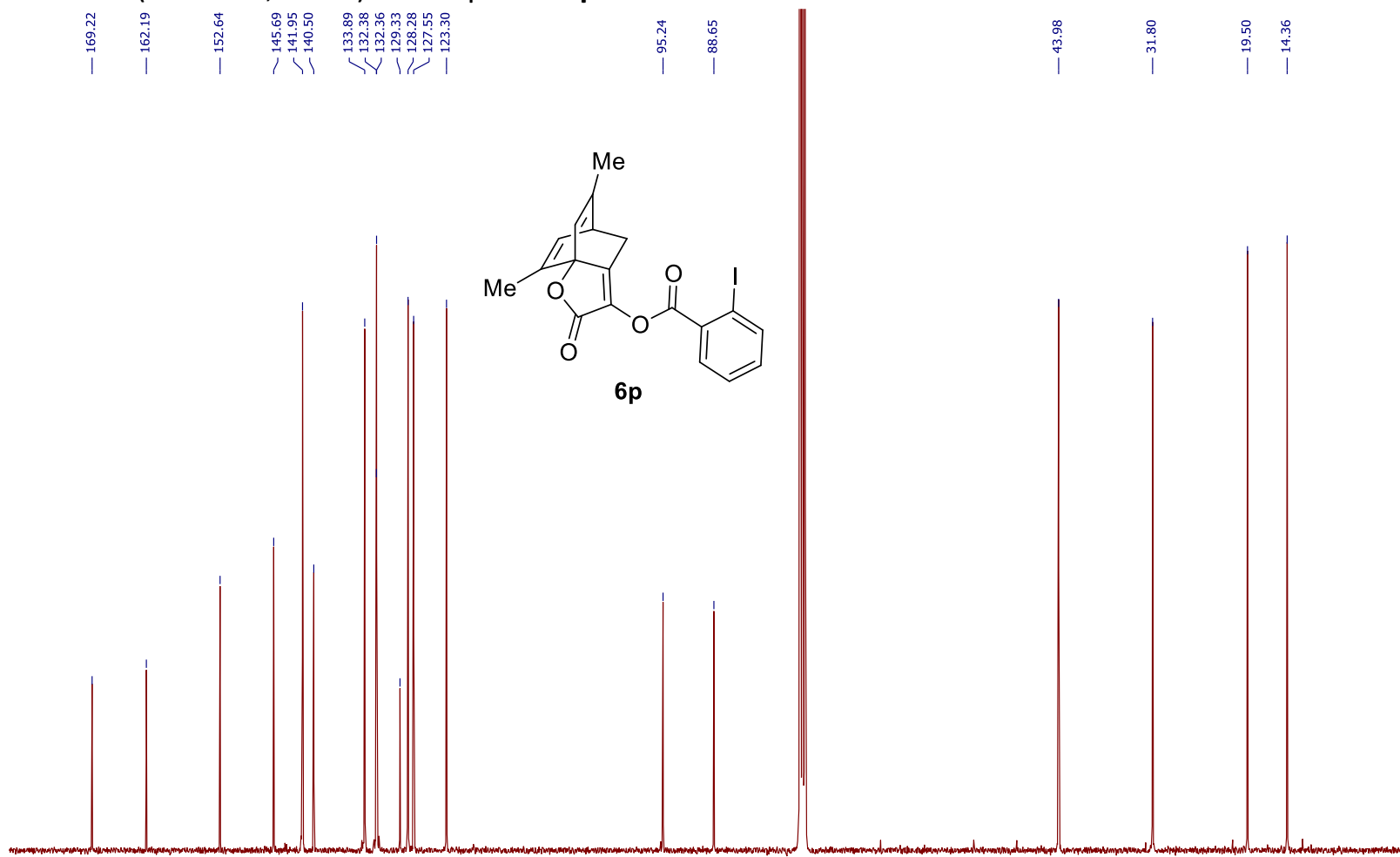

170

160

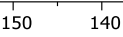

130 
${ }^{1} \mathbf{H}-\mathrm{NMR}\left(400 \mathrm{MHz}, \mathrm{CDCl}_{3}\right.$ ) of compound $\mathbf{6 q}$

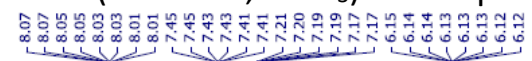

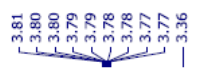

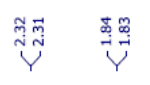
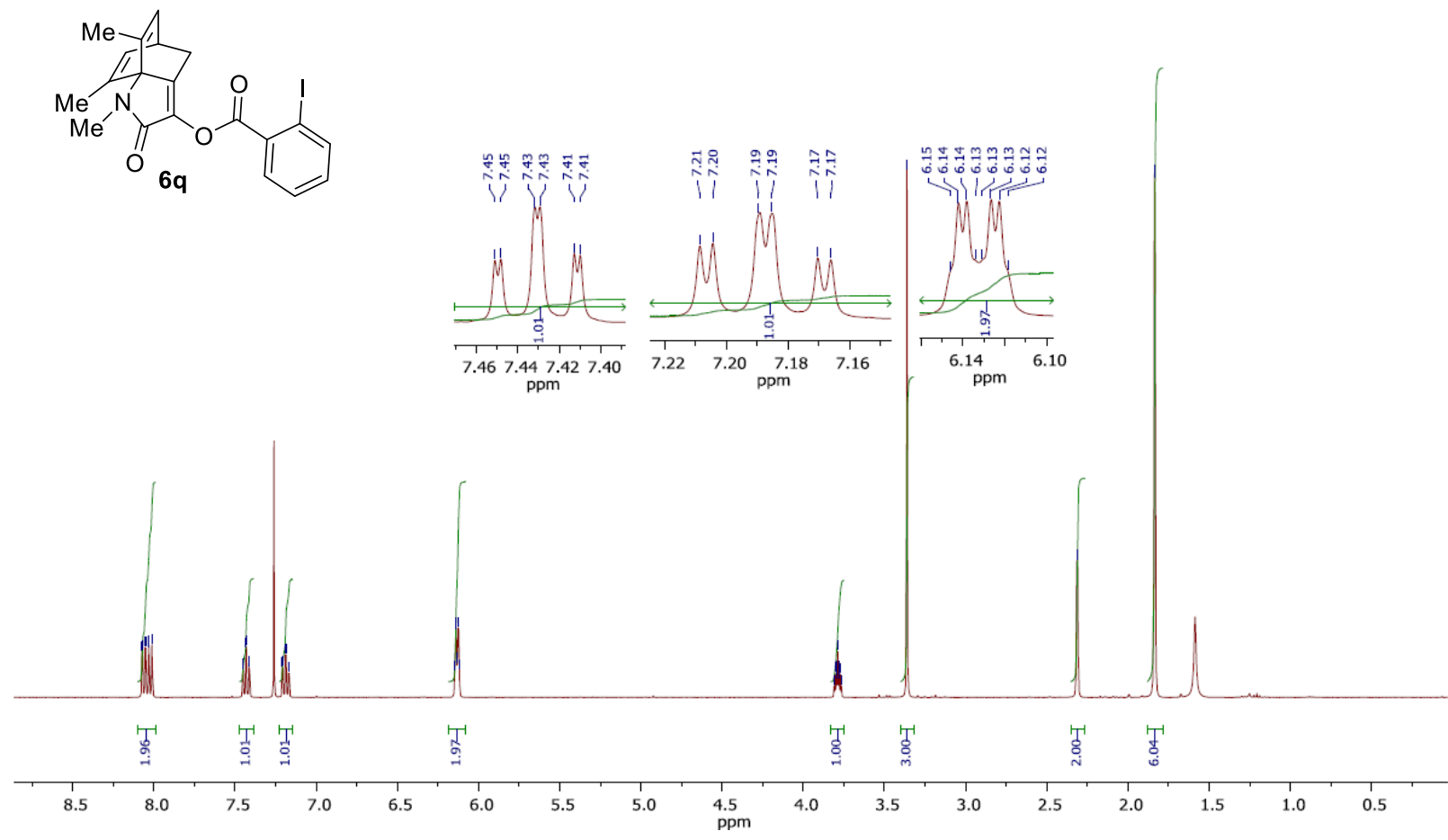

${ }^{13} \mathrm{C}$-NMR (100 MHz, $\mathrm{CDCl}_{3}$ ) of compound $\mathbf{6 q}$
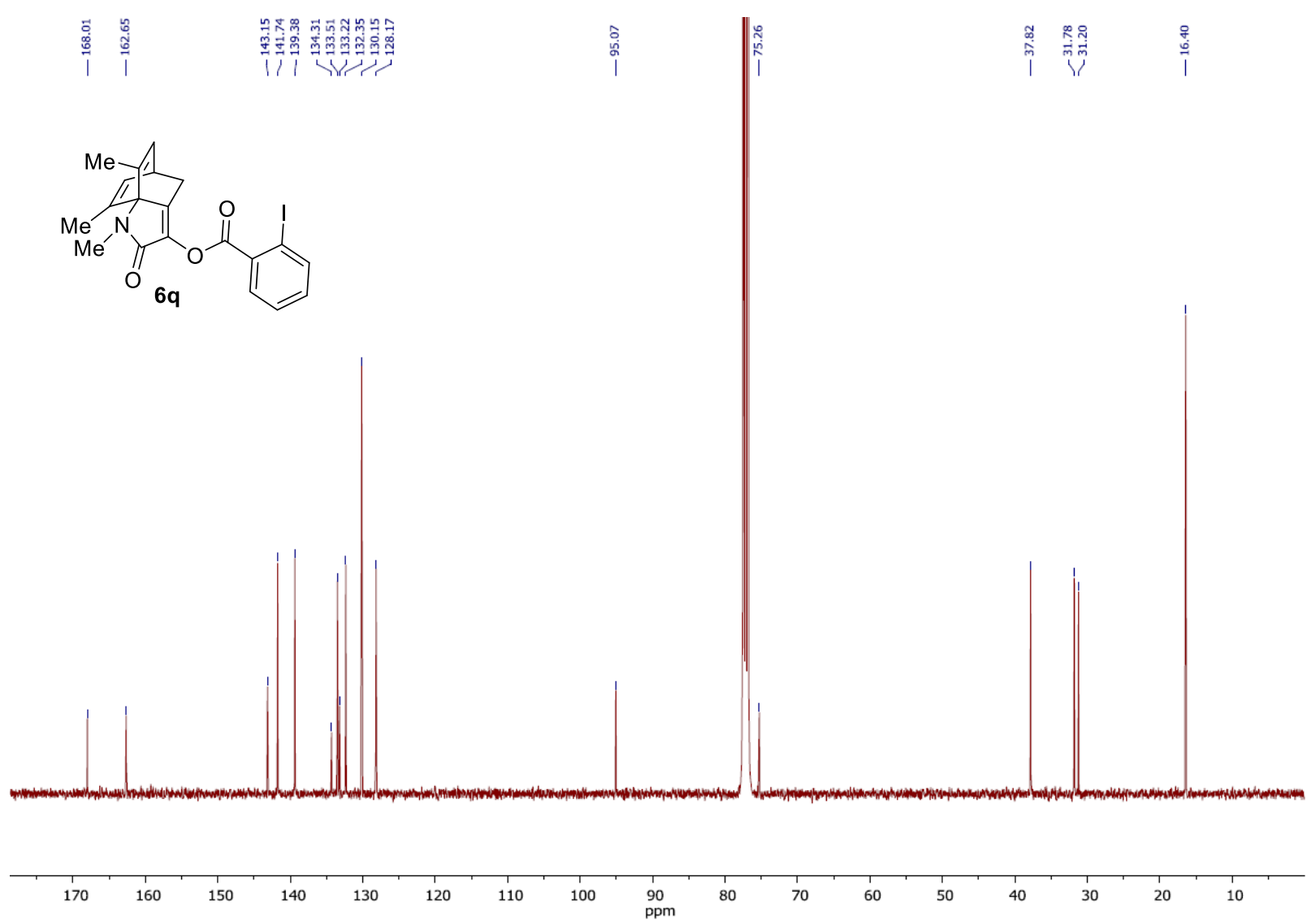

S171 
${ }^{1}$ H-NMR (400 MHz, $\mathrm{CDCl}_{3}$ ) of compound $\mathbf{6 r}$

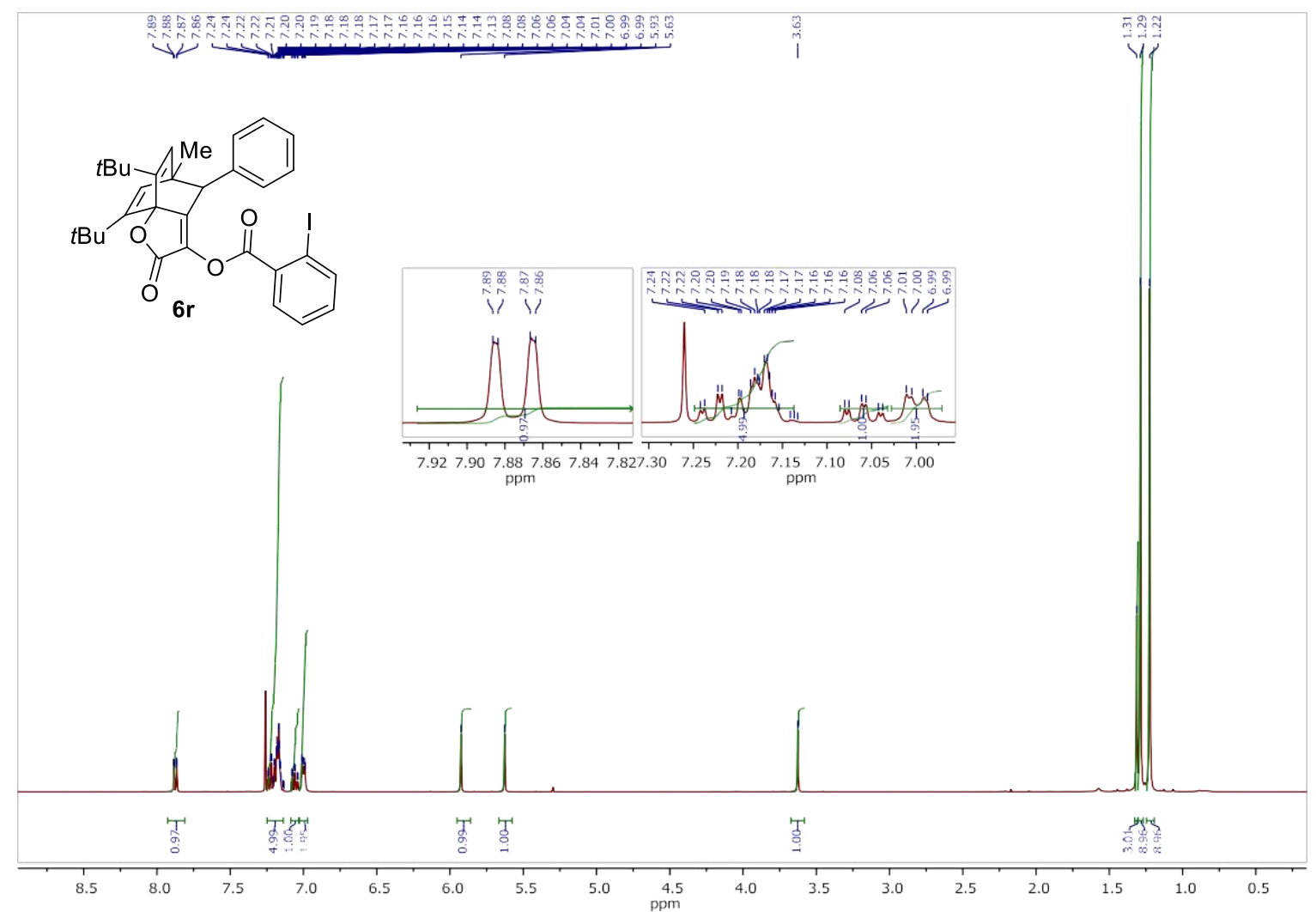

${ }^{13}$ C-NMR (100 MHz, $\mathrm{CDCl}_{3}$ ) of compound $\mathbf{6 r}$

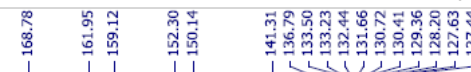
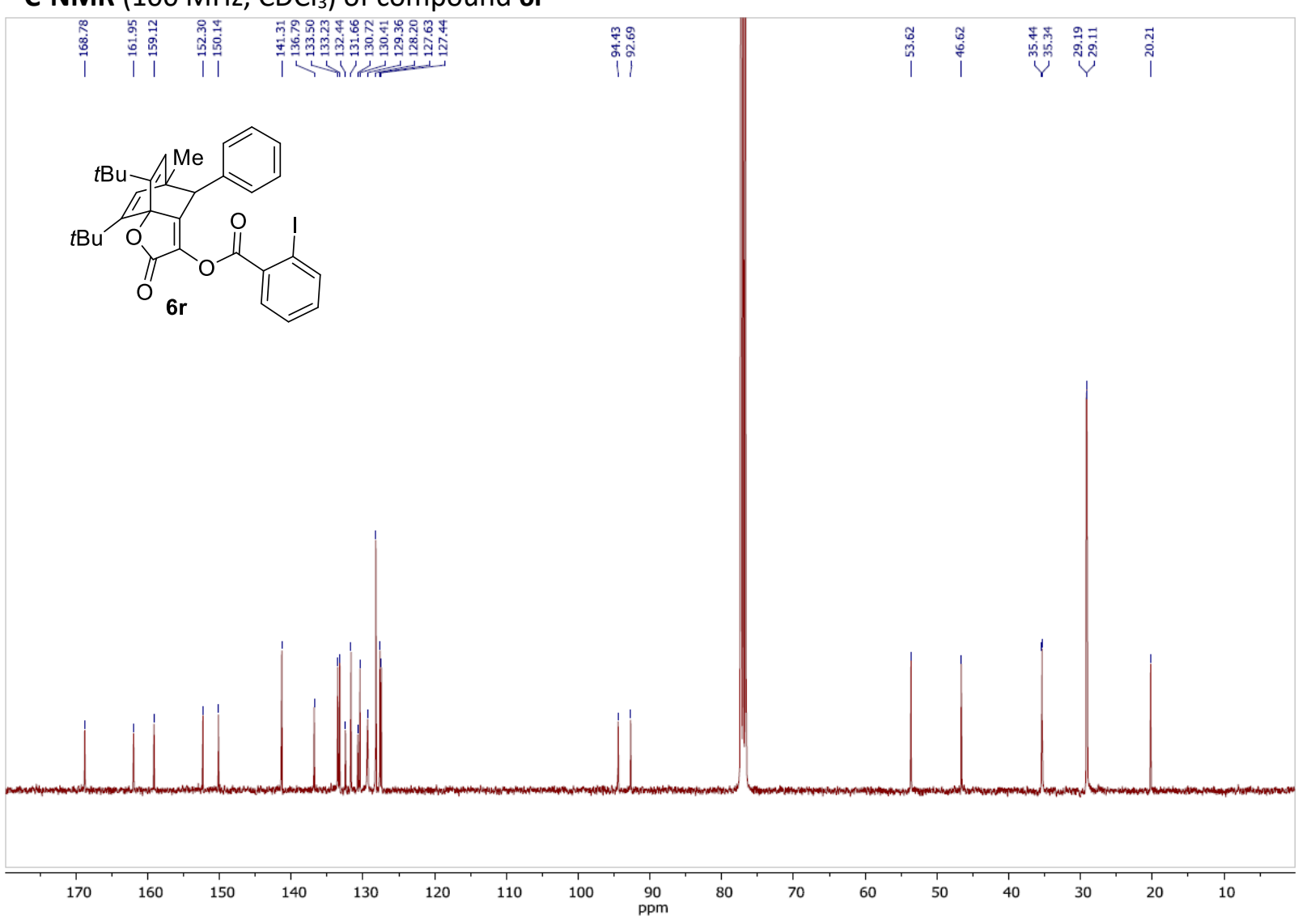
IR of compound $\mathbf{6 r}$

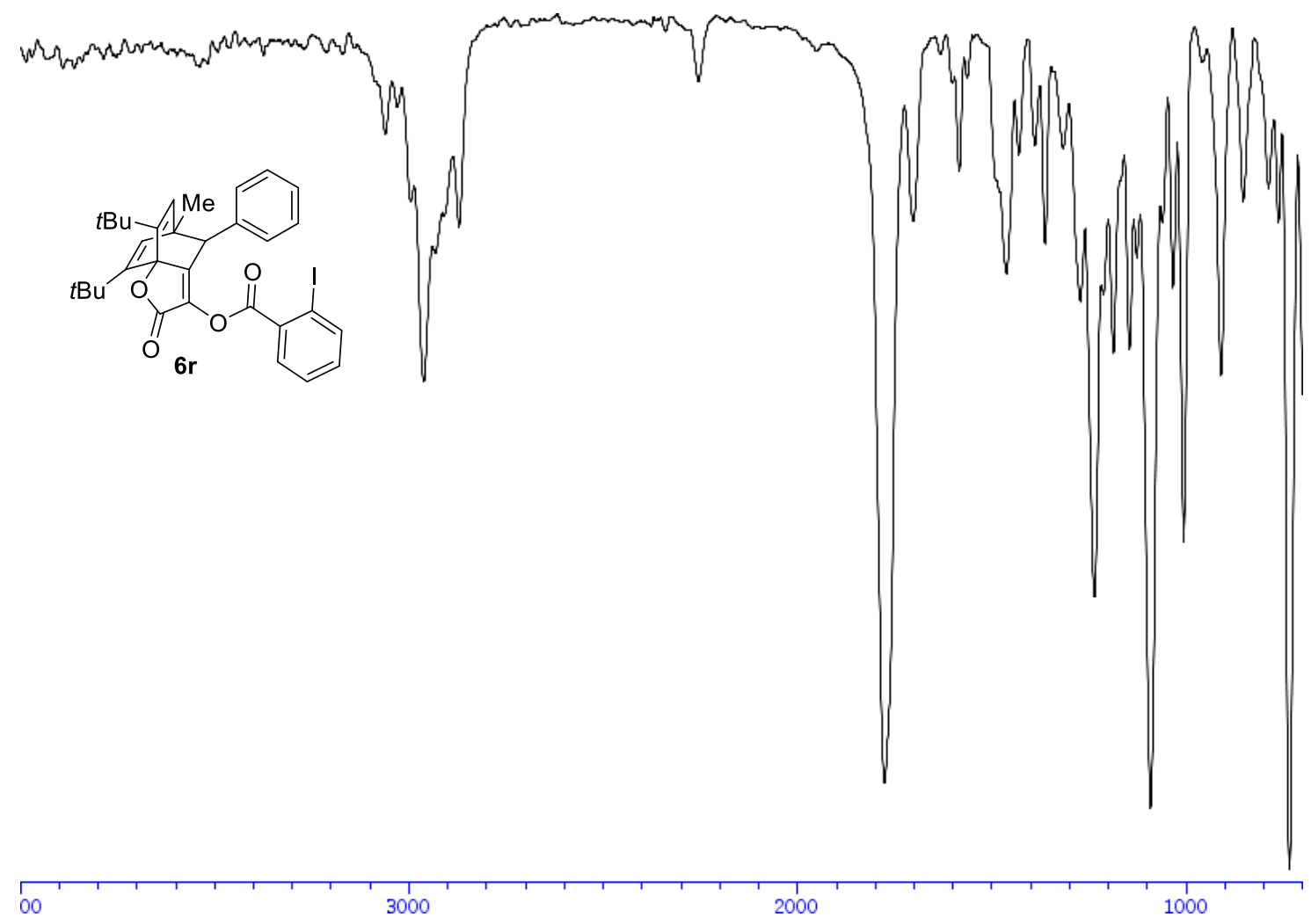


${ }^{1} \mathbf{H}$-NMR (400 MHz, $\mathrm{CDCl}_{3}$ ) of compound $\mathbf{6 s}$

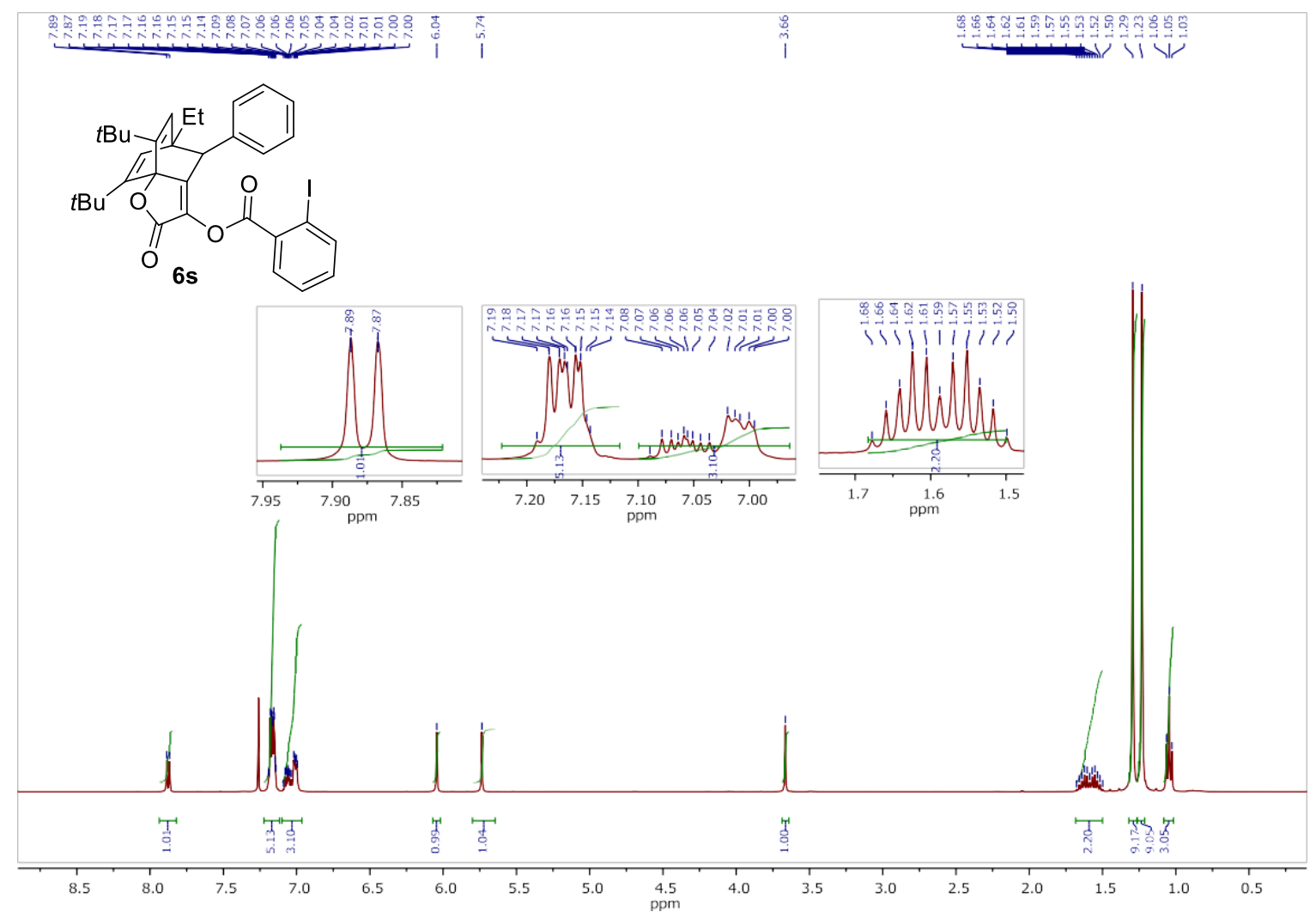

${ }^{13} \mathrm{C}$-NMR (100 MHz, $\mathrm{CDCl}_{3}$ ) of compound 6s

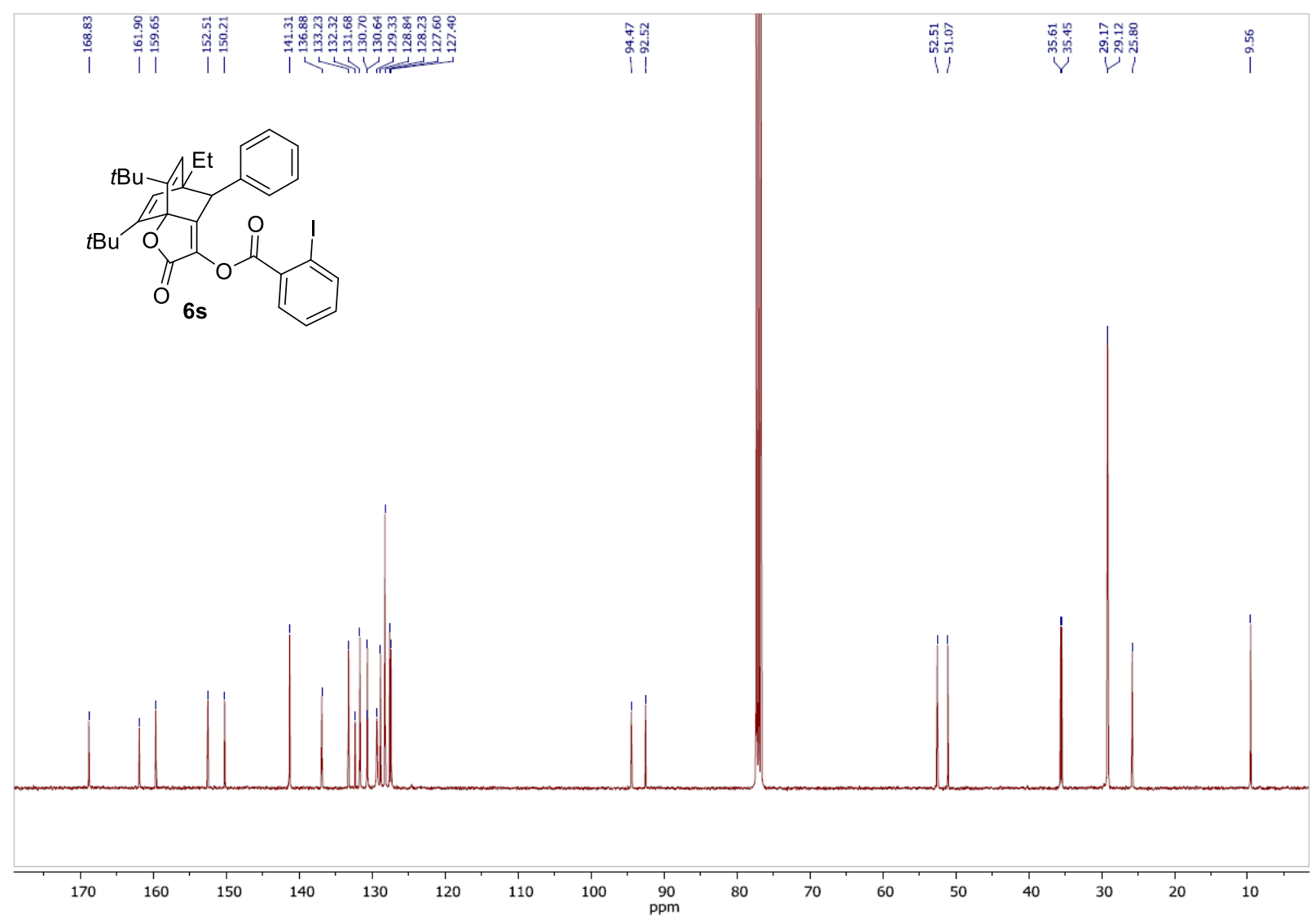


IR of compound 6 s

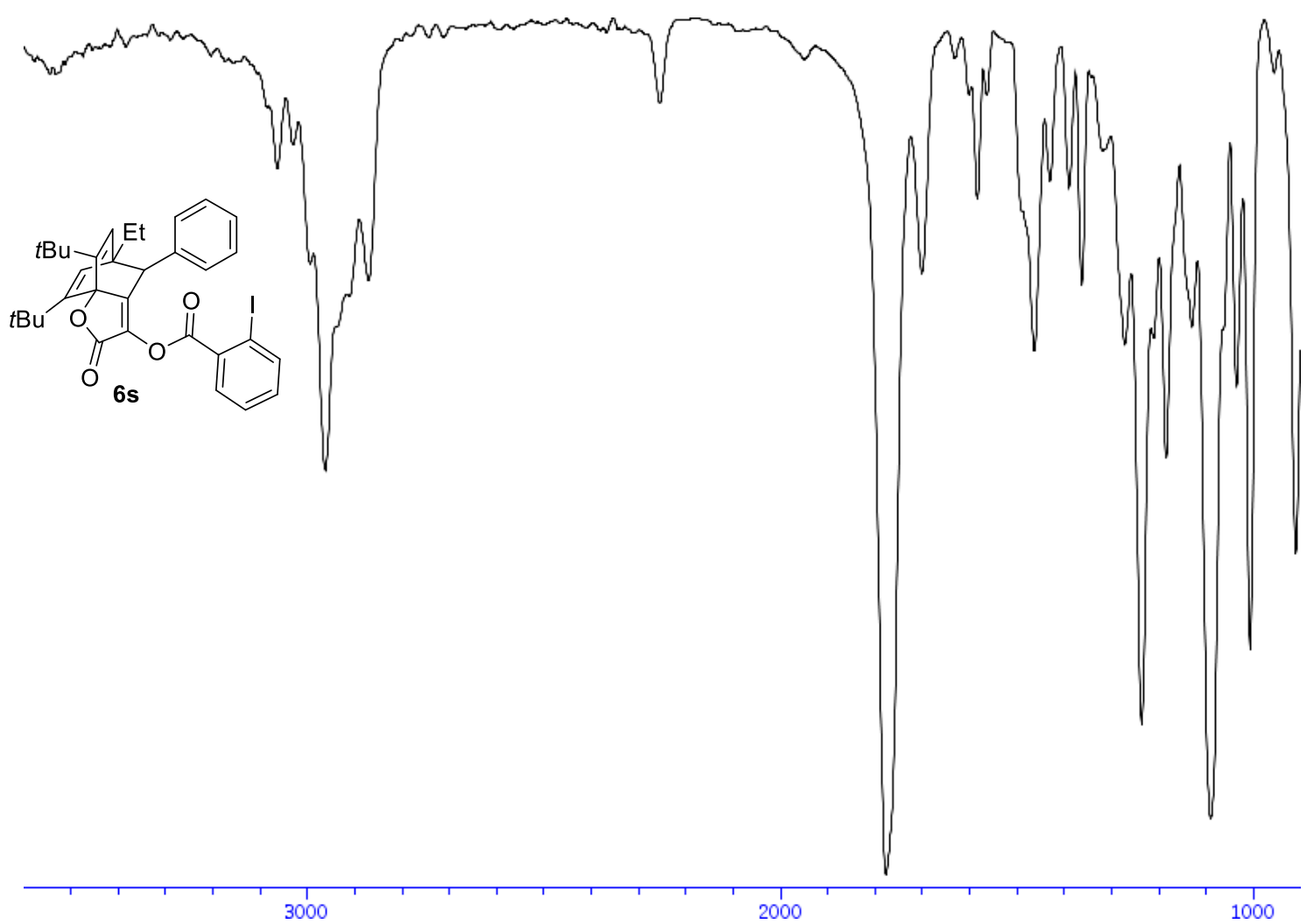


${ }^{1} \mathbf{H}-\mathrm{NMR}\left(400 \mathrm{MHz}, \mathrm{CDCl}_{3}\right.$ ) of compound $\mathbf{6 t}$

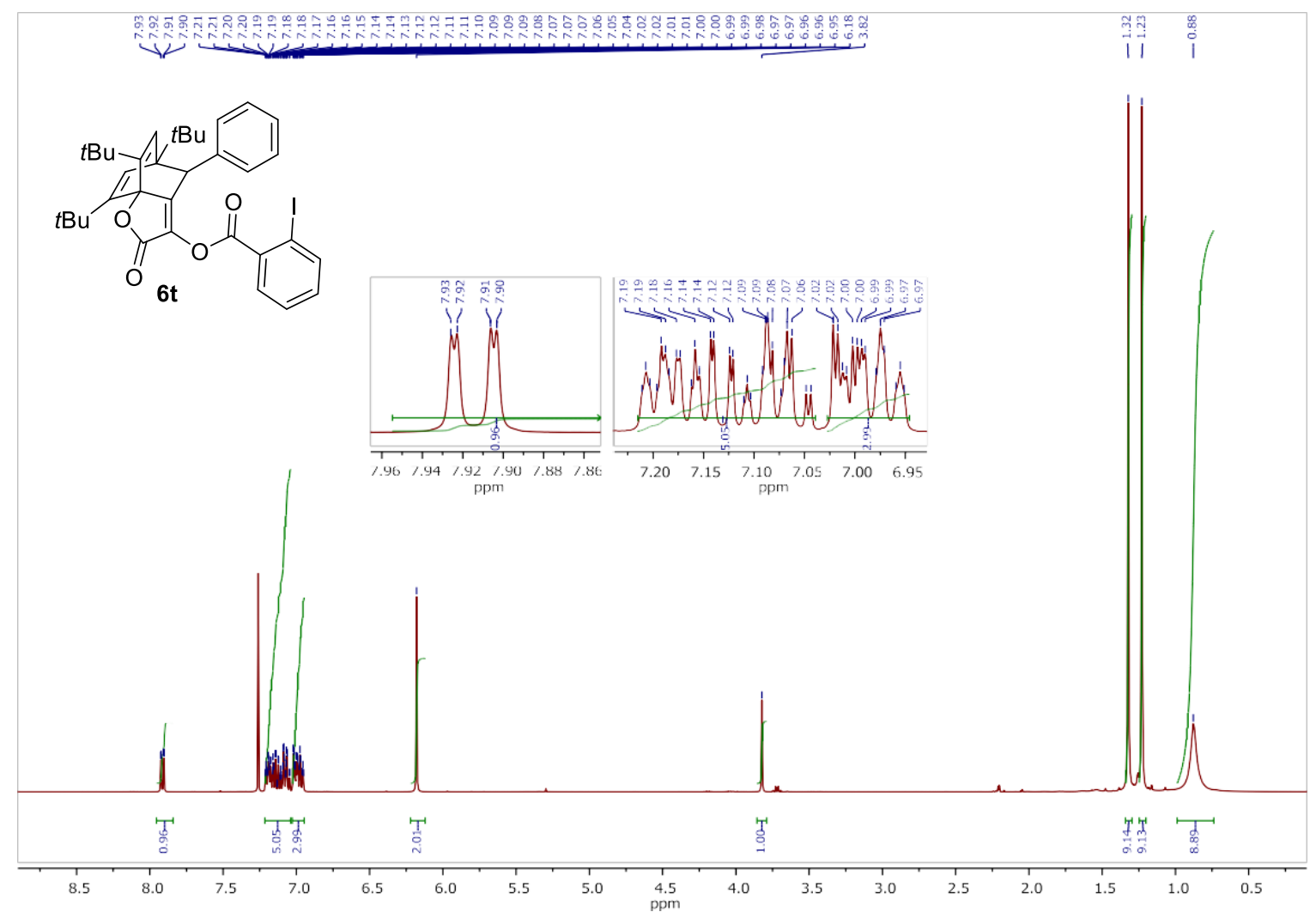

${ }^{13}$ C-NMR $\left(100 \mathrm{MHz}, \mathrm{CDCl}_{3}\right)$ of compound $6 \mathbf{t}$

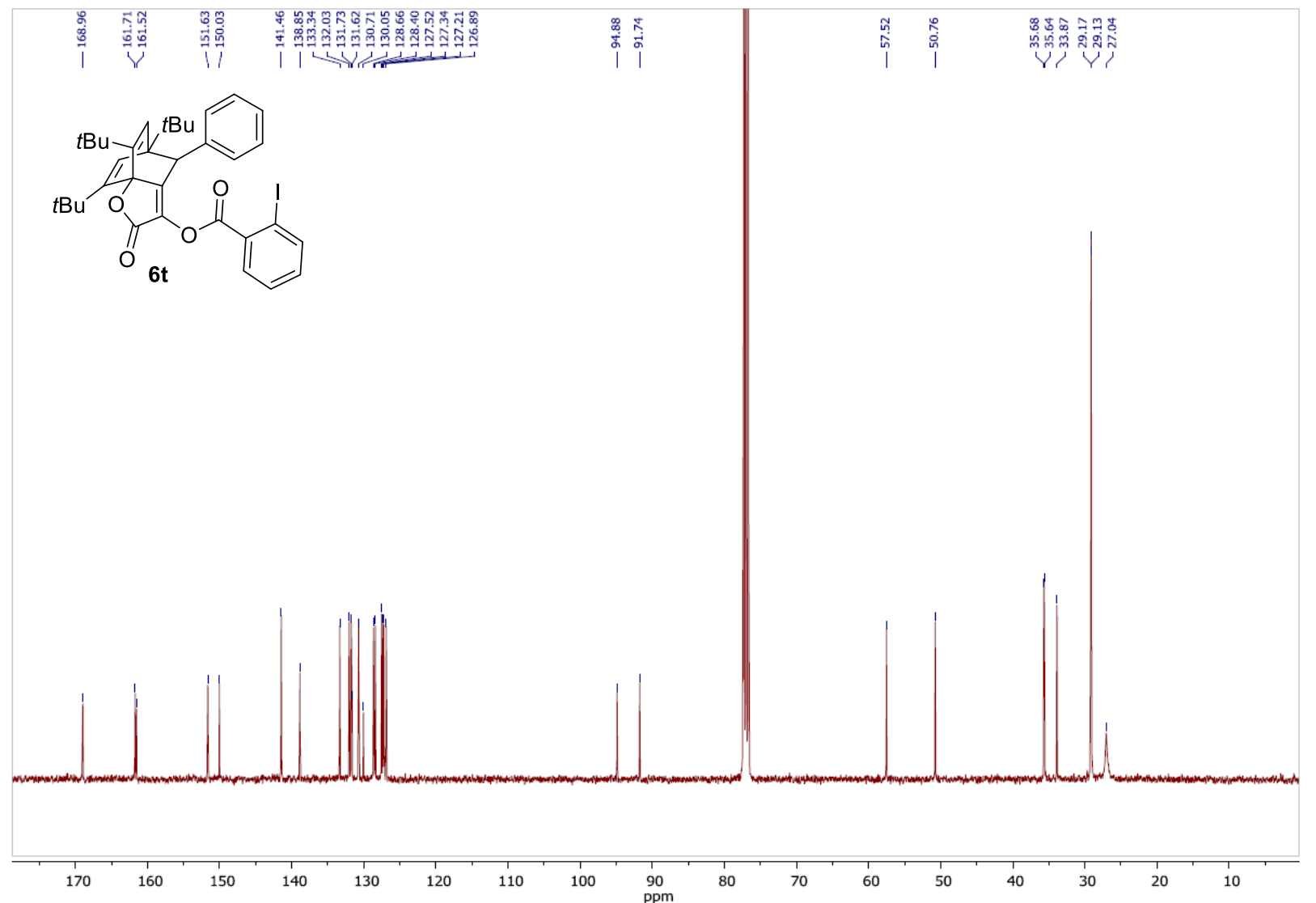


IR of compound $\mathbf{6 t}$

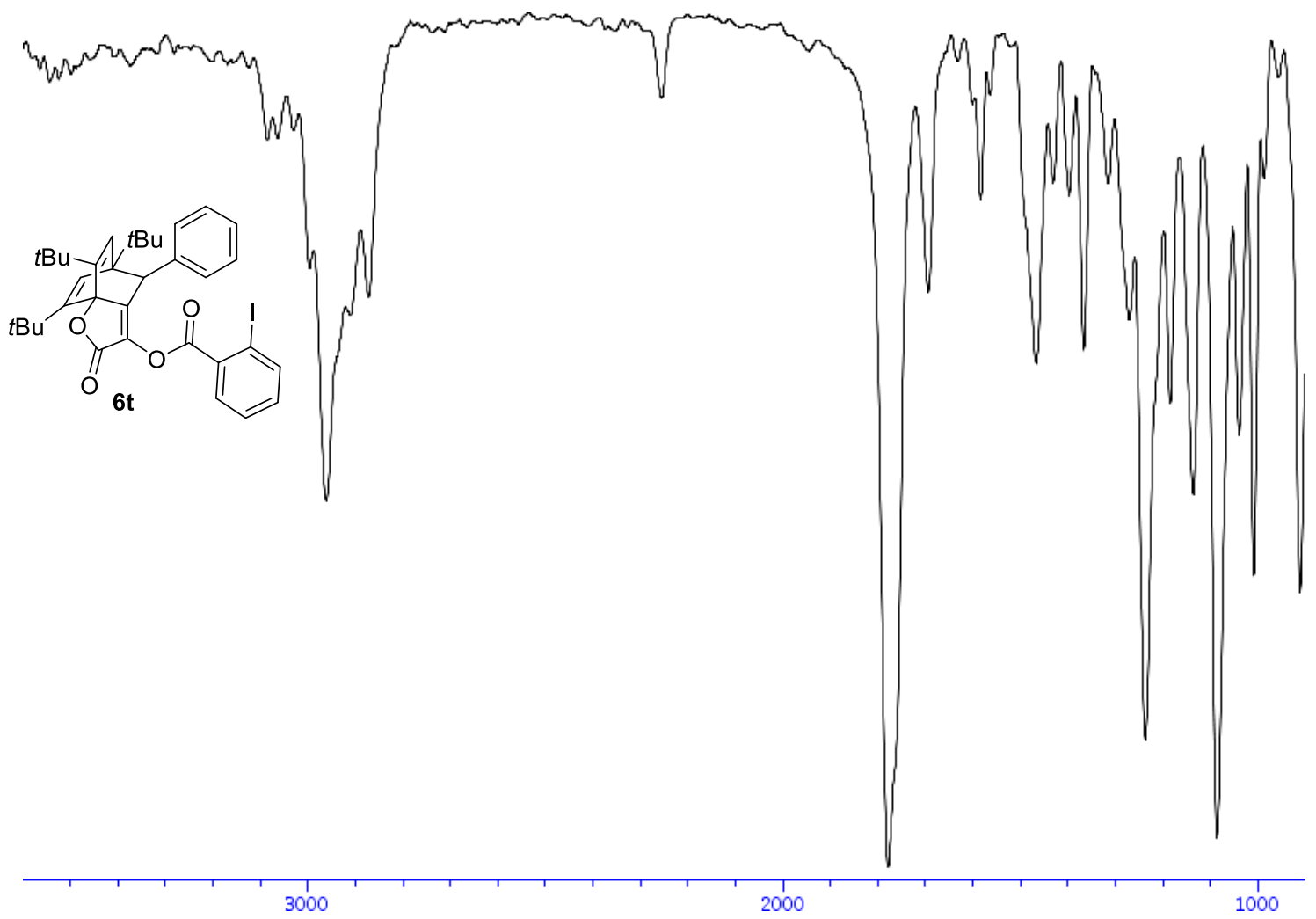


${ }^{1} \mathbf{H}-\mathrm{NMR}\left(400 \mathrm{MHz}, \mathrm{CDCl}_{3}\right.$ ) of compound $\mathbf{6 u}$

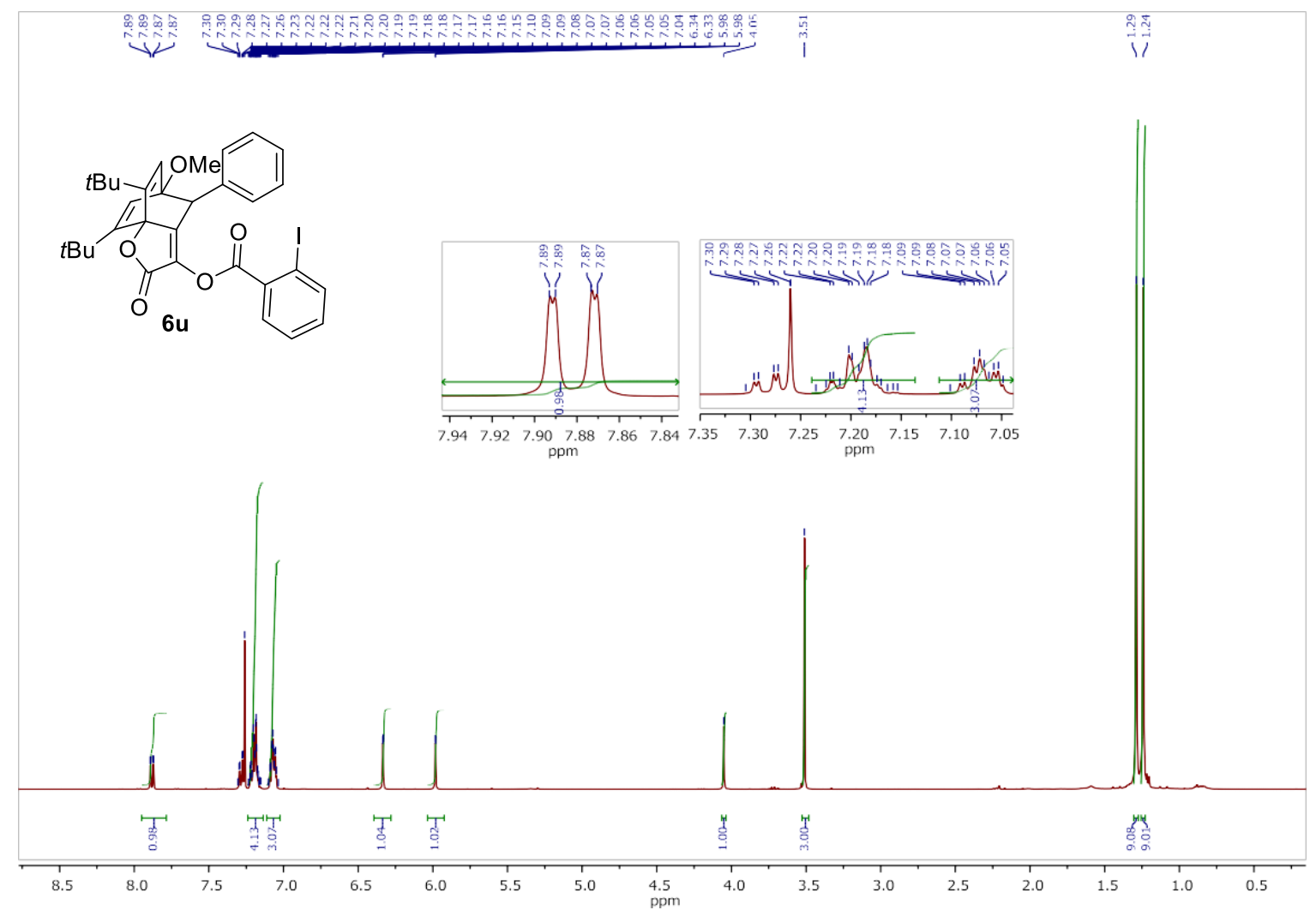

${ }^{13} \mathrm{C}$-NMR (100 MHz, $\mathrm{CDCl}_{3}$ ) of compound $\mathbf{6 u}$

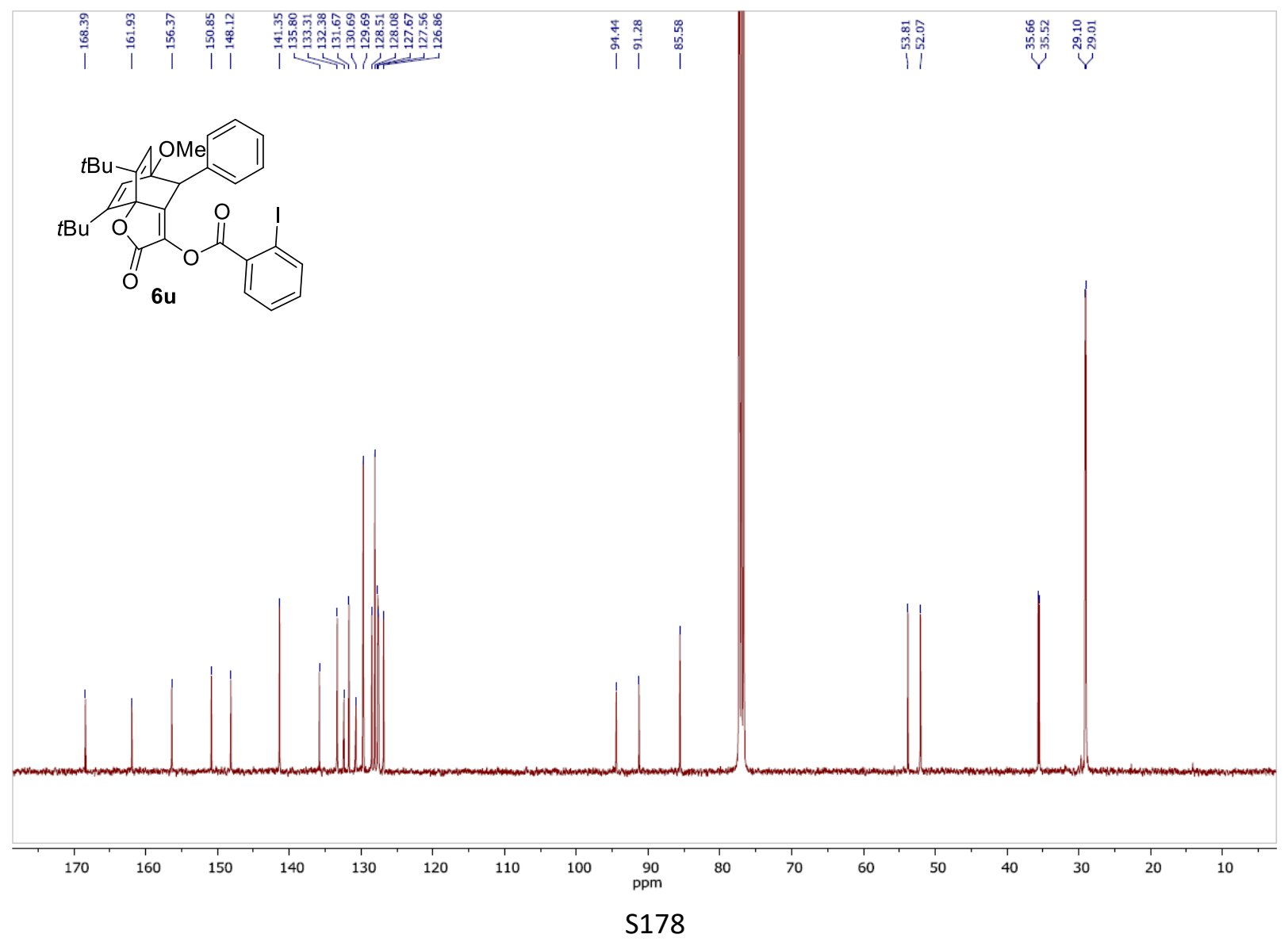




\section{IR of compound $\mathbf{6 u}$}

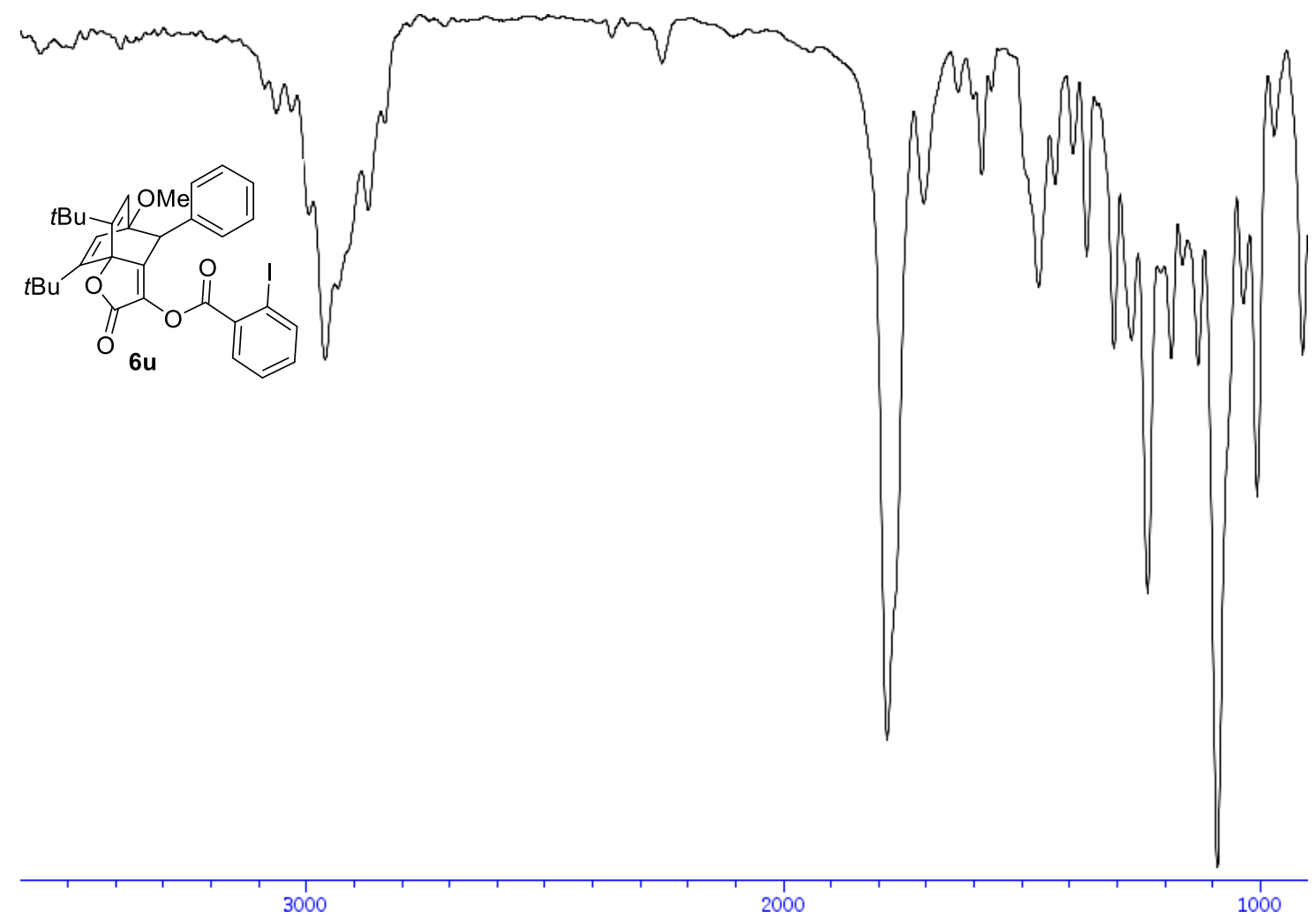


${ }^{1} \mathbf{H}-\mathrm{NMR}\left(400 \mathrm{MHz}, \mathrm{CDCl}_{3}\right.$ ) of compound $\mathbf{6 v}$

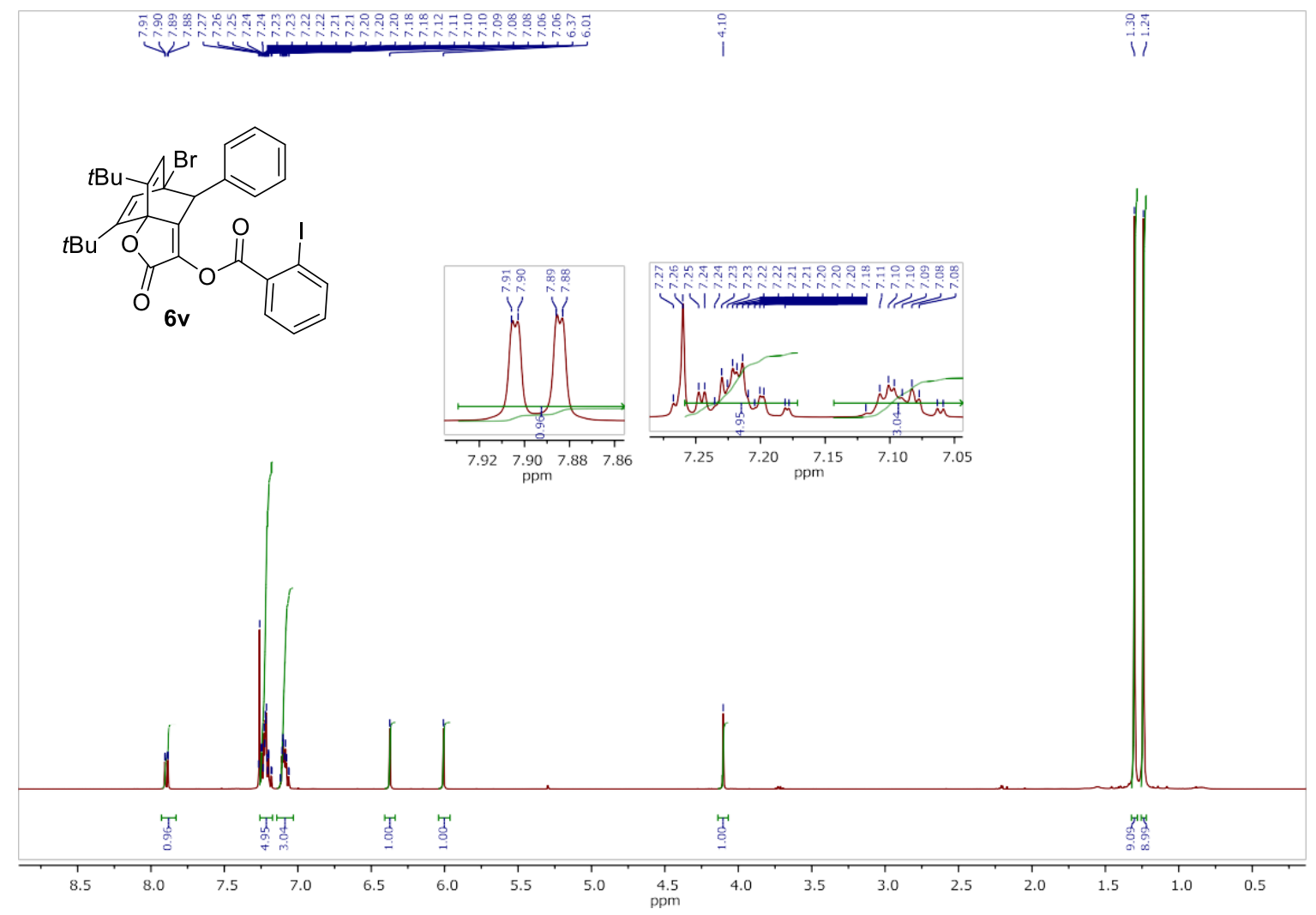

${ }^{13} \mathrm{C}-\mathrm{NMR}\left(100 \mathrm{MHz}, \mathrm{CDCl}_{3}\right)$ of compound $\mathbf{6 v}$

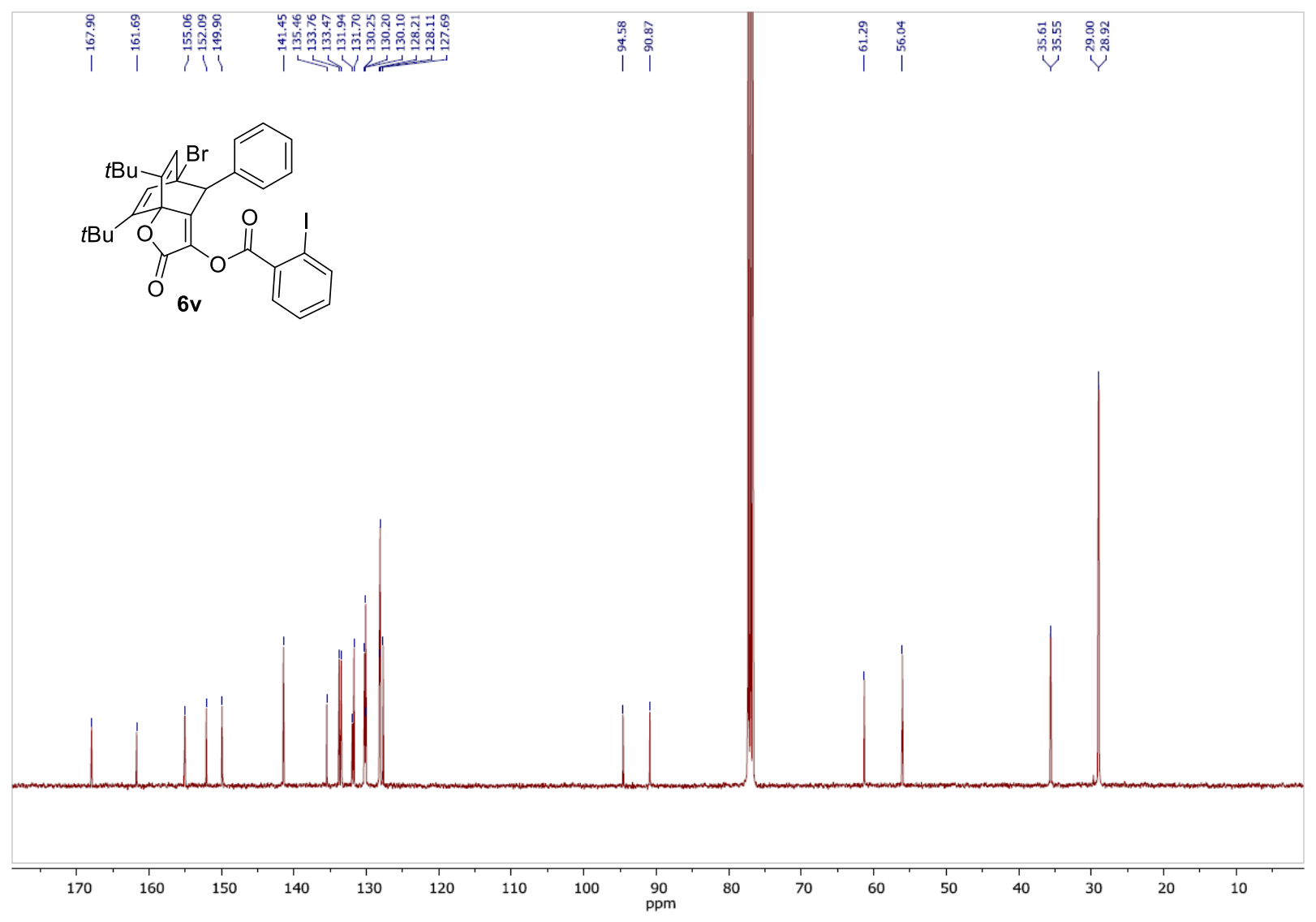

S180 
IR of compound $\mathbf{6 v}$

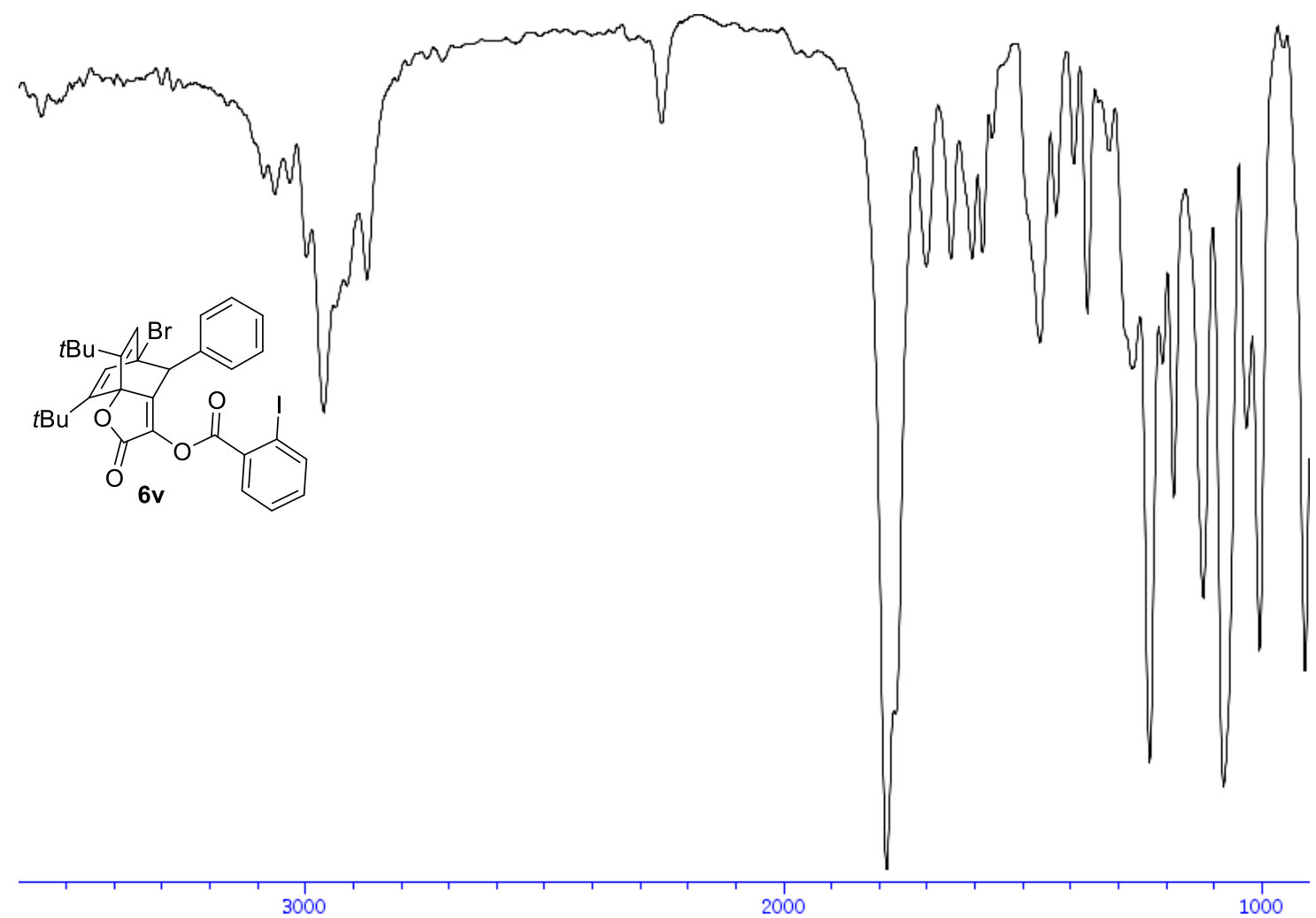


${ }^{1} \mathbf{H}-\mathrm{NMR}\left(400 \mathrm{MHz}, \mathrm{CDCl}_{3}\right.$ ) of compound $\mathbf{6 w}$

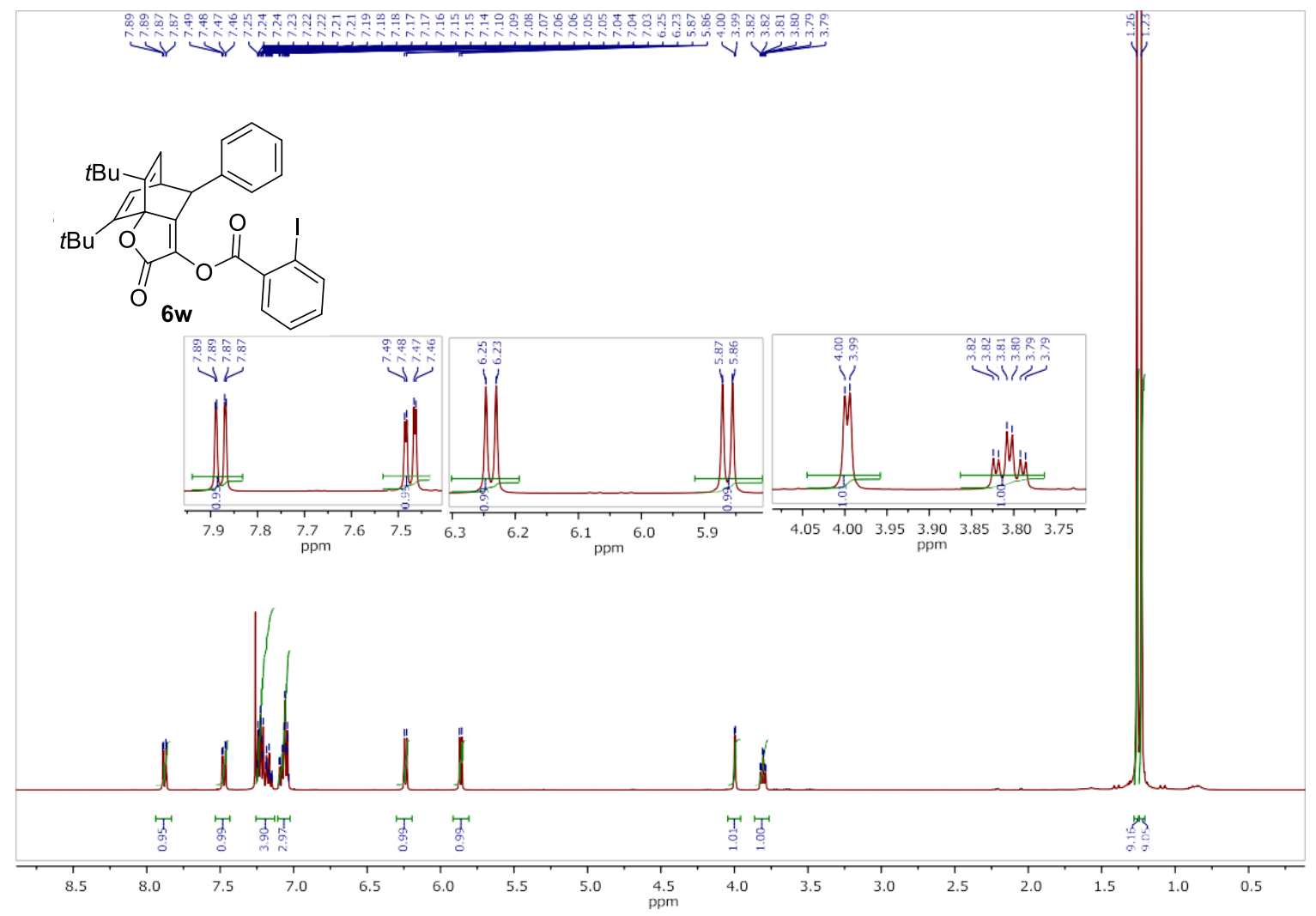

${ }^{13} \mathrm{C}-\mathrm{NMR}\left(100 \mathrm{MHz}, \mathrm{CDCl}_{3}\right.$ ) of compound $\mathbf{6 w}$

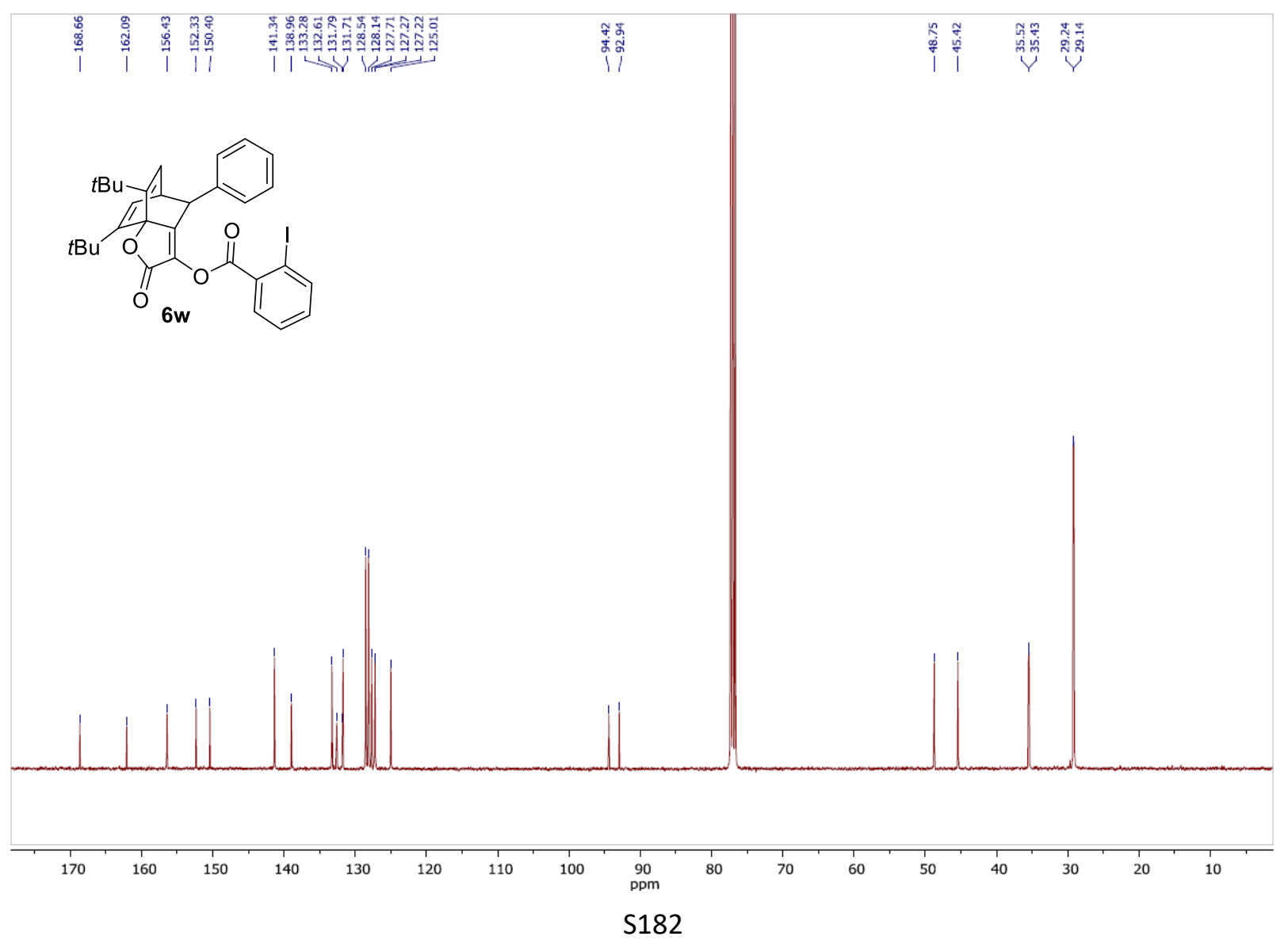


IR of compound $\mathbf{6 w}$

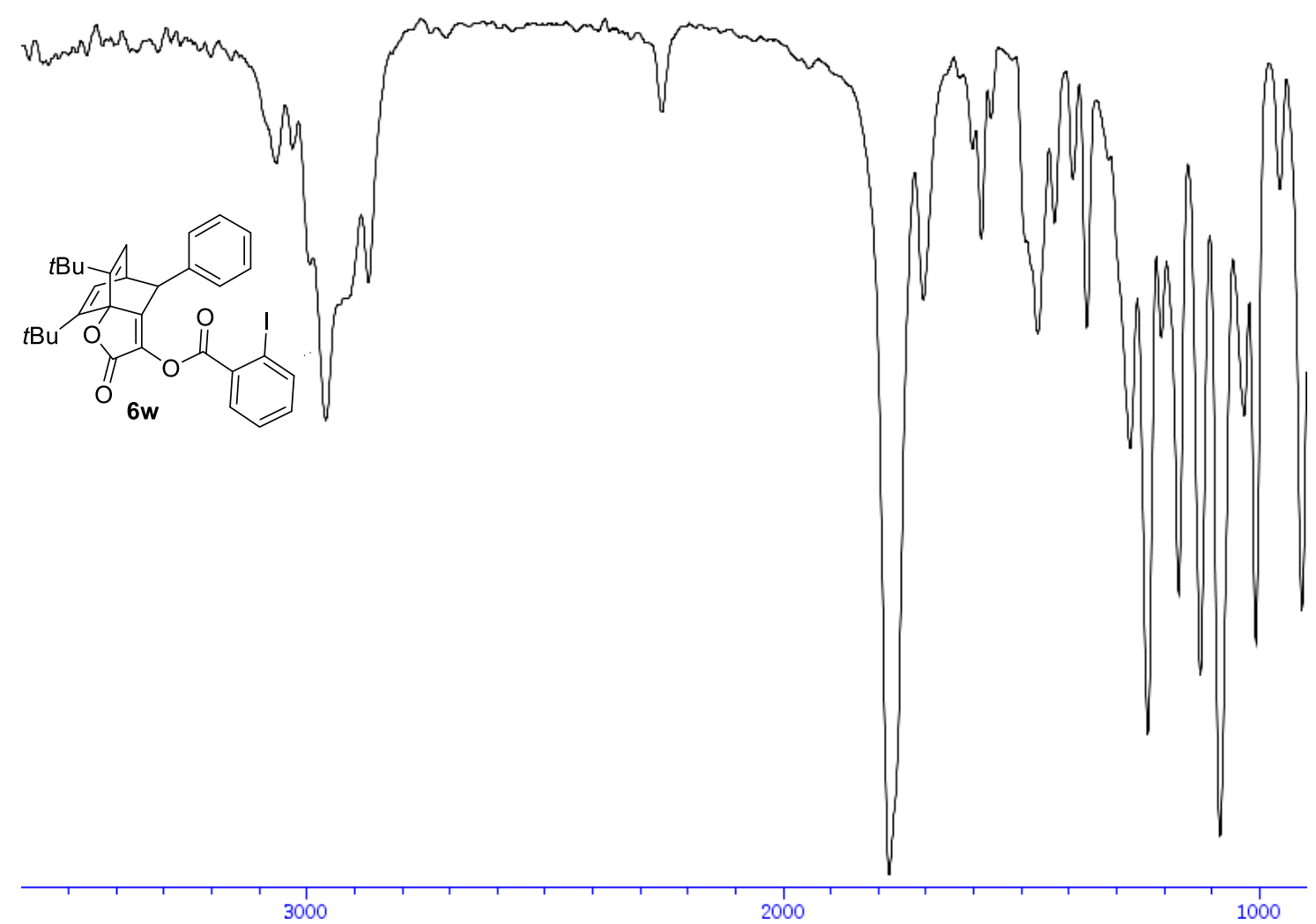


${ }^{1} \mathbf{H}-\mathbf{N M R}\left(400 \mathrm{MHz}, \mathrm{CDCl}_{3}\right.$ ) of compound $\mathbf{6 x}$

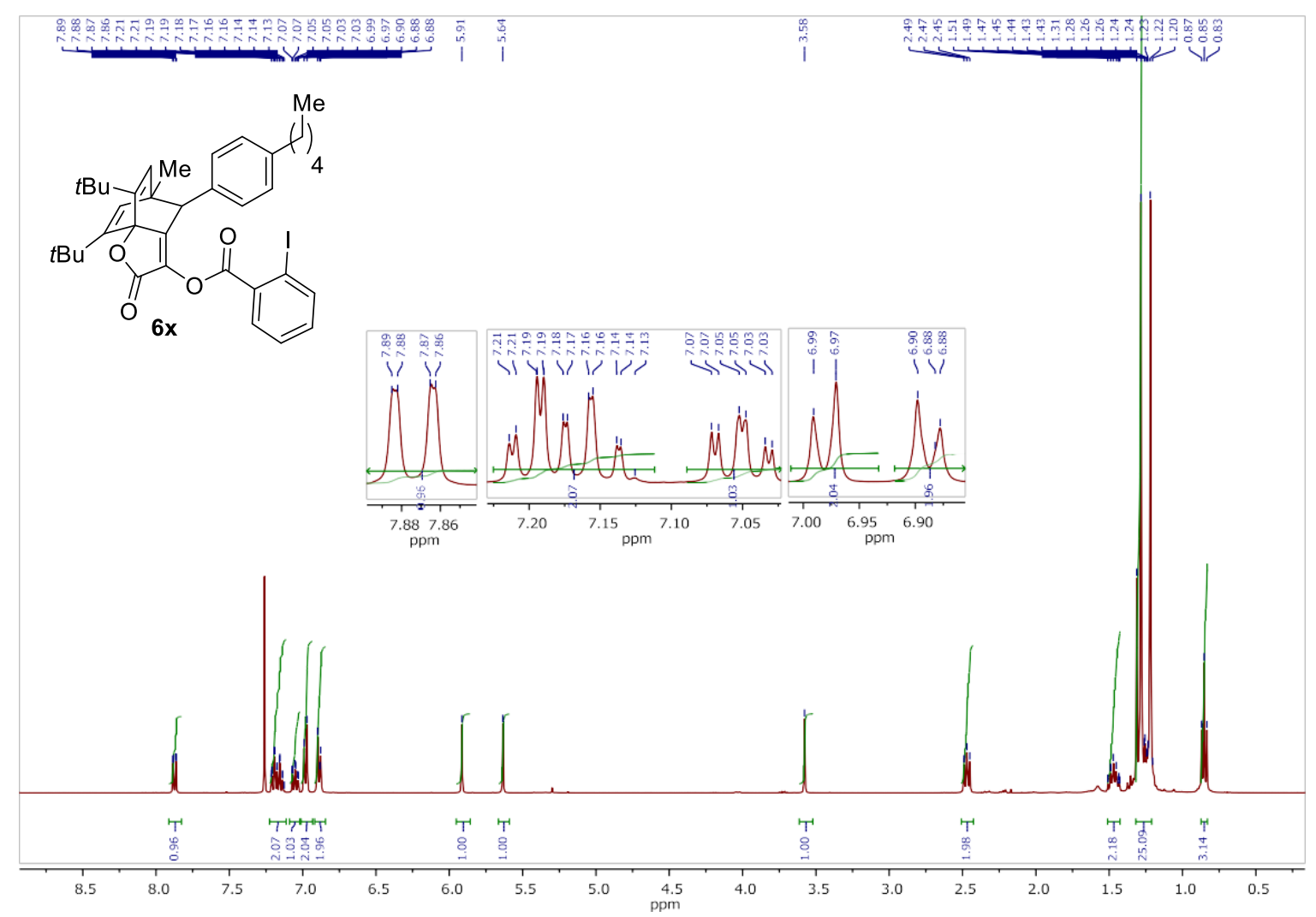

${ }^{13} \mathbf{C}-\mathrm{NMR}\left(100 \mathrm{MHz}, \mathrm{CDCl}_{3}\right.$ ) of compound $\mathbf{6 x}$

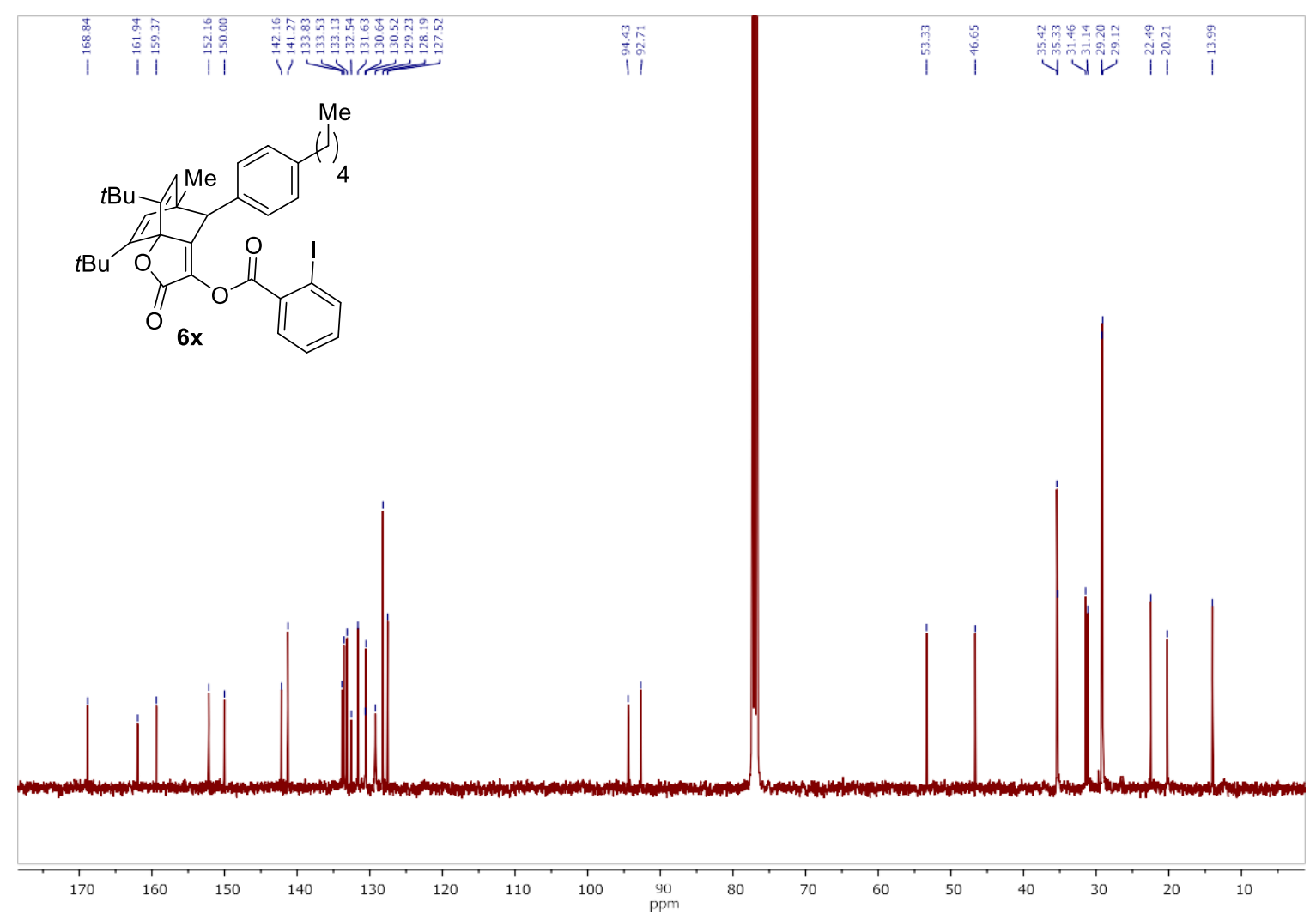


IR of compound $\mathbf{6 x}$

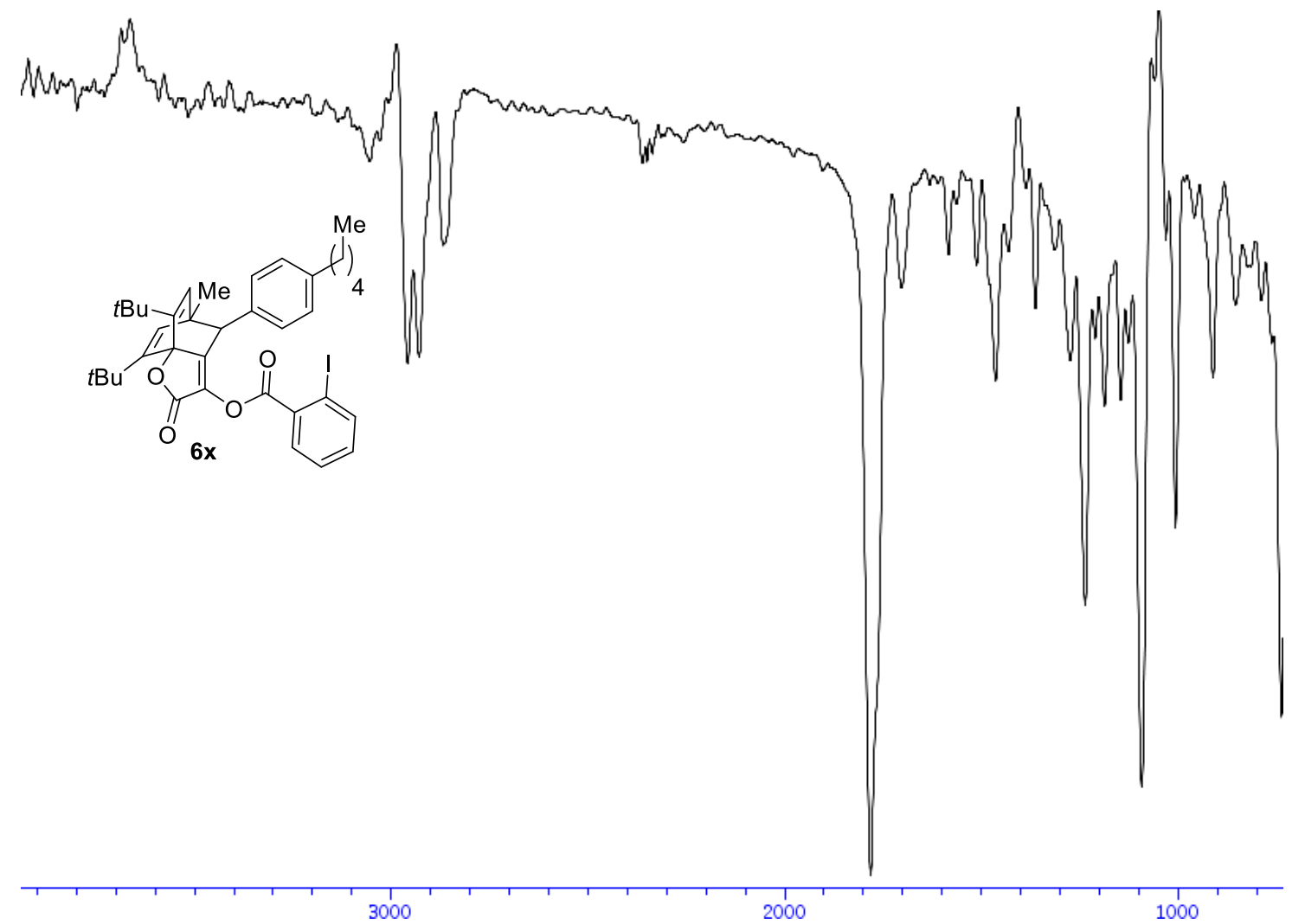


${ }^{1} \mathbf{H}$-NMR (400 MHz, $\mathrm{CDCl}_{3}$ ) of compound $\mathbf{6 y}$

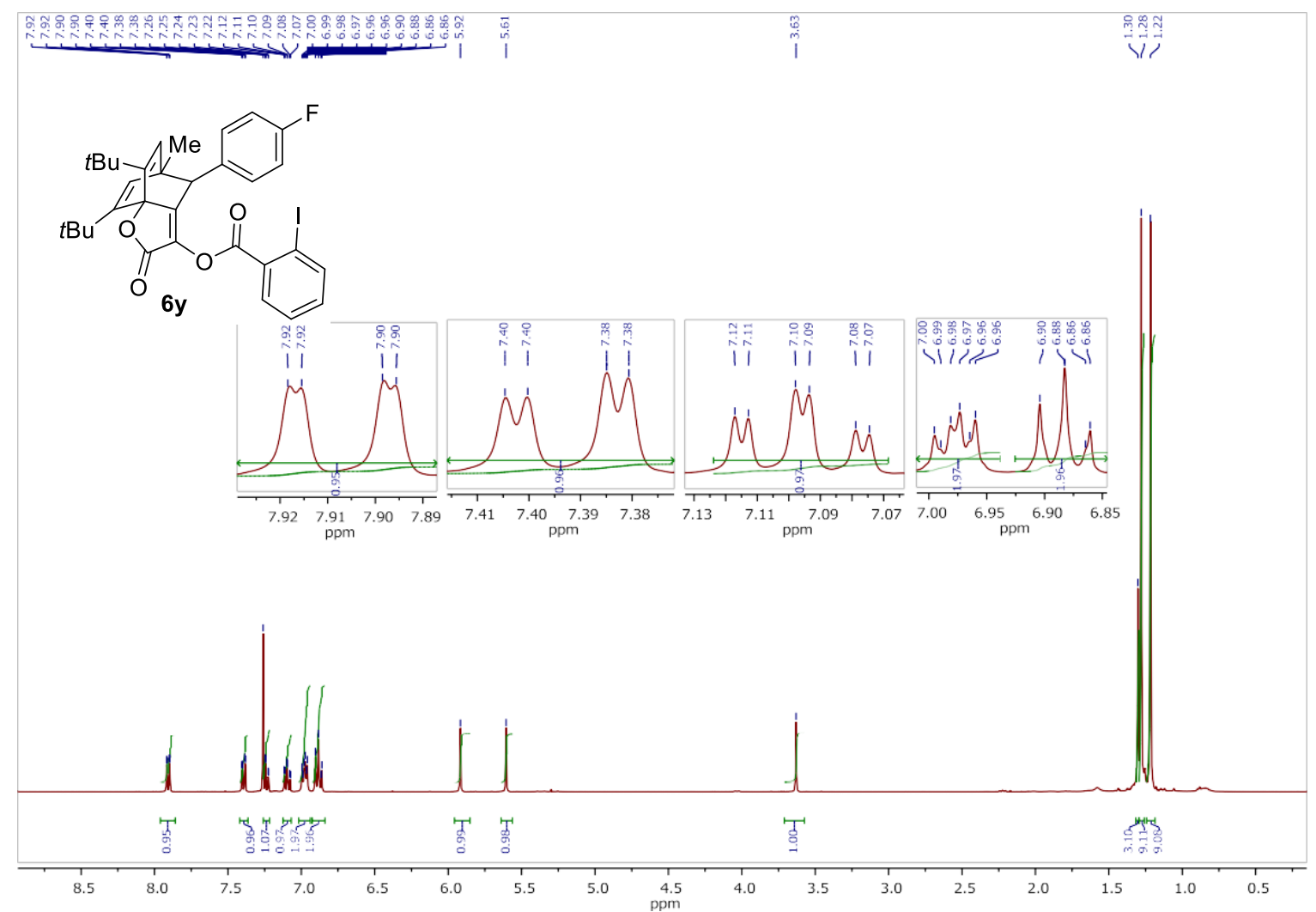

${ }^{13} \mathrm{C}-\mathrm{NMR}\left(100 \mathrm{MHz}, \mathrm{CDCl}_{3}\right)$ of compound $\mathbf{6 y}$

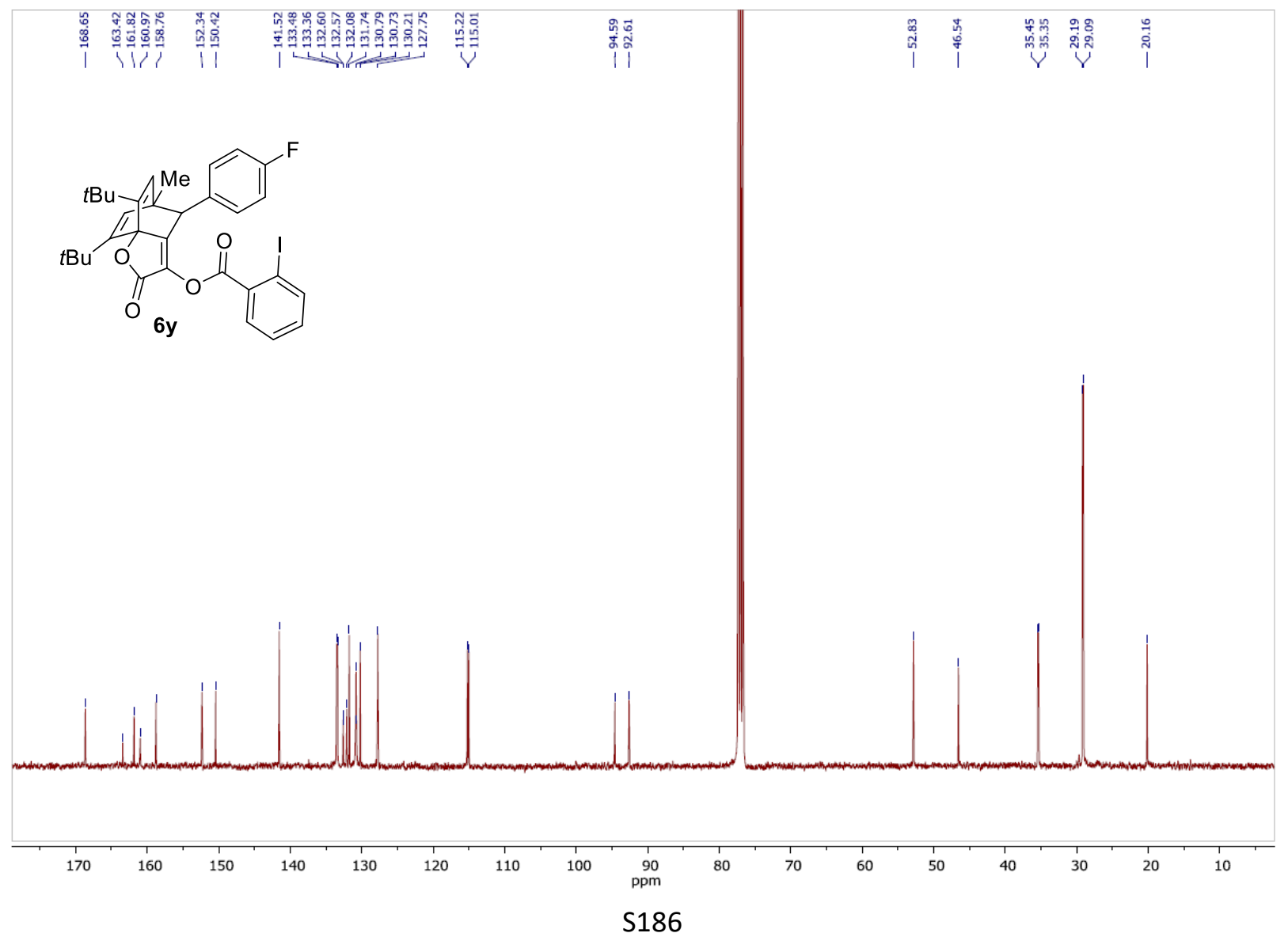


IR of compound $\mathbf{6 y}$

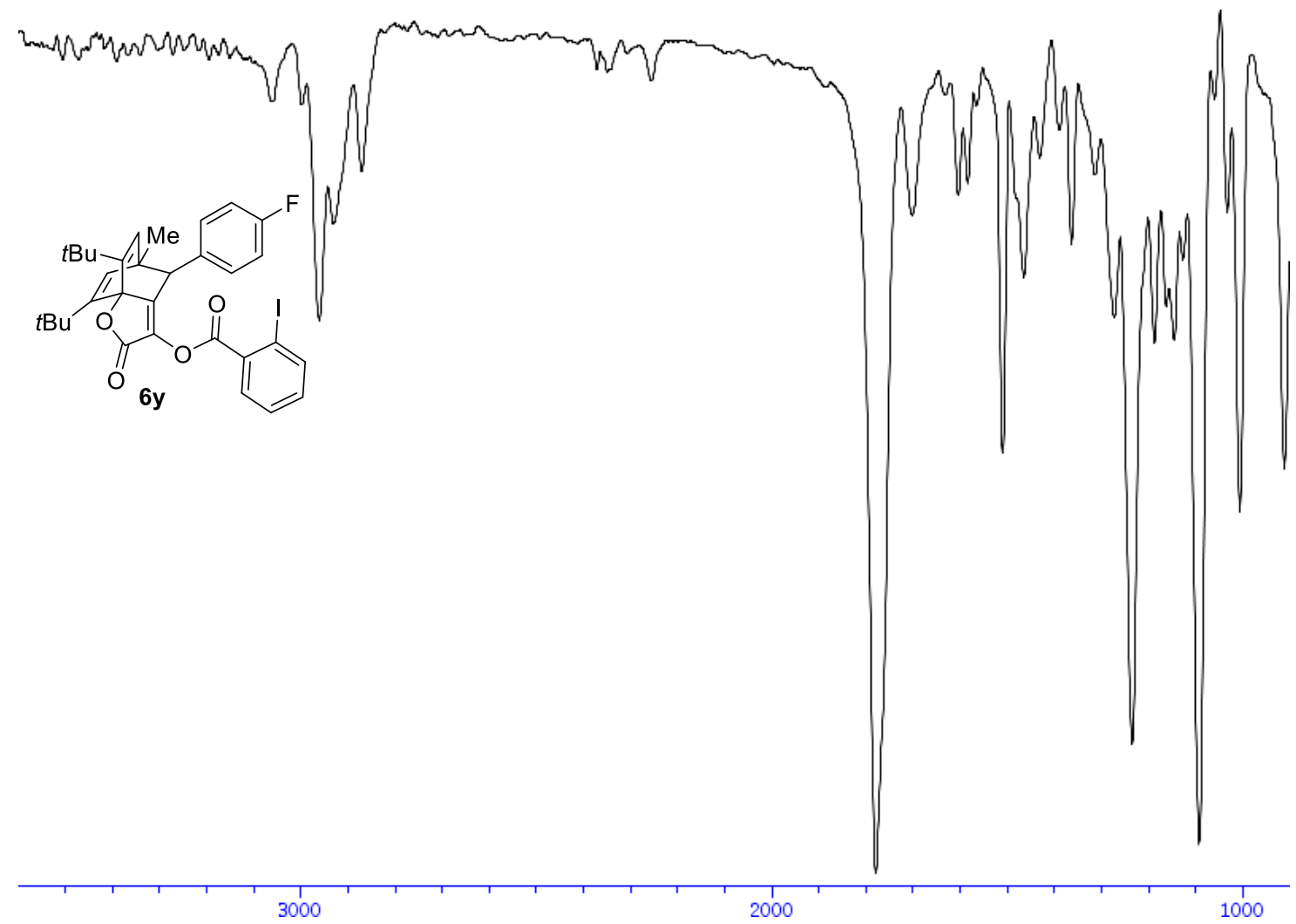


${ }^{1} \mathbf{H}-\mathrm{NMR}\left(400 \mathrm{MHz}, \mathrm{CDCl}_{3}\right.$ ) of compound $\mathbf{6 z}$

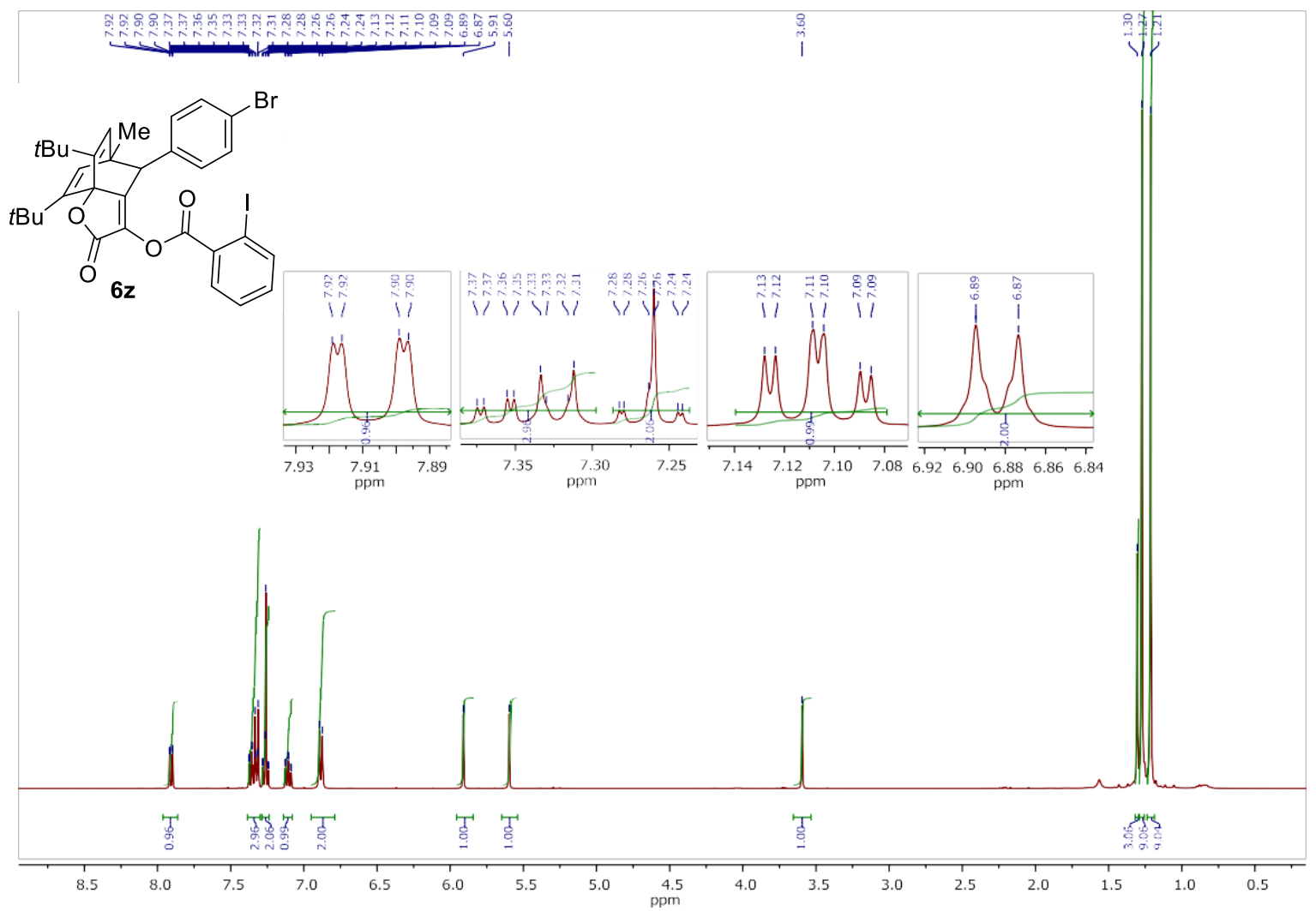

${ }^{13} \mathrm{C}$-NMR (100 MHz, $\mathrm{CDCl}_{3}$ ) of compound $\mathbf{6 z}$

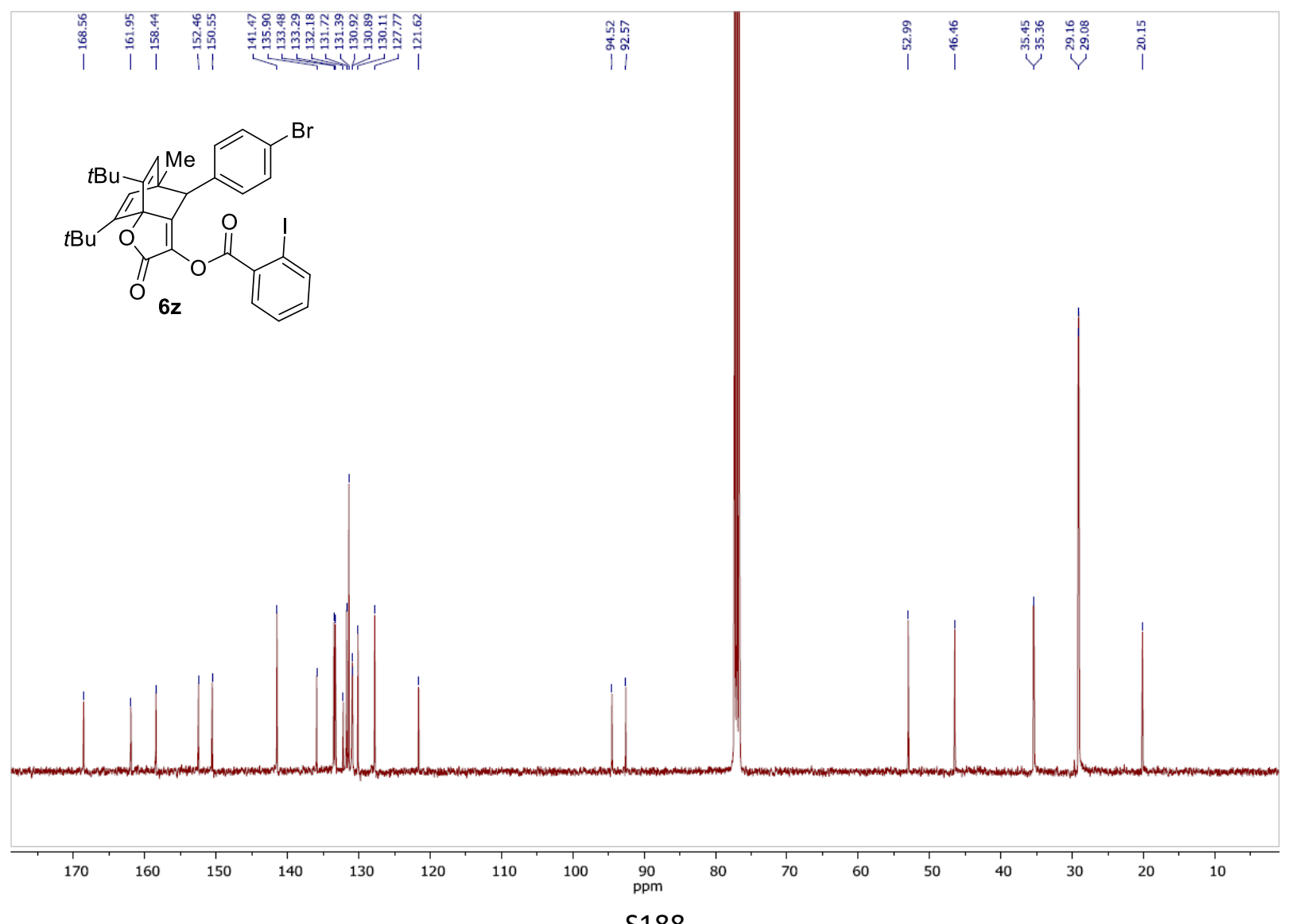

S188 
IR of compound $6 z$

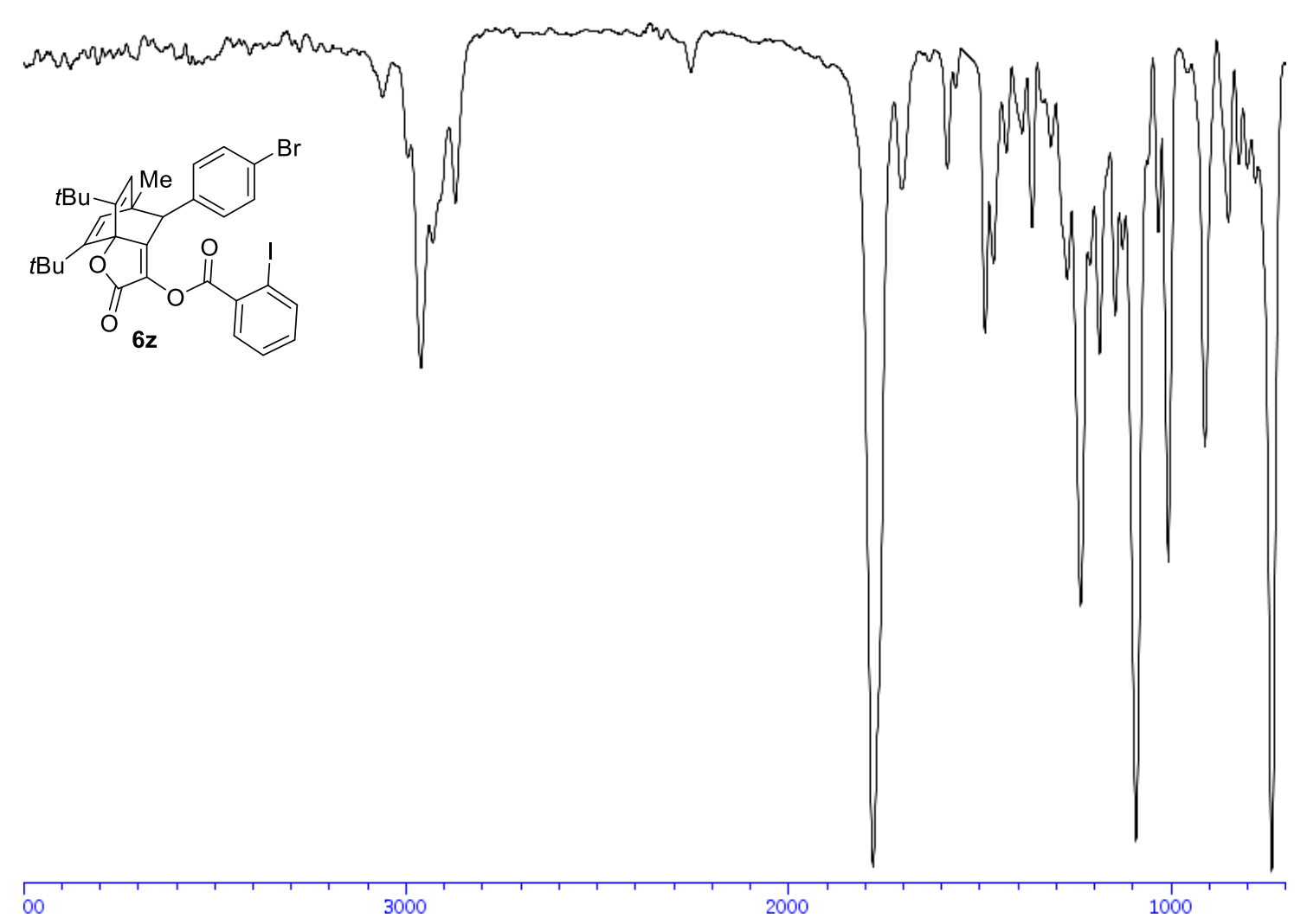


${ }^{1}$ H-NMR (400 MHz, $\mathrm{CDCl}_{3}$ ) of compound 6 aa

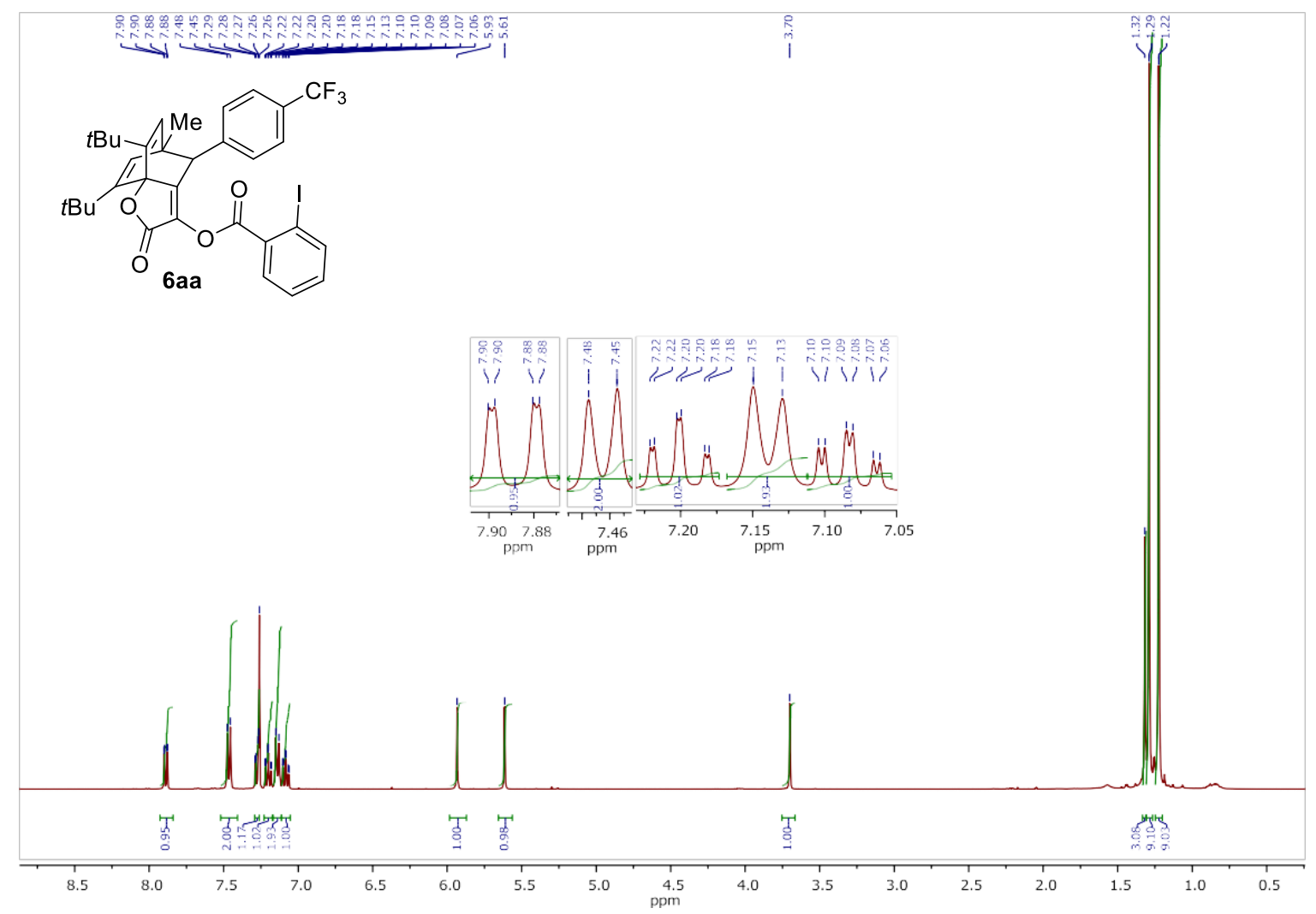

${ }^{13} \mathrm{C}-\mathrm{NMR}$ (100 MHz, $\mathrm{CDCl}_{3}$ ) of compound 6aa

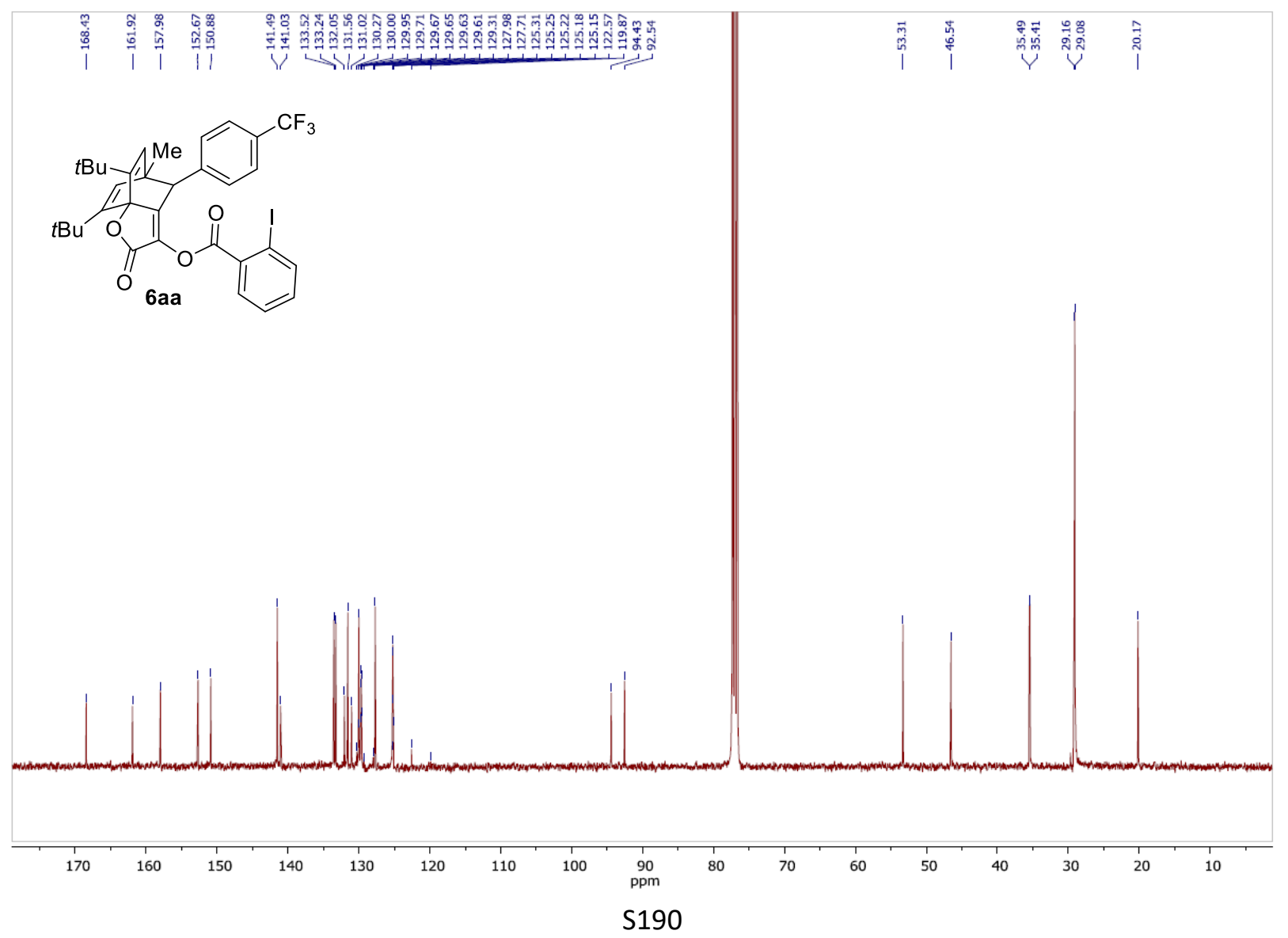


IR of compound $\mathbf{6 a a}$

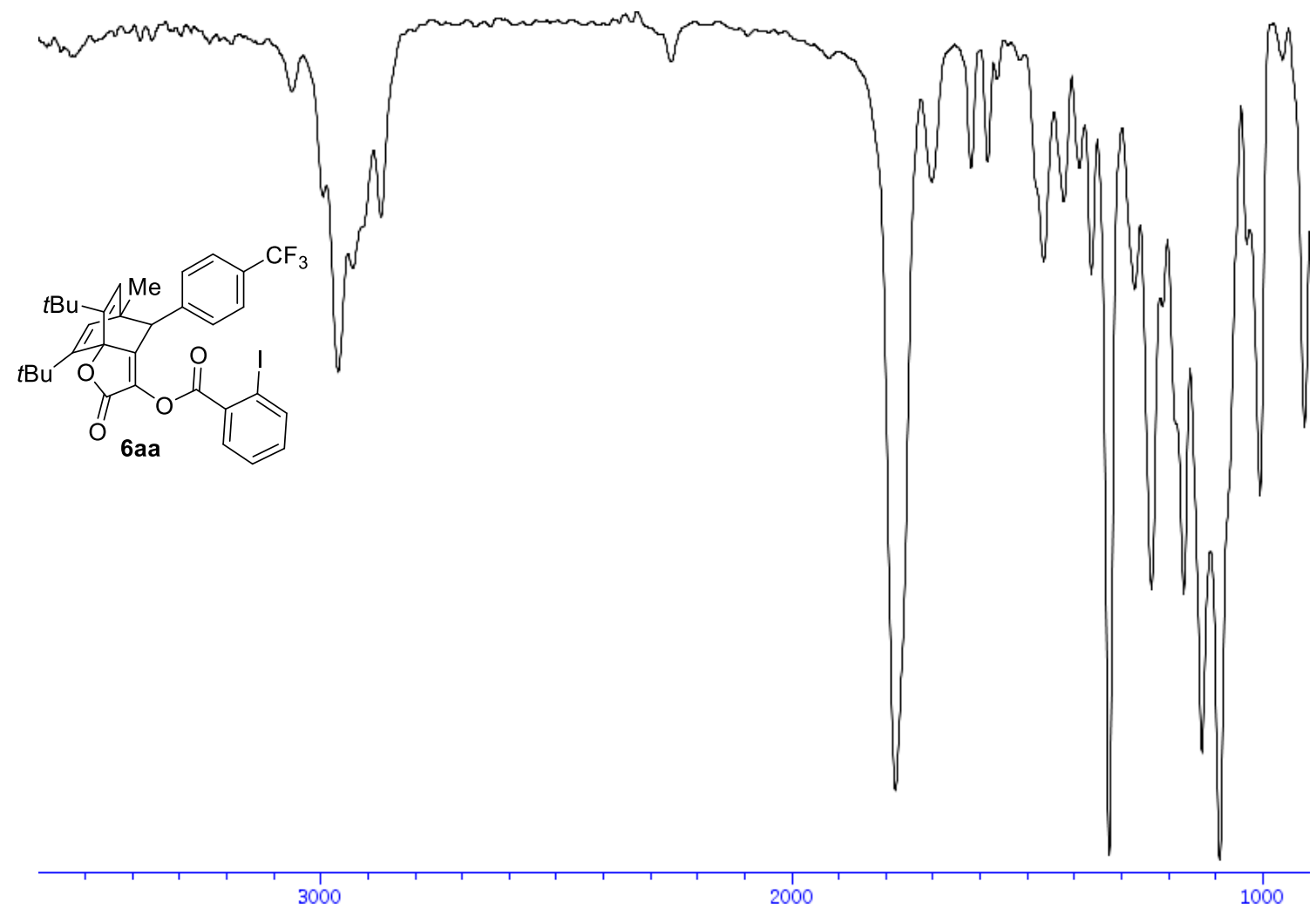


${ }^{1}$ H-NMR (400 MHz, $\mathrm{CDCl}_{3}$ ) of compound $\mathbf{6 a b}$

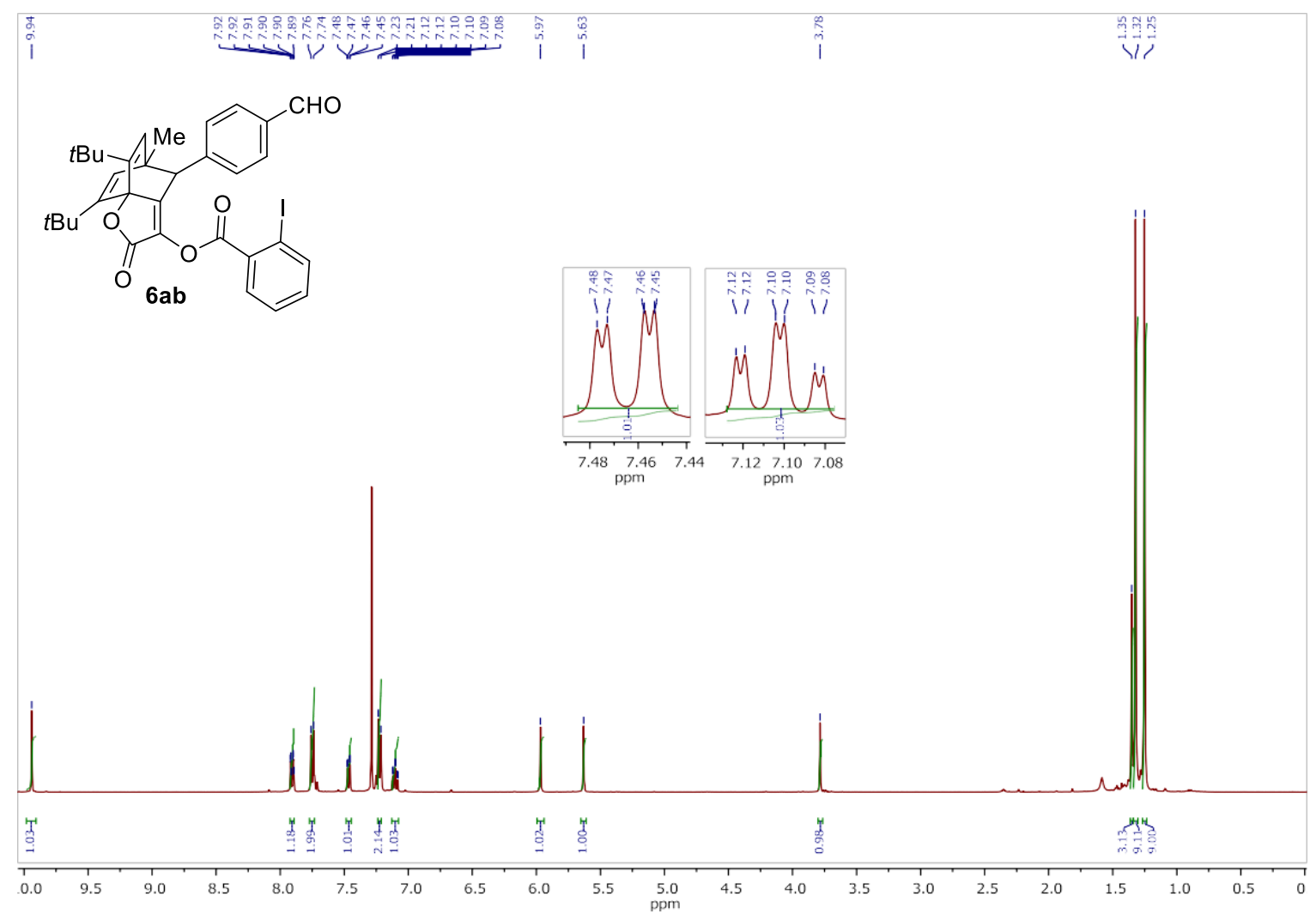

${ }^{13} \mathrm{C}-\mathrm{NMR}\left(100 \mathrm{MHz}, \mathrm{CDCl}_{3}\right.$ ) of compound $\mathbf{6 a b}$

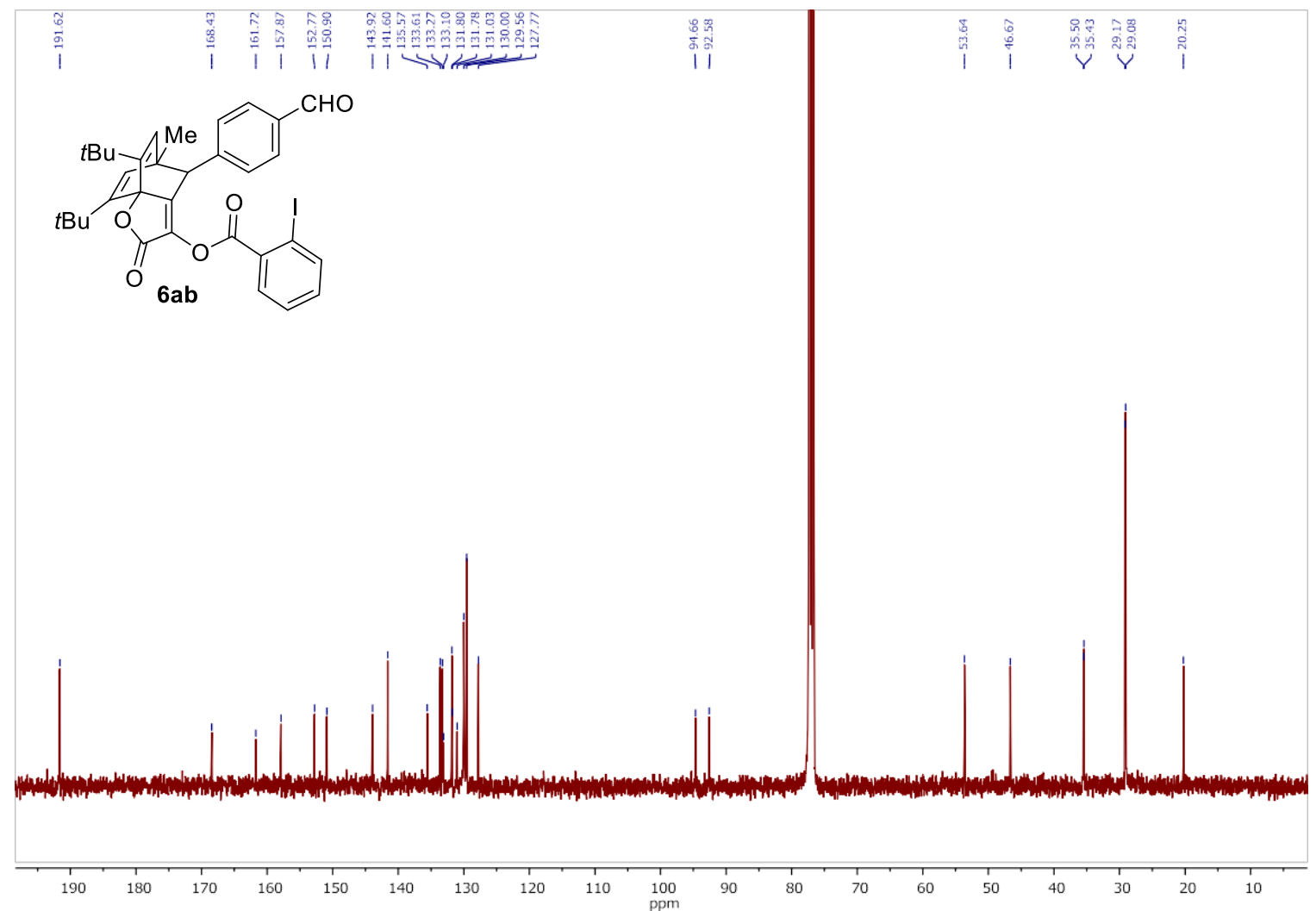


IR of compound $\mathbf{6 a b}$

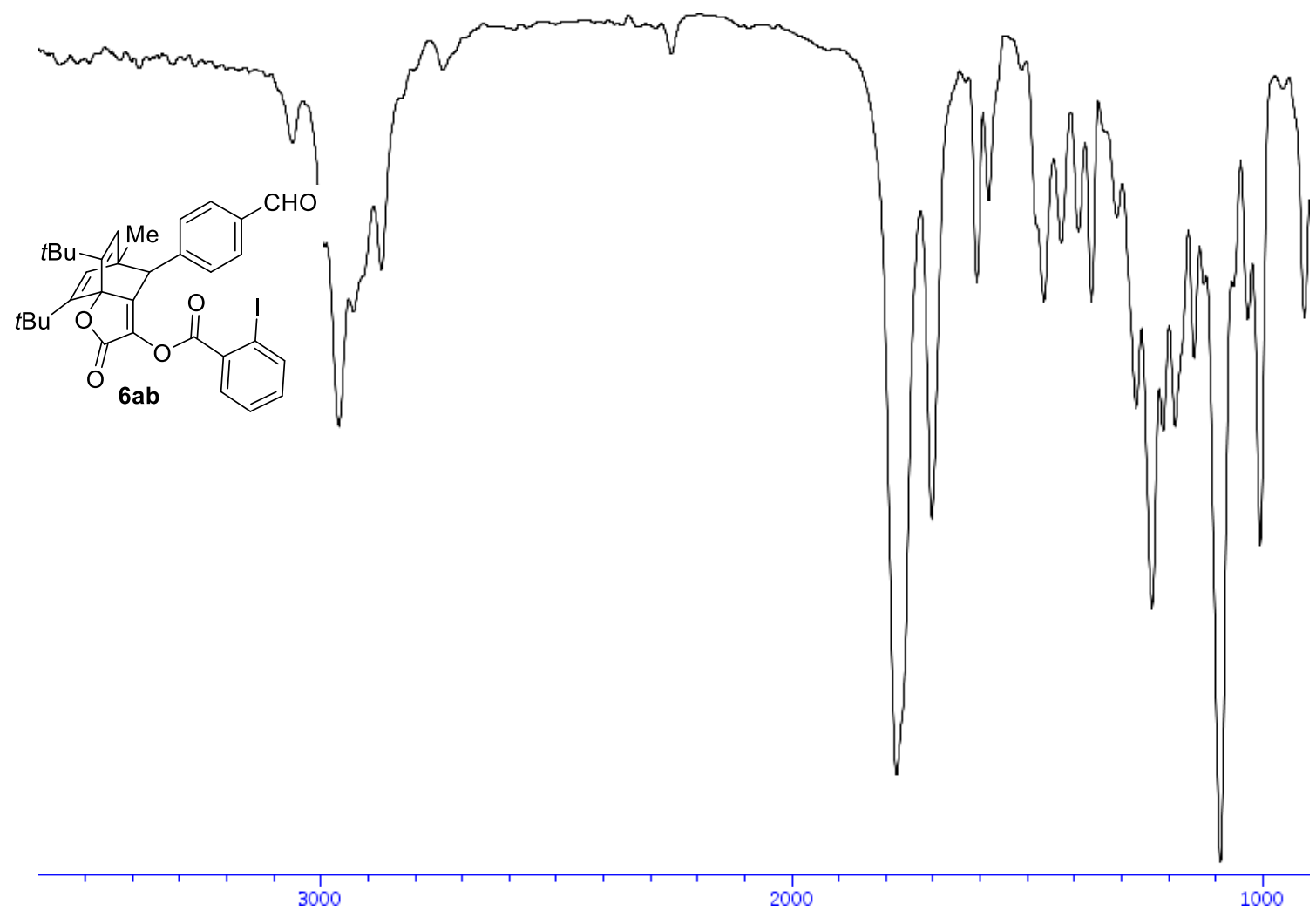


${ }^{1} \mathrm{H}-\mathrm{NMR}\left(400 \mathrm{MHz}, \mathrm{CDCl}_{3}\right.$ ) of compound 6 ac

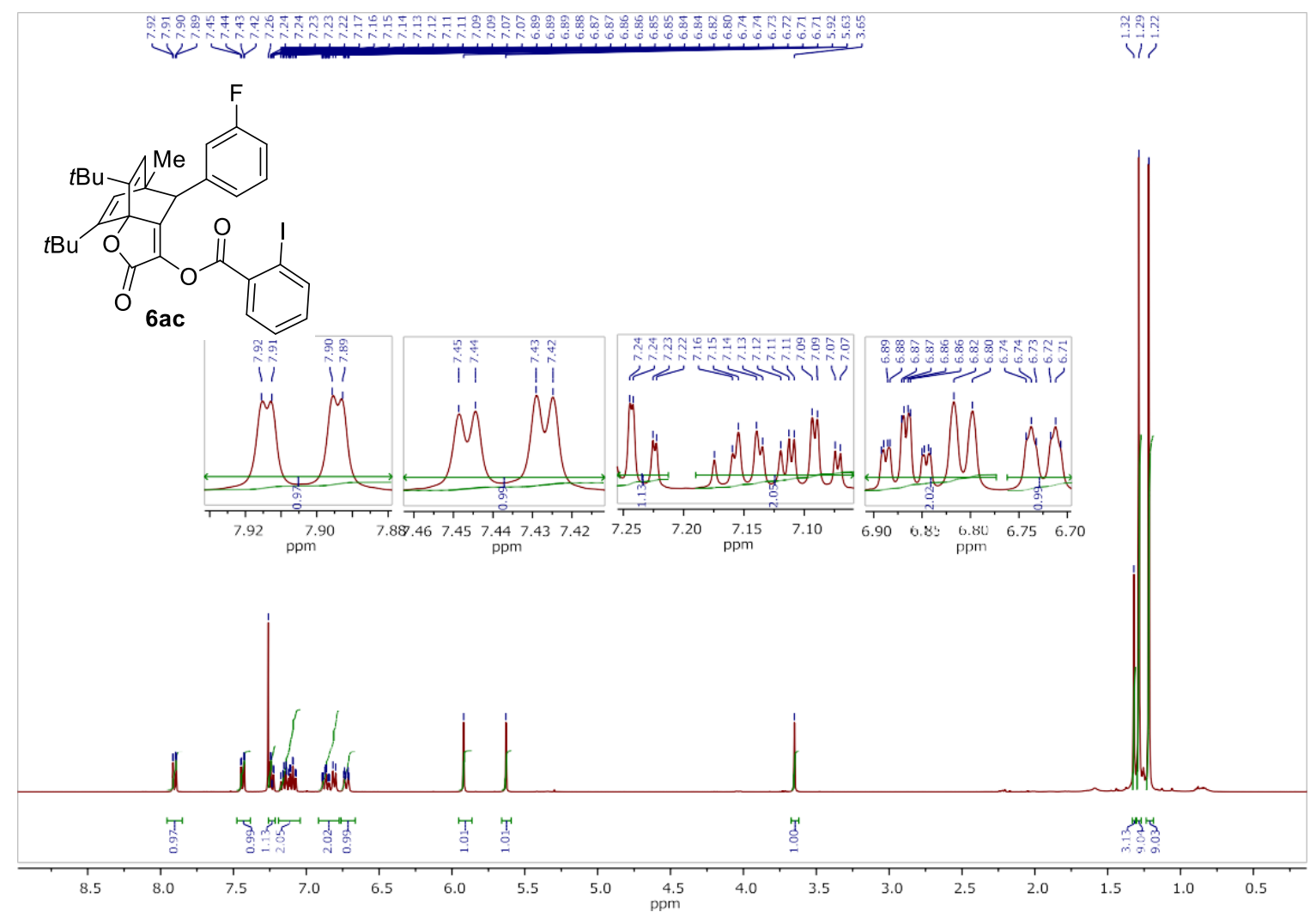

${ }^{13}$ C-NMR (100 MHz, $\mathrm{CDCl}_{3}$ ) of compound 6ac

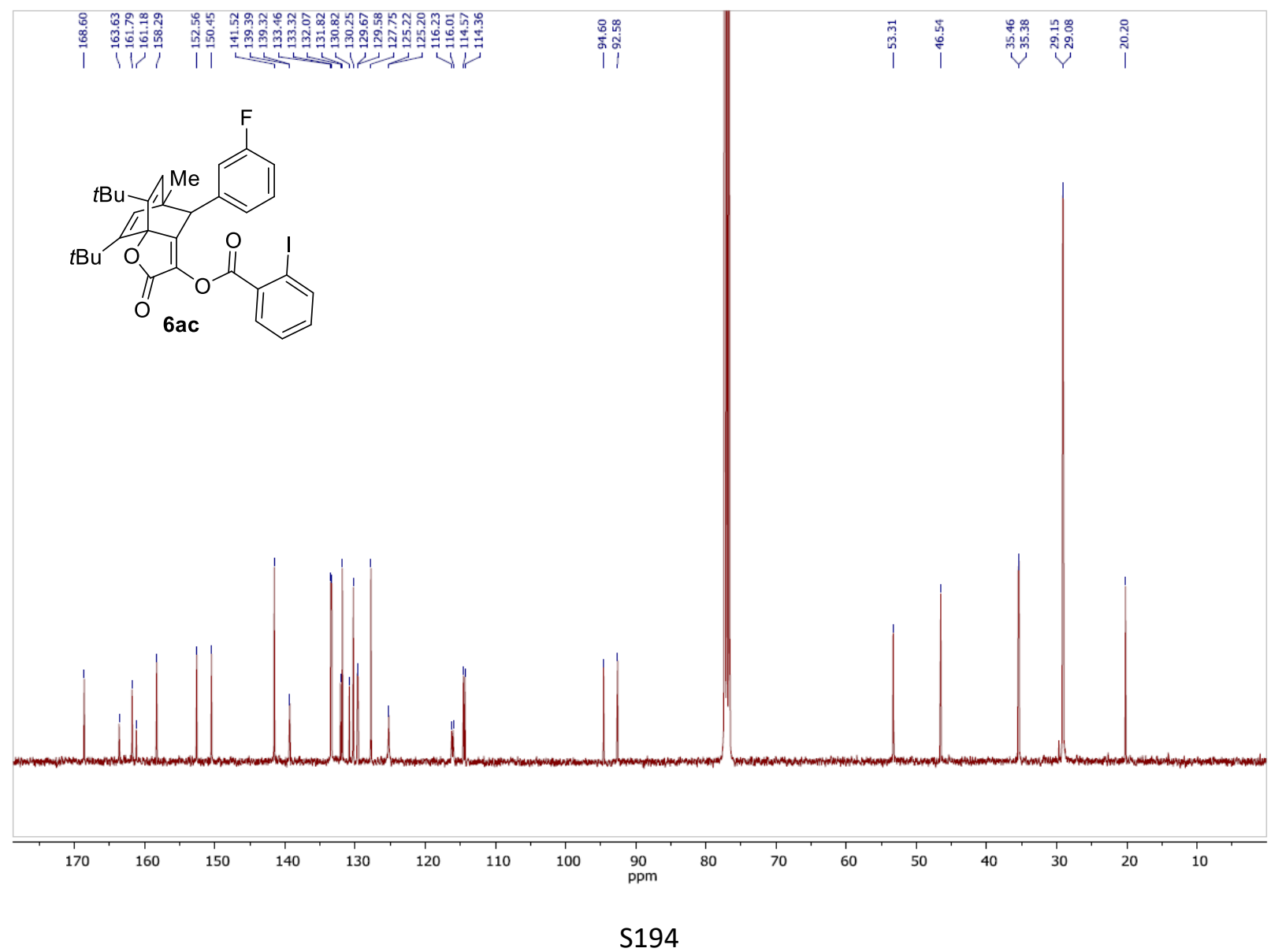


IR of compound $\mathbf{6 a c}$

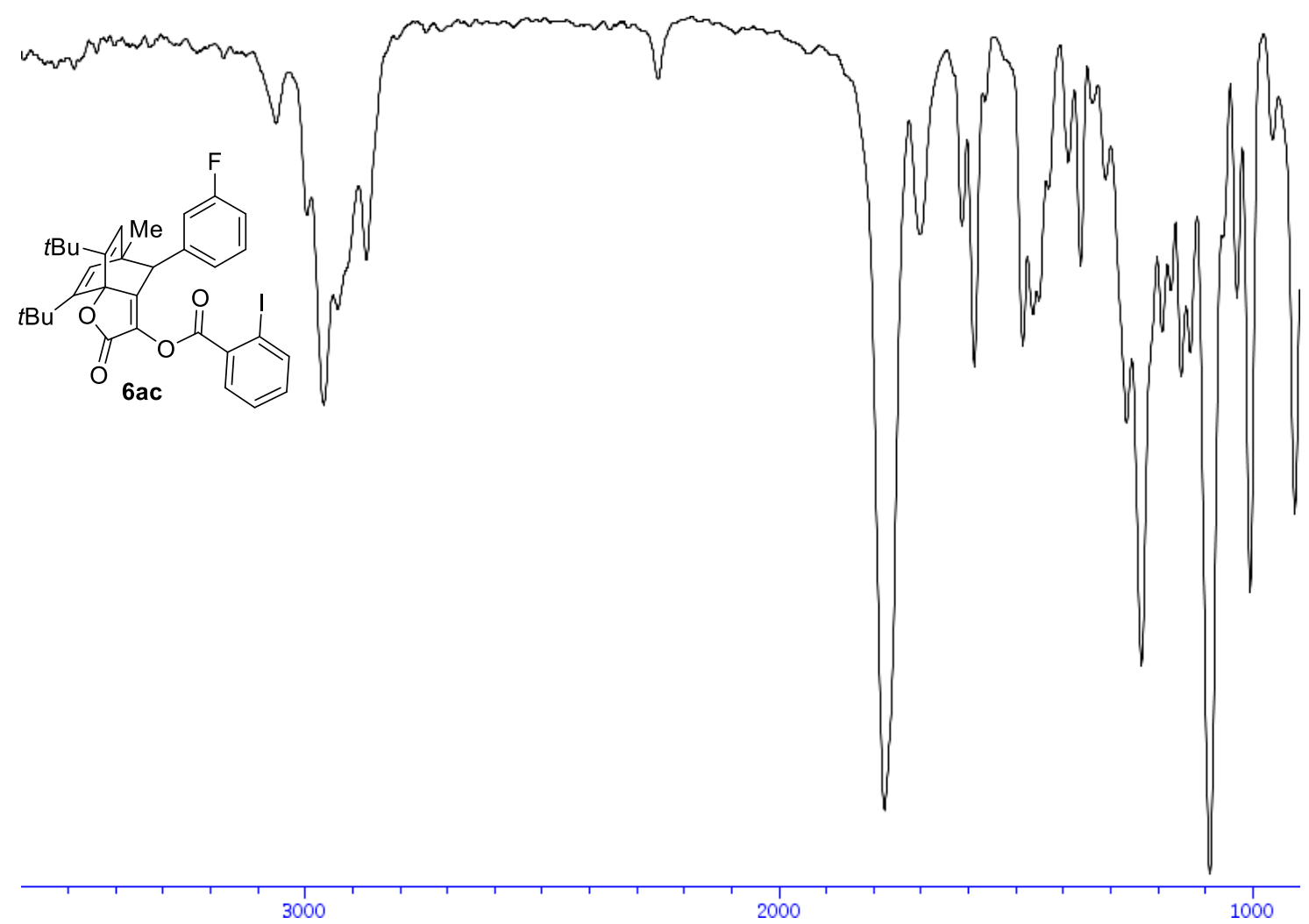


${ }^{1} \mathrm{H}-\mathrm{NMR}\left(400 \mathrm{MHz}, \mathrm{CDCl}_{3}\right.$ ) of compound $\mathbf{6 a d}$

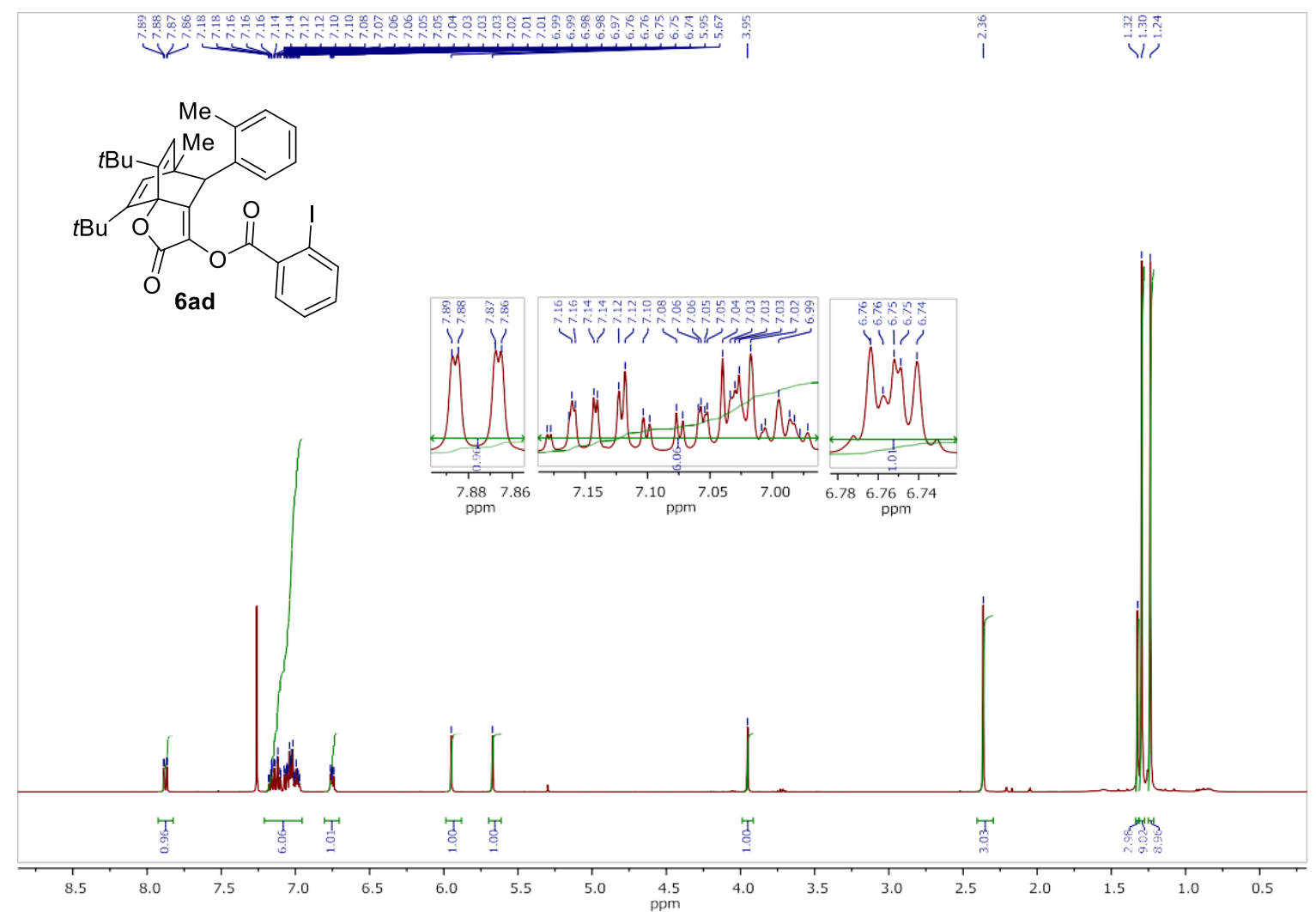

${ }^{13} \mathrm{C}-\mathrm{NMR}\left(100 \mathrm{MHz}, \mathrm{CDCl}_{3}\right.$ ) of compound $\mathbf{6 a d}$

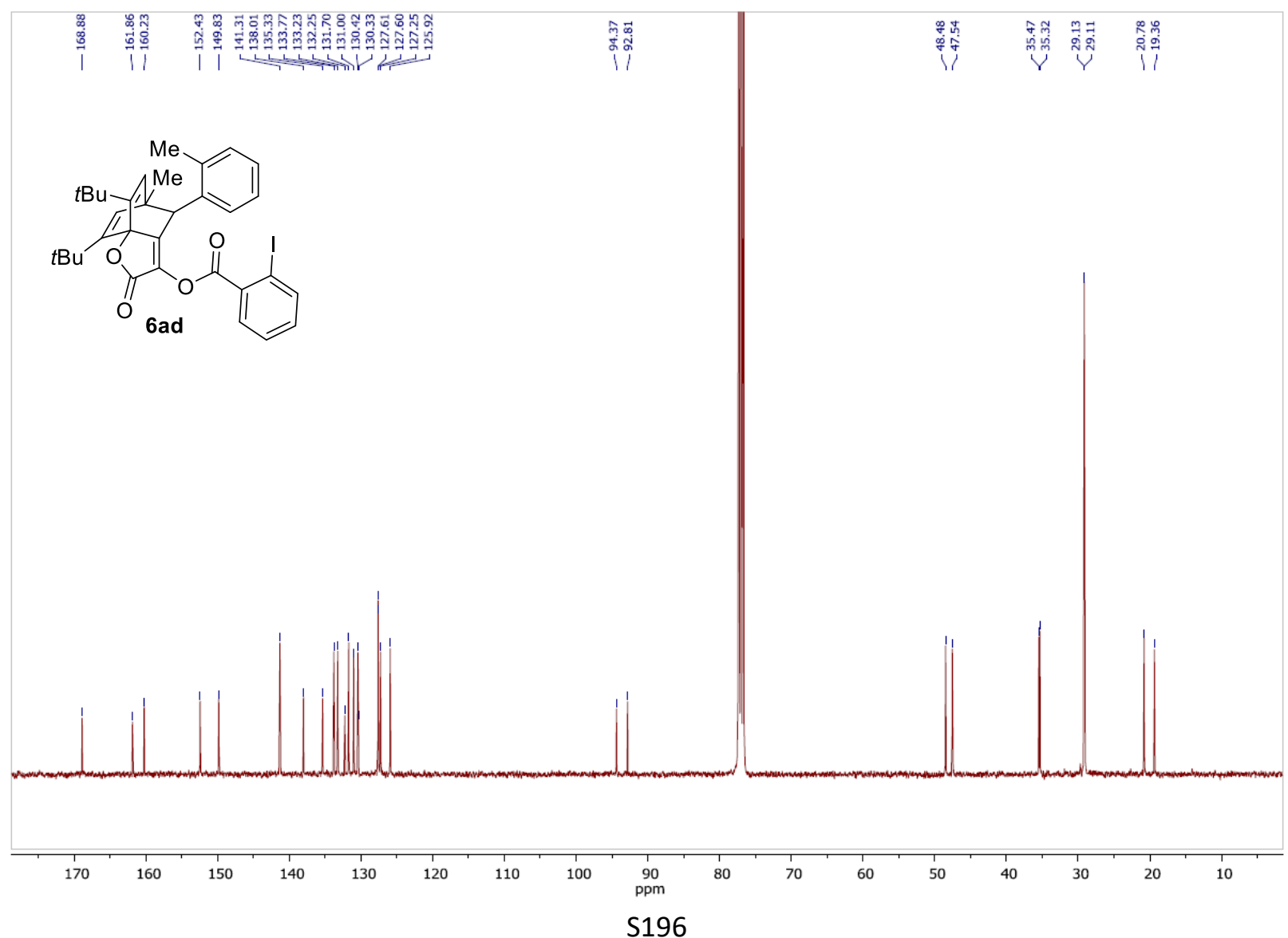


IR of compound $\mathbf{6 a d}$

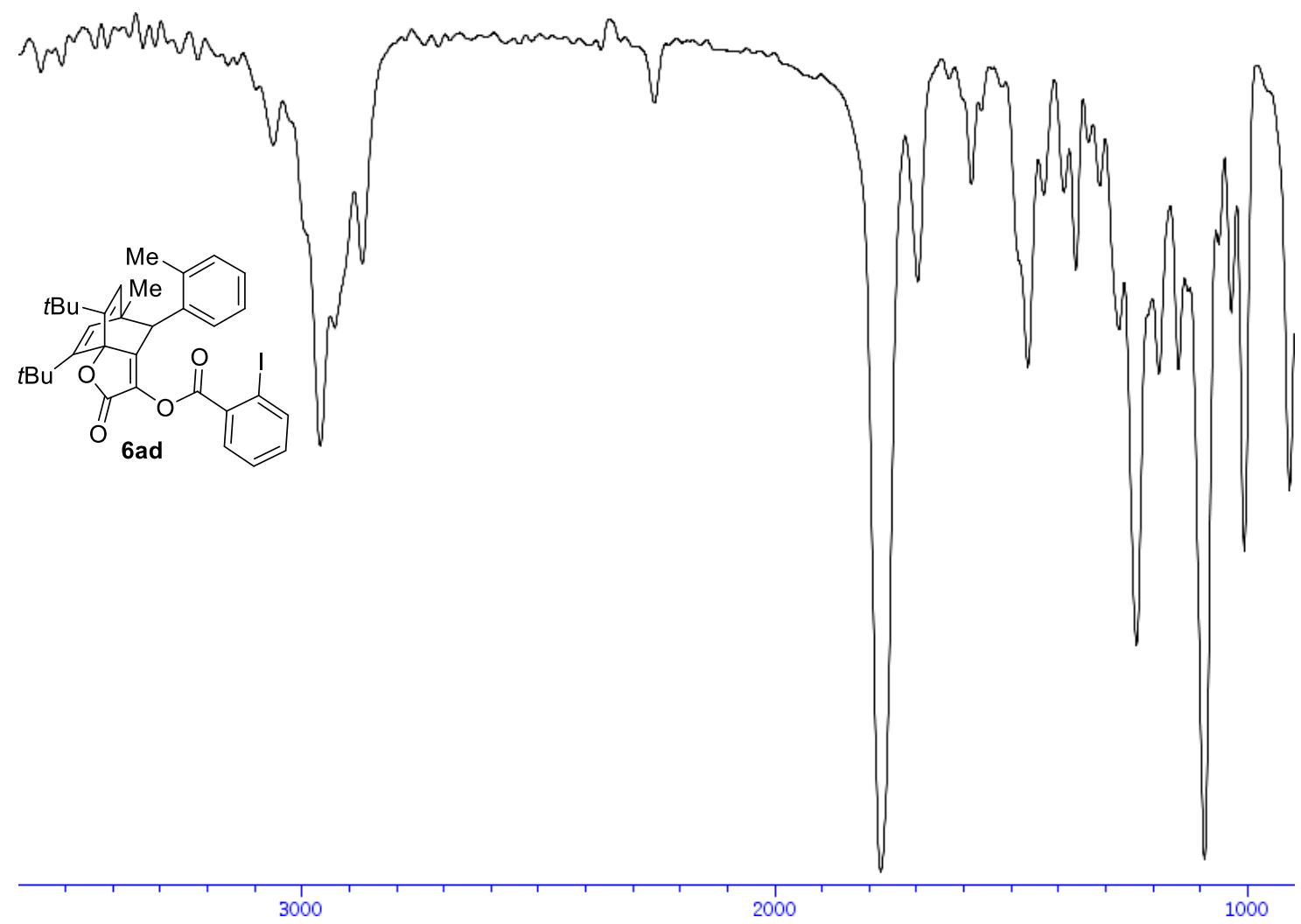


${ }^{1}$ H-NMR (400 MHz, $\mathrm{CDCl}_{3}$ ) of compound 6 ae

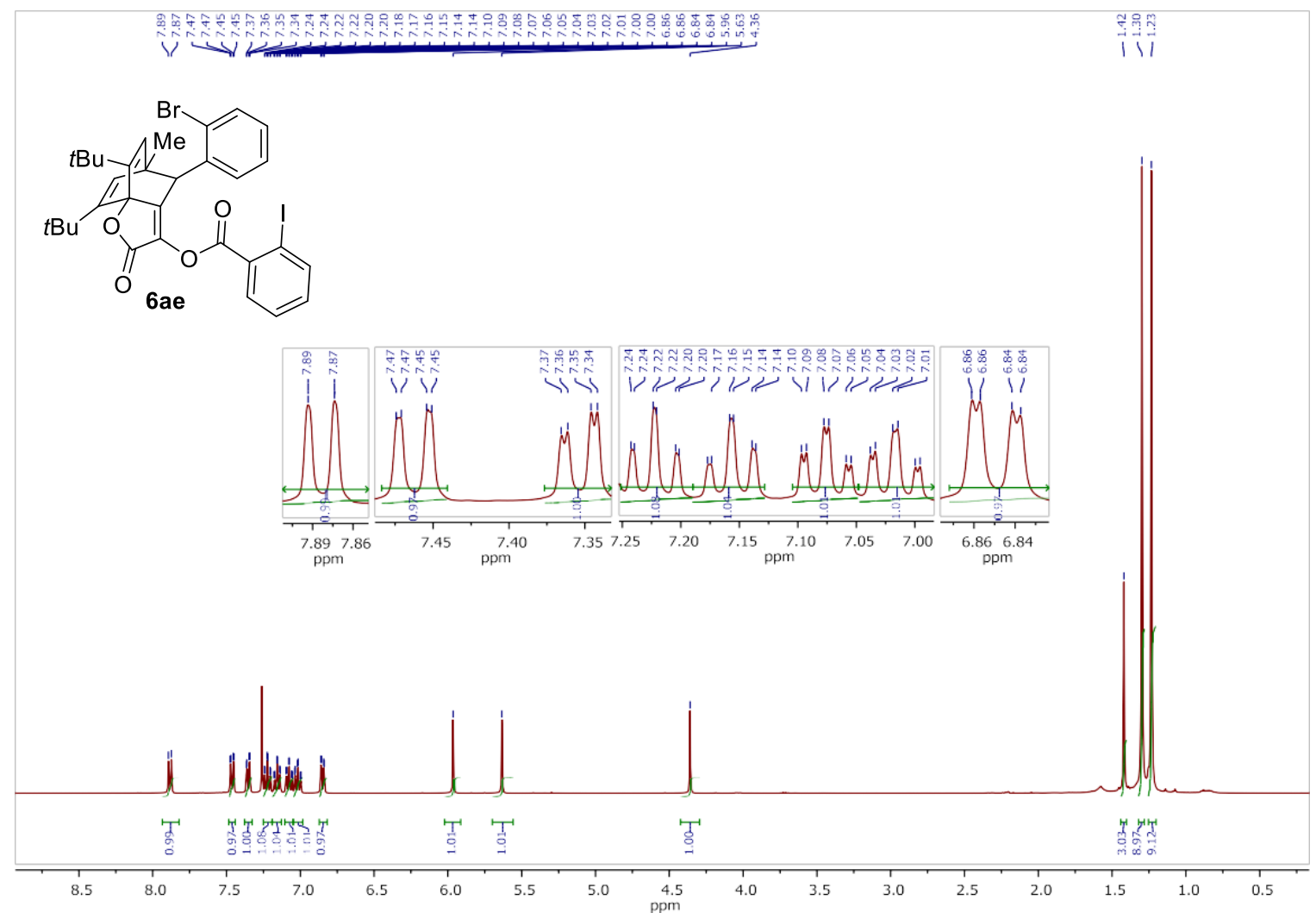

${ }^{13} \mathrm{C}$-NMR (100 MHz, $\mathrm{CDCl}_{3}$ ) of of compound 6ae

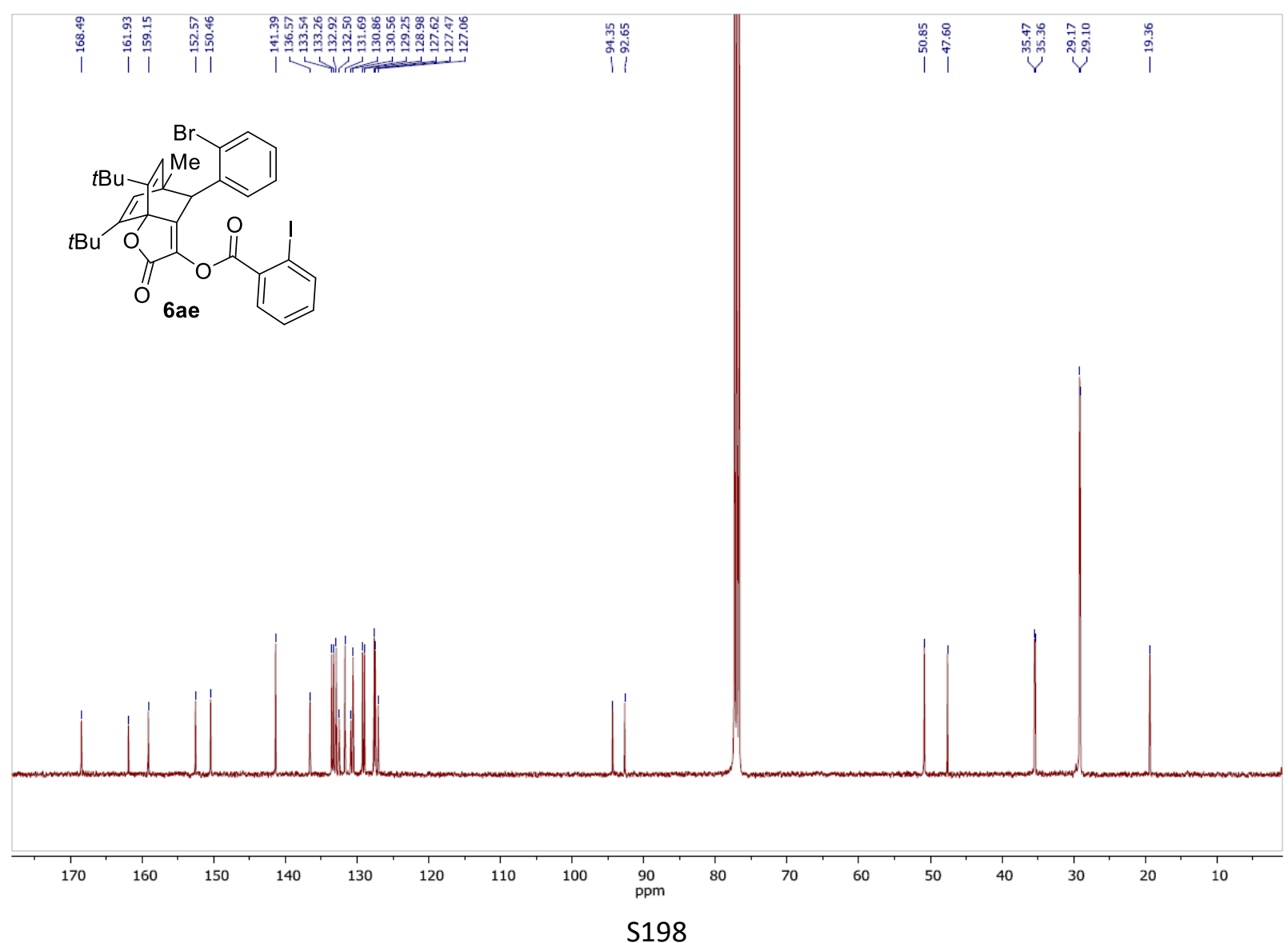


IR of compound 6 ae

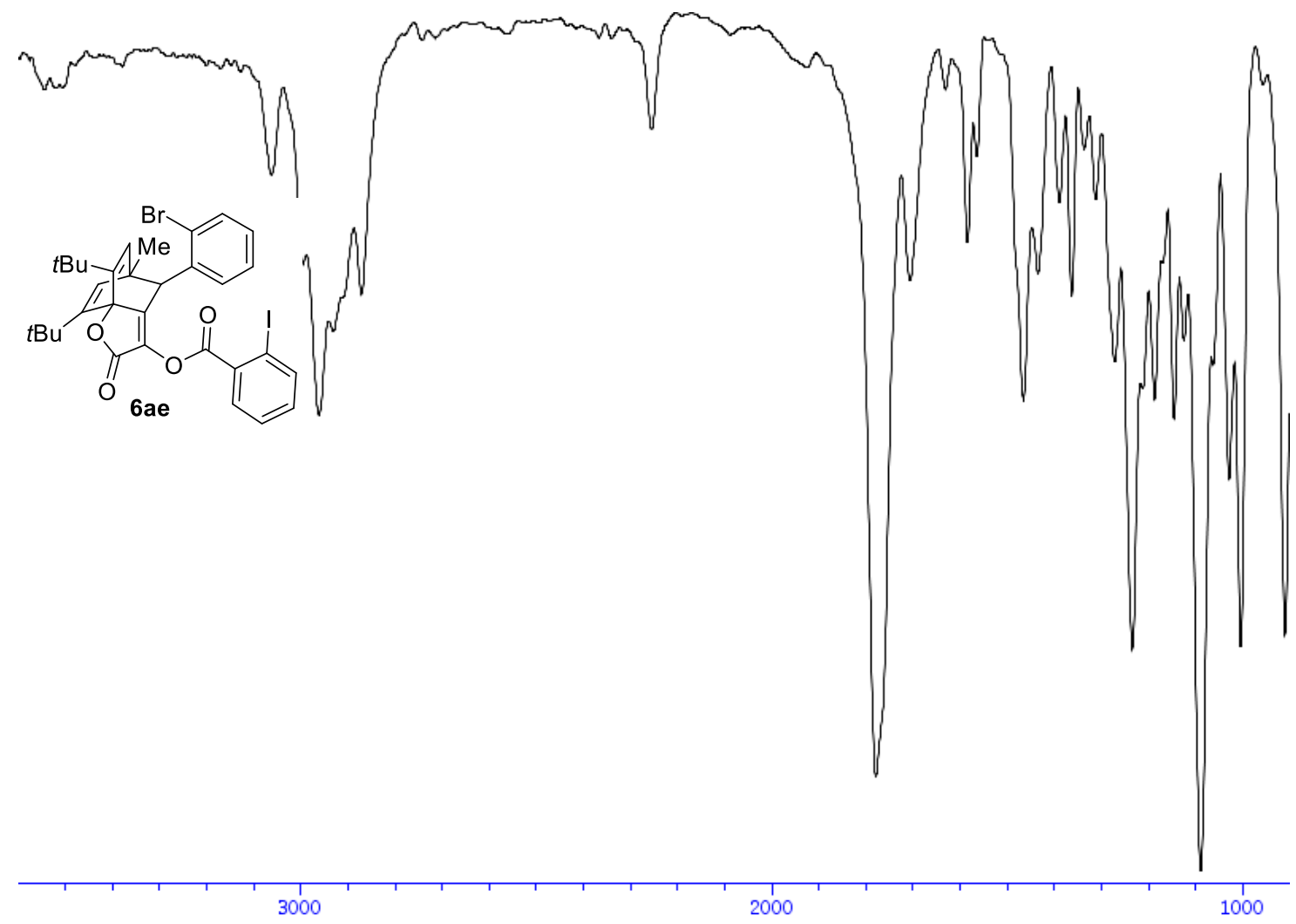


${ }^{1} \mathrm{H}-\mathrm{NMR}$ (400 MHz, $\mathrm{CDCl}_{3}$ ) of compound 6 af

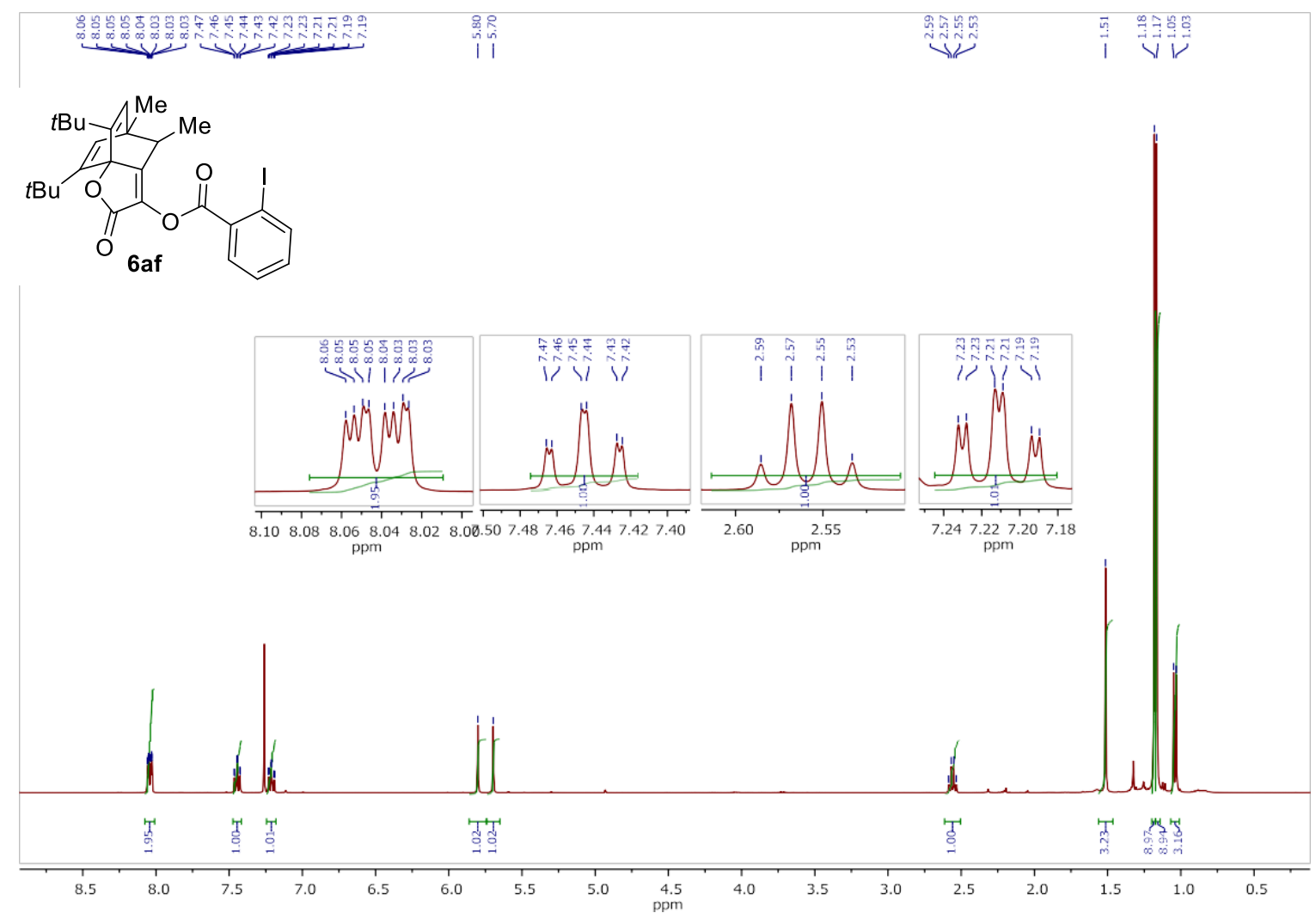

${ }^{13} \mathrm{C}-\mathrm{NMR}\left(100 \mathrm{MHz}, \mathrm{CDCl}_{3}\right)$ of of compound 6 af

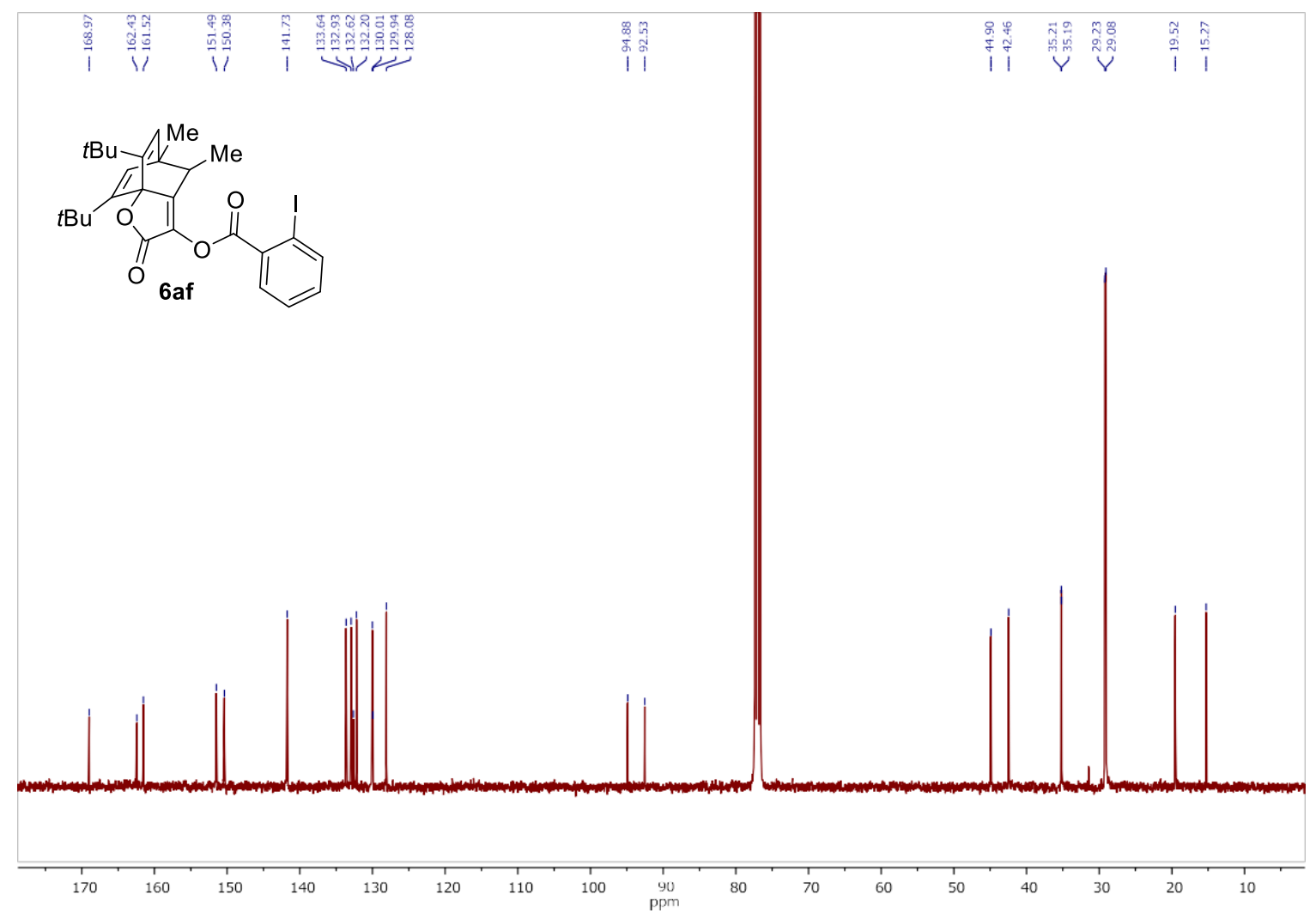




\section{IR of compound 6af}

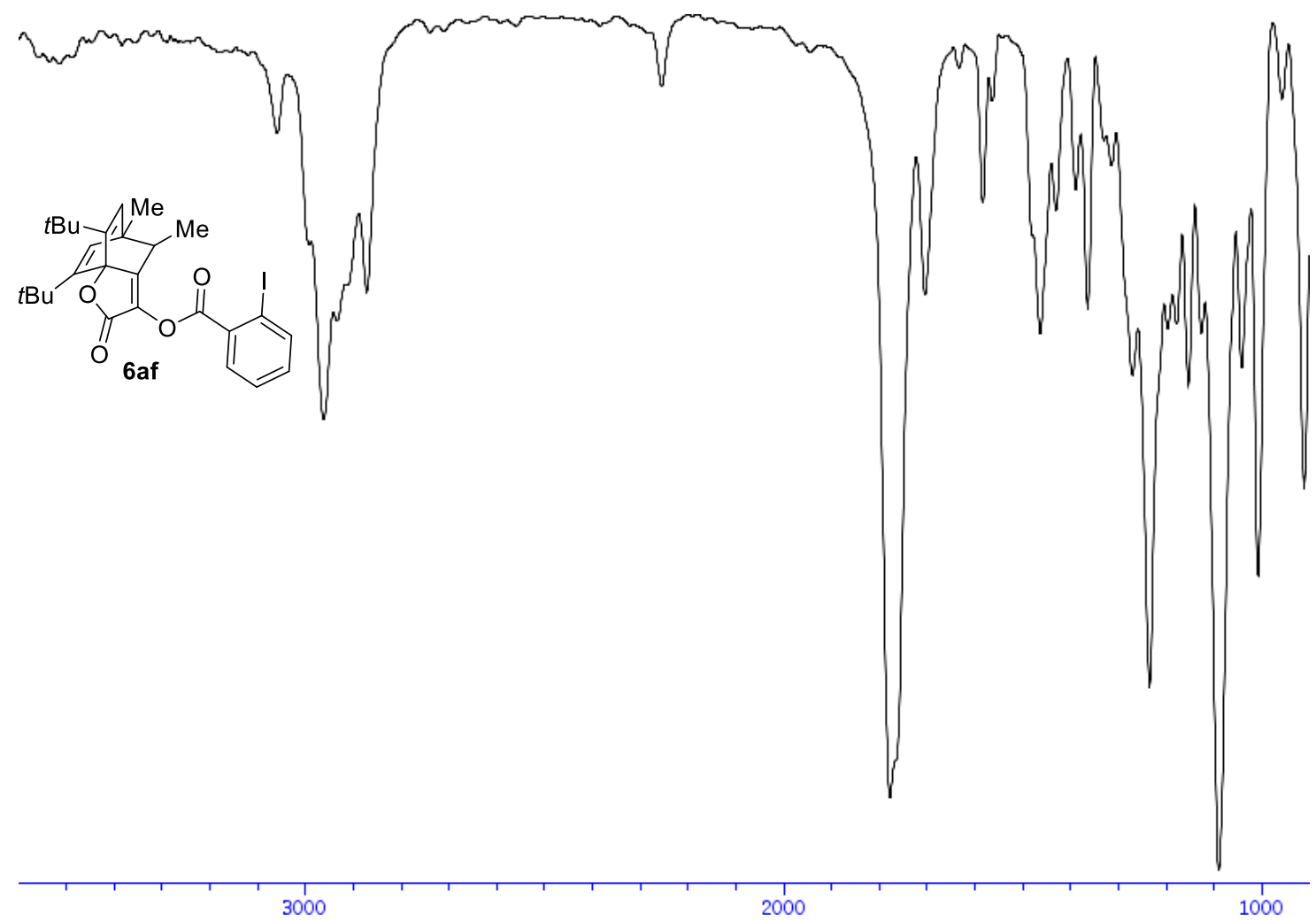


${ }^{1}$ H-NMR (400 MHz, $\mathrm{CDCl}_{3}$ ) of compound 6 ag

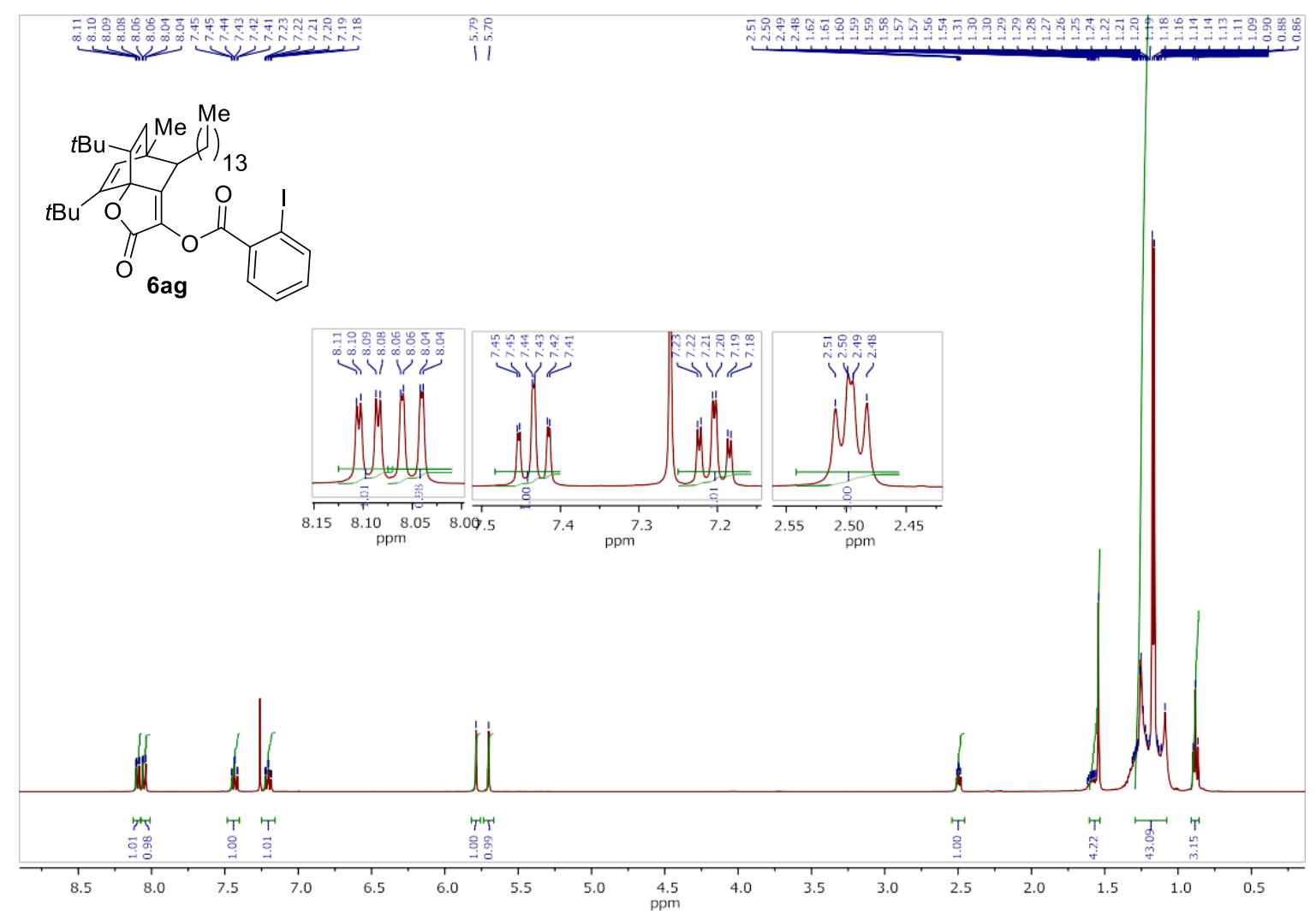

${ }^{13} \mathrm{C}-\mathrm{NMR}\left(100 \mathrm{MHz}, \mathrm{CDCl}_{3}\right)$ of compound $6 \mathrm{ag}$

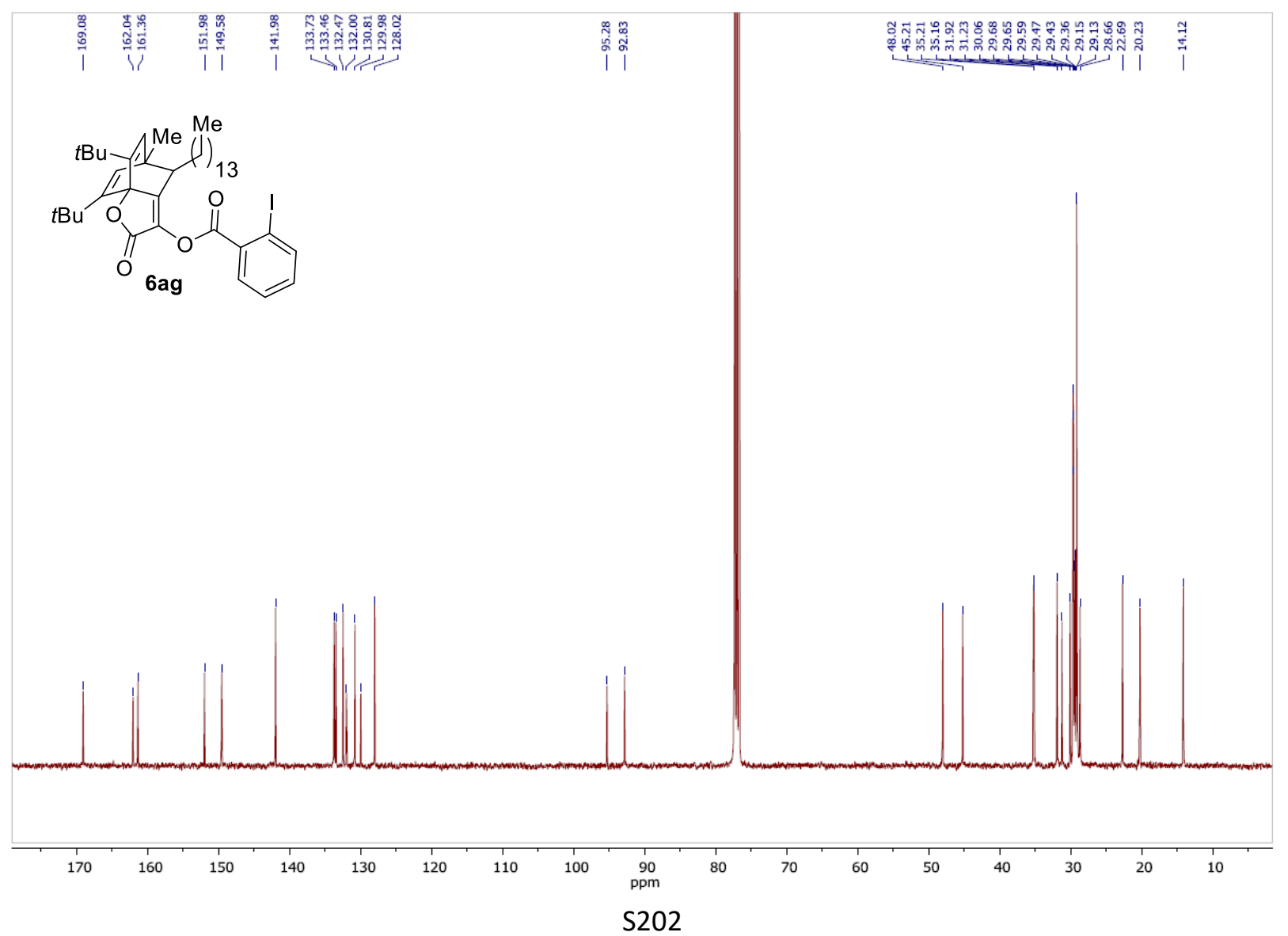


IR of compound $\mathbf{6 a g}$

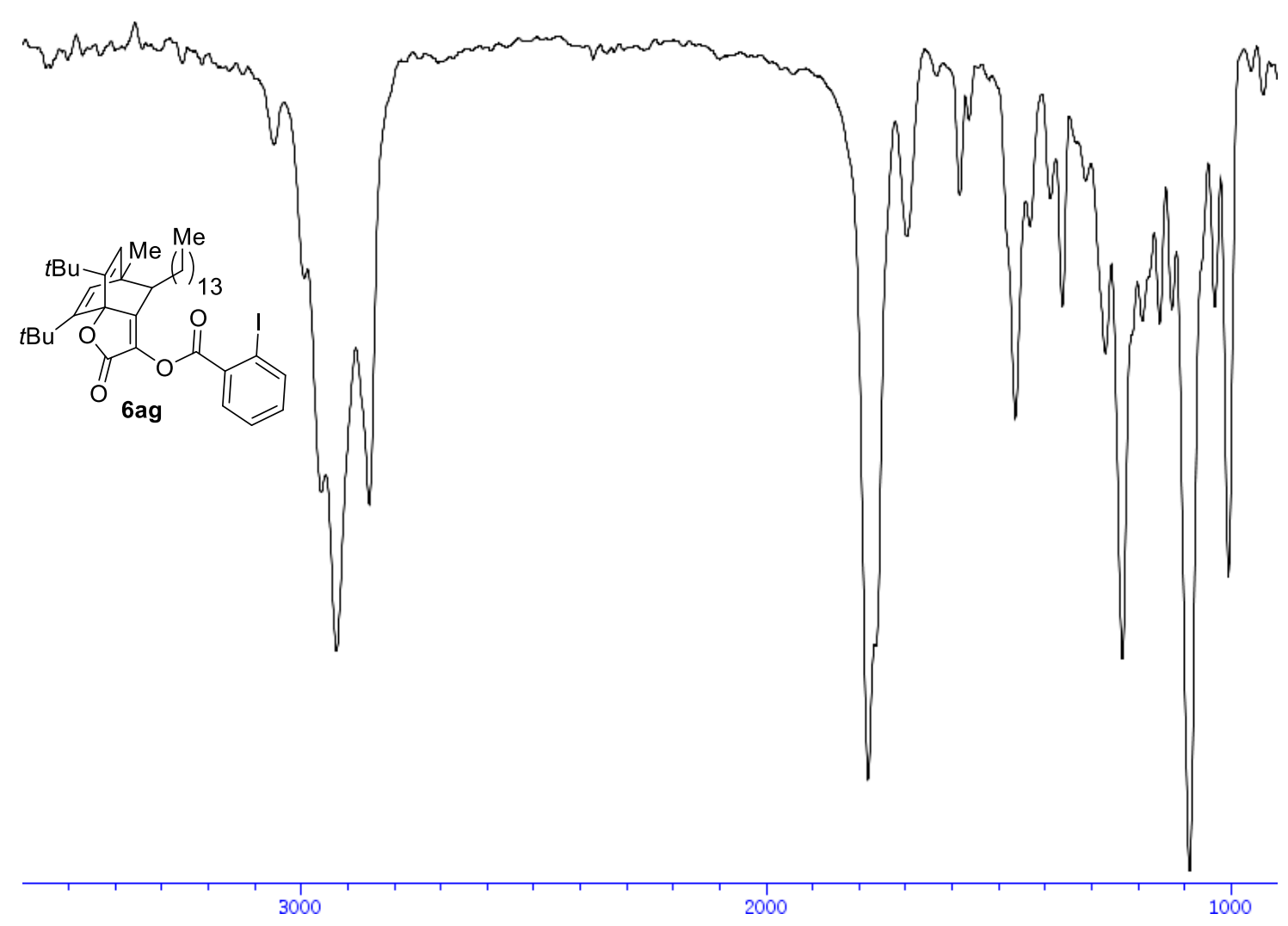


${ }^{1} \mathrm{H}-\mathrm{NMR}$ (400 MHz, $\mathrm{CDCl}_{3}$ ) of compound 6 ah

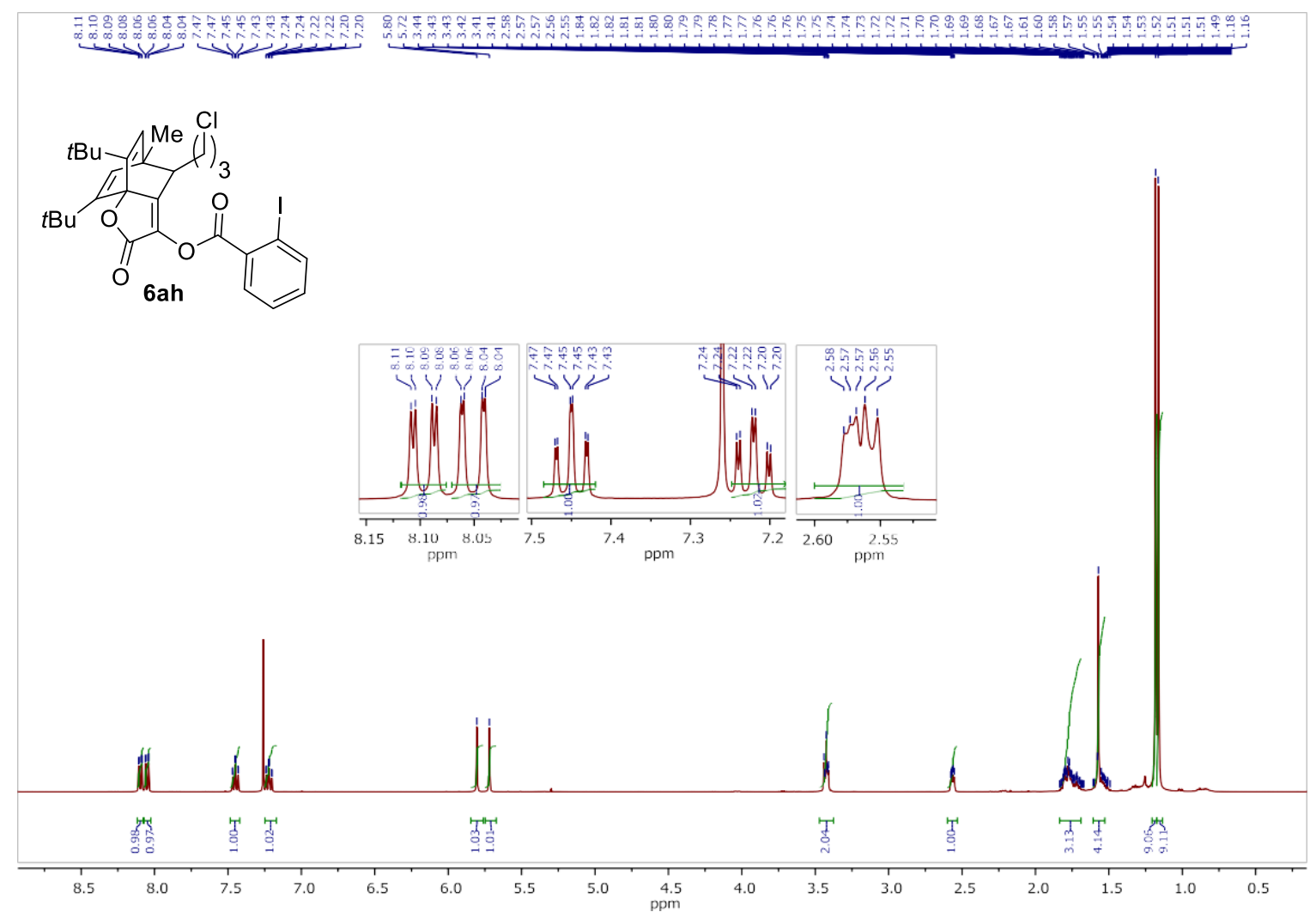

${ }^{13} \mathrm{C}-\mathrm{NMR}\left(100 \mathrm{MHz}, \mathrm{CDCl}_{3}\right)$ of compound $6 \mathrm{ah}$

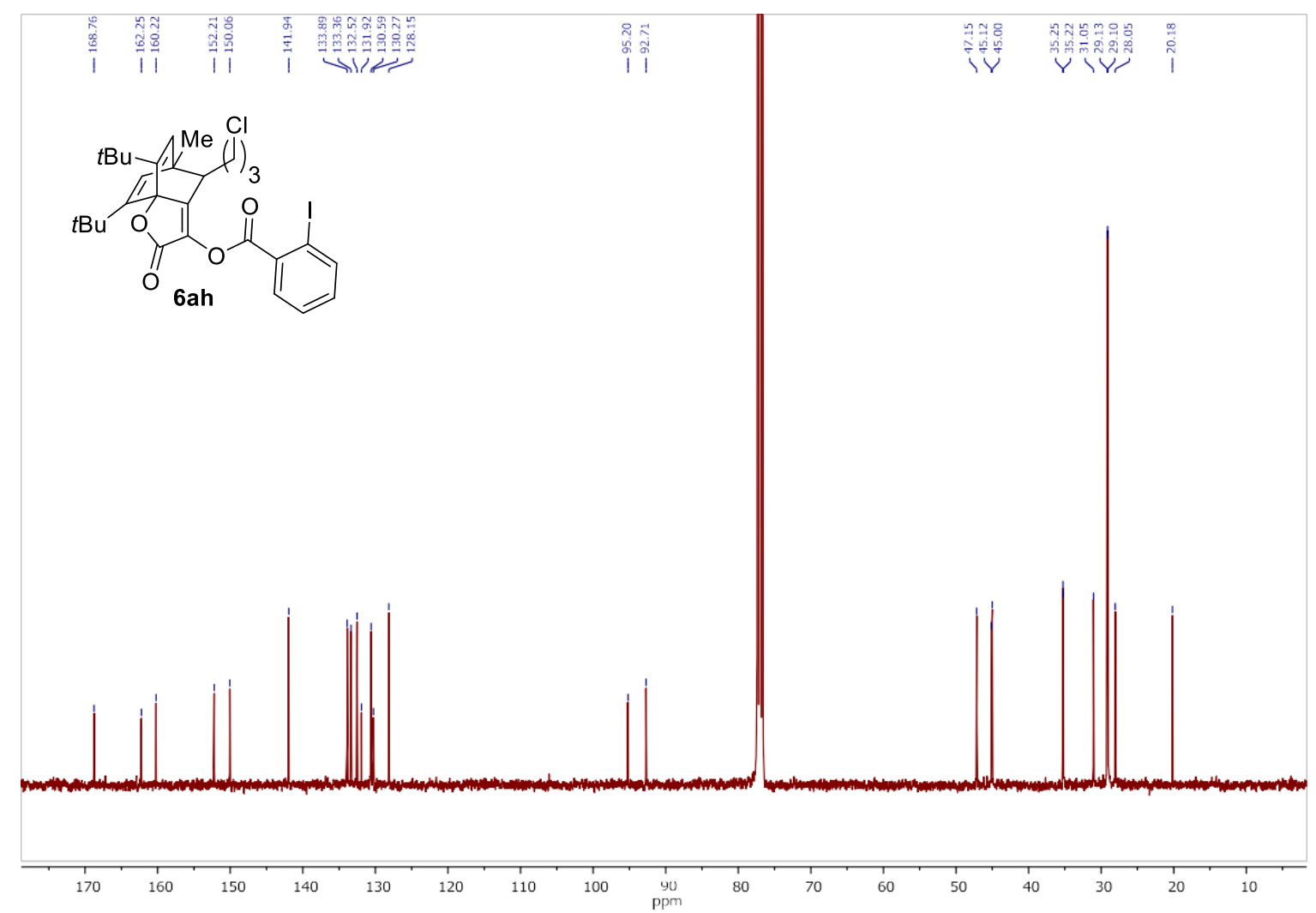


IR of compound $\mathbf{6 a h}$

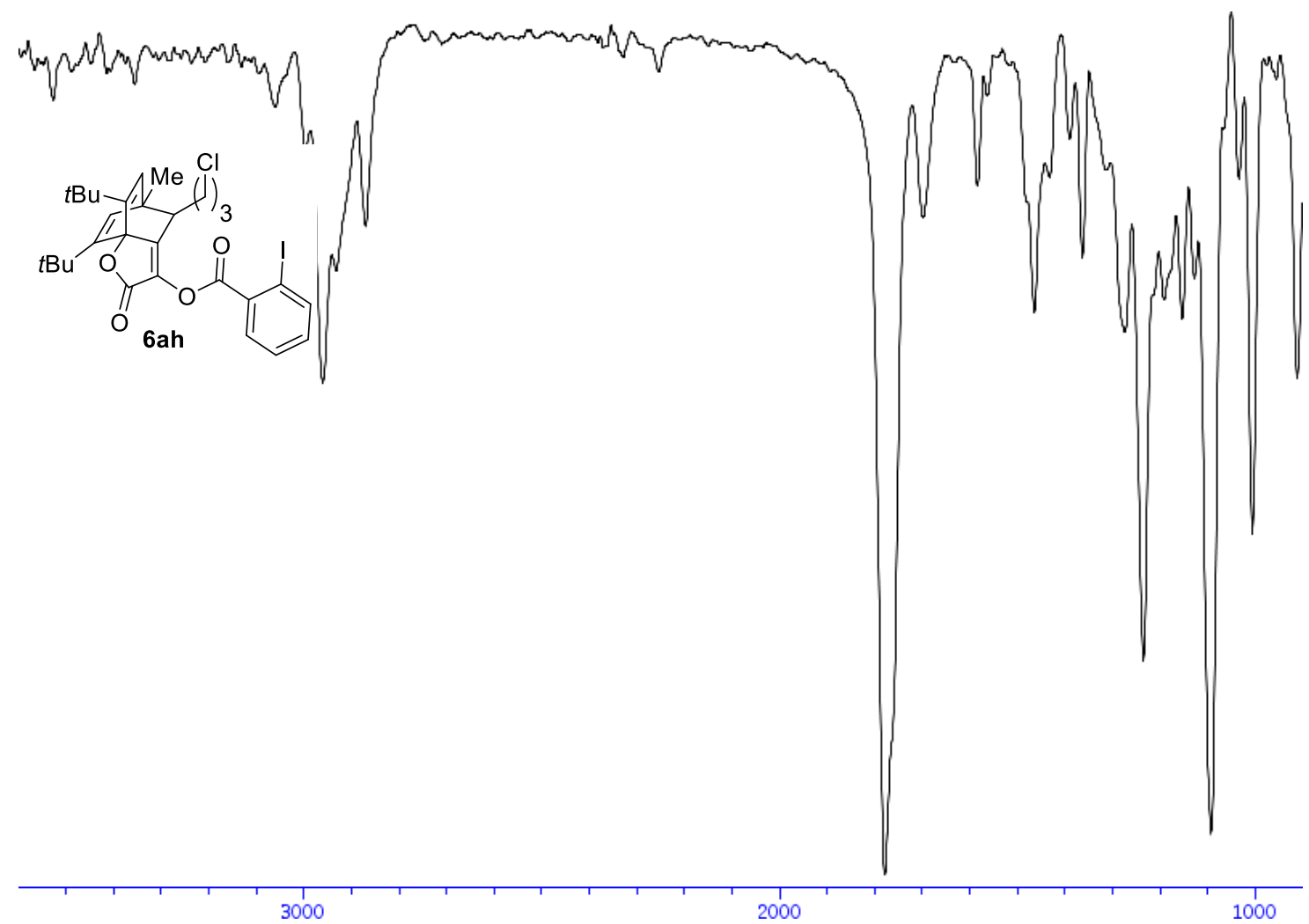


${ }^{1} \mathbf{H}-\mathbf{N M R}\left(400 \mathrm{MHz}, \mathrm{CDCl}_{3}\right.$ ) of compound 6ai

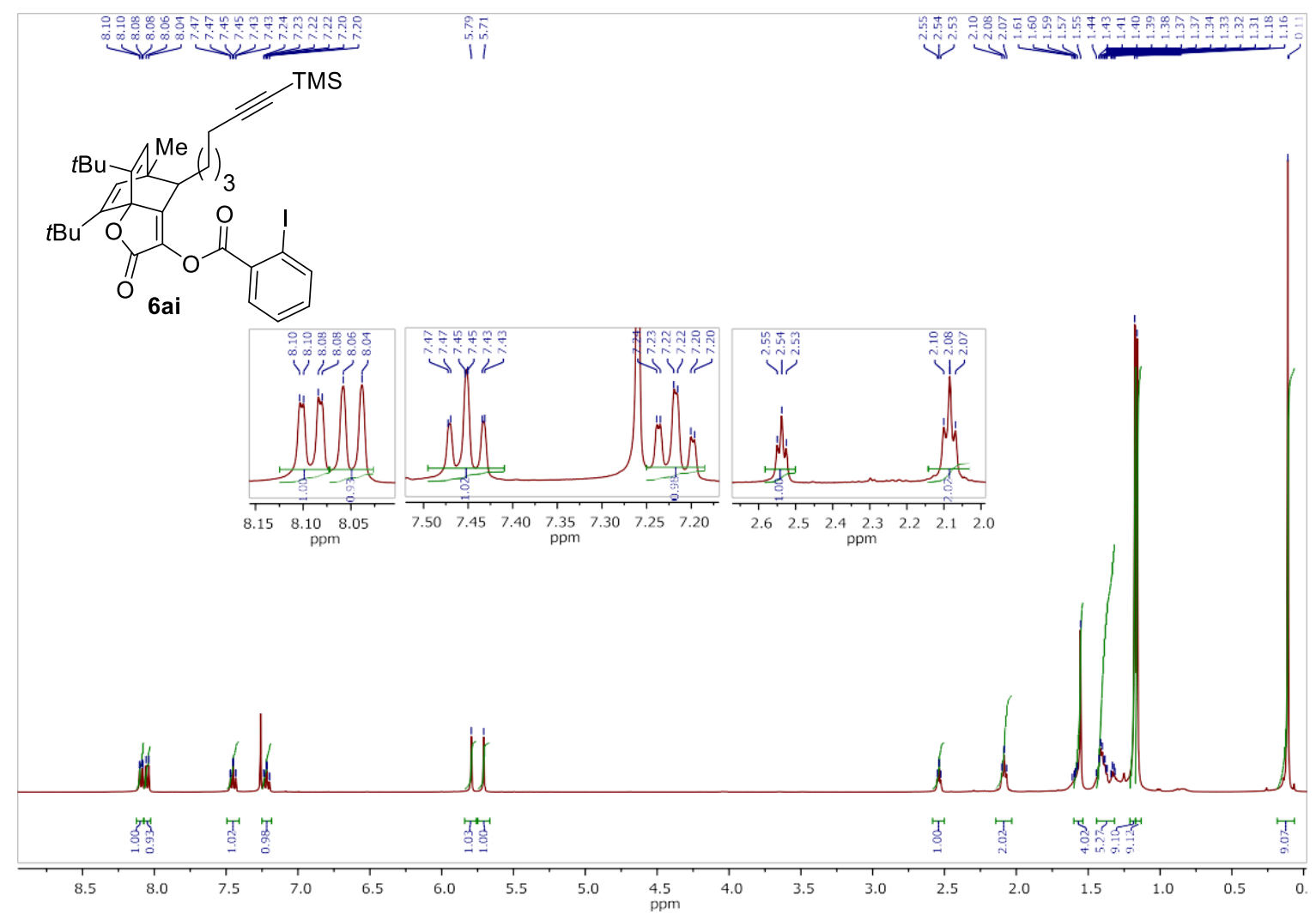

${ }^{13}$ C-NMR (100 MHz, $\mathrm{CDCl}_{3}$ ) of compound 6ai

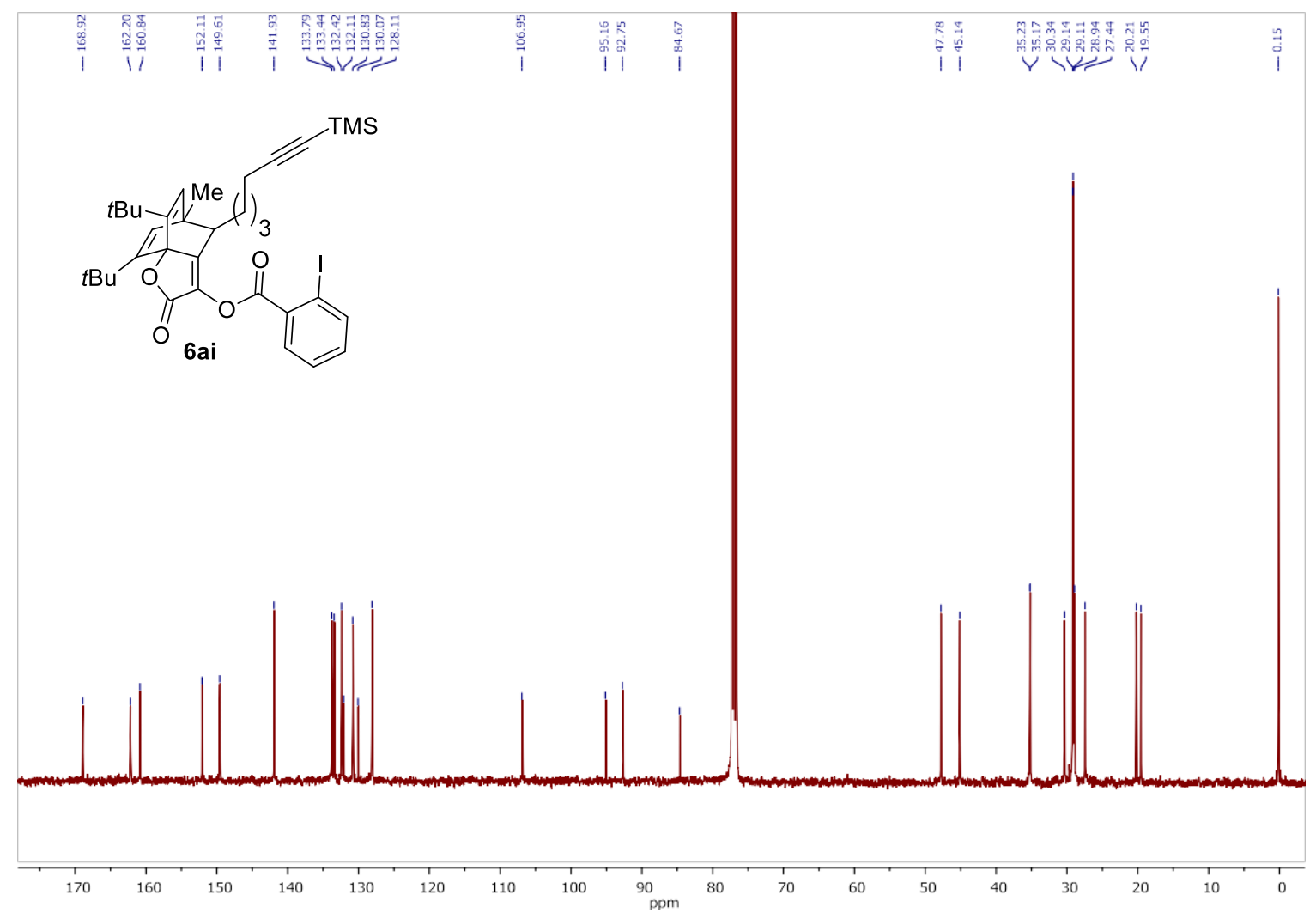


IR of compound 6ai

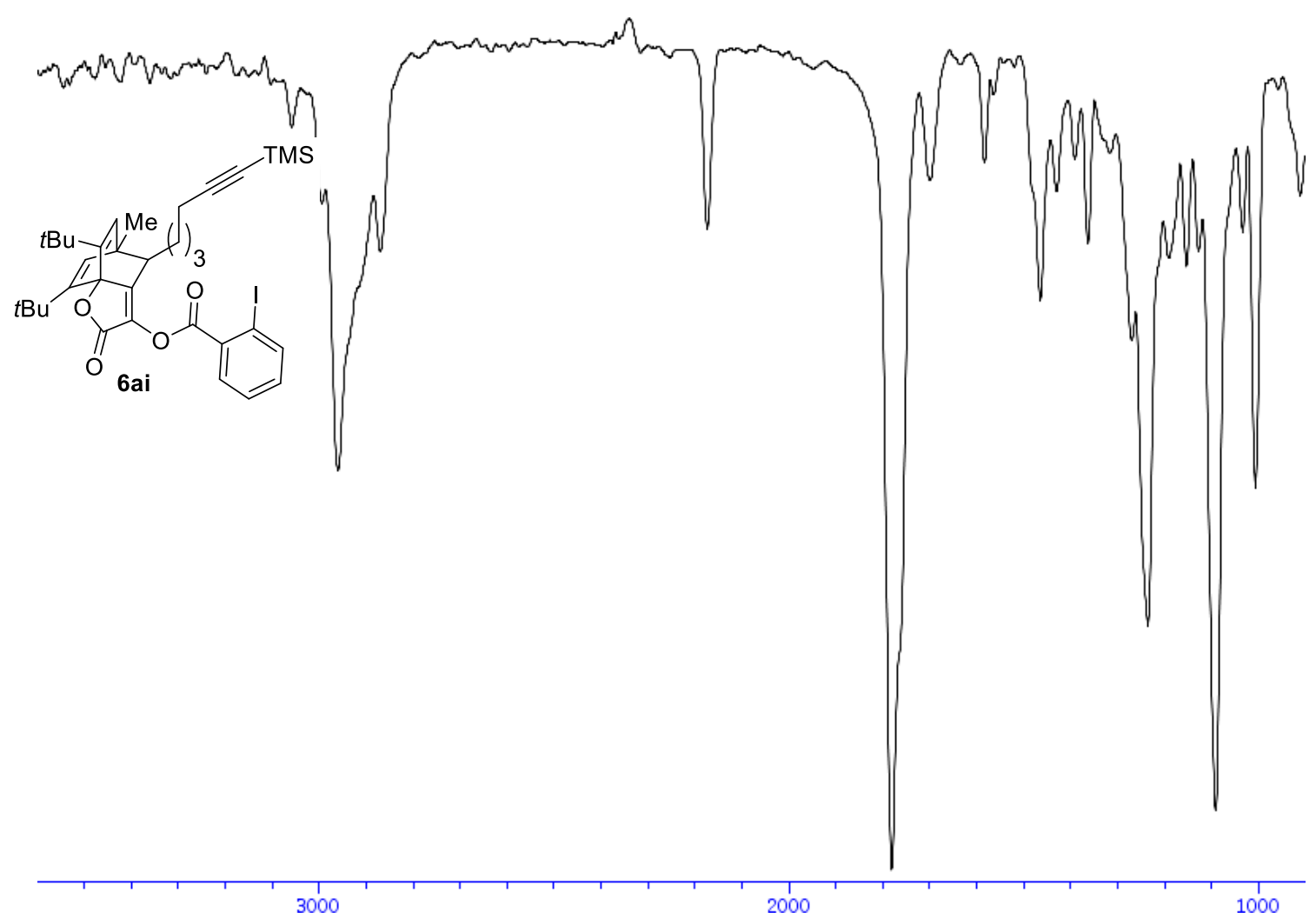


${ }^{1} \mathrm{H}-\mathrm{NMR}\left(400 \mathrm{MHz}, \mathrm{CDCl}_{3}\right)$ of compound 6aj

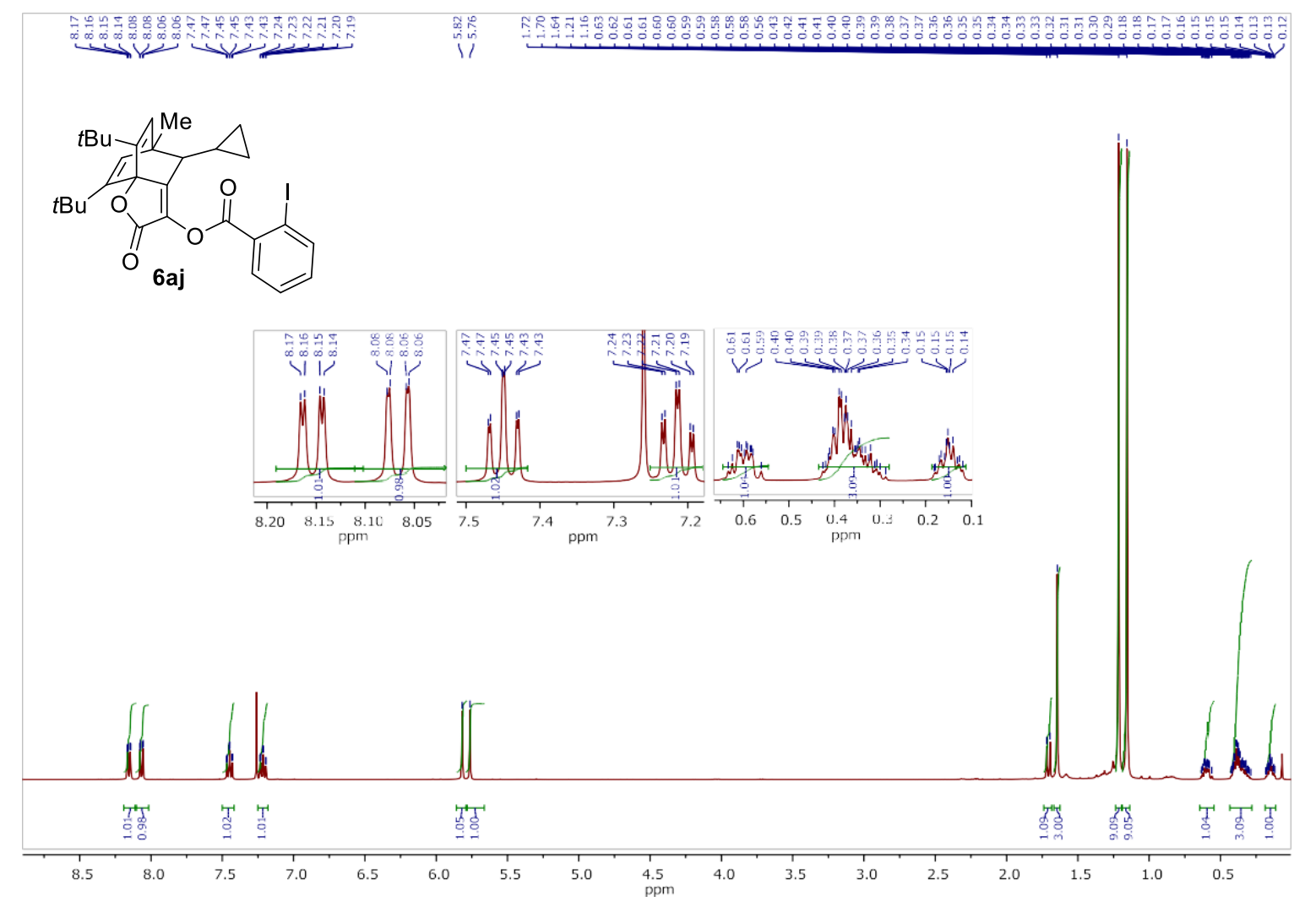

${ }^{13}$ C-NMR (100 MHz, $\mathrm{CDCl}_{3}$ ) of compound 6aj

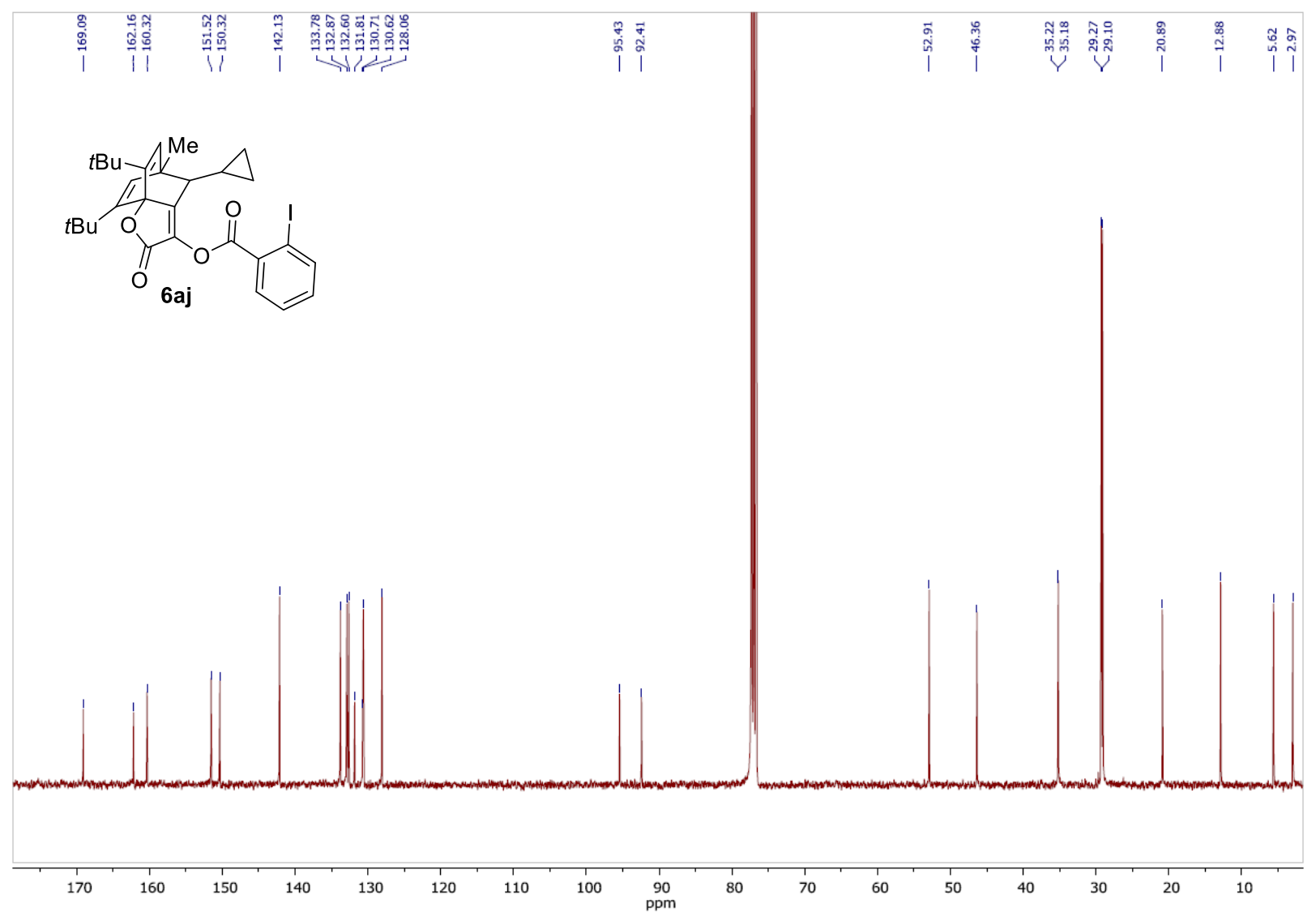

S208 
IR of compound $\mathbf{6 a j}$

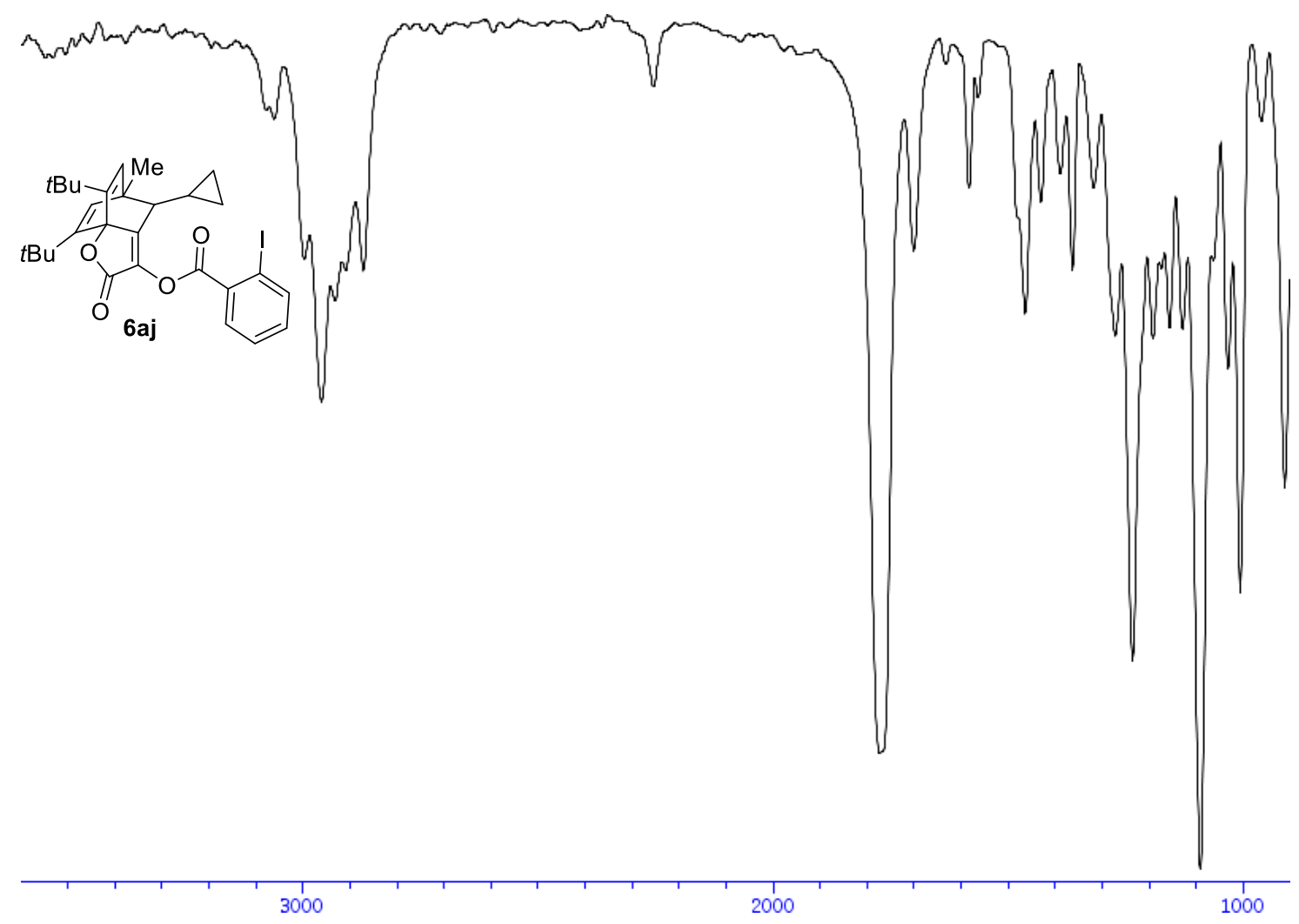


${ }^{1} \mathbf{H}-\mathbf{N M R}\left(400 \mathrm{MHz}, \mathrm{CDCl}_{3}\right.$ ) of compound 6ak

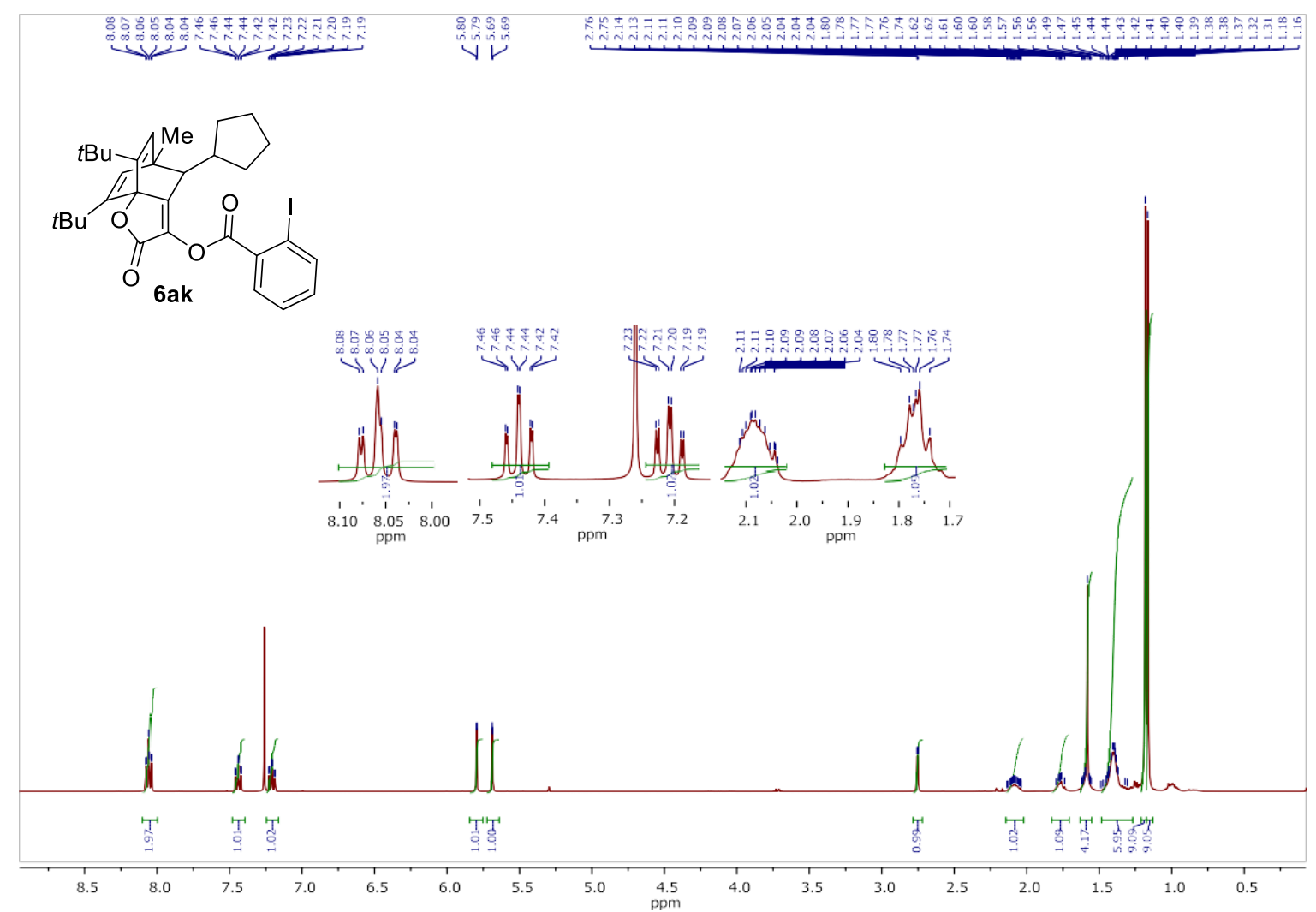

${ }^{13} \mathrm{C}-\mathrm{NMR}\left(100 \mathrm{MHz}, \mathrm{CDCl}_{3}\right)$ of compound 6ak

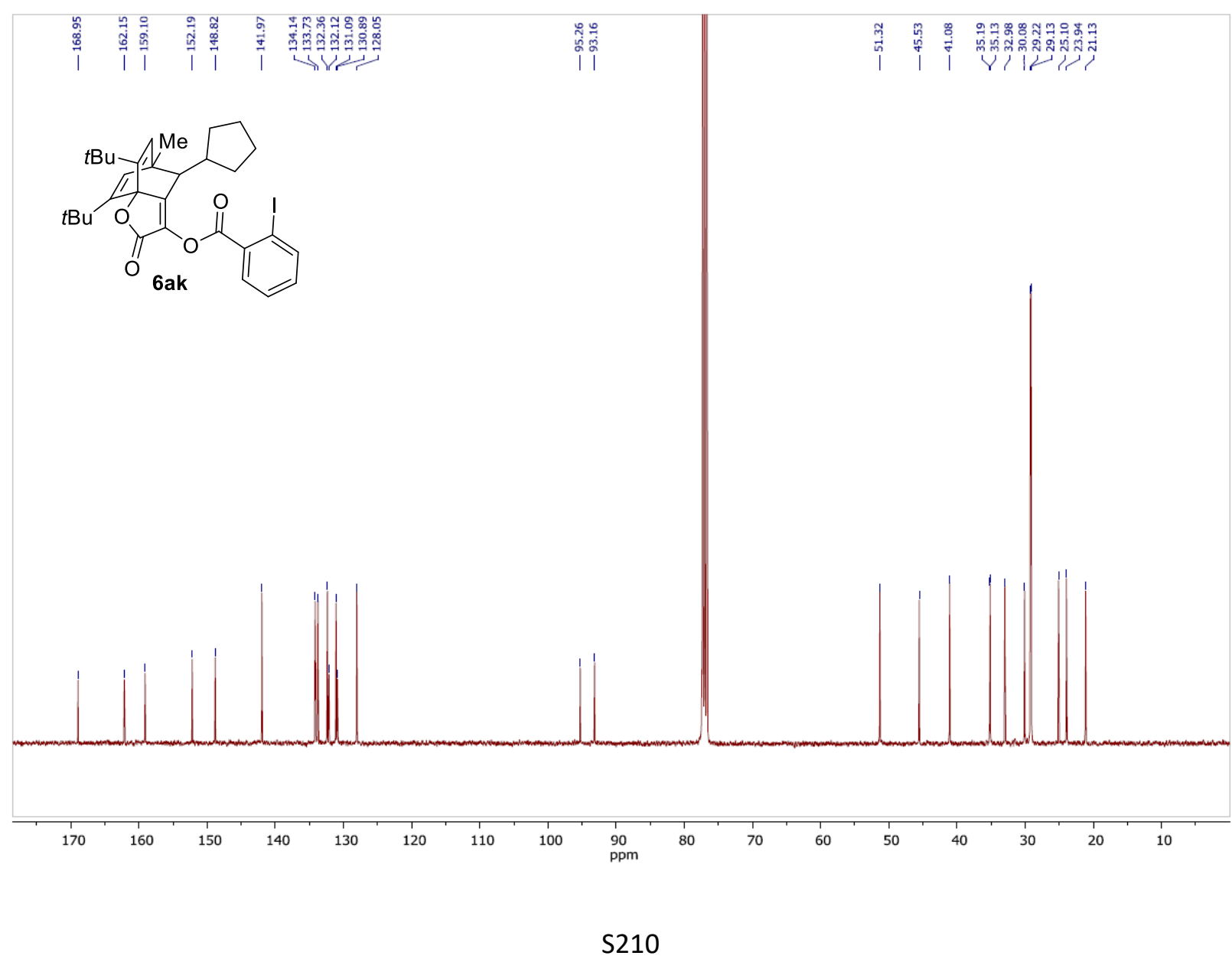


IR of compound 6ak

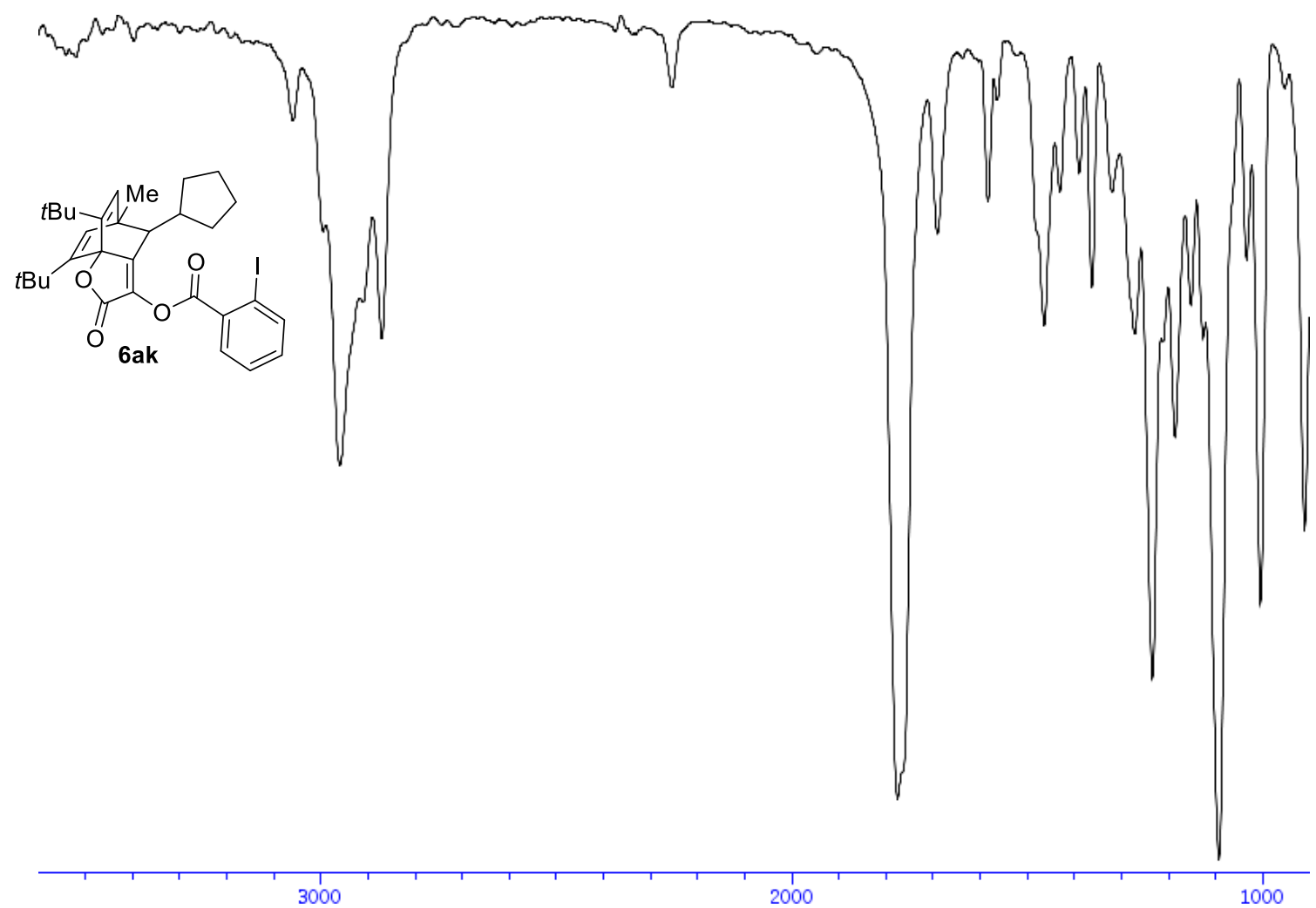


${ }^{1} \mathbf{H}-\mathrm{NMR}\left(400 \mathrm{MHz}, \mathrm{CDCl}_{3}\right.$ ) of compound 6 al

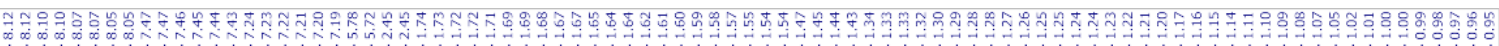
ind<smiles>CC(C)(C)C1OC(=O)C2C(C3CCCCC3)C1C(C(=O)OC(=O)c1ccccc1I)C2C(C)(C)C</smiles>
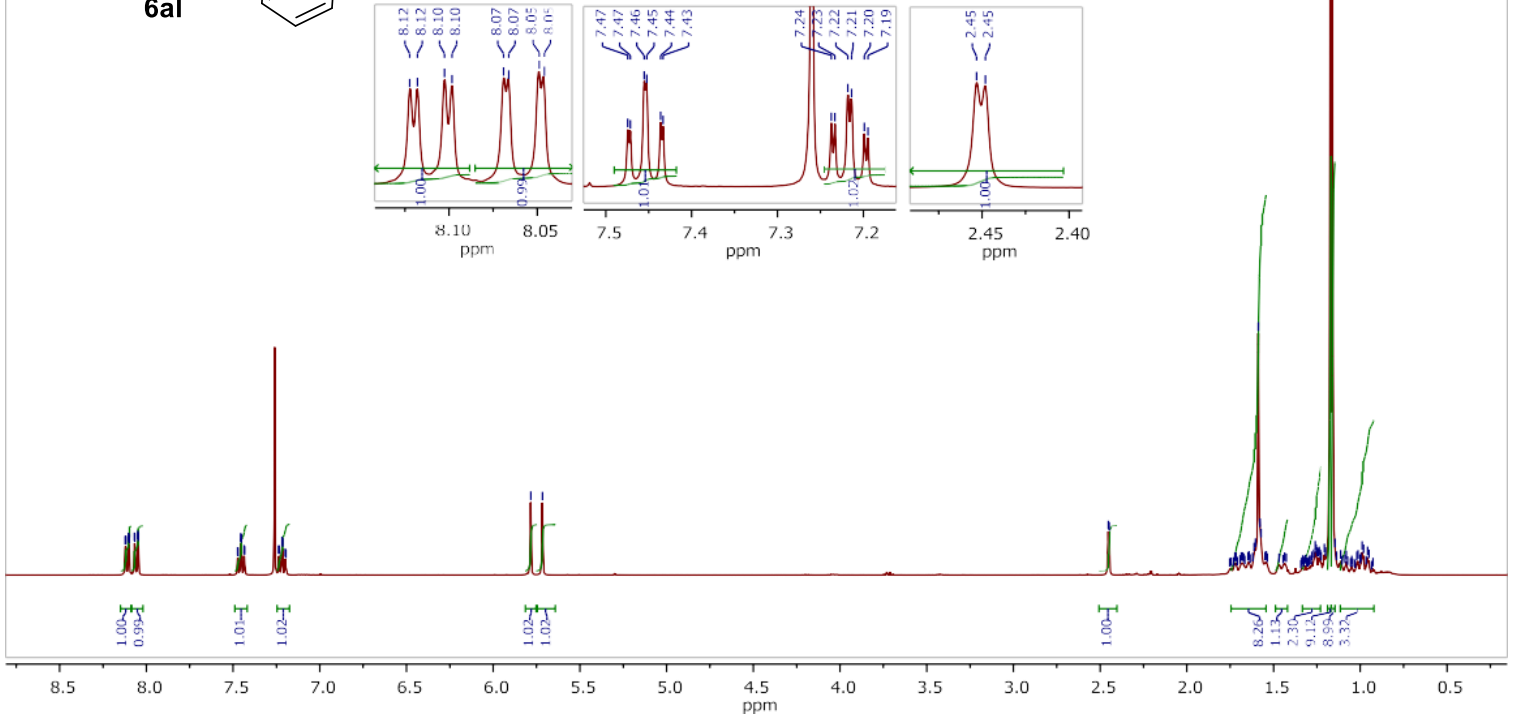

${ }^{13}$ C-NMR (100 MHz, $\mathrm{CDCl}_{3}$ ) of compound 6al

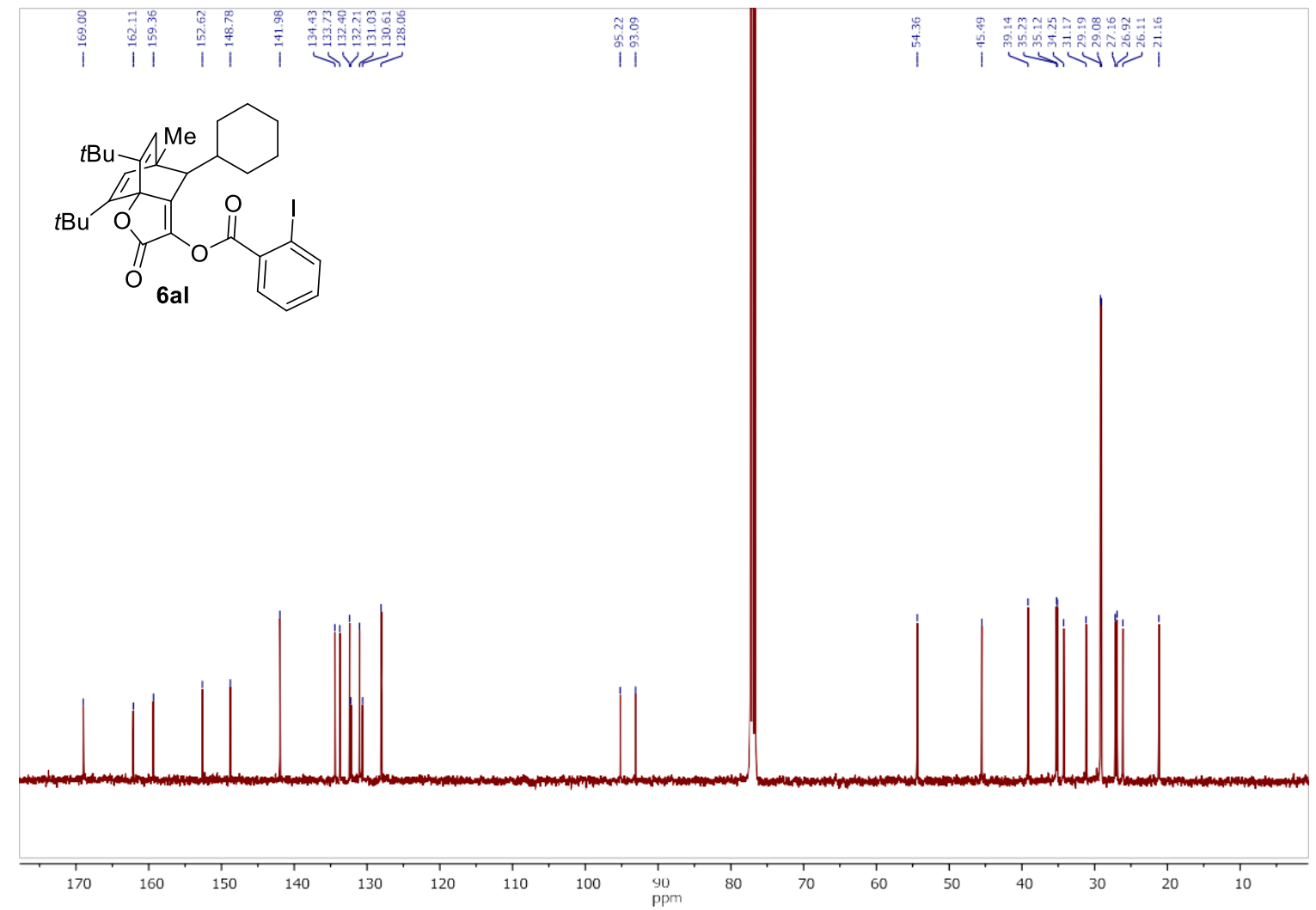


IR of compound $\mathbf{6 a l}$

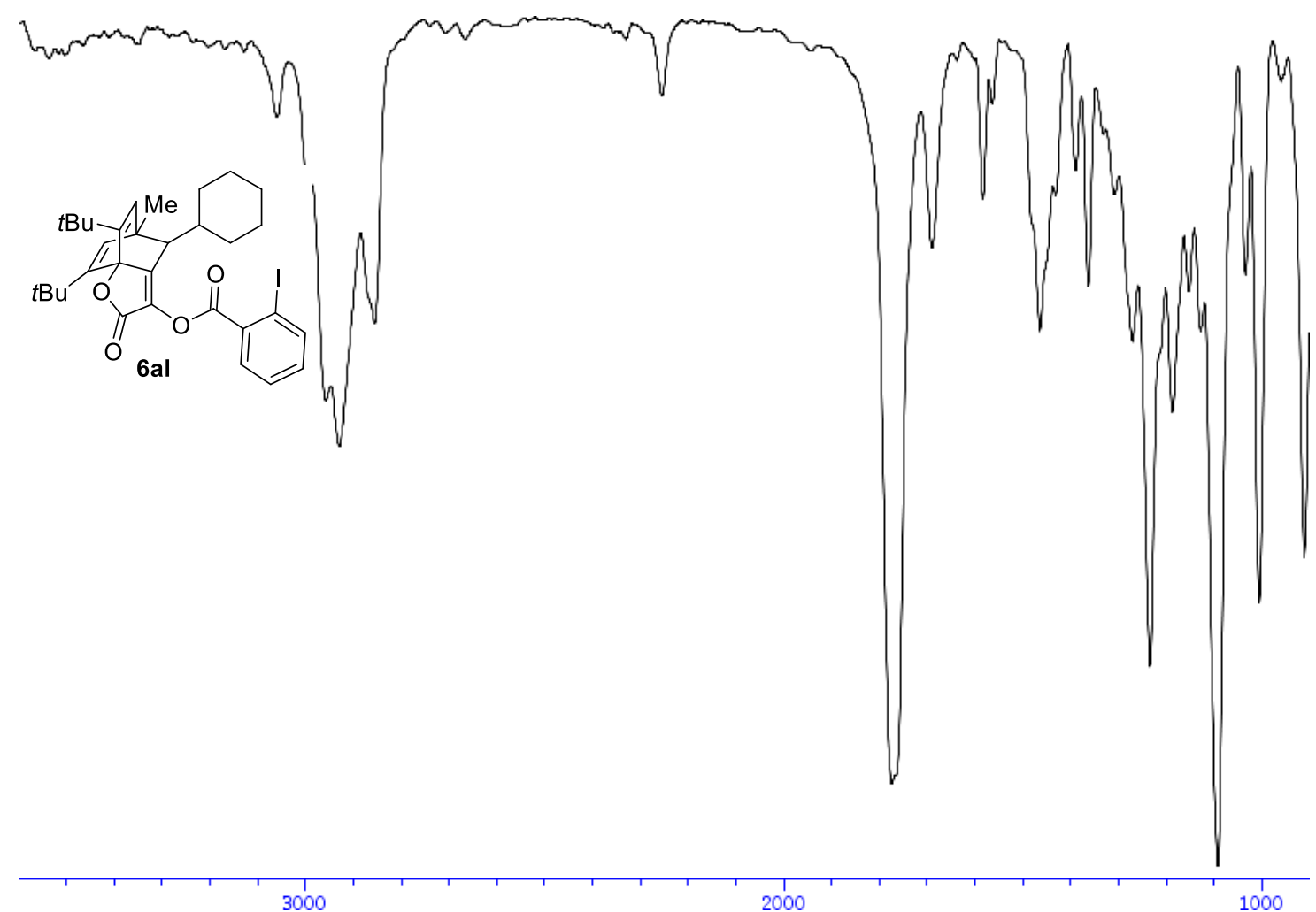


${ }^{1} \mathbf{H}-\mathrm{NMR}$ (400 MHz, $\mathrm{CDCl}_{3}$ ) of compound 13

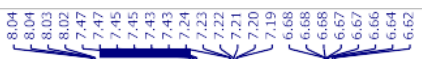

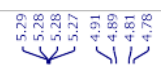

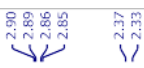
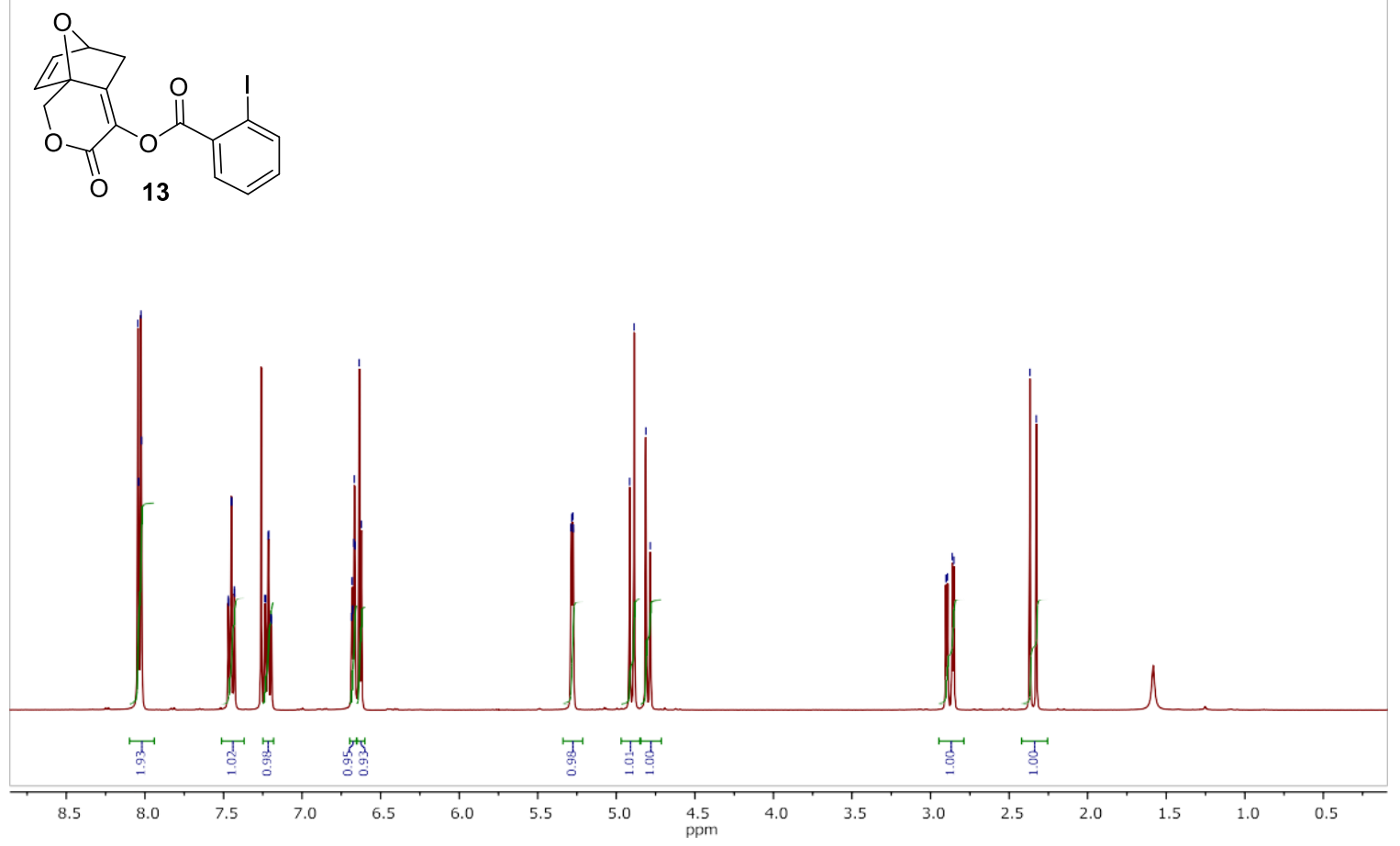

${ }^{13} \mathrm{C}$-NMR (100 MHz, $\mathrm{CDCl}_{3}$ ) of compound 13

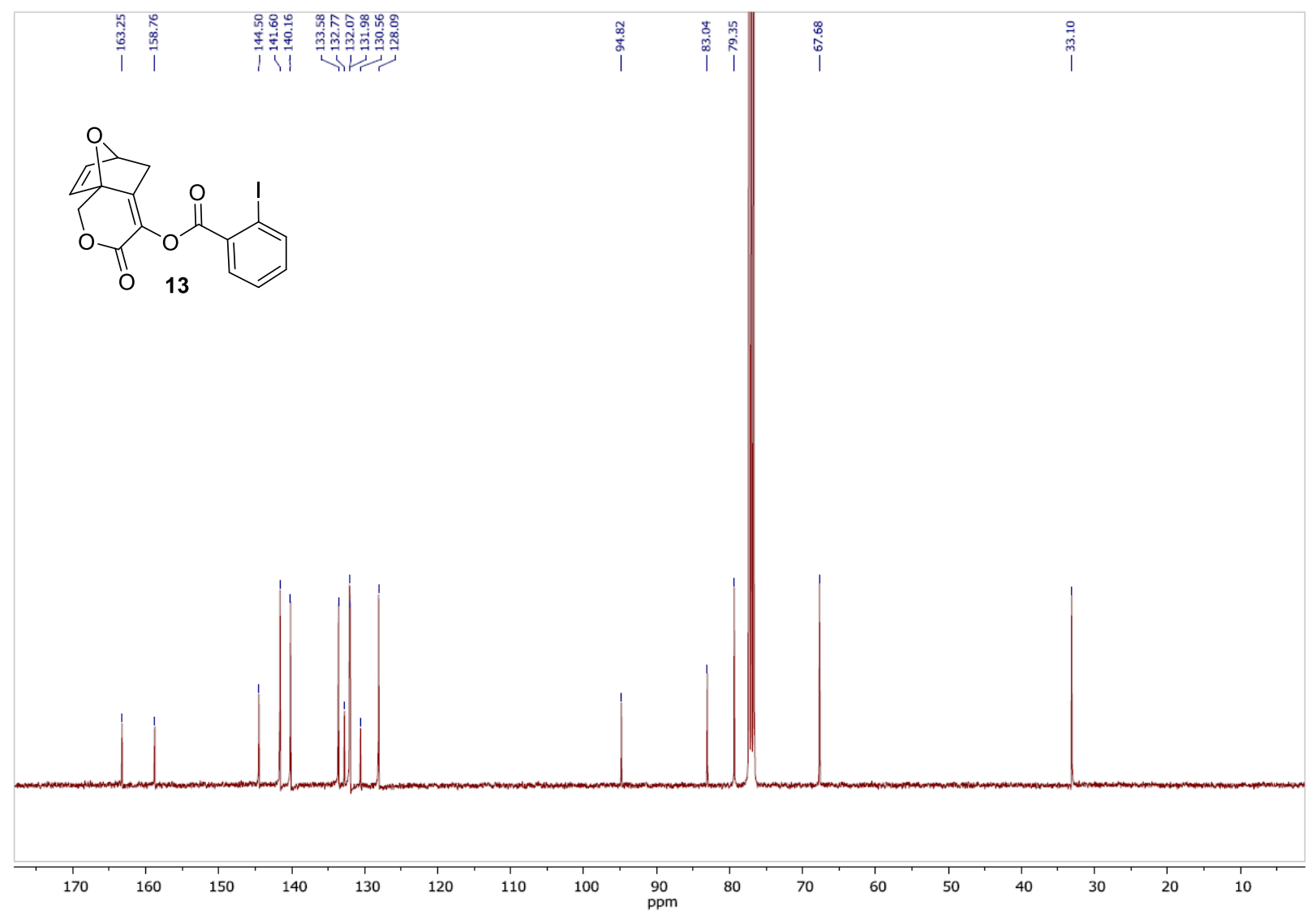

S214 
${ }^{1} \mathbf{H}-\mathbf{N M R}\left(400 \mathrm{MHz}, \mathrm{CDCl}_{3}\right.$ ) of compound $\mathbf{1 4 a}$

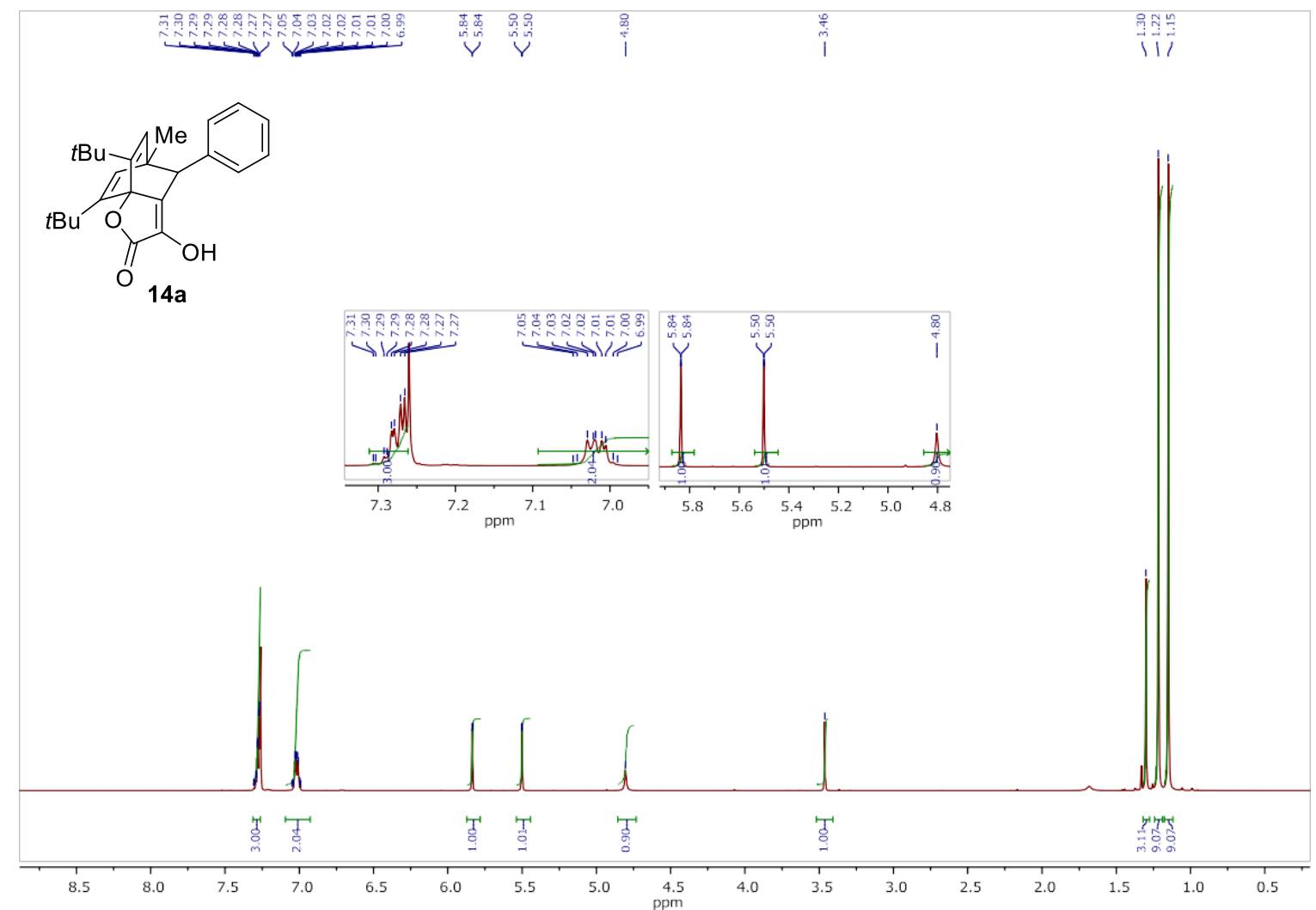

${ }^{13} \mathrm{C}$-NMR (100 MHz, $\mathrm{CDCl}_{3}$ ) of compound 14a

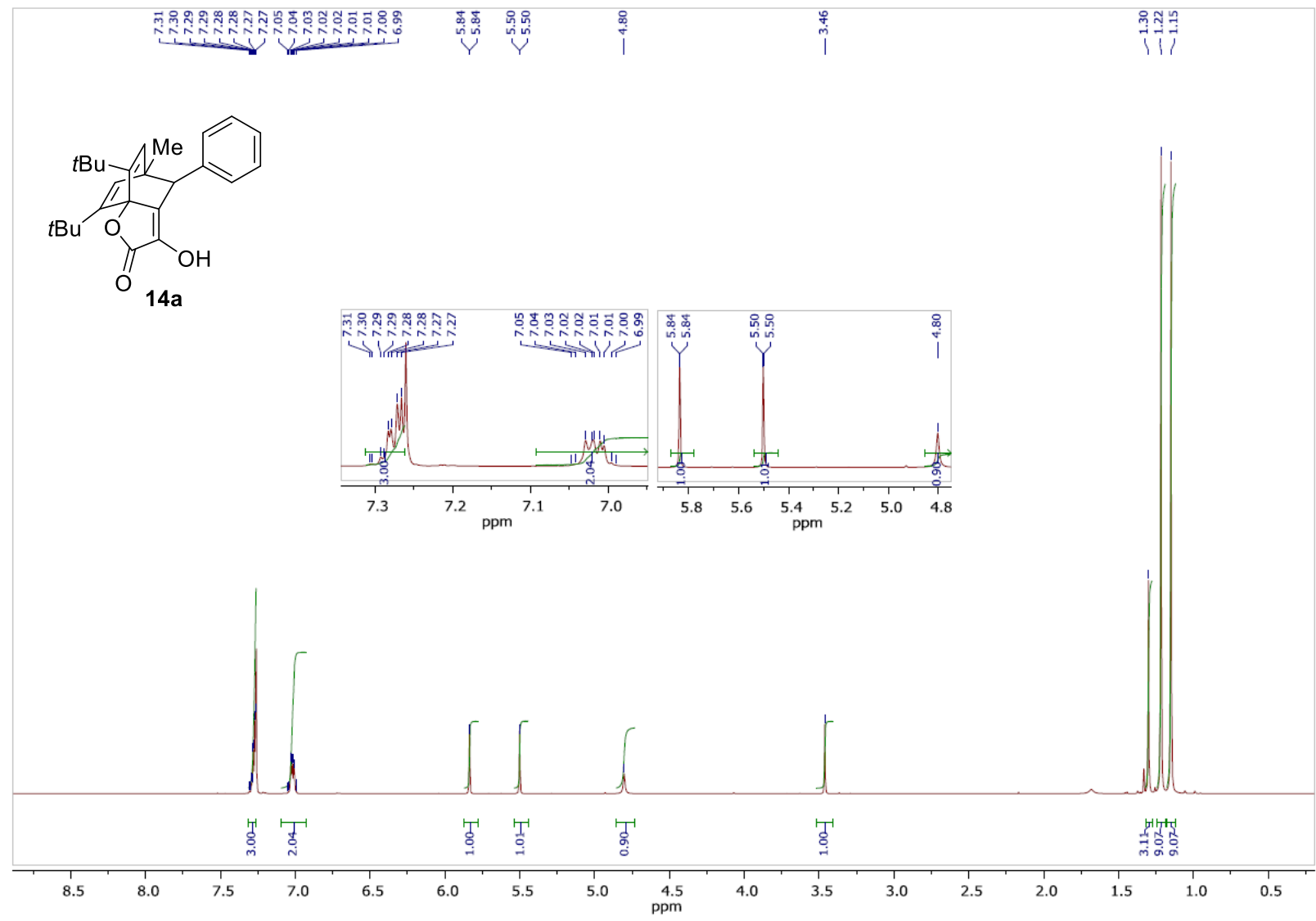


IR of compound 14a

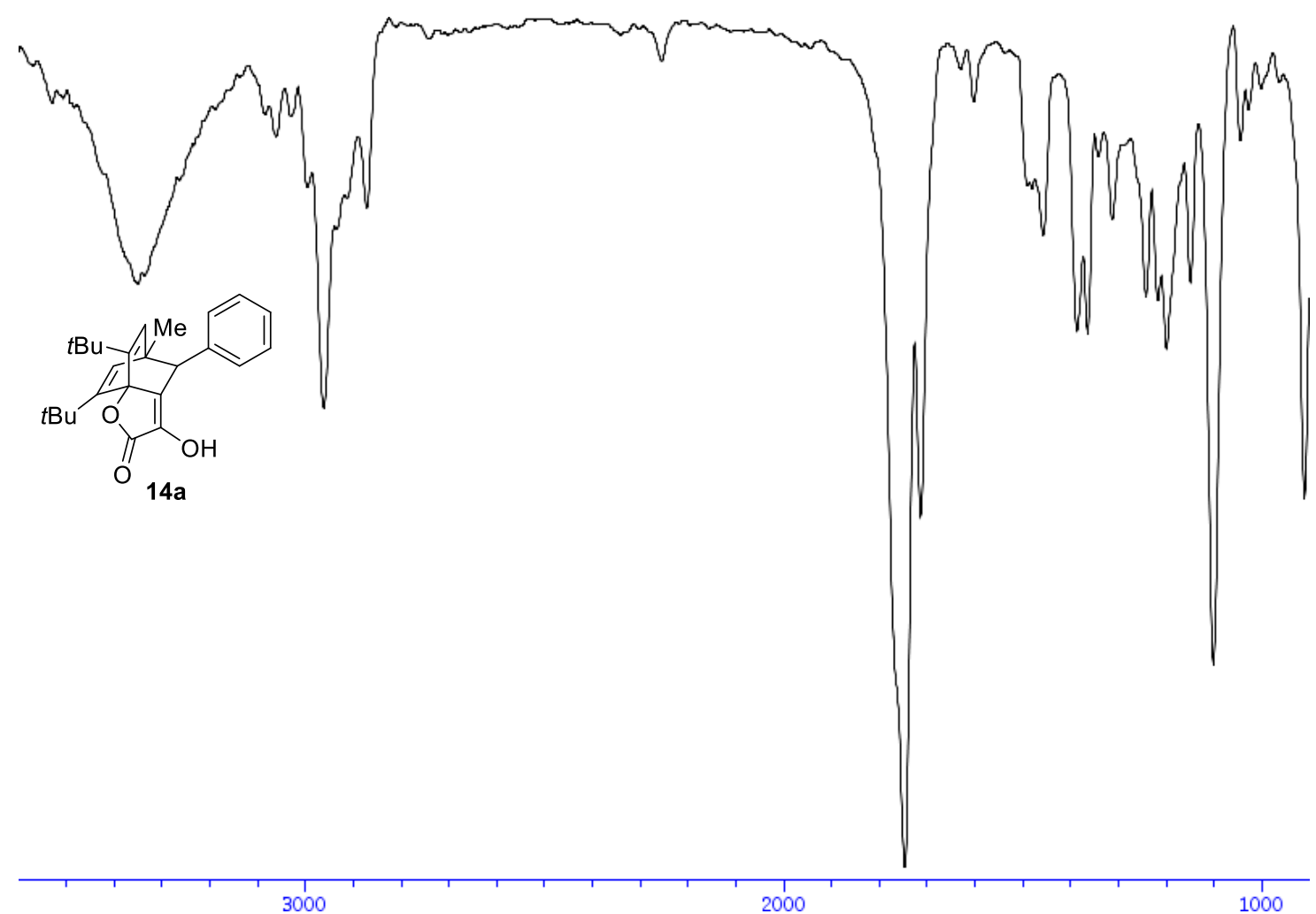


${ }^{1} \mathbf{H}-\mathbf{N M R}\left(400 \mathrm{MHz}, \mathrm{CDCl}_{3}\right.$ ) of compound $\mathbf{1 4 b}$

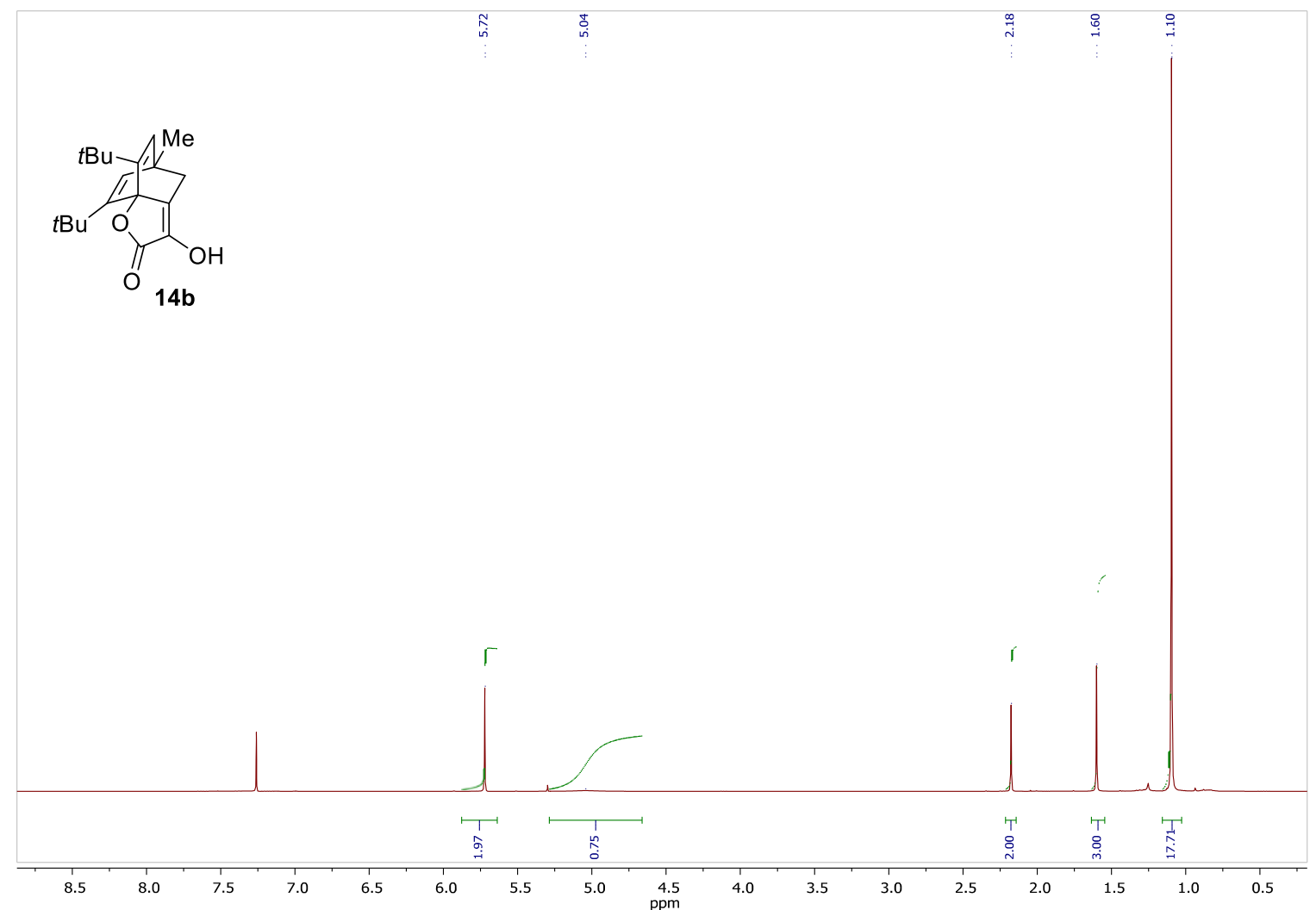

${ }^{13}$ C-NMR (100 MHz, $\mathrm{CDCl}_{3}$ ) of compound 14b

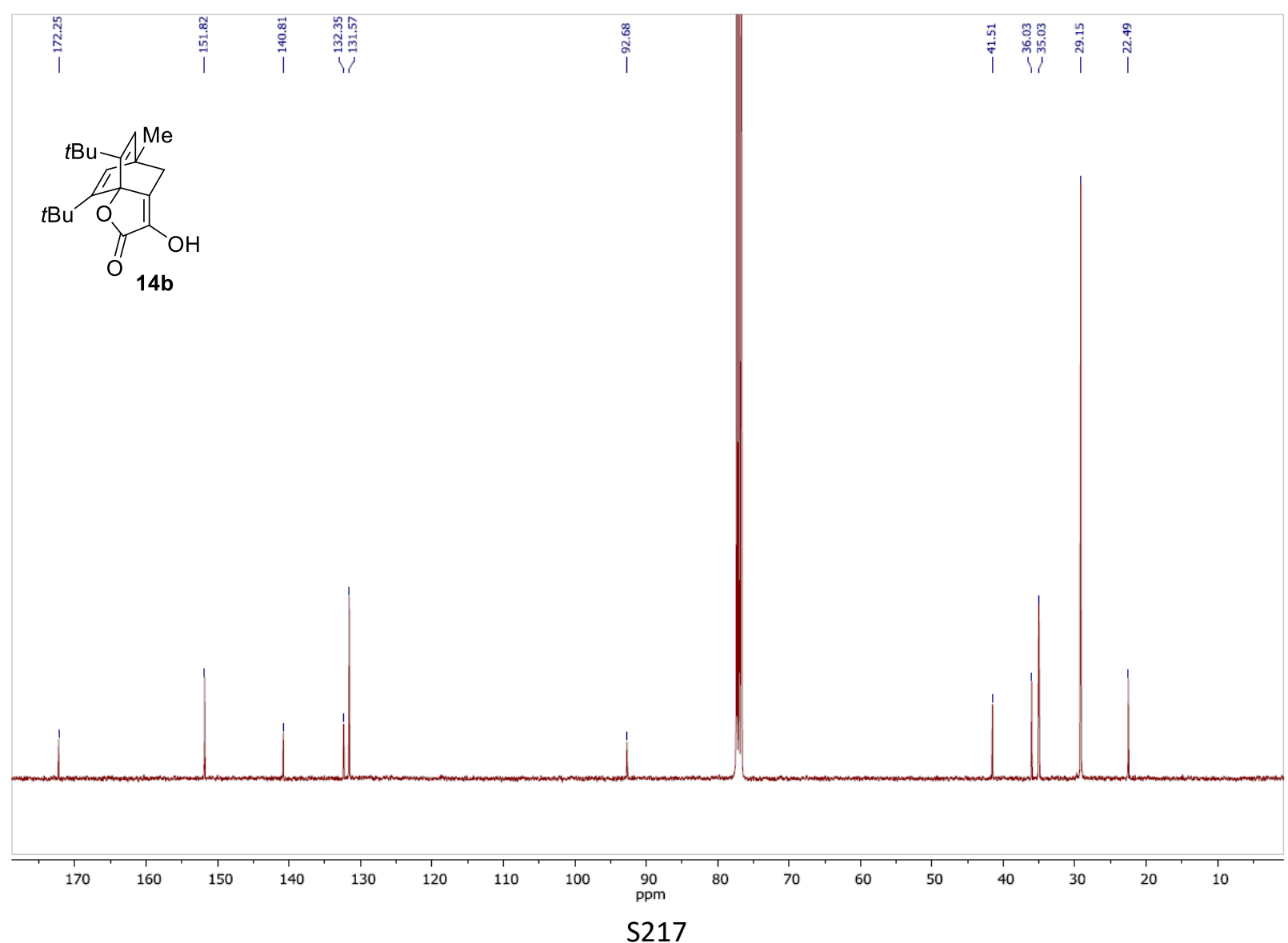


IR of compound 14b

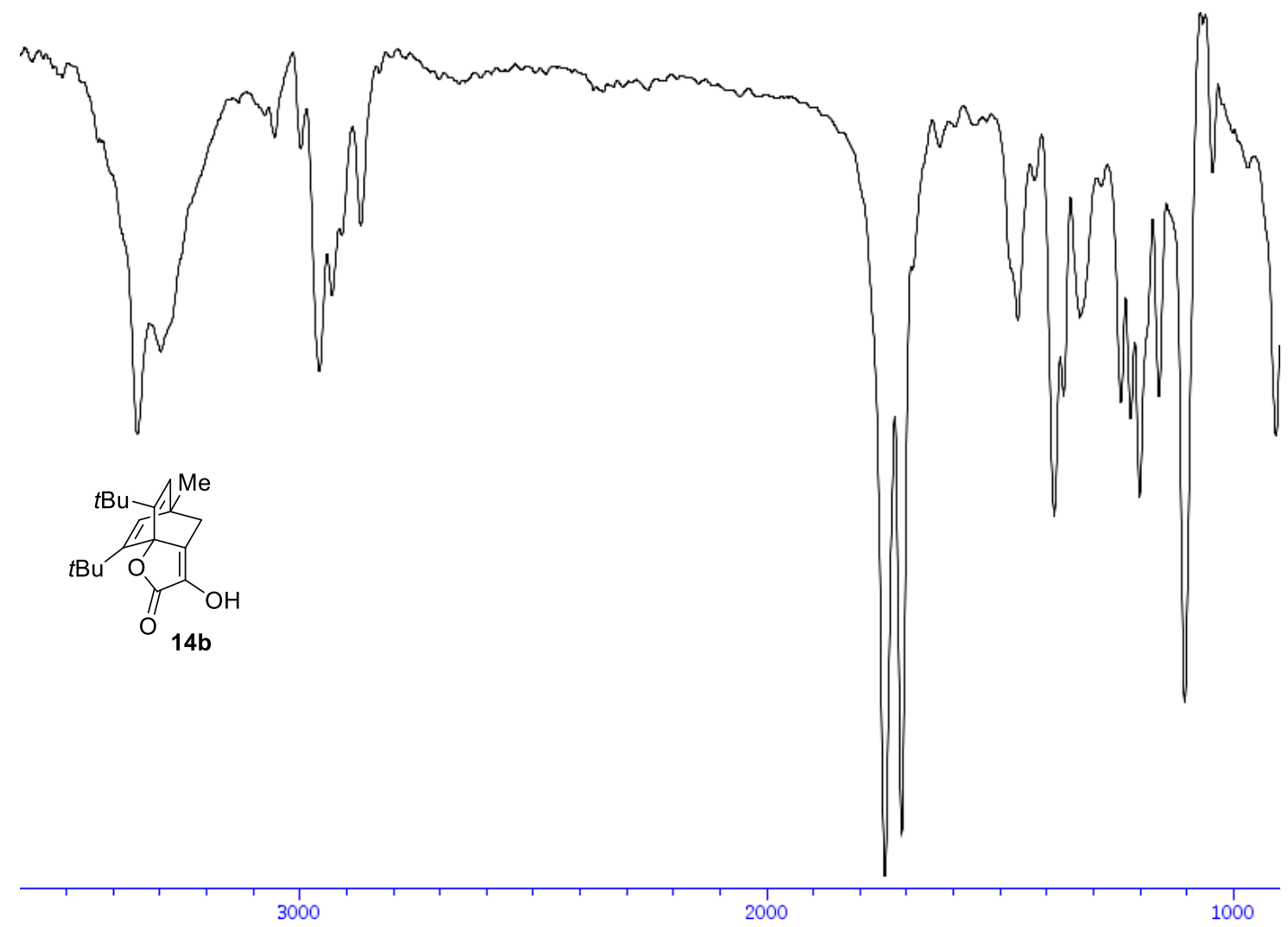


${ }^{1} \mathrm{H}$-NMR (400 MHz, $\mathrm{CDCl}_{3}$ ) of compound 15

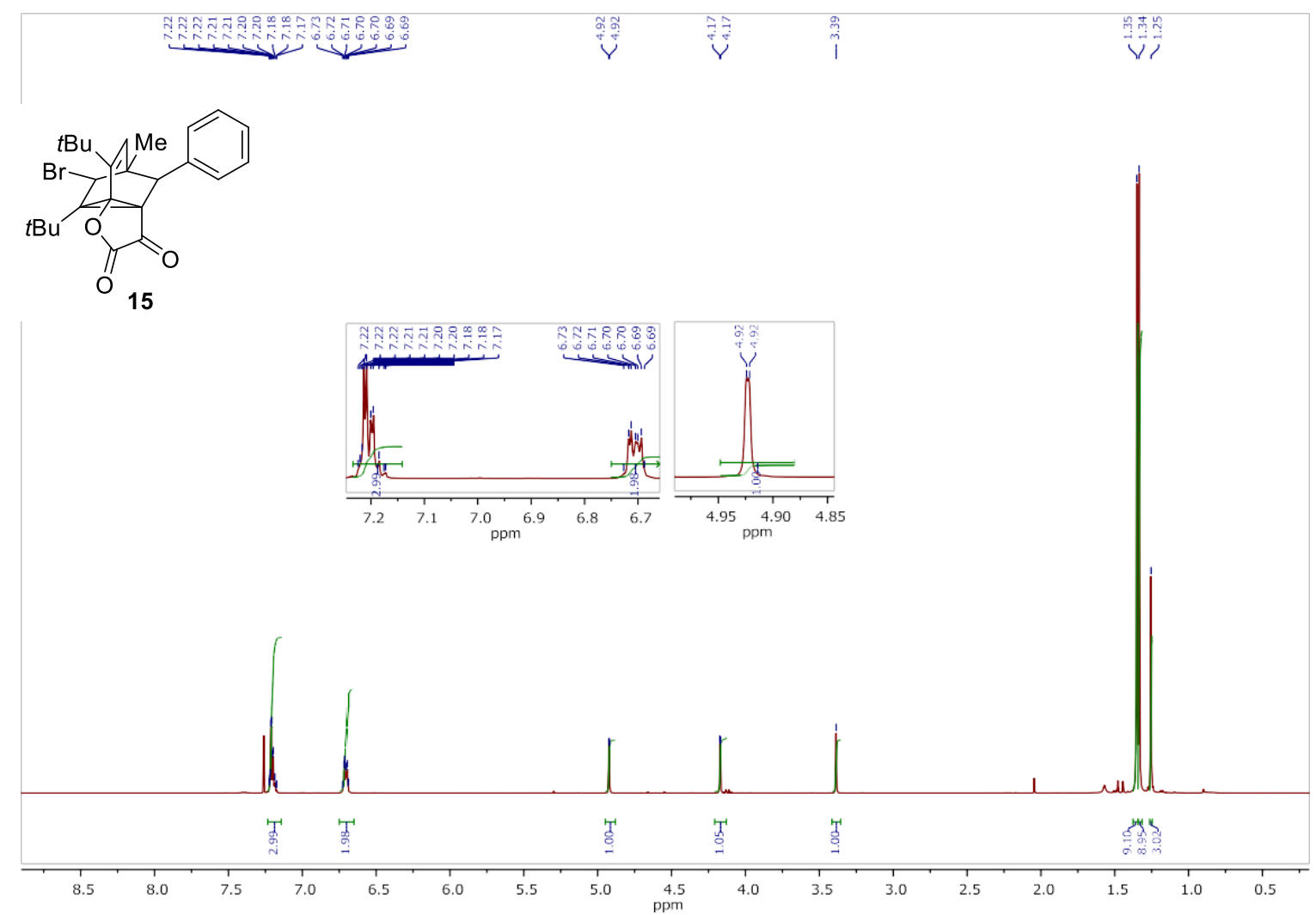

${ }^{13} \mathrm{C}$-NMR (100 MHz, $\mathrm{CDCl}_{3}$ ) of compound 15

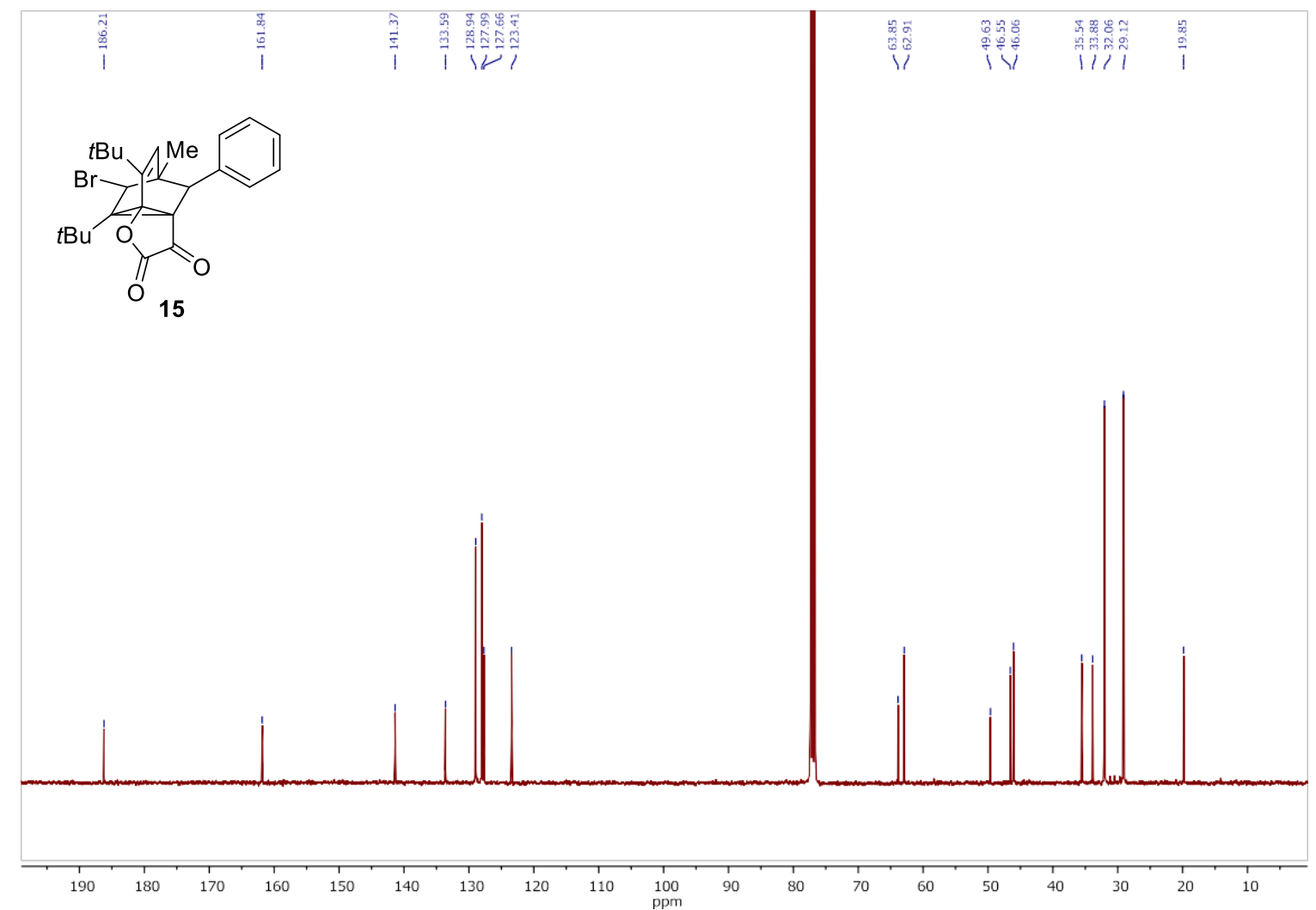


IR of compound $\mathbf{1 5}$

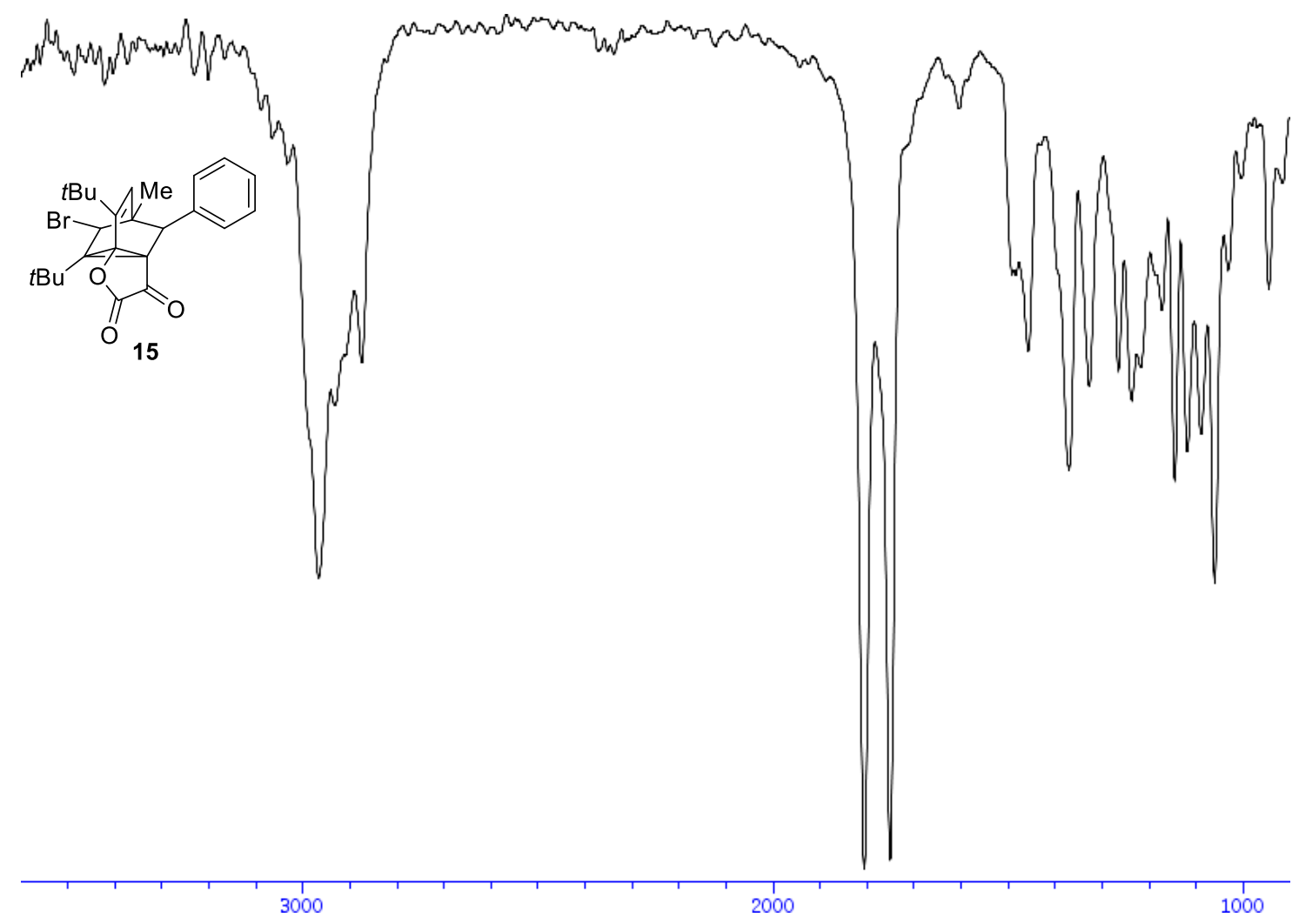


${ }^{1} \mathrm{H}$-NMR (400 MHz, $\mathrm{CDCl}_{3}$ ) of compound 16

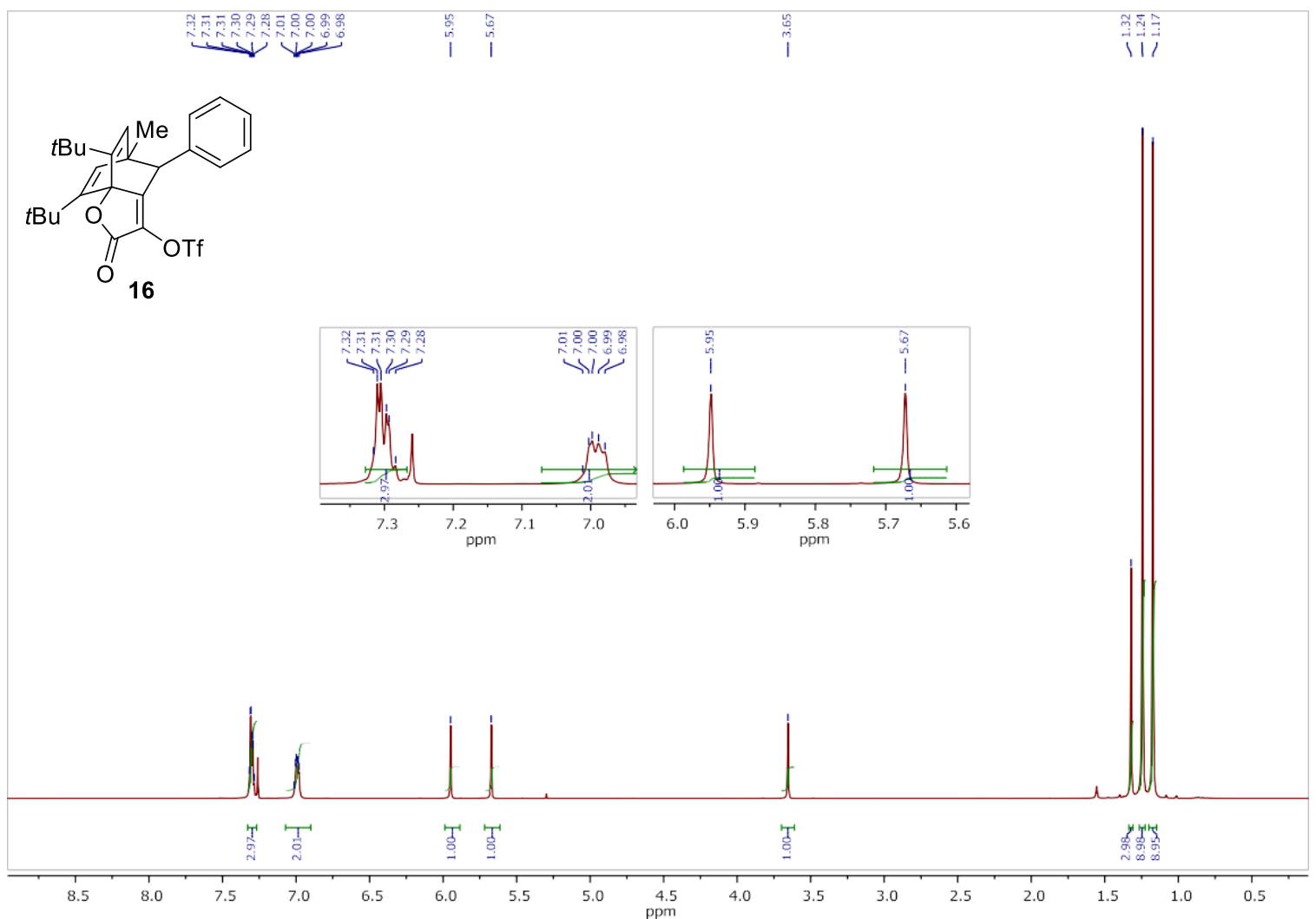

${ }^{13}$ C-NMR (100 MHz, $\mathrm{CDCl}_{3}$ ) of compound 16

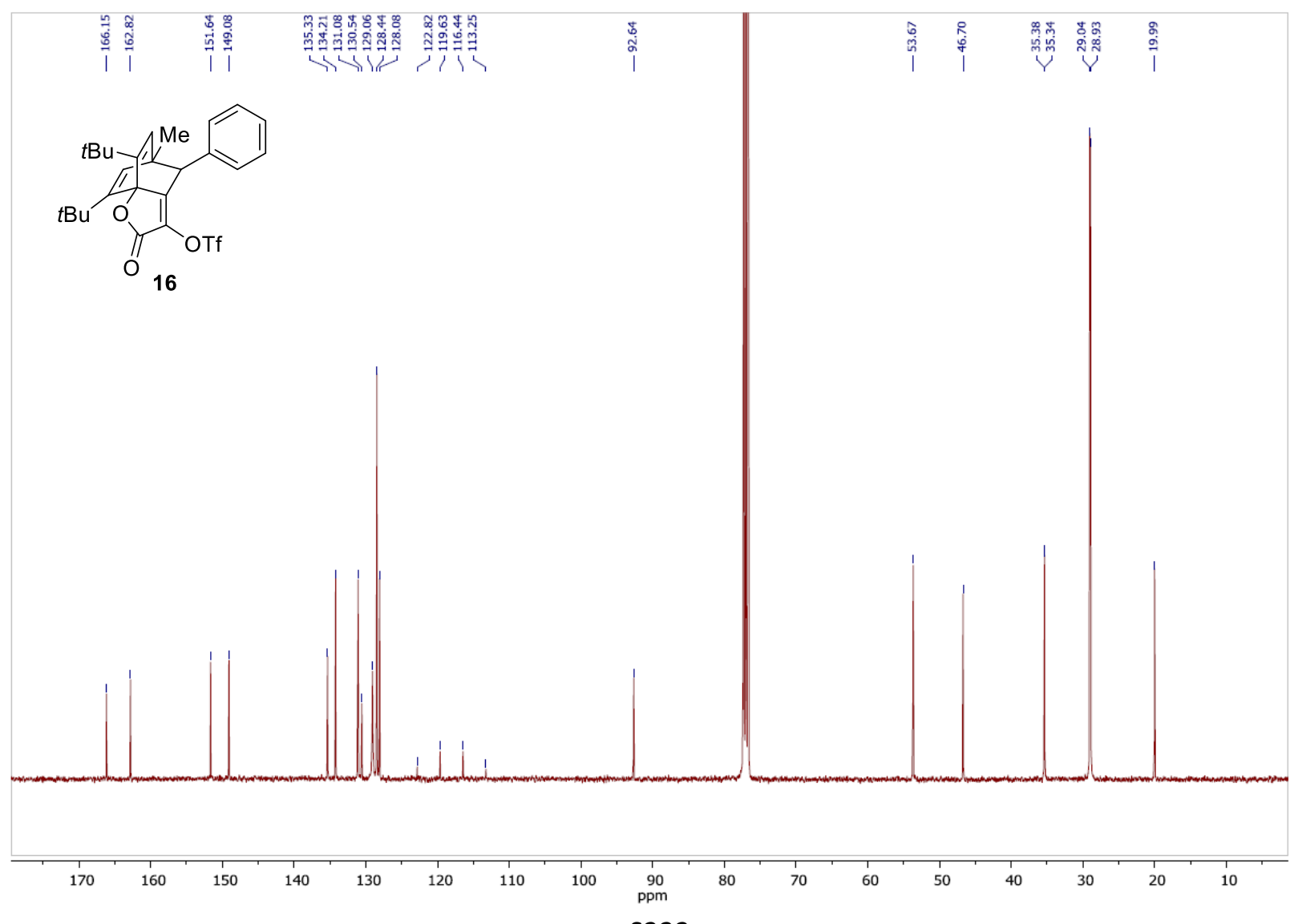


IR of compound $\mathbf{1 6}$

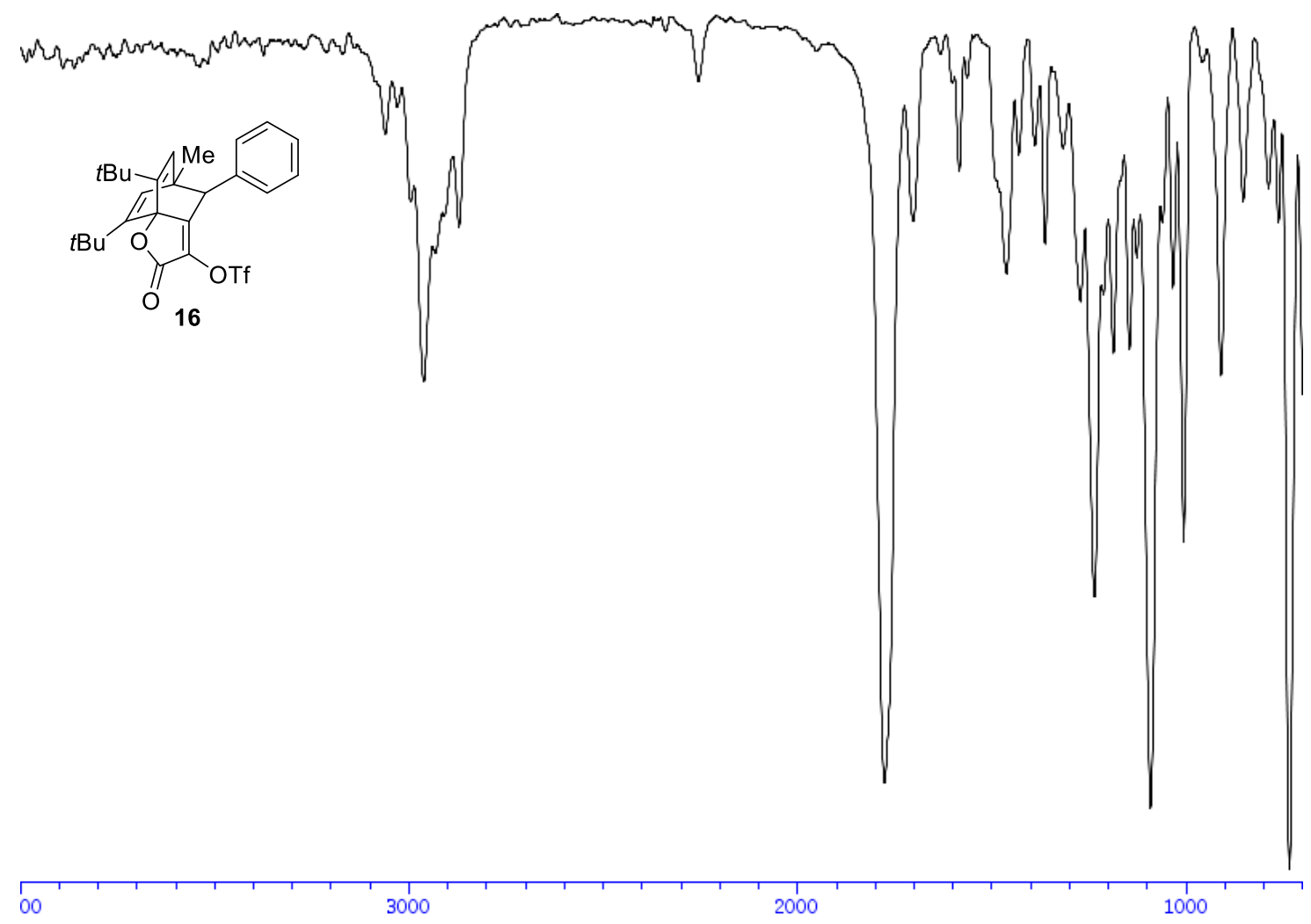


${ }^{1} \mathrm{H}-\mathrm{NMR}\left(400 \mathrm{MHz}, \mathrm{CDCl}_{3}\right.$ ) of compound 17

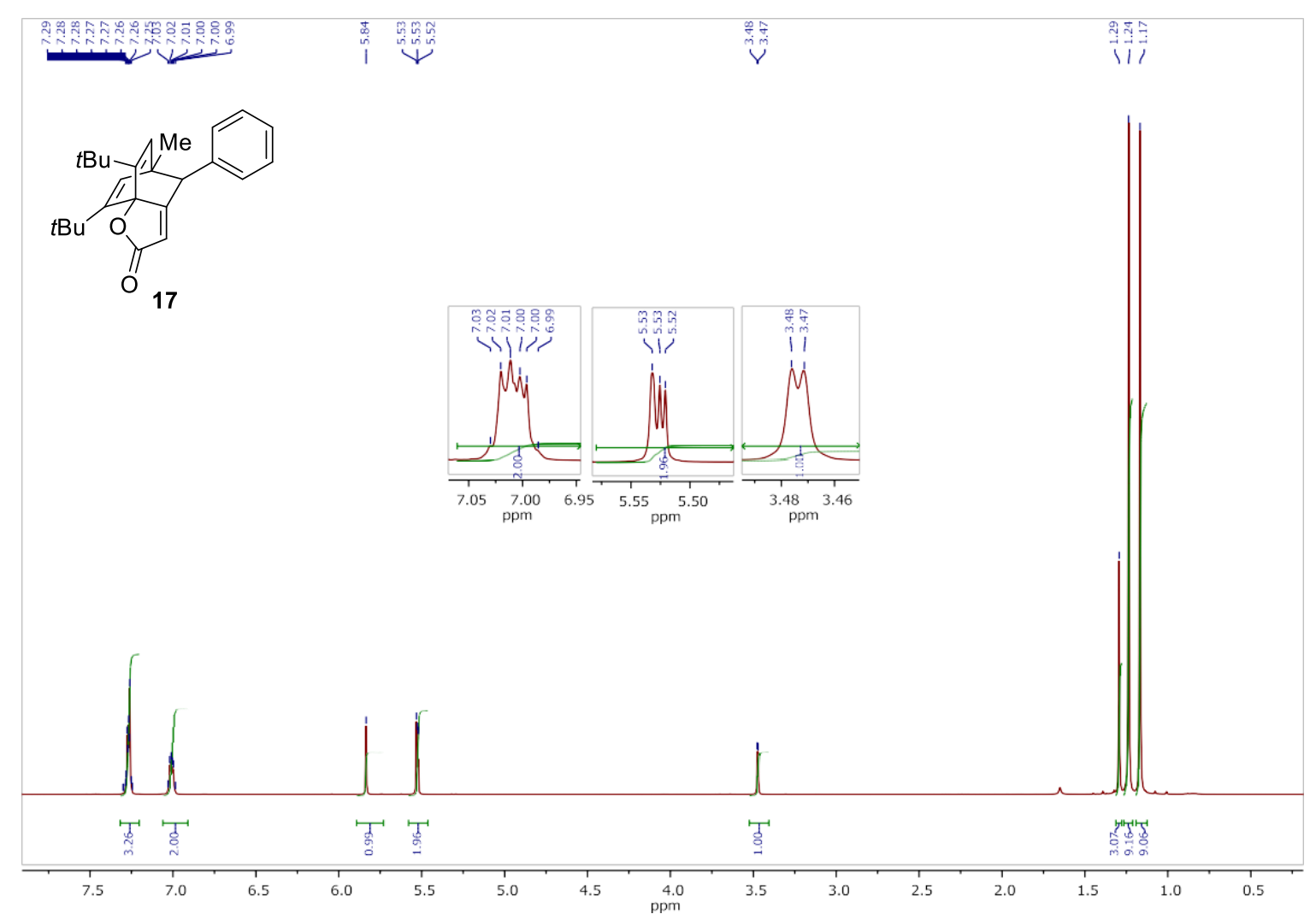

${ }^{13} \mathrm{C}-\mathrm{NMR}$ (100 MHz, $\mathrm{CDCl}_{3}$ ) of compound 17

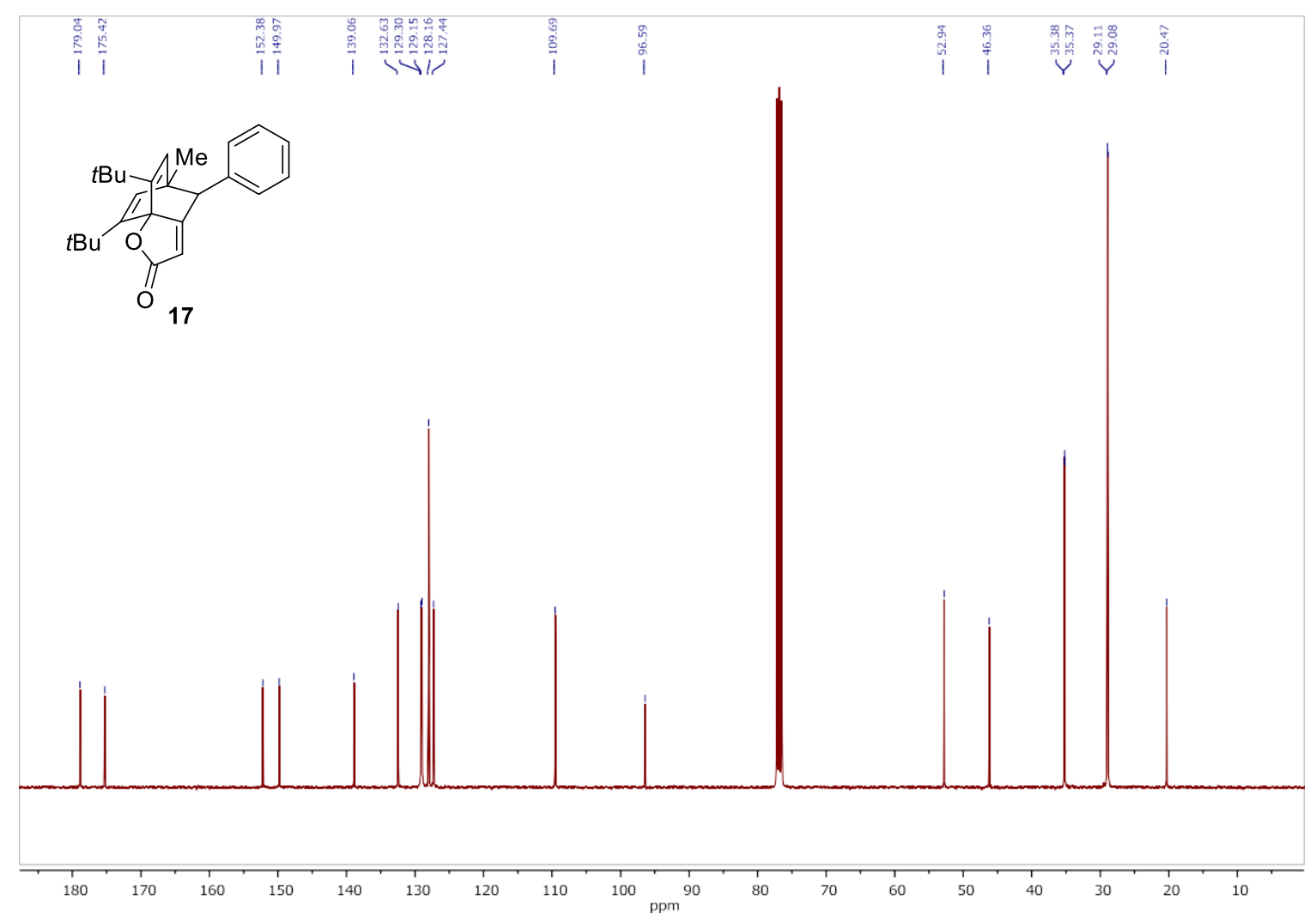


IR of compound $\mathbf{1 7}$

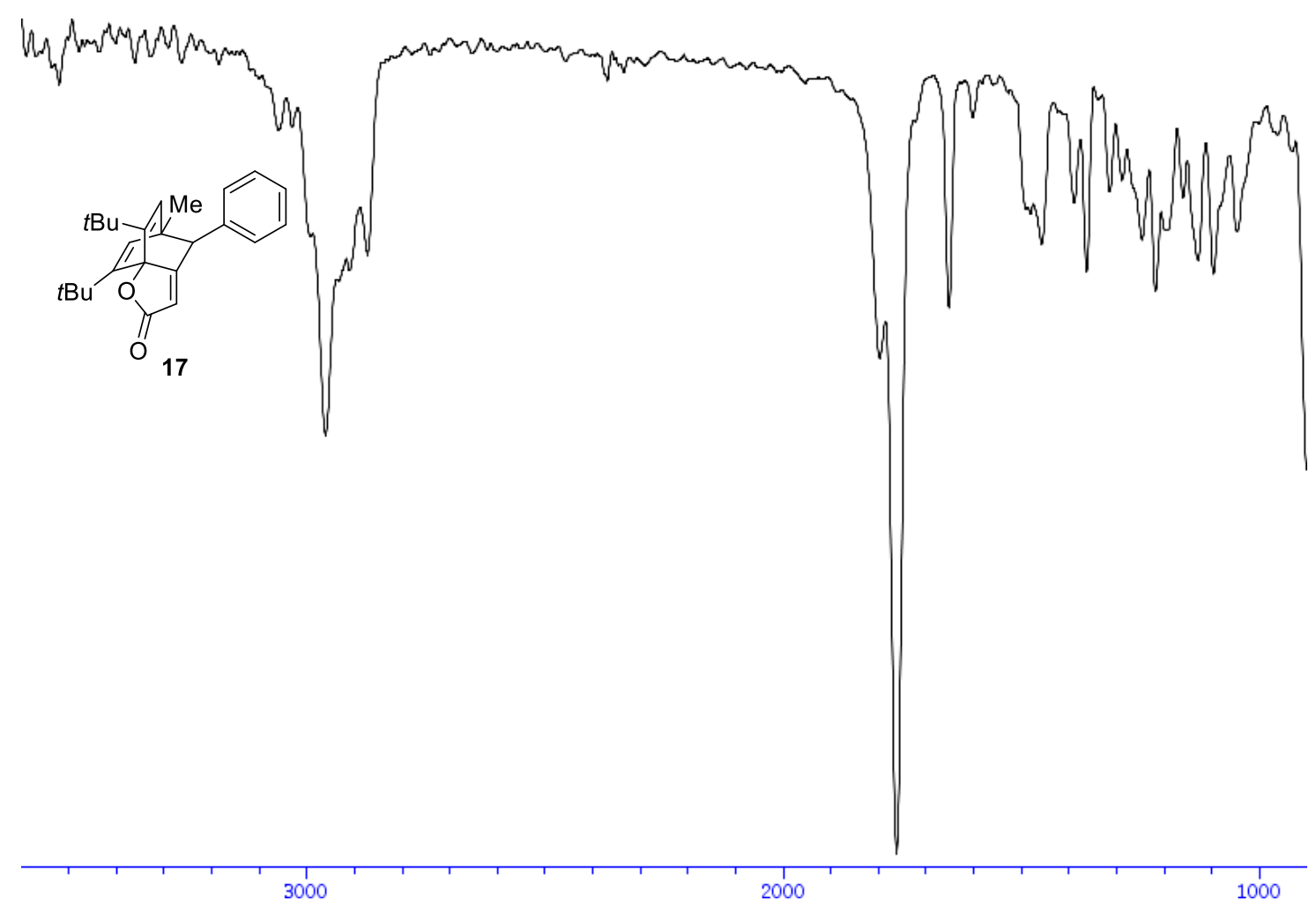


${ }^{1} \mathrm{H}$-NMR (400 MHz, $\mathrm{CDCl}_{3}$ ) of compound 18

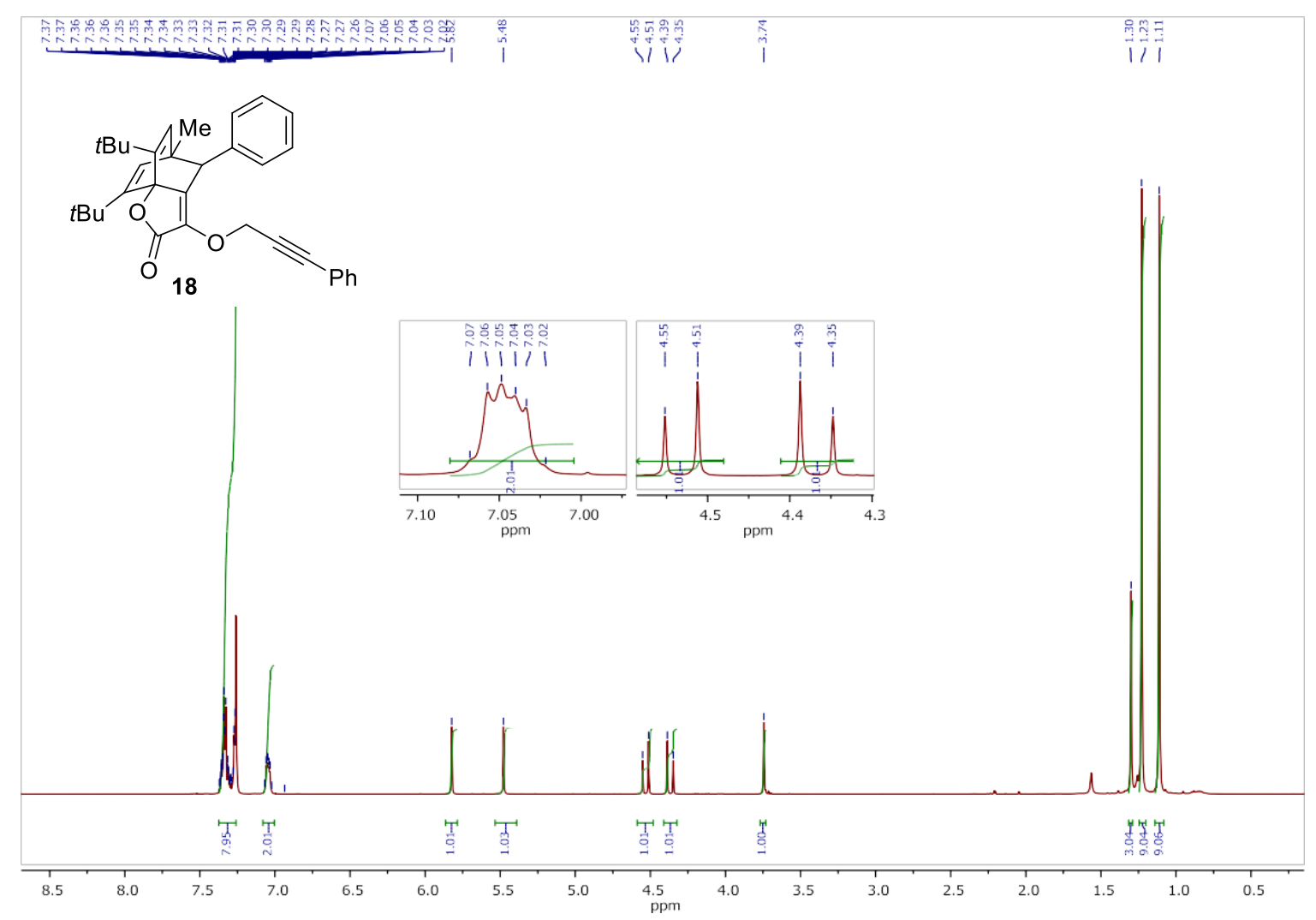

${ }^{13} \mathrm{C}-\mathrm{NMR}\left(100 \mathrm{MHz}, \mathrm{CDCl}_{3}\right)$ of compound 18

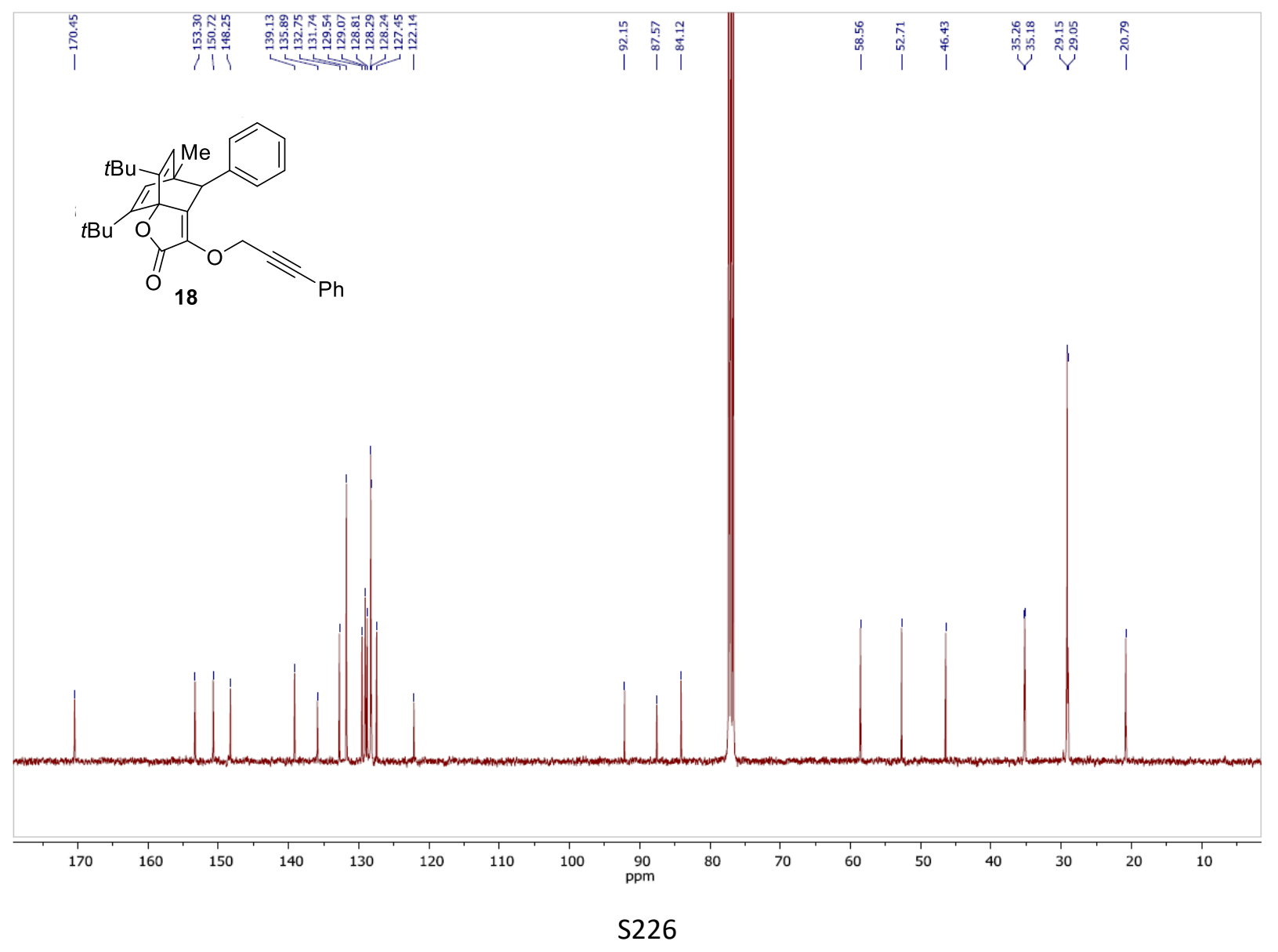


IR of compound $\mathbf{1 8}$

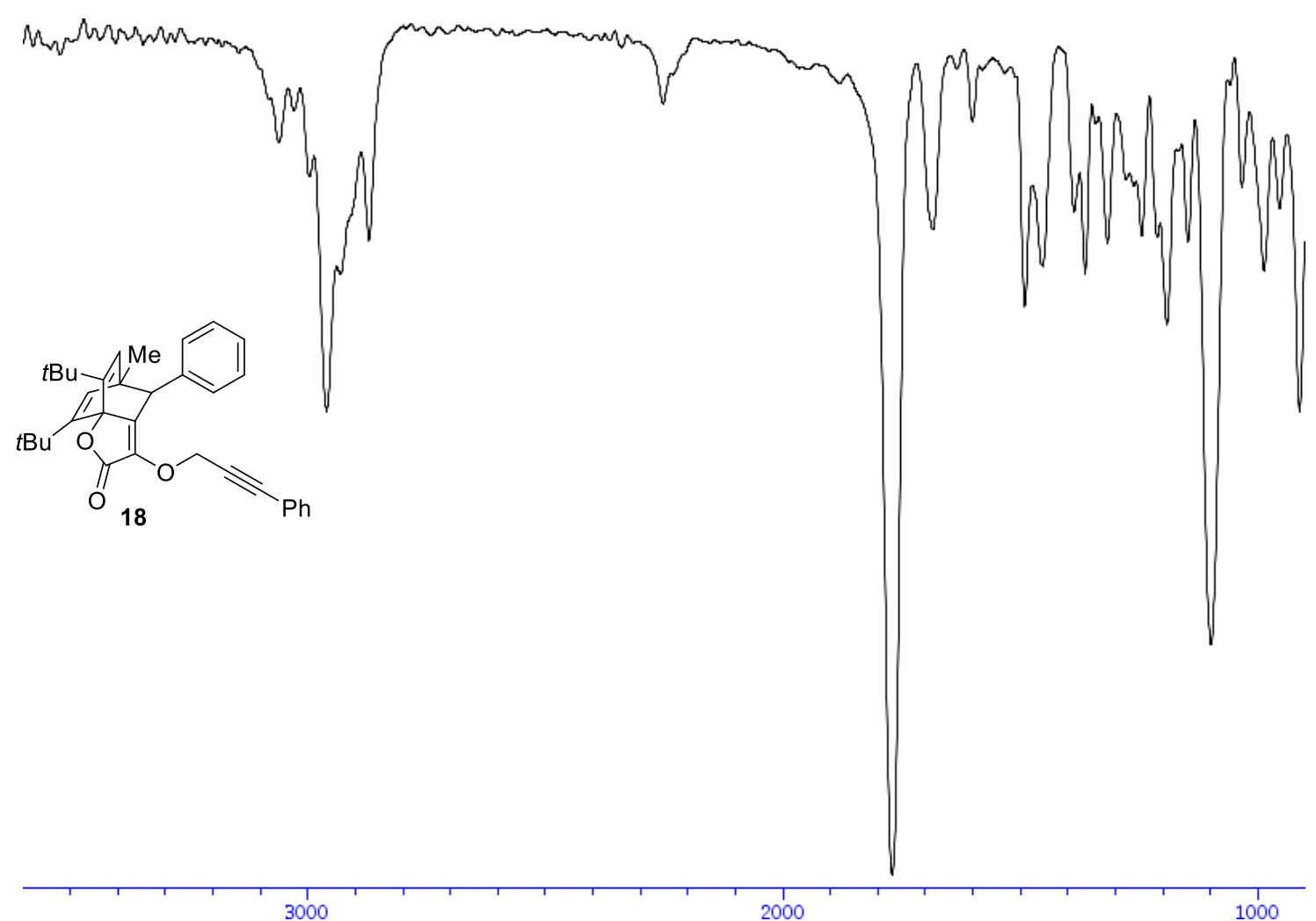


${ }^{1} \mathrm{H}$-NMR (400 MHz, $\mathrm{CDCl}_{3}$ ) of compound 19

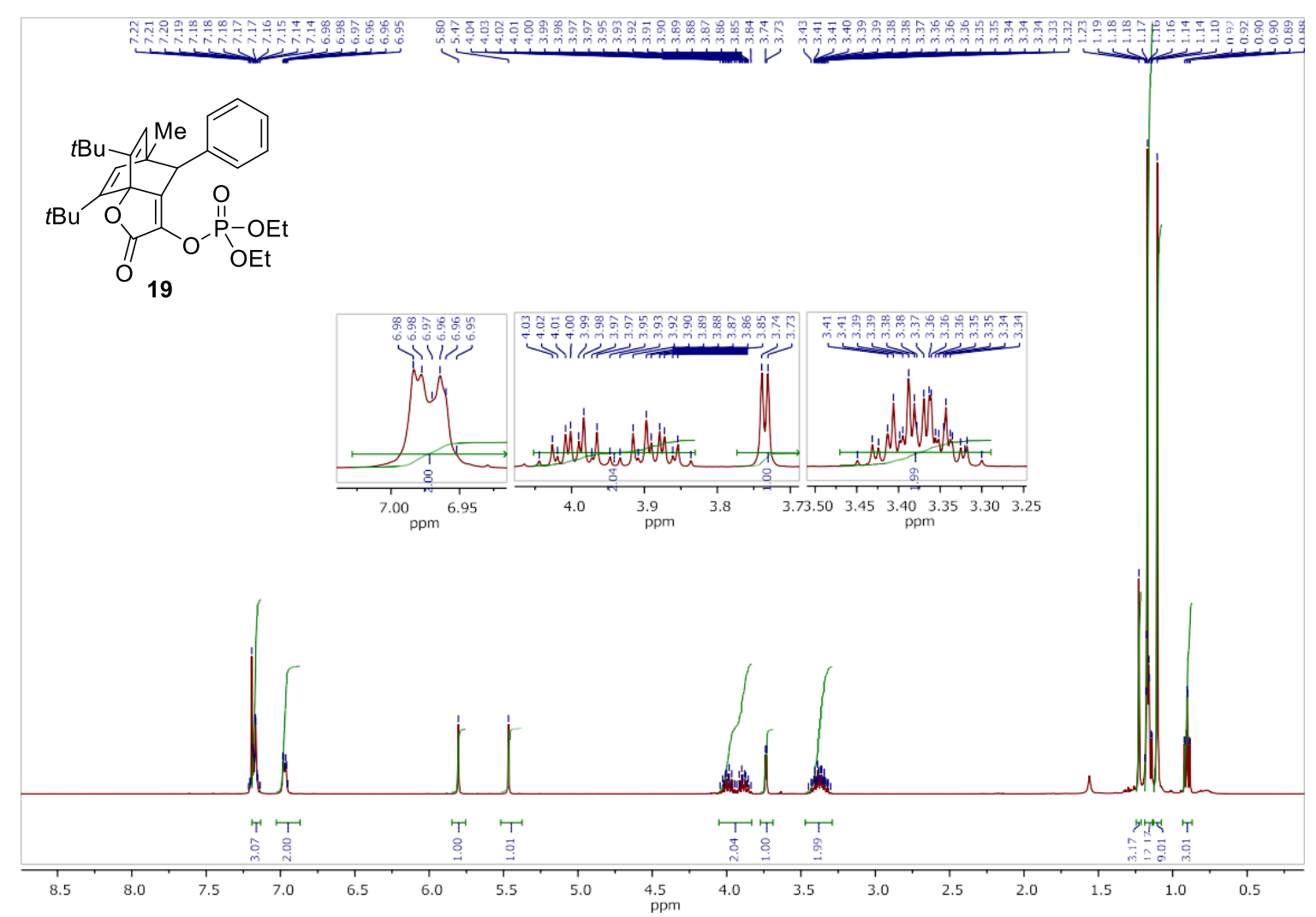

${ }^{13} \mathrm{C}$-NMR (100 MHz, $\mathrm{CDCl}_{3}$ ) of compound 19

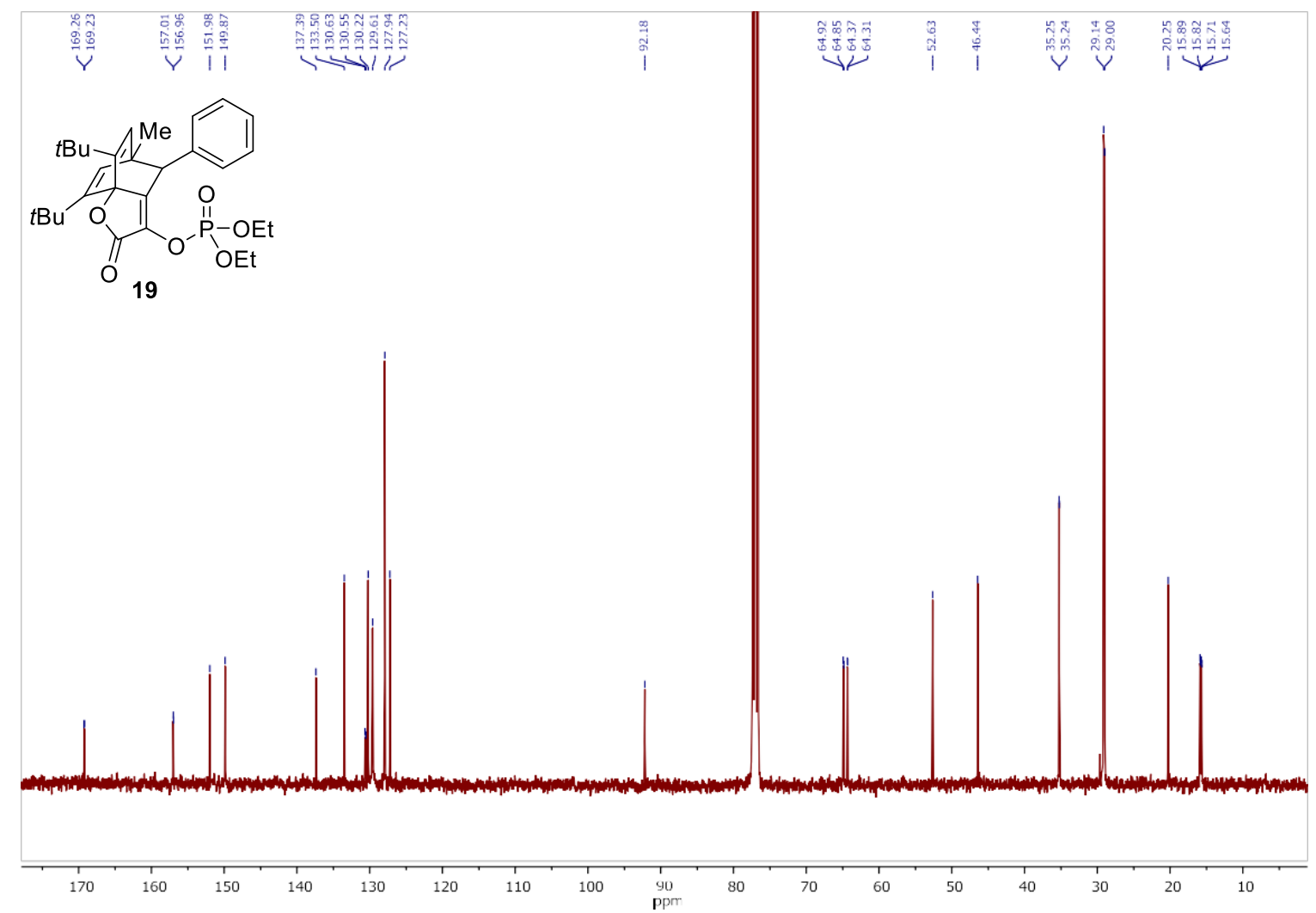


IR of compound $\mathbf{1 9}$

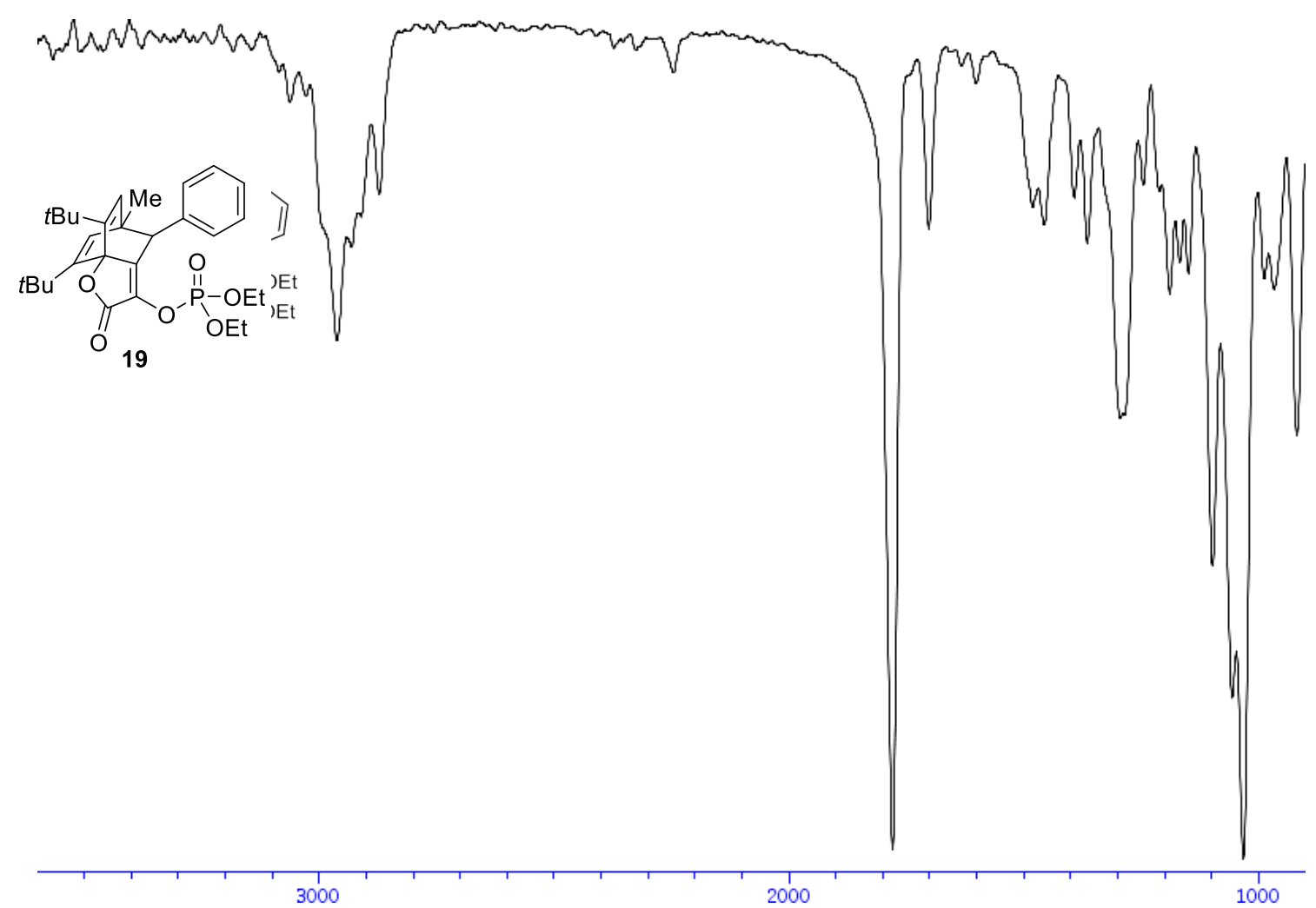


${ }^{1} \mathbf{H}-\mathrm{NMR}\left(400 \mathrm{MHz}, \mathrm{CDCl}_{3}\right.$ ) of compound 20a

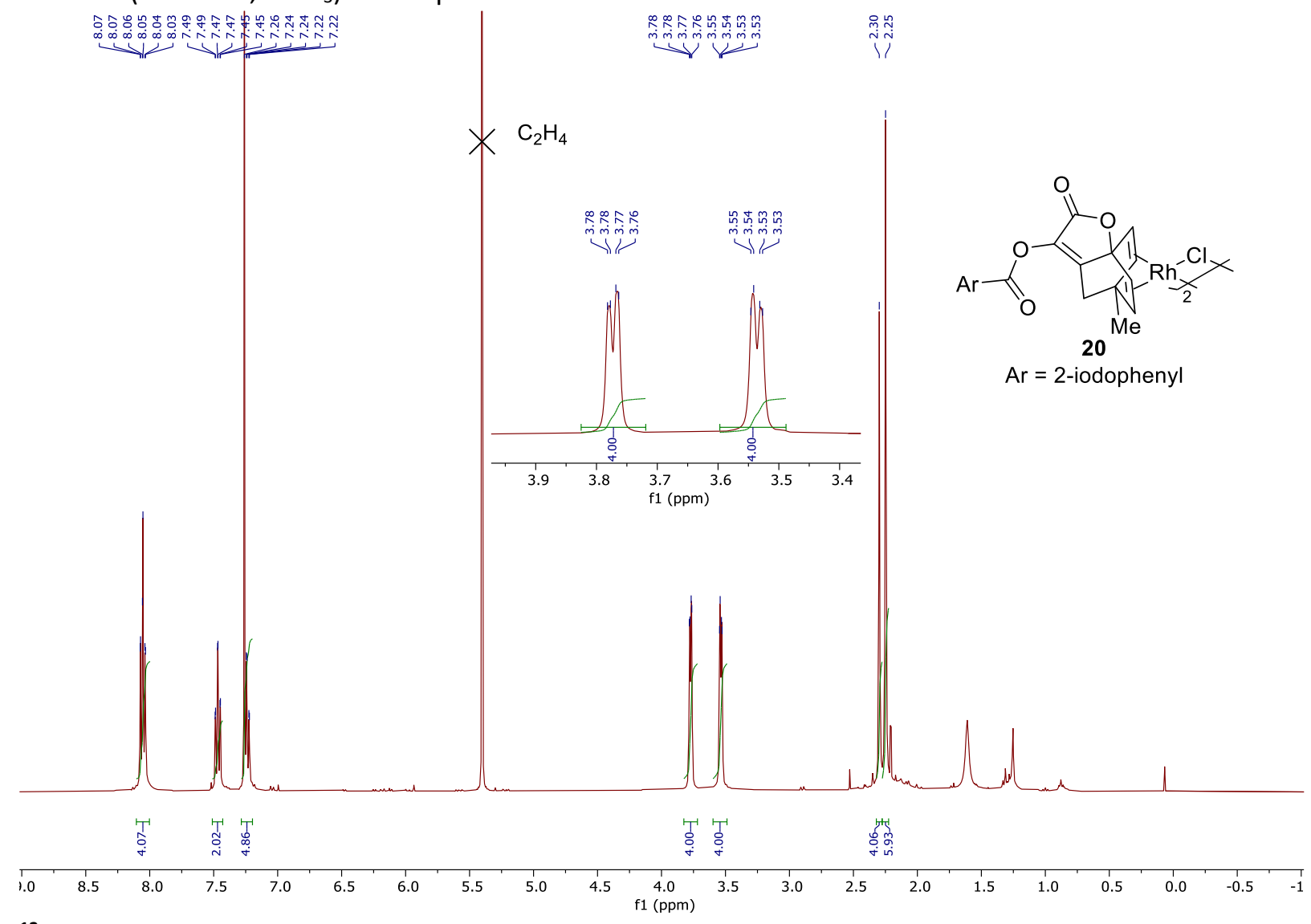

${ }^{13} \mathrm{C}-\mathrm{NMR}\left(100 \mathrm{MHz}, \mathrm{CDCl}_{3}\right.$ ) of compound 20a

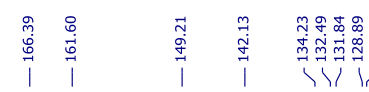

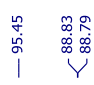

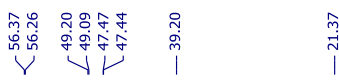

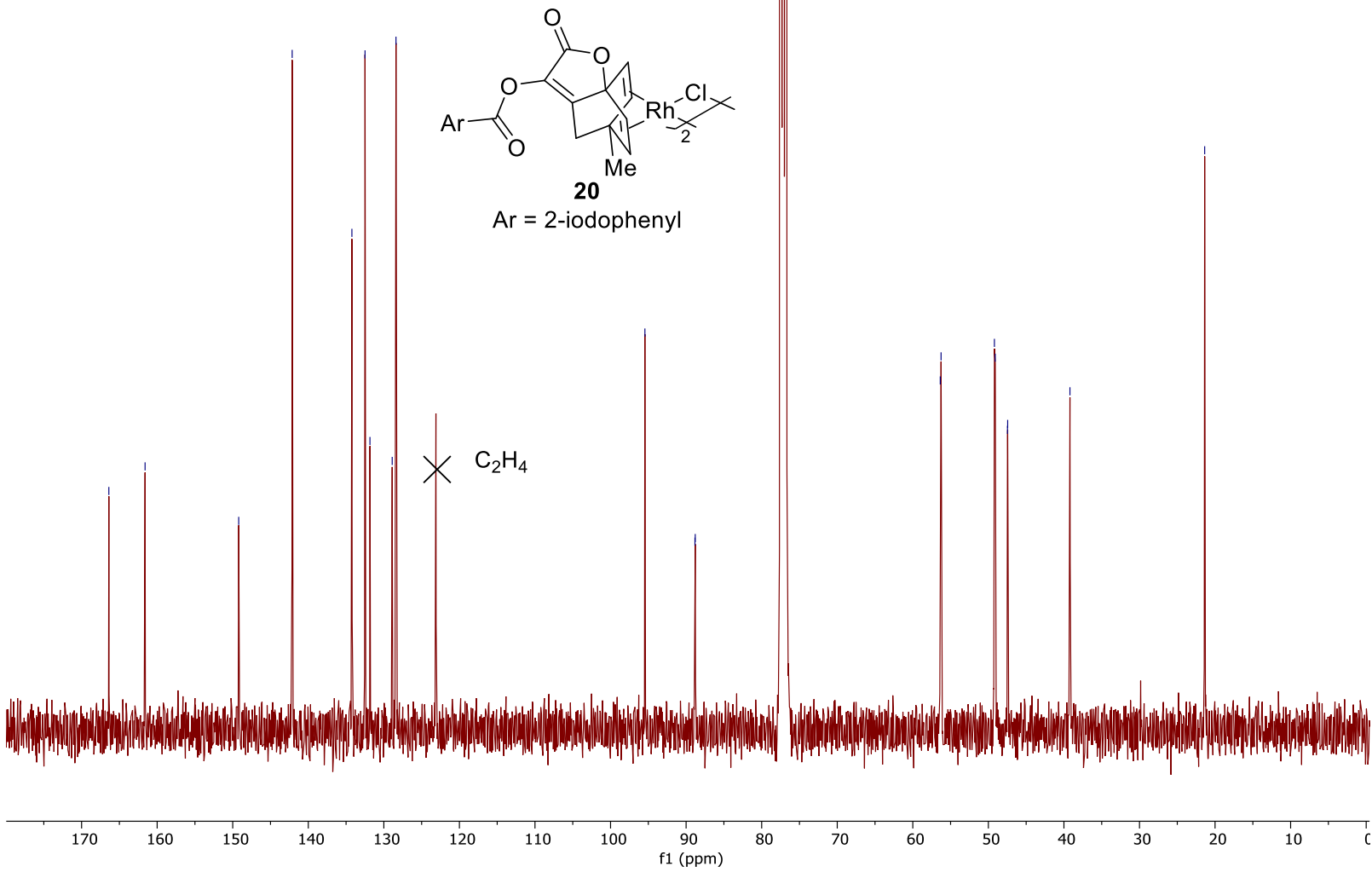


${ }^{1} \mathrm{H}-\mathrm{NMR}\left(400 \mathrm{MHz}, \mathrm{CDCl}_{3}\right.$ ) of compound (-)-20b

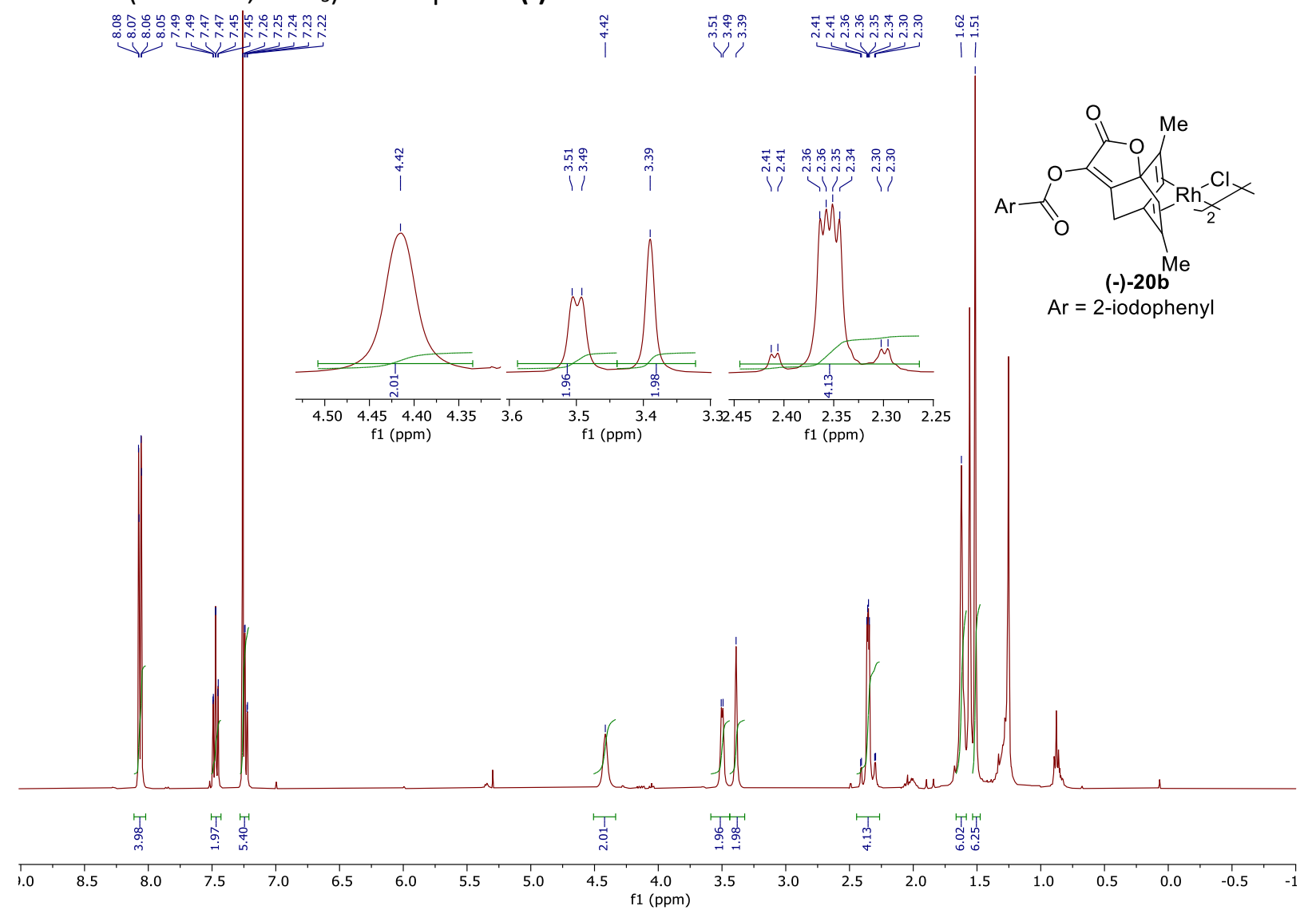

${ }^{13} \mathrm{C}-\mathrm{NMR}\left(100 \mathrm{MHz}, \mathrm{CDCl}_{3}\right.$ ) of compound 20b

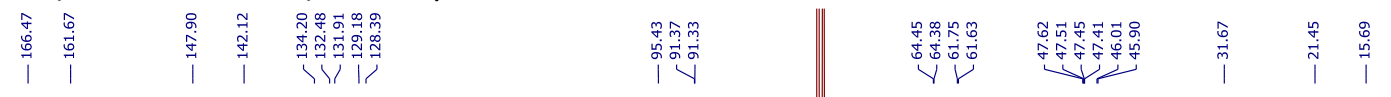

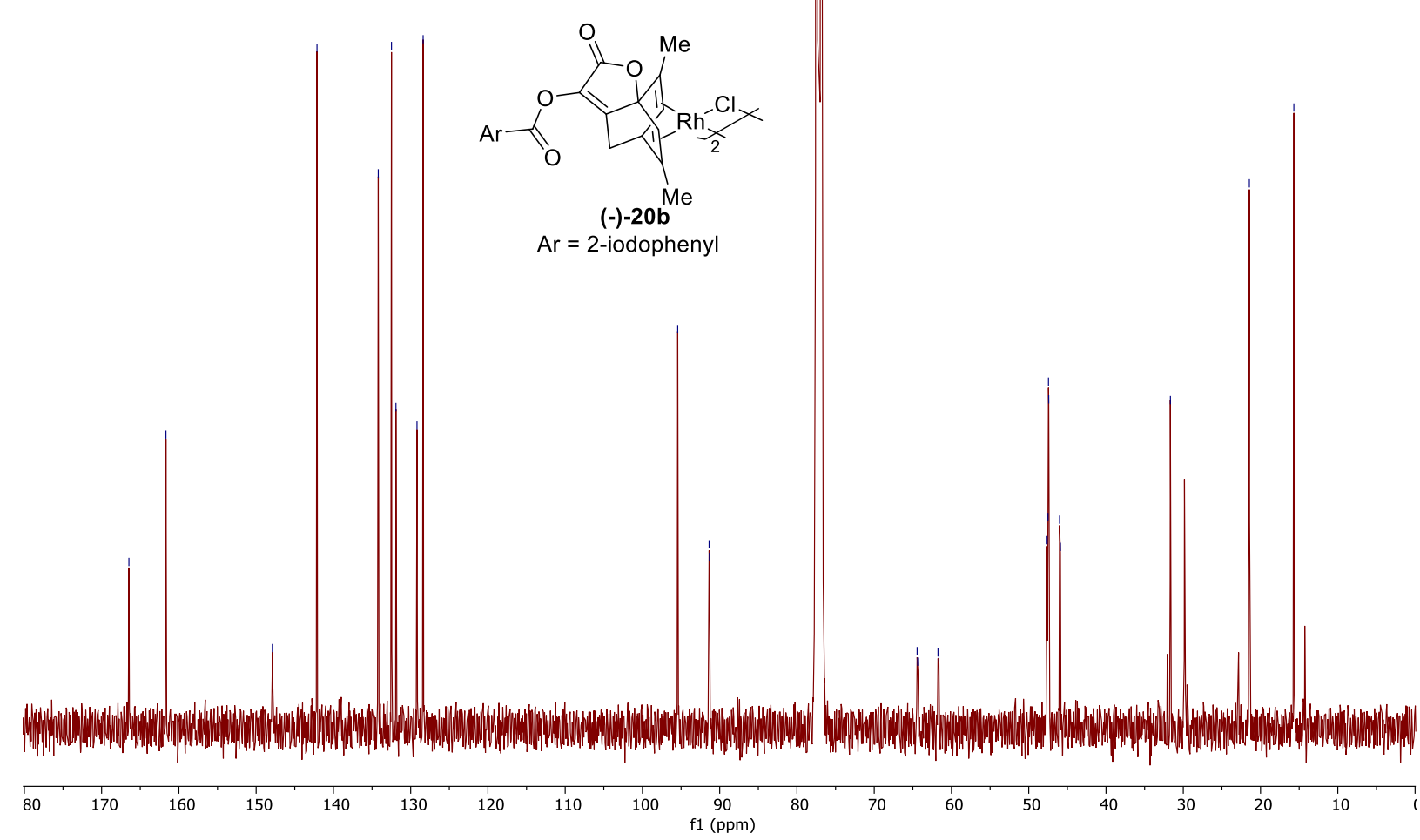


${ }^{1} \mathbf{H}-\mathrm{NMR}\left(400 \mathrm{MHz}, \mathrm{CDCl}_{3}\right)$ of compound $\mathbf{5 g}$

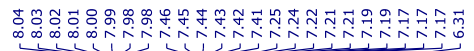<smiles>CC(C)C#CC(OC(=O)c1ccccc1I)C(=O)Oc1c(P)cccc1C(C)C</smiles>

$5 g$

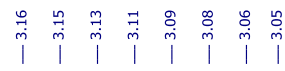

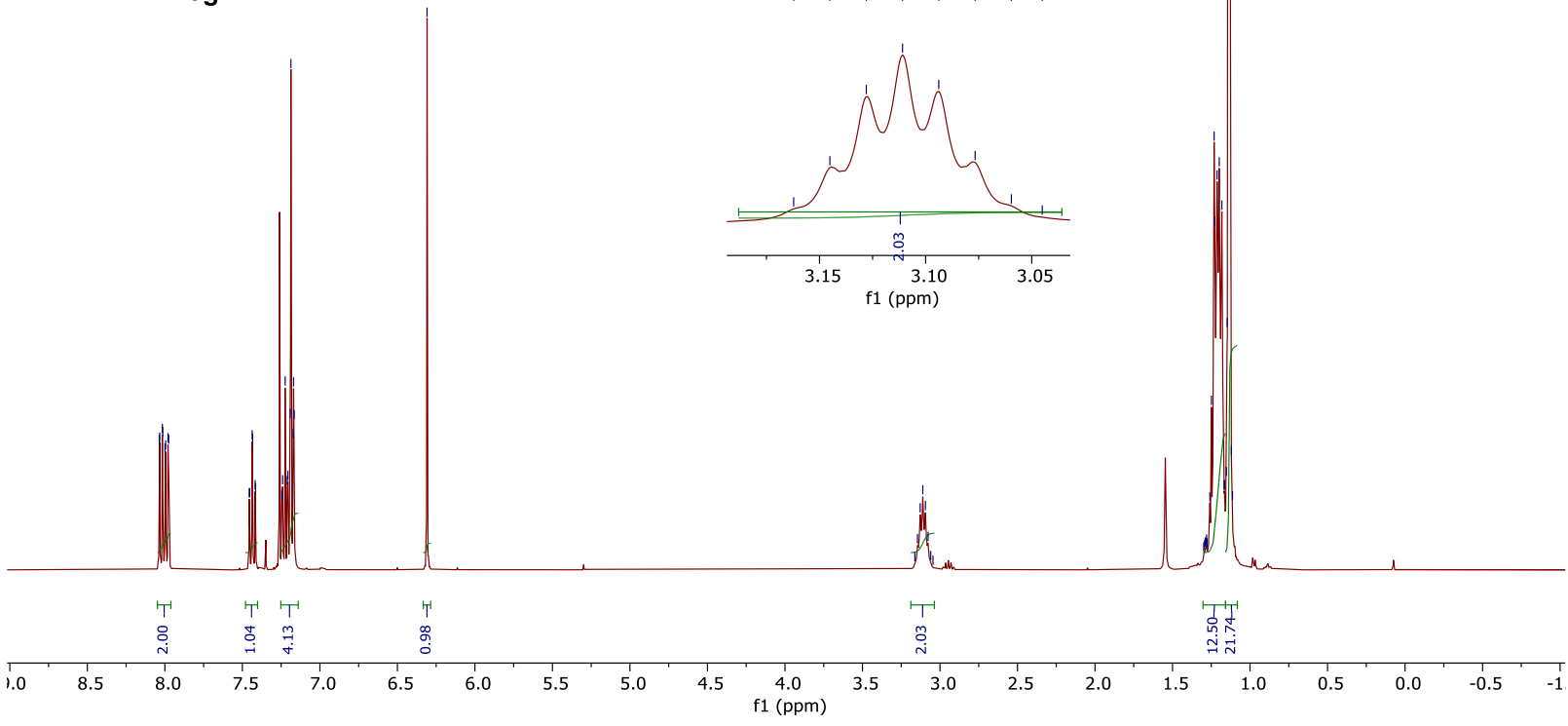

${ }^{13} \mathrm{C}-\mathrm{NMR}\left(100 \mathrm{MHz}, \mathrm{CDCl}_{3}\right)$ of compound $\mathbf{5 g}$

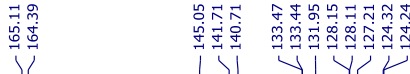

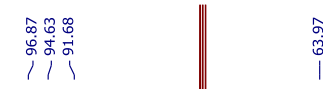

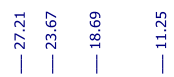<smiles>CC(C)c1cccc(C(C)C)c1OC(=O)C(C#CC(F)(F)F)OC(=O)c1ccccc1I</smiles>

5g

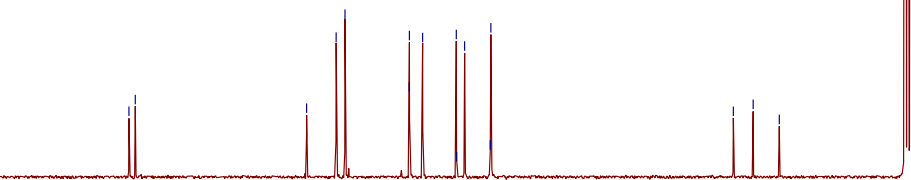

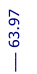

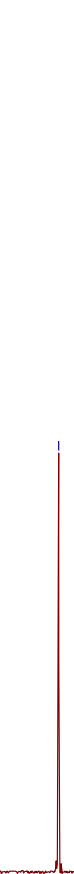

$170 \quad 160 \quad 150$

140

120

90

$80+70,60$

50

40 
${ }^{1} \mathrm{H}-\mathrm{NMR}\left(400 \mathrm{MHz}, \mathrm{CDCl}_{3}\right.$ ) of compound $\mathbf{1 1 g}$

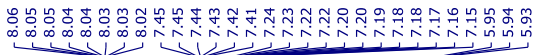

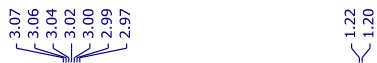<smiles>C=IC(Oc1c(C(=O)Oc2ccccc2I)cccc1C(C)C)C(=O)O</smiles>

119
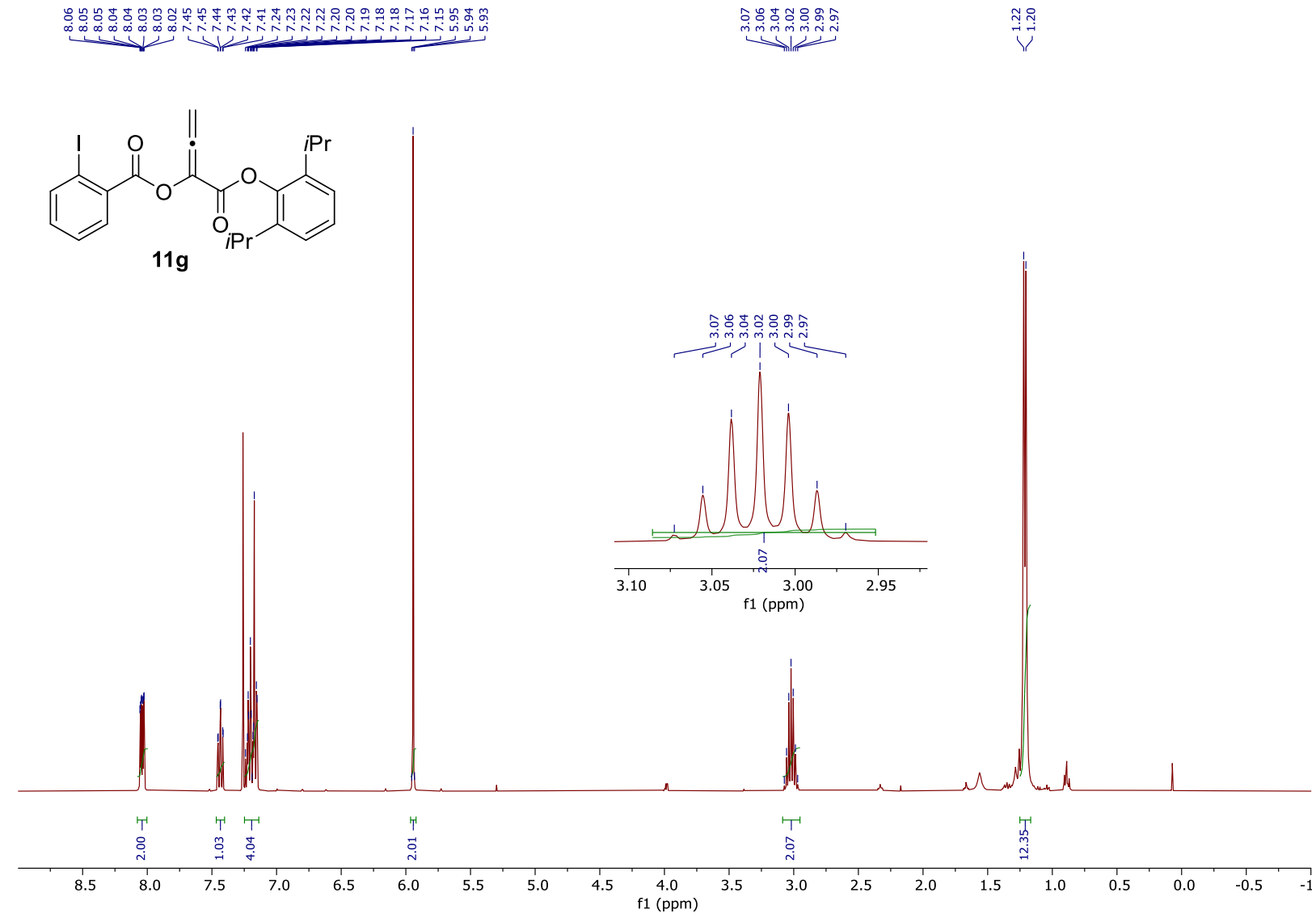

${ }^{13} \mathrm{C}-\mathrm{NMR}\left(100 \mathrm{MHz}, \mathrm{CDCl}_{3}\right.$ ) of compound $\mathbf{1 1 g}$

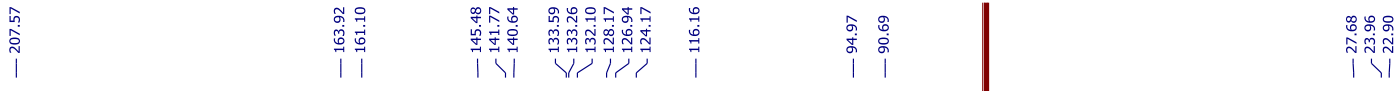<smiles>C=IC(Oc1c(C(=O)O)cccc1C(C)C)C(=[IH])OC(=O)c1ccccc1I</smiles>

$11 \mathrm{~g}$
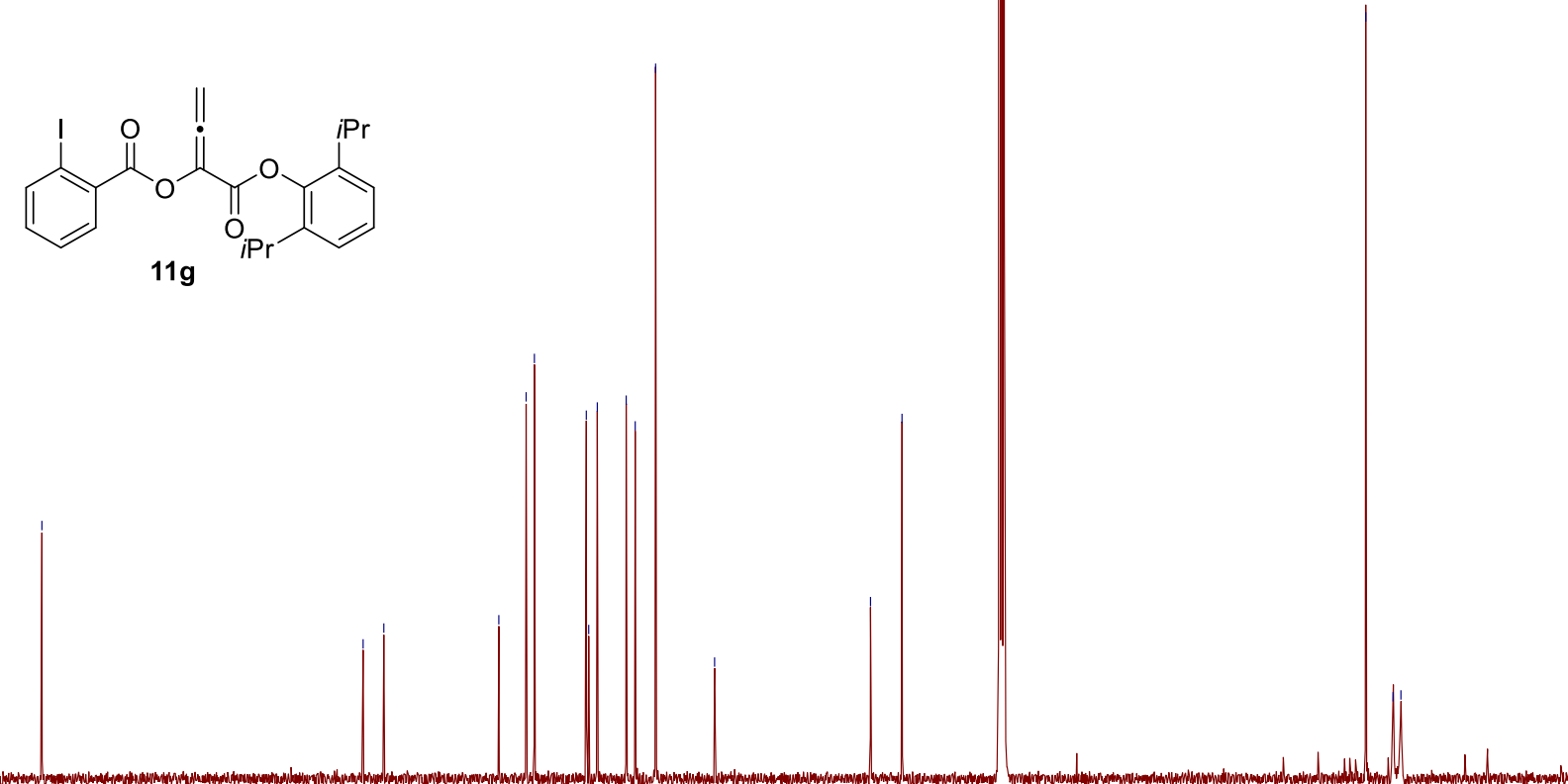

$\begin{array}{lllllllllll}210 & 200 & 190 & 180 & 170 & 160 & 150 & 140 & 130 & 120 & \underset{f 1(p p m)}{110}\end{array}$ 